\title{
SOCIAL ENTERPRISE IN WESTERN EUROPE
} THEORY, MODELS AND PRACTICE

\author{
Edited by \\ Jacques Defourny and Marthe Nyssens
}

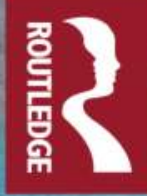




\section{Social Enterprise in Western Europe}

In the last two decades, the quest for a widely accepted definition of social enterprise has been a central issue in a great number of publications.

The main objective of the ICSEM Project on which this book is based was to show that the social enterprise field would benefit much more from linking conceptualisation efforts to the huge diversity of social enterprises than from an additional and ambitious attempt at providing an encompassing definition. Starting from a hypothesis that could be termed "the impossibility of a unified definition", the ICSEM research strategy relied on bottom-up approaches to capture the social enterprise phenomenon in its local and national contexts. This strategy made it possible to take into account and give legitimacy to locally embedded approaches, while simultaneously allowing for the identification of major social enterprise models to delineate the field on common grounds at the international level.

Social Enterprise in Western Europe-the third volume in a series of four ICSEM-based books on social enterprise worldwide-will serve as a key reference and resource for teachers, researchers, students, experts, policy makers, journalists and others who want to acquire a broad understanding of the social enterprise and social entrepreneurship phenomena as they emerge and develop in this region.

Jacques Defourny is a professor emeritus at the Centre for Social Economy, HEC Management School, University of Liege, Belgium. He was a founder and the first president of the EMES International Research Network.

Marthe Nyssens is president of the EMES International Research Network and professor and Pro-Rector "Society and Transition", UCLouvain, Belgium. 


\section{Routledge Studies in Social Enterprise and Social Innovation \\ Series Editors: Jacques Defourny, Lars Hulgård and Rocío Nogales}

Social enterprises seek to combine an entrepreneurial spirit and behaviour with primacy of social or societal aims. To various extents, their production of goods or services generates market income which they usually combine with other types of resources. A social innovation consists of the implementation of a new idea or initiative to change society in a fairer and more sustainable direction.

Routledge Studies in Social Enterprise and Social Innovation seeks to examine and promote these increasingly important research themes. It particularly looks at participatory governance and social innovation dynamics in social enterprises and more widely in partnerships involving third sector and civil society organisations, conventional businesses and public authorities. In such a perspective, this series aims at publishing both breakthrough contributions exploring the new frontiers of the field as well as books defining the state of the art and paving the way to advance the field.

Social Enterprise in Asia

Theory, Models and Practice

Edited by Eric Bidet and Jacques Defourny

Social Enterprise in Latin America

Theory, Models and Practice

Edited by Luiz Inácio Gaiger, Marthe Nyssens and Fernanda Wanderley

Social Enterprise in Western Europe

Theory, Models and Practice

Edited by Jacques Defourny and Marthe Nyssens

Social Enterprise in Central and Eastern Europe

Theory, Models and Practice

Edited by Jacques Defourny and Marthe Nyssens

For more information about this series, visit: https://www.routledge.com/ Routledge-Studies-in-Social-Enterprise--Social-Innovation/book-series/ RSESI 


\section{Social Enterprise in Western Europe}

Theory, Models and Practice

Edited by Jacques Defourny and Marthe Nyssens 
First published 2021

by Routledge

52 Vanderbilt Avenue, New York, NY 10017

and by Routledge

2 Park Square, Milton Park, Abingdon, Oxon, OX14 4RN

Routledge is an imprint of the Taylor \& Francis Group, an informa business

(C) 2021 Taylor \& Francis

The rights of Jacques Defourny and Marthe Nyssens to be identified as the authors of the editorial material, and of the authors for their individual chapters, have been asserted in accordance with Sections 77 and 78 of the Copyright, Designs and Patents Act 1988.

All rights reserved. No part of this book may be reprinted or reproduced or utilised in any form or by any electronic, mechanical or other means, now known or hereafter invented, including photocopying and recording, or in any information storage or retrieval system, without permission in writing from the publishers.

Trademark notice: Product or corporate names may be trademarks or registered trademarks, and are used only for identification and explanation without intent to infringe.

Library of Congress Cataloging-in-Publication Data

A catalog record for this title has been requested

ISBN: 978-0-367-15118-8 (hbk)

ISBN: 978-0-367-72431-3 (pbk)

ISBN: 978-0-429-05514-0 (ebk)

Typeset in Sabon

by MPS Limited, Dehradun 


\section{Contents}

Preface and Acknowledgements

viii

Editors

List of Contributors

Introduction: Documenting, Theorising, Mapping and Testing the Plurality of SE Models in Western Europe

JACQUES DEFOURNY, MARTHE NYSSENS AND SOPHIE ADAM

\section{PART I}

National Overviews of Social Enterprise

1 Unity in Diversity: Exploring the Multiple Facets of the Belgian Social Enterprise Landscape BENJAMIN HUYBRECHTS, MARTHE NYSSENS AND JACQUES DEFOURNY

2 Social Enterprise in Denmark: Historical, Contextual and Conceptual Aspects

LINDA LUNDGAARD ANDERSEN, LARS HULGÅR AND GURLI JAKOBSEN

3 A New Typology of Social Enterprise in Finland: Capturing the Diversity

HARRI KOSTILAINEN, EEVA HOUTBECKERS AND PEKKA PÄTTINIEMI

4 Social Enterprise in France: At the Crossroads of the Social Economy, Solidarity Economy and Social Entrepreneurship?

FRANCESCA PETRELLA, NADINE RICHEZ-BATTESTI, LAURENT FRAISSE, JEAN-LOUIS LAVILLE AND LAURENT GARDIN 
vi Contents

5 Social Enterprise in Germany: Between Institutional Inertia, Innovation and Cooperation

NICOLE GÖLER VON RAVENSBURG, GEORG MILDENBERGER AND GORGI KRLEV

6 Social Enterprise in Iceland: The Long Journey Towards a Hybrid Welfare Model STEINUNN HRAFNSDÓTTIR AND ÓMAR H. KRISTMUNDSSON

7 Social Enterprise in Ireland: State Support Key to the Predominance of Work-Integration Social Enterprise (WISE) PATRICIA O'HARA AND MARY O'SHAUGHNESSY

8 Social Enterprise in Italy: A Plurality of Business and Organisational Models SIMONE POLEDRINI AND CARLO BORZAGA

9 Social Enterprise in the Netherlands: Between Hope and Hype PHILIP MARCEL KARRÉ

10 Social Enterprises in Norway: Models and Institutional Trajectories BERNARD ENJOLRAS, JILL M. LOGA, LARS U. KOBRO AND HANS A. HAUGE

11 Social Enterprise in Portugal: Concepts, Contexts and Models

SÍLVIA FERREIRA AND JOANA ALMEIDA

12 Social Enterprise in Spain: From a Diversity of Roots to a Tentative Typology of Models MILLÁN DÍAZ-FONCEA, ESTHER VILLAJOS, TERESA SAVALL, CARMEN GUZMÁN, FRANCISCO JAVIER SANTOS, MARTA SOLÓRZANO-GARCÍA, CHAIME MARCUELLO-SERVÓS, RAFAEL CHAVES-ÁVILA AND CARMEN MARCUELLO

13 Social Enterprises in Sweden: Intertextual Consensus and Hidden Paradoxes MALIN GAWELL

14 Social Enterprise Approaches in Switzerland MICHAËL GONIN, NICOLAS GACHET AND PHILIPP ERPF 
15 Social Enterprise in the UK: Models and Trajectories

MIKE AIKEN, ROGER SPEAR, FERGUS LYON, SIMON

TEASDALE, RICHARD HAZENBERG, MIKE BULL AND ANNA

KOPEC MASSEY

\section{PART II}

Comparative Analyses and Perspectives

16 Social Enterprises in France, Portugal and Spain:

Between Path Dependence and Institutional Creation?

FRANCESCA PETRELLA, NADINE RICHEZ-BATTESTI, MARTA

SOLÓRZANO-GARCÍA AND SÍLVIA FERREIRA

17 Social Enterprise in Belgium, Germany and the Netherlands: Where the Old Meets the New PHILIP MARCEL KARRÉ

18 Between Coercive and Mimetic Institutional Isomorphism: Social Enterprise and the Universal Scandinavian Welfare State

BERNARD ENJOLRAS, LINDA LUNDGAARD ANDERSEN, MALIN GAWELL AND JILL M. LOGA

19 How Context Shapes the Character of Cooperative Social Enterprises: Insights from Various Countries NICOLE GÖLER VON RAVENSBURG, RICHARD LANG, SIMONE POLEDRINI AND MARZENA STARNAWSKA

20 Testing the Relevance of Major Social Enterprise Models in Western Europe JACQUES DEFOURNY, MARTHE NYSSENS AND OLIVIER BROLIS

Conclusion: Social Enterprise, Welfare Regimes and Policy Implications 


\section{Preface and Acknowledgements}

This book is part of a series of four volumes produced under the "International Comparative Social Enterprise Models (ICSEM) Project" and focusing respectively on Asia, Latin America, Central and Eastern Europe and Western Europe. Various countries not belonging to these major regions were also covered by the Project; the contributions linked to these countries have been published in a special issue of the Social Enterprise Journal (2017, vol. 13, no. 4).

Launched in July 2013, the ICSEM Project is the result of a partnership between an "Interuniversity Attraction Pole on Social Enterprise" (IAPSOCENT), funded by the Belgian Science Policy (BELSPO), and the EMES International Research Network. Over eight years, it gathered around 230 researchers from some 55 countries across the world to document and analyse the diversity of social enterprise models and their ecosystems. In the last three years, this research was also based upon work from COST Action 16206 Empower-SE, supported by COST (European Cooperation in Science and Technology; www.cost.eu).

First and foremost, the production of these volumes relied on the efforts and commitment of local ICSEM Research Partners. It was also enriched through discussion in the framework of Local ICSEM Talks in various countries, Regional ICSEM Symposiums and Global ICSEM Meetings held alongside EMES International Conferences on Social Enterprise. We are grateful to all those who contributed, in one way or another, to these various events and achievements of the Project.

All ICSEM-related publications also owe much to the outstanding editorial work of Sophie Adam, Coordination Assistant, to whom we express special thanks. We are also grateful to Elisabetta Severi, who provided valuable assistance in the cleaning of the data collected through a common questionnaire in most countries. 
Preface and Acknowledgements ix

We also want to express warm thanks to BELSPO and to our Supporting Partners, the "Fondation Crédit Coopératif" and the "Groupe Caisse des Dépôts" (France) as well as the "InBev-Baillet Latour Fund" (Belgium), for their crucial financial support.

Jacques Defourny and Marthe Nyssens, Scientific Coordinators of the ICSEM Project 


\section{Editors}

Jacques Defourny is a professor of non-profit and cooperative economics and comparative economic systems at HEC Liege-Management School of the University of Liege (Belgium), where he served as the director of the Centre for Social Economy from 1992 to 2020. He was also the founding coordinator (1996-2001) and the first president (2002-2010) of the EMES International Research Network, which gathers fourteen university research centres working on social enterprise and various facets of the third sector. He also acts as the scientific coordinator, together with Marthe Nyssens, of the "International Comparative Social Enterprise Models (ICSEM) Project" (2013-2020), which involves some 230 researchers from 55 countries in all world regions. His research interests focus on conceptual and theoretical approaches of the social economy and its various types of organisations (cooperatives, non-profit organisations, mutual societies, social enterprises, etc.) in industrialised and developing countries.

Marthe Nyssens is a full professor at the School of Economics of the Catholic University of Louvain (UCLouvain, Belgium) and a member of the Interdisciplinary Research Centre on Work, State and Society (CIRTES, UCLouvain). She acts as a scientific coordinator, together with Jacques Defourny, of the "International Comparative Social Enterprise Models (ICSEM) Project", which involves some 230 researchers from 55 countries in all world regions. She was a founding member and is currently the president of the EMES International Research Network. She holds a Master of Economics (University of California at San Diego, US) and a PhD in Economics (UCLouvain). Her research work focuses on conceptual approaches to the third sector, both in developed and developing countries, as well as on the links between third-sector organisations and public policies. Her research deals with the socio-economic logics of "not-for-profit organisations"; she analyses the role of these organisations and their relations with public policies, the market and civil society in fields such as work integration, care or the commons. 


\section{Contributors}

Sophie Adam holds a Master of Interpretation (1994) and a Master of Translation (1995, University of Mons-Hainaut, Belgium) as well as a Specialised Master of Development Management (1998, University of Liege, Belgium). She has worked as a professional editor for the Centre for Social Economy (Belgium) and the EMES International Research Network for more than 20 years. She also worked as a coordination assistant for the SOCENT research programme on social enterprise and, more specifically, within this programme, for the ICSEM Project (2013-2020).

Mike Aiken is an independent researcher engaged in the European third sector. He holds a Master of Social Policy (University of Sussex, UK) and a $\mathrm{PhD}$ (Open University, UK) and has published in Voluntas, Voluntary Sector Review, Public Management Review and Interface. Mike Aiken has lived in Germany and Mexico, where he taught community social work and social policy. His recent research with the Institute for Voluntary Action Research examined advocacy and community assets. He is active in campaigns to support health rights for migrants.

Joana Gomes de Almeida is a researcher in CEISXX (University of Coimbra, Portugal). She holds a PhD in Sociology (Labour Relations, Social Inequalities and Syndicalism), a Master of Social Intervention, Innovation and Entrepreneurship and a Degree in Social Work from the University of Coimbra. As a research fellow, she has developed work in the area of social enterprises and labour transitions, with a particular focus on issues such as unemployment, self-employment and social inequalities.

Linda Lundgaard Andersen, $\mathrm{PhD}$, is a professor in learning, evaluation and social innovation at Roskilde University (Denmark), co-director of the Centre for Social Entrepreneurship and director of the $\mathrm{PhD}$ School of People and Technology. Her research interests include learning and social innovation in welfare services, democracy and forms of governance in human services, ethnographies of the public sector, voluntary organisations and social enterprises and, recently, 


\section{xii Contributors}

the current neoliberal transformations and shifts of paradigms in Danish and Scandinavian welfare services.

Carlo Borzaga is a senior professor of economic policy at the University of Trento (Italy). His research interests include cooperatives, social enterprise, the economic and social role of non-profit organisations and their interactions with welfare policies. He has chaired EURICSE (Italy) since its foundation, in 2008. He is also a founding member of the EMES International Research Network and a member of the board of the IRIS Network (Italy). He sits on the editorial board of several journals and is co-editor of the Journal of Entrepreneurial and Organisational Diversity.

Olivier Brolis holds a $\mathrm{PhD}$ in Economics. He is an expert consultant for IDEA Consult (Belgium), director of the Senior Montessori association, and affiliated professor (social enterprises and statistics) and researcher at the University of Louvain (Belgium). His research focuses, inter alia, on social enterprises/organisations, well-being at work and social-policy elaboration and evaluation, with a particular interest in the field of personal household services.

Mike Bull is a reader in social enterprise at Manchester Metropolitan University Business School (UK). His research themes of interest are the tensions in social and enterprise; the definition of social enterprise; social-enterprise ethics; social and solidarity economy; sociology of value; and football ownership and governance. He lectures in critical management studies and responsible enterprise.

Rafael Chaves-Avila is a senior professor of economic policy at the IUDESCOOP research institute of the University of Valencia (Spain). His research has focused on the study of social economy, statistics and public policies towards cooperatives, social enterprises, voluntary organisations and new economic paradigms. He has been the chairman of CIRIEC's Scientific Committee and he is currentlya member of the European Commission Expert group on social economy and social enterprises (GECES) and an editor of Ciriec-España revista de economía pública, social y cooperativa.

Millán Díaz-Foncea holds a $\mathrm{PhD}$ in Economics and Management of Organisations from the University of Zaragoza (Spain), where he holds a position in the Department of Business Management. His research has been developed within the GESES-University of Zaragoza Research Group and focused on the study of social economy, collective entrepreneurship, social enterprises and new economies (solidarity-based economy, sharing economy...).

Bernard Enjolras is a research professor and director of the Centre for Research on Civil Society and Voluntary Sector at the Institute for Social 
Research (Norway). His research interests are related to different aspects of civil society (social media and digitalisation, terror and trust, freedom of speech), the third sector (non-profit organisations, social enterprises, advocacy and democracy) and public policies and governance. He holds a $\mathrm{PhD}$ in Sociology from the University of Québec in Montréal (Canada) and $\mathrm{a} \mathrm{PhD}$ in Economics from the University of Paris I Panthéon-Sorbonne (France).

Philipp Erpf is a co-director and senior researcher at the Institute for Research on Management of Associations, Foundations and Cooperatives (VMI) at the University of Fribourg (Switzerland). He holds a $\mathrm{PhD}$ in the field of social entrepreneurship. His research examines social enterprises and social entrepreneurship, entrepreneurial orientation in nonprofit organisations as well as social innovation.

Sílvia Ferreira holds a $\mathrm{PhD}$ in Sociology. She is an assistant professor at the Faculty of Economics of the University of Coimbra (Portugal) and a researcher at the Centre for Social Studies of this university. She has been involved in research on social-security reform, third sector and social policy, social entrepreneurship and social innovation in the social and solidarity economy, social enterprises, volunteering and state/third-sector partnerships in local governance. She is particularly interested in the evolving nature of the welfare state and of welfare mixes.

Laurent Fraisse is a sociologist and an associate researcher at the Laboratoire Interdisciplinaire pour la Sociologie Économique (LISE/ CNAM, Paris, France). He is also a member of the EMES International Research Network and of the Inter-University Network on the Social and Solidarity Economy (RIUESS, France). His main research fields are the social and solidarity economy, social enterprises, social innovation, the third sector, the governance of welfare policies and social-care services.

Nicolas Gachet is currently head of Social and Strategic Intelligence at the Hospice Général in Geneva (Switzerland). He has conducted several research projects on the social and solidarity economy at the University of Lausanne (Switzerland) and has extensive field experience in this area, both in Northern and Southern countries.

Laurent Gardin is a lecturer at the Centre de recherche interdisciplinaire en sciences de la société (CRISS) of Université Polytechnique Hautsde-France (UPHF, France). He is a co-founder of the ChairESS of Hauts-de-France and of the Inter-University Network on the Social and Solidarity Economy (RIUESS, France). His research themes focus mainly on the emergence and recognition of solidarity-based initiatives, social enterprises, the theorisations of the social and solidarity economy and public policies that support these initiatives. 
Malin Gawell is an associate professor at the School of Social Sciences of Södertörn University in Stockholm (Sweden). For many years, she has studied social entrepreneurship, social enterprises and different types of civil-society organisations. Her research themes include conceptual as well as empirical studies, often based on action-oriented collaborative methodologies. Her special interest in entrepreneurial and innovative dynamics, combined with critical analysis, has led to contributions to the field on micro, meso and macro levels of analysis.

Nicole Göler von Ravensburg holds a PhD in Economics. She is a tenured professor in socio-economics at Frankfurt University of Applied Sciences (Germany). Her main interests include organisation, finance and innovation in the German welfare system; cooperative economics; startup and organisational development of social enterprises and cooperatives; and social intervention at the organisational level. Her major research themes are pupils' cooperatives, international comparative cooperative research, social cooperatives and sustainability education.

Michaël Gonin is dean and professor of ethics at the Haute École de Théologie in St-Légier (Switzerland) as well as an associate scholar at the Institute for Research on Management of Associations, Foundations and Co-operatives (VMI, Switzerland). He holds a $\mathrm{PhD}$ in Business Ethics as well as a Master of Marketplace Theology. His research and teaching focus on the meaning of work from a theological perspective as well as on social entrepreneurship as an expression of meaningful work at the intersection of business, society and non-profit.

Carmen Guzmán is an assistant professor in the department of Applied Economics I at the University of Seville (Spain). She completed her PhD in Economic Development and Social Entrepreneurship at the University of Huelva (Spain). Her research is mainly focused on social entrepreneurship and social economy. She has been a visiting researcher in several universities, participates in different international and national research projects and has published articles in several international journals.

Hans A. Hauge is an associate professor in sociology at the Department of Health, Social and Welfare Studies of the University of South-Eastern Norway. His doctoral research explored empowerment processes among employees engaged in interdisciplinary collaboration in welfare services. His main research areas are the relationship between social enterprises and welfare services; social innovation in work inclusion for people with intellectual disabilities; and education as a means for public innovation in welfare services.

Richard Hazenberg (BA, MA, PhD) is a principal researcher and the director of the Institute for Social Innovation and Impact at 
the University of Northampton (UK). He has research interests in the areas of social innovation, social finance, public-service innovation and social-impact measurement. He has contributed to international/ national government policy, including for the European Commission, OECD, Cabinet Office (UK) and HM Treasury (UK). Richard Hazenberg is an associate editor of the Social Enterprise Journal and Journal of Social Entrepreneurship.

Eeva Houtbeckers holds a PhD in Economic Sciences. She works in the transdisciplinary field of design for sustainability transitions. Her ongoing sensory and institutional ethnographic research, funded by the Maj and Tor Nessling Foundation and the Kone Foundation, focuses on the everyday practices of post-growth economy, work and livelihoods in the global North. Her doctoral dissertation, Mundane social entrepreneurship, focused on Finnish micro-entrepreneurs' work in sectors that address sustainability challenges.

Steinunn Hrafnsdóttir is a professor at the Faculty of Social Work, School of Social Sciences of the University of Iceland. She holds a PhD in Social Work and a Master's degree in Management from the University of Kent (UK). Her main fields of research include thirdsector organisations and volunteering, social enterprises and ecosystems, social innovation and administration and working environment of welfare organisations.

Lars Hulgård, $\mathrm{PhD}$, is a professor of social entrepreneurship at Roskilde University (Denmark), visiting professor at Tata Institute of Social Sciences, Mumbai (India), and co-director of the Centre for Social Entrepreneurship (Denmark). He is engaged in research, teaching and consultancy in the fields of (social) innovation, solidarity economy, social policy, social economy, social enterprise/entrepreneurship, public service, civil society and transformation of the welfare state. $\mathrm{He}$ is the co-editor of the Routledge Studies in Social Enterprise \& Social Innovation series.

Benjamin Huybrechts is an associate professor in social and cooperative entrepreneurship at HEC Liège Management School, Liège University (Belgium) and an affiliate professor at emlyon business school (France). He holds a $\mathrm{PhD}$ in Management from Liège University and spent his post-doctoral research stay at the University of Oxford (Said Business School, UK). His research topics include the emergence and governance of social enterprises as hybrid organisations, and partnerships and networks in the context of institutionalising social enterprise models.

Gurli Jakobsen, $\mathrm{PhD}$, is a lecturer at the Centre for Social Entrepreneurship at Roskilde University (Denmark); a researcher at 
the Centre for Civil Society Studies at Copenhagen Business School (Denmark); and a member of CIRIEC's Scientific Commission. Her research deals with social and cooperative entrepreneurship and the dynamics of learning cooperation and democracy. Recent projects include a contribution to a mapping of social enterprises and their ecosystems in Europe, and a study on the formation of policies about cooperatives and the social economy in the EU.

Philip Marcel Karré, PhD, is an assistant professor at the Department of Public Administration and Sociology at Erasmus University Rotterdam in the Netherlands. His research focuses on hybrid organisations and hybrid governance arrangements, social enterprises and other forms of social innovation at the nexus of state, market and society.

Lars U. Kobro is CEO and a senior researcher of the Norwegian Centre for Social Entrepreneurship and Social Innovation (SESAM) at the University of South-Eastern Norway. His academic background includes comparative politics, sociology and rhetoric. His work focuses on social innovation and entrepreneurship questions raised by the challenges faced by the Nordic welfare model. Lars U. Kobro has provided several reports for Norwegian ministries and other public stakeholders in Norway.

Anna Kopec Massey (BA, MA, PhD) is a lecturer at Bournemouth University (UK). Her teaching interests include social justice, culture and qualitative research methodologies. Anna Kopec Massey's research interests are in the areas of empathy, care ethics, social-enterprise development and leadership.

Harri Kostilainen holds a $\mathrm{PhD}$ in Social Sciences. He is a researcher at Diaconia University of Applied Sciences (Helsinki, Finland) and the executive director of the Finnish Social Enterprise Research Network (FinSERN). He has 25 years of experience in the field of research on social innovations and social enterprises in the context of the renewal of welfare and employment services, both nationally and internationally, and he has taken part in several international research and development projects.

Ómar H. Kristmundsson is a professor at the Faculty of Political Sciences, School of Social Sciences, University of Iceland. He holds a PhD in Public Administration and Public Policy from the University of Connecticut (US). His main fields of research include public governance, public leadership, decision-making in public administration, the governance of third-sector organisations, social enterprises and their ecosystems and social innovation.

Gorgi Krlev holds a PhD from the University of Oxford (Kellogg College, UK). He is a researcher at the Centre for Social Investment (CSI) at Heidelberg University (Germany), where his current work focuses on 
(social) innovation and entrepreneurship, impact investing, and social impact measurement.

Richard Lang is an assistant professor at the Institute of Innovation Management at Johannes Kepler University Linz (Austria), and an honorary senior research fellow at the School of Social Policy of the University of Birmingham (UK). His research interests include social innovation and social-enterprise models in the context of sustainable urban and regional development. His research has been published in scholarly journals such as the International Small Business Journal, Journal of Rural Studies, Technological Forecasting and Social Change and Voluntas.

Jean-Louis Laville is a professor at the Conservatoire national des arts et métiers (Cnam, Paris, France), where he holds a Chair in Solidarity Economy. He is involved in many international research networks. He is the European coordinator of the Karl Polanyi Institute of Political Economy, and a founding member of the EMES International Research Network and of the Network of Latin American Researchers on the Social and Solidarity Economy (RILESS). He has written books that have been translated in Italian, Portuguese, English, Spanish and Japanese.

Jill Merethe Loga holds a PhD in Political Science. She is a professor in organisation and management at the Department of Business administration of Western Norway University of Applied Sciences. She is a former coordinator of the Centre for Research on Civil Society and Voluntary Sector (Norway) and her research interests are related to different aspects of civil society and voluntary organisations, public policy and governance, innovation in the public sector and social entrepreneurship.

Fergus Lyon is a professor of enterprise and organisation at Middlesex University Business School in London (UK) and deputy director of the ESRC Centre for the Understanding of Sustainable Prosperity. $\mathrm{He}$ previously led the social-enterprise theme in the Third Sector Research Centre. His research interests include social and sustainable enterprises, social investment and enterprise support policy. He has carried out research in the UK, Ghana, Nigeria, India, Pakistan, Bhutan and Nepal.

Carmen Marcuello is a professor in the Department of Business Management and director of the GESES research group at the University of Zaragoza (Spain). She is president of the IberoAmerican Observatory for Employment, the Social Economy and Cooperatives (OIBESCOOP) and vice-president of CIRIEC-Spain. She is a member of the International Scientific Commission on "Social and Cooperative Economy" of CIRIEC-International and of the Scientific Commission for the Social Economy of CIRIEC-Spain. 
Chaime Marcuello-Servós teaches social work and social services in the Department of Psychology and Sociology and is a professor with the doctoral and master programmes in sociology of public and social policies at the University of Zaragoza (Spain). He is a member and cofounder of the Third Sector Social and Economic Studies Group (GESES, Spain). From 2014 to 2018, he was the president of Research Committee 51 on Sociocybernetics of the International Sociological Association.

Georg Mildenberger is head of the research department of the Centre for Social Investment (CSI) at the University of Heidelberg (Germany). He holds a doctoral degree from Darmstadt University (Germany) and a master's degree in philosophy and political science from the University of Tübingen (Germany). In recent years, he has conducted research on social investment, impact measurement, social innovation and social enterprises. His recent research includes projects on the metrics of social innovation, civic engagement and sustainable agriculture.

Patricia O'Hara, $\mathrm{PhD}$, is a sociologist who has held positions in research, teaching and policy analysis and has published widely on regional and rural society and economy. Until her retirement in 2019/20, she was adjunct professor at Maynooth University (Ireland), and served as chair and member of various boards and advisory bodies to government, including the Irish National Statistics Board and the European Statistical Governance Advisory Board (ESGAB), as well as NGOs concerned with regional development, housing and youth mental health.

Mary O'Shaughnessy, $\mathrm{PhD}$, is a senior lecturer at Cork University Business School, University College Cork (UCC, Ireland). Her research interests include social enterprise, collaborative social entrepreneurship and placebased rural development. She sits on the editorial board of Social Enterprise Journal, is the short-term scientific mission manager to the EU COST Action 16206 "Empowering the next generation of social enterprise scholars" and UCC P1 of RurAction, Marie Sklodowska Curie Action focused on social enterprise and rural development.

Pekka Pättiniemi holds a PhD in Social Sciences. He is the president of the Finnish Social Enterprise Research Network Association (FinSERN), a member of the board of Coop Finland ry, and a member of the Scientific Commission of CIRIEC.

Francesca Petrella is a professor in economics and co-director (with Nadine Richez-Battesti) of a master's degree in the management of third-sector organisations and of a chair on the social and solidarity economy at AixMarseille University (France). She is a researcher at the Institute of Labour Economics and Industrial Sociology (LEST, France). Her research focuses 
on social and solidarity economy organisations, their transformation and interactions with public policies, social innovation and the governance of welfare services (child care and care for the elderly in particular).

Simone Poledrini is a research fellow at the University of Perugia (Italy), where he earned his $\mathrm{PhD}$ in management in 2008. His primary research interest is about social enterprises, with a particular focus on the different typologies, the theory of reciprocity and the strategic assets pursued by social enterprises. Since 2019, he has been a member of the EMES Board of directors. He has published in several international journals and is an associate editor of the Journal of Entrepreneurial and Organizational Diversity (JEOD) and Impresa Sociale (an Italian journal on social enterprise).

Nadine Richez-Battesti is a professor of economics at Aix-Marseille University (France) and a researcher at the Institute of Labour Economics and Industrial Sociology (LEST, France). Her research focuses on the transformations of social- and solidarity-economy (SSE) organisations, in particular associations and cooperatives, and the emergence of social enterprises from an institutional perspective. She is co-directing, with Francesca Petrella, a master programme and a chair in social and solidarity economy. She is a member of the French Higher Council for Cooperation.

Francisco J. Santos is an associate professor in the Department of Applied Economics I at the University of Seville (Spain). His PhD dissertation was about entrepreneurship and economic development and his main interests of research are social entrepreneurship, female entrepreneurship, social capital and entrepreneurship, entrepreneurial orientation and entrepreneurial intentions. He participates in different research projects and has publications about those topics in several international journals.

Teresa Savall Morera holds a Master of Economics (2010) and PhD in Social Economy (2015) from the University of Valencia (Spain), and she is currently a university lecturer in the Department of Applied Economics of this university. Her main research interests include the social economy and public policies, social entrepreneurship, public economy (specifically regarding inequality and poverty) and policy evaluation. She has published articles in scientific journals and has participated in different international, national and regional research projects and contracts.

Marta Solórzano-García is an associate professor of organisational studies at the Universidad Nacional de Educación a Distancia (UNED, Spain). She is the director of the Social Entrepreneurship and Social Innovation Postgraduate Programme. Her research focuses on organisational theory, social entrepreneurship and social innovation. She has participated in 
several research projects with the Chamber of Commerce of Madrid, the Ministry of Employment and Immigration, and the Department of Finance and Public Administration, as well as in several European projects.

Roger Spear is an emeritus professor of social entrepreneurship at Open University (UK), a member of CIRIEC's Scientific Committee, and a founder member of the EMES International Research Network. He is also a guest professor in the Centre for Social Entrepreneurship at Roskilde University (Denmark), contributing to an International Master in Social Entrepreneurship. Recent research projects include a mapping of social enterprises and their ecosystems in Europe, and a Policy and Practice Study of Cities, the Social Economy and Inclusive Growth (JRF funded project).

Marzena Starnawska, $\mathrm{PhD}$, is a senior research fellow at the Centre for Entrepreneurship, Faculty of Management, University of Warsaw (Poland). Her main areas of interest are enterprising communities, social entrepreneurship, institutional theory, social enterprise governance and social capital in entrepreneurship. Her major research themes cover collaboration in social entrepreneurship and the role of different institutional logics in social enterprise.

Simon Teasdale is a professor of public policy and organisations and assistant vice principal on social innovation at Glasgow Caledonian University (UK). His research focuses on the intersection between public policies, discourse and organisational behaviour, with an emphasis on social enterprise. His research has been funded by bodies including the UK's Economic and Social Research Council, Scottish Government, OECD and UK government. His work has been published in journals such as Economy and Society, Public Administration and Journal of Social Policy.

Esther Villajos holds a PhD in Human Resource Psychology and a Master in Social Economy from the University of Valencia (Spain). She is the director of the MBA programme and a lecturer and researcher at Valencian International University (Spain). Her research interests include the study of human resources practices, employees' well-being and performance, the study of context in HRM and the management of social enterprises. She is the lead researcher of the Research Group on Sustainable Organisations at Valencian International University. 


\title{
Introduction
}

\section{Documenting, Theorising, Mapping and Testing the Plurality of SE Models in Western Europe}

\author{
Jacques Defourny, Marthe Nyssens and \\ Sophie Adam
}

The last two or three decades have witnessed a high number of conceptual attempts to define the notions of social enterprise, social entrepreneurship and social entrepreneur. Many early works tended to consider these three notions as different facets of the same phenomenon. Some underlined a strong kinship between social entrepreneurship and social entrepreneurs. Other works only focused on social enterprise (SE). In this body of literature, it is rather easy today to identify the criteria or distinctive features that were most debated in such conceptual discussions: the search for market income in non-profit organisations, as early developed by Skloot (1983), and then more widely in "mission-driven businesses" (Austin et al. 2006); the primacy of social aims (Nicholls 2006); the specific profile of individual social entrepreneurs, as described by Dees (1998); the place of innovation, as analysed by Young (1983) and later by Mulgan (2007), who highlighted social innovation; and the issue of governance as a tool to achieve a sustainable balance between economic and social objectives, as highlighted by the EMES International Research Network (Borzaga and Defourny 2001).

In the last decade, various researchers, like Dacin et al. (2010), Brouard and Larivet (2010), Bacq and Janssen (2011), Alegre et al. (2017), AliagaIsla and Huybrechts (2018) or Persaud and Bayon (2019), among others, proposed overviews of existing definitions of social enterprise and social entrepreneurship. Some of them tried to build their own syntheses, in an attempt to reach larger conceptual agreements which would serve as foundations and key references for the academic sphere, public authorities promoting SE development and intermediary bodies providing various types of services (advocacy, legal or technical tools, financial support, and so on).

In spite of all these efforts, it is today acknowledged, to a large extent, that the SE field is too wide and too diversified to be embraced by a single definition which would be unanimously accepted. Against such a background, an increasing number of scholars tend to adopt an alternative research strategy, whose main principle is to accept, a priori, the variety of social enterprises, and to describe the various SE types or categories. Some go a step further, looking for factors that could account for such diversity. 
This book clearly adopts this alternative strategy. It focuses on social enterprise-as the main unit of analysis-in Western Europe. This is not to say that the diversity of social enterprises cannot be observed through the other two notions, that is, social entrepreneurship and social entrepreneur, or in other world regions. In fact, this volume is part of a series of four books on social enterprise, covering, respectively, Asia (Bidet and Defourny 2019), Latin America (Gaiger et al. 2019), Central and Eastern Europe (Defourny and Nyssens 2021) and Western Europe (this volume).

In Europe, the very first study of social enterprise covering several countries and comparing SE types dates back to the late 1990s (Borzaga and Defourny 2001). ${ }^{1}$ In line with this pioneering work, the EMES Network then went on to deepen the analysis of SE types operating in a specific field and with a specific mission: the work integration of disadvantaged and disabled people (Nyssens 2006). ${ }^{2}$ Since then, various research projects have been developed at the European level, oriented to management tools, policy instruments and challenges related to the promotion and development of social enterprises. ${ }^{3}$

In such context, the comparative analysis of SE types or models still lacked strongly integrated theoretical foundations and, even more, empirical surveys that would enable researchers to statistically test typologies of SE models; this was all the more true at the international level, as empirical relevance should be sought beyond national borders.

This book aims precisely at documenting SE diversity in Western Europe, as well as addressing the lack of a scientifically robust typology of SE models by providing an analysis that combines two key strengths: (1) it is rooted in sound theoretical grounds, allowing for a wide diversity of SE models within each country and across countries; and (2) it is supported by strong empirical evidence, provided by the statistical exploitation of a large international dataset, resulting in turn from a survey carried out in the same way in many countries.

The International Comparative Social Enterprise Models (ICSEM) Project was designed in this twofold ambitious perspective. This large research project was carried out over several years by a large number of research partners from all world regions. In this introductory chapter, we will show how this Project was structured and developed along three major phases, which took place one after the other in most cases, but not exactly at the same time across countries, as many researchers actually joined the project at different times during its first years.

\subsection{Documenting SE Diversity (Phase 1 of the ICSEM Project)}

The ICSEM Project was presented and launched at the end of the 4th EMES International Research Conference on Social Enterprise, which was held in 
Liege (Belgium) in early July 2013. From the outset, some 100 researchers from 25 countries decided to get involved and committed themselves to carrying out the proposed work over at least four years. Over the following twelve months, some 80 additional researchers joined the Project; finally, the ICSEM community of active research partners gathered 230 researchers from some 55 countries from all regions of the world. ${ }^{4}$

In short, the main objective of the ICSEM Project was to document the diversity of SE models as a way (1) to overcome most problems related to the quest for a unifying and encompassing conceptualisation of social enterprise; (2) to try to theoretically and empirically build an international typology of SE models; and, consequently, (3) to pave the way for a better understanding of SE dynamics and ecosystems.

\subsubsection{Country-Based Contributions about the SE Landscape}

All researchers involved in the project were first asked to provide a "country contribution" about the SE landscape in their respective countries. Two distinctive features of this approach should be underlined. First, no a priori strict definition of social enterprise was imposed for these national contributions. We broadly delineated the field of analysis as "made of organisations that combine an entrepreneurial dynamic to provide services or goods with the primacy of their social aims". The emphasis was put on the embeddedness of the SE phenomenon in local contexts. Secondly, most research was carried out by teams rather than by individual researchers, and this fostered discussion at the local or national level, thereby reducing the risks of biases induced by purely personal perceptions.

On such a basis, researchers were requested to follow a work plan made of three main parts.

Part A-entitled "Understanding concepts and context"-aimed to address questions such as: Is the notion of social enterprise explicitly used in your country? If so, in which circles: academic spheres, among policy makers, civil-society organisations ...? What is (are) the major existing or emerging conception(s) of social enterprise in your country? Is it (are they) rooted in any specific social, political or cultural background? Which other terms or concepts tend to be used in your country (instead of or beside that of social enterprise-for example, social entrepreneurship, non-profit organisation, social economy, voluntary organisation, NGO, etc.)? Do public authorities tend to be interested in the notion of social enterprise? If so, which kind of conception tends to be adopted in their discourse or policies?

In a similar perspective, a recent EU-funded study on "Social Enterprises and their Ecosystems in Europe" proposed a comparative analysis of the degree of acceptance of the concept of social enterprise across European countries (see table 0.1). It is striking to note how the 
acceptance of the SE concept as such may vary from various points of view. The concept seems particularly challenged by other notions, such as the social and solidarity economy, corporate social responsibility or social innovation. Most Western European countries fall in three categories, thereby suggesting different types of challenges to be addressed. Such complexity is reflected throughout ICSEM country contributions.

Part B-entitled "Mapping SE categories"-aimed to identify and characterise various sets of social enterprises as well as their fields of activity, social mission, target groups, the public or private forms of support they receive, their operational and governance models, stakeholders, etc. In such a perspective, researchers were encouraged to collect and analyse all available literature and documentation, to establish a first classification of the main groups/categories of social enterprises, either on the basis of existing classification(s) or through personal intuitive attempts, and to select the main indicators or variables reflecting the major features that differentiate these various categories.

It was suggested to use, as one among other tools, the three dimensions of the EMES "ideal type" of social enterprise-namely the nature of the social mission or social aims, the type of economic model and the governance structure- to inform the diversity of social enterprises.

Table 0.1 Degree of acceptance of the SE concept in European countries

\begin{tabular}{|c|c|}
\hline Degree of acceptance & Country \\
\hline $\begin{array}{l}\text { Politically and legally } \\
\text { accepted-large self-recognition }\end{array}$ & Ireland, Italy, United Kingdom \\
\hline $\begin{array}{l}\text { Challenged by social economy/ } \\
\text { social and solidarity economy }\end{array}$ & $\begin{array}{l}\text { Belgium, France, Greece, } \\
\text { Luxembourg, Portugal, Spain }\end{array}$ \\
\hline $\begin{array}{l}\text { Not commonly used-limited space } \\
\text { due to traditional welfare } \\
\text { institutions }\end{array}$ & $\begin{array}{l}\text { Austria, Denmark, Finland, } \\
\text { Germany, Iceland, Netherlands, } \\
\text { Norway, Sweden }\end{array}$ \\
\hline $\begin{array}{l}\text { Politically and legally accepted but } \\
\text { narrow understanding (work } \\
\text { integration)-weak self- } \\
\text { recognition }\end{array}$ & $\begin{array}{l}\text { Bulgaria, Croatia, Czech Republic, } \\
\text { Finland, Hungary, Latvia, } \\
\text { Lithuania, Poland, Romania, } \\
\text { Slovakia, Slovenia, Serbia, } \\
\text { Sweden }\end{array}$ \\
\hline $\begin{array}{l}\text { Challenged by other concepts, such } \\
\text { as corporate social responsibility, } \\
\text { social entrepreneurship and social } \\
\text { innovation }\end{array}$ & $\begin{array}{l}\text { Cyprus, Denmark, Estonia, Iceland, } \\
\text { Montenegro, Netherlands, } \\
\text { Norway, Sweden }\end{array}$ \\
\hline Emerging acceptance & $\begin{array}{l}\text { Albania, Malta, North Macedonia, } \\
\text { Turkey }\end{array}$ \\
\hline
\end{tabular}

Source: European Commission (2020: 35). 
In the EMES approach to social enterprise, each of these three major dimensions may be apprehended through various indicators. These indicators were never intended to represent a set of conditions that an organisation should meet to qualify as a social enterprise; rather than constituting prescriptive criteria, they describe an "ideal-typical" social enterprise in Weber's terms, that is, an abstract construction or a tool, analogous to a compass, which helps locating social enterprises ("stars") or groups of social enterprises ("constellations") relative to one another in the "galaxy" of social enterprises. Therefore, the EMES SE ideal type has to be seen as an analytical construct to locate different enterprises with respect to this "abstract model".

Part C-entitled "Analysing institutional trajectories of the main SE categories or types"-aimed to identify and describe the main "institutions" (at large) shaping the profile of social enterprises: legal frameworks used by social enterprises, public policies and programmes, major forms of financial support, tools such as norms or accreditations, federations of social enterprises, private charters to which they subscribe, etc.

All the country contributions prepared during this first phase were presented and discussed during ICSEM Meetings, which took place in different parts of the world. ${ }^{5}$ Then, revised versions of these country contributions were published in the series of ICSEM Working Papers. ${ }^{6}$ The quantity and the average quality of these Working Papers led us to consider the publication of three "ICSEM" books, focusing on three different parts of the world-namely Asia, Latin America and Europe. As already mentioned above, the two first books, covering Asia and Latin America, were published in 2019 (Bidet and Defourny 2019; Gaiger et al. 2019), but the number of contributions on European countries kept increasing, thanks to the support of a European COST (COoperation in Science and Technology) Action ${ }^{7}$ whose first Working Group aimed at the production of exactly the same kind of "country contributions" as the ICSEM Project for a dozen additional EU or neighbouring countries. As a result, two books, instead of one, were finally prepared to cover the European landscape--one on Western Europe and one on Central and Eastern Europe. ${ }^{8}$

The first part of the present volume, dedicated to Western Europe, is made of contributions covering Belgium, Denmark, Finland, France, Germany, Iceland, Ireland, Italy, the Netherlands, Norway, Portugal, Spain, Sweden, Switzerland and the United Kingdom.

\subsubsection{Transversal and Comparative Analyses}

In addition to-and on the basis of-country contributions, which represent the bulk of the output of the ICSEM Project's first phase, several international research teams were formed in order to address some transversal issues through a comparative analysis. In such a perspective, four chapters (namely chapters 16, 17, 18 and 19) were prepared to 
highlight some specific SE features across Western European countries. These four chapters correspond to a second level in the first phase of the ICSEM Project, which aimed to "document SE diversity".

In three countries, namely France, Portugal and Spain (Petrella et al., Chapter 16 in this book), the strong heritage of the social economy influences the development of social enterprise, thereby supporting the hypothesis of the existence of a path dependence. As a matter of fact, in these countries, the social economy as a sector has recently been institutionalised through the adoption of a specific law (in 2011 in Spain, 2013 in Portugal and 2014 in France). This process of institutionalisation has also been deeply marked, in all three countries, by a tradition of collaboration between social-welfare social-economy organisations and public authorities. France is characterised by a corporatist welfare-state regime relying on socialsecurity contributions from employers and employees and on the role played by associations, which benefit from significant public support and are major providers of social services, complementing public provision. Spain and Portugal have a Mediterranean welfare-state regime, characterised by the presence of elements of corporatism and gaps in terms of protection; the welfare system developed belatedly, the role of civil society is limited, and social organisations show a strong dependence on public administrations.

From a different angle, comparisons between the three countries enable the authors to identify a relatively common experience, characterised by (1) the strengthening of non-profit organisations (NPO)s' role as providers of services, which implied a progressive professionalisation of the non-profit sector; (2) the loss, to a certain extent, of NPOs' civic/political function; (3) a greater selective competition with the forprofit sector, simultaneously with the development of various forms of cooperation to develop social-inclusion projects; (4) an increasing competition among non-profit organisations, due to reduction in funding, but with the emergence of new forms of cooperation and networking; and (5) a reorientation of social work, due to the emergence of new social needs, requiring more complex interventions.

As a result of this evolution of the institutional environments in the three studied countries, organisations meeting the EMES indicators of the idealtypical social enterprise are in most cases-but not exclusively-socialeconomy organisations that had to adapt and experiment with new organisational forms and ideas. Through a systemic and comparative approach, different responses can be identified along the axis between path dependence and path creation. In analytical terms, social enterprises may also be seen, in the three countries, as located between three poles: the social economy, the solidarity economy and social entrepreneurship.

Unlike what was the case in Defourny and Nyssens' (2017a) identification of SE models across various social missions, work-integration 
social enterprises (WISEs) are considered here as a separate model, since they have followed their own development path, with roots in the associative sector (rather than in the cooperative one) and a relatively strong reliance on public policies supporting work integration.

The second transversal contribution (Karré, chapter 17 in this volume) focuses on the relationship between an emergent form of social enterprise, namely "social start-ups", established by socially minded entrepreneurs and strongly anchored in the market economy, on the one hand, and more traditional third-sector organisations, on the other hand, in countries-Belgium, Germany and the Netherlands-shaped by a corporatist tradition. In these strong welfare regimes, non-profit organisations play an important role in the provision of social services, in close partnership with public bodies. They provide services of general interest, funded and regulated by the state. Today, these organisations are expected to behave in a more entrepreneurial fashion and, in some cases, are pushed to reinforce the market orientation of their activities, in line with new public management (NPM) principles. What is at stake is a kind of "reconfiguration" or "externalisation" of services of general interest under the organisational form of social enterprise, with the expressed aims of improving and innovating in the provision and delivery of services, but potentially also with a view to limiting the size of the state and to reducing public expenditure.

Social start-ups use terms such as "social businesses" to distinguish themselves from more traditional non-profit organisational forms, which they often see as bureaucratic and not very innovative. Their discourse is rooted in the Anglo-Saxon school of thought, which views social enterprise as a mission-driven business (Defourny and Nyssens 2010) and was introduced in Belgium, Germany and the Netherlands by external actors such as Ashoka and the Schwab Foundation. More traditional third-sector parties criticise these new competitors and their rhetoric for commercialising social-welfare provision and for "social-washing" commercial activities.

These tensions can be explained by the fact that the rationale behind social business has been shaped in countries where there is a strong dichotomy between the private and public sectors, and where the realms of state, market and society are seen as distinct from one another. This school of thought has been exported to countries-such as Belgium, Germany and the Netherlands-where these spheres are, however, much more closely interwoven, giving rise to "welfare-mix" configurations. In this context, to embrace the diversity of SE organisational forms, discussions will have to be conducted on how the relationship between "the new and the old generations" of social enterprises can become more productive, in a world in which societal problems are often ambiguous, complex, volatile and wicked, and have to be dealt with using various approaches. 
In Scandinavian countries, that is, Denmark, Norway and Sweden (Enjolras et al., chapter 18 in this book), welfare-state reforms constitute the policy context for the emergence of social enterprise. social enterprises. Indeed, in those countries, although the rise of social enterprise is anchored in a strong civil society and cooperative tradition, and it has been driven mainly by grassroots entrepreneurial initiatives, the opportunity structure for the emergence and further developments of social enterprises is to a great extent delimited by the framework of welfare policies. There is also a tension, in these three countries, between the recent policy discourse at the local level-which emphasises social innovation, civil-society initiatives, collaborative governance-and the policy instruments that, at the central level of government, are still inspired by NPM principles and remain characterised by their market orientation and reliance on quasi-market mechanisms.

In such an institutional environment, social enterprises are likely to be exposed to different forms of isomorphic pressures and to be at risk of losing their organisational specificities and their capacity for innovation. However, the three countries seem to take different developmental paths. The marketisation of welfare services-opening up market opportunities for social enterprises, but also resulting in increased competition from the for-profit sector-is most pervasive in Sweden. Denmark appears to keep a large public sector, which increasingly plays an active role in fostering social innovation and social enterprises. Norway lies somewhat in between Denmark and Sweden, at a crossroads where it can choose to increasingly rely on market mechanisms or to foster social innovation based on post-NPM approaches.

A fourth transversal contribution (Göler et al., chapter 19 in this volume) focuses on one of the most striking features among the various forms or models of social enterprise, that is, the emergence of a new type of cooperative, often referred to as "cooperative social enterprise" (CSE) as it is supposed to serve the community or general interest, beyond its members' interests. More precisely, the research question addressed in this chapter is the following: which elements of the institutional context shape the characteristics of CSE? Through a three-step screening process applied to eighteen ICSEM country papers from various regions of the world, the authors propose an analytical framework and a grid to map the interplay between contextual factors, on the one hand, and characteristics of CSE, on the other hand.

In order to avoid any simplification about the general-interest orientation of CSE, it is interesting to note that CSEs often remain in line with the whole cooperative tradition, therefore serving their members first, while their "concern for the community" usually remains a secondary goal. At the same time, it is clear that their actual orientation to the community, beyond the group of members, distinguishes CSEs from other cooperative-type enterprises. 
Not surprisingly, the state appears as a key enabler for the development of CSE, especially through specific legislations and/or specific funding streams, for instance in the fields of renewable energy, residentled housing, public-service delivery and management of common-pool resources. It would of course not make much sense to speak about "the best specific legal form" for CSE across countries, but the most prominent CSE-related policy is definitely the Italian social-cooperative legislation, which has influenced social-economy related policies in several Eastern and Western European countries. Work-integration social enterprises (WISEs), also strongly promoted by the Italian law of 1991, clearly appear as a dominant form among social enterprises in general and among CSEs, in particular.

The importance of the cooperative tradition, the adoption of new laws creating a cooperative form oriented towards the general interest, the implementation of active public policies fostering WISEs, the importance of WISEs among all SE forms, the role of the state as an enabler are all features that may be seen as "bridges" between this analysis of the social-cooperative model and various parts of the other transversal chapters.

\subsection{Theorising and Mapping Major SE Models (Phase 2 of the ICSEM Project)}

In emerging fields, it is common to develop descriptive works as well as classifications of observed facts or entities to be compared to an ideal type. This may particularly take place in an exploratory research step aimed at developing conceptual tools for future research purposes. Discrepancies between the ideal type and the facts or entities actually observed can then give rise to a set of hypotheses aimed at providing explanations. It is in this perspective that we developed a framework to theorise the diversity of SE models and to highlight theoretically a few major SE models.

Considering that social enterprises are often seen as belonging to the "third sector" or as being somehow related to the latter (Defourny 2014), we chose to build our analysis upon some of the strongest theoretical frameworks focusing on this sector's identity, such as those proposed by Gui (1991) and Hansmann (1996). Leaving aside "capitalinterest-driven" or capitalist enterprises, which distribute their profits to their investors, who also control these for-profit firms, Gui (1991) defines the third sector as composed of "mutual-benefit organisations" and "public-benefit organisations". "Mutual-benefit organisations" are those in which the stakeholders (other than the investors) who have the ultimate decision-making power (the "dominant category") also make up the "beneficiary category", that is, the category of stakeholders to whom the residual income is explicitly or implicitly distributed. Indeed, such 
convergence of control and benefit ensures that members' mutual interest is the objective pursued by the organisation. As for "public-benefit organisations", they correspond to those entities in which the beneficiary category is different from the dominant category: they are voluntary organisations oriented to serving other people (beneficiaries) than the stakeholders who control the organisation. Beneficiaries are those who are at the heart of the organisation's mission-more precisely, in the case of social enterprises, of the enterprise's social mission (Santos et al. 2015).

\subsubsection{Three "Principles of Interest" as a Cornerstone}

These distinctions lead us to consider three distinct major drivers or "principles of interest" that can be found in the overall economy: the capital interest (CI), the mutual interest (MI) and the general interest (GI). We propose to represent them as the vertices of a triangle in which mixes of principles can also be represented along the sides (see figure 0.1).

Before locating types of social enterprise on our graph, we note that all traditional cooperatives and associations that are pursuing the interests of their members (for instance sport clubs) are located in the "mutualinterest" angle. By contrast, those associations (voluntary organisations, charities, etc.) that are pursuing a public benefit as defined by Gui may be

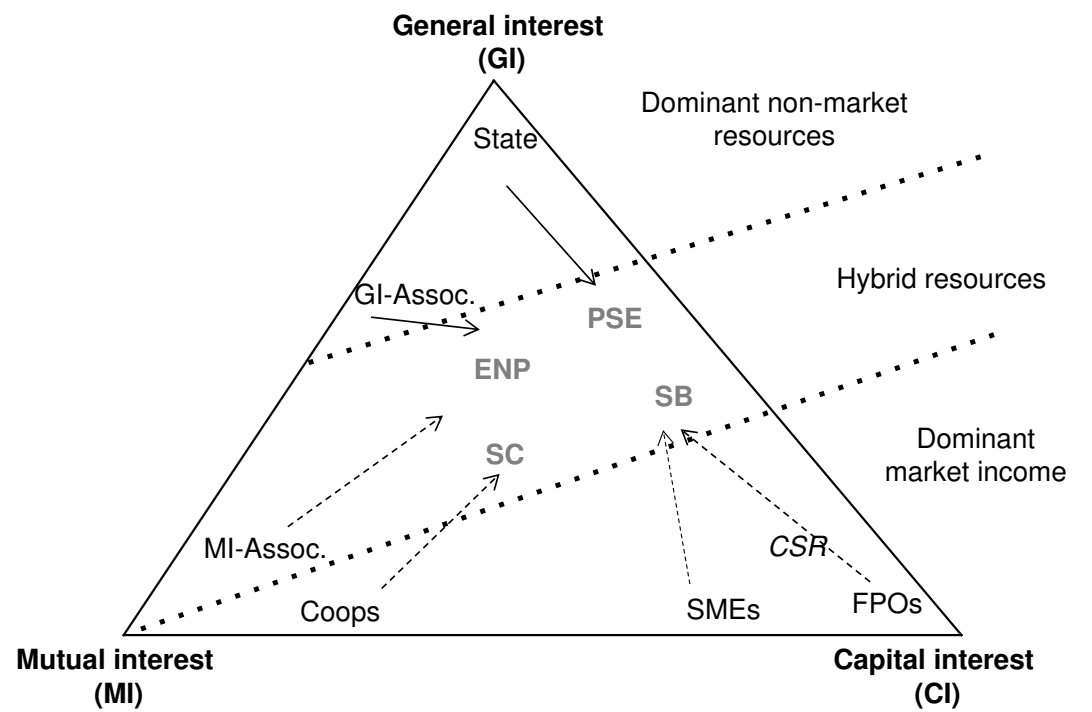

Figure 0.1 Institutional logics and resulting SE models.

Source: Defourny and Nyssens (2017a: 2479). 
seen as located close to the general-interest angle. However, they are not in the vertex itself, as their general interest (the community they serve) is usually not as wide as the one targeted by the state. On the right-hand side of the triangle, shareholder companies are located in the "capital-interest" vertex. However, when they develop corporate social responsibility (CSR) strategies, through which they tend to express a concern for some issues of general interest, such concern may be represented as a limited move upward along this side of the triangle.

The figure's lower (horizontal) side represents a continuum between the cooperative treatment of profits and the capitalist stance on profits. The search for profit in a cooperative is mainly instrumental to its productive activity. Profits may only be distributed as dividends with a cap and/or put into collective reserves with an asset lock; by contrast, the main goals of shareholding companies are profit distribution and increasing the value of their shares. Many small- and medium-sized enterprises, though, especially family businesses, although capitalist, may balance in a different way the search for profits and non-financial goals (Zellweger et al. 2013).

\subsubsection{Market Reliance and the Resource Mix as Key Issues}

Many publications and discourses on social enterprise underline a significant move towards market activities as a key feature of social enterprise. When trying to identify social enterprises, many observers suggest to look at the proportion of market income and might require that at least half of the enterprise's resources come from market sales. Such a stance, however, is often far from the field reality in many countries, and it is not shared by all schools of thought (Defourny and Nyssens 2010). However, we fully acknowledge that market reliance is a major issue in the debate, and it is why we have drawn two dotted lines across our triangle to take into account the various combinations of resource types (market income, public grants, philanthropic resources). Let us also note that the lower dotted line divides the "mutual-interest" angle: cooperatives mainly operate on the market and they appear below this dotted line, as do all enterprises earning all or most of their income from the market; by contrast, mutual-interest associations, like leisure voluntary organisations, are located above the line, because they generally rely on a mix of market resources (membership fees, sales at a bar or cafeteria) and other resources, such as volunteering and various types of public contributions.

\subsubsection{Institutional Logics Generating SE Models}

On the basis of the various elements presented above, we tried to show how various "institutional logics" in the whole economy may generate SE models (Defourny and Nyssens 2017a). 
As shown in figure 0.1, SE models (in grey) emerge from six traditional models through two distinct institutional logics.

1. The first type of logic generating social enterprises can be observed among non-profits or public organisations experiencing a downward move towards marketisation (solid-line arrows):

- The entrepreneurial non-profit (ENP) model gathers all nonprofit organisations, most often general-interest associations (GI-Assoc.), that are developing any type of earned-income activities in support of their social mission (Fitzgerald and Sheperd 2018).

- The public-sector social-enterprise (PSE) model results from a movement towards the marketisation of public services which embraces "public-sector spin-offs". These social enterprises are usually launched by local public bodies, sometimes in partnership with third-sector organisations, to provide services which are outsourced (such as care services) or new services (such as those offered by work-integration social enterprises).

2. The second type of logic corresponds to an upward move of conventional cooperativesand mutual-interest associations towards a stronger general-interest orientation; such a move may also be observed through some advanced CSR initiatives launched by the traditional business world (dotted arrows).

- The social-cooperative (SC) model differs from traditional mutual-interest organisations-that is, cooperatives (Coops) and mutual-interest associations (MI-Assoc.)--in that it combines the pursuit of its members' interests (mutual interest) with the pursuit of the interests of the whole community or of a specific group targeted by the social mission (general interest).

- The social-business (SB) model is rooted in a business model driven by shareholders' (capital) interest, but social businesses mix this logic with a "social entrepreneurial" drive aimed at the creation of a "blended value", in an effort to balance and better integrate economic and social purposes.

At first sight, when looking at figure 0.1, the four SE models seem to arise from new dynamics at work in pre-existing organisations. Thus, it may seem that social enterprises cannot be created from scratch. Such an interpretation would be clearly misleading, as a new (social) enterprise can emerge everywhere in the triangle; its location will depend on its general-interest orientation and on the way in which it balances social and economic objectives and financial resources. 
As suggested above, our typology of SE models is based on some key dimensions, but we do not pretend that it covers all possible SE cases. Especially, we are aware of the many types of hybridity that can be observed in the field. For example, partnerships between for-profits and non-profits as well as those involving local public authorities in a community-development perspective are quite common.

\subsubsection{Social Missions across Models}

Most SE approaches in the literature, if not all, share the view that social enterprises combine an entrepreneurial dynamic to provide services or goods with the primacy of a social mission. For Nicholls (2006: 13), "the primacy of social mission over all organisational objectives is the first key determinant of a potentially socially entrepreneurial venture". Dees (1998: 2) also argues that "for social entrepreneurs the social mission is explicit and central". For Chell (2007), it is the centrality of the social mission that distinguishes social enterprises from commercial ventures. As we summarised elsewhere, "for all schools of thought, the explicit aim to benefit the community or the creation of social value is the core mission of social entrepreneurship and social enterprises" (Defourny and Nyssens 2010: 44).

In our analytical construction, the social mission is also central, but implicitly assumed through the notion of "general interest". However, to what extent are our SE models able to accommodate the diversity of social missions carried out by social enterprises? We do not intend to analyse this question in depth here, but for illustrative purposes, we just present table 0.2 , in which the work integration of disadvantaged persons, which seems to be a particularly widespread mission for social enterprises, is presented in the first column. Other types of social mission may have more or less importance in the SE landscape of various countries, though, depending on social or societal challenges that are particularly pressing and poorly addressed by the existing public and private sectors. The other columns of table 0.2 illustrate this fact for some social missions (among others, of course) such as ensuring access to health and social services, implementing ecological transition, fighting poverty and social exclusion, promoting more ethical economic behaviours and access to social finance or housing.

\subsection{Testing SE Models (Phase 3 of the ICSEM Project)}

The approach we had adopted in the previous section to build a typology of SE models was theoretical. In order to test the relevance of the latter, we relied on the data collected through a large survey that we coordinated and which was carried out by researchers from 43 countries across the world. 


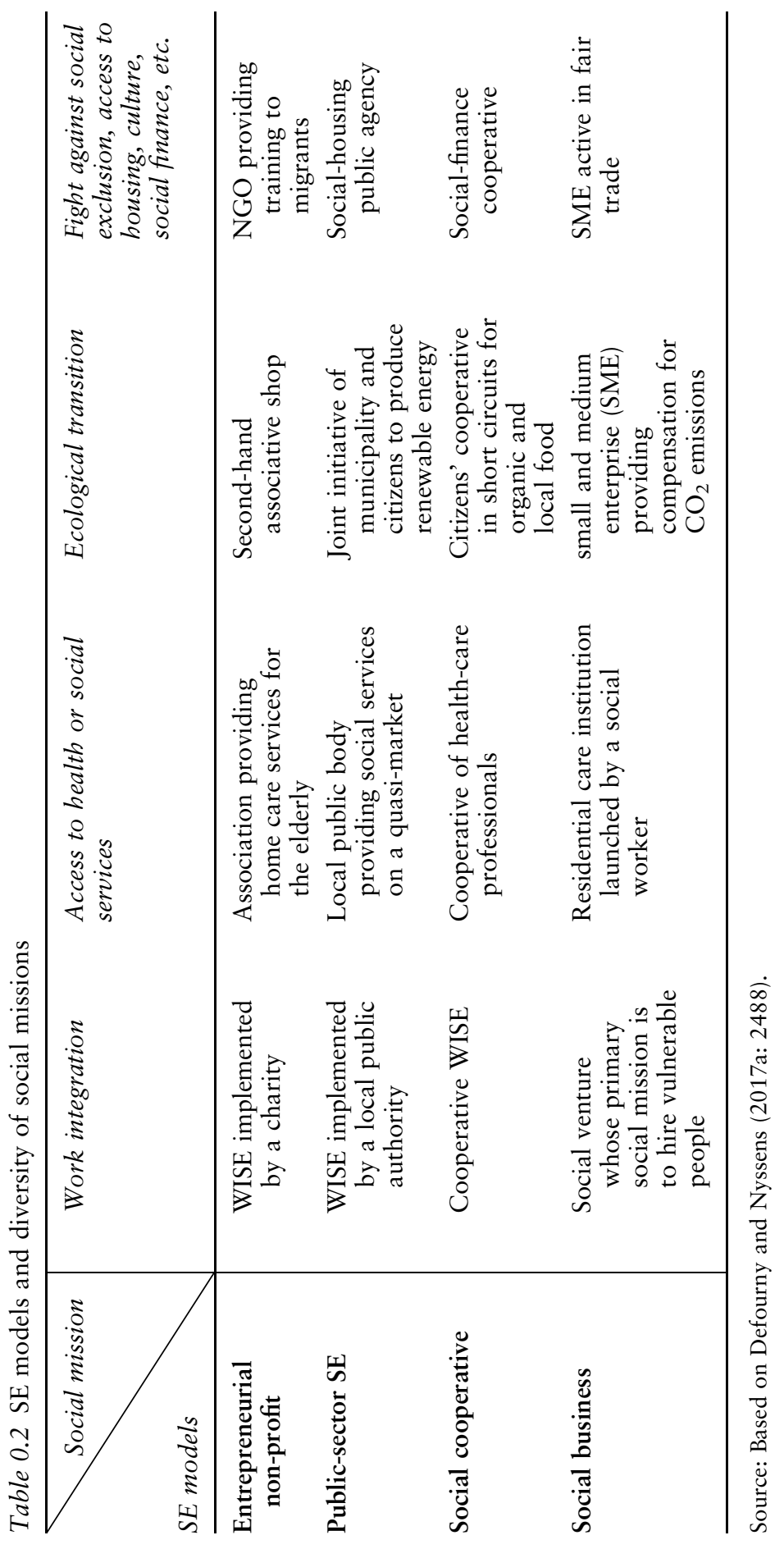


In order to address the lack of reliable datasets at enterprise level, indepth information was collected about social enterprises on the basis of a common questionnaire. Researchers were asked to collect information regarding the nature of the enterprise's social mission or social aims, type of economic model and governance structure, relying on the hypothesis that these three dimensions particularly informed the diversity of social enterprises, in line with the use of the EMES ideal type as an analytical tool.

More precisely, ICSEM research partners interviewed the managers of three to five social enterprises that were deemed emblematic of each of the SE types which they had identified in the project's first phase. As a result, detailed data were collected in a rather homogenous way for 721 social enterprises from 43 countries. Within this dataset, a subset of data covering 164 social enterprises from 12 Western European countries was extracted to provide a workable statistical basis.

In the last step, which also corresponds to the last chapter of this book, the dataset built through the ICSEM survey was exploited to see if it provided any empirical support to the proposed typology of SE models in Western Europe. More precisely, a hierarchical cluster analysis was performed in order to identify relevant clusters. A careful analysis of each of these clusters was carried out and paved the way to the identification of three of the four theorised SE models (see section 0.2.3): the entrepreneurial non-profit model, the social-cooperative model and the social-business model. No significant support was found for the public (or quasi-public) SE model.

This book's introduction was designed as a guide to navigate the various steps of the ICSEM Project and their specific objectives: a first phase to document SE diversity in each country; a second phase to theorise SE diversity and to map SE models through an original analytical framework; and finally a third phase to empirically test the relevance of these SE models in Western Europe.

\section{Notes}

1 This EU-funded research project was carried out from 1996 to 1999. It focused on "the Emergence of Social Enterprise in Europe"-hence the acronym "EMES", which was subsequently retained by the research network that had carried out the project.

2 This large EU-funded research project was based on a detailed survey covering 160 "work-integration social enterprises" (WISEs) across eleven Western European countries.

3 Major EU-funded research projects included EFESEIIS (2013-2016), TSI (2014-2017) and SEFORIS (2014-2017); see also European Commission (2020). Although it was much less oriented toward academic research, the "Social Business Initiative", launched by the European Commission in 2011, also played a significant role in fostering SE development across Europe.

4 One outstanding feature of the ICSEM Project was that participants did not get any financial support. Only accommodation costs and sometimes part of 
travel costs to take part in meetings were covered by the Belgian Science Policy Office, national and international foundations as well as a COST Action at the European level.

5 So-called "ICSEM Local Talks" were organised in a dozen countries. At the regional level (Latin America, Eastern Asia, Western Europe, Central and Eastern Europe), ICSEM Symposiums took place in Chile, Belgium, South Korea, Albania, Brazil and France, and at the worldwide level, ICSEM General Meetings were organised in Finland, Sweden, Belgium and the United Kingdom, in relation to the EMES International Research Conferences, in 2013, 2015, 2017 and 2019.

6 All these country contributions are available on the website of the ICSEM Project: https://www.iap-socent.be/icsem-working-papers.

7 This COST Action (2017-2021) was named "Empowering the next generation of social enterprise scholars", and it was coordinated by M. Nyssens and S. Ferreira.

8 The ICSEM Project also generated a set of country contributions that did not fit the "regional approach" adopted for the four books. Most of these contributions were published in a special issue of the Social Enterprise Journal (Defourny and Nyssens 2017b), which included country contributions about Australia, Canada, Israel, the US the UAE, Rwanda, South Africa and South Korea.

\section{References}

Alegre, I., Kislenko, S. \& Berbegal-Mirabent, J. (2017) "Organized chaos: Mapping the definitions of social entrepreneurship", Journal of Social Entrepreneurship, Vol. 8, No. 2, pp. 248-264.

Aliaga-Isla, R. \& Huybrechts, B. (2018) “From 'push out' to 'pull in' together: An analysis of social entrepreneurship definitions in the academic field", Journal of Cleaner Production, Vol. 205, pp. 645-660.

Austin, J., Stevenson, H. \& Wei-Skillern (2006) "Social and commercial entrepreneurship: Same, different or both", Entrepreneurship Theory and Practice, Vol. 30, No. 1, pp. 1-22.

Bacq, S. \& Janssen, F. (2011) "The multiple faces of social entrepreneurship: A review of definitional issues based on geographical and thematic criteria", Entrepreneurship \& Regional Development: An International Journal, Vol. 23, No. 5, pp. 373-403.

Bidet, E. \& Defourny, J. (eds) (2019) Social Enterprise in Asia. Theory, Models and Practice, London and New York: Routledge.

Borzaga, C., \& Defourny, J. (eds) (2001) The Emergence of Social Enterprise, London and New York: Routledge.

Brouard, F. \& Larivet, S. (2010) "Essay of clarifications and definitions of the related concepts of social enterprise, social entrepreneur and social entrepreneurship", in Fayolle, A. \& Matlay, H. (eds) Handbook of Research on Social Entrepreneurship, Cheltenham: Edward Elgar, pp. 29-56.

Chell, E. (2007) "Social enterprise and entrepreneurship: Towards a convergent theory of the entrepreneurial process", International Small Business Journal, Vol. 25, pp. 5-26.

Dacin, P., Dacin, M. \& Matear, M. (2010) "Social entrepreneurship: Why we don't need a new theory and how we move forward", Academy of Management Perspectives, Vol. 24, No. 3, pp. 37-57. 
Dees, J. G. (1998) “The Meaning of Social Entrepreneurship”, The Social Entrepreneurship Funders Working Group.

Defourny, J. (2014) "From third sector to social enterprise: a European research trajectory", in Defourny, J., Hulgård, L. \& Pestoff, V. (eds) Social Enterprise and the Third Sector, London and New York: Routledge, pp. 17-41.

Defourny, J., \& Nyssens, M. (2010) "Conceptions of social enterprise and social entrepreneurship in Europe and the United States: Convergences and divergences", Journal of Social Entrepreneurship, Vol. 1, No. 1, pp. 32-53.

Defourny, J. \& Nyssens, M. (2017a) "Fundamentals for an international typology of social enterprise models", Voluntas, Vol. 28, No. 6, pp. 2469-2497.

Defourny, J. \& Nyssens, M. (eds) (2017b) “Mapping social enterprise models: An international perspective", Social Enterprise Journal, Vol. 13, No. 4 (special issue), pp. 318-442.

Defourny, J. \& Nyssens, M. (eds) (2021) Social Enterprise in Central and Eastern Europe. Theory, Models and Practice, London and New York: Routledge.

European Commission (2020) Social Enterprises and their Ecosystems in Europe, Comparative Synthesis Report (authors: Borzaga, C., Galera, G., Franchini, B., Chiomento S., Nogales, R. \& Carini, C.), Luxembourg: Publications Office of the European Union.

Gaiger, L. I., Nyssens, M. \& Wanderley, F. (eds) (2019) Social Enterprise in Latin America. Theory, Models and Practice, London and New York: Routledge.

Gui, B. (1991) “The economic rationale for the third sector", Annals of Public and Cooperative Economics, Vol. 62, No. 4, pp. 551-572.

Hansmann, H. (1996) The Ownership of Enterprise, Cambridge: Harvard University Press.

Mulgan, G. (2007) Social Innovation. What it is, Why it Matters and How it can be Accelerated, London: Young Foundation.

Nicholls, A. (ed.) (2006) Social Entrepreneurship. New Models of Sustainable Change, Oxford: Oxford University Press.

Nyssens, M. (ed.) (2006) Social Enterprise. At the Crossroad of Market, Public Policies and Civil Society, London: Routledge.

Persaud, A. \& Bayon, M. (2019) "A review and analysis of the thematic structure of social entrepreneurship research: 1990-2018”, International Review of Entrepreneurship, Vol. 17, No. 4.

Skloot, E. (1983) "Should not-for-profits go into business?", Harvard Business Review, Vol. 61, No. 1, pp. 20-27.

Santos, F., Pache, A.-C. \& Birkholz, C. (2015) "Making hybrids work: Aligning business models and organizational design for social enterprises", California Management Review, Vol. 57, No. 3, pp. 36-58.

Young, D. (1983) If not for Profit, for What?, Lexington: Lexington Books.

Zellweger, T. M., Nason, R. S., Nordqvist, M. \& Brush, C. G. (2013) "Why do family firms strive for nonfinancial goals? An organizational identity perspective", Entrepreneurship Theory and Practice, Vol. 37, No. 2, pp. 229-248. 


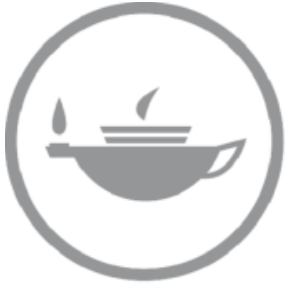

Taylor \& Francis Taylor \& Francis Group http://taylorandfrancis.com 


\section{Part I}

\section{National Overviews of Social Enterprise}




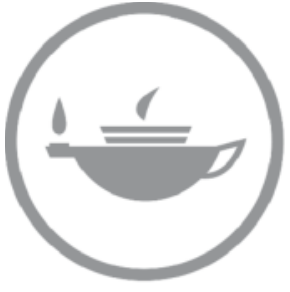

Taylor \& Francis Taylor \& Francis Group http://taylorandfrancis.com 


\title{
1 Unity in Diversity \\ Exploring the Multiple Facets of the Belgian Social Enterprise Landscape
}

\author{
Benjamin Huybrechts, Marthe Nyssens \\ and Jacques Defourny
}

\section{Introduction}

Over the last two decades, the notion of social enterprise (SE) has increasingly gained visibility in the Belgian landscape. Nevertheless, unlike more established notions such as the social economy and the non-profit sector, social enterprise is still a fuzzy and debated notion in Belgium. Some use this term as a synonym for social-economy organisations. Others refer to any business focusing on generating social impact, regardless of its legal structure and governance practices. Still others use social enterprise to describe the entrepreneurial approach adopted by an increasing number of non-profit organisations. In this chapter, we build on the EMES Network's ideal type of social enterprise, which defines the economic and entrepreneurial dimension in a broad way, emphasising dynamics of production and risk-taking rather than strict criteria in terms of market-based incomes, as is the case in other SE approaches (Defourny and Nyssens 2006; 2010). Such a view of social enterprise has affinities with the notion of "social economy" (Defourny 2001).

In Belgium, since 1990, the social economy has become increasingly recognised both in Flanders (the Northern, Dutch-speaking part) and in Wallonia (the Southern, French-speaking part). All regional governments now have a minister in charge of this domain (often with other spheres of competencies). As a result of this recognition, various tools have been set up in the last ten years to provide social enterprises with credit facilities, securities and seed capital as well as technical support through dedicated consultancy agencies. However, in some cases, the concept tends to be understood in a quite narrow sense, due to its association with specific missions. In Flanders and in Brussels, as a competence of the Ministry of Labour, the social economy has often been associated only with the integration of low-skilled workers on the labour market. In Wallonia, as a competence of the Ministry of Economy, it has frequently been considered only in its more market-oriented version.

This chapter is structured as follows: The first section reviews the main historical roots that have led to the emergence of a diversity of models 


\section{Huybrechts, Nyssens \& Defourny}

related to social enterprise and the social economy in Belgium. The second section reviews the legal recognition of the concept and its evolution over time. The third section sketches how the main SE models, as observed internationally, find resonance in the Belgian context, and what these models imply in terms of building statistics. Finally, the conclusion sketches some of the main challenges lying ahead for social enterprises and their supporters in the Belgian context.

\subsection{Historical Roots}

The SE phenomenon in Belgium has been fed by various traditions: the associative, cooperative and mutual traditions, often highlighted as the backbone of the "social economy"; the support by public authorities in the context of specific public policies; the support of philanthropic actors through donations and "social investment"; and the inputs of a more business-oriented approach. These different roots have led to specific SE models, but they have also enriched each other; the notion of social enterprise is thus best understood as the combined outcome of a plurality of roots.

\subsubsection{The Associative Tradition}

A first historical tradition that has contributed to feeding the practices and conceptualisations of social enterprise is the associative tradition. The law of 27 June 1921 regulates the associative form in the civil code, stating that it is a private grouping of people that does not aim to provide personal gains to its members. This law was substantially amended in 2019. The law of associations is now incorporated into the Belgian Commercial Code. This new law defines an association as "constituted by an agreement between two or more persons, called members. It pursues a disinterested goal in the exercise of one or more specific activities that constitute its purpose. It may not distribute or procure, directly or indirectly, any patrimonial benefit to its founders, members, directors or any other person except for the disinterested purpose determined by the bylaws of the association".

Contrary to what was the case before the 2019 amendment, associations can-like commercial companies-develop economic activities of an industrial or commercial nature, even as their main activity, but the income generated by these economic activities has to be allocated to the achievement of the association's disinterested purpose. With this new law, the only criterion that distinguishes a company from an association is the fact that, in an association, there are no formal owners and the distribution of profits or the granting of benefits to the organisation's members, partners, or managers is prohibited. As a result, marketoriented activities that, in other countries, would typically be undertaken 
by cooperatives (such as work integration or fair trade) can be conducted under the associative form in Belgium.

From 2004 onward, specific statistics on associations have been constructed under the supervision of the Belgian National Bank (through a satellite account). In 2017, there were 109,000 active associations in Belgium, of which, however, only 17,000 had salaried workers. Employment in Belgian associations exceeded 350,000 full-time equivalents (FTEs), representing nearly $12 \%$ of all employment in the country (Fondation Roi Baudouin 2018). There are, however, boundary cases of organisations and fields that are located close to the public sector, such as associative hospitals and schools that are highly regulated by the state in their practices. Competition and entrepreneurial practices and discourses are, nowadays, part of the everyday life of associations, especially those with paid workers. The entrepreneurial behaviour is also a matter of legitimating one's activities as worthy of attention, including in economic terms (Dart 2004). Illustrative of this trend is the "rebranding" of the major employers' associations in the non-profit sector, from "non-profit" or "non-market" (non-marchand) into "social-profit" organisations.

\subsubsection{The Cooperative Tradition}

As in many other countries, cooperatives emerged in Belgium around the middle of the $19^{\text {th }}$ century. The cooperative legal form was officially recognised in 1873 but, unlike in other countries, compliance with the rules and practices prescribed by the International Cooperative Alliance (ICA) was not embedded in the law until the recent reform of 2019; the resulting ambiguity around the cooperative legal form was an obstacle to building a strong identity and recognition for cooperatives in Belgium (Defourny et al. 2002; Van Opstal et al. 2008). The new law adopted in 2019 brings more clarity, to the extent that the "transactional relationship" between a cooperative and its members is now part of the identity of this legal form: meeting the needs of members is the ultimate goal of a cooperative. Organisations that hitherto operated as cooperatives but do not want to adopt such identity can choose to transform into limited-liability companies. However, in this new cooperative law, there is still no reference to the other principles of the International Cooperative Alliance (regarding, e.g., the distribution of profit or voting rights). As a consequence, the cooperative legal form still remains very flexible. For cooperatives willing to comply with the seven ICA principles, an accreditation process through the "National Council for Cooperation", created in 1955, remains possible. Moreover, a "socialenterprise" label has been created by the law of 2019. Surprisingly, the access to this SE label is now restricted to cooperatives; by contrast, the "social-purpose" qualification, that had been created in 1995 but has 


\section{Huybrechts, Nyssens \& Defourny}

now been abolished, was accessible to all types of companies willing to express their strong social orientation. In other words, although the Belgian legislation about cooperatives was in need of clarification regarding the very identity of the latter, the recent law tends to add confusion in terms of identification of social enterprises in the Belgian landscape.

The bulk of "true" cooperatives appeared at the end of the 19th and the beginning of the 20th centuries in a few key sectors: agriculture, retail pharmacy industry, retail shops, banking and insurance. Cooperatives organised themselves in networks that were not really structured on an industry basis (except for agriculture), but rather on an ideological basis, corresponding to the major "pillars" in Belgian society: socialist, Christian and, to a lesser extent, liberal. In spite of major developments and economic successes until the 1960s, traditional cooperatives then began to suffer from economic crises and from competition with conventional enterprises in most of their fields of activity. As a consequence, a large number of important cooperatives disappeared (typically in the retail sector) or were bought by large businesses (e.g., in the banking and insurance sector). Cooperatives were more resilient in certain sectors, though-such as, typically, agriculture and pharmacy, where cooperatives still play an important role today (Dujardin and Mertens 2008; Van Opstal et al. 2008).

In parallel, new cooperatives also appeared in-and existing cooperatives diversified their activities towards-new (sub-)fields of activity, focused on ethics and social or environmental innovation and often more clearly oriented towards the general interest. The new cooperatives created in the last decades or the existing cooperatives that have evolved towards explicitly tackling societal challenges (Gijselinckx et al. 2011) experiment with new ways of pursuing a general-interest orientation (Huybrechts and Mertens 2014). They also have a more flexible approach in terms of joining or forming cooperative networks outside of the traditional "pillars". New cooperatives do not only explicitly tackle societal challenges; they are also characterised by novel governance arrangements, involving multiple stakeholders and experimenting with new ways of implementing democracy and participation (Mertens et al. 2008; Huybrechts et al. 2014).

\subsubsection{The Tradition of Mutuals}

A third tradition, which shares some similarities with both the associative and the cooperative traditions, is that of mutualism. Mutual-aid societies (mutuals) in Belgium have become institutionalised and play a central role in the health-care system, to such an extent that people may tend to consider them as parastatal organisations that do not have much in common with the current discussions on social innovation and social 
enterprise. However, when we look more closely at the emergence and specific features of mutuals in Belgium, they appear as private, entrepreneurial solutions to pressing societal needs.

Mutuals emerged in the 19th century: workers mutualised their financial means to support each other in the event of illness or work incapacity. A law of 1851 recognises these "mutual-insurance societies", which were initially organised at the local level (company or sector in a given region). To increase their insurance coverage and mutual-support possibilities, the local mutuals then started joining forces in federations, which were organised by sectors of activity as well as, increasingly, by ideological branches (socialist, Christian, liberal and "neutral"). Between the two world wars, and especially after World War II, mutuals became increasingly supported by the government, in the context of the new social security system. A law of 1944 made illness and invalidity insurance compulsory and delegated the organisation of this insurance scheme to mutuals. Membership in a mutual became compulsory for all Belgians (in a few cases, they could join the public scheme offering insurance under the same conditions). The law was revised in 1963 to regulate the tariffs applied by health-care providers and to ensure that basic health insurance could be provided to all. Later on, mutuals started providing additional insurance schemes, typically to cover hospitalisation costs.

Nowadays, due to the pressure on social security and to European regulations putting mutuals in competition with private insurance companies, mutuals have revitalised their entrepreneurial spirit to develop innovative solutions to social needs with regard to health in the broad sense-including prevention and education. Although mutuals are highly regulated by the state, their economic activities, which aim to pursue the interests of their members and, more broadly, the general interest, as well as their democratic governance justify their being considered as belonging to the "SE map"-albeit only within the health sector and in a very institutionalised setting.

\subsubsection{The Inputs of Public Policies}

Moreover, public authorities at the federal and regional levels have become increasingly interested in social enterprise as a tool to fulfil their goals. The actors and networks promoting social enterprise have also been instrumental in advocating for public policies in their areas of action. The most striking illustration of this interest is obviously to be found in the field of work integration of different types of low-skilled workers (long-term unemployed, disabled people and other target groups). Providing social enterprises targeting disadvantaged people with financial support through training, coaching and jobs was an interesting and relatively low-cost way for governments to include these "hard-toplace" jobseekers in their programmes against unemployment. 


\section{Huybrechts, Nyssens \& Defourny}

Most public policies targeted-and still target-specific sectors of activity (such as recycling or health) or social missions (work integration, "proximity services", etc.). Even though the regions and communities have currently inherited most of the central government's competences with regard to social enterprise, much work to structure and support the sector was achieved in the 1980s and 1990s at the federal level. In particular, measures to recognise and support work-integration social enterprises (WISEs), such as "SINE" and the "service-voucher system" (see section 1.2, on public policies), were developed at the federal level, through collaborations between the government, practitioners' networks and supporting stakeholders. Over time, public action has also sought to enrich the organisational landscape beyond work integration and precise social missions, and to accommodate new organisational forms or support existing ones in relation to social enterprise. For example, in Flanders, the "Work and Social Economy" department of the administration continues to support traditional WISEs, but it has also favoured the emergence of new social enterprises and cooperatives as a way of enhancing sustainable and ethical business. In Wallonia, in recent years, the Ministry of Economy has put a special emphasis on cooperatives, whatever their sector of activity.

\subsubsection{Philanthropy and Social Investment}

More recently, the development and visibility of social enterprise have also been boosted by the support provided by foundations and philanthropic actors. Philanthropic funds and foundations, both private and public (such as the King Baudouin Foundation, Inbev-Baillet Latour Fund, Cera, BNP Paribas Foundation, Philipson Foundation, Fondation pour les Générations Futures, etc.), have been instrumental in further developing the sector, for example, through grants for early-stage social entrepreneurs, support for established social enterprises, funding of research and master theses on the topic, actions to increase public visibility, etc.

The support provided by foundations to social enterprises can be situated within a broader trend to move away from "traditional" philanthropy, relying on grants, towards "social-investment" schemes, within which payback and interests are expected. This type of "new philanthropy" is less altruistic and tends to favour social enterprises that are more commercially robust. Although this evolution has been criticised for favouring returns on investment at the expense of social commitment and societal-change orientation, it is an important trend in Belgium, as evidenced, for example, by the success of social-investment schemes, such as Kois Invest and the SI2 fund, supported by the Oksigen Ecosystem. Public authorities have also started to display an interest in supporting social-investment schemes, notably through the experimentation of "social-impact bonds". 


\subsubsection{A More Business-Oriented Approach}

In line with the emergence of social investment, a more market-oriented trend has developed that echoes international trends and translates into the notions of social entrepreneurship and social entrepreneurs rather than social enterprise. These notions have been introduced by international networks and organisations, such as Ashoka and the Schwab Foundation for Social Entrepreneurship. Specific Belgian support structures, such as Oksigen, Poseco and the Sociale InnovatieFabriek, have also been created to promote the concepts of social innovation and social entrepreneurship in the public debate, and more particularly among various actors, such as universities and business schools, think tanks, foundations, leaders from the business and social sectors and the media. However, these approaches have not led to new certification schemes or legal evolutions. The focus has mainly been on supporting new social entrepreneurs and innovative social-entrepreneurship initiatives dealing with unmet social needs. Although connections exist with the broader corporate social responsibility (CSR) approach, supporters of social entrepreneurship have emphasised the distinctiveness of social entrepreneurship in terms of prioritising social impact over financial returns.

\subsection{Legal Evolution and Public Policies}

There is no consensus in Belgium as to what a social enterprise is and, more precisely, where the boundaries of this concept should be placed. The approaches are obviously distinct depending on the different actors concerned. Politicians and public authorities view social enterprise according to their specific public policies and competence categorisations (e.g., economy or social affairs); practitioners may tend to focus on selfidentified social enterprises; and university scholars seek to build conceptually consistent definitions that do not necessarily echo the views of practitioners and politicians. There is no specific legislation fully embracing the SE scope either. There is, rather, a set of laws, decrees (at the regional level) and public provisions related to specific legal forms, sectors of activity and types of social mission. A large array of policies and legal provisions potentially apply to social enterprises in various sectors and it is impossible to provide an exhaustive list of all these measures. There are also regional differences that should be recalled, although they should not be overestimated.

At the federal level, there used to be ministers (1999-2004) and secretaries of state (2004-2007) for the social economy, supported by a specific administrative unit. Over the years, however, as the competences for economy-related matters were gradually transferred to the regions, the regulation of and support to social enterprises increasingly became a 
regional matter. For example, after the broad institutional reform of 2008, several federal measures, such as SINE and the service-voucher system, were transferred to the regions. Until 2014, the federal administration for social integration retained responsibility for a few support and coordination tools, more specifically through the department in charge of social integration, fight against poverty, social economy and large cities. Since 2014, all the policies around social enterprise and the social economy have been defined and managed autonomously by each region. Nevertheless, the federal department still promotes the exchange of information and practices and represents Belgium, as a federal state, in the European Commission's Expert group on social economy and social enterprises (GECES).

In French-speaking Belgium (Wallonia and partly Brussels), social enterprise is typically presented as the most entrepreneurial subset of the social economy, or as a synonym for the latter, which had been defined as follows in 1990:

[The] social economy is made up of economic activities carried out by cooperatives and related enterprises, by mutual societies and by associations whose ethical stance is represented by the following principles: a purpose of serving members or the community rather than seeking profit, an independent management, a democratic decision-making process, and the primacy of people and labour over capital in the distribution of income.

Conseil Wallon de l'Économie Sociale (1990)

In Wallonia, social enterprise has historically been at the intersection of the competences of the Ministry of Economy and those of the Ministry of Social Affairs and Employment. In Brussels, a decree was voted in 2018 which defines a social enterprise in a way that closely matches the EMES approach (economic project, social purpose and democratic governance).

In Flanders, "social enterprise/social entrepreneurship" and "social economy" are not used as synonyms, but over the past decades, the notion of social entrepreneurship has been increasingly embraced by actors traditionally rooted in the social economy. Indeed, while historically, the social economy in Flanders tended to be restricted to the integration of low-skilled workers in the labour market (WISEs), this has evolved over time, and the social economy is now legally defined as a set of "social entrepreneurial values" developed within various organisational forms and sectors of activity. Still, the social economy appears as a sub-field of social enterprise and social entrepreneurship in Flanders, while in Wallonia, it is the other way round.

In terms of public policy, in Flanders, social enterprise lies at the crossroads of the competences of the Ministries of "Work and the Social Economy" and "Economy, Science and Innovation", although the topic 
is most explicitly related to the former and dealt with by the Minister for Local and Provincial Government, Civic Integration, Housing, Equal Opportunities and Poverty Reduction. In Flanders, historically, as already mentioned, social enterprise tended to be restricted mainly to the integration of specific target populations (such as unemployed or disabled people) through a working activity as well as to the area of local services. From 2009 to 2019, an important restructuration of the support provided to the SE field was prepared and gradually implemented; different decrees were adopted by the Flemish government to its support.

Overall, various broad public policies have an important impact on social enterprises, although they are not specifically targeted at them. These policies cannot be presented extensively here, but a few examples can be provided for illustrative purposes.

One example of a scheme not restricted to-but commonly used by-social enterprises is the service-voucher system. This system has been particularly instrumental in the development of WISEs. The servicevoucher scheme, developed by the federal government in 2001, is mainly designed to foster the development of regular jobs for low-qualified people in the housework field, where services were hitherto mostly provided on the black market. Any person willing to get housework services can buy vouchers and benefit from tax reductions. The user chooses an accredited provider, which sends a worker to the client's house. Workers are hired by the providers and not directly by the households, which are clients of the providers (Defourny et al. 2010). The combination between the WISE model and the service-voucher system has been widely applied in the Walloon and Brussels Regions (not in Flanders), which contributed to the development of the workintegration field. Again, it is likely that the regions, which are now in charge of managing the service-voucher system, will adapt it according to their public policies and budgetary possibilities.

Another area where public support is available to social enterprises is that of public procurement. The Belgian legislation allows for the inclusion of social, environmental and ethical clauses in public procurement. A federal decision (circulaire) of 2014 specifies the different schemes and avenues through which this can be achieved in practice. Thanks to this decision, local, regional and federal public authorities are authorised to demand compliance with a number of social and environmental criteria. In most cases, social enterprises are indirectly encouraged, but the contract remains open to any type of provider, including conventional enterprises. In some cases, however, contracts can be reserved for certain types of organisations, thereby making it possible to directly favour social enterprises (typically WISEs).

Support measures specific to social enterprises often address WISEs in particular. Competences linked to work-integration were previously managed at the federal level, but they have gradually been regionalised, 
thus resulting in different accreditation schemes in the three Regions of the country. Although similarities remain, there have been increasing differences, depending on how WISEs have been used as tools for social integration through employment. In the three regions, the recognition of WISEs has led to an increase in the number of initiatives that applied for and obtained the specific accreditations, which contributed in turn to the integration of those WISEs in public policies (Lemaître and Nyssens 2012).

\subsection{Statistics and Characteristics of Social Enterprise in Belgium}

The regional and policy-related differences in terms of conceptual interpretation tend to fade away in a context of internationalisation of the discourses and practices in this domain, and also when examining the concrete SE realities and ecosystems.

\subsubsection{Four Main SE Models}

In order to map the SE landscape in Belgium, it is useful to draw on the four main SE models emphasised in the context of the "International Comparative Social Enterprise Models" (ICSEM) Project, which was carried out in cooperation with the EMES Network (Defourny and Nyssens 2017). Each of these models can be associated with one or several of the traditions described in the previous section, but is not exclusively restricted to one specific legal form or public policy: the general interest pursued in an entrepreneurial way is typical of either associations and foundations ("entrepreneurial non-profits"), or "public-sector social enterprises"; the combination of the mutual and general interests is typical of the "social cooperative" model embraced by cooperatives and mutuals; and the combination of the private interest with the general interest is increasingly observed in "social businesses", that is, companies with a legally or otherwise defined social purpose. Table 1.1 provides an overview of the four SE models and their corresponding underlying dynamics as well as their main features in Belgium.

\subsubsection{Number of Social Enterprises}

The different definitions and models of social enterprise taken into account have, of course, important implications when attempting to estimate the weight and number of social enterprises. The difficulties in providing precise figures are related to the blurry nature of the boundary lines of the SE concept and of its different models. Several attempts to provide figures have been made; however, they all face limitations and there is neither general agreement on where exactly to put the boundaries nor on precise figures. Two types of calculations exist: "bottom-up" 
Belgium 31

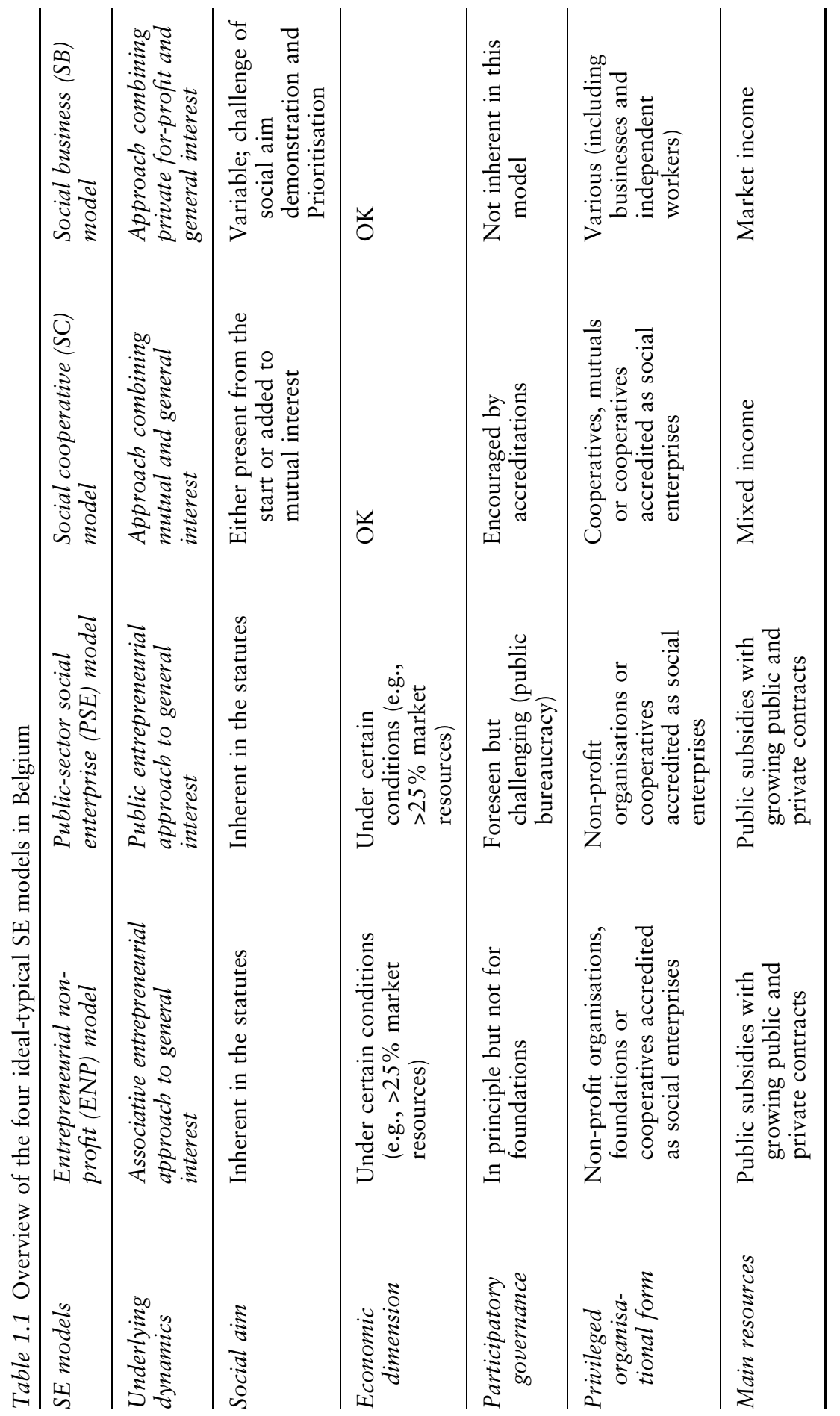




\section{2}

Huybrechts, Nyssens \& Defourny

approaches, summing up the available figures for some of the most easily defined types of social enterprise, and "inclusive" approaches, aggregating figures about populations of organisational forms of which a certain share could be considered as social enterprises. Among the bottom-up approaches, a report on social enterprises in Belgium was produced by I-Propeller (now part of Oksigen ecosystem) for the King Baudouin Foundation in 2013 (Huysentruyt et al. 2013). The mapping counted between 2,210 and 3,170 social enterprises. Inclusive approaches extend the "radar coverage" to be sure to include all social enterprises, but by doing so, they probably also include organisations that are located farther from the SE ideal type. According to the data collected by the ConcertES platform (Concertation des organisations représentatives de l'économie sociale) in the context of the "Observatory for the social economy" (Observatoire de l'économie sociale), there were more than 18,000 social enterprises in Belgium in 2018.

\subsubsection{Fields of Activity}

Providing an exhaustive list of social enterprises' (SEs') fields of activity is not possible. The most commonly cited fields include social services, integration of low-skilled workers and recycling, among others. However, social enterprises are active in a much broader set of fields, which may be related to the production of goods (food, garments, furniture, energy, etc.) or services (retail, transport, home care, education, health, culture, insurance, finance, IT, construction and refurbishing, etc.). In certain sectors, the set of social enterprises is quite homogeneous, especially when public regulation is important; in other sectors, different SE types, more or less closely related to the different models mentioned above, can be found.

\subsubsection{Employment in Social Enterprises}

Most studies agree on the fact that employment in social enterprises has been growing over the last two decades. While employment in the public and private for-profit sectors decreased between 2008 and 2014, it strongly increased in the same period in social enterprises $(+11.5 \%$ at the country level); the growth was particularly dramatic in Brussels $(+25 \%)$, but it was also considerable in the other two regions $(+9.1 \%$ in Flanders and $+7.2 \%$ in Wallonia). Between 2014 and 2017, employment in social enterprises increased $(+6 \%)$ much more than in the public sector $(+1 \%)$, but less than in the whole private sector $(+9 \%)$. According to the inclusive approach, with 393,000 full-time equivalents(FTEs), social enterprises represented $12 \%$ of employment in Belgium in 2017. Table 1.2 provides more detailed information not only by region but also by legal form, thereby confirming the overwhelming prevalence of the "non-profit association" legal form, 


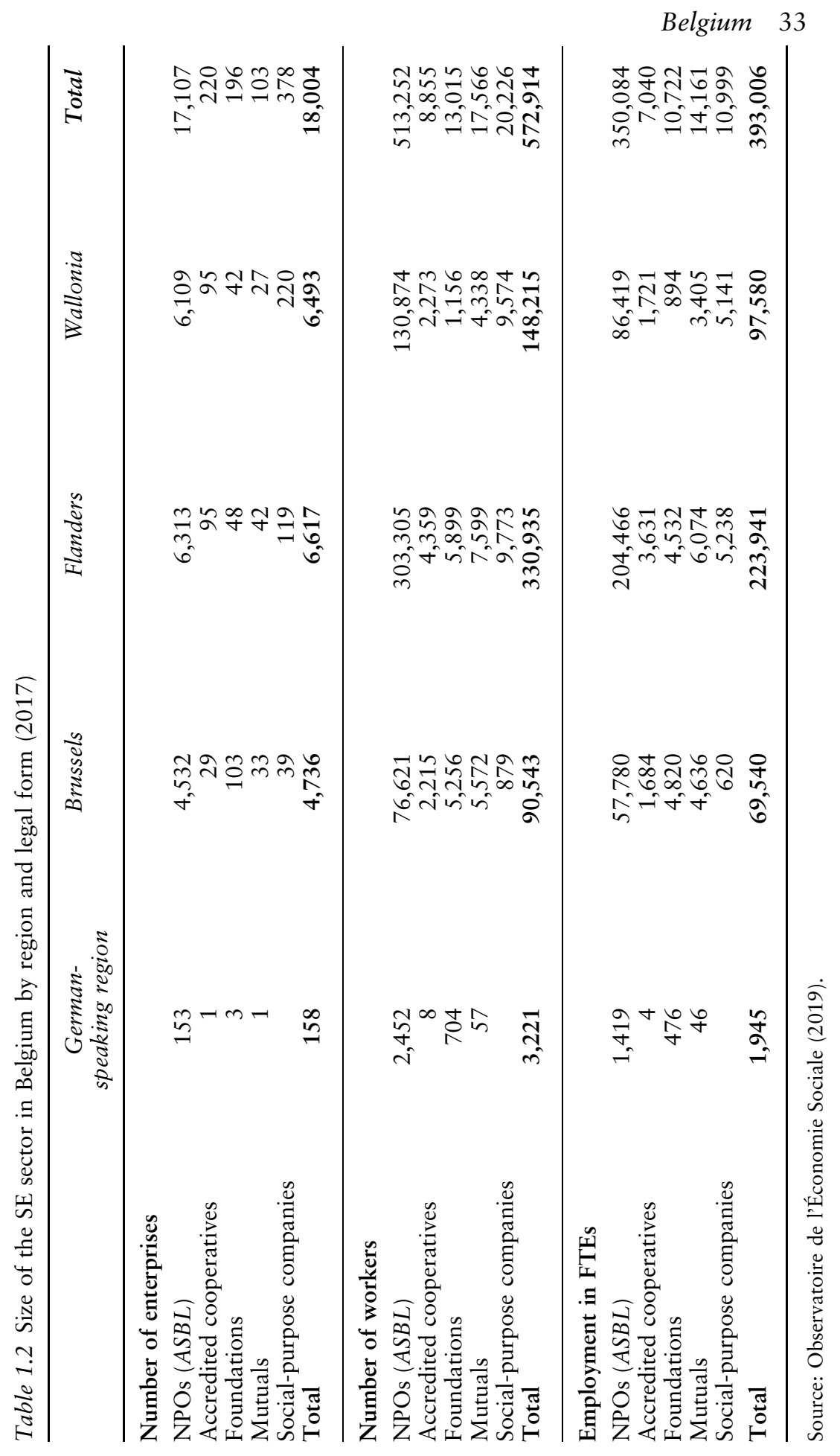




\section{Huybrechts, Nyssens \& Defourny}

chosen by $95 \%$ of employing social enterprises and representing $90 \%$ of workers in the whole picture of social enterprise (and the social economy) in Belgium.

\section{Conclusion}

Several trends can currently be observed in the SE field in Belgium, and social enterprises face various challenges. Instead of trying to provide an exhaustive overview, we focus here on three major issues: recognition, social impact and communication.

Public authorities and other stakeholders increasingly recognise that the concept of social enterprise should not be restricted to a specific organisational form, nor should it be considered to concern only some specific sectors of activity; it should rather appear as an umbrella notion, covering a broad scope of initiatives. The evolution of public policies in the three regions of the country is indicative of this trend. In this context, the focus of the SE notion on organisational models that are not tied to given sectors or legal forms and underlying logics reflects the vision of a diversified landscape. Nevertheless, despite this recognition, when it comes to concrete matters of support, regulation or funding, social enterprises are still likely to find themselves working at the crossroads of several policy areas and thus "falling between two chairs". Moreover, as they aim for social impact and often rely partly on non-market resources, such as subsidies and donations, social enterprises are not always considered as "true businesses", in spite of their economic importance. Social entrepreneurs often report that the challenge of being both economically sustainable and socially relevant requires even more innovation and professionalism than in conventional enterprises.

A second challenge facing social enterprises is the demonstration of their social impact. Funders and other stakeholders increasingly require that social enterprises demonstrate precisely what added value they can bring in developing solutions to social needs. This may be a complex and costly process for social enterprises taken individually, which is why networks and federations, together with support structures and universities, have started exploring the most relevant ways to measure and communicate about their social impact. Instead of a common crosssector measure, such as the social return on investment (SROI), more tailor-made and multi-indicator measures have been favoured, for example, in the context of the Interreg project "VISES". ${ }^{1}$

Finally, a third challenge-and an obstacle in terms of visibility and communication-is the fact that several terms still co-exist to refer to SElike initiatives, and they are each supported by specific actors, which leads to a set of scattered communication actions that fail to successfully diffuse any of these notions. This variety of terms is a challenge when communicating with the media and the general public. Several SE 
networks and support structures have started working together to assess how this challenge could best be overcome. Much energy is certainly required in order to educate and sensitise Belgian society about the importance and relevance of social enterprise.

\section{Acknowledgements}

This chapter is a synthesis and update of three previous contributions: the ICSEM Working Paper on social enterprise in Belgium, edited by Benjamin Huybrechts, with the collaboration of Jacques Defourny, Marthe Nyssens, Thomas Bauwens, Olivier Brolis, Peter De Cuyper, Florence Degavre, Marek Hudon, Anaïs Périlleux, Thomas Pongo, Julie Rijpens and Séverine Thys (Huybrechts et al. 2016); and the two most recent reports on social enterprise in Belgium commissioned by the European Commission in the mapping studies of social enterprises and their ecosystems in different countries (Huybrechts 2016; Nyssens 2019).

\section{Note}

1 See http://www.projetvisesproject.eu/.

\section{References}

Conseil Wallon de l'Économie Sociale (1990) Rapport à l'Exécutif Régional Wallon sur le secteur de l'économie sociale, Namur: Conseil Wallon de l'Économie Sociale.

Dart, R. (2004) "The legitimacy of social enterprise", Nonprofit Management $\&$ Leadership, Vol. 14, No. 4, pp. 411-424.

Defourny, J. (2001) "From third sector to social enterprise", in Borzaga, C. \& Defourny, J. (eds) The Emergence of Social Enterprise, London: Routledge.

Defourny, J. \& Nyssens, M. (2006) "Defining social enterprise”, in Nyssens, M. (ed) Social Enterprise. At the Crossroads of Market, Public Policies and Civil Society, London: Routledge.

Defourny, J. \& Nyssens, M. (2010) "Conceptions of social enterprise and social entrepreneurship in Europe and the United States: Convergences and divergences", Journal of Social Entrepreneurship, Vol. 1, No. 1, pp. 32-53.

Defourny, J. \& Nyssens, M. (2017), "Fundamentals for an International Typology of Social Enterprise Models", Voluntas, Vol. 28, No. 1, pp. 2469-2497.

Defourny, J., Simon, M. \& Adam, S. (2002) The Cooperative Movement in Belgium: Perspectives and Prospects, Brussels: Luc Pire.

Defourny, J., Henry, A., Nassaut, S. \& Nyssens, M. (2010) "Does the Mission of Providers Matter on a Quasi-Market? The case of the Belgian 'service voucher' scheme", Annals of Public and Cooperative Economics, Vol. 81, No. 4, pp. 583-610.

Dujardin, A. \& Mertens, S. (2008) "Les coopératives agréées en Belgique: une perspective macroéconomique", in Van Opstal, W., Gijselinckx, C. \& Develtere, P. (eds) Entrepreneuriat coopératif en Belgique. Theories et pratiques, Leuven: Acco. 
Fondation Roi Baudouin (2018) Baromètre des Associations, Brussels: Fondation Roi Baudouin.

Gijselinckx, C., Coates, A. \& Deneffe, P. (2011) Cooperatieve antwoorden op maatschappelijke uitdagingen, Leuven: Onderzoek in opdracht van het VIONA-programma van de Vlaamse overheid, beheerd door het Departement Werk en Sociale Economie.

Huybrechts, B. (2016) An update of the Mapping Study of Social Enterprise and Their Ecosystems in the European Union. Country Study: Belgium., Brussels: European Commission.

Huybrechts, B. \& Mertens, S. (2014) "The relevance of the cooperative model in the field of renewable energy", Annals of Public \& Cooperative Economics, Vol. 85, No. 2, pp. 193-212.

Huybrechts, B., Mertens, S. \& Rijpens, J. (2014) "Explaining stakeholder involvement in social enterprise governance through resources and legitimacy", in Defourny, J., Hulgard, L. \& Pestoff, V. (eds) Social Enterprise and the Third Sector: Changing European Landscapes in a Comparative Perspective, London \& New York: Routledge.

Huybrechts, B., Defourny, J., Nyssens, M., Bauwens, T., Brolis, O., Cuyper, P. D., Degavre, F., Hudon, M., Périlleux, A., Pongo, T., Rijpens, J. \& Thys, S. (2016) Social Enterprise in Belgium: A Diversity of Roots, Models and Fields, ICSEM Working Papers, Liege: The International Comparative Social Enterprise Models (ICSEM) Project.

Huysentruyt, M., Kint, A. \& Weymiens, S. (2013) Mapping of Social Enterprises in Belgium: I-Propeller, with Support of the King Baudoin Foundation.

Lemaître, A. \& Nyssens, M. (2012) "Les entreprises sociales d'insertion en Belgique, région wallonne”, in Gardin, L., Laville, J.-L. \& Nyssens, M. (eds) Entreprise sociale et insertion. Une perspective internationale, Paris: Desclée de Brouwer.

Mertens, S., Bosmans, P. \& Van de Maele, C. (2008) Entrepreneuriat Coopératif: Coup de projecteur sur une économie humaine, Brussels: Conseil National de la Coopération.

Nyssens, M. (2019) Social Enterprises and Their Ecosystems: A European Mapping Report - Updated Country Report: Belgium, Brussels: European Commission.

Observatoire de l'Économie Sociale (2019) "État des lieux de l'économie sociale", Cahiers de l'Observatoire, Louvain-la-Neuve: Concert-ES.

Van Opstal, W., Gijselinckx, C. \& Develtere, P. (eds) (2008) Entrepreneuriat coopératif en Belgique. Théories et pratiques, Leuven: Acco. 


\title{
2 Social Enterprise in Denmark \\ Historical, Contextual and \\ Conceptual Aspects
}

\author{
Linda Lundgaard Andersen, \\ Lars Hulgård and Gurli Jakobsen
}

\section{Introduction}

Until 2006, social enterprise (SE) was not a part of the political and scientific vocabulary in Denmark. In 2006 and 2007, however, the Danish Parliament awarded two important grants in this area: First, the Centre for Social Entrepreneurship at Roskilde University was allocated a €3million grant to build competencies and skills through the setting up of an executive MA in social entrepreneurship, learning programmes, research and outreach. Secondly, in 2007, the Parliament awarded another grant, enabling the creation of the Centre for Social Economy, launched by the Danish cooperative employers' organisation (Kooperationen). These two events were crucial in the establishment of social enterprise as an organisational, scientific and educational field in Denmark. However, in order to understand the institutional trajectory of social enterprise in Denmark, we must dig deeper into the history of the evolution of the Danish welfare state.

\subsection{Institutional Trajectories of Social Enterprise in Denmark: Strong Roots in Social Movements and State Formation}

Institutional interest in the SE field has appeared rather late in Denmark, but a broader phenomenon, which could be labelled the social economy, has a long history in Danish society. Grassroot movements and organisations have played a significant and substantial role both in the historic formation of the welfare state and in more recent processes of welfare state modernisation. From a macro perspective, three major periods can be identified in the institutionalisation of SE models in Denmark; such institutionalisation can also be approached by analysing the "individual" institutional trajectories of the main models of social enterprise.

With a view to situating social entrepreneurship, social enterprise and the social economy in the Danish context, we define social entrepreneurship as referring to the way in which non-governmental and 
civil organisations implement an increasingly hybrid economic model and diversify their activity profile (Ridley-Duff and Bull 2015). In such perspective, social enterprises are organisations that implement social and economic values as equally important values in a certain governance structure. Social economy could be a more generic term, allowing for the definition and discussion of a multiple and diversified economy (Eynaud et al. 2019; Hulgård and Andersen 2019). All three notions have been influential in the history of social enterprise in Denmark and remain important for its current development.

\subsubsection{First Period: Development of the Cooperative Sector}

At the European and international levels, a first period of emergence of the various types of organisations making up the social economy (cooperatives, mutual societies and associations) can be observed in the middle of the 19th century. In Denmark, as in other European countries, the historical basis for modern social enterprises can be found in the development of cooperative-like enterprises (including conventional cooperatives) that took place from the mid-1800 onwards (Hulgård and Andersen 2015). At the time, the workers and farmers' cooperative movements constituted two distinct and very influential actors, which played an important role in shaping Denmark as a modern constitutional democracy and, later on, as a universally oriented welfare state. The cooperative movement was of significant value for the protection and facilitation of farmers' economic, social and political interests. This movement was also directly linked to social movements with majorpossibly even crucial-influence on the making of modern Danish society, namely Grundtvigianismen (a social movement based on Grundtvig's conception of nationalism, Christianity and culture) and the Danish Folk High Schools Movement (højskolebevogelsen). The national cooperative movement included several small-scale rural cooperative movements as well as urban cooperatives. This movement was the "first strong voluntary cooperative movement in the world" (Svendsen and Svendsen 2004: 1). The main reason for this strength was the cooperative sector's success in generating a specific production factor, that is, social capital, which was partly explained by a well-working collaboration and connections between the local cooperatives and the national cooperative organisation (Svendsen and Svendsen 2004: 86).

\subsubsection{Second Period: Interrelated Crises}

A long time span separates the first period of emergence of the social economy at the international level, in the middle of the 19th century, from the second period, from the mid-1980s onward. During that period, in Denmark, the importance of social-economy organisations 
slowly faded due to the emergence of the welfare state. Public services gradually developed and grew into a quite strong infrastructure, and cooperatives lost ground.

In the Danish case, the period of re-emergence of the social economy was strongly rooted in the social sector and civic society. In this period, three interrelated crises developed, thereby paving the way for different social enterprises to emerge and develop (Hegland and Hulgård 1998; Andersen 2015a):

- a resource crisis, resulting from very rapidly rising public demands for public-welfare spending in health services, education and public administration;

- a functional crisis, which manifested itself in welfare-state services gradually developing into rigid structures and routines. The standardised, functional and organisational forms of the welfare state were no longer fully able to meet the population's nuanced needs in a rapidly changing society;

- a crisis of legitimacy of the welfare state, weakening the popular support for a solidarity- and needs-based social policy.

Adding to this, two political factors influenced the institutionalisation of social enterprise in Denmark: first, the implementation of numerous crosssectoral development and pilot programmes aimed at facilitating bottomup solutions to social problems, and secondly, the soft transition from a universal welfare state to a Schumpeterian workfare state. A new type of social enterprise and social entrepreneurs started to emerge as one type of response to the shortcomings of welfare-state organisations. Between 1985 and 2000, many pilot and action programmes within the field of social policy and urban regeneration facilitated the emergence of a new sector of social enterprise and social entrepreneurship. Although similar programmes appeared simultaneously in other European countries, the Danish pilot and experimental programmes were comparatively large. The largest programme was the so-called "Social Development Programme" (with a €47million budget), which aimed to increase participation and cross-sectoral collaboration in the provision of social services, thereby funding many of the dominant social entrepreneurs and social enterprises in the third development phase of social enterprise. To a certain degree, it is fair to say that a bottom-up movement, facilitated by enthusiastic and talented local social entrepreneurs, dominated this emergence of new social enterprises.

\subsubsection{Third Period: Emergence and Institutionalisation of Social Enterprise}

The third period, which started in the early 2000s, corresponds to the institutionalisation process of social enterprise in Denmark. In this 
period, social enterprises developed, moving from the stage of embryonic initiatives to that of full emergence and institutionalisation. This period was first characterised by the fact that the social economy, social entrepreneurship and social enterprise all received great attention from all agents. Third-sector organisations had to reformulate and develop a balance between traditional forms of advocacy, impact awareness and representation of interests as regards the delivery of welfare services on the market. Secondly, strategies to promote social enterprise were incorporated into Danish public policies and strategies for the renewal of welfare (Andersen and Hulgård 2016). This period also witnessed the emergence of a national strategy for social enterprise, which will be analysed later in this chapter.

\subsection{Legal Forms of Social Enterprise in Denmark}

A number of business legal forms can be adopted by social enterprises in Denmark; they are presented below. The roots of these legal forms can be traced back to organisational types developed in the 19th century: cooperatives, mutuals, associations and so-called "self-owned" and "self-governed" organisations. ${ }^{1}$

\subsubsection{Association (Forening)}

The association (forening) is a union of people or organisations with a common aim, managed according to democratic rules and procedures. There is no single act governing associations in Denmark, so requirements depend on specific types and sectors. Since 1849, an association has had legal validity when it fulfils the general condition of having a set of by-laws democratically approved in a member-based general assembly. The law distinguishes between business-oriented associations and non-profit associations; they are subject to different rules of taxation, and are in general governed respectively by the general rules for non-profit and for-profit enterprises and by those for organisations (Jakobsen 2001).

\subsubsection{Self-Governing Institutions (Selvejende Institution)}

Self-governing institutions (selvejende institution) include both publicly founded and funded institutions and private ones. Both types have a set of bylaws that defines them legally as being "self-owned" and non-profit. Both are common within welfare service like kindergartens, nursing homes, schools, etc. Private self-governing institutions often function with public contracts. They are defined by their social purpose and managed by an independent board (elected or appointed). They generally do not have volunteers. 


\subsubsection{Public-Utility Funds (Almennyttige Fonde)}

Public-utility funds (almennyttige fonde) are charitable foundations that usually have a social purpose; they are endowed with assets for a specific purpose, they are governed by a board and they are non-profit. They often award grants or funding for education and research, and organise cultural and sport activities.

\subsubsection{Cooperatives (Andelsselskab)}

Cooperatives (andelsselskab) are member-owned organisations that trade economically and are democratically managed to further the common interest of their members (Ibsen and Haberman 2005). There is not a specific cooperative law in Denmark, but the existing legislation follows the cooperative principles of the International Cooperative Alliance regarding membership, ownership and the way in which economic surplus is distributed to members. Companies can benefit from a special tax regime as cooperatives; this is also possible for capital-based companies, provided their bylaws and praxis are recognised as functioning according to these cooperative principles (Jakobsen 2010).

\subsection{The Innovative and Entrepreneurial Welfare State}

As described above, the Danish welfare state has demonstrated a sustained and long-term commitment to the development of a welfare system able to perform social tasks effectively. In this sense, both innovation and social entrepreneurship have been on the Danish agenda for a long time-even far longer than the rhetorical interest in these subjects. However, in the recent decades, new developments have occurred: interesting Danish—and perhaps even Nordic-(social) entrepreneurial welfare-state position and practice have emerged, that we identify as the "innovative and entrepreneurial welfare state". We use this term to emphasise how the welfare state positions itself within areas like welfare policy, educational policy and in relation to civil society-in a proactive manner and forming, funding and initiating programmes of "modernisation" (Andersen 2015b; Andersen and Hulgård 2016; Andersen et al. 2016).

It has historically been some of the welfare state's core areas to design and implement welfare and education policies. This is in alignment with international analyses that point to how the state is an understated agent of (social) innovation (Mazzucato 2013). Civil society has not been similarly subject to policy planning, but this is increasingly changing so that NGOs and civil society are now part of public policies and interventions (Andersen 2018). And in the case of Denmark, we are not just talking about a state that analyses, decides and develops through policies, programmes and performance criteria, but also, to a very large 
extent, about a government that acts and reacts responsively to its various citizens and stakeholders' needs and desires.

The universal welfare state was an asset of a society that quickly developed in the post-war period (Titmuss 1987). Some indicators of the evolution of the welfare state are the experimental and developmental programmes that have been implemented both at European level and in the Nordic countries, thus creating a renewed and user-sensitive approach in social work, urban development, culture and health. As mentioned above, many of the organisations in Denmark that we today would label social enterprises have their origin in such national and European experimental programmes. Another landmark, and a factor that has paved the way for the emergence of social enterprise and social entrepreneurship, is constituted by the numerous Danish modernisation programmes that have been implemented throughout the 1980s, 1990s and 2000s. These programmes have primed public-sector development through performance management and have led to a "trimming" of the welfare state, promoting quasi-market services and more efficient and rationalised services (Andersen 2015b).

\subsection{The Danish Ecosystem of Social Enterprise}

The Danish ecosystem of support for social entrepreneurship and social enterprise consists of different dimensions. Andersen and Hulgård (2014) argue that four dimensions-namely practice, policy, education and research-are particularly significant in stimulating and consolidating social enterprise in the Nordic countries. Often, ecosystem models focus on entrepreneurial-related issues, such as legal frameworks, social-impact markets and measurements, networks and mutual support structures and mechanisms, as well as on specialist business development (see, e.g., ICF Consulting Services for the European Commission 2014: 6)—which can be considered to correspond to the "practice" and "policy" dimensions. However, the Danish (and more broadly Nordic) case illustrates the fact that, in order to understand the development of social entrepreneurship and social enterprise, the approach to the SE ecosystem must be expanded to include education and research (Andersen et al. 2016). Indeed, an educational system permeated by a social entrepreneurial way of thinking and acting generates knowledge as well as social and cultural forms of capital that increase action potential, which in turn can affect practice in many different ways (Hulgård and Andersen 2015: 59). Analysing the current situation in Denmark through the lens of this four-dimensional model reveals a system that both hinders and supports the development and consolidation of social enterprise.

The four dimensions highlighted by Andersen are all well-established features of the Danish societal infrastructure and state capacity, and the subject of public-, civil- and private-driven development. The educational dimension has been particularly important in developing the SE support ecosystem. 
In principle, the ecosystem covers elementary school, youth programme training and education, but bachelor/master programmes and doctorates related to social entrepreneurship and social enterprises are probably the most established and consolidated forms of education in the field of social enterprise in Denmark as in the Nordic countries in general. The Centre for Social Entrepreneurship at Roskilde University has been spearheading the educational and knowledge infrastructure in the country, providing a parttime master as well as a full degree programme in social entrepreneurship, social enterprises and management (Andersen and Hulgård 2014; Andersen et al. 2016). A number of educational institutions, such as university colleges, Copenhagen Business School and the University of Southern Denmark have also included courses on social enterprise in their curriculum. For the past ten years, the education and knowledge dimension of the ecosystem have been growing more than other dimensions, like the legal and financial framework and support structures (Andersen and Hulgård 2019).

From a legal perspective, in June 2014, the Danish Parliament passed the Act on Registered Social Enterprises; ${ }^{2}$ since 2015, social enterprises have thus been able to register as such within the Danish fiscal framework. According to the Act of 2014, social enterprises have to meet five criteria: they must have a social purpose; they must carry out a significant commercial activity; they must be independent from public authorities; they must have an inclusive and responsible governance; and they must implement a social reinvestment of profits. The fiscal framework targeting social enterprise in Denmark differs according to the legal form adopted by the organisation: associations, foundations and limitedliability companies can all apply to a differentiated fiscal framework. The most important incentive for registering as a social enterprise is the visibility: registered social enterprises are easy to recognise for potential partners and customers (Hulgård and Chodorkoff 2019).

The Danish SE ecosystem has gone through significant changes and developments in the decade between 2007 and 2018 (Andersen and Hulgård 2019). From 2007 onwards, a far-ranging interest for social enterprise has been significant in the country, both among politicians at the national and municipal levels and among interest organisations.All displayed some awareness of the potential and possible outcomes of social enterprise as a new welfare agent. A number of national mapping projects and capacity-building centres were supported by a variety of stakeholders, including politicians at the local and national levels. The period of public attention culminated in 2013-2014 with the ambition displayed by politicians to develop a national SE ecosystem. At the core of this ecosystem was the establishment of the National Growth Centre for Social Enterprise, in 2013; the design of a National Strategy for Social Enterprise, published in 2014; and the creation of the "registered social enterprise" tool (registreret socialøkonomisk virksomhed, or RSV). 
Whereas the RSV tool still exists today, the government closed the Growth Centre by the end of 2015, the SE ecosystem has become more fragmented, and public interest for this ecosystem at the national level has decreased. However, interest in capacity building remains strong at the local level, and many municipalities as well as interest organisations and social entrepreneurs remain active in the area, developing social economic welfare strategies and providing small seed funding and consultancies (Hulgård and Chodorkoff 2019).

It can thus be said that, in Denmark, the governmental and political understandings, positioning and decisions reveal a somewhat "zigzagging" legal and financial response to social enterprise. At the beginning of the year 2000, a firm and genuine interest in social enterprise could be observed, with a foreseen budget of over DKK30 million (about €4.02 million) over 8 years to initiate and sustain social entrepreneurship and social enterprise pursuing a broad societal interest. Following this, however, the political and governmental route has taken a much more neoliberal turn, with a vague and neoliberal discourse in which social enterprise is seen as part of corporate social responsibility (Andersen 2018). Moreover, an interesting schism has emerged between top-down initiatives and bottom-up ones: the number of top-down initiatives has been decreasing lately, whereas bottom-up initiatives have been flourishing. A growing number of municipalities have been developing socioeconomic strategies in order to initiate, feed and strengthen SE initiatives and business as part of local welfare and labour-market strategies (Lund and Sørensen 2018; Hulgård and Andersen 2019).

As far as numbers are concerned, social enterprises have been researched in a number of studies (Schøtt 2009; Governmental Committee on Social Enterprises 2012; Jensen 2012; Jacobsen 2013; Thuesen et al. 2013), but the SE field still remains, from the point of view of scientific documentation, a new discipline, not yet defined by consistent criteria or monitoring-it is rather, so far, the subject of various unconnected studies. The fact that the various available studies are based on different definitions of social enterprise and have produced different results in terms of numbers of social enterprises questions the reliability of these results and points to the need for further research.

Most recent studies document that, in October 2018, 282 social enterprises were registered in the VIRK Database-a publicly hosted database on social enterprises in Denmark. Of these, 123 were associations, 46 were foundations, 90 were limited-liability companies and 23 were registered under "other legal forms". As it is estimated that a good part of the 23 organisations recorded as undefined in legal terms were in reality independent projects implemented under existing associations or foundations, these data show that around three quarters of social enterprises in Denmark have kept their rooting as third-sector entities (Hulgård and Chodorkoff 2019). Another study identified 637 "socially 
responsible enterprises", and it is estimated that 315 among these could qualify for a "registered social enterprise" (RSV) accreditation (Lund and Sørensen 2018: 42).

The policy discourse on social enterprise in recent years has raised interest from both the conventional business sector and the general public; such interest is mainly linked to the central role of workintegration social enterprises (WISEs) in policy frameworks. However, the SE field in Denmark is not limited to WISEs, but is broader and more diversified. This is increasingly true: whereas almost $80 \%$ of social enterprises pursuing thematic objectives were linked to employment and social issues in 2013, this figure was down to $57 \%$ in 2018 . The most significant evolution in terms of objectives concerns environmental objectives: while only $6 \%$ of social enterprises pursued such objectives in 2013 , this figure reached $14 \%$ in 2018 . This reflects the fact that social enterprises are in line with prioritised societal problems that are not being addressed adequately by dominant and traditional organisations and policies. Accordingly, there are a great potential and results to harvest for policies that would provide incentives for the setting up of social enterprises aiming to overcome severe societal challenges, such as climate change and health issues. Overall, social enterprises' objectives have become much more diversified (Hulgård and Chodorkoff 2019: 32).

\subsection{Significant Conception(s) and Practices of Social Enterprise: Five Platforms}

In the Danish landscape, social enterprise and social entrepreneurship remain a contested phenomenon, which many actors have tried to influence and define. Table 2.1 illustrates how five significant and influential platforms, bringing together various actors, have developed SE-related concepts and practices. The table offers an overview of the different platforms' definition, strategy and implications, and highlights the existence of different Danish key agents investing in and influencing the emergence of social enterprises. The table is based on the platforms' self-representations of their objectives, activities and strategies such as they are disseminated through their website, in their mission statements or through information products and annual reports. The five selected platforms are the following:

- the Centre for Social Economy (Center for Socialøkonomi, or CSE), a consultancy and knowledge centre supported by governmental social funding; ${ }^{3}$

- the think tank Monday Morning (Mandag Morgen), which promotes social entrepreneurship through analyses and reports to enhance documentation and policy-making;

- the Centre for Social Development ${ }^{4}$ (Socialt Udviklingscenter), which has initiated and launched an initiative named "social inventions"; 


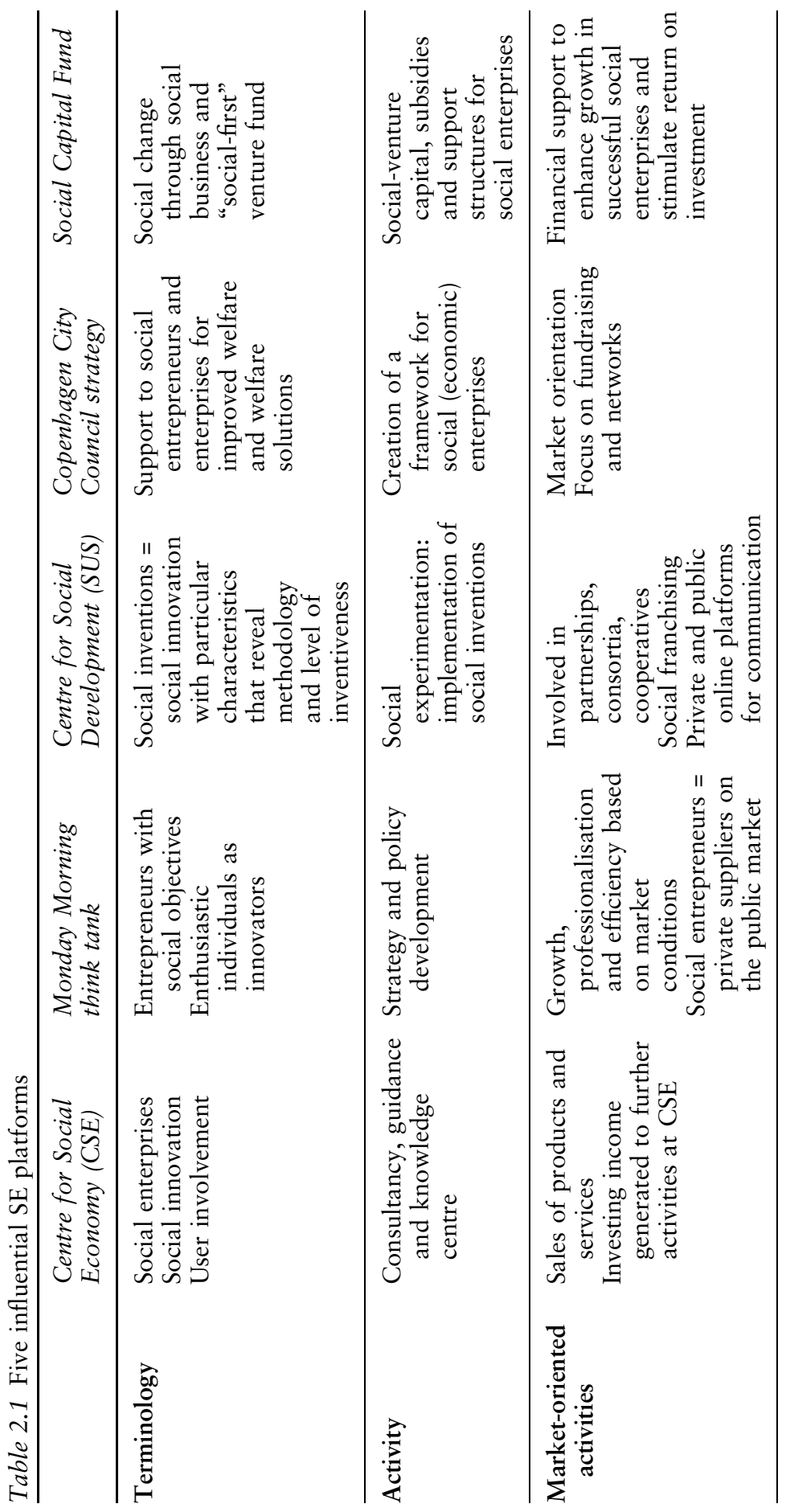




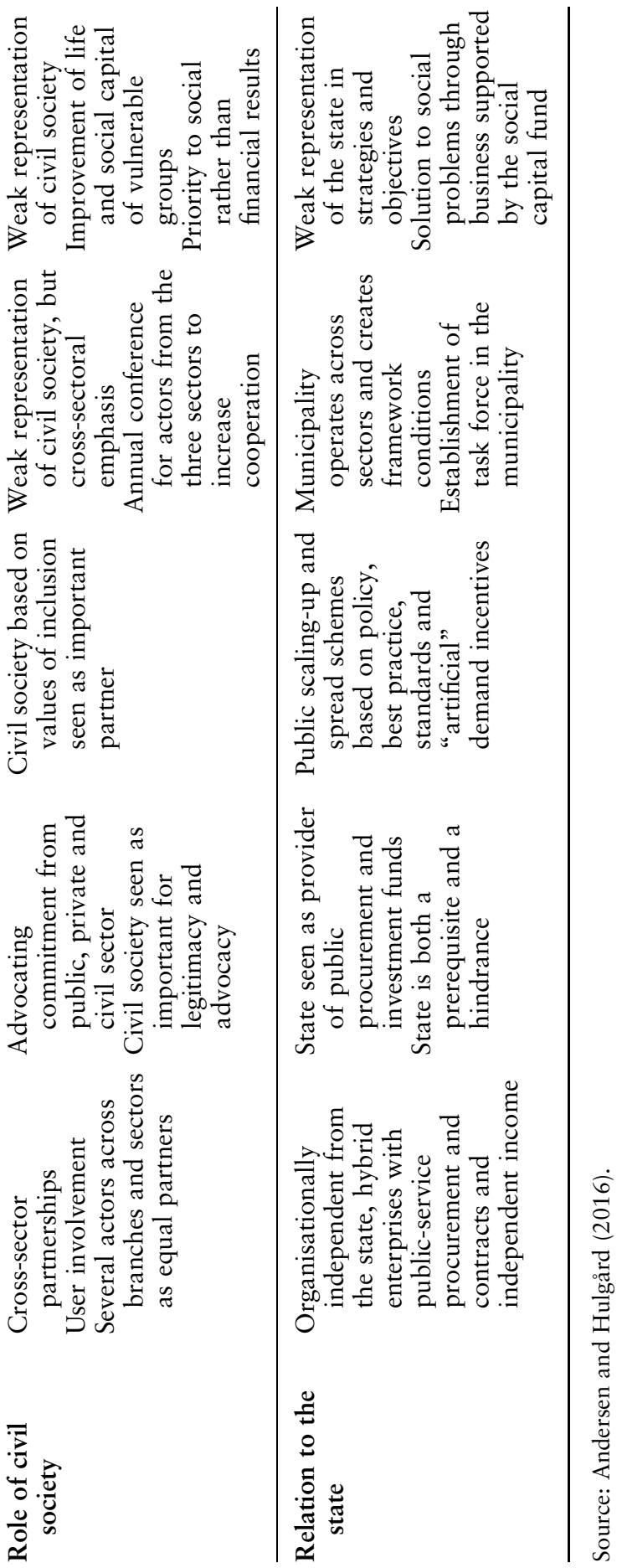


- the Copenhagen City Council strategy, ${ }^{5}$ as an example of a localgovernment social-economy strategy initiating social enterprises as a tool for reintegrating marginalised citizens;

- the Social Capital Fund ${ }^{6}$ (Den Sociale Kapitalfond), which is the first Danish social-venture fund aiming to provide financial support to social enterprises.

The analysis of the five platforms is interesting in several ways. First, it reveals that supporting social entrepreneurship and social enterprises through platform services is a rather new phenomenon in Denmark, as four of the five platforms have emerged since 2010, while the oldest one (namely the CSE) had been established in 2007 (it had to close down in 2014 due to lack of funds).

Secondly, the platforms reveal a high degree of pluralism and diversity in terms of views and definitions of the SE field. The various agents use different terms in Danish, which may be translated as "social economic enterprises", "social entrepreneurial initiatives", "social inventions" and "social entrepreneurship"-all of which have become part of the Danish public discourse.

Thirdly, social enterprise has very rapidly achieved a considerable institutional anchoring in terms of support structures, representation of interests, access to resources and knowledge production. The CSE targets social enterprises, but in practice, its activities are broadly aimed at social entrepreneurs through networking, mentoring, and advice and policy development. Several local community councils (in about a dozen communities) have developed SE strategies and have created support structures like "consultancy and start-up teams", and they provide small pools of seed money to finance SE start-ups. In such plans and documents, social enterprises are positioned as key initiatives for the development of new welfare strategies (see, for instance, Copenhagen City Council 2009 and Aarhus City Council's strategy for social economic entrepreneurs in 2012). Likewise, the introduction of social entrepreneurship into the educational system must also be seen as a resource and capacity-building measure. ${ }^{7}$

Fourthly, all platforms are concerned with acting and positioning themselves according to trends in the market and in civil society. All agents view the market as probably the most central arena for entrepreneurship, and if the five platforms share a common denominator, it would seem to be the considerable attention given to faith in the market as the primary arena for social entrepreneurs. The market is linked with notions of sales and growth, economic value, incentives, motivation, efficiency, professionalism and return on investment. On the other hand, most platforms are also concerned with involving civil society in their activities and strategies (the City Council strategy and the Social Capital Fund constitute exceptions in this regard). The civil society evokes notions of partnerships, user involvement, commitment, legitimacy, advocacy and vulnerable citizens. 


\section{Conclusion}

In this chapter, we have provided, through a brief overview of the history of the Danish welfare state, an understanding of the institutional trajectory and legal forms of social enterprise. We have outlined the organisational, scientific and educational field of social enterprise in Denmark. Social-economy organisations have a long history in Denmark, and they have played a significant and substantial role both in the historic formation of the welfare state and in more recent processes of modernisation of the latter. In terms of numbers, social enterprises have only been investigated from the mid-2000s onward, but recent figures point to an interesting development, implying that the SE field becomes broader and more diversified; while some of social enterprises' characteristics (such as the fact that they are strongly anchored in civil society) remain unchanged, these initiatives develop activities in new areas, addressing environmental and urban issues. The political interest has lost momentum and the SE ecosystem is not further developing, but the interest and initiatives from social entrepreneurs is still present. It will be interesting to see how the Danish SE ecosystem will develop in the future, and whether this trend towards the diversification of social enterprises will continue.

\section{Notes}

1 In English texts, "selvejende institution" (literally, "self-owned institution") is often translated as "foundation".

2 Social Enterprise Law on Registered Social Enterprises, No. 148 (see www. retsinformation.dk/Forms/R0710.aspx?id=161853; accessed November 9, 2015).

3 The Center for Social Economy was funded from 2007 to 2013 by the Danish Parliament.

4 See www.sus.dk.

5 See Copenhagen City Council's strategy for social enterprises (2010). https:// www.kk.dk/sites/default/files/edoc_old_format/OEkonomiudvalget/25-052010\%2015.15.00/Referat/26-05-2010\%2012.35.12/5451624.PDF.

6 See www.densocialekapitalfond.dk/.

7 Social entrepreneurship is growing both in practice and in education. Roskilde University offers an international full master programme on Social Entrepreneurship and Management (https://ruc.dk/en/master/social-entrepreneurshipand-management-int) and a part-time open master's level course (https://ruc.dk/ master-i-socialt-entreprenoerskab); Copenhagen Business School offers social entrepreneurship as an integral part of core courses and elective courses at Bachelor and Master levels (www.cbs.dk/en/knowledge-society/interdisciplinary-initiatives/ entrepreneurship/organization/clusters/social-entrepreneurship); university colleges have introduced social enterprise in their curriculum. The Danish Social Innovation Club (DANSIC; see www.facebook.com/danishsocialinnovationclub) is a voluntary, student-run, non-profit organisation for social innovation and social entrepreneurship among students, and the interest organisation Social Entrepreneurs in Denmark is growing in size and activities. 


\section{References}

Andersen, L. L. (2015a) Social Entrepreneurship and Social Innovation: Human Economy, Governance and Vvoluntarism Revisited, CURSIV, No. 15, Aarhus: Aarhus University Press.

Andersen, L. L. (2015b) "Micro-processes of collaborative innovation in Danish welfare settings: A psychosocial approach to learning and performance", in Agger, A., Damgaard, B., Hagedorn, A. K. \& Sørensen, E. (eds) Collaborative Governance and Public Innovation in Northern Europe, Sharjah: Bentham Science Publishers, pp. 249-268.

Andersen, L. L. (2018) "Neoliberal drivers in hybrid civil society organisations: Critical readings of civicness and social entrepreneurism", in Masoud K. \& Jönsson, J. H. (eds) Neoliberalism, Nordic Welfare States and Social Work, London: Routledge, pp. 43-52.

Andersen, L. L. \& Hulgård, L. (2014) "Social innovation and collaborative learning Roskilde University - a critical and problem-oriented approach", Sport Journal for University Pedagogy, Vol. 4, Roskilde University, pp. 22-38.

Andersen, L. L. \& Hulgård, L. (2016) "Social Entrepreneurship: Demolition of the Welfare State or an Arena for Solidarity?", in Andersen, L. L., Gawell, M. \& Spear, R. (eds) Social Entrepreneurship and Social Enterprises: Nordic Perspectives, London: Routledge, pp. 22-40.

Andersen, L. L., \& Hulgård, L. (2019) "Social enterprise in Denmark: Emerging, institutionalized or colonized?", Paper presented at the 7th EMES International Research Conference on Social Enterprise: Sustainable Development through Social Enterprise, Co-operative and Voluntary Action.

Andersen, L. L., Gawell, M. \& Spear, R. (2016) "Social Entrepreneurship and Social Enterprises in the Nordics: Narratives Emerging from Social Movements and Welfare Dynamics", in Andersen, L. L., Gawell, M. \& Spear, R. (eds) Social Entrepreneurship and Social Enterprises: Nordic Perspectives, London: Routledge, pp. 1-18.

Copenhagen City Council (2009) Policy for Social Economic Enterprises in 2010. Available HTTP: https://www.kk.dk/sites/default/files/edoc_old_format/ OEkonomiudvalget/25-05-2010\%2015.15.00/Referat/26-05-2010\%2012.35 . 12/5451624.PDF.

Eynaud, P., Laville, J.-L., dos Santos, L. L., Banerjee, S., Avelino, F. \& Hulgård, L. (2019) Theory of Social Enterprise and Pluralism. Social Movements, Solidarity Economy, and Global South. Theory of Social Enterprise and Pluralism, London: Routledge https://doi.org/10.4324/9780429291197.

Governmental Committee on Social Enterprises (2012) Recommendation Report, Copenhagen.: Committee on Social Enterprises. Available HTTP: http:// socialvirksomhed.dk/en/files/recommendationreport.pdf (accessed April10, 2015).

Hegland, T. J., \& Hulgård, L. (1998) "Socialpolitik og forsøgsvirksombed", Socialpolitik, Munksgaard.

Hulgård, L., \& Andersen, L. L. (2015) Sosialt entreprenørskap og sosial innovasjon. Kartlegging av innsatser for sosialt entreprenørskap og sosial innovasjon $i$ Norden, Nordisk Ministerråd, Tema Nord 2015:502.

Hulgård, L. \& Andersen, L. L. (2019) "Reconfiguring the social and solidarity economy in a Danish/Nordic welfare context", in Eynaud, P., Laville, J.-L., dos Santos, L. L., Banerjee, S., Avelino, F., \& Hulgård, L. (eds) Theory of 
Social Enterprise and Pluralism Social Movements, Solidarity Economy, and the Global South, London: Routledge, pp. 69-89.

Hulgård, L. \& Chodorkoff, L. (2019) European Commission. Social enterprises and their ecosystems in Europe. Updated country report: Denmark, Luxembourg: Publications Office of the European Union. Available HTTP: https://europa.eu/!Qq64ny.

Ibsen, B. \& Habermann, U. (2005) “Defining the nonprofit sector: Denmark", Johns Hopkins Comparative Nonprofit Sector Project Working Paper, No. 44, Baltimore: The Johns Hopkins Center for Civil Society Studies.

ICF Consulting Services for the European Commission (2014) A Map of Social Enterprises and their Ecosystems in Europe: Executive Summary, Brussels: European Commission.

Jacobsen, H. R. (2013) Virksombeder med udvidet socialt ansvar, Centre for Economic and Business Research (CEBR), Copenhagen: Copenhagen Business School.

Jakobsen, G. (2001) “Organisationsformer i ‘den sociale økonomi’ i Danmark og disses samspil med det offentlige", Kooperation, Social Kapital och Medarbetare Insatser Kooperativ Arsbok 2001, Stockholm: Föreningen Kooperativa Studier, pp. 79-100.

Jakobsen, G. (2010) Study on the Implementation of the Regulation 1435/2003 on the Statute for European Cooperative Society (SCE): National Report Denmark, Brussels: Council of European Union. Available HTTP: https://op. europa.eu/en/publication-detail/-/publication/494bb15b-c34d-4bdf-8518$75 \mathrm{~d} 6 \mathrm{bde} 38 \mathrm{cbb}$ (accessed June2020).

Jensen, E. (2012) Fokus på socialøkonomiske virksombeder. Notat om socialøkonomiske virksombeder med beskcftigelsesfremmende og jobskabende formal, Århus: CABI.

Lund, A. B. \& Sørensen, K. I. (2018) Komparative Analyser af dansk socialøkonomi: Sorgfrit udkomme \& timeligt velvore?, Copenhagen: Copenhagen Business School, Centre for Civic Studies.

Mazzucato, M. (2013) The Entrepreneurial State. Debunking Public vs. Private Sector Myths, London: Anthem Press.

Ridley-Duff, R., \& Bull, M. (2015) Understanding Social Enterprise: Theory and Practice. London: Sage.

Schøtt, T. (ed.) (2009) Social and Commercial Entrepreneurship in Denmark, Odense: Syddansk Universitetsforlag.

Svendsen, G. L. H. \& Svendsen, G. T. (2004) The Creation and Destruction of Social Capital - Entrepreneurship, Co-operative Movements and Institutions, Cheltenham: Edward Elgar.

Thuesen, T., Bach, H. B., Albæk, K., Jensen, S., Hansen, N. L. \& Weibel, K. (2013) Socialøkonomiske virksombeder $i$ Danmark: Når udsatte bliver ansatte, Copenhagen: The National Research Centre on Welfare, No. 13:23, Institute of Social Research (SFI).

Titmuss, R. M. (1987) The Philosophy of Welfare: Selected Writings of Richard M. Titmuss, Crows Nest: Allen \& Unwin. 


\title{
3 A New Typology of Social Enterprise in Finland Capturing the Diversity
}

\author{
Harri Kostilainen, Eeva Houtbeckers \\ and Pekka Pättiniemi
}

\section{Introduction $^{1}$}

Research on social enterprise (SE) is often introduced by referring to different schools of thought (Defourny and Nyssens 2010); other analyses refer to different models, either within a country (Kerlin 2006) or within and across countries (Defourny and Nyssens 2017). Such analyses enable comparisons between regions and discussions about developments in the SE field; however, they might not capture the diversity within regions. This paper aims to capture the diversity of contemporary social enterprises in Finland by analysing to what extent Finnish social enterprises correspond to SE models identified in previous research and to what extent they represent reactions to changes in the institutional environment and to new types of socio-ecological challenges.

In order to answer these research questions, we review the institutionalised and non-institutionalised forms of social enterprise in Finland. They are influenced by social-economy traditions, changes in SE-related legislation and recent developments in the understanding of the role of businesses and the economy in general. To illustrate our findings, we present four concrete examples-cases illustrating the new typology of social enterprise in Finland that we had put forward in a previous publication (Kostilainen et al. 2016) and on which we base our analysis here. The proposed typology includes four categories: (1) social enterprises providing public (welfare) services; (2) emerging alternative economic initiatives; (3) impact businesses and "smart-ups"; and (4) social-impact redistributors. We argue that this newly developed typology reflects the diversity in the contemporary field of Finnish social enterprises in more detail than earlier categorisations did.

This chapter proceeds as follows. First, we review the context in which social enterprises operate in Finland. We then provide an overview of the institutionalised and non-institutionalised forms of social enterprise in the country. In the third section, we present the new typology of social enterprise in Finland, as well as four emblematic examples illustrating the different types of social enterprise. In the fourth section, we discuss 
social-value creation in different aspects of social enterprises' activity, before analysing our typology in relation to the findings generated by the ICSEM project.

\subsection{The Finnish Context for Social Enterprises}

Finland is one of the North European welfare states-the others being Denmark, Iceland, Norway and Sweden. The Nordic countries are known for their universalist welfare states, which guarantee equal opportunities for all citizens. According to Hjorth (2008), the characteristic elements of the Nordic welfare states include high women representation in the national parliaments, compared to other European countries; a wide offer of government services, enabling citizens' individual independence; and higher birth rates than in Southern Europe, due to government support for parenthood.

As in other Nordic countries, in Finland, the government has had-and still has-a central role in providing services for its citizens. These services are funded through taxes, which are legitimised by the wide-ranging availability of public services. This welfare-society policy is one of the reasons that can account for the slow development of social enterprise in the country; the state-rather than social enterprises-has been taking care of services to its citizens. There has been a strong political will to promote education, health care and equal opportunities, with an emphasis on the state and municipalities as producers of these services.

\subsubsection{Social-Economy Organisations in the Finnish Welfare State}

In Finland, there exists a long tradition of social-economy organisationsthat is, cooperatives, mutual societies, associations and foundations-carrying out economic activities; this tradition can be traced back to the late 19th century (Pättiniemi 2006). The role of traditional social-economy organisations has been-and still is-strong and recognised, inter alia through legal frameworks ${ }^{2}$ and dedicated financial instruments, such as the Funding Centre for Social Welfare and Health Organisations (STEA), whose predecessor, Finland's Slot Machine Association (Raha-automaattiyhdistys, or RAY), was established in 1938 to finance social and health-care associations (Kostilainen and Pättiniemi 2013: 40).

The traditional forms of social-economy organisations fought inequality and fostered social and economic development. Social-economy organisations emerged where there was a lack of vital services and resources were scarce. The role of social-economy organisations changed when the welfare state emerged, developed and matured, in the period that extended from the 1940 s to the 1980 s. Some social innovations implemented by these 


\section{Kostilainen, Houtbeckers \& Pättiniemi}

traditional social-economy organisations were transferred to the municipalities, which took over the responsibility of organising and financing most of the universal welfare-service functions, while traditional socialeconomy organisations maintained their role as service providers to meet various specific needs of different vulnerable groups, such as people with hearing, speech or a visual impairment, disabled war veterans, people with respiratory problems and several other groups (Kostilainen and Pättiniemi 2016: 60).

\subsubsection{Evolution of New Social Enterprises}

There is no common definition of social enterprise in Finland. The different types of social enterprise, as well as their activities and tasks, have been evolving in the welfare state since the recession that hit the country in the beginning of the 1990s. Kostilainen and Pättiniemi (2016) identified four phases of social enterprise's recent evolution in Finland: (1) social enterprises as a social movement; (2) social enterprises as a labour-market measure; (3) social enterprises as a vehicle for renewing welfare-state services; and (4) institutionalisation of SE concepts. The institutionalisation was achieved through the Act on Work-Integration Social Enterprises and the implementation of the so-called "Social Enterprise Mark" (see section 3.2). Social enterprises are now expected to combine the business skills of the private sector with a strong social mission, producing social innovations that might play an important role in delivering public (welfare) services and in labour-market integration.

After the turn of the millennium, a social enterprise started to raise more interest. Some consider social enterprises as potentially more appropriate service providers than private companies (see, e.g., Bland 2010). Especially in health and social services, where national and local governments are reducing their own production of services, the need for alternatives has become intense. The target being improved efficiency, the services are outsourced to non-governmental organisations and private companies. According to critics, this trend towards outsourcing to private companies is problematic, in that it makes it possible to redistribute the profits generated to the shareholders at the expense (at least to some extent) of citizens and taxpayers. In comparison to purely marketoriented providers, social entrepreneurship is thus seen as a better solution, since social enterprises may include clauses limiting profit distribution and consequently ensure that profits are used for developing the social mission of the organisation.

It could thus be considered that the provision of welfare services is now "returning" to the civil-society organisations that had previously developed and taken care of these services. However, the public sector has changed, and so have civil society and the private sector. 
Social entrepreneurship is also seen as a means to enhance sustainability in deprived urban and rural areas. These areas may suffer from depopulation and diminishing employment possibilities. The local activities aiming to fight these trends mobilise the local people and empower them to contribute to their own community (Pearce 2003). However, critics point out that rural areas, which are not densely populated, may not offer the necessary conditions for any commercially related activity to be sustainable without government support (Pihlaja 2010). At the moment, the 311 Finnish municipalities are responsible for organising health and social services; the government (2015-2018) had committed that, in connection with the health and social-service reform, this responsibility would be transferred to the counties. As part of this reform, clients' freedom of choice would have been increased-"freedom of choice" refers to the fact that clients have the right to choose where to get health and social services, by using, for example, service vouchers and personal budget. The planned reform also provided that publicly funded health and social services would be provided by public, private and third-sector operators, such as associations and foundations; such marketisation of public social and health-care services would open up chances for different types of enterprises to become service providers. The reform also concerned business advice and employment services. Although the reform finally did not take place, the measures that it foresaw will most likely serve as a basis for further negotiations in the future. Experiments are currently being conducted to apply social-impact bonds and social clauses in public procurements. Social enterprises are also trying to find their niche in this marketisation of welfare and employment services.

In Finland, the growing body of small enterprises and entrepreneurs see business opportunities in solving contemporary complex socio-ecological problems (Houtbeckers 2014). For some, social entrepreneurship is a more meaningful career choice than the work in large, established organisations, whose activities may be seen as unethical or where work contracts can be unstable (Demos Helsinki 2010). Additionally, working as a social entrepreneur or having a job in a social enterprise constitutes ways through which the workers can contribute back to society (see, e.g., Elkington and Hartigan 2008).

\subsection{Institutionalised and Non-Institutionalised Social Enterprises}

Based on our understanding of the field, we divide Finnish social enterprises into two major categories: institutionalised and non-institutionalised social organisations. Institutionalised (see table 3.1) social enterprises include work-integration social enterprises and organisations that have been awarded the "Social Enterprise Mark" label. Work-integration social enterprises (sosiaalinen yritys) offer employment to the disabled and the long-term unemployed; they are regulated by Act 1351/2003. The second 
Table 3.1 Key figures about institutionalised social enterprises (November 2019)

\begin{tabular}{lccc}
\hline & $\begin{array}{c}\text { No. of } \\
\text { enterprises }\end{array}$ & Total turnover & No. of employees \\
\hline $\begin{array}{c}\text { Work-integration } \\
\text { social enterprises }\end{array}$ & 26 & $\begin{array}{c}\text { About } € 9 \\
\text { million }\end{array}$ & $\begin{array}{c}\text { About } 100 \text { target } \\
\text { beneficiaries }\end{array}$ \\
$\begin{array}{c}\text { Social enterprises } \\
\text { with the Social } \\
\begin{array}{l}\text { Enterprise Mark } \\
\text { label }\end{array}\end{array}$ & 240 & $\begin{array}{c}\text { About } € 5.2 \\
\text { billion }\end{array}$ & About 23,600 \\
\hline
\end{tabular}

group is formed, as just mentioned, by the enterprises that have been granted the Finnish Social Enterprise Mark (ybteiskunnallinen yritys) label; this label is intended for businesses that aim to address social or ecological problems and which promote social aims, reinvest the majority of their profits to promote their social or environmental aims, and have an open and transparent business model.

Given the needs of Finnish society and the priorities according to which available funding is allocated, the government's focus in terms of SE development has been on work-integration and welfare services provision. Simultaneously, social enterprises are diversifying their activities and finding new fields of action.

There are reliable data only on institutionalised forms of social enterprise in Finland: the register of work-integration social enterprises is updated frequently by the Ministry of Economy and Employment, and the Association of Finnish Work holds an up-to-date register of Social Enterprise Mark organisations. By contrast, criteria and data about the non-institutionalised spectrum of social enterprises-initiatives producing social value through their products or services, mostly in the field of social services and welfare-and their impact remain insufficient, thus resulting in the "invisibility" of these organisations and in ignorance of their specific features and needs.

Non-institutionalised forms of social enterprise include new cooperatives, private work-integration organisations, social- and welfare-service organisations (owned by associations and foundations), and soci(et)al-impact-oriented small businesses ("smart-ups"). The Research Institute of the Finnish Economy conducted a comprehensive survey (Kotiranta and Widgrén 2015) to analyse the state of social enterprise in Finland; the study estimated that there were around 19,000 self-identified social enterprises in Finland, employing about 125,000 persons. Despite the lack of institutional support for these organisations, practitioners and researchers consider them to be part of the SE field in Finland, for reasons explained below.

The old cooperative movement has a distinct history in Finland, which we do not cover here; it should however be mentioned that "old" 
cooperatives can also be-and usually are-considered as social enterprises. Compared to "old cooperatives", "new cooperatives", which emerged in the early 1990s, played a more important role in providing employment to the unemployed during the economic crisis that hit the country at that time (Pättiniemi 2004: 5) and thereafter. There are about 1,600 new cooperatives in the country (Pellervo 2015: 67). New cooperatives also play a role in many sparsely populated areas and villages, organising services (e.g., for the elderly) and offering work opportunities to farmers in their spare time and to the unemployed. Some cooperatives are established to offer work opportunities to different groups in culture and arts. Various cooperatives are set up by young people interested in social media and information technologies (Moilanen et al. 2014: 105-7). There are about 1,500 water and sewage cooperatives that provide fresh water, mainly to households and farms, and play an important ecological role, protecting the environment. Although new cooperatives are marginal compared to the overall number of companies in Finland, their work seems to be meaningful in their local areas (Pihlaja 2010).

In the Finnish inclusive welfare system, there are some "special-need areas", in the fields of social, welfare and work-integration services, where the provision is ensured by specific associations and foundations. These organisations have been established to provide services to their members and/or target groups. They have emerged in three waves: first, during the early urbanisation and industrialisation stage, from 1860 to 1920 (Nygård 2001: 182-9); secondly, after World War II, from 1945 to the 1960s (Nylund and Yeung 2005: 45-6); and finally, from the 1990s up to the present (Kostilainen and Pättiniemi 2013: 43-6). These periods correspond to times of change and fast-growing social needs (Kostilainen and Pättiniemi 2013: 44). In recent years, some of these organisations have separated their voluntary activities from their professional activities by establishing social enterprises, with a view to professionalising their business activities to adapt to ongoing public-sector reform.

Social- or societal-impact-oriented small businesses refer to activities that are legally organised as businesses (limited-liability companies or even publicly listed companies), but which pursue the goal of generating positive social or societal impact. In Finland, there is a growing body of small enterprises and individual entrepreneurs who see business opportunities in solving complex contemporary problems and envisage adopting the legal form of a business organisation as a means to achieve positive social or societal impacts (Houtbeckers 2016a). It is argued that young Finnish professionals in particular want to contribute to solving pressing global problems (Demos Helsinki 2010).

Social entrepreneurs active in sectors dealing with contemporary issues (such as veganism, up-cycle design or open software development) seem to avoid the institutionalised forms of social enterprise (Houtbeckers 2016b). Instead of following the institutionalised models, these social 
entrepreneurs choose to work outside such forms; and instead of seeking continuous growth or economic success, they try to balance social and ecological impacts with economic ones.

\subsection{New Typology of Finnish Social Enterprises and Illustrative Examples}

In this section, we present the new typology of social enterprises in Finland put forward by Kostilainen and his colleagues in a previous publication (Kostilainen et al. 2016). The different types of social enterprise identified in this new typology were (1) social enterprises providing public welfare services, which offer a wide range of social-welfare and health-care or employment services; (2) emerging alternative economic initiatives, which are part of the growing sharing-economy trend; (3) impact businesses and smart-ups, some of which are supported by the Slush Global Impact Accelerator programme ${ }^{5}$ and by +Impact by Danske Bank; ${ }^{6}$ and (4) socialimpact redistributors, that is, organisations that manage capital to create measurable social and environmental impact alongside financial return.

Between 2016 and 2018, we carried out a study using the analytical framework designed by the International Comparative Social Enterprise Models (ICSEM) Project: we used the ICSEM questionnaire to conduct interviews with the managers of 19 Finnish organisations and matched the interview data with publicly available data. For the purpose of the present chapter, we then chose four organisations (all presented under a pseudonym), each of which is representative of one of the categories of the new typology. The characteristics of these four organisations are summarised in table 3.2. We selected them because their activities adequately reflected the spirit of the category they represented. Moreover, at the time of the writing of the present chapter, they had all been granted the Social Enterprise Mark label; they were thus fairly stable and all belonged to the category of institutionalised Finnish social enterprises-so their SE status was clear.

\subsubsection{Social Enterprises Providing Public (welfare) Services}

\section{Overall Description}

Most institutionalised social enterprises-that is, organisations included in the register of work-integration social enterprises maintained by the Ministry of Employment and Economy and those that have obtained the Social Enterprise Mark label-belong to this category. Many noninstitutionalised enterprises can also be classified in this category, which has developed due to the transformation of welfare-service provision and to the emergence of a "welfare mix" in the provision of various public services. The public sector (and in particular municipalities) provide the 


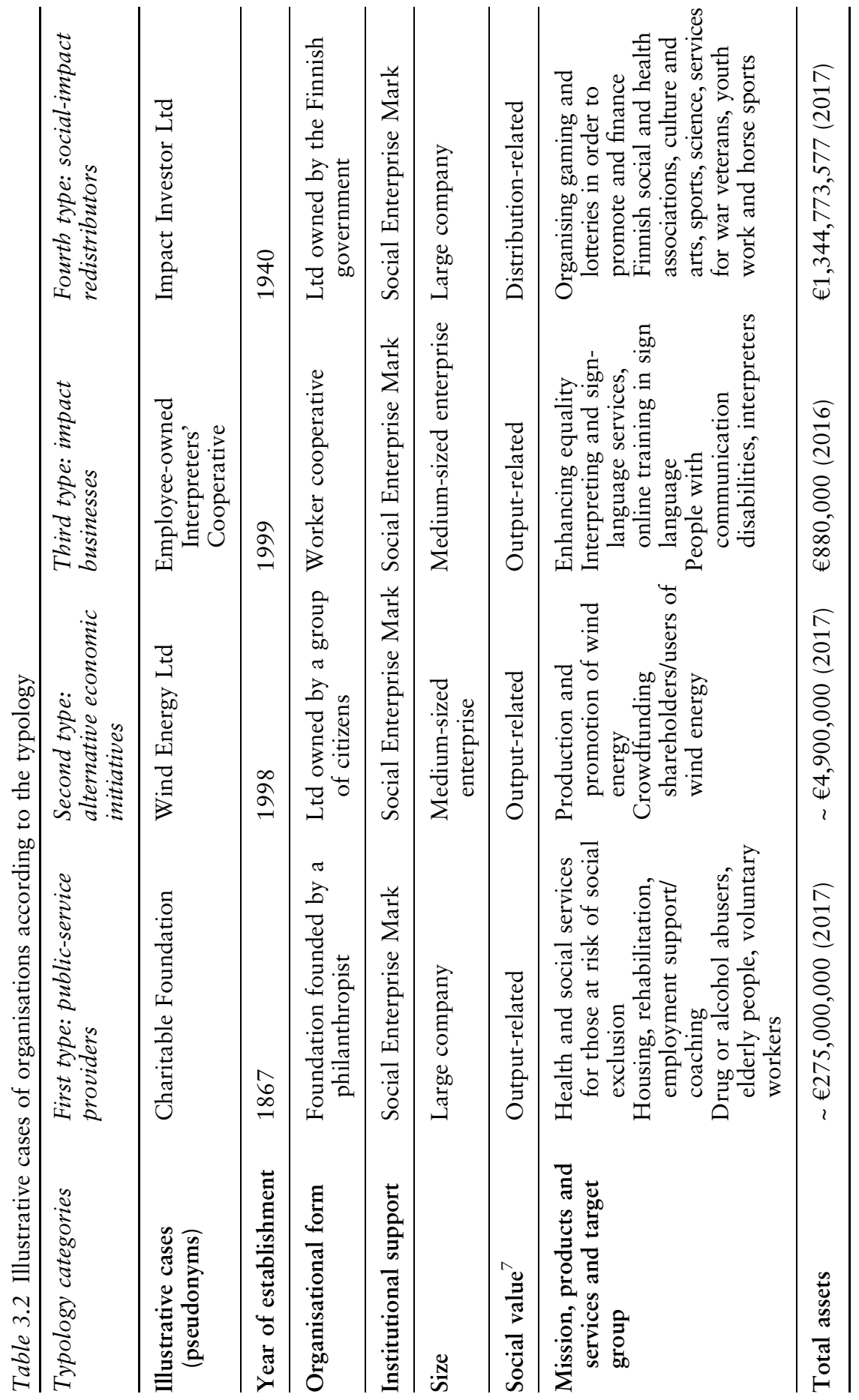


market for organisations in this category through public procurement, service vouchers and other types of contracting. These organisations work mainly in the field of welfare services, but also in work-integration and capacity-building activities.

\section{An Example: "Charitable Foundation"}

Charitable Foundation, established in the mid-1990s, forms, together with its subsidiaries, an SE group providing a range of social and healthcare services, as well as educational services. The social-value creation of the SE group lies in providing specialised social and health services to the public sector. The group has been granted the Social Enterprise Mark label and it identifies itself as an expert and leader in tackling difficult social issues in the major cities in Finland.

The group's business model is based on the mission defined by Charitable Foundation's owner-namely to create new solutions in parts of society where, for one reason or another, people are in danger of falling beyond the reach of conventional services. The social objective of the group is to uphold human dignity by providing help to people at risk of social exclusion.

The foundation operates in accordance with the Finnish Foundation Act (109/1930, amendments up to 487/2015) and its subsidiaries follow company law (Act 349/2017). The SE group is an active player in local, national and international networks, and these are important for the realisation of the group's mission.

According to the company's latest available financial statement (2017), the total assets of the SE group amounted to almost $€ 275$ million. The profits were around $€ 87$ million, mainly due to the fact that the foundation sold one of its subsidiaries to the largest health-care service company in Finland. The group employs about 1,000 professionals and over 2,000 volunteers and people providing peer support to clients.

\subsubsection{Emerging Alternative Economic Initiatives}

\section{Overall Description}

Organisations in this group aim to introduce alternative economic models for providing services that have social impacts or contribute to social change. This group consists mainly of new cooperatives and associations with values related to community development, equality and ecological sustainability. The chosen organisational model is closely linked to the values of these initiatives, although some cooperatives have grown economically strong, compete with private-sector firms, and thus may have fewer connections to the grassroots actors than what used to be the case. 
An Example: "Wind Energy Ltd"

In the late 1990s, a group of environmental activists established Wind Energy Ltd, the first Finnish nationwide customer-owned green electricity company producing wind power. Today, it has more than 1,200 shareholders, including private citizens, companies, societies and local communities.

This social enterprise creates social value by producing green energy that is sold only to its shareholders. The company has been granted the Social Enterprise Mark label and it identifies itself as a forerunner promoting sustainable-energy solutions through its unique customerownership concept.

The development of the company's ethical business model was made possible by the liberalisation of the Finnish electricity market. The company's mission was to create new sustainable solutions to provide green energy. It was achieved by building wind generators and by raising awareness about and advocating for wind-energy experiences among the general public and decision-makers. The growth model has been based on a combination of different funding measures, including inter alia crowdfunding and bonds.

The enterprise operates in compliance with company law (Act 349/2017) and it is active in the national network of wind-energy producers. According to its by-laws, the company allocates its surplus to investments in new windenergy generators. According to the enterprise's latest available financial statement (2017), the total assets of the social enterprise amounted to almost $€ 5$ million, and the profits were around $€ 95,000$.

\subsubsection{Impact Businesses and "Smart-Ups"}

\section{Overall Description}

This group consists of organisations with a for-profit legal form-including limited-liability companies, cooperatives and sole proprietorships-that aim for social value or social impacts. While many of these enterprises' values echo those of emerging alternative economic initiatives, organisations in this third group differ from those in the second category to the extent that they rely on models enabling the accumulation of wealth by a limited number of people, since they do not all have asset locks nor limits on the distribution of profits (the cooperative model being an exception in this regard). In practice, only few of these organisations have become economic success stories; most of them employ and thus support only a limited number of people. This model enables the emergence of new, experimental, and often crossdisciplinary professions via entrepreneurship; such positions would not be supported or would be limited in the public sector or in large organisations. 


\section{2}

An Example: 'Employee-Owned Interpreters' Cooperative”

Employee-owned Interpreters' Cooperative enhances equality by producing interpreting, sign-language-related services to hearing-impaired people, who have a subjective right to receive these services covered by the government. The staff founded the cooperative in order to create a safe, pleasant and innovative working community, in addition to securing a regular income for themselves. All terms and conditions of work are defined in an extensive collective agreement. As one of the largest small-scale cooperatives in Finland, Employee-owned Interpreters' Cooperative operates efficiently, employing over a hundred interpreters organised in teams.

Employee-owned Interpreters' Cooperative strives for profitability and follows cooperative law. The enterprise invests in the training and welfare of its staff, and it aims to deliver the best possible quality of work. According to this organisation, decision-making in the annual general meeting is democratic, each member has one vote, and the company operates in accordance with the international cooperative principles, with the aim of actively and legitimately developing the entire interpreting field. Every employee and cooperative member has the possibility to influence the company's operations. The cooperative has obtained the Finnish Social Enterprise Mark label.

According to the latest available financial statement (2017), the turnover of the enterprise amounted to $€ 4,662,000$, and the profits were around $€ 14,000$.

\subsubsection{Social-Impact Redistributors}

\section{Overall Description}

Social-impact redistributors are income generators for social-impactoriented social organisations belonging mainly to the category of social enterprises providing public (welfare) services (described in subsection 3.3.1). Social-impact redistributors operate solid businesses, generating profits which they re-invest into their other (innovation-oriented) social objectives.

\section{An Example: "Impact Investor Ltd"}

Impact Investor Ltd is a Finnish betting limited-liability company. It is owned by the Finnish state and is subject to regulations on limited-liability companies and to the State Shareholdings and Ownership Steering Act (1368/2007). The company's operations are regulated by the Lotteries Act (1047/2001), according to which the company has an exclusive legal betting license on lotteries and sports betting in the country.

The company's task is to operate betting in such a manner that the legal protection of those engaging in betting activities is guaranteed, 
abuse and criminal activity are prevented, and any economic, social and health-related problems are prevented and reduced.

Betting is estimated to generate nearly $€ 1$ billion a year in Finland. The revenue is used for the benefit of Finnish society in its entirety. Beneficiaries are active in the fields of culture, sports, science, youth work, social welfare, health and the equine industry. The funds are distributed to the beneficiaries by the relevant ministries; for example, the Ministry of Social Affairs and Health operates the Funding Centre for Social Welfare and Health Organisations (STEA), which manages the funding granted to projects which are non-profit by nature and promote health and well-being.

The social enterprise creates social value by distributing profits to socialimpact-oriented organisations. According to the latest available financial statement (2017), the turnover of the social enterprise amounted to $€ 1,344,773,577$, and the profits were around $€ 1$ billion.

\subsection{Findings}

In this last section, we discuss the results of our analysis, based on the four emblematic cases presented above and the survey conducted in nineteen Finnish social enterprises. Out of these nineteen cases, seven organisations can be considered as public-service providers; three, as alternative economic initiatives; four, as impact businesses; and five, as social-impact redistributors. Fifteen of the nineteen studied organisations had obtained the Social Enterprise Mark label.

After analysing the creation of social value by these enterprises, we compare the Finnish examples to ICSEM findings.

\subsubsection{Social Value: Input, Output, Process and Profit Distribution}

When we consider the collected data, there seems to be a division between large, well-established initiatives, on the one hand, and small, more contemporary organisations, on the other hand. The former organisations have a healthy balance sheet, while small organisations have small revenue streams and less assets.

Regardless of their size, social enterprises create different kinds of social value in the areas of input, output, process and profit distribution (Alegre 2015; Kostilainen and Tykkyläinen 2015). Input-related socialvalue creation refers to social enterprises having a social focus on input in the production process-for example, fair-trade businesses. Outputrelated social value is created when the social value is embedded in the product or service, as this is for example the case for social services. Process-related social-value creation occurs in enterprises having a social focus on the process part of the production, as for example, workintegration social enterprises. Finally, distribution-related social value is 
created by businesses that generate profits to support the social mission of other social enterprises.

Our findings align with previous research about social-value creation in the Finnish context: social-impact redistributors (fourth type), as could be expected, mainly focus on social-value creation linked to profit distribution. Social enterprises providing (public) welfare services (first type) focus on the outputs. However, work-integration social enterprises, which we consider as initiatives belonging to the first type as well, focus on processrelated social-value creation. Emerging alternative economic initiatives (second type) seem to be interested in output-related social-value creation combined with process-related social-value creation. Finally, impact businesses and smart-ups (third type) seem to constitute the most diversified group in reference to the social-value-creation models presented above: while some enterprises in this category emphasise inputs, others focus on outputs, and others still on processes.

\subsubsection{Comparing Finnish Typology to ICSEM Models}

The ICSEM Project has put forward a typology including four major models of social enterprise, namely the entrepreneurial non-profit (ENP), the social-cooperative (SC), the social business (SB) and the public-sector social enterprise (PSE) models (Defourny and Nyssens 2017). In this section, we offer a brief overview of possible correspondences between this typology and types of Finnish social enterprises.

The role of entrepreneurial non-profit (ENP) social enterprises in Finland is connected to the ongoing reform of public-sector service provision. Traditional social-welfare associations and foundations react to increasing competition and the opening of welfare and employment markets by adopting more market-oriented behaviours. They also seek to "complement public grants and donations with new sources of funding" (Defourny and Nyssens 2017: 2480).

In the Finnish context, public-sector social enterprises (PSE model) refer to enterprises owned by municipalities or the government. Often, they focus on work-integration activities or social services.

Our example illustrating the social-impact redistributor type of social enterprise in the Finnish typology can be considered to share traits with both the PSE and the ENP models. This reflects the ideas of new public management and the changes that have occurred in terms of responsibility for organising public services in Finland. Non-profit organisations increasingly apply business approaches in their activities, while they are expected to take more responsibility in the production of public services. Such social-impact redistributors, combining traits of the ENP and PSE models, seem to constitute an example of a unique form of social enterprise in Europe.

In Finland, although the characteristics of cooperative-type social enterprises (SC model) are reflected in the description of the category of 
emerging alternative economic initiatives in our typology, cooperatives are actually met across all types, as shown by the illustrative example of the category of impact businesses. Overall, in the country, there is a long tradition of employee-owned cooperatives in Finland. However, emerging alternative economic initiatives and new cooperatives seem to lack institutional support.

The category of social business reflects the philosophy of the Finnish Social Enterprise Mark label, which emphasises a view of social enterprises as businesses. The organisations which we classified, in our typology, as impact businesses and "smart-ups" share with social businesses an emphasis on scalability and innovations. Some Finnish cases highlight heroic social entrepreneurs who are believed to change the world through their unique social business.

\section{Conclusion}

In this chapter, we attempted to capture the diversity of SE models in Finland. We examined to what extent contemporary Finnish social enterprises follow the traditions of social enterprises identified in previous research, and to what extent they represent reactions to the changes in the institutional environment and to new types of socio-ecological challenges. We conclude that different understandings of the institutional development of social enterprises interact with one another. Social enterprises, whatever the extent of institutional support they receive, need to adapt to the changing environment.

The Finnish business environment is characterised by the fact that it makes the limited-liability company the preferred legal form among enterprises. This results in a narrow conception of possible forms for enterprises, let alone social enterprises. While the start-up hype, including the start-up event Slush, has increased awareness about developing new businesses, there is still a little emphasis on developing social enterprises. Rather, the focus is on (high-)growth businesses. As a result, actors in the SE field experience that there is little reputational and no "governmental" benefits to be gained from launching and operating a social enterprise. Moreover, some actors in the field report opposition toward social enterprises on the part of some entrepreneurship and innovation organisations, which (falsely) argue that social enterprises get more government support than other enterprises.

From a plural-economy perspective, such an opposition between social and "regular" entrepreneurship is unnecessary. Different categories of enterprises, such as "start-ups", "growth enterprises", or "social enterprises" have different activities, impossible to summarise under one heading without analysing the activity. In a toolbox approach developed by Gibson-Graham et al. (2013), labour, enterprise, transactions, property and finance may all have capitalist, alternative (to capitalism) and non-capitalist orientations. For instance, an organisation may obtain its funding from the mainstream market while relying on waged or subsidised labour, such as work for welfare, and 
using open-access property, such as wind. This results in navigating these different orientations when it comes to organising labour, enterprise, transactions, property and finance.

As a result of such "navigation", organisations may pursue their goals in different ways. Likewise, social enterprise, as an organisation, can be encountered in various settings. Therefore, social enterprises have various legal forms. Some use the form of a limited-liability company, while others adopt cooperative, association or foundation models. Such diversity is welcomed, and it can be observed in the contemporary field of social enterprise in Finland. This diversity is difficult to capture in any typology or model.

Despite the neutral - and sometimes even hostile-environment, there exist social enterprises in Finland. Some of them are well established and financially stable, while others struggle to maintain their activities. The latter category would no doubt benefit from more institutional support. Given the scarcity of institutional support for all social enterprises, it seems obvious that actors in many social enterprises must be highly motivated to carry on and develop their initiatives' activities. For example, some nonprofit organisations have successfully used social enterprise as a model for business activities. The changes in the institutional environment have also opened up possibilities for social enterprises and diverse forms of economic activity. Time will tell how organisations seize these opportunities.

\section{Acknowledgements}

We thank Soilikki Viljanen for being part of the ICSEM team in Finland and for contributing to discussions, as well as Prabesh Khatiwada for generating parts of the Finnish ICSEM survey data.

\section{Notes}

1 This book chapter is partly based on Kostilainen Houtbeckers and Pättiniemi (2016).

2 Cooperative Law of 1902 (latest amendment in 2014); Law on Association of 1919 (latest amendment in 1989); Foundation Law of 1930 (latest amendment process completed in 2015). Mutual (insurance and financial) companies are regulated by the Cooperative Law and the Insurance Company Law.

3 Information collected from publicly available databases on economic information (www.is.fi/yritykset) and from the register of work integration social enterprises (https://tem.fi/rekisteriin-merkityt-yritykset, accessed on November 22, 2019).

4 Information from the Association of Finnish Work (accessed on November 22, 2019) and database of the Association of Finnish Work (https://suomalainentyo. fi/tietoa-meista/jasenyritykset/\#merkki/yhteiskunnallinen-yritys, accessed on November 22, 2019).

5 See www.slush.org/gia/.

6 See https://plusimpact.io/.

7 Alegre (2015); Kostilainen and Tykkyläinen (2015). For an explanation of the different kinds of social value, see section 3.4.1 in this chapter. 


\section{References}

Alegre, I. (2015) "Social and economic tensions in social enterprises: Does it exist?", Social Business, Vol. 5, No. 1, Westburn Publishers Ltd, pp. 17-32.

Bland, J. (2010) Yhteiskunnallinen yritys - ratkaisu 2000-luvun haasteisiin Ison-Britannian malli ja sen kokemukset, Helsinki: Työ- ja elinkeinoministeriö julkaisuja.

Defourny, J. \& Nyssens, M. (2010) “Conceptions of social enterprise and social entrepreneurship in Europe and the United States: Convergences and divergences", Journal of Social Entrepreneurship, Vol. 1, No. 1, pp. 32-53.

Defourny, J. \& Nyssens, M. (2017) "Fundamentals for an international typology of social enterprise models”, VOLUNTAS: International Journal of Voluntary and Nonprofit Organisations, Vol. 28, No. 6, pp. 2469-2497.

Demos Helsinki (2010) Parempi diili - ybteiskunnallisen yrittäjän riemulaulu, Helsinki: Demos.

Elkington, J. \& Hartigan, P. (2008) The Power of Unreasonable People: How Social Entrepreneurs Create Markets That Change the World, Boston: Harvard Business Press.

Gibson-Graham, J. K., Cameron, J. \& Healy, S. (2013) Take Back the Economy: An Ethical Guide for Transforming Our Communities, Minneapolis; London: University of Minnesota Press.

Hjorth, D. (2008) "Nordic Entrepreneurship Research", Entrepreneurship Theory and Practice, Vol. 32, No. 2, pp. 313-338.

Houtbeckers, E. (2014) "Yhteiskunnallisen yrittäjyyden toimijoiden kirjo Suomessa”, Tieteessä tapahtuu, No. 3, pp. 7-11. Available HTTP: https:// journal.fi/tt/article/view/41558/10651 1.8.2020.

Houtbeckers, E. (2016a) Mundane Social Entrepreneurship: A Practice Perspective on the Work of Microentrepreneurs, Aalto University Publication Series "Doctoral Dissertations", 171/2016, Aalto: Aalto University.

Houtbeckers, E. (2016b) "The tactics of ecopreneurs aiming to influence existing practices”, Small Enterprise Research, Vol. 23, No. 1, pp. 22-38.

Kerlin, J. A. (2006) "Social enterprise in the United States and Europe: Understanding and learning from the differences", VOLUNTAS: International Journal of Voluntary and Nonprofit Organisations, Vol. 17, No. 3, pp. 246-262. Available HTTP: https://doi.org/10.1007/s11266-006-9016-2.

Kostilainen, H. \& Pättiniemi, P. (2013) "Evolution of the social enterprise concept in Finland”, in Kostilainen, H. \& Pättiniemi, P. (eds) (2013) Avauksia ybteiskunnallisen yritystoiminnan tutkimukseen. Yhteiskunnallisen yritystoiminnan tutkimusverkosto ry FinSERN, Riika: In Print.

Kostilainen, H. \& Pättiniemi, P. (2016) "Evolution of the social enterprise concept in Finland", in Lundgaard Andersen, L., Gawell, M. \& Spear, R. (eds) Nordic Contributions to Social Entrepreneurship, London and New York: Routledge.

Kostilainen, H. \& Tykkyläinen, S. (2015) “The characteristics of Finnish social enterprise", in Kostilainen, H. \& Pättiniemi, P. (eds) Ybteiskunnallisen yritystoiminnan monet kasvot. FinSERN 2. Konferenssijulkaisu. Diakoniaammattikorkeakoulu. C katsauksia ja aineistoja 42, Tampere: Juvenes Print Oy, pp. 21-43. 


\section{Kostilainen, Houtbeckers \& Pättiniemi}

Kostilainen, H., Houtbeckers, E. \& Pättiniemi, P. (2016) "Social enterprise in Finland", ICSEM Working Papers, No. 37, Liege: The International Comparative Social Enterprise Models (ICSEM) Project. Available HTTP: https://www.iap-socent.be/sites/default/files/Finland\%20-\%20Kostilainen \%20et\%20al.pdf (1.8.2020).

Kotiranta, A. \& Widgrén, J. (2015) "Esiselvitys ybteiskunnallisesta yrittämisestäKatsaus ybteiskunnallisiin yrityksiin ja vaikuttavuusinvestoimiseen Suomessa”, ETLA Raportit, No. 46.

Moilanen, H., Peltokoski, J., Pirkkalainen, J. \& Toivanen, T. (2014) Uusi osuuskunta: tekijöiden liike, Helsinki: Into Kustannus Oy.

Nygård, T. (2001) Erilaisten historiaa. Marginaalirybmät Suomessa 1800 luvulla ja 1900-luvun alussa, Jyväskylä: Areena Kustannus.

Nylund, M. \& Yeung, A. B. (eds) (2005) Vapaaehtoistoiminta anti, arvot ja osallisuus, Tampere: Vastapaino.

Pättiniemi, P. (2004) "La nuova legge impresse sociali in Finlandia”, Impressa Sociale, No. 4/2004, Brescia.

Pättiniemi, P. (2006) Social Enterprises as Labour Market Measure, Kuopio: University of Kuopio.

Pearce, J. (2003) Social Enterprise in Anytown, London: Calouste Gulbenkian Foundation.

Pellervo (2015) Osuustoiminnan vuosikirja 2015.

Pihlaja, R. (2010) Kolmas sektori maaseutukunnissa, Helsinki: Helsingin yliopisto Ruralia-instituutti. 


\title{
4 Social Enterprise in France At the Crossroads of the Social Economy, Solidarity Economy and Social Entrepreneurship?
}

\author{
Francesca Petrella, Nadine Richez- \\ Battesti, Laurent Fraisse, Jean-Louis \\ Laville and Laurent Gardin
}

\section{Introduction $^{1}$}

Social enterprise (SE) is a notion that is little discussed in France, by comparison with other national contexts. The guiding hypothesis of this chapter is that the SE notion, as initially conceptualised within the EMES International Research Network (Defourny 2004), is little used in France since it does not correspond to a stabilised approach. In fact, it takes different forms, situated (as represented in figure 4.1) between three "poles" that characterise the current French situation: the social economy, the solidarity economy and social entrepreneurship.

The criteria traditionally defining social-economy organisations in France are the following: They combine a group of persons and a production unit of goods (or services) that are reciprocally linked in a dual relationship of activity and membership (Vienney 1994). They develop socially necessary activities within the framework of specific rules: democratic functioning, rules for the allocation of surpluses and collective ownership. These criteria were included in the Social-Economy Charter, written by the organisations themselves in 1980.

The solidarity economy, for its part, brings together all the activities contributing to the democratisation of the economy through citizen involvement. The major characteristic of this perspective is that it considers these activities not only in terms of the legal form under which they are carried out (association, cooperative, mutual society, etc.), but also through their dual-economic and political-dimension (Eme and Laville 2006).

The aim of social entrepreneurship is to create a profitable or costefficient economic activity responding to social and environmental needs in the framework of a private initiative serving the general interest (Dees 1998). The emphasis is thus placed on the combination of economic efficiency and a social objective, with the purpose of reinvesting economic surpluses into the social mission. In France, the concept of social entrepreneurship is closely related to that of social entrepreneur, 


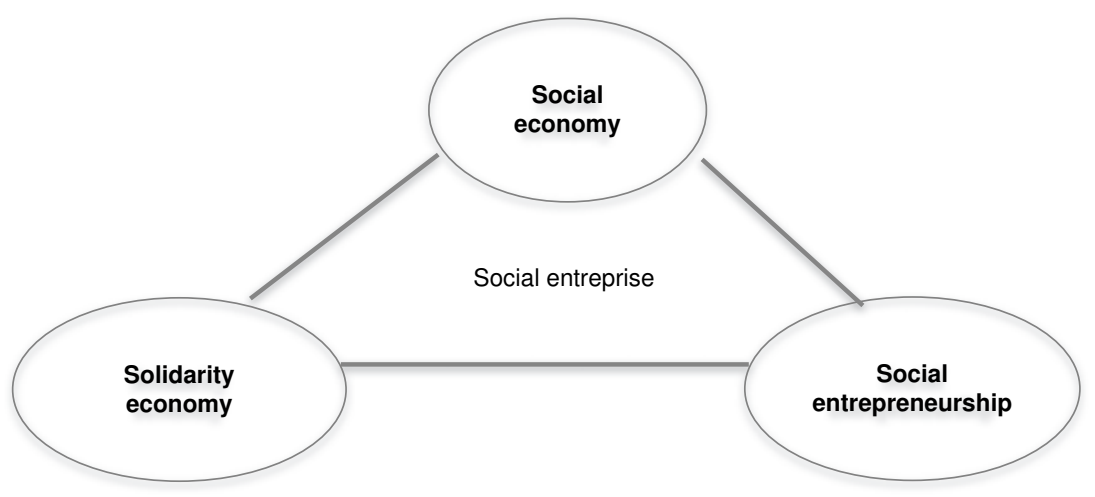

Figure 4.1 Social enterprise in France: at the crossroads of three "poles".

highlighting the individual characteristics of the entrepreneur and his/her behaviour (Mair and Marti 2006).

Nevertheless, the most commonly used concept today to refer to private organisations whose main objective is not to maximise profit but to address unmet societal needs and whose governance is democratic (following the "one person, one vote" principle) is that of the social and solidarity economy (SSE). This SSE notion is the result of an institutional compromise, reached at the end of the 1990s between actors from the social economy and the solidarity economy, as explained below, but the two poles still exist. The SSE, which accounts for more than $10 \%$ of the country's total employment, is now recognised as a major force in the French economy. An important step towards its institutionalisation was achieved with the adoption, in July 2014, of a specific framework law that lists the criteria defining an SSE enterprise. Until this framework law was passed, in the current vocabulary and in national statistics, the SSE included only associations, cooperatives, mutual societies and foundations; the law opened up the field of the SSE to commercial companies that fulfil a set of conditions (which will be described later in the chapter).

In the first part, we briefly review the history of these various socioeconomic practices, identifying their different phases of institutionalisation and giving some hints to understand their current coexistence and the institutional compromise that constitutes the SSE. In the second part, building upon the EMES approach to social enterprise, we identify three models or ideal types of what could be regarded as social enterprise in France-even though the term is not often used by the organisations themselves-and the main tendencies that researchers in the field consider as important. In the third part, we analyse how these models differ from or, conversely, are linked to the tradition of the social and solidarity 
economy, which dominates today in the French context. The conclusion summarises the limits and prospects of SE initiatives in France.

\subsection{Social Enterprise and the SSE: Historical Overview of Their Institutionalisation Process}

With a view to understanding the current issues linked to social enterprise and the SSE in France, we look back at history. The roots of the social and solidarity economy can be traced back to the middle of the 19th century, in relation to the industrial revolution. The first workers' organisations and social movements developed in response to social demands for democratic solidarity, in the context of the rise of associationism (which combined such demands with the claim for equal rights for all citizens), leading to the creation of the first mutual societies and cooperatives. In the second half of the 19th century, the legal forms of cooperative, mutual society and association were progressively and separately recognised by law, and they became distinct from trade unionism. At the end of the 19th century, the notion of a "social debt" gave a central role to the principle of redistribution and to the welfare state. At the same time, however, the sight was lost of the role that associations could play in the construction of solidarity and of the more horizontal, reciprocal dimension of solidarity which they embodied. Public redistribution seemed sufficient to correct the inequalities created by the market.

After World War II, the society was understood as the simple addition of the market and the welfare state. Associations became service providers for public authorities. They were enrolled in social policies through relations submitted to supervisory regulations; public authorities financed activities for which they set the norms. In parallel, mutual societies were more or less integrated in the social-welfare system and considered complementary service providers, while cooperatives increasingly asserted themselves as noncapitalist enterprises on the market. The distance between associations, mutual societies and cooperatives increased to the point where, for a number of them, the very idea of common identity was lost.

Nevertheless, a historic alliance was forged in the late 1970s between representatives of cooperatives, mutual societies and associations around common statutory principles. They joined together in 1976 to create the national liaison committee of mutualist, cooperative and associative activities (CNLAMCA). ${ }^{2}$ This committee elaborated a Charter of the Social Economy in 1980 and a Joint Declaration in 1991. The social economy tried to demonstrate that non-capitalist enterprises, which are characterised by property rights that are not proportional to the capital held, could exist. In this sense, cooperatives-enterprises initiated by the voluntary grouping of associates-were at the heart of the theorisation of the social economy (Demoustier 2001). The exhaustion of the state-market 
synergy that was a fundamental characteristic of the "Glorious Thirty" (i.e., the thirty years-1945-1975 — of unprecedented growth that followed the end of World War II) also contributed to the institutionalisation of the social economy. More than in other European countries, the social economy in France sought to organise itself and to secure its own recognition in the political and institutional spheres as a set of organisations whose operating rules were distinct from those of capitalist enterprises.

In the course of time, however, with the growth of some of its organisations and the transformation of their environment, the social economy suffered from a tendency to banalisation, in the sense that social-economy organisations tended to become increasingly similar to traditional enterprises, limiting their mission to their economic dimension and neglecting their political and social-transformation aim. Some social-economy organisations indeed encountered difficulties in the exercise of democracy, in mobilising their associates or in supporting processes of emancipation, especially when they were growing.

The solidarity economy emerged in a context of crisis and in reaction to the institutionalisation of the social economy and to its tendency towards market isomorphism; it claimed to have a political capacity of social transformation. The distinction-of political nature-between the solidarity economy and the social economy lies in the fact that solidarityeconomy organisations are considered to belong to the public domain, in the sense that these are not envisaged as private organisations, but as citizens' initiatives calling for public action.

Between the 1970s and the 1990s, the solidarity economy favoured a return to solidarity practices, a reflection on the dynamics of participation and a theorisation of exchange (Laville 1994), and it was marked by a resurgence of the principles of the pioneering associationism of the first half of the 19th century. The reaffirmation of the political dimension was accompanied by questions on the economic dimension. As regards the economic order, the solidarity economy builds upon Polanyi's denunciation of the "economistic fallacy", which equates the economy with the market, and on the distinction established by this author between the orthodox, formal economy and the substantive economy. Indeed, all economic activities can be envisaged as involving a combination of various economic principles (redistribution, reciprocity and the market), rather than by referring solely to the market principle.

After a period of tensions between social-economy organisations and solidarity initiatives, these two groups forged an alliance that strengthened their position in the dialogue with public bodies. As mentioned above, a compromise was achieved in the 2000s on the term "social and solidarity economy" (SSE). It resulted from another step of the institutionalisation process, in which the main milestones were the creation of a state secretariat for the solidarity economy, which existed from 2000 to 2002, and the emergence, for the first time, of local elected politicians in charge of the 
solidarity economy, with the constitution of a "Network of territories for the solidarity economy" (Réseau des territoires pour l'économie solidaire, or RTES). The local politicians-who aimed to marshal a broad coalition of actors and networks to construct the legitimacy of a new field of action for local authorities-and part of the practitioners and researchers used the term "social and solidarity economy", influencing in return the structuring of the territorial grouping of the actors, who progressively adopted this terminology. But this compromise does not resolve internal tensions between the social economy and the solidarity economy concerning democratic issues, the political dimension and the banalisation process.

Moreover, social entrepreneurship—strongly—raises the question of the integration, into the social and solidarity economy, of organisations that do not adopt the traditional legal forms of the SSE (association, mutual society, cooperative, foundation). By contrast to what is the case with the solidarity economy, the growing interest towards social entrepreneurship is linked to the rise of the ideology of the enterprise, which is increasingly seen as the only legitimate form of collective action (Laval 2007; Foucault 2008).

The Law on the Social and Solidarity Economy (Law No. 2014-856), which was adopted on 31 July 2014, opted for an inclusive definition of the SSE. This law has an important symbolic significance: it gives official recognition to another way of conducting economic activities and provides a legal basis for the social and solidarity economy, the principles of which are summarised in Article 1 (SSE organisations must pursue an objective other than the distribution of profits; they must have a democratic governance; profits must be reinvested in the activity; there must be asset lock, etc.). With these principles, only the legal statutes of association, mutual society, cooperative and foundation were included in the SSE, leading to what was called the "statutory" approach of the SSE. The novelty lies in Article 2, which opens up the field of the SSE to commercial companies whose economic activity pursues a social-utility aim (support to persons in fragile situations, fight against exclusion and inequalities, education in citizenship, promotion of sustainable development) and whose management corresponds to specific requirements (reinvestment of part of the profits, restrictive takeover conditions, etc.). Commercial companies meeting these requirements can be granted the specific label of "social-utility solidarity enterprise" (entreprise solidaire d'utilité sociale, or ESUS), as detailed in Article 11. Enterprises with the ESUS label could be considered, strictly speaking, as the only type of officially recognised social enterprise in France. In March 2019, according to the Ministry of Economy and Finance, about 1,700 enterprises had received this label. ${ }^{3}$ But limiting the analysis of the French SE field to enterprises with the ESUS label would be too restrictive an approach, in particular with the EMES indicators describing the ideal-typical social enterprise in mind. 
Due to the spreading of market regulation and competition and the evolution of contemporary capitalism towards the inclusion of more ethical or environmental considerations, the links between the three existing poles in France (the social economy, the solidarity economy and social entrepreneurship) appear more or less "stretched". It is in this context that the notion of social enterprise has emerged in France. Although the concept is not often used by practitioners, its apparition questions the links and boundaries between these three poles.

\subsection{Three Models of Social Enterprise}

Within the French context, which socio-economic practices could be considered as corresponding to the notion of social enterprise, and which ideal types could be identified among these?

Building upon the conceptual approach of the EMES Network (Defourny and Nyssens 2012), we distinguish three main models or ideal types of social enterprise, although French stakeholders do not necessarily name them as such. The first two can both be seen as resulting from the evolution of French SSE initiatives. The first one emphasises the enlargement of governance to multiple stakeholders that led to the emergence of new legal forms within the SSE, and in particular to the creation of the legal form of collective-interest cooperative and to the formalisation of territorialised cooperation among a diversity of stakeholders (pôle territorial de coopération économique, or PTCE). The second one results from an evolution of the socio-economic model of associations, in a context marked by budgetary constraints, pressure on welfare states and increased competition. In such a context, many associations have adopted a more entrepreneurial model. The third model is linked to the emergence of commercial businesses with a social purpose, in line with the social-entrepreneurship pole described earlier.

\subsubsection{General-Interest and Multiple-Stakeholder Organisations}

The first model corresponds to general-interest and multiple-stakeholder organisations.

Historically, the cooperative form is the most entrepreneurial type of social-economy organisation. Traditional cooperatives are in general mainly governed by one type of stakeholder (workers, consumers, producers). However, as in many European countries, where new SE legal forms appeared in the 1990s and 2000s (Laville and Nyssens 2000), the need to take into account the interests of a plurality of stakeholders and to pursue a general-interest purpose emerged (Nyssens and Petrella 2009) among cooperatives in France, leading to the creation, in 2001, of a new legal form, the collective-interest cooperative (société coopérative d'interêt collectif, or SCIC). 
The SCIC form allows for the involvement of multiple stakeholders, thanks to a specific governance structure characterised by the existence of several possible "colleges" (of employees, users, volunteers, local authorities; any physical or legal person who contributes to the activity can belong to a college). At least three colleges are required, of which two are obligatory: the college of employees and that of users. The economic activity is clearly carried on for the benefit of the community rather than for that of the organisation's members alone; the socialutility character of the production is recognised by public authorities.

SCICs' social-utility character and multi-stakeholder governance are their most specific features; these characteristics distinguish them from the earlier, more traditional types of cooperative and bring them closer to the EMES ideal type of social enterprises, as far as the governancerelated and social criteria are concerned.

Although steadily rising, the number of SCICs created so far remains modest: there were 974 SCICs in 2019. ${ }^{4}$ This slow development can be put down, among other causes, to the complex functioning of the multistakeholder cooperative form, and to the fact that recognition of the social utility does not entitle the organisation to any particular tax or regulatory regime as compared to commercial companies.

The enlargement to multiple stakeholders is also observed at the interorganisational level, in the emergence in 2012 of "territorial poles of economic cooperation" (pôles territoriaux de coopération économique, or PTCEs). Territorial poles were recognised by the 2014 Law (Article 9); each pole gathers different organisations in a given territory, such as commercial enterprises, SMEs, local public authorities, research and training centres and SSE organisations; they all cooperate in order to develop innovative projects to foster sustainable local development. ${ }^{5}$ In 2017, there were over 150 PTCEs in France. PTCEs are quite similar to clusters and industrial districts, but they differ from these in that they are initiated by SSE actors, who are at the heart of their multi-stakeholder governance (Fraisse 2017; Demoustier and Itçaina 2018).

An example of social enterprise corresponding to this first SE model is provided by "A taste of illusion" (Un goût d'illusion). This SCIC is a limitedliability company that supports cultural and artistic projects in performing arts. It helps to professionalise cultural organisations, which often lack administrative, managerial and strategic expertise. The project started in Montpellier with the creation, in 2000, of the association Illusion et Macadam. In 2010, the association decided to adopt the SCIC form, with the name "A taste of illusion", as the project had reached the limits of the associative legal form. The innovative choice of this cooperative status was motivated by the will to take into account the diversity of stakeholders' interests and to reinforce the collegial functioning in a context of the lack of volunteers. The multi-stakeholder governance indeed facilitates the involvement of the multiple stakeholders by formalising their partnerships and the 
"network-type organisation" increases the initiative's capacity to adapt to new opportunities and anticipate changes in the environment.

\subsubsection{Entrepreneurial Associations}

The second model corresponds to entrepreneurial associations, which typically mix resources and tend to scale up.

The institutional developments of the 2000s led some segments of the associative world to evolve in a more entrepreneurial direction and to scale up to position themselves on the market and stand up to the growing competition. Indeed, the increase in public procurement practices (Tchernonog 2013), which replaced to some extent the traditional mode of financing by grants, combined with the entry of for-profit enterprises into sectors such as home-care services (Fraisse and Petrella 2012) or child care (Petrella and Richez-Battesti 2013), led to a diversification of associations' strategies. The growing recourse to contracting-out practices is leading associations to merge or join forces to reach a critical mass in order to be able to respond to this evolution. Several strategies of growth (through mergers or takeovers), mutualisation or grouping (through membership in a federation or the creation of territorial or sectoral networks) have been observed and have radically changed the structure of the associative sector across the national territory (Richez-Battesti and Malo 2012).

This managerial turn (Hoarau and Laville 2011) takes different forms: diversification of activities, managerial professionalisation through the adoption of managerial tools and practices, etc. Some communityeducation federations (Bucolo 2011) or more recently created mediumsized associations managing several structures, as in the case of child-care services (Petrella and Richez-Battesti 2013), set up central headquarters covering the whole country and offer their services to local authorities in areas in which they had previously not been historically active. These practices call the associative project into question, whenever associations' role evolves into managing local services of general interest in a top-down way, in the framework of public procurement and managerial requirements defined by public authorities.

These transformations have led the Associative movement (Mouvement associatif), which represents the federations in sectors as diverse as social work, community education and sport, to try to position itself and make proposals in the public debate. It expresses a new and strong awareness of a need for change in the socio-economic model of associations, with a view to integrating a plurality of types of exchange (Mouvement associatif 2014). Associations adopting such a socio-economic model are close to the EMES ideal type of social enterprise, even though they do not explicitly refer to it.

This model can be illustrated by Family Help (Association pour l'aide aux familles), in Valréas. This association, created in 1961 as an organisation of 
volunteers, provides home-care services (housekeeping and support for children's education) to families in need and dependent persons (elderly and disabled persons). It succeeded, until now, to adapt to the constraints of its environment while keeping strong social, ethical and associative values. It is, however, a constant challenge. A major strength of the association lies in its willingness to improve the quality of both jobs and services. Some forty years after the organisation's creation, the board appointed a director to face the increasing volume of activity and change in the legislative environment. ${ }^{6}$ Relying on his solid experience both in the financial and business world and in the social and cultural world (community centres, vocational training), the director initiated changes in the governance and management of the organisation.

\subsubsection{Commercial Businesses with a Social Purpose and Social Entrepreneurs}

Work-integration social enterprises (WISEs) are one of the oldest SE models; the first WISE emerged in France in the late 1970s (Gardin 2013). WISEs were progressively institutionalised in the 1990s as an instrument of employment policies. They are referred to as "organisations for integration through economic activity" (structures d'insertion par l'activité économique, or SIAE). The SIAE sector is composed of a large variety of organisations: some are more oriented towards social integration, while others are more focused on work integration; some are clearly operating on the market, while others are more dependent on public subsidies. Organisations' characteristics depend inter alia on the characteristics of the workers whom they try to integrate. While many SIAE initiatives belong to the first or the second models presented above, others can be considered to be part of a third model, which corresponds to commercial businesses with a social purpose and to social entrepreneurs. Some historic leaders of the work-integration field define themselves as social entrepreneurs and are among the founders of the "Movement of social entrepreneurs" (Mouvement des entrepreneurs sociaux, or Mouves), a network of social entrepreneurs created in France in 2010 .

These common roots of work-integration enterprises and social entrepreneurship tend to relativise the hypothesis of a simple "importation" of the SE concept from the English-speaking world. Some leaders of Mouves now aim to move beyond the role of simple "intermediation" that they have been playing on the labour market and to enter dynamics of concentration and merging. In such context, social entrepreneurship would then be in part (but not solely) an evolution of some SIAEs aiming at a change of scale and pursuing a goal of local economic development, thus contributing to the emergence of the third model.

This model of social enterprise generally emphasises the central role of the social entrepreneur, who is an individual with an entrepreneurial 
spirit dedicated to a social purpose. This conception of social enterprise is thus more related than the other two models to the social-innovation school of thought (Dees and Anderson 2006). The statutory form appears secondary, while the process and the social purpose predominate. The legal form is neither a necessary condition nor a sufficient one to characterise social entrepreneurship; common principles-solidarity and economic efficiency-are more important.

This model is close to the EMES ideal type of social enterprise, even though the participative-governance dimension or limits imposed on profit redistribution are not always central and the individual dimension of entrepreneurship is dominant. As a matter of fact, within this group, some social enterprises may have neither a democratic voting system ("one person, one vote") nor a participatory decision-making process (involving a diversity of stakeholders, such as workers or users), and some of them might not impose a clear limitation on the distribution of profit (although a social or societal purpose does exist, it is not sufficient in itself to ensure that a limitation is imposed on the distribution of profits). In most cases, no criteria linked to the legal form, governance issues and limitation of profit distribution are mentioned in the bylaws, the focus being on the priority given to the social mission. An analysis, on a case-by-case basis, of enterprises' bylaws and profit-distribution criteria is thus necessary here to determine whether the social enterprise implements democratic or participatory governance or not.

An example illustrating this model is provided by a WISE named La Varappe. It was originally an association, but it changed its structure, legal form and scale to face the evolutions of its competitive and institutional environment. La Varappe was first created in close cooperation with local public authorities to foster work integration on their territory. Being active on competitive markets, La Varappe had to grow and change scale. It chose to adopt a commercial legal form (société par action simplifiée) to attract capital to develop its activity. Today, the founding association is part of a holding (Optima), composed of different subsidiary WISEs, and it owns more than one-third of the shares of the holding, along with other shareholders (in particular, solidarity investment funds and managers). Throughout this evolution, though, La Varappe was very careful to adopt important safeguards to guarantee that the pursuit of the social mission remained the priority goal of the holding and to protect the association's values. The holding has been labelled as a work-integration social enterprise and as a social-utility solidarity enterprise (ESUS). In 2017, 87\% of La Varappe's workforce was composed of workers in integration and at least $20 \%$ of the benefits of the organisation were allocated to asset lock.

Finally, these three models are partially converging towards the EMES ideal type of social enterprise-even though the main divergences, resulting from the different models' social, historical and political embeddedness within the SSE, are likely to persist in the future. Not all 
social enterprises from the third model correspond to the EMES indicators, but the border is hard to draw in France for the time being.

\subsection{Social Enterprises: Between Rupture and Continuity}

The first two major sections of this chapter highlight the importance of the boundaries or, conversely, of recognition of an entrepreneurial continuum between different socio-economic practices that combine, in various ways, an entrepreneurial dimension with a social mission. Indeed, we identify several elements of continuity between the three models presented above and the SSE tradition in France (Gardin 2013; Petrella and Richez-Battesti 2014); but, at the same time, the "social-impact-investment" (Martin 2013) and the "socialbusiness" (Yunus 2007) trends are now calling these continuities into question and suggesting the existence of "breaking points" between these different approaches.

The individual entrepreneur often plays an important role in social enterprises: in the third model, the emphasis is on the personal characteristics of the entrepreneur, as in Ashoka's approach. ${ }^{7}$ By contrast, in the SSE and in the first and second models of social enterprise presented above, although the question of the founder of the enterprise remains important, the role of the individual entrepreneur is often eclipsed by the collective and participatory dimension of entrepreneurship, in particular in terms of the attention paid to a wide range of stakeholders, whether internal or external to the organisation. This difference in focus creates a dividing line between the third model, on the one hand, and the first and second models of social enterprise, on the other hand.

The focus on an economic dimension, embedded in the market, which is observed in all models of social enterprise, goes back to the founding model of the social economy, which was marked by cooperatives. However, this anchoring in the market should be weighed against the mechanisms of redistribution and reciprocity (Eme and Laville 2006; Laville and Nyssens 2000: 323-7) which, combined with the market mechanism, lead in social enterprises to a hybridisation of resources that is more important than in a purely market-based model. In this regard, a dividing line emerges between the advocates of the SSE and of the first and second models, on the one hand, who favour resource hybridisation, and those of social entrepreneurship and of the third model, on the other hand, who emphasise integration into the market.

The form of governance and, more broadly, the internal democratic process constitute crucial dimensions distinguishing the SSE and the first and second models, on the one hand, from some visions of social enterprise or social entrepreneurship (from the American schools of thought) and some social enterprises belonging to the third model, on the other hand (Petrella and Richez-Battesti 2013). Indeed, the democratic rule of "one person, one vote" is fundamental in social enterprises belonging to the first 
two models and distinguishes these organisations from capitalist enterprises and from some social enterprises belonging to the third model, within which the decision-making power is proportionate to the capital invested. For some social enterprises belonging to the third model, the criterion of democratic governance is not relevant. These enterprises differ from capitalist enterprises mainly through the social or environmental objectives they pursue, to which at least part of the enterprise's profits is devoted. But these social enterprises' behaviour is quite similar to that of capitalist enterprises adopting corporate social responsibility (CSR) practices.

As the boundaries between the different SE models are becoming increasingly blurred, the questions of capital holding, allocation of profits, distribution of decision-making power and involvement of a diversity of stakeholders in various governance mechanisms of the organisation become primordial and must be studied on a case-by-case basis. The pursuit of a social mission is not enough for an enterprise to be considered as a social enterprise belonging to the SSE, and this is where a major difference lies with some social enterprises belonging to the third model and considered as social enterprises by some actors (from Mouves or Ashoka) while not meeting all the EMES indicators of the ideal-typical social enterprise.

The three models that we identified are linked to SSE initiatives, which highlight solidarity not solely directed towards their members or their users. But while the social-utility dimension is shared by SSE organisations and social enterprises, evidencing a degree of continuity between the SSE and social enterprises, a point of divergence can be identified in the political positioning of the projects. Although the social-entrepreneurship approach specific to the third model underlines a will to "re-socialise the enterprise", bringing competitive markets into the social field, importing private-enterprise management style and moving closer to major groups may lead to a "depoliticising" of the social question and to the belief that this question can be handled by managerialism alone.

In synthesis, although we have observed that social enterprises present many elements of continuity with the SSE, the major point of divergence between social enterprise and the SSE concerns the fact that, in some social enterprises, in particular among those belonging to the third model, the legal form and the democratic governance principle (which goes along with the focus on the social objective of these organisations) become less important. Moreover, the "drift" that can be observed in many "social businesses", which totally reject the hybridisation of resources and prioritise alliances with big corporations, has also been pointed out as an element of differentiation between some social enterprises and the SSE.

\section{Conclusion}

We have observed diversity of models among the organisations that could be referred to as social enterprises in France. These models 
highlight important evolutions of the SSE, notably in terms of enlarging the involvement of multiple stakeholders, reinforcing the entrepreneurial dimension or changing scale. The development of commercial businesses with a social aim, labelled as "social-utility solidarity enterprises", which fit into the third model identified above and which are considered by law to be part of the SSE, reinforces the heterogeneity of the SSE. One major risk associated with this growing diversity is a weakening of the overall recognition of the SSE, despite the attempts of the law to promote such recognition.

More generally, the difficulties of "positioning" social enterprises in France are related to larger debates. These debates have been strongly influenced by North-American schools of thought, which emphasise the social mission and the figure of the individual entrepreneur. By contrast, the European EMES approach is rather marked by a multidimensional perspective, based on the identification of three types of indicators, namely economic, social and governance-related indicators. These indicators combine elements relative to the organisational and institutional dimensions of social enterprise. In France, the two perspectives-a strictly organisational conception of social enterprise and one that combines the organisational and institutional dimensions-are coexisting.

If we analyse social enterprise through the lens of the organisational conception, the three models offer a way out of the binary oppositions between economic and social dimensions, and between the for-profit and the non-profit stances. Social enterprise creates "porosities"; it shifts the boundaries and seeks to create articulations where there were barriers. It strives to articulate at least three rationalities, by aiming simultaneously to produce a social good or a social service in an innovative way; to construct a viable and efficient economic model within the framework of limited profitability; and to associate its stakeholders, in particular its users, through strategies of co-production. These rationalities can, however, collide, be hierarchised (with one being given the priority over others) or be subject to compromises. In any case, they presuppose a successful combination of private initiative and satisfaction of the general interest by responding to demands hitherto unsatisfied or poorly satisfied. Few impact studies have so far been made on these new organisations and their real contributions to economic and social development, and there is not yet sufficient hindsight to assess their capacity to persist in the long term. These emerging models are undeniably succeeding in transforming the imaginative capacities of entrepreneurship and in promoting original responses to the challenges that society is facing, but so far they have contributed little to new modes of regulation of the economy.

The perspective that articulates the institutional and organisational dimensions is, for its part, related to the current international debates on social enterprise (Petrella and Richez-Battesti 2014; Coraggio et al. 2015), which call for a recognition of economic pluralism. Beyond their 
economic and social activity, social enterprises are also sites for expression, which contribute to the construction and management of the common good through a dialogue with public authorities that is at once conflictual and constructive. Their economic and social dimensions cannot be separated from their institutional dimension. They must assume their deliberative function, come together and speak up more strongly for a new dialogue with public authorities. But recognition of their institutional role presupposes an approach that is not focused on the Anglo-American definitions, but turns to a deeper analysis of the realities of social enterprise in continental Europe, Africa, Asia and South America.

\section{Notes}

1 This chapter is based on a Working Paper produced under the International Comparative Social Enterprise Models (ICSEM) Project (Fraisse et al. 2016).

2 Created in 1970 by cooperatives and mutual societies, this liaison committee was enlarged to associations in 1976. In 2001, this committee changed its name to become the "Council of enterprises and groupings of the social economy" (Conseil des Entreprises et Groupements de l'Économie Sociale, or CEGES). Since the 2014 Law, it has become the Chamber of the Social and Solidarity Economy (Chambre française de l'Économie Sociale et Solidaire, or ESS France).

3 See https://www.tresor.economie.gouv.fr/banque-assurance-finance/financesociale-et-solidaire/liste-nationale-agrements-esus.

4 Les SCIC en chiffres. Available on www.les-scic.coop/.

5 See http://www.lelabo-ess.org/+-PTCE-+.html.

6 A new law concerning social services was passed in 2002 (Loi de janvier 2002 rénovant l'action sociale et medico-sociale).

7 Ashoka defines itself as a community of leading social entrepreneurs that supports people, not projects; see https://www.ashoka.org/sites/www.ashoka. org/files/2013-Impact-Study-FINAL-web.pdf.

\section{References}

Bucolo, E. (2011) "Fédération Léo Lagrange, des orientations pour l'avenir", Rapport d'étude, Paris, October.

Coraggio, J., Eynaud, P., Ferrarini, A., Carvalho de França Filho, G., Gaiger, L. I., Hillenkamp, I., Kitajima, K., Laville, J. L., Lemaitre, A., Sadik, Y., Veronese, M., Wanderley, F. (2015) "Theory of the social entreprise and pluralism: The social enterprise of the solidarity type", in Laville, J.-L., Young, D. \& Eynaud, P. (eds) Civil Society, the Third Sector and Social Enterprise, London and New York: Routledge.

Dees, J. G. (1998) “The Meaning of 'Social Entrepreneurship'”, Working Paper, Stanford: Stanford University, Graduate School of Business.

Dees, J. G. \& Anderson, B. B. (2006) "Framing a theory of social entrepreneurship: Building on two schools of practice and thought", Research on Social Entrepreneurship: Understanding and Contributing to an Emerging Field, ARNOVA Occasional Paper Series, 1(3), pp. 39-66. 
Defourny, J. (2004) “L'émergence du concept d'entreprise sociale", Reflets et Perspectives, Vol. XLIII, No. 3, pp. 9-23.

Defourny, J. \& Nyssens, M. (2012) "The EMES approach of social enterprise in a comparative perspective”, EMES Working Papers, No. 12/03, Liege: EMES International Research Network. Available HTTP: http://emes.net/content/ uploads/publications/EMES-WP-12-03_Defourny-Nyssens.pdf.

Demoustier, D. (2001) L'Économie sociale et solidaire: S'associer pour entreprendre autrement, Paris: La Découverte.

Demoustier, D. \& Itçaina, X. (2018) Faire territoire par la coopération: l'expérience du Pôle territorial de coopération économique Sud Aquitaine, Sarrant: Editions La Librairie des territoires.

Eme, B. \& Laville, J.-L. (2006) "L'économie solidaire”, in Laville, J.-L. \& Cattani, A. D. (eds) Dictionnaire de l'autre économie, Paris: Gallimard, pp. 303-312.

Foucault, M. (2008) The Birth of Biopolitics: Lectures at the Collège de France, 1978-1979, Basingstoke: Palgrave Macmillan.

Fraisse, L. (2017) "Mieux caractériser les PTCE face à un processus rapide d'institutionnalisation", RECMA - Revue internationale de l'économie sociale, No. 343, pp. 19-39.

Fraisse, L. \& Petrella, F. (2012) "Introduction", in Petrella, F. (ed.) Aide à domicile et services à la personne. Les associations dans la tourmente, Rennes: Presses Universitaires de Rennes, pp. 9-22.

Fraisse, L., Gardin, L., Laville, J.-L., Petrella, F. \& Richez-Battesti, N. (2016) "Social Enterprise in France: At the Crossroads of the Social Economy, Solidarity Economy and Social Entrepreneurship?”, ICSEM Working Papers, No. 34, Liege: The International Comparative Social Enterprise Models (ICSEM) Project. Available HTTP: http://iap-socent.be/sites/default/files/France\%20-\%20Fraisse $\% 20$ et\%20al_0.pdf.

Gardin, L. (2013) "Entrepreneurs sociaux et économie sociale et solidaire, continuités et ruptures", XXXIIIes Journées de l'Association d'Économie Sociale, Les nouvelles frontières de l'ESS, Cahiers du CIRTES, Presses Universitaires de Louvain, HS, No. 3, pp. 121-148.

Hoarau, C. \& Laville, J.-L. (2011) La gouvernance des associations, Paris: Erès. Laval, P. (2007) L’homme économique, Paris: Gallimard.

Laville, J.-L. (ed.) (1994) L'économie solidaire: une perspective internationale, Paris: Desclée de Brouwer.

Laville, J.-L. \& Nyssens, M. (2000) "Solidarity-based third sector organisations in the 'proximity services' field: A European francophone perspective”, Voluntas Journal of Voluntary and Nonprofit Organisations, Vol. 11, No. 1, pp. 67-84.

Mair, J. \& Marti, I. (2006) "Social entrepreneurship research: A source of explanation, prediction, and delight", Journal of World Business, Vol. 41, pp. 36-44.

Martin, M. (2013) "Making Impact Investible", Impact Economy Working Papers, Vol. 4, Impact Economy, Geneva: Impact Economy. Available HTTP: https://www.impacteconomy.com/download/Impact \%20Economy\%20\%202013\%20-\%20Making\%20Impact\%20Investible.pdf.

Mouvement associatif (2014) Repenser l'économie avec les citoyens. Available HTTP: https://nanopdf.com/download/repenser-leconomie-avec-les-citoyenspropositions_pdf. 


\section{Petrella, Richez-Battesti, Fraisse et al.}

Nyssens, M. \& Petrella F. (2009) “Finalité sociale et partenariat public-privé dans l'offre de services quasi-collectifs locaux: une forme innovante de propriété", Economie et Sociétés, Série EGS, No. 10, pp. 747-774.

Petrella, F. \& Richez-Battesti, N. (2013) "Business social, entreprise sociale et ESS: quelles formes de gouvernance? Entre similitudes et divergences ...”, in Hiez, D. \& Lavillunière, E. (eds) Vers une théorie de l'économie sociale et solidaire, Bruxelles: Editions Larcier, pp. 353-370.

Petrella, F. \& Richez-Battesti, N. (2014) "Social entrepreneur, social entrepreneurship, social enterprise: Semantics and controversies", Journal of Innovation Economics \& Management, No. 14, 2014/2.

Richez-Battesti, N. \& Malo, M.-C. (2012) "ESS et mutations organisationnelles”, RECMA - Revue Internationale de l'Economie Sociale, No. 325, July, pp. 36-47.

Tchernonog, V. (2013) Le paysage associatif français, mesures et évolutions, Hors-série, Paris: Juris associations, Editions Dalloz.

Vienney, C. (1994) L'économie sociale, Paris: La Découverte, Collection Repères.

Yunus, M. (2007) (with the collaboration of Jolis, A.) Vers un monde sans pauvreté, Paris: Le livre de poche. 


\title{
5 Social Enterprise in Germany Between Institutional Inertia, Innovation and Cooperation
}

\author{
Nicole Göler von Ravensburg, Georg \\ Mildenberger and Gorgi Krlev
}

\section{Introduction}

Although the term social enterprise (SE) is not legally defined and no precise common understanding of the concept exists in Germany today, around 70,000 German entrepreneurial organisations aim to promote the common benefit rather than individual gain (Göler von Ravensburg et al. 2018: 58-64). Some of them can look back on a long history, stretching back over 150 years. These organisations operate under a wide variety of forms, which emerged in different times and contexts, and against the background of different philosophies or traditions. They do not act or see themselves as a coherent "SE sector"; they are organised in separate groups or "families", with different identities, institutional and legal frameworks, research affiliations, education and training organisations, etc. The general "SE debate" in Germany is thus split and takes place-with some few exceptions-within these groups or families.

In the present chapter, we will outline the main discussion lines and models of what could be considered as social enterprise according to the indicators that make up the EMES Network's approach of the idealtypical social enterprise. These indicators have been used as a common frame of analysis within the ICSEM Project. ${ }^{1}$ We will discuss the current promotion of SE initiatives by public authorities as well as the general societal and the most relevant socio-economic conditions they face. As their numbers are greatest in the welfare sector, we will focus our assessment of potentials and likely future trends in this sector.

\subsection{The SE Debate in Germany}

The term "social enterprise" first entered the German context in the middle of the 1990s as Sozialer Betrieb, whose meaning was limited at the time to the concept of work-integration social enterprise (WISE). But the term Sozialer Betrieb (with some variations), which even referred to legal status in some German Länder (e.g., in Lower Saxony), soon fell 
into oblivion again, as WISEs failed to deliver on their promises (Birkhölzer and Lorenz 2001a).

At about the same time, the concept of "third sector" was introduced into German academic discourses by the International Society for Third-Sector Research (ISTR) ${ }^{2}$ and the Johns Hopkins Comparative Non-Profit-Sector Project $^{3}$ (Anheier et al. 1997; updated by Priller et al. 2012). The underlying concept of "third-sector organisation" (TSO) was subsequently used by several German surveys, including the "civil society in numbers" survey (Zivilgesellschaft in Zablen, or ZiviZ; see ZiviZ 2017). "Civil-society organisation" (CSO) was another term used. Yet, the statistics on TSOs and CSOs cover a far wider range of organisations than social enterprises, while neglecting recent SE start-ups. Consequently, in the absence of specific statistics on social enterprise, extrapolations are necessary to provide even a rough estimate of the number of social enterprises in Germany (Göler von Ravensburg 2018: 57-61).

The term "social economy", which appeared for the first time on the European Union agenda in the early 1990s, cannot easily be transferred to Germany, where the literal translation of the term is Sozialwirtschaft, which is used only for-public as well as private-enterprises/institutions offering statutorily defined welfare services. It thus neglects initiatives in fields other than social services, such as the production or use of common goods, culture, education, housing or ecology.

\subsection{Development and Models of "Social Enterprise” in Germany}

Social enterprises currently active in Germany have several historical precursors. There are strong associative roots in the country, as well as cooperative, mutual and other self-help groups traditions, usually associated with the "social economy" in much of Western and Southern Europe. Some social enterprises are supported by philanthropic actors through donations and "social investment", others by more businessoriented actors. There are very few social enterprises owned by public authorities; for the purpose of this exercise, they can be neglected. So far, most specific SE models tend to emphasise their differences rather than their common features; these models will be presented more or less in chronological order of their emergence.

\subsubsection{Associative Tradition, Charitable Roots and the Development of the Welfare State}

Germany has a very strong tradition of compulsory corporatist association from feudal and pre-modern times (Hartwig 1997). From the middle ages onward, church associations ran hospitals, soup kitchens and other similar initiatives, while craft or guild-related associations 
looked after social welfare and craft education, among other things. In the 17th and 18th centuries, new associations filled many of the gaps left by the end of feudal structures, including the management of natural resources (e.g., forest owners' associations, drainage and irrigation associations).

Enlightenment and the growth of civic society in the 18th century led to educated elites organising new common-good activities in voluntary associations, such as reading clubs. In 1794, Prussia was the first state in what is now Germany to grant its citizens the right to gather and associate freely. Truly German associative legislation (Reichsvereinsgesetz) recognising associations as non-commercial private-law entities (eingetragene Vereine, or e.V.) was only passed in 1908.

Federative structures for welfare-oriented associations were developed through a slow process matching the German nation-building and, later on, the development of the welfare state. The first umbrella organisations developed around the middle of the 19th century. With the codification of the welfare state in the Weimar Republic, these federal structures became important for liaising with the federal government, so most of the welfare organisations became members of one of the six federal organisations. These federated groups of voluntary associations, together with hundreds of non-affiliated local associations, gradually became the service-delivery agents of the growing welfare state.

Besides these welfare-delivering associations, many thousands of leisure, sports and cultural associations developed in the 20th century (Kirchheim 2013). But while the number of associations keeps increasing, the average number of members has been shrinking lately (Stiftung für Zukunftsfragen 2014). While $62 \%$ of all Germans were members of at least one association in 1990, this was only true for $44 \%$ of the population in 2013 .

\subsubsection{Cooperative Traditions}

Industrialisation and urbanisation in Germany resulted in dire distress among small farmers, craftsmen and small retailers in the second half of the 19th century. The cooperative idea seemed a functional antidote to this issue. In particular, the model of credit and savings cooperative soon became promoted very effectively by Raiffeisen and Schulze-Delitzsch. In rural areas, credit- and savings-related activities were usually combined with agricultural purchasing and marketing activities, while in urban areas, credit and purchasing were usually dealt with in separate cooperatives. The shortage of urban housing, coupled with the fact that a great number of local municipalities and regional governments gave housing cooperatives a public-benefit status (Gemeinnützigkeit), thereby exempting them from most taxes, also brought about a strong movement in the housing sector, albeit this movement developed a little later (in the 19th and early 20th centuries) than that of credit and savings cooperatives. 
By contrast, the number of consumer cooperatives remained rather small, and worker cooperatives have always been a marginal phenomenon. Generally speaking, the German cooperative history has been more oriented towards small and medium enterprises and farmers than towards the working class (see, among others, Engelhardt 1994).

For historical reasons, German cooperatives (eingetragene Genossenschaften, or eG) have been intent on adopting commercially viable business models and on achieving autonomy from the state right from the beginning. In order to achieve this, all cooperative sectors established strong structures for institutional collaboration, such as secondary-level cooperatives and companies for the organisation of bulk purchasing or common marketing (Verbünde), and central cooperative banks as well as federations (Verbände) at regional and national levels. In order to protect cooperative members from possible abuse, the federations assumed auditing responsibilities and the state obliged all cooperatives to become members of at least one auditing federation.

\subsubsection{Mutual Traditions}

There is a rich tradition in accident, fire, health and originally also burial mutual insurance (Versicherungsvereine auf Gegenseitigkeit, or VvaG) in Germany. In the early stages of the welfare state, many of these mutual insurances concluded contracts with the compulsory health insurance scheme introduced by the state, whereby they became subsidiary delivery agents. They remained private and autonomous in their governance but became subject to certain delivery norms set by the state. They are still non-profit seeking, continue to use surplus predominantly to improve their services for the members, and maintain an asset lock (Wendt 2013: 383). Many of them have since amalgamated several times, bought out other types of insurance firms, formed a myriad of daughter firms, and grown enormously: mutuals covered about $22 \%$ of the entire insurance market in Germany in 2003 (Wendt 2013: 384).

\subsubsection{Philanthropic Traditions}

In the 19th century, many industrialist families started foundations or gave their money to humanist, religious or art initiatives. The two world wars, hyper-inflation and the policies of the National Socialist regime brought an end to many foundations; yet a substantial number of these survived the 20th century, but few new ones were started until the late 1990s. Since then, politically supported initiatives for more civic engagement (e.g., change of trust law and public-benefit law in 2000) have resulted in the creation of thousands of new foundations.

An entirely new form of foundations was also introduced and popularised from the late 1990s by national and federal states' governments, 
namely the citizen foundation (Bürgerstiftung). Rather than relying on the money of a few big benefactors, this kind of trust can collect small donations from many people. At the last count, there were 408 Bürgerstiftungen, geared towards establishing a sustainable financial base for local-development initiatives (Stiftung Aktive Bürgerschaft 2019). The objectives of these citizen foundations are usually commonbenefit-oriented but with a local focus (Tietze 2013).

All foundations can either donate funds to other organisations, develop their own projects or do both. Most private foundations are merely funding third-party endeavours; a smaller part implements their own projects and programmes.

\subsubsection{Work-Inclusion and Work-Integration Social Enterprises (WISEs)}

In Germany, two different types of social enterprise offer opportunities for labour-market integration and work inclusion to two more or less distinct groups of people: people with disabilities (in Germany, the term "work inclusion" is now preferred for this group of people) and people with other labour-market handicaps.

\section{Work Inclusion of Persons with Disabilities}

Germany's tradition of sheltered work for people with severe physical or mental handicaps or irreversible psychological problems can be traced back to the late 19th century. It was drastically interrupted by the National Socialist regime in the 1930s. Post-World War II developments of regulating work integration for the handicapped only began again with the Social Welfare Act (Bundessozialhilfegesetz) in 1961 (BAGWfbM 2013). This Act created the financial basis for sheltered workshops (Werkstätten für behinderte Menschen, or WfbM). Partially as a result of an increasingly popular assisted-living movement, additional legislation was passed in 1974 to regulate the eligibility criteria and employment conditions for the 50,000 heavily impaired workers who were hired at the time in sheltered workshops. Another type of work-integration enterprise, employing a mix of persons with and without disabilities, became more and more popular. These initiatives were first called "integration enterprises" (Integrationsbetriebe), but they have since come to call themselves "inclusion enterprises" (Inklusive Unternehmen); they became legally acknowledged in 2001.

Since 1980, sheltered workshops have been recognised as organisations offering work integration rather than employment; the state covers part of the salaries and of the special integration services, such as transport. Employees are protected against dismissal, and their numbers have grown dramatically. In 1996, the Welfare Act was revised in such a way that 
workshops were forced to reduce their services; however, this did not stop the increase in the numbers of both workshops and jobs created.

Activities of and public financial support to workshops and inclusive enterprises are strictly regulated, and all these organisations are registered with state authorities. The latest discussions on the implementation of the International Convention on the Rights of Persons with Disabilities are likely to bring about new changes in this system in the near future (Göler von Ravensburg and Zillinger 2017).

\section{Work Integration for Long-Term Unemployed Persons}

The first WISEs aimed at the (re-)qualification and maintenance of employability of non-handicapped people (Beschäftigungs- und Qualifizierungsgesellschaften) were set up in West Germany in the 1980s for workers who would otherwise have been made redundant in the context of technological change in traditional industries, e.g. in NordrheinWestfalen. These enterprises were initiated either by workers, with the aid of trade unions, or by local authorities (Evers and Schulze-Böing 2001). Later on, several consortia of local authorities, welfare associations, churches and educational institutions took over; this was particularly frequent in the case of WISEs aiming to re-qualify their workers.

As a consequence of the unification process between East and West Germany, in the early 1990s, about 330 new WISEs were set up in East Germany (FES 1991; Vomberg 2013). These primarily aimed to train staff in new technological and entrepreneurial skills.

The number of WISEs for non-handicapped elderly and long-term unemployed has dwindled since the introduction of Labour Market reforms (especially "Hartz IV") in the early 2000s. The remaining WISEs largely take in adolescents and young adults without sufficient schooling, for courses of up to 18 months. They aim at an eventual integration into the general labour market. Most of their income stems from contracts based on the number of clients, won in calls for tenders issued by the Federal Labour Office (Bundesanstalt für Arbeit), augmented by sales income and project finance from (EU and regional) structural funds earmarked for the creation of new job opportunities (Vomberg 2013).

\subsubsection{From Community Action to Neighbourbood and Community Enterprises}

In the 1970s and 1980s, many so-called "alternative initiatives" were launched (on grassroots initiatives, see Birkhölzer and Lorenz 2001b). They were largely environmentally and ecologically oriented, and they soon formed a movement that eventually resulted in the creation of the political party Die Grünen/Bündnis 90. In entrepreneurial terms, these movements resulted in many self-governing enterprises, active in a broad 
array of activities - the enterprises set up included for example left-wing book shops, the first cooperative-type producers of solar cells, shops selling organic food, the first car-sharing organisations and initiatives similar to local exchange trading systems (LETS, also referred to as Tauschringe in Germany; see, e.g., Kuhn 2002). Many of these initiatives were never formalised, and were thus automatically treated as civil-law partnerships (Gesellschaft bürgerlichen Rechts, or GbR). Others grew and became limited-liability companies (Gesellschaft mit beschränkter Haftung, or GmbH). Although many of these organisations were, in essence, worker cooperatives, they usually shied away from registering as such, due to the requirements linked to this legal form (compulsory membership in the cooperative federations and relatively costly auditing). Today, most of them have become more or less "traditional" private enterprises. Those that continue to embody transformative ideas do not tend to identify with the term "social enterprise", although they frequently have significant market sales and demonstrate economic autonomy.

\subsubsection{Business Background}

The advent of social enterprises of a social-business kind and of corporate social responsibility (CSR) activities in the Anglo-Saxon understanding of the term can be traced back to the early 2000s. One of the milestones in the promotion of social entrepreneurship in the country was the foundation of Ashoka Germany, in 2003. ${ }^{5}$ Individuals as well as groups of social entrepreneurs set up enterprise models relying on innovation, niche markets and local or regional needs not yet covered by existing actors. Typical examples of this can be found in non-formal or complementary education, upcycling, fair trade and community services. These initiatives place a great deal of emphasis on the business approach as a means to serve hitherto underserved communities, such as migrants and people with certain types of handicaps. They frequently rely on public relations in order to obtain the needed additional non-market private-sector funding. Today, such innovative start-ups are frequently supported by organisations like Ashoka, Grameen Creative Labs, Genesis, Phineo, Schwab Foundation, BonVenture, enorm, Social Lab or Social Hub.

\subsection{Promotion by Public Authorities}

In 2010, in the course of its strategy to foster citizen engagement (Nationale Engagementstrategie), the German government explicitly embraced the goal to promote social enterprise. It used a definition of the term provided in the national strategy for citizen engagement that states, in a somewhat circular way (and interestingly, switches to individuals), that "social entrepreneurs 


\section{2}

Göler von Ravensburg, Mildenberger \& Krlev

are persons who, based on their individual engagement, set up social organisations which solve social challenges through innovative and entrepreneurial means" (Deutscher Bundestag 2012 2). The 2013 federal coalition agreement (Deutsche Bundesregierung 2013) also made specific mention of social innovation and social entrepreneurship. However, neither was repeated in the 2018 coalition agreement (Deutsche Bundesregierung 2018) and so far, SE promotion remains just one of several parts of the national strategy to foster citizen engagement. ${ }^{6}$

While several ministries have dealt with social enterprise in the past ten years (Göler von Ravensburg et al. 2018: 27-9), there seems to be an unspoken agreement at the moment that no precise definition is needed and no special legal form will be imposed. Little state support is exclusively targeted at social enterprises. At the same time, there is a great deal of freedom for the landscape to continue developing, but this situation also hampers precise data collection on social enterprises and the interpretation of the phenomenon in Germany.

Nevertheless, certain areas where the public sector at the federal level directly supports social enterprise can be identified.

First, with its engagement strategy, implemented through the Federal Ministry for Family Affairs, Senior Citizens, Women and Youth (Bundesministerium für Familien, Senioren, Frauen und Jugend, or BMFSFJ) from 2001 onwards, the federal government has publicised and promoted "citizen (or community) foundations" (Bürgerstiftungen, see above) (Deutscher Bundestag 2017: 320). The number of these citizen foundations has grown quickly in the first decade of this century, but it now seems that a kind of saturation has been reached.

Secondly, the rapid advent of about 850 energy cooperatives, with approximately 180,000 members (DGRV 2019), can be attributed to nine federal acts passed since 1999. These acts opened the possibility for small producers to feed electricity into the grid and gave priority to environmentalfriendly production (wind, solar, etc.) over conventional energy production. It also opened ways for citizens' investments into the transformation of the energy system. However, not all energy cooperatives can be considered as social enterprises from the point of view of the EMES indicators. In particular, not all energy cooperatives give primacy to the social (in this case ecological) aim over the economic one.

Thirdly, the first steps to create (state-aided) financing instruments for social enterprises have been introduced in 2012 by the BMFSFJ through the German credit bank for reconstruction (Kreditanstalt für Wiederaufbau, or KfW) (Göler von Ravensburg et al. 2018: 77).

\subsection{Societal Environment for Social Enterprise in Germany}

Several general socio-economic factors are currently influencing the environment for social enterprises in Germany. 


\subsubsection{General Socio-Economic Influences}

First, the role of civil society and citizen engagement are currently debated in the country, and this may lead to a redefinition of the relationship between the market, the state and civil society. Secondly, many municipalities can no longer afford to maintain certain infrastructures or services which they traditionally financed, even though they were not obliged to do so (e.g., sociocultural centres, as mentioned above, but also public swimming pools or sports arenas). This opens up a space of action for social enterprises. This is also the case in regions where structural unemployment is high (which has led to the emergence of community cooperatives and other new employment-creation initiatives) or where demographic change has led to publicly owned infrastructure decaying and commercial activity dwindling to such a degree that the remaining population seeks to mitigate the situation with civil-engagement strategies (e.g., by starting village shops or revitalising pubs and railway stations through self-help initiatives of various kinds). These trends are reinforced by the recent upsurge in public awareness created by various "social-entrepreneurship" promotion agencies.

The likelihood that individuals set up a SE venture is reduced by cultural predispositions in Germany, which tend to discourage social enterprise in three ways: entrepreneurial failure is viewed particularly critically; entrepreneurial culture is not very well developed in comparison to what is the case in other industrialised countries, and Germans are not overly apt to set up a business (Leppert 2008; Brixy et al. 2010).

There does not appear to be any overt party/political, church or tradeunion support for the idea of social enterprise (Vogt 2013a: 145; 2013b, based on Klemisch et al. 2010: 56), except by individuals at a relatively low decision-making level.

It is difficult to assess the role the German philanthropic culture plays in terms of supporting social enterprise: Germany is ranked $22^{\text {nd }}$ in the CAF World Giving Index 2018 in terms of help to strangers and time and money donated, and 19th when it comes to financial donations (CAF 2018). Yet, no one has so far established what portion of that giving goes into SE ventures. And although there are more high-networth individuals (HNWI) in Germany than virtually anywhere in the EU (Statista 2019), quite few of them seem to support social enterprise. In other words, there might be an untapped potential here (Glänzel et al. 2013; Scheuerle et al. 2013; Glänzel and Scheuerle 2016).

This said, the particular German opportunities for social enterprise outlined above, as well as Germany's relatively high per-capita income and economic strength, which make it possible for consumers to co-finance SE ventures and buy ethically, create market opportunities for SE ventures (Scheuerle et al. 2013; Kwan and Glänzel 2014). 


\subsubsection{Institutional Landscape of the Welfare System}

Many German social enterprises deliver welfare services and are facing, as a result hereof, some institutional peculiarities-if not obstacles-linked to Germany's welfare system (Nock et al. 2013).

Welfare services are largely publicly financed and they are provided in a subsidiary way: the state outsources service delivery to more than 100,000 organisations, most of which are associations belonging to one of the six large welfare associations (Wohlfahrtsverbände). The strength of the associative system relies on two specificities: first, associations have existed for a long time and have thus been able to acquire significant assets; and secondly, they have charitable, common-interest status (Gemeinnützigkeit), which, as already stated, entitles them to certain advantages in fiscal terms. This status also entails an asset lock and a non-distribution clause for surpluses as well as an obligation to render services to everyone in need; it is perhaps best described as a mixture of "not-for-profit" and "for the common benefit". It has developed as a consequence of the German tradition of subsidiarity in the field of social policy: the state would establish the law (at the federal and state level) and make funds available (at the municipal or district level), while non-state organisations of the "autonomous commonbenefit welfare" (freie Wohlfahrtspflege), as they call themselves, did the actual work. "Autonomous" in this context indicates independence from any government (non-governmental character-a fact which they are eager to emphasise). When granted charitable, common-benefit status (Gemeinnützigkeit), these organisations (as well as many leisure, sports, cultural and ecological associations) are exempted from income-related taxes (Abgabenordnung AO 1977, $\$ 52$ (2), Abs. 9). In the eyes of the general public, this status became the mark by which an organisation proved that it was a "non-profit organisation" (NPO). This status even came to be seen by social-welfare authorities as proof of worthiness and subsequently led to extended legally granted rights for such organisations to co-govern public social planning and allocation decisions.

However, Gemeinnützigkeit has two great disadvantages in terms of entrepreneurial activity: First, the surplus generated has to be spent "promptly" (zeitnah, as the law expresses this; in practice, within two years [Abgabenordnung AO 1977, $\$ 55$ Abs. 1, Nr. 5]), thus making longterm savings for future investments almost impossible. Secondly, the law describes specific activities which are deemed to be "for the common benefit", but excludes a lot of activities which might also be considered as being "for the common benefit" or "in the general interest".

On the other hand, Gemeinnützigkeit offers political influence. Their legally granted co-governing role allows these organisations and in particular their federations to exercise significant influence on policymaking and standard setting in social welfare (and in other policy areas, 
such as sports policy). Old associations are also frequently well capitalised, which gives them a competitive advantage. Newcomers in welfare delivery find it difficult to enter (quasi-)markets, and even more so since access often presupposes accreditation with the local or regional government and contracts are frequently still allotted as a result of negotiations rather than tenders.

\subsubsection{Social-Policy Environment}

Most German welfare organisations have experienced increasing strain in the last decade. Rights to services were personalised, public financing largely changed from subsidies to output-oriented contracting, and certification of quality standards was introduced. Welfare organisations were forced to take serious strategic decisions and have since been straining their managerial capacities (e.g., Brinkmann 2010: 247). A certain amount of scepticism on their part regarding the idea of social entrepreneurship and, in particular, a business-type social enterprise must be read in the light of the dramatic overall changes that have occurred in the governance of social services. Reacting to European endeavours to support social entrepreneurship, the consortium of the six big national welfare federations offered, in 2012, to cooperate with all "suitable social enterprises" (BAGFW 2012: 5; translation by the authors). The consortium acknowledged the importance of new actors for innovation and-albeit tentatively-offered to play a role in supporting their development (BAGFW 2012: 2).

At the same time, policymakers and service-delivery agents at the local and regional levels are either not convinced that "social enterprise" is anything more than another word for privatisation and for transferring service delivery into the hands of organisations pursuing for-profit interests (Skerutsch 2004; Heinze et al. 2013: 339-40; Scheuerle et al. 2015), or they have not yet actively stated any position of their own (Fuchs 2014: 93). Although social law, in several instances, stipulates that small and new suppliers should be preferred in communal contracting (see, e.g., the opening in SGB IX $\mathbb{S} 41$ ), these are still discriminated against (Göler von Ravensburg 2013) or experiencing serious problems with municipal lethargy, bureaucratic procedure and (socio-) political bias in favour of established actors (Heinze et al. 2013: 339-40; Fuchs 2014: 472-94).

It is also worth mentioning that the more innovatively a social enterprise behaves, the less likely it is to access sustainable long-term financing from (quasi-)public sources. Both external financing and service-contract conditions linked to public sources are designed to minimise risk rather than foster innovation. The institutional environment thus generally leads to enormous insecurities and high long-term risks for social enterprises. 
The more market-oriented the new service suppliers are, the more suspicion they also raise on the part of both professionals in the field of social welfare and the general public. Meanwhile, traditional welfare organisations carefully avoid public discussions on the economic aspects of their own activities, to the point where social-work professionals tend to neglect or even deny the need for economic considerations altogether. Future developments in the definition of the common-benefit status are seen to be important, not only in regard to taxation, but also in regard to possible equity and market revenues.

\subsection{Current Conceptual Debate in Germany}

Despite some fascination for creative business-type approaches to meeting unfulfilled social and ecological needs, current German attempts at conceptualising social enterprise do not stress structural, transformative or even political elements. Civil-society organisations, private citizens and companies largely engage in SE activities which complement (but do not replace) services commonly or legally falling into the responsibility of the state. Much cooperative and civic engagement, like that of citizen foundations, is seen by (local) public authorities as part of a local-development approach.

Currently, the main challenge in Germany is to overcome dogmatic attitudes which still alienate existing social welfare organisations and new social enterprises as well as to develop models for cooperation between these two kinds of organisation. While the non-profit sector seems to begin to accept entrepreneurial behaviour when it is coupled with social innovation, social enterprises without asset lock and limitations on profit distribution will have to prove that they are not just part of a social- or green-washing trend.

But welfare organisations are becoming increasingly aware of the opportunities that social entrepreneurship represents. All but one federal welfare associations have begun in 2017 to cooperate in the Social Enterprise Network Deutschland (S.E.N.D. e.V.), which aims to foster both intrapreneurship and cooperation with newer types of social enterprise. Combining the innovative power of SE start-ups with the knowledge, market access, capacities and financing power of well-established organisations is seen to be the way forward. Stakeholders that took part in the 2019 European Commission Mapping Report as well as those that participated in the EMES Cost Workshop on Social Enterprise in Social and Health Services, held in Frankfurt in early 2019, both emphasise the potential of mutual learning (EMES 2019).

\section{Conclusion}

In Germany, a broad and inclusive-if somewhat fuzzy-concept of social enterprise is in use. It can accommodate both entrepreneurially 
active common-benefit associations (BAGFW 2012) and more commercial, new-type social enterprises. Cooperative federations have not, so far, committed to any particular concept. Many of the new-style social enterprises emphasise their innovativeness, if not their transformative potential. Most academic conceptualisations also put a major emphasis on innovation. When compared to the SE conceptualisation put forward by the EMES Network, the biggest discrepancy probably lies in the fact that, in Germany, participatory governance is not yet recognised as a possible mitigation of commercialisation or even just as an issue worthwhile of a thorough debate.

New shortages of (urban) housing, depopulation trends in rural areas losing social infrastructure, an ageing population, digitalisation, shortages in skilled labour and growing demands for more individualised services are but some of the current challenges Germans face.

Most new-style social enterprises and their supporting ecosystems tend to be urban-based (Unterberg et al. 2015: 68). These enterprises are usually started by young people, frequently using digital means and the latest (communication) technologies. While they appear to be somewhat hesitant to agree that established providers can also be social enterprises, they will continue to have an impact on how the traditional third sector works and understands itself, either by being effective competitors or by cooperating.

In rural areas, some traditional cooperatives begin to support SE efforts to maintain social life (e.g., in old-age and child care). For one thing, the cooperative form is generally better known there than in urban areas. And secondly, energy cooperatives, which are often based in rural areas, begin to serve as a model for social-cooperative development in other fields of activities, wherever democratic decision-making is of social and economic importance.

\section{Notes}

1 See https://www.iap-socent.be/icsem-project.

2 See http://www.istr.org/.

3 See https://ccss.jhu.edu/research-projects/comparative-nonprofit-sector-project/.

4 See http://www.ziviz.info/ziviz-survey-2017.

5 See https://www.ashoka.org/de/country/germany-0.

6 The second civil-engagement report by the Federal Ministry for Families, Senior Citizens, Women and Youth (BMFSFJ) to the German Parliament (Deutscher Bundestag 2017) refers to social enterprise and cooperatives at some length in its section 5.7.

\section{References}

Anheier, H., Priller, E., Seibel, W. \& Zimmer, A. (eds) (1997) Der Dritte Sektor in Deutschland, Berlin: edition sigma. 
BAGFW (2012) Soziale Innovationen in der Freien Wohlfahrtspflege - Position der BAGFW, Bundesarbeitsgemeinschaft der Freien Wohlfahrtspflege, December 2012. Available HTTP: https://www.bagfw.de/fileadmin/ user_upload/Veroeffentlichungen/Publikationen/2013_12_17_Soziale_ Innovationen_FWp.pdf (accessed April 15, 2019).

BAGWfbM (2013) Was sind eigentlich "Werkstätten für behinderte Menschen”?, Bundesarbeitgemeinschaft Werkstätten für Behinderte Menschen. Available HTTP: https:/www.bagwfbm.de/page/29 (accessed March 28, 2018).

Birkhölzer, K. \& Lorenz, G. (2001a) “Germany: Work Integration through Employment and Training Companies in Berlin and its Surrounding Region", in Spear, R., Defourny, J., Favreau, L. \& Laville J. L. (eds) Tackling Social Exclusion in Europe. The contribution of the Social Economy, Aldershot: Ashgate.

Birkhölzer, K. \& Lorenz, G. (2001b) “Grassroots local partnerships in the Federal Republic of Germany: Instruments for social inclusion and economic interaction?", in Geddes, M. \& Benington, J. (eds) Local Partnerships and Social Exclusion in the European Union. New forms of local social governance?, London and New York: Routledge.

Brinkmann, V. (2010) Sozialwirtschaft. Grundlagen - Modelle - Finanzierung, Wiesbaden: Gabler Verlag.

Brixy, U., Hundt, C., Sternberg, R. \& Vorderwülbecke, A. (2010) Global Entrepreneurship Monitor, Länderbericht Deutschland. Hannover/Nürnberg.

CAF (2018) CAF World Giving Index 2018, Charities Aid Foundation. Available HTTP: https://www.cafonline.org/docs/default-source/about-us-publications/caf_ wgi2018_report_webnopw_2379a_261018.pdf (accessed on April 11, 2019).

Deutsche Bundesregierung (2013) Deutschlands Zukunft gestalten: Koalitionsvertrag zwischen CDU, CSU und SPD: 18. Legislaturperiode, pp. 111-112. Available HTTP: https://www.cdu.de/sites/default/files/media/dokumente/koalitionsvertrag. pdf (accessed April 14, 2019).

Deutsche Bundesregierung (2018) Ein neuer Aufbruch für Europa Eine neue Dynamik für Deutschland Ein neuer Zusammenhalt für unser Land Koalitionsvertrag zwischen CDU, CSU und SPD 19. Legislaturperiode. Available HTTP: https://www.cdu.de/system/tdf/media/dokumente/koalitionsvertrag_2018. pdf?file=1 (accessed March 23, 2019).

Deutscher Bundestag (2012) Drucksache 17/10926, Antwort der Bundesregierung auf die Kleine Anfrage der Abgeordneten Ulrich Schneider, Britta Haßelmann, Beate Walter-Rosenheimer, weiterer Abgeordneter und der Fraktion BÜNDIS 90/ DIE GRÜNEN - Drucksache 17/10731 - zur Förderung von Sozialunternehmen, datiert 05.10.2012. Available HTTP: http://dip21.bundestag.de/dip21/btd/17/ 107/1710731.pdf (accessed April 14, 2019).

Deutscher Bundestag (2017) Unterrichtung durch die Bundesregierung. Zweiter Engagementbericht. Demografischer Wandel und bürgerschaftliches Engagement: Der Beitrag des Engagements zur lokalen Entwicklung und Stellungnahme der Bundesregierung, Drucksache 18/11800, 18. Wahlperiode, 30.03.2017. Available HTTP: http://dipbt.bundestag.de/dip21/btd/18/118/ 1811800.pdf (accessed August 22, 2019).

DGRV (2019) Bundesgeschäftsstelle Energiegenossenschaften, Deutscher Genossenschafts- und Raiffeisenverband e.V. Available HTTP: https:// 
www.genossenschaften.de/bundesgesch-ftsstelle-energiegenossenschaften (accessed March 23, 2019).

EMES (2019) Stakeholder Brief \#4. Social Enterprise in Social and Health Services, Available HTTP: http://www.empowerse.eu/results/stakehoder-brief4-social-enterprise-in-social-and-health-services/ (accessed April 11, 2019).

Engelhardt, W. W. (1994) "Zu einer Struktur- und Funktionsanalyse der Produktivgenossenschaft”, Zeitschrift für das gesamte Genossenschaftswesen, Bd. 44, Heft 1/1994, S.4-27.

Evers, A. \& Schulze-Böing, M. (2001) "Germany - Social enterprises and transitional employment”, in Borzaga, C. \& Defourny, J. (eds) (2001) The Emergence of Social Enterprise, London and New York: Routledge.

FES (1991) "Arbeitsmarktpolitische Initiativen am Beispiel Mecklenburg Vorpommerns", in FES (ed.) Wege zum Aufschwung am Arbeitsmarkt: berufliche Neuorientierung durch Weiterbildung, Umschulung und Arbeitsbeschaffung in Mecklenburg-Vorpommern; eine Tagung der Friedrich-Ebert-Stiftung am 26. September 1991 in Schwerin, Bonn: Friedrich Ebert Stiftung. Available HTTP: http:/library.fes.de/fulltext/fo-wirtschaft/00290004.htm (accessed August 7 , 2018).

Fuchs, P. (2014) “'Soziale Innovation' durch 'Sozialunternehmen'. Schlüssel zur Lösung gesellschaftlicher Probleme?”, Forschungsjournal Soziale Bewegungen, Vol. 27, No. 2, pp. 90-99.

Glänzel, G. \& Scheuerle, T. (2016) "Social impact investing in Germany Current impediments from investors' and social entrepreneurs' perspectives", Voluntas: International Journal of Voluntary and Nonprofit Organizations, Vol. 27, No. 4, pp. 1638-1668.

Glänzel, G., Krlev, G. \& Mildenberger, G. (2013) "Report on potentials and feasibility of future instruments for capitalising social innovators", deliverable of The Theoretical, Empirical and Policy Foundations for Building Social Innovation in Europe (TEPSIE) project, European Commission - 7th Framework Programme, Brussels: European Commission, DG Research.

Göler von Ravensburg, N. (2013) "Chancen für die eingetragene Genossenschaft in der Sozialwirtschaft”, ZögU, Vol. 31, No. 2-3, pp. 89-105.

Göler von Ravensburg, N. (2018) "Institutionelle Rabmenbedingungen für neue Genossenschaften in der Sozialwirtschaft", Zeitschrift für öffentliche und gemeinwirtschaftliche Unternehmen 2/2018, 41st year.

Göler von Ravensburg, N. \& Zillinger, J. (2017) "Die eG in der Behindertenhilfe im Lichte der Umsetzung von Inklusion", Zeitschrift für öffentliche und gemeinwirtschaftliche Unternehmen (ZögU), Heft 1/2017, pp. 50-67.

Göler von Ravensburg, N., Krlev, G. \& Mildenberger, G. (2018) "Social enterprises and their ecosystems in Europe- Country Report Germany”. Available HTTP: https://ec.europa.eu/social/main.jsp?pager.offset=20\&advSearchKey=Social +Enterprises $\&$ mode $=$ advancedSubmit $\&$ catId $=22 \&$ doc_submit $=\&$ policyArea $=0 \&$ policyAreaSub=0\&country=0\&year=0 (accessed August 21, 2019)

Hartwig, W. (1997) Genossenschaft, Sekte, Verein in Deutschland. Vom Spätmittelalter bis zur Französischen Revolution, München: C. H. Beck.

Heinze, R., Schönauer, A.-L., Schneiders, K., Grohs, S. \& Ruddat, C. (2013) "Social Entrepreneurship im etablierten Wohlfahrtsstaat. Aktuelle empirische Befunde zu neuen und alten Akteuren auf dem Wohlfahrtsmarkt", in Jansen, S. A., Heinze, R. G. \& Beckmann, M. (eds) Sozialunternehmertum in 
Deutschland - Analysen, Trends und Handlungsempfehlungen, Wiesbaden: Springer VS, pp. 315-346.

Kirchheim, K. (2013) "Verein", in Grunwald, K., Horcher, G. \& Maelicke,B. (eds) Lexikon der Sozialwirtschaft (2nd actualised and completely reworked edition), Baden-Baden: Nomos, pp. 1083-1084.

Klemisch, H., Sack, K. \& Ehrsam, C. (2010) "Betriebsübernahmen durch Belegschaften. Eine aktuelle Bestandsaufnahme; Studie im Auftrag der Hans Böckler Stiftung”, in Klaus Novy Institut (ed.) knipapers, 10/2001. Available HTTP: https://www.boeckler.de/pdf_fof/97336.pdf (accessed April 16, 2019).

Kuhn, N. (2002) Tauschringe - Möglichkeiten und Grenzen einer "geldlosen" Wirtschaft, Marburg: ifg Marburg.

Kwan, A. \& Glänzel, G. (2014) "Renewable Energy Co-operatives in Germany”, deliverable of The theoretical, empirical and policy foundations for building social innovation in Europe (TEPSIE) project, European Commission - 7th Framework Programme, Brussels: European Commission, DG Research.

Leppert, T. (2008) "Social Entrepreneurs in Deutschland - Ansätze und Besonderheiten einer spezifischen Definition", in Braun, G. \& French, M. (eds) Social Entrepreneurship - Unternehmerische Ideen für eine bessere Gesellschaft, Rostock: Rostock University.

Nock, L., Krlev, G. \& Mildenberger, G. (2013) Soziale Innovationen in den Spitzenverbänden der Freien Woblfahrtspflege - Strukturen, Prozesse und Zukunftsperspektiven, Berlin: Bundesarbeitsgemeinschaft der Freien Wohlfahrtspflege.

Priller, E., Aischer, M., Droß, P. J., Paul, F., Poldrack, C. J., Schmeißer, C. \& Waltkus, N. (2012) Dritte-Sektor-Organisationen heute, Berlin: Wissenschaftszentrum Berlin für Sozialforschung.

Scheuerle, T., Glänzel, G., Knust, R. \& Then, V. (2013) Social entrepreneurship in Deutschland - Potentiale und Wachstumsproblematiken, Studie im Auftrag der KfW, Available HTTP: https:/www.kfw.de/PDF/Download-Center/ Konzernthemen/Research/PDF-Dokumente-Studien-und-Materialien/SocialEntrepreneurship-in-Deutschland-LF.pdf (accessed August 23, 2019).

Scheuerle, T., Schmitz, B., Spiess-Knafl, W., Schües, R. \& Richter, S. (2015) Mapping social entrepreneurship in Germany - a quantitative analysis, International Journal for Social Entrepreneurship and Innovation, Vol. 3(6), pp. 483-511.

Skerutsch, C. (2004) "Sozialgenossenschaften aus Sicht von Verwaltung und Politik", in Göler von Ravensburg, N. (ed) Perspektiven für Genossenschaften aus Sicht der Sozialen Arbeit; Marburger Beiträge zum Genossenschaftswesen, Marburg: ifG Marburg, pp. 44-48 \& pp. 51-2.

Statista (2019) Population of high net worth individuals in Europe from 2013 to 2017 , by country (in 1,000s). Available HTTP: https://www.statista. com/statistics/424981/europe-high-net-worth-individuals-wealth-population/ (accessed March 23, 2019).

Stiftung Aktive Bürgerschaft (2019) Available HTTP: https://www.aktivebuergerschaft.de/buergerstiftungen/buergerstiftungen-in-zahlen/ (accessed March 23, 2019).

Stiftung für Zukunftsfragen (2014) Forschung aktuell, Newsletter 254, Year 35, April 16. Available HTTP: https://www.stiftungfuerzukunftsfragen.de/fileadmin/ 
user_upload/forschung_aktuell/PDF/Forschung-Aktuell-254-Immer-mehrVereine-Immer-weniger-Mitglieder_01.pdf (accessed April 16, 2019).

Tietze, A. (2013) "Bürgerstiftung”, in Grunwald, K., Horcher. G. \& Maelicke, B. (eds) Lexikon der Sozialwirtschaft, 2 nd actualised and completely reworked edition, Baden-Baden: Nomos, pp. 184-187.

Unterberg, M., Richter, D., Jahnke, T., Spiess-Knafl, W., Sänger, R. \& Förster, N. (2015) "Herausforderungen bei der Gründung und Skalierung von Sozialunternehmen". Welche Rahmenbedingungen benötigen Social Entrepreneurs? Endbericht für das Bundesministerium für Wirtschaft und Energie (BMWi). Available HTTP: https://ism-mainz.de/fileadmin/Dateien/Studien/ Sozialunternehmen_Endbericht_2016.pdf (accessed April 17, 2019).

Vogt, W. (2013a) "Die Rolle der Genossenschaften im Rahmen der Gesamtwirtschaft", Zeitschrift für das Gesamte Genossenschaftswesen (ZfgG), 2/2013, pp. 141-146.

Vogt, W. (2013b) “Alternatives Wirtschaften und Mitbestimmung - ein Dilemma?", in Hans Böckler Stiftung (ed) Magazin Mitbestimmung, 1+2/ 2013. Available HTTP: http://www.boeckler.de/42171_42216.htm (accessed April 16, 2019).

Vomberg, E. (2013) "Beschäftigungsgesellschaft”, in Grunwald, K., Horcher, G. \& Maelicke, B. (eds) Lexikon der Sozialwirtschaft (2nd actualised and completely reworked edition), Baden-Baden: Nomos, pp. 123-125.

Wendt, W. R. (2013) "Gegenseitigkeitsgesellschaften", in Grunwald, K., Horcher, G. \& Maelicke, B. (eds) Lexikon der Sozialwirtschaft (2nd actualised and completely reworked edition), Baden-Baden: Nomos, pp. 383-384.

ZiviZ (2017) ZiviZ Survey 2017. Vielfalt verstehen, Zusammenhalt stärken, Essen: Stifterverband. Available HTTP: http://www.ziviz.info/download/file/ fid/276 (accessed August 7, 2018). 


\title{
6 Social Enterprise in Iceland \\ The Long Journey Towards a Hybrid Welfare Model
}

\author{
Steinunn Hrafnsdóttir and \\ Ómar H. Kristmundsson
}

\section{Introduction}

Although the terms "social innovation", "social entrepreneur" and "social enterprise" were relatively unknown in public discourse in Iceland until the start of the 21st century, the country has a long history of collective initiatives directed towards social objectives which correspond to the EMES Network's approach to the concept of social enterprise. ${ }^{1}$ As elsewhere in Europe, the freedom of association, which was recognised in Iceland in the 19th century, urbanisation and a growing middle class formed the background against which new associations, social movements and cooperatives appeared and developed in the late 19th and early 20th centuries.

In the first part of this chapter, the historical roots of social enterprise (SE) in Iceland will be analysed. Then, concepts and definitions that describe social enterprise will be addressed, and a tentative categorisation of social enterprise will be put forward. Finally, the SE-related policy, legal environment within which social enterprises operate and support for these initiatives will be discussed.

\subsection{Historical Roots of Icelandic Social Enterprise}

It is generally agreed that Iceland belongs to the Nordic welfare model (as do Denmark, Finland, Norway and Sweden). The Nordic welfare states are known for their universal welfare services and equal opportunities for their citizens. However, Iceland has always deviated from the Scandinavian countries in some respects, and it has been suggested that the Icelandic system is a hybrid of the Nordic welfare model and the liberal model (Ólafsson 2012). This has been explained by the country's late modernisation and industrialisation and different political landscape, in comparison to the other Nordic countries, which gave social enterprises a larger role in welfare services (Ólafsson 1999; Hrafnsdóttir and Kristmundsson 2012a). 


\subsubsection{Industrialisation and Mass Movements at the Turn of the 20th Century}

The urbanisation and economic upswing that followed industrialisation at the turn of the 20th century created several mass movements focusing on human rights and public-welfare objectives (Hrafnsdóttir 2006, 2008; Hrafnsdóttir and Kristmundsson 2012b). Women's associations were established which, in addition to pressing for women's fundamental rights, performed charity and humanitarian work. A powerful temperance movement also became, in a short time, one of the largest mass movements in the country. In the late 19th and early 20th centuries, these new movements established and began to run hospitals and other social and health institutions, which were for the most part financed by the associations and the patients themselves. The role of the government, be it as financer or provider of these welfare services, remained limited.

\subsubsection{Continued Importance of Associations in the Developing Icelandic Welfare System in the First Half of the 20th Century}

In the second and third decades of the 20th century, the direct involvement of the government in welfare programmes increased, finally leading to the foundation of the present Icelandic welfare system. There were several reasons for these changes. First, the national income increased considerably as a result of the industrialisation of fishing, and this resulted, in turn, in growing urbanisation. Secondly, a new political system, which focused more on domestic problems, was established. Finally, labour unions became influential in public policy-making and, together with other associations, led the public debate on the need for improvement in health and social security (Hrafnsdóttir and Kristmundsson 2012a, 2012b).

All these factors paved the way for increasing public intervention and contributions to the welfare sector in the form of sickness, injury and support insurance. This development led to a substantial increase in welfare expenditure and created the first stable foundation on which private entities operating in the welfare sector could establish themselves. The Icelandic government passed legislation on public insurance in 1936 and a Social Security Act in 1947. These two acts formed the backbone of the state's welfare legislation (Ólafsson 1999, 2012; Jónsson 2001). Despite this ground-breaking legislation, however, non-profit institutions continued to take the initiative in terms of setting up of new welfare institutions (Hrafnsdóttir and Kristmundsson 2012b). The construction of hospitals was primarily in the hands of private organisations, such as the Catholic Church and women's associations, and affluent individuals. The number of associations operating in the welfare sector did not increase substantially during this period, but patients' associations were established for the first time; these campaigned for their clients' interests, 
but also took the initiative in establishing and running treatment facilities. Other types of collective movements also emerged, including powerful unions and political parties, which formed strong alliances as in the other Nordic countries. Cooperative societies became prominent and were instrumental in increasing the number of commercial and industrial jobs in the country.

Despite the establishment of the social security system, associations continued to fund and operate various welfare institutions (Hrafnsdóttir and Kristmundsson 2012b). The official system, however, provided an important regular income in the form of day rates, that is, an amount of money paid by the government based on the number of patients and care days. In some cases, governmental subsidies also covered construction expenses. Yet official funding levels remained low, so that an examination of the history of various associations from this period reveals constant financial problems and requests for increased governmental support.

\subsubsection{From Informal Relations between the State and NPOs to New Public Management in the Late 20th Century}

In the 1970s and 1980s, various patients' organisations and memberoriented associations formed an umbrella group, the Icelandic Disability Alliance (Öryrkjabandalagið), which became a powerful means of putting pressure on the welfare state, urging it to take responsibility for dealing with various problems. The group also insisted on being given a role in the policy-making process.

It was not until the latter half of the 20th century that fundamental changes occurred in relations between non-profits and the government, following the establishment of the Icelandic welfare state, economic growth and social changes. The government gradually took over general hospitals and some other activities in the health sector. As a consequence, some non-profits became quasi-governmental agencies. However, increasing public responsibility did not crowd out as many non-profits as might have been expected. Indeed, several welfare services-notably, those offered by nursing homes, rehabilitation centres, residential services for the disabled and treatment facilities for alcohol and drug abusers-remained the responsibility of the non-profit sector, though with government funding. In these areas, non-profit organisations are still large or even dominant today in terms of both their level of activity and staff numbers (Sigurdardottir et al. 2016; Hrafnsdóttir and Kristmundsson 2019).

Historical research (Hrafnsdóttir and Kristmundsson 2012b) shows that civil society has been a great contributor to social innovation and entrepreneurship in Iceland. Furthermore, there was a close relationship between the state and interest organisations in implementing public policies. Non-contractual informal relations were the norm until the 1990s, 
but with the establishment of new public management (NPM), in 1991, a development was initiated towards more detailed unit-cost contracts. For the first time, a government's white paper included privatisation objectives and goals linked to the outsourcing of programmes to private organisations in order to assure efficient and effective public services. This development led to an increase in different types of formal service contracts at various administrative levels (Kristmundsson 2009). A legislative framework for contracting and tendering was created. However, most of the contracts made in this period were so-called "soft" and less specific contracts, focusing on cooperation rather than competition, and on trust rather than distrust. State/non-profit communication in general was largely based on trust, although monitoring and surveillance were also part of the agreement. For the most part, the government contracted with parties that were considered trustworthy and had a good reputation. Emphasis was put on market mechanisms to regulate third-sector organisations in welfare services, with specific emphasis on business and privatisation. The development towards more formal relations between government and non-profit organisations seems to have occurred at a slower pace in Iceland than in the other Nordic countries, even though the period has been characterised, as elsewhere, by formal contracts and NPM. Iceland also witnessed an increase in membership of all kinds of advocacy groups, fighting for various causes and even establishing new initiatives (Hrafnsdóttir and Kristmundsson 2019).

\subsubsection{Increasingly Formalised Relations between Third-Sector Organisations and the State in the Aftermath of the 2008 Crisis}

Like many other countries worldwide, Iceland experienced a financial collapse in 2008, with serious consequences. The gross domestic product contracted by some $10 \%$ in two years (2009 and 2010), and unemployment rose from $1 \%-2 \%$ in $2007-2008$ to about $9 \%$ in 2009 . Real earnings were drastically reduced, private consumption contracted by some $24 \%$ between 2007 and 2009, and household, corporate and government debt escalated. Iceland had to apply to the IMF and neighbouring countries for emergency assistance, loans and guidance (Hrafnsdóttir and Kristmundsson 2011; Ólafsson 2013).

The role of third-sector organisations after the crisis has not been studied systematically with regard to their innovative or entrepreneurial role. However, analysis of official documents from the Ministry of Welfare and of the annual reports of relevant third-sector organisations indicates that they played some innovative and entrepreneurial role during the crisis. Third-sector organisations joined forces with the government in establishing all kinds of labour-market incentives, voluntary work for unemployed people and food distribution, and they participated at government level in policy-making and consultation on 
reactions to the crisis (Hrafnsdóttir and Kristmundsson 2011; Friðleifsdóttir et al. 2017). The number of third-sector organisations in work-integration activities grew considerably after the crisis; they focused on work-related activities with vulnerable groups, sometimes providing them with a way of entering the mainstream labour market. A time-series study of the effects of the crisis on the third sector also revealed new and extensive challenges: since the turn of the century, the sector has been facing problems related to funding and capacity. The environment is becoming more competitive, resulting in greater marketisation of the non-profit sector and increased formalisation of the relations between the state and the sector (Hrafnsdóttir and Kristmundsson 2016).

\subsection{Categories of Social Enterprises}

Even though, as underlined above, there is no specific legal framework for social enterprises in Iceland, various entities can be categorised under the term such as it is understood by the EMES Network.

Drawing inspiration from Defourny and Nyssens' typology, we identify three main categories of social enterprise in Iceland: entrepreneurial non-profits, public-sector social enterprises and social cooperatives. ${ }^{2}$ These three categories are explored below, and a synthetic overview is offered in table 6.1.

\subsubsection{Entrepreneurial Non-Profits}

According to Defourny and Nyssens (2017: 2480), the entrepreneurial non-profit (ENP) model gathers "all non-profit organisations developing any type of earned-income business in support of their social mission". The term also explicitly includes a non-distribution constraint. ${ }^{3}$ Approximately nine Icelandic social enterprises out of ten can be categorised as entrepreneurial non-profits. These include associations (the verbatim translation of the Icelandic term is "free associations"; in juridical discourse, "general associations"), which are defined as "entities consisting of a number of persons who unite or join together on a voluntary basis for some special non-profit purpose" (Björgvinsdóttir 2008). There is no legally defined framework for associations in Iceland. Icelandic associations operate in several sectors.

\subsubsection{Public-Sector Social Enterprises}

A public-sector social enterprise is defined as “a kind of 'reconfiguration' or 'externalisation' of public services under the organisational form of social enterprise, with the expressed aims of improving and innovating in the provision and delivery of services" (Defourny and Nyssens 2017: 2485). 
Iceland 107

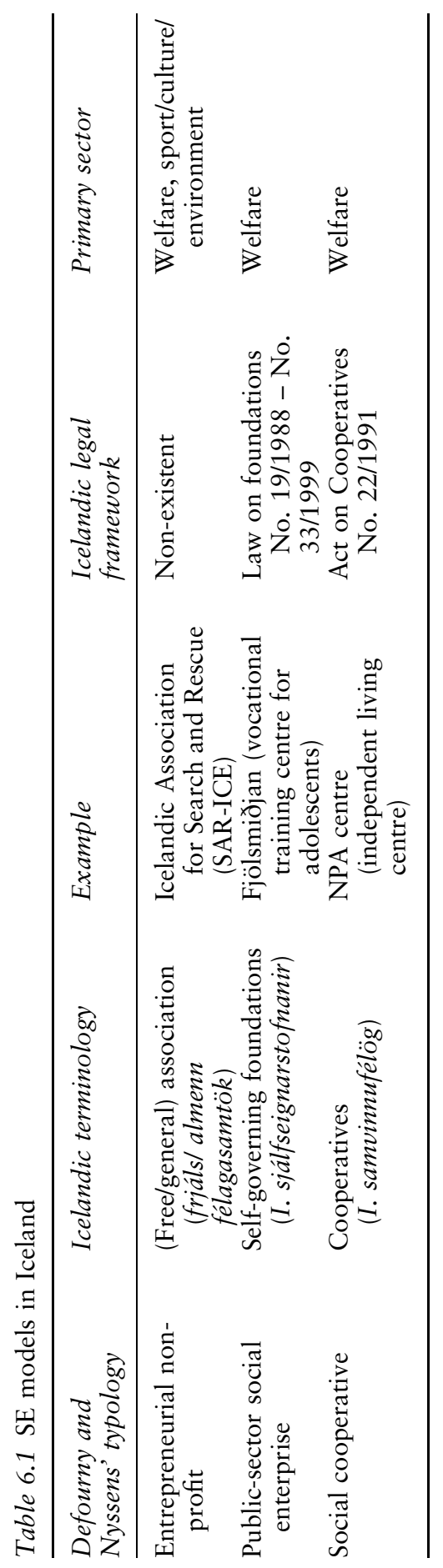




\section{8}

This model accounts for approximately one out of ten Icelandic social enterprises. In most cases, these consist of self-governing foundations, established by either local or central government, and associations. Most of them operate in the welfare sector, for example, in the area of vocational training, work rehabilitation and services for the elderly and disabled people. Self-governing foundations have independent boards in charge of managing the assets. The distribution of profits to members of the board is not allowed. Operations are based on the Act on Funds and Institutions Operating According to Approved Charters, No. 19/1988, and the Act on Foundations Engaging in Business Operations, No. 33/1999.

\subsubsection{Social Cooperatives}

Cooperatives are "first and foremost mutual-interest enterprises, owned and (democratically) controlled by their members for their own noncapitalist interests" (Defourny and Nyssens 2017: 2481). A very small number of cooperatives exist in Iceland. Historically, however, consumer and credit and savings cooperatives were prominent actors in the Icelandic economy during a large part of the 20th century. In the last quarter of this century, most of them were replaced by businesses using other operational forms, but a small number of user-oriented entities operating in the welfare sector have revitalised the cooperative form. Special legislation on cooperatives exists in Iceland (Act No. 22/1991).

\subsection{Policy, Legal Environment and Support}

The terms "social enterprise", "social innovation" and "social entrepreneurs" have rarely been cited in Icelandic public policy. As has already been mentioned, there are no specific legal form nor regulations for social enterprises in Iceland. There is legislation on self-governing foundations (Acts No. 19/1988 and No. 33/1999) and on cooperatives (Act No. 22/1991), but there is no general law on associations either. In such legal context, entities that can be categorised under the term "social enterprise" (i.e., those listed in the three categories described in section 6.2) are registered as "self-governing foundations", "cooperatives", "associations" or "private companies".

There is no special policy or support structure aimed at social enterprises either. Iceland lags behind many European countries in implementing specific large-scale policy initiatives to support and strengthen social enterprises, social entrepreneurs and social innovation. Indeed, the same applies in general to the third sector. There is interest in entrepreneurship and some initiatives to support it, often related to technical solutions, but there has been little political interest in social enterprises, social entrepreneurship and social innovation until recently. However, a few initiatives can be mentioned. In 2015, for example, the 
Ministry of Welfare implemented a special policy on innovation in welfare services and technology (Ministry of Welfare 2015). As part of that policy, the Ministry established a social-innovation fund to promote social entrepreneurship and social innovation; both municipalities and other entities providing social services are eligible for application. In April 2017, the first Icelandic business accelerator for social innovation was launched, in cooperation with various universities and official bodies. The endeavour is meant to strengthen diversity in Icelandic innovation and create a forum for social entrepreneurial activities.

There are thus some signs of a growing interest in this field in Iceland, not least because of a general distrust of for-profit solutions in the welfare sector, following the financial crisis. Like previous governments, the new coalition government that came into power in the fall of 2017 focused on innovation-including social innovation-in its white paper.

\section{Conclusion}

In this chapter, we have reviewed the development of Icelandic social enterprises and the context within which they operate, and we have presented a first attempt to identify SE models in Iceland, based on Defourny and Nyssens' (2017) typology. Three main SE categories were identified, based on available historical material, legal framework, official publications and available data: entrepreneurial non-profits; entrepreneurial non-profits; public-sector social enterprises; and social cooperatives. However, as has been discussed above, identifying different SE models is a hard exercise in the Icelandic context, because of limited official data and the lack of in-depth research on the different categories of social enterprise in the country. Furthermore, in many respects, the concept of social enterprise and other related concepts, such as social innovation and social entrepreneurship, are still in their infancy in Iceland. The country needs to deepen its knowledge and understanding of social innovation and social enterprises. There is also a need for regulation and institutional frameworks to support Icelandic social enterprises.

In future studies, it will be important to analyse the various types of social enterprise and develop a more in-depth typology of the different SE models.

\section{Notes}

1 For example, see the following definition: "Social enterprises (SE) are organisations which combine an entrepreneurial dynamic to provide services or goods with a primacy of social aims. [Social enterprises] naturally cross various types of borders: sectoral [borders] (public, business, cooperatives, associations) [as well as borders in terms of] resources (drawing them from the market, public procurement, grants, and philanthropy) and [of] activity fields 
(personal services, finance, recycling industry, energy and transport, food supply chains ...)" (COST Association 2017: 3).

2 The fourth SE model identified by Defourny and Nyssens, namely that of social businesses, defined as "businesses that apply market-based strategies to achieve a social or environmental purpose" (Defourny and Nyssens, 2017: 2474), does not correspond to any specific category of social enterprise in Iceland.

3 Non-profit organisations are commonly defined as entities that meet the following criteria: (1) they must not distribute profit; (2) they are self-governing and organisationally separate from the government; (3) they must have some formal structure, defined by regulations or formal rules and (4) they must be based on free membership, and involve, to some extent, voluntary work (Hrafnsdóttir, 2008).

\section{References}

Björgvinsdóttir, Á. (2008) "Réttarstaða almennra félaga”, in Kristmundsson, Ó. H. \& Hrafnsdóttir, S. (eds) Stjórnun og rekstur félagasamtaka, Reykjavík: Háskólaútgáfan, pp. 42-64.

COST Association (2017) Memorandum of Understanding for the implementation of the COST Action "Empowering the next generation of social enterprise scholars" (EMPOWER-SE) CA16206, June 23, 2017, Brussels: COST Association AISBL. Available HTTP: http://www.empowerse.eu/wp-content/ uploads/2018/02/Memorandum-of-understanding-COST-action-CA16206.pdf.

Defourny, J. \& Nyssens, M. (2017) "Fundamentals for an international typology of social enterprise models", Voluntas: International Journal of Voluntary and Nonprofit Organizations, Vol. 28, No. 6, pp. 2469-2497.

Friðleifsdóttir, S., Eydal, G. B., Jónsdóttir, S. \& Ólafsson, S. (2017) The Nordic Welfare Watch, TemaNord, No. 563, Copenhagen: Nordic Council of Ministers.

Hrafnsdóttir, S. (2006) "The Icelandic voluntary sector. Development of research", in Matthies, A.-L. (ed.) Nordic Civic Society Organisations and the Future of Welfare Services. A Model for Europe?, TemaNord, No. 517, Copenhagen: Nordic Council of Ministers, pp. 194-211.

Hrafnsdóttir, S. (2008) "Frjáls félagasamtök og sjálfboðaliðastörf á Íslandi”, in Kristmundsson, Ó. H. \& Hrafnsdóttir, S. (eds) Stjórnun og rekstur félagasamtaka, Reykjavík: Háskólaútgáfan, pp. 21-41.

Hrafnsdóttir, S. \& Kristmundsson, Ó. H. (2011) "Félagasamtök og sjálfseignarstofnanir sem starfa að velferðarmálum á Íslandi”, Stjórnmál \& Stjórnsýsla, Vol. 2, No. 7, pp. 445-463.

Hrafnsdóttir, S. \& Kristmundsson, Ó. H. (2012a) "Próun og einkenni priðja geirans í velferðarbjónustu”, in Eydal, G. B. \& Ólafsson, S. (eds) Próun velferðarinnar 1988-2008, Reykjavík: Félagsvísindastofnun Háskóla Íslands, pp. 107-123.

Hrafnsdóttir, S. \& Kristmundsson, Ó. H. (2012b) “The role of non-profit organisations in the development and provision of welfare services in Iceland", Moving the Social. Journal of Social History and The History of Social Movements, Vol. 48, pp. 179-192.

Hrafnsdóttir, S. \& Kristmundsson, Ó. H. (2016) "Volunteers for NPOs in welfare services in Iceland: A diminishing resource?", Voluntas, Vol. 28, No. 1, pp. 204-222. 
Hrafnsdóttir, S. \& Kristmundsson, Ó. H. (2019) Social Enterprises and Their Ecosystems in Europe. Country Fiche: Iceland, European Commission, Luxembourg: Publications Office of the European Union.

Jónsson, G. (2001) "Agents and institutions in the creation of the Icelandic welfare state, 1880-1946”, in Christensen, H. R., Lundberg, U. \& Petersen, K. (eds) Frihed, Lighed og Tryghed. Velfordspolitik $i$ Norden, Vol. 48, Århus: Jysk Selskab for Historie, pp. 61-89.

Kristmundsson, Ó. H. (2009) "The changing relationship between the government and the nonprofit sector in Iceland”, Stjórnmál og stjórnsýsla, Vol. 2, No. 5, pp. 249-266.

Ministry of Welfare (2015) Stefna um félagslega nýsköpun og velferðartækni, Reykjavík: Ministry of Welfare.

Ólafsson, S. (1999) “The Icelandic model: Social security and welfare in a comparative perspective”, in Bouget, D. \& Pallier, B. (eds) Comparing Social Welfare Systems in Nordic Europe and France, Nantes: Mire \& Maison des Sciences de l'Homme Ange Guépin.

Ólafsson, S. (2012) "Velferðarríkið og próun velferðarútgjaldanna”, in Eydal, G. \& Ólafsson, G. B. (eds.) Próun velferðarinnar 1988-2008, Reykjavik: Háskólaútgafan, pp. $29-46$.

Ólafsson, S. (2013) “Crisis and recovery in Iceland”, in Jónsson, G. \& Stefánsson, K. (eds) Retrenchment or Renewal? Welfare States in Times of Economic Crisis, NordWel Studies in Historical Welfare State Research 6, Helsinki. Nordic Centre of Excellence Nordwel.

Sigurdardottir, S., Hrafnsdóttir, S. \& Kristmundsson, Ó. (2016) “Care of older adults in Iceland: Policy objectives and reality", Journal of Social Service Research, Vol. 42, No. 2, pp. 233-245. 


\title{
7 Social Enterprise in Ireland
}

State Support Key to the

Predominance of Work-

Integration Social

Enterprise (WISE)

\author{
Patricia O'Hara and \\ Mary O’Shaughnessy
}

\section{Introduction}

Social enterprise (SE) in Ireland takes on many forms across a spectrum from local community-based entities to large businesses trading internationally. The SE sector is regarded as being part of the wider social economy, which includes cooperatives, mutual societies, non-profit associations and foundations. Understanding of the sector-its boundaries, scale and potential-has been influenced by academic and policy approaches. In Irish academic discourse, conceptualisation of social enterprise owes much to both US and European academic traditions. By contrast, more than two decades of Irish public-policy debate has viewed social enterprise as a mechanism of job creation/integration and service provision in disadvantaged communities-a policy perspective significantly influenced by European policy on the sector. These variations in approach have contributed to ambiguity about the nature and extent of the social economy as a sector and social enterprises as distinctive entities, which, in turn, has compromised attempts to estimate the scale and potential of the sector in Ireland.

The National Social Enterprise Policy for Ireland 2019-2022 marked the first significant policy declaration on social enterprise; it states that social enterprises "make a valuable contribution to the economic and social progress of Ireland through the creation of jobs and delivery of a broad range of services" (Government of Ireland 2019: 5). While there is still some ambiguity about the phenomenon's extent and potential, this development has helped to bring greater clarity about the nature of social enterprise in Ireland and reinforced the view of social enterprises as businesses whose core objective is to achieve a social, societal or environmental impact through labour-market integration and the delivery of a range of services, including the provision of training. It is clear that much of the financial support for Irish social enterprises, to date, is provided through labour-market activation schemes and that this 
accounts for the dominance of the work-integration social enterprise (WISE) model in the Irish SE landscape. WISEs exist mainly to improve the employability and employment prospects of people furthest from the labour market; they often combine this objective with an additional goal of providing a range of community-based goods and services.

The objectives of this chapter are to discuss how the social economy and social enterprise are understood in Ireland; to explain how WISEs have evolved as the dominant Irish SE model to date; and to describe some of the current challenges facing WISEs and their prospects for the future. The chapter is structured into three parts. In the first two parts, we discuss the influence of the US (Salamon and Anheier 1997; Dees 1998) and European/EMES (Pestoff 1998; Borzaga and Defourny 2001; Nyssens 2006; Defourny and Nyssens 2010, 2012) academic traditions, and of EU and national policy perspectives, since the early 1990s, on Irish academic and policy discourse, respectively. While academic studies, drawing on a variety of sources, have yet to agree on the boundaries of the social economy or social enterprise, policy approaches have evolved considerably. We argue that the labour-market integration approach to the development of the Irish social economy, adopted by successive Irish governments in recent decades, has shaped the sector and contributed to the emergence of one dominant SE type, namely the WISE. In the third part of the chapter, we present a brief overview of the typical Irish WISE operational model and the challenges these enterprises face in the context of wider developments in the SE landscape.

\subsection{Social Enterprise in Irish Academic Discourse-US and European Influences}

Although Ireland has a long and rich tradition of social-economy-type organisations (including social enterprises), it is only since the early 1990s that the sector has been subjected to significant academic attention and that the concept of social enterprise has become prominent. Early Irish academic discourse tended to reflect US work on the non-profit sector (e.g., Powell and Guerin 1997; Salamon and Anheier 1997; Donoghue 1998; Donoghue et al. 1999; Acheson et al. 2003; Prizeman and Crossan 2011) or be influenced by the European tradition, particularly that of the EMES Network (O'Hara 2001; O'Shaughnessy 2008; Curtis et al. 2011). This is in line with approaches elsewhere, which can be broadly characterised as either US or European, depending on the weight given to individualistic and hierarchical organisational structures, on the one hand, or collectivisation and democratic ownership, on the other (Spear and Bidet 2005; Nicholls 2006; Mendell 2010; Teasdale 2011).

Most studies of the Irish non-profit sector grounded in the US tradition were based on the Johns Hopkins' definition of non-profits (Salamon and Anheier 1997; Donnelly-Cox 1998). One of the earliest investigations 
(Donoghue 1998), using the Johns Hopkins' definition (Salamon and Anheier 1997) to map the sector, pointed to the long history of nonprofits, the absence of a specific policy milieu and the reliance of these organisations on public funds and volunteering. A further mapping exercise (Donoghue et al. 2006) used the International Classification of Non-Profit Organisations. Thus, the term social enterprise did not appear in any academic mapping exercise of the Irish non-profit sector (influenced by the US non-profit approach) until a philanthropicsponsored study of the sector was published in 2011. Prizeman and Crossan's (2011) mapping exercise was influenced by the US emphasis on social innovation and social entrepreneurship (Dees 1998; Dees and Anderson 2006). In this study, the authors considered social enterprises as one type of initiatives among a wider set, ranging from individual social entrepreneurs to social entrepreneurial initiatives. This research provided an insight into the entrepreneurial behaviours of individuals/ enterprises; their role in public service delivery; their networks, relationships and stakeholders; their financial and human resources; and their impacts, values and governance. It also confirmed the highly diverse and multifaceted nature of the Irish social economy and the complex missions, organisational structures, networks and entrepreneurial behaviours that characterised individual Irish social entrepreneurs and social enterprises.

While the term social enterprise was not used in US-influenced academic studies of the Irish non-profit sector until 2011, the concept appeared much earlier-in 2001 already-in studies influenced by the European/EMES tradition. O'Hara (2001) delineated five broad categories of Irish social enterprises according to the conceptual framework of the EMES International Research Network and using the set of nine EMES indicators. ${ }^{1}$ Focusing on objectives, activities and operation, rather than on organisational forms, the categories were (1) workintegration social enterprises, associated with insertion of members of excluded groups into the labour force; (2) credit unions; (3) social enterprises concerned with housing provision; (4) social enterprises providing personal and proximity services; and (5) local-development organisations.

Work-integration social enterprises provide work and labour-market integration primarily for people with disabilities in what was conventionally referred to as "workshops" or "sheltered employment". Structured as cooperatives, credit unions provide financial services and have a very high membership in Ireland. Social enterprises concerned with housing provision, including housing cooperatives and voluntary/philanthropic housing associations, are significant providers of social housing in the country. Similarly, social enterprises that provide personal and proximity care are an important element of the Irish care sector, particularly in the provision of child care and services to older persons. Local development organisations or 
community-based service organisations emerged in the 1990s as part of the state response to the persistence of long-term unemployment and disadvantaged communities and gave rise to a new generation of social enterprises in the context of state support for labour-market integration. These five categories were not seen as mutually exclusive; they were rather to be viewed as being at different points on what Defourny and Nyssens (2012) later referred to as the "galaxy" of social enterprises, with the first four types being more typical of the non-profit/voluntary sector or established social economy.

This EMES-type approach was not applied again to any systematic mapping of the Irish social economy until a study sponsored by the European Commission was undertaken, in 2014, as part of a mapping exercise of SE activity and ecosystems across the EU (this study was subsequently updated, in 2016 and 2019; see European Commission 2014, 2016, 2019). The operational definition of social enterprise used for these exercises was based on that used in the 2011 European Commission's Social Business Initiative (European Commission 2011) and closely mirrored the widely accepted EMES definition. Six types of Irish organisations that might be considered as social enterprises were identified: (1) community-based organisations receiving grant aid to provide temporary employment and job training; (2) charities and voluntary organisations delivering public services on a grant or contract basis; (3) friendly societies; (4) socially entrepreneurial individuals launching socially motivated businesses; (5) entrepreneurial sports, cultural and community organisations; and (6) credit unions and cooperatives. These types closely resembled the categories originally outlined by O'Hara (2001), with the exception of the omission of social enterprises concerned with social housing as a separate category, and inclusion of two additional types in the 2014/2016 mapping studies, that is, socially entrepreneurial individuals and friendly societies. The inclusion of the former reflected the influence of the US social-innovation school of thought, while the latter are a legal form that was often used by non-profits until 2018. ${ }^{2}$ This mapping exercise also referred to the interchangeable use of concepts such as social enterprise and social entrepreneurship in Irish discourse, underlining the general vagueness surrounding these concepts in Ireland.

In summary, Irish academic discourse on the social economy and social enterprise reflects a variety of conceptualisations and definitions that draw upon different academic traditions. The results of this have been an ambiguous understanding of concepts and an unreliable assessment of the true scale and potential of the sector. As noted in the European Commission's report on social enterprises and their ecosystems in Ireland (European Commission 2014, 2016, 2019), there are considerable knowledge gaps about Irish social enterprises, including about their scale, social impact and overall contribution to the national economy and society in general. Numerous small-scale surveys confirm 
SE activity in food and catering, tourism, arts, culture, music, recycling, transport and distribution; social enterprises serve both the businessto-business and public-sector markets, and they also sell directly to individual markets (Hynes 2016). However, there is no real consensus about the size of the sector or its parameters, and indeed, many of the practitioners within the sector have a confused understanding of-and do not identify with-the terms "social economy" and "social enterprise". Social enterprises are not included in official statistics, and estimates vary greatly and can be easily contested.

\subsection{Social Enterprise in Irish Policy Discourse}

By contrast with what is the case in the academic field, conception of the social economy in Irish policy discourse has been more vigorous and less confused, having been strongly influenced, since the early 1990s, by a European policy perspective that promoted the social economy and social enterprise as a community-based strategy to tackle unemployment and social and economic exclusion.

\subsubsection{The First Two Decades: The 1990s and 2000s}

The terms "social economy" and "social enterprise" first emerged in Irish policy discourse in the 1990s and reflected European policy trends of the time (European Commission 1993, 1995a, 1995b). The initial Irish policy debate on the sector was influenced by a study that identified social enterprises as having the potential to provide goods and services to disadvantaged communities in the instance of market and public-service failure, and to facilitate local labour-market integration (National Economic and Social Forum 1995). The National Economic and Social Forum $(\mathrm{NESF})^{3}$ recommended that government action be taken to develop the social economy by creating support structures for socialeconomy enterprises and providing subsidies to those enterprises that would recruit from the unemployed. These recommendations were subsequently supported by advocacy groups for the unemployed, who produced position papers on how the sector could be developed and supported to provide community-based services and tackle unemployment and social exclusion (see PLANET 1997, 2005; WRC Social and Economic Consultants 1999).

The Irish government responded by establishing a Working Group on the Social Economy to undertake a detailed examination of the potential of the sector to provide employment and services in disadvantaged communities. In its 2000 report, the Working Group reiterated the NESF's earlier call for government support and reinforced the association between the social economy, labour-market integration and service delivery to disadvantaged communities. They recommended the 
establishment of a national social-economy programme that would use existing labour-market integration programmes wherever possible to support the sector. This led to the establishment of the Social Economy Programme (SEP) in 2000. The objective of the SEP was to support social enterprises with specific characteristics such as community ownership, a local development focus and a mission to provide work-integration opportunities for the long-term unemployed. These features reflected key elements of the EMES ideal type of social enterprise and the European policy focus on linking development of the social economy to tackling unemployment (Nyssens 2006; Defourny and Nyssens 2012). The SEP was introduced at a time when Ireland was experiencing virtually full employment and attracting significant inward migration to fill the jobs available. Thus, participating social enterprises were required to have a specific focus on funding local services and providing employment opportunities for particularly disadvantaged groups (including those distant from the labour market), or to address market or public-service failure in communities, usually as a consequence of either geographical or social isolation. In this way, the establishment of new social enterprises was linked explicitly to government objectives of labourmarket re-integration, local and community development and the provision of local services.

An evaluation of the SEP found that the programme had limited capacity to support the development of social enterprises and that there was insufficient start-up support and enterprise training; the evaluation also questioned the long-term sustainability of the social enterprises supported under the programme (WRC Social and Economic Consultants 2003). This led to further calls for a mapping of the social economy and the development of a new national policy to strengthen and support the sector (PLANET 2005). ${ }^{4}$ By 2006, responsibility for the SEP had been transferred from the government department concerned with enterprise and employment to that with responsibility for community and rural affairs, and the SEP was renamed as the Community Services Programme (CSP). This change of name and the transfer of administrative responsibility for the programme strengthened the association of social enterprises with locally based community development rather than with enterprise and entrepreneurship. CSP social enterprises are not expected to become financially sustainable, and many remain dependent on state funding. However, they are encouraged to secure income from trading and other sources to deliver properly resourced and viable services. In a 2009 study, Curtis et al. (2011) found that, for a third of social enterprises in the programme, trading accounted for less than $20 \%$ of total income. Fewer than a quarter $(22 \%)$ generated more than half their income from trade. Four out of ten enterprises surveyed on their views on the requirement to generate a traded income responded that they would prefer a funding stream that did not have this 
requirement. Thus, it is clear that a very significant share of organisations that participate in the CSP are not enterprise-driven and that they exhibit an extensive reliance on, and operate primarily as conduits for, state funding programmes (WRC Social and Economic Consultants 2003; Clann Credo 2011; Curtis et al. 2011).

In short, state labour-market activation schemes became the key stimulus and support for the development of Irish social enterprises from the 1990s onward. Consequently, the social enterprises that have emerged from this type of state support typically support labour-market integration and are engaged in community service provision, and they can generally be categorised as WISEs.

\subsubsection{Emerging from Recession: A New Definition}

In 2012, the Irish government published an Action Plan for Jobs as part of its response to the national recession, which was characterised by a crisis in public finances and high unemployment. This Action Plan contained a series of concrete actions to maximise employment creation and included a working definition of social enterprises as business models set up to tackle social, economic or environmental issues and engaged in trading or commercial activities to produce social and community gain (Government of Ireland 2012: 67). A subsequent review of the job-creation potential of social enterprise, carried out by Forfás, ${ }^{5}$ defined social enterprises as not-for-profit organisations, driven by social objectives, separate from government, where at least part of the income generated is from trading activity and the surplus is reinvested in social objectives. Social enterprises were identified as operating on an economic continuum, with varying degrees of commercial focus and engagement with the public and private sectors. At one end of this continuum are those enterprises that deliver core social programmes, such as services for people with disabilities or older people, and that are funded primarily by the state. These are driven by the need to generate enough income to maintain their viability and sustainability so that they can respond to social needs. At the other end are those social enterprises that are seen to interface more closely with the commercial sector and that present themselves as businesses that aim at profit maximisation in order to fund their social objectives. Social enterprises were considered by Forfás to be rooted in local and community development and to play an important role in providing jobs to those most distant from the labour market, both spatially and socially (Forfás 2013).

Four types of social enterprise were distinguished by Forfás, largely on the basis of their objectives and activities, rather than their organisational forms: 
- social enterprises that create employment opportunities for marginalised groups, such as people with disabilities or ex-offenders;

- local enterprises that are involved in local and community development and respond to a gap in infrastructure or services, such as community enterprises or community shops;

- organisations that deliver public services, such as child-care or eldercare services;

- organisations that trade in services or products that deliver a social dividend and have a high income-generation capacity, such as environmental services enterprises.

These four types are not mutually exclusive, and it is acknowledged that, in practice, there is overlap. However, the first type-social enterprises creating employment opportunities for marginalised groups—can be seen to correspond to the basic definition of a WISE. Social enterprises involved in local and community development and the delivery of child-care and elder-care services typically utilise labour-market integration programmes, so that they too can be characterised as WISEs. Six case studies were chosen to reflect the diversity of Irish social enterprises (Forfás 2013: 15). Five of these were WISEs, with a clear objective of job creation/training and/or labour-market integration of the long-term unemployed and persons with intellectual/physical disabilities; this choice of examples confirms the dominance of the WISE model in the Irish context to date. This prominence is in line with developments across Europe, where assisting the integration, into the workplace, of unemployed individuals and/or others at risk of social and economic exclusion has become a key objective of European public policy (Nyssens et al. 2012).

\subsubsection{A New National Social Enterprise Policy for}

Ireland (2019-2022)

Following the publication of the Forfás review, a number of developments paved the way for the publication, in 2019, of Ireland's first National Social Enterprise Policy. The lack of direct support to social enterprises was being continually highlighted in various reports (GECES 2016; Hynes 2016; OECD/European Union 2017). In 2017, responsibility for social enterprise was transferred from the government Department of Business, Enterprise and Innovation to the newly established Department of Rural and Community Development (DRCD); in the same year, the Department of Justice and Equality also supported a Social Enterprise Strategy. ${ }^{6}$ A research partnership between the DRCD and the Social Finance Foundation (SFF) led to the publication of a report in 2018 which provided the evidence base for the new policy. Data sources for this study included the Irish Social Mapping Exercise referred to above, a series of thematic national stakeholder consultations, SE site visits and an online survey of SE stakeholders. 
The findings confirmed the extensive range of activities undertaken by Irish social enterprises, including tackling social and environmental issues, fulfilling government contracts to provide social services, generating employment and providing services to the most marginalised groups in society. Six categories of social enterprises were identified: communitybased social enterprises; social-entrepreneurs-initiated social enterprises; work-integration social enterprises; service providers to the state; enterprise-development social enterprises (i.e., social enterprises that support the creation of other enterprises, for example, through the provision of office space and other facilities); and environmental social enterprises (Department of Rural and Community Development and Social Finance Foundation 2018). ${ }^{8}$ The research also pointed to the predominance of social "micro-enterprises", with low levels of earned income, relatively few employees and a high reliance on volunteers. The provision of training and employment opportunities, establishment and maintenance of community facilities/buildings and delivery of community services were found to be the most significant areas of activity among social enterprises, confirming the continued dominance of the WISE model.

The National Social Enterprise Policy for Ireland 2019-2022, based on the research and consultations outlined above, sets out the following broad definition of social enterprise:

- A social enterprise is an enterprise whose objective is to achieve a social, societal or environmental impact, rather than maximising profit for its owners or shareholders.

- It pursues its objectives by trading on an ongoing basis through the provision of goods and/or services, and by reinvesting surpluses into achieving social objectives.

- It is governed in a fully accountable and transparent manner and is independent of the public sector. If dissolved, it should transfer its assets to another organisation with a similar mission.

While the lack of comprehensive data on the full extent and impact of social enterprise SE in Ireland is acknowledged, social enterprises are seen as delivering a wide range of goods and services and as contributing to the achievement of government policy goals in areas such as labour-market activation, health care, climate action, social cohesion and rural development. Social enterprises are regarded as taking on a variety of different forms, including WISEs. This current Irish national definition of social enterprise parallels the three main dimensions of the EMES approach to social enterprise ${ }^{9}$ and the EU operational definition, ${ }^{10}$ as illustrated in table 7.1. 
Ireland 121

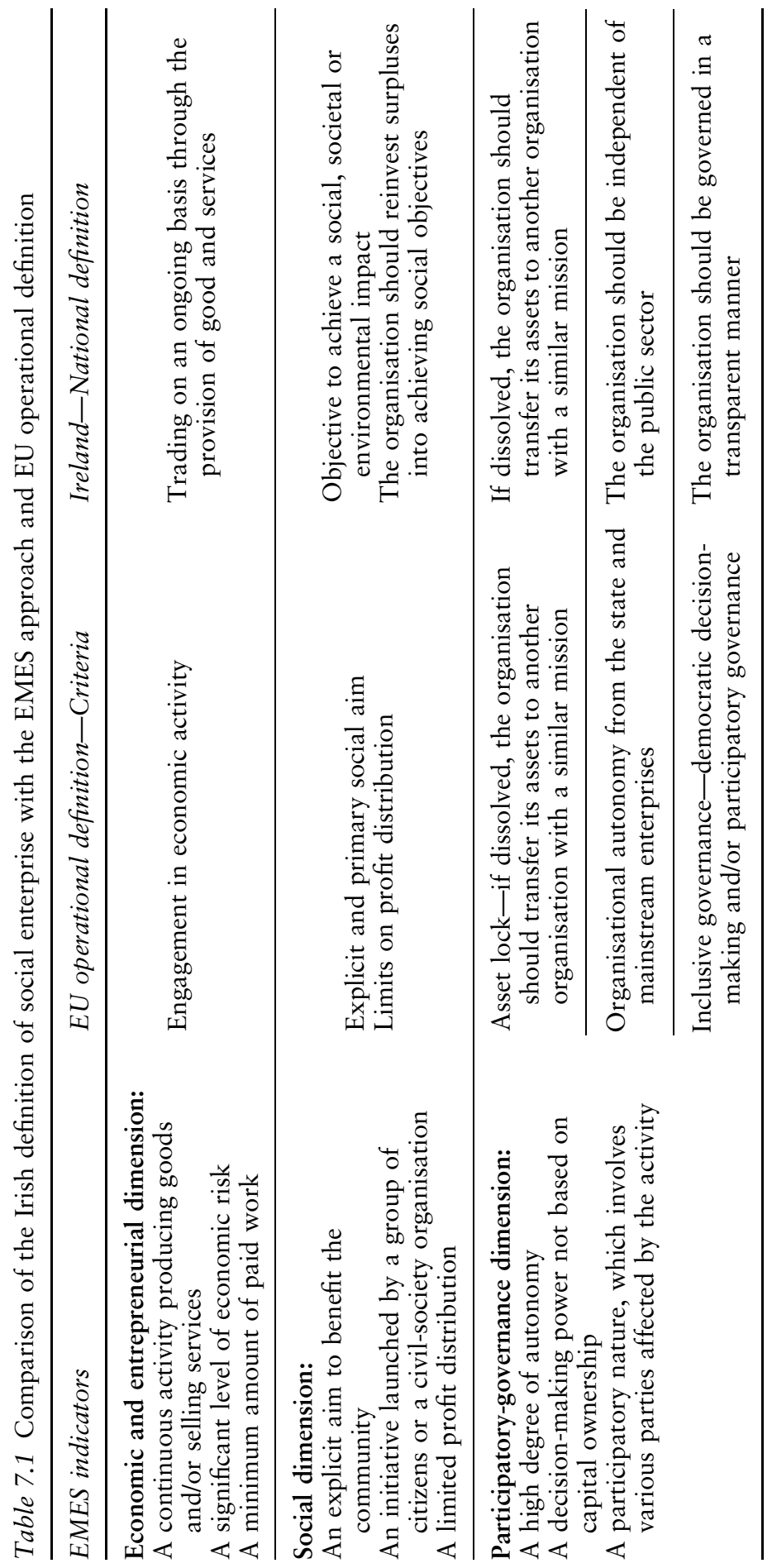




\subsection{WISEs: A Typical Operational Model in Ireland}

In this section, we provide a brief overview of the typical operational model of Irish WISEs-their form and structure, objectives, the services they provide and some of the challenges they face.

\subsubsection{Legal Form and Governance Structure}

There is no specific legal form for Irish social enterprises in general, nor for WISEs in particular. Four different legal structures are available to social enterprises under Irish law: company limited by guarantee (CLG); company limited by shares; designated activity company; and unincorporated association. CLG is the most popular legal form for Irish notfor-profits, including WISEs, because no shares are issued and there are provisions in the articles of association that prohibit the payment of dividends to the members of the enterprise. Because a CLG does not have shares, it cannot raise funds by way of equity investment.

Irish WISEs that carry out charitable activities may also apply for charitable status and thus benefit from certain tax exemptions, subject to approval from the Irish Revenue authorities. However, charitable status also requires additional regulatory reporting and statutory filing obligations, and certain clauses (including the prohibition of remuneration to the board of directors) must be included in the WISE's governance rules.

National advocacy groups for the sector have called for a specific legal identity for social enterprise in order to distinguish social enterprises from other organisations, provide greater visibility for the sector and facilitate greater accuracy in the measurement of the true scale of its social and economic impact (Moroney and O'Shaughnessy 2017: 5).

\subsubsection{Social Objectives and Sustainability}

The primary social objective of a WISE is to hire people who are most distant from the labour market, to improve their employability and increase their employment rates while providing goods and services. WISEs deal with workers who are vulnerable due to factors such as disability, intergenerational unemployment, long-term unemployment, a history of substance abuse, low educational attainment level or criminal conviction. Apart from employment, WISEs provide targeted support, such as mentoring and training, to improve employees' self-confidence and work readiness.

Irish WISEs mobilise a diversity of resources to self-sustain. They typically generate a traded income by providing a range of goods and services and may benefit from corporate social responsibility (CSR) initiatives and philanthropy. They utilise state labour-market activation schemes, such as CSP, to support wages or cover part of the cost of provision of services to 
users; they may access the Dormant Accounts Fund (DAF) $)^{11}$ to provide training and mentoring.

\subsubsection{Goods and Services Provided}

Irish WISEs tend to be locally based and provide a diversity of goods and services which benefit their communities and create local training and employment opportunities. Typical goods and services include child/ elder care, environmental/recycling services, sporting, cultural and leisure services, mattress recycling, maintenance of community buildings, tourism, food production/catering services, crafts, training and educational services. A growing sector of Irish WISEs are specifically focused on people with criminal convictions, who face a wide range of barriers in securing and maintaining employment. These types of WISE benefit from targeted state support through the Department of Justice and Equality Kick Start Social Enterprise Fund, launched in 2018, and they typically deliver bicycle, wheelchair and lawnmower repair services, wooden furniture upcycling, catering and contract packing.

\subsubsection{Challenges for WISEs}

In this section, some of the key challenges faced by Irish WISEs are briefly discussed.

\section{Limitation of the Labour-Market Pool}

As noted throughout this chapter, state support for WISEs typically takes the form of labour-market activation programmes. While it is widely acknowledged that this type of support can help reduce the costs of doing business for the social enterprise, the strict requirements of such schemes are perceived as a challenge for WISEs that are ambitious to be more commercially driven, competitive and keen to widen their offer of goods and services. Since Irish WISEs work with vulnerable individuals, they bear the associated costs of providing significant support to meet their needs and, in some instances, of adjusting the workplaces accordingly. These costs can mitigate against the competitiveness of the WISE and/or its ability to be commercial. As we have noted above, WISEs typically emerged in the context of a political response to high national unemployment levels, and as a way of providing essential goods and services to vulnerable communities. However, in more buoyant economic times, with high employment rates, ${ }^{12}$ WISEs are increasingly challenged by having to provide extensive support to employees, often sourced from a limited labour-market pool, and distant from the labour market for extensive time periods. 


\section{O’Hara \& O’Shaughnessy}

\section{Lack of Business and Leadership Skills}

Irish social enterprises, including WISEs, are largely area based and managed by community members. They contribute to local community, social and economic development, increase social cohesion and retain local social capital (O'Shaughnessy and O'Hara 2013; Hynes 2016). However, localisation can also be a challenge for WISEs if they do not have access to a diverse and skilled voluntary board of directors with a knowledge of local, regional, national and international market opportunities, strategic vision and a strong (social) entrepreneurial focus. The enterprise and management skills required throughout the business life cycle of Irish WISEs include administrative support in scheme application and compliance, long-term business planning and the development of market-sector networks (Department of Rural and Community Development and Social Finance Foundation 2018; Olmedo et al. 2019). In an online consultation of 376 Irish social enterprises carried out in $2017,71 \%$ of the respondents said that current business supports did not meet the specific needs of the sector. Furthermore, 329 respondents expressed a need for additional training in business and leadership skills, including performance and impact measurement, marketing, sales, HR and recruitment, tendering and procurement (Department of Rural and Community Development and Social Finance Foundation 2018). The challenge of upskilling in business tendering and procurement is particularly pressing, given the Irish government's 2018 commitment to incorporating social considerations into public procurement as part of their efforts to encourage more social enterprises to participate in competitive tendering for public contracts. ${ }^{13}$

\section{Unstable Resource Environments}

Social enterprises, including WISEs, have demonstrated a capacity to mobilise and combine a diverse range of resources to achieve their objectives (di Domenico et al. 2010; Cooney et al. 2016; O'Shaughnessy and O'Hara 2016). Irish WISEs are, to a greater or lesser extent, reliant on philanthropy, initiatives associated with corporate social responsibility and high levels of volunteerism. Consequently, they operate in an unstable resource environment, as well as being subject to the challenge of short-term public-sector contracts, rule changes to government programmes, changes in volunteering trends, and the increasingly demanding regulatory and reporting requirements imposed on the charity and not-for-profit sector.

As just mentioned, volunteerism is a critical resource for Irish social enterprises, including WISEs. In a 2018 survey of community-based social enterprises, it was estimated that, on average, each social enterprise had 16 volunteer workers and 7 voluntary trustees (Department of Rural and 
Community Development and Social Finance Foundation 2018). However, national trends in volunteering are changing and this has implications for the long-term survival of Irish WISEs. An estimated 29\% of Irish adults volunteer (CSO 2015), but volunteers now tend to seek more flexible, shortterm and one-off volunteering opportunities (Volunteer Ireland 2018). ${ }^{14}$ Furthermore, volunteers in the not-for-profit and charity sectors (including WISEs) are increasingly critical of the time they are required to spend on what they perceive to be excessive administration and form filling to meet regulatory requirements.

\section{Conclusions}

In this chapter, we have attempted to provide an insight into how the social economy and social enterprise are understood in Ireland and to explain why WISEs have evolved as the dominant Irish SE model to date. We have argued that, while there is diversity in the academic approaches to understanding and defining these concepts, there is less ambiguity in public-policy discourse. Successive Irish governments' strategies to date, of developing the social economy in general, and social enterprise more specifically, have evolved via labour-market integration programmes. From the early 1990s, the state has also been informed by a European policy perspective that promotes the social economy and social enterprises as a civil-society-based solution to a range of localised social and economic problems, most notably unemployment and service provision to disadvantaged communities. Therefore, Irish state support for the sector has mainly taken the form of active labour-market schemes, and WISE has evolved as the dominant SE type.

Historically, Irish WISEs emerged to improve the employability/social integration of people most distant from the labour market and to provide a range of community-based goods and services, most often in disadvantaged urban and rural locations. These WISEs are the by-product of government support for social enterprise through active labour-market schemes, in the absence of any clear national policy or strategy on social enterprise. However, publication of Ireland's first National Social Enterprise Policy 2019-2022 represents the culmination of a notable and growing national political, academic and public interest in social enterprise, which has been particularly noticeable since the recession of the late 2000s. The new policy, within months of publication, has stimulated several initiatives, including public information events; the first National Social Enterprise Conference; the emergence of a new national social-economy research network; and the incorporation of SE support and development strategies in local authorities' economic and community plans. ${ }^{15}$

Aside from policy support for social enterprise, there has also been a notable growth, in recent years, in the availability of cash grants, philanthropic investment, and mentoring/business advisory supports for social 
enterprises and more specifically social entrepreneurs. National organisations such as Social Entrepreneurs Ireland and the Social Innovation Fund Ireland (SIFI) focus on supporting high-potential social entrepreneurs to scale up their impact and, in the case of SIFI, social innovations that deal with a range of contemporary issues, such as managing food waste and tackling food poverty/insecurity, improving peoples' mental health and well-being, and addressing sustainability issues that respond to the challenges of global warming and climate change. These new players in the national SE ecosystem, by supporting socially entrepreneurial individuals launching socially motivated businesses, can be seen to represent the US tradition of social enterprise, that is typically individualistic and philanthropic in nature, and focused on traded income and social innovation. These developments are already giving rise to greater diversity of SE forms in Ireland.

For the foreseeable future, however, it is likely that the Irish state will continue to resource WISE as a way of supporting disadvantaged people to prepare for, and participate in, the labour market and as a means of providing a range of community goods and services in disadvantaged urban and rural locations. WISEs are perceived as valuable entities, with the capacity to utilise and replenish social capital and to harness volunteerism in communities. For these reasons, they are likely to continue to dominate in the broader spectrum of social enterprise. However, WISEs are also constrained by their dependency on limited employment grants to deliver local community goods and services. They are hampered by an unstable resource environment; high employee support costs; weak internal leadership and business skills and capacity to navigate regulatory requirements; and limited ability to provide evidence of social and economic impact. Unless these challenges are addressed, and WISEs appropriately supported, most initiatives are unlikely to realise their potential to contribute to the Irish state's ambitious plan for social enterprise as a vehicle for the identification and implementation of innovative ways to address societal issues and help create a sustainable and inclusive future for all citizens.

\section{Notes}

1 EMES is an international research network, established in 1996, with a focus on social enterprises. EMES outlines nine indicators of social enterprise, namely a continuous activity producing good and/or selling services; a significant level of economic risk; a minimum amount of paid work; an explicit aim to benefit the community; an initiative launched by a group of citizens or civil-society organisations; a limited profit distribution; a high degree of autonomy; a decision-making power not based on capital ownership; and a participatory nature which involves various parties affected by the activity.

2 Friendly societies are registered under the Friendly Societies Acts 1896-2018. They were established for various purposes, mostly to provide small lifeassurance benefits, sick benefits and death benefits to members, to provide benefits to non-members, or to promote particular activities or interests. 
3 The NESF was established by the Irish Government in 1993 to develop economic and social-policy initiatives.

4 PLANET is a partnership network representative of area-based partnership organisations established to tackle unemployment in Ireland.

5 Forfás was, until 2014, the national policy advisory board for enterprise, trade, science, technology and innovation in Ireland. When it was dissolved, most of its functions were incorporated into the government department responsible for Business, Enterprise and Innovation.

6 The Irish Probation Services, in cooperation with the Irish Prison Service supported by the Department of Justice and Equality, launched a Social Enterprise Strategy in 2017. The strategy is designed to support workintegration social enterprises to help ex-offenders reintegrate into the labour force.

7 The Social Finance Foundation (SFF) was established in 2007 by the Irish Government to address the needs of community organisations and social enterprises for loan funding.

8 Some social enterprises fall under more than one category.

9 Defourny and Nyssens (2010) define a set of nine indicators to identify organisations likely to be termed social enterprises.

10 This EU operational definition is an operationalisation of the concept of social enterprise as articulated in the EC's Social Business Initiative (SBI) communication adopted on 23 May 2012. This definition incorporates the three dimensions of social enterprise-namely the entrepreneurial, social and governance-related dimensions.

11 The Dormant Accounts Fund (DAF) was established in 2012 to distribute unclaimed funds from accounts in credit institutions in Ireland to support a range of social and economic development initiatives.

12 At the time of writing, Ireland had a national employment rate of just under $95 \%$.

13 This commitment was made on foot of the 2014 EU Procurement Directive and is contained in an information note on public procurement (Office of Government Procurement 2018).

14 In contrast, corporate volunteering initiatives are on the increase, as the corporate world seeks out new CSR opportunities.

15 A number of local authorities have incorporated a goal to support the social-economy sector in their Local Economic Community Plans.

\section{References}

Acheson, E., Harvey, B., Kearney, J. \& Williamson, W. (2003) Two Paths, One Purpose: Voluntary Action in Ireland, North and South, A Report to the Royal Irish Academy Third Sector Research Programme, Coleraine: Centre for Voluntary Action Studies, University of Ulster.

Borzaga, C. \& Defourny, J. (eds) (2001) The Emergence of Social Enterprise, London and New York: Routledge.

Clann Credo (2011) The Economic and Social Contribution of Clann Credo the Social Investment Fund, Dublin: Clann Credo.

Cooney, K., Nyssens, M., O’Shaughnessy, M. \& Defourny, J. (2016) “Public policies and work integration social enterprises: The challenges of institutionalism in a neoliberal era", Nonprofit Policy Forum, Vol. 7, No. 4, pp. 415-433. 
CSO (2015) Statistical Release-QNHS Volunteering and Wellbeing Q3, 2013, CSO: Ireland.

Curtis, A., O'Shaughnessy, M. \& Ward, M. (2011) “An examination of the tensions and challenges associated with operating as a social enterprise-The case of Irish social enterprises", 3rd EMES International Research Conference on Social Enterprise, "Social Innovation through Social Entrepreneurship in Civil Society”, 4th-7th July, 2011, Roskilde, Denmark.

Dees, J. G. (1998) The Meaning of Social Entrepreneurship, Kansas City and Palo Alto: Kauffman Foundation and Stanford University.

Dees, J. G. \& Anderson, B. B. (2006) "Framing a theory of social entrepreneurship: Building on two schools of practice and thought", Research on Social Entrepreneurship, ARNOVA Occasional Paper Series, Vol. 1, No. 3, pp. 39-66.

Defourny, J. \& Nyssens, M. (2010) “Conceptions of social enterprise and social entrepreneurship in Europe and the United States: Convergences and divergences", Journal of Social Entrepreneurship, Vol. 1, No. 1, pp. 32-53.

Defourny, J. \& Nyssens, M. (2012) “The EMES Approach of Social Enterprise in a Comparative Perspective”, EMES Working Papers, No. 12/03, Liege: EMES International Research Network.

Department of Rural and Community Development and Social Finance Foundation (2018) Social Enterprise in Ireland. Research Report to Support the Development of a National Social Enterprise Policy, Dublin: Government of Ireland.

Di Domenico, M., Haugh, H. \& Tracey, P. (2010) "Social bricolage: Theorizing social value creation in social enterprises", Entrepreneurship Theory and Practice, Vol. 34, No. 4, pp. 681-703.

Donnelly-Cox, G. (1998) "A white paper for the Irish voluntary sector Linkages between policy and third sector organizations", Paper presented to the CVO 20th Anniversary Conference, London School of Economics, September 17-18.

Donoghue, F. (1998) "Defining the non-profit sector: Ireland", in Salamon, L. M. \& Anheier, H. K. (eds) Working Papers of the Johns Hopkins University Comparative Non-profit Sector Project, No. 28, Baltimore: The Johns Hopkins Institute for Policy Studies.

Donoghue, F., Anheier, H. K. \& Salamon, L. M. (1999) Uncovering the NonProfit Sector in Ireland-Its Economic Value and Significance, Dublin: National College of Ireland and Baltimore: Johns Hopkins University.

Donoghue, F., Prizeman, G., O’ Regan, A. \& Noel, V. (2006) The Hidden Landscape-First Forays into Mapping Non-Profit Organisations in Ireland, Dublin: Trinity College Dublin.

European Commission (1993) White Paper on Growth, Competitiveness and Employment, European Commission, Brussels.

European Commission (1995a) Action to Turn Growth into Jobs, European Commission, Brussels.

European Commission (1995b) Local Development and Employment Initiatives, European Commission, Brussels.

European Commission (2011) The Social Business Initiative of the European Commission, European Commission Publication, Luxembourg: Publications Office, European Union. 
European Commission (2014, 2016, 2019) Mapping Study on Social Enterprise Ecosystems-Country Report on Ireland, Luxembourg: Publications Office, European Union.

Forfás (2013) Social Enterprise in Ireland, Sectoral Opportunities and Policy Issues, Dublin: Forfás, Dublin, Ireland.

GECES (2016) Social Enterprises and the Social Economy Going Forward, Brussels: Commission Expert Group on Social Entrepreneurship, European Union.

Government of Ireland (2012) Action Plan for Jobs 2012, Dublin: Government Publications.

Government of Ireland (2019) National Social Enterprise Policy for Ireland 2019-2022, Dublin: Government Publications.

Hynes, B. (2016) Creating an Enabling, Supportive Environment for the Social Enterprise Sector in Ireland, Report/submission to the Irish Local Development Network, Ireland.

Mendell, M. (2010) "Reflections on the evolving landscape of social enterprise in North America”, Policy \& Society, Vol. 29, No. 3, pp. 243-256.

Moroney, A. \& O'Shaughnessy, M. (2017) Developing the Social Enterprise Sector in Ireland: A Comparative Perspective, Report prepared for the Social Finance Foundation, Dublin.

National Economic and Social Forum (1995) Jobs Potential of the Services Sector, Report No. 7, Dublin: Government Publications.

Nicholls, A. (ed.) (2006) Social Entrepreneurship. New Models of Sustainable Social Change, New York: Oxford University Press.

Nyssens, M. (ed.) (2006) Social Enterprise-At the Crossroads of Market, Public Policies and Civil Society, London and New York: Routledge.

Nyssens, M., Defourny, J., Gardin, L. \& Laville, J.-L. (2012) “Work Integration Social Enterprises and Public Policy-An Analysis of the European Situation", EMES Working Paper, Liege: EMES International Research Network.

OECD/European Union (2017) Boosting Social Enterprise Development Good Practice Compendium, Paris: OECD Publishing.

Office of Government Procurement (2018) Information Note-Incorporating Social Considerations into Public Procurement, Government of Ireland: Dublin.

O’Hara, P. (2001) “Social enterprises and local development”, in Borzaga, C. \& Defourny, J. (eds) (2001) The Emergence of Social Enterprise, London: Routledge.

Olmedo, L., van Twuijver, M. \& O’Shaughnessy, M. (2019) Community-Based Social Enterprises. Fostering Inclusive Development in Peripheral European Rural Areas, SSE Knowledge Hub, UN Inter-Agency Task Force on Social and Solidarity Economy, United Nations Research Institute for Social Development, Geneva.

O'Shaughnessy, M. (2008) "Statutory support and the implications for the employee profile of rural based Irish Work Integration Social Enterprises (WISEs)", Social Enterprise Journal, Vol 4, No. 2, pp. 126-135.

O'Shaughnessy, M. \& O'Hara, P. (2013) Social Enterprise in Rural Communities, National Rural Network, Ireland

O'Shaughnessy, M. \& O'Hara, P. (2016) “Rural social enterprises-Patterns of emergence and development", International Review of Sociology, Vol 26, No. 2, pp. 223-233. 
Pestoff, V. (1998) Beyond the Market and State. Civil Democracy and Social Enterprises in a Welfare Society, Aldershot: Ashgate.

PLANET (1997) Building the Social Economy: New Areas of Work, Enterprise and Development, Dublin: Pobal.

PLANET (2005) Third Sector Policy Group-Development of Model for Social Economy in Ireland, Dublin: PLANET.

Powell, F. \& Guerin, D. (1997) Civil Society and Social Policy: Voluntarism in Ireland, Dublin: A \& A Farmer.

Prizeman, G. \& Crossan, D. (2011) Mapping Social Entrepreneurship in Ireland, Dublin: Centre for Nonprofit Management, Trinity College.

Salamon, L. M. \& Anheier, H. K. (1997) Defining the Nonprofit Sector, A CrossNational Analysis, Manchester: Manchester University Press.

Spear, R. \& Bidet, E. (2005) "Social enterprises for work integration in 12 European countries: A descriptive analysis", Annals of Public and Cooperative Economics, Vol. 76, No. 2, pp. 195-231.

Teasdale, S. (2011) "What's in a name? Making sense of social enterprise discourses", Public Policy and Administration, Vol. 27, No. 2, pp. 99-119.

Volunteer Ireland (2018) Strategic Plan 2018-2022, Dublin: Ireland.

WRC Social and Economic Consultants (1999) Social Enterprises and the Social Economy, Dublin: WRC Social and Economic Consultants.

WRC Social and Economic Consultants (2003) Evaluation of the Social Economy Programme, Dublin: WRC Social and Economic Consultants. 


\title{
8 Social Enterprise in Italy \\ A Plurality of Business and Organisational Models
}

\author{
Simone Poledrini and Carlo Borzaga
}

\section{Introduction}

In recent years, several scholars have engaged in the study of Italian social cooperatives from different perspectives, such as work quality and job satisfaction (Borzaga and Depedri 2005; Borzaga and Tortia 2006; Becchetti et al. 2014), theoretical framework (Bacchiega and Borzaga 2001; Borzaga and Tortia 2009; Poledrini 2015), various networking strategies (Daniele et al. 2009) or the impact of the recent financial crisis (Costa and Carini 2016). The focus on this type of enterprise has led over the years to the belief that social cooperatives are the only type of social enterprise (SE) that exists in Italy, or at least that they constitute the great majority of all Italian social enterprises.

Social cooperatives, however, do not exhaustively represent the whole SE "phenomenon" in Italy (Poledrini 2018); indeed, other non-profit organisations can also be considered as social enterprises in all respects, even though not all of them declare or consider themselves as such. The activities managed by social enterprises are also wider than those managed by social cooperatives. In fact, social enterprises have expanded their sectors of activity in recent years: whereas the first social enterprises only provided social, health-care, educational and work-integration services, SE activities now include the provision of other, innovative services such as environmental, cultural, sport and recreational activities, the promotion of economic development, etc. Moreover, the "Italian" concept of social enterprise is increasingly being flanked by those of "community enterprise", "community cooperative" and "citizens' cooperative", and these types of social enterprise seem to have a considerable potential for growth.

In light of the above considerations, this chapter aims to present the widely varied landscape of social enterprise in Italy. In particular, the chapter will consider all the non-profit organisations characterised by a non-profit distribution constraint and by a clear social purpose but which behave as enterprises, despite not being legally classified as social enterprises. In other words, within the scope of the present analysis, the 


\section{Poledrini \& Borzaga}

term social enterprise will refer not only to the organisations considered as social enterprises by Italian law, such as social cooperatives and social enterprises ruled by Legislative Decree No. 155 of 2006, but also to de facto social enterprises, established as associations, foundations and religious institutions. In particular, we will consider as social enterprises all the non-profit organisations that derive at least $50 \%$ of their total revenue from contracts or agreements with public institutions or from the sale of goods and services, and that have at least one employee.

The research questions we intend to answer are the following: "How many different types of social enterprise are there in Italy?"; "How many social enterprises of each type are there?" and "How do these various types differ?" To answer these research questions, we will present the various types of social enterprise and we will describe them in both qualitative and quantitative terms. The major future prospects of each SE type will be briefly taken into consideration, while the quantitative aspects will be presented in a more detailed analysis, based mainly on information from the 2011 census on non-profit institutions; the aspects that will be considered are (1) the number of employees; (2) the geographical distribution; (3) the sector of activity; and (4) the main sources of revenues.

The chapter is structured as follows: The first section describes the evolution of Italian social enterprises. The second section illustrates the research methodology and the general context of the analysis. The following four sections present the various types of Italian social enterprises, along with their key features, and analyse the quantitative information available for each type. The final section presents the conclusions.

\subsection{Evolution of Italian Social Enterprises}

To understand the origins and evolution of social enterprise in Italy, both as a concept and as a reality, it is important to bear in mind the economic, social and cultural changes that have taken place in the country since the 1970s. In fact, the 1970s and the following decades brought about the conditions that led to the formation of the first Italian social enterprises (Borzaga et al. 2017). In the following paragraphs, we briefly summarise this period in four main steps.

\subsubsection{The 1970s: Emergence of a Growing Gap between the Demand for and Supply of Social Services}

In the 1970s, Italy experienced for the first time a growing rift between new, emerging needs and the public welfare system's ability to cope. The emergence of these new needs created a new "demand" for social services, which the public welfare system was not prepared to deal with. Moreover, in contrast to other countries, the non-profit sector was also poorly 
developed (Barbetta 1997; Perlmutter 1991); existing non-profit organisations dealt almost exclusively with advocacy. Furthermore, according to the wording of the Civil Code, associations and foundations could not perform productive and commercial activities. All these elements resulted in a situation in which neither the Italian public welfare system nor the private-both for-profit and non-profit-sector was able to cope adequately with the new social needs of Italian society.

\subsubsection{The 1980s: Emergence of an Organised Civic Response to the New Needs}

In the 1980s, the marginalisation of various segments of the population (a phenomenon linked inter alia to the "new poverties") gradually began to gain ground, due not only to the emerging new needs but also to the progressive closure of the traditional facilities for people with health and social problems, such as all-encompassing institutions that segregated people by limiting their relations with their family and community. As a reaction to these situations and in an attempt to answer those needs, groups of people, bound by idealistic values and serving mainly as volunteers, began to establish new services. After a few years, these voluntary organisations realised that public institutions would not step in to meet these new needs, and they gradually concluded that the range of services they were offering should be consolidated and extended, among other means by adopting the cooperative form. In those new, so-called social-solidarity cooperatives, in comparison to traditional cooperatives, elements of internal mutuality were attenuated, while those concerning solidarity were boosted. These organisations carried out work-integration and service-provision activities, running drug rehabilitation communities, group homes for children, reception facilities for the homeless, home-care services for the elderly, etc.

\subsubsection{The 1990s: Recognition of Voluntary Organisations and Social Cooperatives}

The major turning point in the development of Italian social enterprises, and particularly of those operating under the form of associations and cooperatives, took place in the late 1980s and early 1990s, when the fast multiplication of these organisations made necessary for public institutions to adopt specific regulations. This led to the implementation of a series of legislative measures, which resulted in turn in a further increase in the number of both voluntary organisations and social cooperatives throughout Italy during the following years. Particularly worth mentioning, among these legal actions, are the adoption of Law No. 381, in 1991, and of Law No. 266, in the 


\section{Poledrini \& Borzaga}

same year, which recognised and regulated respectively social cooperatives and voluntary organisations.

\subsubsection{The 2000s: Recognition of Social Enterprises' Pluralism}

During the following years, numerous additional legal provisions were adopted. Some of them aimed to reorganise social policies, and more particularly the provision of social and general-interest services, while others were intended for acknowledging and regulating new types of non-profit organisations. In particular, in 2005, the Parliament approved Law No. 118 on social enterprises, which was complemented, in 2006, by Legislative Decree No. 155. This law recognises and regulates the possibility to establish a social enterprise under any legal form other than that of social cooperative and provided for by the Italian Civil Code. This legislation clearly constitutes, at least in theory, a significant change in the field of Italian social enterprise; indeed, this law makes it possible to create a social enterprise without necessarily making use of the socialcooperative form.

\subsection{Research Methodology and General Context}

When reviewing the various definitions of social enterprise used in the literature in recent years, the approach put forward in the late 1990s by the EMES International Research Network (Borzaga and Defourny 2001; Defourny and Nyssens 2008) remains the most comprehensive and influential. To date, it is supported by many scholars, and it is even used by the legislators of various European countries, as well as by the European Commission itself. According to this approach, a social enterprise is a private legal entity, independent from the government, that carries out production activities, regardless of the legal form adopted; moreover, unlike conventional businesses, social enterprises have an explicit social aim and engage in activities that generate direct benefits for a community or for disadvantaged persons; they are constrained — at least partially —in their profit distribution; and they tend to be characterised by an inclusive and participative governance. Following such approach, we can identify in Italy four groups of social enterprises: (1) social cooperatives which are regulated by Law No. 381/ 1991; (2) social enterprises operating under the form of association; (3) social enterprises operating under the form of foundation or religious institution; and (4) social enterprises registered as limited companies.

It is possible to assess the number of Italian social enterprises by drawing on two different sources of data. The first one is the 2011 Census on Non-profit Institutions (ISTAT - National Institute for Statistics 2011), which provides information on social cooperatives, associations, foundations and religious institutions; the second one is the Business Register of the Italian Chamber of Commerce, which provides information on social 
enterprises operating under the limited-company legal form. Data from the Business Register used in the present analysis refer to information regarding the year 2013 .

Since all the 301,191 organisations included in the Census are, by law, submitted to a (total or partial) non-distribution constraint, have a social aim and perform activities of general interest, in order to identify social enterprises among them, we simply had to single out those that could be regarded as enterprises. Against this background, we considered as social enterprises all the non-profit organisations surveyed by the Census that met the following two criteria: (1) they derived at least $50 \%$ of their income from the sale of goods and services to private consumers and other enterprises or from contracts/agreements with public institutions; and (2) they had at least one employee.

Based on these criteria, out of a total of 301,191 non-profit organisations surveyed, we identified 20,431 social enterprises $(6.8 \%$ of the total number of non-profit institutions). These figures probably underestimate the real size of the sector, not only because the joint use of these two parameters is very selective, but also because traditional cooperatives performing activities similar to those of social enterprises were not included in the Census.

Adding to these 20,431 social enterprises the 235 organisations established as limited companies and registered by the Italian Chamber of Commerce (which are not included in the Census) gives a total of 20,666 social enterprises. These are distributed by legal form as follows:

- $41.1 \%$ of all social enterprises (8,491 organisations) are social cooperatives;

- $38.1 \%$ (7,883 organisations) are associations;

- $16.1 \%$ (3,324 organisations) are foundations and religious institutions;

- $1.1 \%$ (235 organisations) are limited-company social enterprises;

- $3.6 \%$ (733 organisations) are initiatives classified as "others", because they could not be assigned to one of the four groups of social enterprise, since the available information was incomplete. ${ }^{1}$

As regards the distribution of the labour force, ${ }^{2}$

- social cooperatives employed 303,715 people, which represented $55.7 \%$ of the 545,270 workers employed by all social enterprises except limited companies and $44.6 \%$ of all the employees working for non-profit organisations (680,811 workers);

- foundations and religious institutions had 148,977 employees, representing $27.3 \%$ of all the workers employed by social enterprises except limited companies, and $21.9 \%$ of employees of the entire nonprofit sector; 


\section{Poledrini \& Borzaga}

- associations represented $12.7 \%$ (69,421 workers) of all the employees working for social enterprises except limited companies, and just over $10 \%$ of all the staff working for non-profit organisations.

Finally, it is worth noting that the first two types of social enterprise listed above (social cooperatives and foundations and religious institutions) represented $8 \%$ of the whole non-profit sector in terms of number of organisations but employed $66.5 \%$ of the whole labour force of the sector.

Information provided by the Census on Non-profit Institutions (ISTAT - National Institute for Statistics 2011) and the Italian Chamber of Commerce also allows for more in-depth analyses of the four types of social enterprise; these are presented in the following sections. ${ }^{3}$

\subsection{Social Cooperatives}

Article 1 of Law No. 381/91 defines "social cooperatives" as those cooperatives that aim to pursue the general interest of the community and the human promotion and social integration of citizens through (1) the provision of social, health-care and educational services, or

(2) the performance of any other activity with the aim of providing employment for disadvantaged people. The first type is referred to as A-type social cooperatives, while organisations of the second type are called B-type social cooperatives.

Despite being part of the cooperative sector, social cooperatives have several characteristics that distinguish them from traditional cooperatives, three of which are particularly salient: First of all, as just mentioned, social cooperatives pursue the general interest of the community, and not only the interests of their members. The second difference lies in the possibility for social cooperatives to include volunteers as members, up to $50 \%$ of the total membership. Finally, in B-type social cooperatives, disadvantaged workers must also be members.

Out of the 8,491 social cooperatives that comply with the definition of social enterprise, 5,621 are A-type or mixed cooperatives (i.e., organisations that are both providing social services and employing disadvantaged people), and 2,870 are B-type social cooperatives. As far as these organisations' geographical distribution is concerned, $43.5 \%$ of all social cooperatives are located in the Northern regions, while Southern Italy and the Islands are home to respectively $23 \%$ and $14.9 \%$ of social cooperatives. The remaining $18.6 \%$ are located in Central Italy (see table 8.1 ).

As expected, $75.3 \%$ of social cooperatives are concentrated in two sectors: social services $(40.6 \%$ of social cooperatives) and economic development and social cohesion $(34.7 \%)$ - a sector of activity that includes almost only work-integration social cooperatives (see table 8.2). The large majority $(77.1 \%)$ of A-type and mixed social cooperatives 
Italy 137

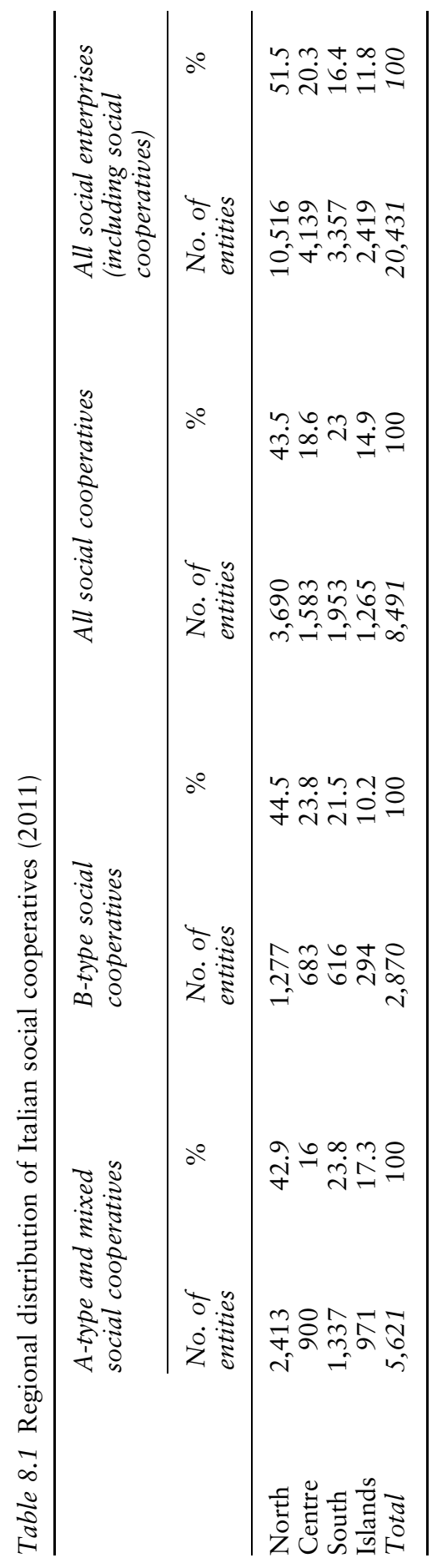




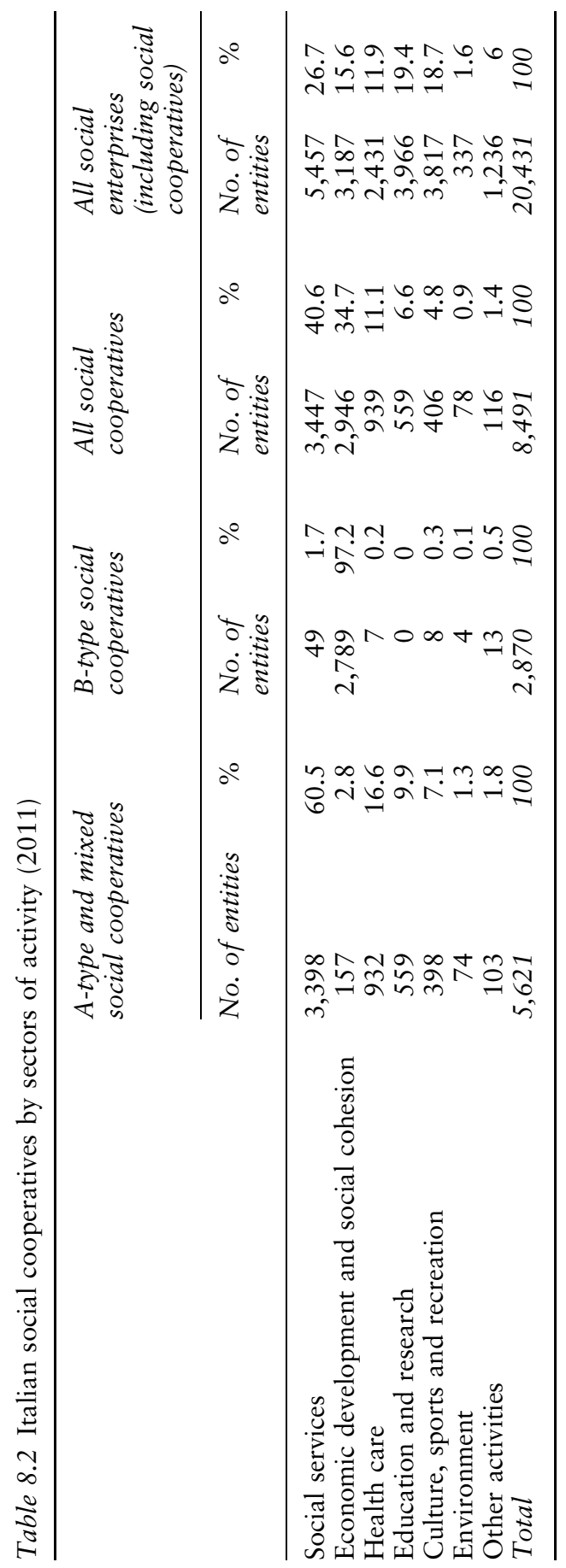


provide social and health services, and $97.2 \%$ of B-type social cooperatives have work-integration activities.

A-type and mixed social cooperatives derive approximately $70 \%$ of their income from "contracts and/or agreements with public institutions" and $26.2 \%$ from the "sale of goods and services to private clients" (see table 8.3). Other sources of income, like donations, play a very limited role. B-type social cooperatives rely, more than their A-type counterparts, on resources derived from private clients: $37.8 \%$ of their total resources come from the "sale of goods and services to private clients", and only $57.1 \%$ of their resources originate in "contracts and/ or agreements with public institutions" - and these are often obtained as a result of participation in competitive tenders.

\subsection{Social Enterprises Operating under the Associative Form}

Associations are organisations established by groups of people to pursue a common goal, consisting in an advocacy activity for members and nonmembers or in the provision of services. In most countries, associations cover a vast and varied area within the non-profit sector, including both rudimentary and small-scale organisations (like recreational or amateur sports clubs) and larger and better-known entities, with complex organisational structures. Traditionally, in Italy, the legal form of association was not used to run a business activity (or only a very marginal one), nor was such possibility provided for by the Civil Code. However, in the last decades, the context has changed, and many associations have started managing the production of services.

Like the other kinds of Italian social enterprises, associative social enterprises are more concentrated in Northern Italy. This part of the country is indeed home to slightly over half of all associative social enterprises. In fact, the distribution of associative social enterprises in the various regions is quite similar to that of social enterprises in general: Associative social enterprises located in the Central regions represent $23.2 \%$ of the total number of associative social enterprises (the corresponding figure for all social enterprises is $20.3 \%$ ), and associative social enterprises located in Southern Italy and in the Islands represent approximately one quarter of all associative social enterprises (the corresponding figure for all social enterprises is slightly higher; see table 8.4).

Concerning the activities performed, $37 \%$ of all associative social enterprises operate in the field of "culture, sports and recreation" (see table 8.5); also worth noting is the fact that associative social enterprises represent $77 \%$ of all social enterprises working in this field. Even though only about $12 \%$ and $3 \%$ of all the activities performed by associative social enterprises fall respectively within the categories of "other activities" and "environment", associative social enterprises in these two 


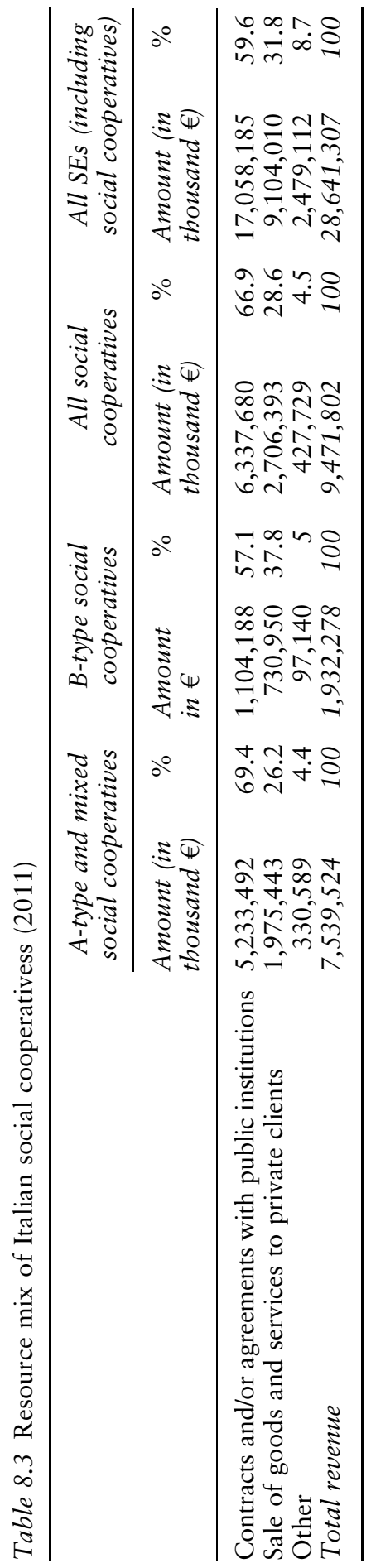


Table 8.4 Regional distribution of Italian associative social enterprises (2011)

\begin{tabular}{lcccc}
\hline & \multicolumn{2}{c}{ Associative social enterprises } & \multicolumn{2}{c}{$\begin{array}{c}\text { All social enterprises (including } \\
\text { associative social enterprises) }\end{array}$} \\
\cline { 2 - 5 } & No. of entities & $\%$ & No. of entities & $\%$ \\
\hline North & 4,101 & 52 & 10,516 & 51.5 \\
Centre & 1,828 & 23.2 & 4,139 & 20.3 \\
South & 1,008 & 12.8 & 3,357 & 16.4 \\
Islands & 946 & 12 & 2,419 & 11.8 \\
Total & 7,883 & 100 & 20,431 & 100 \\
\hline
\end{tabular}

Table 8.5 Sectors of activities of associative social enterprises (2011)

\begin{tabular}{lcrrr}
\hline & $\begin{array}{l}\text { Associative social } \\
\text { enterprises }\end{array}$ & \multicolumn{2}{l}{$\begin{array}{l}\text { All social enterprises } \\
\text { (including associative } \\
\text { social enterprises) }\end{array}$} \\
\cline { 2 - 5 } & No. of entities & $\%$ & No. of entities & $\%$ \\
\hline Culture, sports and recreation & 2,925 & 37.1 & 3,817 & 18.7 \\
Education and research & 1,469 & 18.6 & 3,966 & 19.4 \\
Social services & 1,155 & 14.7 & 5,457 & 26.7 \\
Health care & 1,012 & 12.8 & 2,431 & 11.9 \\
Environment & 226 & 2.9 & 337 & 1.6 \\
Economic development and & 165 & 2.1 & 3,187 & 15.6 \\
$\quad$ social cohesion & 931 & 11.8 & 1,236 & 6.0 \\
Other activities & 7,883 & 100 & 20,431 & 100 \\
Total & & & & \\
\hline
\end{tabular}

sectors represent respectively $75.3 \%$ and over $67 \%$ of all Italian social enterprises active in these fields. Finally, the activity in which these social enterprises are less present is that of "economic development and social cohesion", that is, the work integration of disadvantaged people. In fact, there are only 165 associative entities operating in this area, which corresponds to $2.1 \%$ of the total, while about $16 \%$ of all Italian social enterprises are active in the same area.

Social enterprises established as associations derive slightly over half of their revenues (about $€ 3$ billion in total) from "contracts and/or agreements with public institutions" (see table 8.6). Associative social enterprises thus depend less on public resources than social enterprises overall. Among all Italian social enterprises, they are the model with the highest percentage of "other" sources of funding $(13.9 \%)$; these are primarily constituted by membership fees. 
Table 8.6 Resource mix of associative social enterprises (2011)

\begin{tabular}{|c|c|c|c|c|}
\hline \multirow[t]{2}{*}{ Types of revenues } & \multicolumn{2}{|c|}{$\begin{array}{l}\text { Associative social } \\
\text { enterprises }\end{array}$} & \multicolumn{2}{|c|}{$\begin{array}{l}\text { All social enterprises } \\
\text { (including associative } \\
\text { social enterprises) }\end{array}$} \\
\hline & $\begin{array}{l}\text { Revenues (in } \\
\text { thousand } € \text { ) }\end{array}$ & $\%$ & $\begin{array}{l}\text { Revenues (in } \\
\text { thousand } € \text { ) }\end{array}$ & $\%$ \\
\hline $\begin{array}{l}\text { Contracts and/or agreements } \\
\text { with public institutions }\end{array}$ & $2,942,209$ & 52.0 & $17,058,185$ & 59.6 \\
\hline $\begin{array}{l}\text { Sale of goods and services } \\
\text { to private clients }\end{array}$ & $1,935,277$ & 34.2 & $9,104,010$ & 31.8 \\
\hline Other & 784,243 & 13.9 & $2,479,112$ & 8.7 \\
\hline Total revenues & $5,661,729$ & 100 & $28,641,307$ & 100 \\
\hline
\end{tabular}

\subsection{Social Enterprises Operating under the Forms of Foundations and Religious Institutions}

The Italian Civil Code defines foundations as assets dedicated to the pursuit of a public-interest objective. According to the law, a foundation must always be recognised by a public authority and must, therefore, have legal status. As it was also the case for associations, legislation on foundations has changed significantly since the early 1990s. As a consequence, the sector has been strengthened.

Religious, charitable institutions-which almost all belong to the Catholic Church-are not formally foundations, but since they have a similar form of governance, they can be included in the category of foundations, and more specifically in the subcategory of operational foundations. These organisations conduct different charitable activities, such as providing educational, health and social services, and they are quite well known and spread across the country.

Among the various types of social enterprise, the group of organisations operating under the legal form of foundation or religious institution is that with the greatest concentration in the North of Italy. Indeed, over $70 \%$ of these institutions are located in the Northern regions (see table 8.7). Throughout the rest of Italy, this form of social enterprise is distributed in the following manner: $17 \%$ of these social enterprises are located in Central Italy, and $12.3 \%$ in Southern Italy and on the Islands.

Like those included in the previous two groups, social enterprises operating under the form of foundations and religious institutions concentrate their efforts on specific areas of activity. In fact, slightly over half of these social enterprises operate in the field of education and research (table 8.8), and they account for $44 \%$ of all social enterprises operating in the field of education and research. Other important 
Table 8.7 Regional distribution of social enterprises operating under the form of foundations or religious institutions (2011)

\begin{tabular}{|c|c|c|c|c|}
\hline & \multicolumn{2}{|c|}{$\begin{array}{l}\text { Social enterprises operating } \\
\text { under the form of foundations or } \\
\text { religious institutions }\end{array}$} & \multicolumn{2}{|c|}{$\begin{array}{l}\text { All social enterprises } \\
\text { (including foundations and } \\
\text { religious institutions) }\end{array}$} \\
\hline & No. of entities & $\%$ & No. of entities & $\%$ \\
\hline North & 2,351 & 70.7 & 10,516 & 51.5 \\
\hline Centre & 564 & 17.0 & 4,139 & 20.3 \\
\hline South & 286 & 8.6 & 3,357 & 16.4 \\
\hline Islands & 123 & 3.7 & 2,419 & 11.8 \\
\hline Total & 3,324 & 100 & 20,431 & 100 \\
\hline
\end{tabular}

Table 8.8 Sectors of activity of social enterprises operating under the form of foundations or religious institutions (2011)

\begin{tabular}{|c|c|c|c|c|}
\hline & \multicolumn{2}{|c|}{$\begin{array}{l}\text { Social enterprises } \\
\text { operating under the } \\
\text { form of foundations or } \\
\text { religious institutions }\end{array}$} & \multicolumn{2}{|c|}{$\begin{array}{l}\text { All social enterprises } \\
\text { (including foundations } \\
\text { and religious } \\
\text { institutions) }\end{array}$} \\
\hline & No. of entities & $\%$ & No. of entities & $\%$ \\
\hline Education and research & 1,726 & 51.9 & 3,966 & 19.4 \\
\hline Social services & 672 & 20.2 & 5,457 & 26.7 \\
\hline Health care & 408 & 12.3 & 2,431 & 11.9 \\
\hline Culture, sports and recreation & 371 & 11.2 & 3,817 & 18.7 \\
\hline $\begin{array}{l}\text { Economic development and } \\
\text { social cohesion }\end{array}$ & 18 & 0.5 & 3,187 & 15.6 \\
\hline Environment & 11 & 0.3 & 337 & 1.6 \\
\hline Other activities & 118 & 3.5 & 1,236 & 6.0 \\
\hline Total & 3,324 & 100 & 20,431 & 100 \\
\hline
\end{tabular}

activities performed by social enterprises in this group are social services, health care, and culture, sports and recreation.

Social enterprises taking the form of foundations or religious institutions are the type of social enterprise with the highest average income per organisation. The total revenues of these organisations amount to over $€ 10$ billion, and account for $35.3 \%$ of all the revenues generated by social enterprises and approximately $16 \%$ of all the revenues produced by the non-profit sector-even though these organisations only represent $1.1 \%$ of all non-profit organisations (table 8.9). Furthermore, social enterprises belonging to this group can be distinguished from the other types of social enterprise by the fact that the revenue they derive from the sale of goods and services to private clients amounts to over $€ 3.4$ 
Table 8.9 Resource mix of social enterprises operating under the form of foundations or religious institutions (2011)

\begin{tabular}{llrlr}
\hline Source of revenues & $\begin{array}{l}\text { Social enterprises } \\
\text { operating under the } \\
\text { form of foundations or } \\
\text { religious institutions }\end{array}$ & $\begin{array}{l}\text { All social enterprises } \\
\text { (including foundations } \\
\text { and religious } \\
\text { institutions) }\end{array}$ & \\
\cline { 2 - 6 } & $\begin{array}{l}\text { Amount (in } \\
\text { thousand } € \text { ) }\end{array}$ & $\%$ & $\begin{array}{l}\text { Amount (in } \\
\text { thousand } € \text { ) }\end{array}$ & $\%$ \\
\hline $\begin{array}{c}\text { Contracts and/or agreements } \\
\text { with public institutions }\end{array}$ & $5,758,260$ & 56.9 & $17,058,185$ & 59.6 \\
$\begin{array}{c}\text { Sale of goods and services to } \\
\text { private clients }\end{array}$ & $3,443,088$ & 34.0 & $9,104,010$ & 31.8 \\
$\begin{array}{l}\text { Other } \\
\text { Total revenues }\end{array}$ & 922,854 & 9.1 & $2,479,112$ & 8.7 \\
\hline
\end{tabular}

billion-a figure that is significantly higher than the corresponding figure for the other types of social enterprise, and which corresponds to approximately $38 \%$ of the total income derived from this source by all social enterprises.

\subsection{Limited-Company Social Enterprises}

Since 2006, following the introduction of Law No. 118 and of Legislative Decree No. 155, a social enterprise has had the possibility to register under the legal form of a joint-stock company or a limitedliability company. In order to qualify as a social enterprise, a limited company must meet three main criteria: (1) it must be privately owned; (2) it must mainly perform business activities, involving the production of goods or the provision of services; and (3) it must act in the interest of the community on a non-profit basis. Social enterprises established as limited companies cannot be controlled by public agencies nor by forprofit companies. Furthermore, the law requires that they respect certain general principles regarding transparency and proper and efficient management, as well as guarantee the participation and protect the interests of both their workers and users (Fici 2006). Finally, thanks to legislative Decree No. 117/2017, social enterprises constituted under the legal form of the limited-liability or joint-stock company are allowed to distribute to their shareowners up to $50 \%$ of their current profits, although they are still not allowed to distribute their assets.

The primary source of data about enterprises of this type is the Business Register managed by the Chamber of Commerce. According to this source, a total of 774 private organisations had registered as social enterprises by the end of 2013. Of these 774 organisations, only 235 (around 30\%) had 
the legal form of limited company. More precisely, 231 were limitedliability companies and four were joint-stock companies. The remaining $70 \%$ were cooperatives (mainly social cooperatives and a few associations), and as such, they were already included in the Census data.

Some more detailed information can be obtained by crossing the data from the Business Register with a sample survey recently conducted by the Iris Network (Venturi and Zandonai 2014). It appears that $55 \%$ of limited-company social enterprises are primarily engaged in education and training activities, with a particular focus on education and educationrelated services. The remaining ones are mainly involved in the provision of social and health-care activities (22\% of organisations), including medical and dental services, and in environmental, cultural and heritagemaintenance activities and social tourism (13\%). These figures reveal that, although the new law allows social enterprises to operate in a wider range of fields than those permitted to social cooperatives, when social enterprises are active in the fields where social cooperatives are allowed to operate, they continue to prefer the cooperative form. Analysis also reveals that a large share $(47.5 \%)$ of limited-company social enterprises are located in the southern regions.

Social enterprises operating under the legal form of limited company can also be distinguished from traditional social cooperatives by their focus on the demands of households. In fact, they mainly offer their services directly to individuals and families, rather than through local authorities.

Not all social enterprises in this category employ workers, and the average number of paid workers is much lower in limited-company social enterprises than in the other types of social enterprise. In fact, in 2013, the average number of employees in these social enterprises was 16 , while for the other types of social enterprise, it was around 27.

Unlike traditional limited companies, limited-company social enterprises were not all created by a small number of capital contributors; rather, as for the other types of social enterprise, several of them were established by groups of people with common ideals and shared values. Some of these social enterprises were constituted by other non-profit institutions, such as associations, foundations and social cooperatives. The main reasons for choosing this legal form included the possibility of "intercepting" a new public demand, combined with the desire to maintain or reinforce the social nature of the activity performed. It should also be noted that a number of these enterprises were constituted before the approval of the law, and only took on the form of social enterprises at a later stage (basically, they already behaved as limited-company social enterprises, although they were not yet recognised as such by law).

Finally, data show that social enterprises constituted as limited companies do not seem particularly dynamic: they have a low propensity for investment and innovation and, when the survey was carried out, the 
vast majority of them closed their balance sheets with neither gains nor losses, and expected to maintain this trend for the following years.

Thus, despite the approval of the law, the limited-company form does not seem to be appealing to those who intend to constitute a social enterprise, at least under the current conditions. People willing to establish a new social enterprise continue to prefer collective-associative or cooperative-entrepreneurial forms.

\section{Conclusion}

This chapter summarises the main developments that have affected and are still affecting Italian social enterprises, and it provides data about these enterprises' importance and key features.

The chapter analyses the dynamics through which social enterprises have developed in the country. The emergence of social enterprise in Italy was clearly a bottom-up phenomenon. Indeed, Italian social enterprises are, to a great extent, and regardless of the legal forms used and the activities carried out, a grassroots phenomenon. This makes the Italian experience unique compared to what happened in other European countries, where social enterprises have often been developed through a top-down process (Hulgård and Spear 2006). In other words, Italian social enterprises arose from spontaneous initiatives of groups of citizens supported by widespread social participation and civic engagement. Only after a decade of development did they start to progressively attract the attention of policy makers, who recognised their role and supported them by allocating significant public resources to finance the services they provided. This was particularly true until the beginning of the 21st century; public support then started growing more slowly, following the economic and financial crisis that erupted in 2007.

In just over two decades, social enterprises have grown in numbers and in economic and social importance, especially in terms of employment and number of users. These users include persons in critical conditions of hardship. Moreover, social enterprises have expanded their activities, from traditional social services and work integration to new areas (cultural services, health, sports, education and research), and these positive trends have persisted despite the economic and financial crisis.

Social enterprise is a complex phenomenon, based on various models (cooperative, association, foundation), each of which is becoming increasingly specialised in terms of types of activity and types of owners. The only organisational type that seems not to be developing to the same extent as the others is that of the limited-liability company. Social enterprises seem to remain primarily collective enterprises, that is, enterprises launched and operated by people and for people. 


\section{Notes}

1 They will not be considered in the following.

2 Unfortunately, the number of employees is not available for limited-company social enterprises.

3 The analyses on social cooperatives and social enterprises operating under the form of associations, foundations and religious institutions are based on data from the Census on Non-profit Institutions (ISTAT - National Institute for Statistics 2011), which concern in total 19,698 organisations, while analyses about limited-company social enterprises are based on the dataset of the Italian Chamber of Commerce, which includes data about 235 social enterprises. We should underline here that, unless otherwise specified, when referring to "all social enterprises" in sections 8.3, 8.4 and 8.5, we mean "all social enterprises except those registered as limited companies".

\section{References}

Bacchiega, A. \& Borzaga, C. (2001) "Social enterprises as incentive structures. An economic analysis", in Borzaga, C. \& Defourny, J. (eds) The Emergence of Social Enterprise, London: Routledge.

Barbetta, G. P. (ed.) (1997) The Nonprofit Sector in Italy, Manchester: Manchester University Press.

Becchetti, L., Castriota, S. \& Depedri, S. (2014) "Working in the for-profit versus not-for-profit sector: What difference does it make? An inquiry on preferences of voluntary and involuntary movers", Industrial and Corporate Change, Vol. 23, No. 4, pp. 1087-1120.

Borzaga, C. \& Defourny, J. (eds) (2001) The Emergence of Social Enterprise, London: Routledge.

Borzaga, C. \& Depedri, S. (2005) "Interpersonal relations and job satisfaction: Some empirical results in social and community care services”, in Gui, B. \& Sugden, R. (eds) Economics and Social Interaction. Accounting for Interpersonal Relations, Cambridge: Cambridge University Press.

Borzaga, C. \& Tortia, E. (2006) "Worker motivations, job satisfaction, and loyalty in public and nonprofit social services", Nonprofit and Voluntary Sector Quarterly, Vol. 35, No. 2, pp. 225-248.

Borzaga, C. \& Tortia, E. (2009) "Social enterprises and local economic development", in Noya, A. (ed.) The Changing Boundaries of Social Enterprises, Paris: OECD, pp. 195-228.

Borzaga, C., Poledrini, S. \& Galera, G. (2017) "Social Enterprise in Italy: Typology, Diffusion and Characteristics”, Euricse Working Papers, 95 I17.

Costa, E. \& Carini, C. (2016) "Northern and southern Italian social cooperatives during the economic crisis: a multiple factor analysis", Service Business, Vol. 10, No. 2, pp. 369-392.

Daniele, D., Johnson, T. \& Zandonai, F. (2009) "Networks as support structures for social enterprises", in Noya, A. (ed.) The Changing Boundaries of Social Enterprises, Paris: OECD.

Defourny, J. \& Nyssens, M. (2008) “Social enterprise in Europe: Recent trends and developments”, Social Enterprise Journal, Vol. 4, No. 3, pp. 202-228. 


\section{Poledrini \& Borzaga}

Fici, A. (2006) "Legal Frameworks for Social Entrepreneurship: A Comparative Perspective", paper presented at the OECD_LEED Seminar on "Emerging Models of Social Entrepreneurship: possible paths for social enterprise development in Central East and South East Europe”, Zagreb, September.

Hulgård, L. \& Spear, R. (2006) "Social entrepreneurship and the mobilization of social capital in European social enterprises", in Nyssens, M. (ed.) Social Enterprise. At the Crossroads of Market, Public Policies and Civil Society, Abingdon: Routledge.

ISTAT - National Institute for Statistics (2011) $9^{\circ}$ Censimento dell'industria e dei servizi e Censimento delle Istituzioni non profit, Roma: ISTAT.

Perlmutter, T. (1991) "Italy: Why no voluntary sector?", in Wuthnow, R. (ed.) Between States and Markets. The Voluntary Sector in Comparative Perspective, Princeton: Princeton University Press.

Poledrini, S. (2015) "Unconditional reciprocity and the case of Italian social cooperatives", Nonprofit and Voluntary Sector Quarterly, Vol. 44, No. 3, pp. 457-473.

Poledrini, S. (2018) "The emergence of new social enterprise models in Italy: First insights from the International ICSEM Project", Impresa Progetto-Electronic Journal of Management, Vol. 2, pp. 1-19.

Venturi, P. \& Zandonai, F. (eds) (2014) L'Impresa Sociale in Italia. Identità e sviluppo in un quadro di riforma, Trento: CreativeCommons. 


\title{
9 Social Enterprise in the Netherlands
}

Between Hope and Hype

\author{
Philip Marcel Karré
}

\section{Introduction}

In the Netherlands, there is big hope, especially among politicians, social entrepreneurs and their advocates, that social enterprise (SE) will be able to help the government and other third-sector actors to tackle major societal problems, especially in cities. However, there is also a hype around social enterprise in the country; these initiatives get a lot of attention from the media, opinion leaders and policy makers, but there is as yet very limited knowledge of what is actually happening. Research is still scarce. Moreover, there is also a lot of confusion concerning social enterprises in the Netherlands. Indeed, there is no specific legal form or policy framework for these initiatives yet, though the Dutch government announced in July 2020 that it intends to establish a legal form and framework for what it calls the "social limited-liability company" (maatschappelijke $B V$, or $\mathrm{BVm}$ ). Until these intentions have been translated into action, every organisation can call itself a social enterprise, and many do, as the "social enterprise" label is seen as more modern than the older labels of "charity" or "foundation". Because of the Netherlands' long history of private initiative by non-profits in the provision of public goods and services, the Dutch third sector is notoriously fragmented and diverse, and it defies easy classifications. This is also true for social enterprises, which somehow remain ill-defined "new kids on the block"; indeed, even though one could say that the Netherlands already have a long tradition with social enterprises, they were not called that until very recently.

This text consists of three parts: in the first part, we describe the concepts linked to social enterprise and the context within which they have emerged and developed; in the second part, we map the SE sector and identify the various SE models in the Netherlands and in the third part, we analyse the relations between social enterprises and public authorities. 


\subsection{Understanding Concepts and Context}

In Dutch, social enterprises are known as "sociale ondernemingen"; social entrepreneurs, as "sociaal ondernemers"; and social entrepreneurship, as "sociaal ondernemerschap". Other terms that are also sometimes used are those of "sociale firma's" (social firms) and "sociale coöperaties" (social cooperatives). The term "maatschappelijke onderneming", or societal organisation, is also used, but it mainly applies to all organisational forms that originated in the third sector rather than in the state and market sectors. It is also important to note that the word "sociaal" has a narrower meaning in Dutch than the word "social" in English, which can better be translated as "maatschappelijk"; indeed, "sociaal" often only refers to the social domain (health care and welfare), though there are also social enterprises in other sectors.

\subsubsection{Definition and Legal Status}

As stated before, there is no specific policy framework or separate legal status for social enterprises in the Netherlands at the moment, and therefore no framework to determine which organisations are social enterprises and which are not. In most publications, the definition of social enterprise coined by the European Commission's Social Business Initiative $(\mathrm{SBI})^{1}$ is used:

A social enterprise is an operator in the social economy whose main objective is to have a social impact rather than to make a profit for their owners or shareholders. It operates by providing goods and services for the market in an entrepreneurial and innovative fashion and uses its profits primarily to achieve social objectives. It is managed in an open and responsible manner and, in particular, involves employees, consumers and stakeholders affected by its commercial activities. ${ }^{2}$

Social Enterprise NL, ${ }^{3}$ an advocacy group that aims to promote social enterprise in the Netherlands, has narrowed down the SBI definition to distinguish its members from what it describes as more "traditional nonprofits" (see table 9.1), stating that social enterprises are only those organisations that are "for a minimum of $50 \%$ financially dependent on trade or other forms of value exchange that are not donations or subsidies". ${ }^{4}$

The lack of a specific policy framework or separate legal status for social enterprises in the Netherlands feeds the confusion about the term. In practice, there is a wide variety of organisations that call themselves social enterprises, and the way in which they operationalise the ingredients of the above-mentioned definition is not clear. 


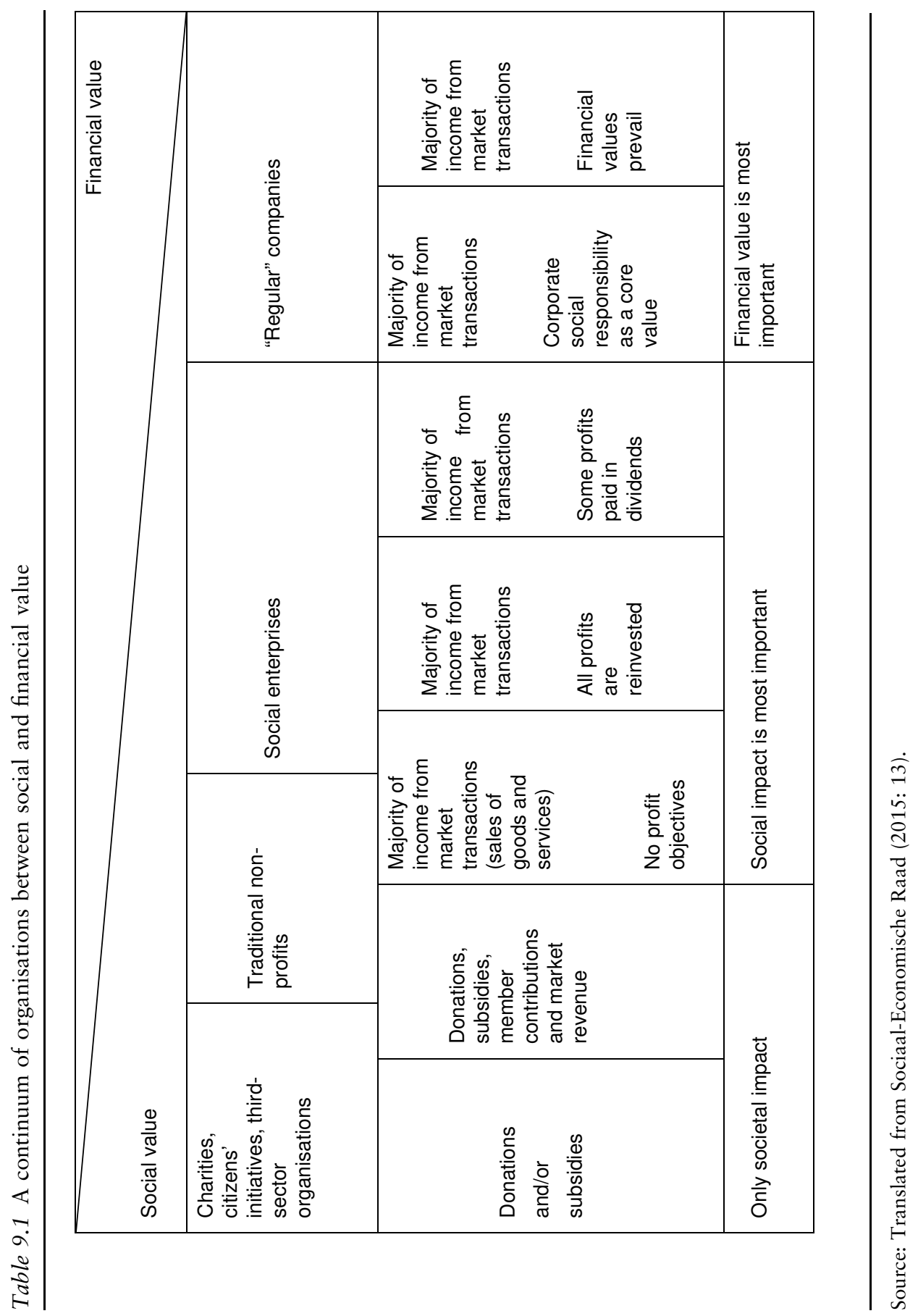




\section{Karré}

Social enterprises can operate under a wide array of legal forms. They can, as commercial enterprises, opt for the form of a private limitedliability company (besloten vennootschap, or $\mathrm{BV}$ ) or that of a public company (naamloze vennootschap, or NV). But they can just as well adopt the form of an association (vereniging), foundation (stichting) or cooperative (coöperatie). Individual social entrepreneurs often opt for the simplest legal form, that of sole proprietorship (eenmanszaak). Several social entrepreneurs can enter into a general partnership, referred to in Dutch as a "vennootschap onder firma" (VOF). These different legal forms come with different levels of requirements regarding statutes, boards, administration and finances. Only foundations are required to be not-for-profit, but that does not mean that the other legal forms cannot be used by initiatives with non-profit purposes. Private limited companies or sole proprietors are the easiest way for new organisations to get started, so the main motivation to (initially) decide on one of these legal forms may simply be because the organisation does not yet have the organisational capacity to comply with the more complex regulatory demands placed on other legal forms.

This organisational diversity is one of the reasons for the confusion and ambiguity concerning the concept of social enterprise in the Netherlands. In practice, the lack of a specific legal form or policy framework for social enterprise means that social enterprises are selfproclaimed; every organisation can label itself a social enterprise. There is a discussion about creating a special legal form for social enterprises; many social entrepreneurs are in favour of introducing such a legal form, and one of the smaller Christian parties has raised the issue in parliament. However, there are also warnings that such a move might be counterproductive, as argued, for example, in a joint report by the OECD and the EU commissioned by the Dutch government (see section 9.3 for more details).

\subsubsection{The Debate about Social Enterprise in the Netherlands}

In the Netherlands, social enterprises have been a topic of debate for some years (Brabander et al. 2009; Schulz et al. 2013; Sterk et al. 2013). The discussion mainly revolves around the role that social enterprises can play in addressing major social problems (Brandsen et al. 2016; Head and Alford 2015; Rittel and Webber 1973) at the local level, in the aftermath of the 2008 financial crisis.

This crisis made government cut-backs necessary in the provision of public goods and services. Simultaneously, Dutch municipalities became responsible for many programmes concerning public health and welfare through a major decentralisation, and they were looking for new and especially cost-effective ways to implement these programmes-an evolution that generated interest in social enterprise in Dutch society. 
Another factor that contributed to the rising interest in social enterprise is the fact that the Netherlands has a long history of private initiative, both profit- and non-profit-driven, in the provision of public services (see also section 1.3) and-also as a result of lay-offs by traditional welfare providers, due to the financial crisis-a new wave of socially engaged people with hands-on experience had become available, some of whom started their own social enterprise.

Dutch social entrepreneurs are good at making their voices heard, for example, through the advocacy group Social Enterprise NL. Moreover, due to the political developments mentioned before, social enterprises receive significant attention from the media and in policy circles-several Dutch cities have for example already adopted special action plans aimed at supporting social enterprises (see section 3). However, despite the buzz, much of the discussion about social enterprise in the Netherlands still has the characteristics of a hype, with a whole industry of workshops, roundtables and inspirational sessions springing up around the phenomenon (ABN AMRO 2017: 5). Societal expectations are high and often fuelled by canny entrepreneurs, adept at marketing their product, but the question is: What is really happening, and what effect does this have? Answering this question is important in order to separate the wheat from the chaff and to learn from really promising practices. For now, insight into how social enterprises work and which societal impact they actually generate is limited; research is only now beginning to emerge (Hogenstijn et al. 2018; Karré 2018).

\subsubsection{Historical Context}

The Netherlands has a large third sector, but also one that is "extraordinarily diverse and defies easy categorisation" (Pape and Brandsen 2016: 3). This is linked to the fact that the country has a rich tradition of provision of public goods and services by other actors than the state itself. ${ }^{5}$ Hybrid organisations that mix the institutional logics of the state, the market and civil society are the norm rather than the exception in the Netherlands in the area of provision of public goods and services. For example, many schools, universities, hospitals and housing corporations were established at the turn of the 19th century at the initiative of (groups of) socially concerned citizens and/or religious groups. Also, many of the Netherlands' public utilities (gas plants, railroads and watersupply systems) were originally established not by the state but through private initiatives of entrepreneurs, who expected a healthy return on their initial investment.

The involvement of religious and political groups in the provision of public services can also be accounted for by another reason, namely the fragmented character of Dutch society. For a long time, the Netherlands was, using the concept coined by Lijphart (1975), a "consociational" 


\section{Karré}

state (i.e., a state based on a system of power-sharing), with major internal divisions along religious and ideological lines but cooperation at the level of political and economic elites. Dutch society was divided into several so-called pillars (namely the Protestant, Catholic, Social Democratic and Liberal pillars), comprising religious as well as ideological groups that lived alongside-rather than with-each other. Each pillar had its own institutions providing public goods and services, such as schools and hospitals, based on the concept of "sphere sovereignty" (soevereniteit in eigen kring). This concept, brought forward by NeoCalvinist theologian Abraham Kuyper (who was to become prime minister later), states that each group should be allowed to deal with its own affairs without outside interference.

The rise of and discussion about social enterprise in the Netherlands must be seen against this historical backdrop, as private initiative still plays an important role in the Dutch welfare state today. At the turn of the 19th century, the state started to intervene in private initiatives, but instead of taking over these initiatives through processes of nationalisation, it rather decided to finance them. For example, we still find today confessional as well as non-confessional schools in the Netherlands, both of which are financed by taxpayers. After World War II, the Dutch government started to play a more prominent role, with the creation of a welfare state, which meant that many public-service providers became more and more dependent on the state and its financial contributions. This changed from the 1990s onwards, when budgetary constraints and a new ideological vision on the provision of public services through market mechanisms made the government rethink its role and gave rise to expectations for public-service providers to behave in a more entrepreneurial fashion. Private initiatives which, over the years, had become "encapsulated" by the state, to a point at which they were hardly distinguishable as private initiatives at all, were expected to act again more independently, to compete for government contracts and to look to the market for additional funding (Andeweg and Irwin 1993: 35-36; van Thiel 2000).

This belief in the market and the related use of new public management (NPM) as a way for the state to deal with public-service providers are now often criticised in the Netherlands as having been excessive. However, at the same time, the government lacks the capabilities and willingness to again become more active. In this general climate, there is now a renewed interest-also fed by a traditional Dutch belief in the power of private initiative-in third-sector organisations in the area of public-service provision. Some organisations in this field, but not all of them, call themselves social enterprises, but this is not a distinct or clearly defined category. Because the Netherlands has always had a large third sector, it has not been necessary to create social enterprises anew, as a third way between the state and the market. Indeed, Dutch social enterprises have always existed, even though they were not called that until recently. 


\subsection{Identification of SE Models}

In this section, we look at the various SE models in the Netherlands and how they can be classified.

\subsubsection{Mapping the SE Sector}

There are three reports that provide an insight into the development of the Dutch SE sector: a report by management consultants McKinsey (Keizer et al. 2016); another one by ABN AMRO bank (ABN AMRO 2017); and a third one by Social Enterprise NL (Social Enterprise NL 2019), an SE advocacy group.

\section{Size and Evolution of the Sector}

As there is no separate legal status for social enterprises and only a broad definition of the concept, information concerning the number of social enterprises in the Netherlands differs widely from one source to another, and data from the three reports cannot readily be compared. McKinsey, using the definition by the European Commission, estimates that there are about 5,000 to 6,000 social enterprises in the Netherlands, with a total staff of about 75,000 , and which contribute $€ 3.5$ billion to the national income (Keizer et al. 2016: 5). ABN AMRO bank uses a broader definition, encompassing every organisation with both a social dimension and an entrepreneurial one, yet only counts 4,000 to 5,000 social enterprises in the Netherlands, with a total staff of 50,000 to 70,000 employees (ABN AMRO 2017: 17).

The Social Enterprise Monitor by Social Enterprise NL includes information collected by means of a survey from 210 social enterprises (Social Enterprise NL 2019: 26). This survey is sent to the 345 members of Social Enterprise NL each year, as well as to social enterprises that are not members of Social Enterprise NL but that receive funding from Stichting DOEN, a foundation financed by three lotteries and supporting social and cultural initiatives, and to social enterprises that have relationships with the municipalities of Rotterdam, The Hague and Amsterdam. The Social Enterprise Monitor does not elaborate on how and on which grounds Stichting DOEN and the municipalities decided which organisations were to be sent the survey, nor does it provide information about the total number of social enterprises that were invited to fill in the survey.

The Dutch SE field has grown dramatically since 2010, writes McKinsey - by 2,000 to 2,500 enterprises; in other words, the sector expanded by about $70 \%$. This growth also represents about $1 \%$ of the total increase in the number of all companies in the Netherlands since 2010. Similar growth can be observed with regard to jobs and revenues: 


\section{Karré}

Since 2010, jobs in the social enterprise sector have increased by more than 60\% to 65,000-80,000 in 2016. These 25,000 new jobs come at a time when the Netherlands lost nearly 75,000 jobs in other sectors. Total revenues in the social enterprise sector rose from about 2 billion in 2010 to 3.5 billion euros in 2015, an increase of $75 \%$.

Keizer et al. (2016: 5)

\section{Areas of Activity}

According to McKinsey, Dutch social enterprises are a highly diverse group, active in a broad range of industries (Keizer et al. 2016: 9). The most important field of activity is that of "health and welfare"; $31 \%$ of social enterprises operate in this industry. It is followed by "energy" $(17 \%)$ and "financial and business services" $(16 \%)$. Also worth noting is the fact that more than $41 \%$ of social enterprises are active in two or more industries.

According to the Social Enterprise Monitor, nearly half of all the 210 social enterprises that responded to the survey see it as their mission to increase the participation of vulnerable groups (the long-term unemployed or people with a disability) in the labour market. Forty-eight percent of respondents cite this as their primary mission and $23 \%$, as their secondary mission. Other activities mentioned are: circular and sustainable production (cited by $17 \%$ of enterprises as their primary mission and by $26 \%$, as their secondary mission); the transition of food production and/or nature preservation $(8 \%$ as primary mission, $10 \%$ as secondary mission); international development and developing fair supply chains ( $9 \%$ as primary mission, $7 \%$ as secondary mission); working on increasing social cohesion in disadvantaged neighbourhoods ( $8 \%$ as primary mission, $24 \%$ as secondary mission), improving health care $(6 \%$ as primary mission, $8 \%$ as secondary mission); and accelerating the Netherlands' energy transition towards a zero-carbon economy ( $4 \%$ as primary mission, $2 \%$ as secondary mission).

\section{Size and Legal Form of the Initiatives}

With regard to the size of social enterprises in the Netherlands, ABN AMRO examined the sample of social enterprises supported by its Social Impact Fund (ABN AMRO 2017: 17). Nearly all of these could be described as small- to medium-sized companies, with a small number of employees (one or two employees in $29 \%$ of cases, and three to nine staff members in $46 \%$ of cases). These organisations were not stock-marketlisted, and most $(71 \%)$ had the form of a private limited-liability company $(\mathrm{BV})$. Less common in this database were foundations $(17 \%)$ and cooperatives $(8 \%)$. About $4 \%$ of the social enterprises listed were soleproprietor businesses, run by individuals working as social entrepreneurs 
on a freelance basis. Of course, as this subset of organisations have all had dealings with ABN AMRO Bank's Social Impact Fund, these figures are not representative of the whole SE sector.

Out of the 210 social enterprises that provided data for the Social Enterprise Monitor, $42 \%$ had a staff of 0 to 5 full-time equivalents (FTEs); $20 \%$ had 6 to $10 ; 12 \%, 11$ to $20 ; 15 \%, 21$ to 50 ; and $11 \%$, more than 50 FTEs. More than half $(52 \%)$ of the organisations in the Social Enterprise Monitor had the legal form of a private limited company (BV). Another big group was that of foundations (24\%). Less common, at least among this group of social enterprises, were organisations combining the legal form of foundation and that of cooperative $(10 \%)$, social enterprises run as sole-proprietor businesses $(4 \%)$, general partnerships (VOFs) $(4 \%)$ and cooperatives $(2 \%)$ (another group, representing $3 \%$ of respondents, indicated their legal form as "other"). Of course, since these figures are based on a survey, they are not representative of the whole SE sector either; a bias might for example result from the fact that the time needed to fill in the survey represents a comparatively larger investment for smaller organisations, thus leading to an over-representation of bigger organisations in the sample.

\section{Failure Rate}

Not all social enterprises are successful. According to McKinsey, about 700 social enterprises-roughly $20 \%$ of those that existed in 2011 - had ceased operations in 2016, mostly because their business models were unsustainable (Keizer et al. 2016: 5). ABN AMRO reports that, when updating the data in their database in 2016, they found that $15 \%-20 \%$ of social enterprises had already ceased trading since 2012 (ABN AMRO 2017: 19).

\section{Age of Entrepreneurs and Enterprises}

Most social entrepreneurs behind the social enterprises in the ABN AMRO database are between 35 and 55 years of age (61\%). Some are younger $(25 \%)$ and some are older $(14 \%)$, but none is under the age of 25 years (ABN AMRO 2017: 18). However, the fact that, on average, social entrepreneurs are middle-aged persons should not be understood as meaning that they have been social entrepreneurs for a long time. Indeed, in general, most social enterprises in the Netherlands are rather young. According to ABN AMRO, about $40 \%-50 \%$ are in an early stage of development, another $40 \%-45 \%$ have reached a somehow more advanced stage of development and only 5\%-15\% have successfully left the start-up phase (ABN AMRO 2017: 17). This matches data from McKinsey, which states that 


\section{Karré}

(...) the average state of growth of social enterprises is low. About half of our survey respondents said they were in the early-stage growth phase [i.e. between 2 and 5 years old] and 20\% in seed [0-2 years] or start-up [1-3 years] phases. That means that only about $30 \%$ are in later stages of growth.

Keizer et al. (2016: 6)

This is also the picture that arises from the Social Enterprise Monitor. Of the 210 social enterprises that provided information for this study, $16 \%$ had been established in or after 2017, 48\% between 2012 and 2016 and $16 \%$ between 2007 and 2011. Older social enterprises are rare: $8 \%$ of those that participated in the study had been established between 2002 and 2006, 6\% between 1995 and 2001 and only 5\% had been established in or before 1995 .

\section{Financial Results}

Information about the turnover and profits of the social enterprises in the ABN AMRO Social Impact Fund database also supports the picture that most social enterprises in the Netherlands are fairly young and in an early stage of development (ABN AMRO 2017: 19). About $80 \%$ have less than $€ 1.5$ million in turnover and $58 \%$, less than $€ 500,000$. There are also social enterprises that generate more than $€ 5$ million in turnover, but these only represent some $4 \%$ of the sample (about 160 to 200 enterprises); they are the biggest social enterprises, such as ethical chocolate maker Tony's Chocolonely, smartphone producer Fairphone and biological supermarket Beebox/Willem\&Drees. Most social enterprises only have a comparatively modest turnover, which is mostly due to the fact that most social enterprises are established to tackle concrete social problems in a certain area and with a limited target group (ABN AMRO 2017: 19). In general, the financial performance of social enterprises in the Netherlands falls behind that of for-profit enterprises. "Fewer than one in three social enterprises is profitable", McKinsey notes (Keizer et al. 2016: 13). According to ABN AMRO (2017: 21), 44\% of the social enterprises they surveyed did not (yet) turn a profit and $36 \%$ just broke even.

Data from the Social Enterprise Monitor show a somewhat different picture (Social Enterprise NL 2019: 13). Here 42\% of social enterprises reported to have made a profit and another $22 \%$ stated that they had broken even. Only $36 \%$ reported that they were losing money. Of course, a simple explanation for the fact that social enterprises having taken part in the Social Enterprise Monitor survey seem to fare better, from the point of view of financial results, than their counterparts analysed by ABN AMRO and McKinsey may be that profitable organisations have more spare time to complete surveys. 


\section{Impact}

Social enterprises find it difficult to measure the impact of their activities. "Barely half of social enterprises measure some form of impact, and 35\% [only] measure a relevant unit, such as $\mathrm{CO}_{2}$ emissions. The other half do not yet measure their social impact" (Keizer et al. 2016: 11). Social enterprises that do not measure their impact declare that this is due to the fact that they lack a good method to measure impact or that they do not have sufficient financial resources-a point also made in the recent survey conducted by the Social and Economic Council of the Netherlands, an independent advisory body (Sociaal-Economische Raad 2015). Because of these difficulties, we do not yet know much about whether social enterprises really make a difference and how we should value the many claims made by social entrepreneurs.

There are initiatives to create insights into the impact of social enterprises, such as the "Impact Path" tool (Het Impactpad), developed by Erasmus University Rotterdam. Until such tools become widely used, the lack of data on the real impact of social enterprises will remain a problem and undermine these initiatives' credibility:

In a segment where adding social value is the single differentiating factor, impact measurement is the currency of the sector's value. Lacking standards for impact measurement, the absence of an impact measurement infrastructure, and high measurement costs for individual enterprises create obstacles for social enterprises individually and for the sector as a whole.

Keizer et al. (2016: 11)

\subsubsection{Synthetic Analysis}

Despite the differences between the three reports, several conclusions can be drawn concerning the different SE models in the Netherlands. How many social enterprises exist in the country is a bone of contention; the lack of a common definition makes analyses and comparisons tricky, and estimates about the number of social enterprises vary widely (from a few hundreds to about 6,000). Some elements about Dutch social enterprises can nevertheless be highlighted: Most social enterprises seem to be small- or mediumsized businesses that have come into being only fairly recently. Most of them provide health and welfare services, and work integration is the most common main social mission. The majority of social enterprises, according to both the report by McKinsey and the Social Enterprise Monitor, have the legal form of private-limited company; the second most common legal form is that of foundation, followed by cooperatives and sole-proprietor businesses. Impact measurement currently remains a challenge. 


\section{Karré}

Based on the information available on the legal forms of social enterprises, an analysis can be made of how they fit the typology put forward by Defourny and Nyssens (2017). These authors describe four major SE models:

- the social-cooperative (SC) model, which is rooted in the third sector, but differs from traditional mutual-interest organisations (cooperatives and associations) in that the enterprises belonging to this model combine the pursuit of the mutual interest of their members with an objective of general interest, benefiting the community at large;

- the social-business (SB) model, which originates in the market place but strives to integrate and combine economic and social purposes;

- the entrepreneurial non-profit (ENP) model, which includes all nonprofit organisations, most often general-interest associations, that use earned-income strategies to support their social mission;

- the public-sector social enterprise (PSE) model, which originates in the public sector and embraces all public-sector spin-offs.

Using these four models as a lens to look at the data from the three reports, at first glance we might conclude that most Dutch social enterprises are closest to the social-business model: they are organisations operating under the legal form of a private limited company that try to achieve a social mission by engaging in commercial activities.

However, as discussed in section 1, in the Netherlands, the SE sector is generally seen as clearly distinct from the traditional non-profit sector, which, in the Netherlands, has a long history, with many organisations established long before the SE label was invented. This limitation is clearly evidenced by the definition used by Social Enterprise NL, which explicitly excludes organisations that derive more than half of their income from donations and subsidies, and all three cited reports use a similar definition. If we, instead of using the conventional Dutch idea of what a social enterprise is, look at the situation in the Netherlands using the much wider approach put forward by Defourny and Nyssens, the number of social enterprises rises dramatically. Indeed, while traditional non-profits are excluded using the Dutch definition of social enterprise, most of them match the definition of "entrepreneurial non-profits" as described by these authors. If we include this type of social enterprise, they make up the largest group by far. Many large institutions, such as universities and hospitals, would be included in this category, dwarfing the other types of social enterprise.

\subsection{Social Enterprises' Relations with Public Authorities}

The government, at both national and local levels, is the main institution that shapes the profile of social enterprises in the Netherlands. 
As explained before, there is no specific legal form for social enterprises in the Netherlands yet, though in July 2020 the national government announced its plans to establish by law what it calls the "social limited-liability company" (maatschappelijke BV, or BVm). Many social entrepreneurs support this initiative, as they hope that this will help them to gain better recognition in society and develop their business. By opting for the introduction of a specific legal form, the government decided to disregard the advice from a joint OECD/EU report it had commissioned. In this report, the OECD and EU indeed advised against such legal evolution on several grounds, recommending that the Netherlands instead adopt an official and operational definition, leading to a registration process either by public authorities or by private stakeholders (OECD/EU 2019).

Relationships with local governments are even more important, for individual social enterprises, than those with the national government. Indeed, discussion about the relationship between public authorities and social enterprises mainly takes place at the local level, as municipalities play a prominent role in the provision of public health and welfare services in the Netherlands. Moreover, most social enterprises are only active at the local level. So far, only about $40 \%$ of local governments have devised specific policies for social enterprises (PwC 2018: 10), but the four largest municipalities in the country (namely Amsterdam, Rotterdam, Utrecht and The Hague) have developed action programmes or action plans on social entrepreneurship ("Actieprogramma Sociaal Ondernemerschap" or "Actieplan Sociaal Ondernemen") (Keizer et al. 2016: 7). These action plans aim to create an ecosystem wherein social enterprises can thrive, but they also make it clear that these initiatives should not expect preferential treatment.

According to the Social Enterprise Monitor, relationships with the local government are cited as the main challenge by Dutch social enterprises striving to achieve a greater impact; this issue is even seen as a bigger obstacle than traditional entrepreneurial challenges, such as attracting funding and extending the customer base (Social Enterprise NL 2019: 11). This is mainly due to the hybrid character of social enterprises (Karré 2018).

A study conducted by the Social and Economic Council of the Netherlands (SER) in 2015 found that many of the social entrepreneurs surveyed felt that they were not adequately recognised by the government and by society at large for what they did, due to the confusion surrounding the term social enterprise (Sociaal-Economische Raad 2015). They also felt themselves thwarted by rules and regulations, which, in their eyes, were ill adapted to the innovative approaches they implemented; European procurement rules, for example, made it difficult for local authorities to grant contracts to social enterprises. The relationship between social enterprises and local governments is also made 


\section{Karré}

complicated by the challenges that social entrepreneurs experience when attempting to measure the impact of their work. Social enterprises are often too small to apply elaborate tools for social-impact assessment; moreover, they often reject them for ideological reasons-for example, because such tools often measure output rather than outcome. The SER recommended that the government improve the financial climate, invest in impact measurement and increase awareness about social enterprises among civil servants.

There are four main challenges in the relationship between social enterprises and municipalities (Karré and Van Meerkerk 2019):

- Awareness and recognition: most municipalities are unfamiliar with the SE phenomenon. They do not know yet how to recognise these initiatives and how to deal with them. Because of this, SE initiatives are often not seen yet as viable alternatives for working together with non-profits or commercial enterprises.

- Funding and procurement: many municipalities are used to funding activities in the sectors in which social enterprises are most active (health and welfare, work integration) by providing subsidies to foundations or associations, but they are not used yet to buying services from a (social) enterprise. Even though Dutch procurement law gives (local) governments some leeway to do business with social enterprises even if there are cheaper alternatives, municipalities usually choose the cheapest supplier for the goods and services they buy. This puts social enterprises at a disadvantage, as they are often more expensive than "regular" companies, because they also pursue social goals, in addition to their commercial goals.

- Difficulties in matching policies with practices of social enterprises: social enterprises and their activities are often innovative; for examples, they work in an "integrative" manner, crossing the boundaries of government "silos" and policy domains. But, government regulation and financial streams are often not yet organised in that way. Because of this, regulations often thwart the plans of social enterprises, for example, when policies from different domains contradict one another.

- Accountability and impact measurement: Because of their hybrid character, at the interface of the state, the market and society, social enterprises find it more difficult than "normal" companies to demonstrate their accountability. Social enterprises have different and often contradictory goals, and measuring their impact is often complex and expensive. This poses a problem for municipalities willing to make use of their services, as accountability requirements linked to the spending of public funds demand more hard and structured information than many social enterprises can provide. 
In summary, what it comes down to is that in practice, municipalities and social enterprises have different and often contradictory institutional logics. They do not speak the same language, have different cultures and different ways of doing things. Social enterprises often do not understand how government and politics work, and the opposite is also true.

\section{Conclusion}

In the Netherlands, there is increased interest in social enterprises but also a lot of confusion about the term. In order to finally end this discussion, in July 2020, the national government announced its intention to introduce a new legal form and framework for social enterprises. So far, little is known about the new law, and with new elections planned in early 2021, which could lead to a new coalition, with new priorities, there is no guarantee that this law will indeed ever be introduced. Another reason for the prevailing confusion is that, due to the country's history of public-service provision by hybrid organisations, the list of organisations that could be labelled as social enterprises is extensive. In order to distinguish social enterprises from so-called traditional nonprofits, social enterprises are often defined as organisations that generate more than half of their income on the marketplace, but such distinction is largely arbitrary. We will have to wait for a first draft of the new law and the discussions surrounding it to establish its chances to ever really coming into effect. In the meantime, the confusion and ambiguity surrounding social enterprise in the Netherlands is likely to continue.

\section{Notes}

1 See http://ec.europa.eu/growth/sectors/social-economy/enterprises_en.

2 See https://www.social-enterprise.nl/english.

3 This charitable foundation was established in 2012 by Willemijn Verloop, founder of the non-governmental organisation War Child Holland, and Mark Hillen, a former management consultant. All social enterprises that meet the European definition and that derive at least $50 \%$ of their income from trade or other forms of value exchange, excluding donations or subsidies, can become members. In 2019, Social Enterprise NL had 345 members and membership fees varied between $€ 295$ and $€ 1,195$ per year.

4 See https://www.social-enterprise.nl/english.

5 For a more elaborate description, see Karré (2011), section 1.2, on which the present section is based.

6 Based on data provided by CBS Statistics Netherlands, the Dutch Chamber of Commerce and McKinsey's own Social Enterprise Survey.

\section{References}

ABN AMRO (2017) De noodzaak van marktontwikkeling voor sociale ondernemingen. De romantiek voorbij, Amsterdam: ABN AMRO. 


\section{Karré}

Andeweg, R. \& Irwin, G. A. (1993) Dutch Government and Politics, Houndmills Basingstoke: Macmillan.

Brabander, R. de Emmerik, R. \& Peters, D. (2009) Een waardevolle spagaat: een verkenning van sociaal ondernemerschap, Antwerpen \& Apeldoorn: Garant.

Brandsen, T., Cattacin, S., Evers, A. \& Zimmer, A. (2016) Social innovations in the urban context, Heidelberg: Springer Verlag GmbH u. Co.

Defourny, J. \& Nyssens, M. (2017) “Mapping social enterprise models: Some evidence from the 'ICSEM' Project”, Social Enterprise Journal, Vol. 13, No. 4, pp. 318-328.

Head, B. W. \& Alford, J. (2015) “Wicked problems implications for public policy and management", Administration \& Society, Vol. 47, No. 6, pp. 711-739. Available HTTP: https://doi.org/10.1177/0095399713481601.

Hogenstijn, M., Meerman, M., \& Zinsmeister, J. (2018) “Developing stereotypes to facilitate dialogue between social entrepreneurs and local government", Journal of Innovation and Entrepreneurship, Vol. 7, No. 1, p. 3. Available HTTP: https://doi.org/10.1186/s13731-018-0084-5.

Karré, P. M. (2011) Heads and Tails: Both Sides of the Coin: An Analysis of Hybrid Organizations in the Dutch Waste Management Sector, The Hague: Eleven International Publishing.

Karré, P. M. (2018) "Navigating between opportunities and risks: The effects of hybridity for social enterprises engaged in social innovation", The Journal of Entrepreneurial and Organizational Diversity, Vol. 7, No. 1, pp. 37-60. Available HTTP: https://doi.org/10.5947/jeod.2018.003.

Karré, P. M. \& Van Meerkerk, I. (2019) Samen werken aan de wijk. Een bestuurskundige reflectie op de relatie tussen wijkcoöperaties en gemeente in Rotterdam, Rotterdam: Kenniswerkplaats Leefbare Wijken.

Keizer, A., Stikkers, A., Heijmans, H., Carsouw, R. \& Van Aanholt, W. (2016) Scaling the Impact of the Social Enterprise Sector, Amsterdam: McKinsey.

Lijphart, A. (1975) The Politics of Accommodation: Pluralism and Democracy in the Netherlands (2d ed., rev.), Berkeley: University of California Press.

OECD/EU (2019) "Boosting social entrepreneurship and social enterprise development in the Netherlands. In-depth policy review", OECD LEED Working Papers, Paris: OECD Publishing.

Pape, U. \& Brandsen, T. (2016) The Third Sector in The Netherlands-Third Sector Impact Project Policy Brief No. 8/2016 [Policy Brief], Nijmegen: Third Sector Impact Project.

PwC (2018) Prille kansen: de samenwerking tussen sociale ondernemingen en gemeenten in Nederland, Amsterdam: PwC.

Rittel, H. W. J. \& Webber, M. M. (1973) "Dilemmas in a general theory of planning”, Policy Sciences, Vol. 4, No. 2, pp. 155-169. Available HTTP: https://doi.org/10.1007/BF01405730.

Schulz, J. M., Steen, M. van der, \& Twist, M. van (2013) De koopman als dominee: sociaal ondernemerschap in het publieke domein, Den Haag: Boom Lemma uitgevers.

Sociaal-Economische Raad (2015) Sociale ondernemingen: een verkennend advies, Den Haag: Sociaal-Economische Raad (SER).

Social Enterprise NL (2019) De Social Enterprise Monitor 2019, Amsterdam: Social Enterprise NL. 
Sterk, E., Specht, M., Walraven, G. \& Zweerts de Jong, S. (2013) Sociaal ondernemerschap in de participatiesamenleving: van de brave naar de eigenwijze burger, Antwerpen \& Apeldoorn: Garant.

van Thiel, S. (2000) Quangocratization: Trends, Causes and Consequences, Amsterdam: Interuniversity Center for Social Science Theory and Methodology. 


\title{
10 Social Enterprises in Norway \\ Models and Institutional \\ Trajectories
}

\author{
Bernard Enjolras, Jill M. Loga, \\ Lars U. Kobro and Hans A. Hauge
}

\section{Introduction}

In Norway, social entrepreneurship and social enterprises are in a much less developed phase than in several other European countries. However, since 2008, there has been a growing interest and increasing attention for social entrepreneurship in the country, and new initiatives have been developing.

The development of social enterprise (SE) in Norway is a typical case of policy diffusion, where policy concepts and models implemented in other countries are imported within another, different institutional context. Indeed, the concept of social entrepreneurship appeared in Norway at the turn of the 21st century, under the influence of both European initiatives stemming from the social-economy tradition and more market-oriented approaches found in the United States and the United Kingdom-two countries that have more developed traditions of philanthropy, social investment and commercial welfare provision than Norway. Although Norway has had a cooperative movement linked to the labour and peasant movement since the middle of the 19th century, cooperatives have played a very limited role in welfare provision in the country in recent decades, and they have consequently had a very limited impact on the development of social enterprise.

Social enterprises have become an increasingly important topic on the national policy agenda. The way in which the policy issues and debates are framed in Norway is contingent upon the national historical and institutional context, constituted by the Nordic welfare-state model. The different origins of the concept and traditions linked to its development (European social economy and US social-venture stream of thought) have produced two distinct types of social enterprise in Norway, but since the SE field is still in a phase of emergence in the country, its institutional trajectories remain open and contested.

In this chapter, we first give a short overview of the historical and institutional context in which social enterprise emerged in Norway. Next, we sketch, based on available empirical data, the main features of 
the two major models of social enterprise in the country. Finally, we discuss the potential trajectories of institutionalisation of social enterprise, given the state and the stakes of the Norwegian debate on welfare policy.

\subsection{Historical and Institutional Context for Social Enterprise in Norway}

The welfare state and its policies as well as the division of labour between the state and the voluntary sector that characterise the Nordic welfare regime constitute the historical and institutional backdrop for the emergence of social enterprise in Norway. Scandinavian (or Nordic) economy, society and politics are often understood as constituting a separate societal model. ${ }^{1}$ This model, characterised by a large public sector, a universal, all-embracing welfare state and a high degree of economic and social equality, has shown itself to be surprisingly successful and robust. The Scandinavian countries have a social-democratic welfare state, with a large public sector that emphasises equal distribution of income as well as gender equality. In terms of democratic governance, the Scandinavian model is characterised by a culture of compromise in politics, local government autonomy and cooperation between the state and civil-society organisations.

In Norway, the specific division of labour and the present state of the institutionalised relationships between the state and civil society can be understood as the result of historical developments. These developments are characterised by, on the one hand, the progressive integration between the state and popular movements and, on the other hand, a social contract between the state and individuals according to which the central purpose of policy is to maximise individual autonomy (Enjolras and Strømsnes 2018).

Historically, the cooperation and integration between public and voluntary agencies in the delivery of welfare services had been effective long before the establishment of the modern welfare state. The voluntary sector played a central role from 1850 onwards in alleviating social problems in the developing "welfare municipalities" at the local level. Over the following decades, voluntary organisations provided publichealth education, created and ran hospitals and clinics, offered treatment and care for the sick and disabled, and offered a channel for citizens to participate in policy-making. This constituted a significant contribution to the further development of the welfare state on a national level after World War II. Local authorities provided limited financial support to the associations and did not usually impose specific conditions on these money transfers. The voluntary organisations often acted as pioneers in this field, making problems visible and initiating institutional arrangements which, in many cases, were later taken over by the public sector. 
The state wished to support existing private services without adversely affecting private philanthropy. In the social-democratic welfare model that developed in the post-war period, associations were not given any explicit role as welfare providers. This phase was characterised by a strong expansion of public welfare, and the public sector overtook most of the institutions and services that were run by the voluntary sector. Many voluntary associations increasingly took on the role of interest mediators, playing a role of pressure group within the newly established neocorporatist institutional structure that organised the cooperation between civil society and the state.

In contemporary Norway, the welfare state provides universal social services to its citizens. Municipalities play a central role in welfareservice provision, as most welfare services are decentralised and delivered by local public agencies. In comparison with most other countries, in Norway, the prevalence of child poverty, social exclusion and exclusion from the job market is low. Still, surveys indicate that the proportion of citizens experiencing such problems is rising, and ensuring that public welfare services reach the most vulnerable groups appears as particularly challenging. Although Norway avoided invasive austerity measures in public services in the aftermath of the 2008 financial crisis, the gap between demands for social services and the welfare state's resources to address them is expected to grow in the foreseeable future. In 2013, the Norwegian government stated in its political platform that it would improve the conditions for social entrepreneurs and voluntary organisations operating within the welfare system.

Within such institutional arrangements between the welfare state and the voluntary/non-profit sector, where state-sponsored and statedelivered social-welfare protection is quite extensive, it is no surprise that the space left for service provision by non-profit organisations is quite constrained. Non-profit providers of welfare services account for only $8 \%$ of total employment in the welfare sector in Norway (Sivesind 2017). However, the welfare state's institutional arrangements are not static; they are subject to constant reforms. From the 1980s onwards, reforms inspired by the new public management (NPM) approach led to the outsourcing of various types of welfare services, and to a growth in the number of market actors competing with established non-profit welfare providers for public assignments. The interest in the potential of social enterprises is part of a broader debate about the division of welfare production between sectors and the promotion of the idea of a "welfare mix" (Evers 2005; Trägårdh 2007; Selle et al. 2018). Policy debates are linked to questions about economic issues on the future sustainability of the welfare state, but also increasingly to questions about democratic aspects and diversity, support to user involvement and individual adaptations. These debates involve stakeholders from different sectors in a cooperative approach to welfare production. 
Current debates revolve around three intertwined themes that have a bearing on the "opportunity structure" for the development of social enterprise; these three themes are related to the "modernisation" of public welfare-service provision and the role of "private" actors (nonprofit and business sectors).

The first bone of contention is about institutional welfare production performed by non-profit and commercial actors under contract with the public sector, for example, for the provision of health or education services. The non-profit sector played a role of service provision in various welfare areas long before the welfare state expanded. This role remains important today, although it is smaller than in the past, and far smaller than in many other European countries. Today, arguments promoting non-profit and commercial welfare services often state that these represent an ideological alternative to public welfare. In the same line, arguments also refer to democratic representation. Most political parties support the idea of a welfare-mix involving different types of providers, but the share of the "market" that these different types of providers should have is subject to political disagreement.

The second issue of debate is about the extent to which voluntary work should supplement public welfare services. The third sector's role as coproducer of welfare is promoted both in the form of voluntary work within or outside voluntary organisations and through institutional voluntarism - that is, volunteering within public institutions or under the auspices of private companies. Mobilisation of this type of voluntary work has gained attention in many countries in recent years and is often described by concepts such as co-creation, governance, co-production and active citizenship (Torfing 2016; Torfing and Triantafillou 2016).

The third theme that is often debated is policy development about social innovation, which has gained renewed political and public attention in recent years. In a large, all-embracing welfare state, both quality and efficiency in services are important for the legitimacy of the model. Civil society was a central arena for innovation in the early stages of the welfare state, as many initiatives aiming to establish new services had their roots in private initiatives of citizens and in civil organisations. With the development of the welfare state, this role has gradually become less significant. Today's renewed interest in innovation is strong in Scandinavia, both in the market and in the public sector, and attention is increasingly directed towards the non-profit sector and collaboration between sectors, including new initiatives such as social entrepreneurship.

\subsection{Main SE Models in Norway}

Undertakings that fall into the organisational definition of social enterprise provided in the EU's Social Business Initiative (launched in 2011) are registered in Norway under several forms. Most of them operate 
either as limited companies or as voluntary organisations. Unlike what is the case in many countries in Europe, very few Norwegian social enterprises are cooperatives.

There is no specific register of social enterprises in Norway. Hence, statistics on social enterprises are based on information from central actors in the field, and information available in several public registers. The statistics presented in this chapter are based on mappings of social entrepreneurs in Norway realised respectively by Eimhjellen and Loga in 2016, by Kobro et al. in 2017 and by Kobro in 2019, based on surveys addressed to potential social entrepreneurs, and estimating the population of social enterprises to be comprised between 295 and 380 enterprises.

The data collected tend to indicate that there are two main models of social enterprise in Norway. The two models have different ideological roots: the voluntary sector, for one of the models, and the business sector, for the other. This dichotomy may be inferred from the initiatives' institutional forms: Between $40 \%$ and $50 \%$ (depending on the mapping methodology) of social enterprises are joint-stock companies, registered either as limited companies or as non-profit limited companies ${ }^{2}$ (about $15 \%$ of social enterprises are non-profit limited-liability companies and some $25 \%$ are "pure" limited-liability companies). The second most common form of organisation is the voluntary/non-profit organisation/ association ( $28 \%$ to $33 \%$ of SEs); it is followed by the legal form of foundation ( $11 \%$ to $15 \%)$. Some social enterprises ( $2 \%$ to $5 \%$ of social enterprises) are also operating as personal businesses; the remaining social enterprises are cooperatives. The distribution of social enterprises between commercial and for-profit legal forms (limited-liability companies, non-profit corporations, business-based foundations and personal businesses) and non-profit or third-sector legal forms (voluntary/nonprofit organisations, foundations and cooperatives) is thus fairly well balanced.

A recent mapping of the SE field in Norway (Kobro 2019) shows a developmental trend towards a steady-though moderate-growth over time. The mapping also shows an organisational landscape that is relatively young; more than half of the identified social enterprises had been established during the ten years preceding the mapping. The largest areas of activities among social entrepreneurs relate to the social integration of disadvantaged groups, work integration, community development, youth and health. In these major fields of activity, the number of nonprofit enterprises is greater than that of for-profit enterprises.

Social enterprises mix revenue from different sources, including income from market activities, private gifts and public support and grants. For almost half $(47 \%)$ of the respondents to the survey, the share of market incomes represents only between $10 \%$ and $20 \%$ of the revenues; on the other hand, for $26 \%$ of the respondents, market incomes are almost the unique source of income. A large share of social enterprises is 
consequently very dependent on private and public supports or grants. Among the enterprises that rely quasi-exclusively on market incomes (about half of the population), 32\% are for-profits and 17\% are nonprofits (Eimhjellen and Loga 2016).

As mentioned above, the field of social entrepreneurship in Norway is relatively young (it really started emerging in 2000) and it is still in development. There is no recognition, in terms of legal status, of social enterprise as a specific type of economic and social entity. Most of the activities of social enterprises are directed towards welfare services, and most social enterprises are dependent on public funding and operate within a highly developed and structured welfare state, to a certain extent. Two main models of social enterprises may be distinguished in Norway (see table 10.1): the entrepreneurial non-profit model and the social-venture model. These ideal-typical models are differentiated in terms of funding sources, legal forms, governance and type of support structure they relate to.

Indeed, based on the available income statistics, social-venture social enterprises appear to be strongly oriented toward market activities, while entrepreneurial non-profit social enterprises rely to a significant extent on public support and grants and operate within the rather traditional framework of the Norwegian welfare state. Social enterprises that are either exclusively market-oriented, with financial resources generated directly by market-based operations, or that are competing for welfareservice tenders are mainly for-profit companies. Those initiatives may be seen and understood as part of a broader movement advocating for a "marketisation" of the welfare state.

But beyond this duality in terms of both ideological roots and orientations, the two "parts" of the SE field tend to melt together in their search for pragmatic solutions, fitting into historically institutionalised structures for collaboration between state and civil society, and adapted to a contextual welfare model that traditionally has a quite narrow

Table 10.1 Characteristics of the two main SE models in Norway

\begin{tabular}{lll}
\hline Ideal type & $\begin{array}{l}\text { Model 1: entrepreneurial } \\
\text { non-profit }\end{array}$ & Model 2: social venture \\
\hline Main legal form & $\begin{array}{c}\text { Voluntary association or } \\
\text { foundation }\end{array}$ & $\begin{array}{c}\text { Limited-liability } \\
\text { company }\end{array}$ \\
Main resources & Public grants and & $\begin{array}{c}\text { Market income, public } \\
\text { cond private grants }\end{array}$ \\
Governance & contracts & Entrepreneurial \\
Main support & Democratic & Venture philanthropists, \\
structure & Umbrella welfare & e.g. Ferd Social \\
& organisations, e.g. & Entrepreneur \\
\hline
\end{tabular}




\section{Enjolras, Loga, Kobro \& Hange}

working space for hybrid models. Most social enterprises are involved in activities related to work integration, inclusion of children and adolescents, refugee matters and elderly care. They provide different services, at different levels, with different business models, and they relate to the public sector in different ways. Some of them sell their services to the public sector (e.g., to the Norwegian Labour and Welfare Administration [NAV], municipalities, schools or public child-care administration), whereas others receive support grants from local authorities.

Table 10.2 gives a few examples of social enterprises. These examples illustrate the diversity of the field and its variety in terms of organisational forms, products, networks and links to the public, private and voluntary sectors.

Different types of organisations and incubator communities support various SE initiatives in various ways, driving the Norwegian field of social enterprise forward. These players invest in social entrepreneurs or support them in other ways by offering knowledge transfer, office sharing and networking. Many of them are also committed to promoting the development of the field at a more general level. At present time, the support ecosystem is constituted by a mix of both private and local public initiatives. The central state is not playing the most significant role.

One example of a private supportive actor for social enterprise in Norway is Ferd Social Entrepreneurs (Ferd SE). Since its creation, in 2009, Ferd has been involved in the SE field. Ferd SE invests in social entrepreneurs and gives them access to capital, competences and networks, and it acts as a venture philanthropist and social investor. Ferd SE, which also organises the annual "Ferd Sosent conference", constitutes a key network arena for social entrepreneurs in Norway today. The Crown Prince Fund, Reach for Change and TD Veen Social Entrepreneurs are other examples of initiatives that provide support to social enterprises in the form of capital, expertise and networks. SoCentral-an Oslo-based SE incubator-represents a promising innovation and advisory environment for organisations and public actors working with local, national and global societal challenges. The Impact Hub plays a comparable role in Bergen. Ashoka is considered to be the oldest and largest international organisation supporting selected social entrepreneurs (Ashoka Fellows); Ashoka is represented in Norway and has elected six Norwegian social entrepreneurs as Ashoka Fellows after a thorough selection process.

In addition to these central organisations and incubator communities, some key non-profit umbrella organisations also work as networking and competence-sharing centres. The Church's City Mission, which is represented in eight Norwegian regions, is an example hereof: It is an important connection point for some social entrepreneurs and has helped to establish new initiatives, which have subsequently become independent organisations. 


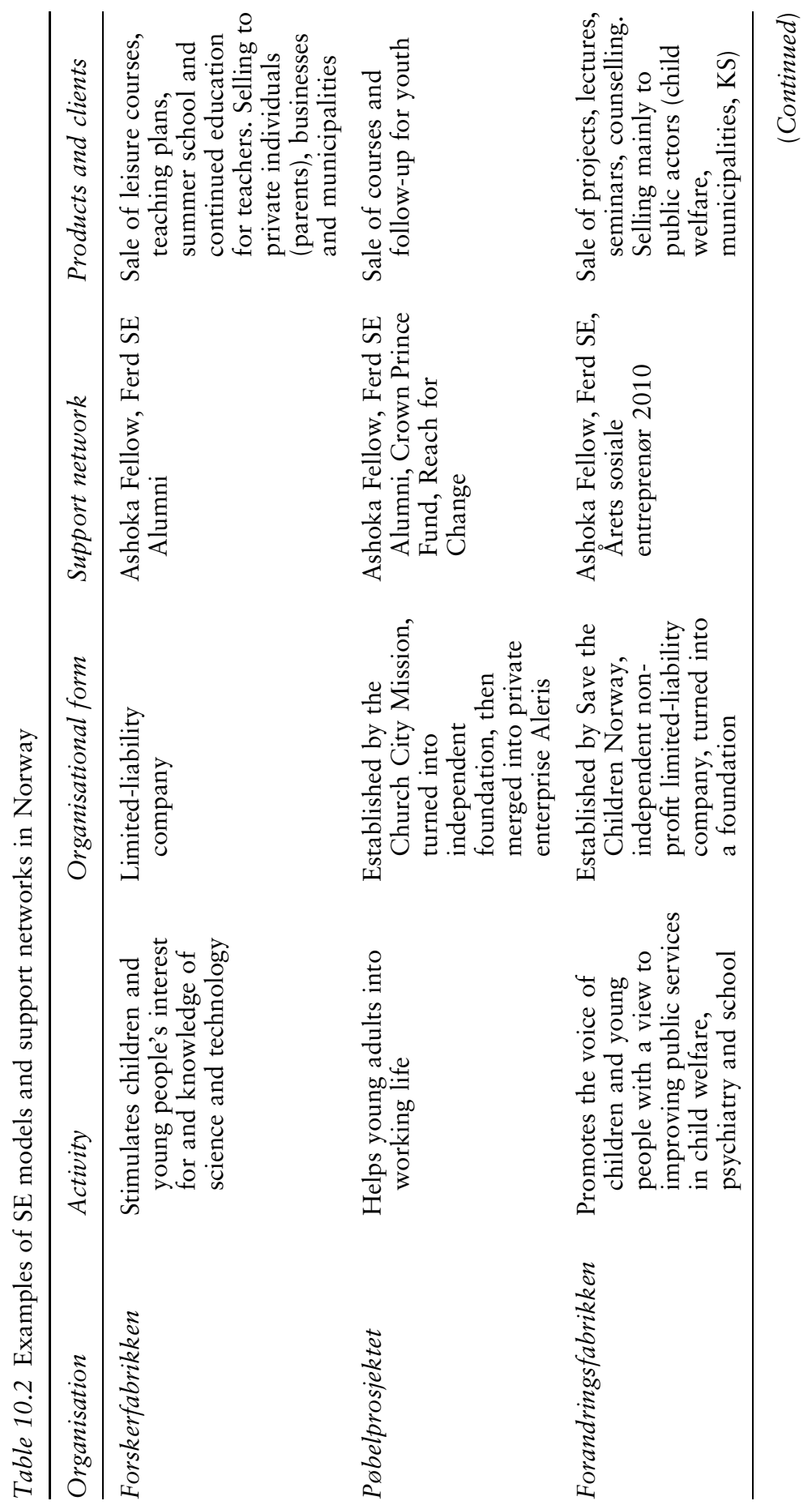




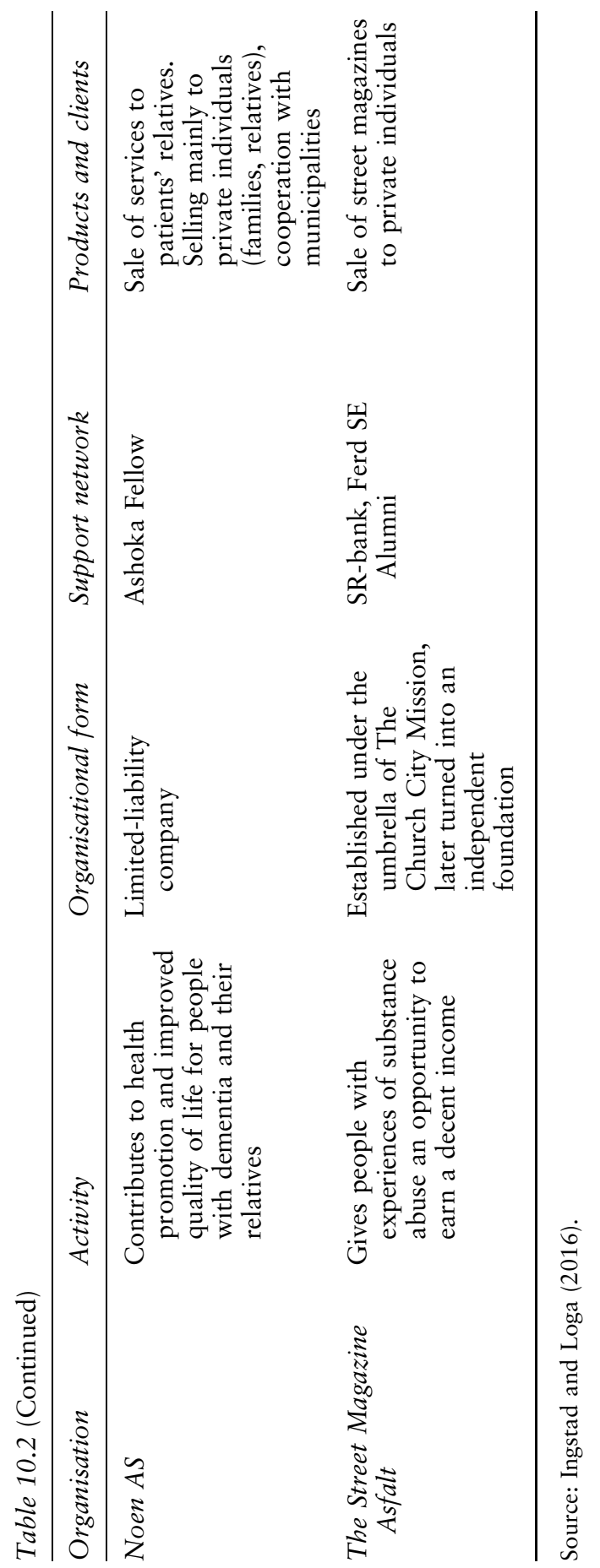


For example, "The Asphalt Magazine" (Gatamagasinet Asfalt) was established as a project by the Church's City Mission in Stavanger and Haugesund and eventually became an independent social enterprise. The City Mission still participates as a sponsor and support network, in collaboration with similar street magazines in other cities in Norway. Asfalt was also integrated in Ferd SE's portfolio. It represents an example of collaboration between non-profit organisations, investors and new social enterprises. In recent years, initiatives have also been taken, in collaboration with municipalities, to establish new platforms for interaction between professionalised non-profit organisations, the public sector and private investors; these initiatives seek to build an enabling environment for the development of social entrepreneurship, both regionally and at the national level. Street Entrepreneurs in Arendal provides an example of such an initiative: The municipality and the Church Mission have joined forces to create a favourable environment for social entrepreneurs, in particular in the field of work integration. The Community Centre in Stavanger and Tøyen UnLimited (Oslo) are other examples.

One additional way of understanding social enterprise in Norway is to focus on initiatives' actual activities. Such focus reveals a praxis field where social enterprises seem to work on one or several levels, depending on their target group and on the purpose that they are pursuing through their activity: individual needs, organisational and local development or systematic change in the welfare society at large.

Many of the rather new SE initiatives in Norway aim at providing better life conditions to vulnerable groups. Medarbeiderne AS, for example, "does not hire people to provide services, but provides services to hire people". The company collects glass, metal, electronics and other waste from private addresses in Oslo through a subscription system. The company employs only persons with a substance-abuse or psychiatric background. Blues Factory AS is another example; the enterprise uses music and playing in a band as a means of providing a sense of belonging. Blues and rock professional musicians are used as instructors.

Although all SE businesses focus, in one way or another, on closing gaps in the welfare state, some of them choose to concentrate their efforts on organisations and systems, rather than directly on individuals. Sykehusklovnene ("hospital clowns") does not only promote health by bringing fun and laughter and thus helping to lift hospitalised children's moods; it also aims at a systemic change of Norwegian health care. Similarly, Forandringsfabrikken ("The change factory") aims at changing Norwegian child welfare in a systemic way. As put by the leader of this organisation: "The idea is simple and effective: if we listen to what children and young people say, the system will provide better services". Since its inception, the enterprise has been engaged in a growing number of identified "gaps", where children and adolescents' own experiences 


\section{Enjolras, Loga, Kobro \& Hange}

are voiced in an effort to change national laws and administrative practices. Children and youngsters themselves play the role of key influencers and change-makers in public service. A number of social enterprises also target social changes in schools. The Norwegian Crown Prince couple has established a fund (Kronprinsparets fond) especially targeted on supporting social entrepreneurs with a focus on schools and youth. JodaCare AS is another example of a social enterprise with a systematic-change focus on the organisational level. When the founder of JodaCare discovered how difficult it was to communicate effectively about matters related to her mother, who was under public care, she had the idea of a digital service. The service is provided to municipalities as a tool for facilitating collaboration and effective communication between public assistance services, users of services and relatives.

\subsection{Institutional Trajectories and Future Developments}

The development rate of social enterprise has been far lower in Norway than in most other western European countries. Several factors may explain this relatively slow development. Firstly, the share of private and non-profit welfare service providers is low in Norway, compared with other European countries. Secondly, as mentioned above, Norway has not been as strongly affected by the economic crisis as many other European countries, and has thus not been forced to develop new solutions and to reform its welfare policies to the same extent as these other countries. The third reason has to do with the Norwegian political discourse. The debate on social enterprise within the social-democratic welfare-state framework seems to have two centres of gravity. One promotes social enterprise as a tool for increasing the role of private actors in welfare provision and the other presents social enterprise as an instrument for social innovation. Neither of these discourses has been conducive so far to the political support that appears necessary for the development of an active and supportive policy in the field of social enterprise.

If we look ahead, trying to foresee what might happen in the SE field further down the road, we will probably see social enterprise as a "remedy" to address some of the shortcomings and failures of both the market and the welfare state (Andersen et al. 2016; Baglioni 2017). Social enterprises are seen, thanks to their entrepreneurial and social dimensions, as able to innovate and develop solutions that mitigate such failures. In Norwegian policy discourses, as in many other parts of Europe, social enterprises are seen as an instrument of economic rejuvenation, providing the means to address the issues of unemployment and social exclusion, and as a way to re-establish the legitimacy of the welfare state, thanks to the initiatives' emphasis on co-creation, 
co-production and co-governance of welfare services. But there is an alternative future as well.

Indeed, social enterprise can alternatively be viewed as a symptom of the development of a "neoliberal welfare state" (Garrow and Hasenfeld 2014), promoting market-based solutions to social issues and reversing the de-commodification of labour achieved through social rights by making the safety net contingent on production and earnings. Such a development would be a strong break from the Norwegian tradition of welfare service. By emphasising the virtues of commercial entrepreneurship, competition and cost effectiveness, social enterprise might reflect the logic and the moral underpinning the neoliberal conception of the welfare society.

The neoliberal conception of the welfare state celebrates the role of the voluntary and private sectors, but it does so by favouring the devolution, marketisation and privatisation of welfare services, and it relies on the ethos of self-interest. In contrast, the traditional Norwegian socialdemocratic conception of the welfare state emphasises social justice and the ideals of universalism and egalitarian society. These ideals have to be achieved by promoting collective responsibility, income redistribution, public-sector provision of welfare services, the ethos of public service, professionalism, impartiality, and trust between citizens and the public sector.

The discourses about social enterprise in Norway-one emphasising the innovative character of social enterprise as a means to renew the welfare state, and the other considering social enterprise as an instrument of neoliberalisation of welfare policies-reflect two conflicting conceptions of the future of social enterprise. Insofar as Norway has not yet entered a process of institutionalisation of social enterprise, the field is still in its emergence phase, and its development remains an open process.

Indeed, internationally, the development of social enterprise seems to have proceeded through different phases-from emergence, innovation and disruption to institutionalisation and formalisation within public policies and programmes. The description provided by Nicholls (2006: 11), according to which "[social] entrepreneurs and their networks demonstrate an unrelenting focus on systemic change that disregards institutional and organisational norms and boundaries" fits well with the disruptive-agency role played by social entrepreneurs in established fields as well as with their role as "sectoral iconoclasts" in the phase of innovation. During the innovation phase, social enterprise has a disruptive effect on established institutional arrangements, challenging existing sector boundaries and organisational forms. However, in most countries, the innovation phase is followed by an institutionalisation phase, in which isomorphic forces come into play. In this institutionalisation phase, regulation of both these initiatives' organisational forms and competitive market distortion generate 
isomorphic tendencies, whereby social enterprises become more homogenous in their organisational forms and modes of operation.

A particular difficulty for the development of social enterprises within the Nordic welfare system is the absence of real potential markets (especially within the social field), given the extensive public funding and public-sector provision that characterise the welfare system. Under such circumstances, social enterprises appear either as disruptive for public and traditional nonprofit actors or as being in search of public-funding sources, that is, as promoting a marketisation of the welfare delivery system. From this viewpoint, the conception according to which "the primary distinction [when it comes to social enterprise] (...) lies in which funding model is adopted with respect to achieving a social objective", and "social enterprises look to move away from grant dependency towards selfsufficiency via the creation of income streams" (Nicholls 2006: 12) has to be qualified. Such a conception entails, in particular in the case of social enterprises operating in the welfare field, the existence of a potential market, that is, unsatisfied needs and purchasing power. Within the Nordic welfare system, where income inequalities are relatively small and the public coverage of social needs through public insurance and public-service provision is extensive, the market for social enterprises outside public procurement is quite limited.

Indeed, the idea of market sustainability of social enterprise, especially within welfare-service provision, cannot be separated from the institutional environment constituted by the type of welfare-state system (or its absence). In many cases, a majority of the population lacks the purchasing power to be able to pay for welfare services (especially when these services aim at alleviating poverty and tackling different forms of social exclusion). For other types of services, such as elderly care, social enterprises' economic sustainability entails a commodification/marketisation of these services, in opposition to the de-commodification operated by the welfare state. Alternatively, social enterprises can develop innovative solutions to social problems (such as work-integration social enterprises), but then market sustainability is not the primary aim.

If social enterprises address areas of unmet needs (Nicholls 2006: 15), as a result of "social market failures", including solidarity failures and institutional failures, those failures are closely linked to the institutional arrangements in which they operate. The institutional arrangements characterising the Norwegian welfare state define the opportunity structure in which this type of initiatives operates and they (will) consequently have a decisive impact on both the emergence and institutional trajectory of social enterprise in Norway.

In this context, the Nordic welfare-state model may be deemed to constitute an impediment to the development of social entrepreneurship, and the sectoral logics differentiating the public, non-profit and corporate sectors may be perceived as an obstacle to the potential regenerative 
role that social enterprise could play in addressing social challenges, by bridging these sectoral logics of action (Hauge 2017). However, such a framing of the issue, which underscores the hybrid and bridging capacity of social enterprise while praising disruptive innovation and grassroots initiatives and practices, overlooks the political dimension as well as the structural and systemic consequences of the prevalence of one model of social entrepreneurship over another.

\section{Conclusion}

The stake, when it comes to the prevalence of a "social-economic" model of social entrepreneurship over a clear-cut business model of social entrepreneurship, is not necessarily a question of choice between sectoral cooperation (social enterprise as crossing the boundaries of established sectors-the public, non-profit and for-profit sectors) and sectoral cooptation (social enterprise as being either within the business sector or the non-profit sector). It can also be seen as a choice between two different roles for social enterprises, which can either contribute to the development of a moral market or be an instrument for the "economisation of morality".

Indeed, although modern society is composed of multiple institutional spheres, each characterised by a specific logic of action, this does not preclude actors' ability to draw from multiple "orders of worth" (Boltanski and Thévenot 2006) in order to achieve their goals through economic exchange, regardless of sectoral location. From such a perspective, as shown by Zelizer $(1997,2009)$, individuals are capable of constructing a "moral market" whereby members engage in economic exchange and market-based transactions as a means to enact their values. Social entrepreneurship and social enterprise may be viewed as an effort to create a civic market, where actors engage in economic exchange and rely on markets as a means to achieve social (non-economic) objectives. However, in order to be successful in creating such a civic economy, social enterprises have to operate in an institutional field characterised by a shared understanding of the purpose and form of their action as well as of the symbolic boundaries that differentiate the field of social entrepreneurship from other fields. In the absence of such an institutionalised field in Norway, enabling the construction of additional (cultural) meaning and values associated to market transactions, social entrepreneurship might contribute to the "economisation" of the civil sphere and of the welfare state. In this respect, the institutional form of social enterprise and the regulatory, allocative and evaluative devices that are institutionalised by public policies all influence social enterprises' ability to generate a civic economy.

From this viewpoint, Norway is probably at a crossroad. There is an increasing interest, among Norwegian policy-makers, for all kinds of 
social entrepreneurship and grassroots initiatives. At the same time, the field is not yet institutionalised and rather appears as a contested terrain of struggle between at least two main conceptions of social enterprise: the social-economic model $v s$. the business model. It is difficult to state, at the time being, which model will prevail in public policies to come, but whatever the direction in which the field will evolve in the future, the societal consequences of the prevalence of one or the other model should not to be underestimated.

\section{Notes}

1 The model is sometimes called the "Nordic model", when it includes Finland and Iceland in addition to the Scandinavian countries (Sweden, Denmark and Norway). But even though Finland and Iceland share several characteristics with the Scandinavian countries, they also diverge on some important dimensions, hence we chose to concentrate, in the present chapter, on the Scandinavian countries.

2 A common institutional form used by social enterprises in Norway is the "non-profit limited company" (Ideelt Aksjeselskap). The non-profit limited company is a specific Norwegian legal form used for companies whose statutes include a set of rules regulating the return on investments outside a strict profit organisational regime. It may be appropriate for social enterprises with a social, cultural or environmental nature; enterprises active in the field of research or with other non-financial interests also make use of it. Legally speaking, however, the non-profit limited company is not a separate organisational form. Like ordinary corporations, it is subject to the Norwegian legislation for limited companies.

\section{References}

Andersen, L. L., Gawell, M. \& Spears, R. (eds) (2016) Social Entrepreneurship and Social Enterprise. Nordic Perspectives, London: Routledge.

Baglioni, S. (2017) "A remedy for all sins? Introducing a special issue on social enterprises and welfare regimes in Europe", Voluntas, Vol. 28, No. 6, pp. 2325-2338.

Boltanski, L. \& Thévenot, L. (2006) On Justification. Economies of Worth, Princeton: Princeton University Press.

Eimhjellen, I. \& Loga, J. (2016) Utvikling av sosialt entreprenørskap I Norge, Bergen: UniResearch Rokkansentret, Rapport 9-2016.

Enjolras, B. \& Strømsnes, K. (eds) (2018) Scandinavian Civil Society and Social Transformations: The Case of Norway, New York: Springer.

Evers, A. (2005) "Mixed welfare systems and hybrid organizations: Changes in the Governance and provision of social services", International Journal of Public Administration, Vol. 28, No. 9-10, pp. 737-748.

Garrow, E. E. \& Hasenfeld, Y. (2014) "Social Enterprises as an embodiment of a neoliberal welfare logic”, American Behavioral Scientist, Vol. 58, No. 11, pp. 1475-1493.

Hauge, H. A. (2017) "Social enterprise in Norway, caught between collaboration and cooptation?", Discussion Paper, Peer Review "Fostering social 
entrepreneurship to tackle unmet social challenges”, EU-DG for Employment, Social Affairs and Inclusion.

Ingstad, E. \& Loga, J. (2016) "Sosialt entreprenørskap i Norge: en introduksjon til feltet”, Tidsskrift for praksisk økonomi og finans, Vol. 32, pp. 21-33.

Kobro, L. U. (2019) Social Enterprises and Their Ecosystems in Europe. Country Fiche NORWAY, European Commission, Luxembourg: Publications Office of the European Union (https://ec.europa.eu/social/BlobServlet?docId=20957\& langId=en).

Kobro, L. U., Skar, C., Røtnes, R. \& Eggen, F. W. (2017) Statlige rammevilkår på ramme alvor. Sosialt entreprenørskap i norsk offentlig kontekst, SESAM rapport 1/2017, Skriftserien fra Høgskolen i Sørøst-Norge.

Nicholls, A. (2006) "Introduction", in Nicholls, A. (ed.) (2006) Social Entrepreneurship. New Models of Sustainable Social Change, Oxford: Oxford University Press.

Selle, P., Strømsnes, K. \& Loga, J. (2018) "State and civil society - a regime change?”, in Enjolras, B. \& Stømsnes, K. (eds.) Scandinavian Civil Society and Social Transformation. The Case of Norway, Berlin: Springer.

Sivesind, K. H. (2017) "The changing role of for-profit and non-profit welfare provision in Norway, Sweden and Denmark, and consequences for the Scandinavian model", in Sivesind, K. H. \& Saglie, J. (eds) Promoting Active Citizenship? Markets and Choice in Scandinavian Welfare, London: Palgrave Macmillan.

Torfing, J. (2016) Collaborative Innovation in the Public Sector, Washington: Georgetown University Press.

Torfing, J. \& Triantafillou, P. (2016) Enhancing Public Innovation by Transforming Public Governance, Cambridge: Cambridge University Press.

Trägårdh, L. (ed.) (2007) State and Civil Society in Northern Europe. The Swedish Model Reconsidered, New York: Berghan Books.

Zelizer, V. (1997) The Social Meaning of Money, New York: Basic Books.

Zelizer, V. (2009) The Purchase of Intimacy: Pin Money, Paychecks, Poor Relief, and Other Currencies, Princeton: Princeton University Press. 


\title{
11 Social Enterprise in Portugal Concepts, Contexts and Models
}

\author{
Sílvia Ferreira and Joana Almeida
}

\section{Introduction}

There is no specific legal form or statute for social enterprises in Portugal. Research on social enterprise is scarce and focused on specific types of organisations and, in the absence of a common definition, the concept is understood in various ways. This chapter provides an overall view of social enterprise in Portugal drawn from the research carried on in the scope of the "TIMES-Institutional Trajectories and Social Enterprise Models in Portugal" project. ${ }^{1}$

The chapter is organised in two parts. In the first part, we explore the concepts and context related to social enterprise in Portugal; through a literature review and policy analysis, we describe how the concept of social enterprise and other relevant concepts, such as social economy and social innovation, are being treated in research and in the political debate, and how this has been translated into various government programmes and measures. In the second major section, based on a literature review and on interviews with key stakeholders, we identify and describe five models of de facto social enterprise in Portugal. In line with the framework developed by Defourny and Nyssens (2017), we privilege organisational forms and statutes and institutional trajectories.

\subsection{Understanding Concepts and Context}

In Portugal, the concept of social enterprise (SE) is scarcely used in the rhetoric of public authorities, practitioners and academics. Meanings currently given to the term "social enterprise" are strongly influenced by the European Union's (EU) policy frameworks, and existing references are to be found, for instance, in the national and some regional operational programmes of EU structural funds, or in the Code of Public Contracts.

Other concepts have become more prominent at the level of research, policy and practice; in particular, the concept of social economy has become established as the dominant one, particularly since the adoption of the Framework Law on the Social Economy. ${ }^{2}$ 
More recent concepts are those of social entrepreneurship and social innovation. During the crisis that started in 2010, the concept of social entrepreneurship was often associated with the discourse on crisis, emergency and workfare policies; it meant a shift of responsibility to solve social problems onto individuals and non-profit organisations. This concept has lost ground in recent years, whereas the concept of social innovation has become established.

The concept of solidarity economy has also gained relevance in the last few years, to a large extent because of the crisis, and it often included in its meanings an explicit criticism of the organisation of the capitalist economy. The emergence of this concept rather results from the mobilisation of scholars and grassroots associations, networks, popular movements and local communities (Hespanha et al. 2015).

All these concepts are relevant when analysing the field of social enterprise, as we will show in the next pages.

\subsubsection{Social Enterprise in Research}

Research on social enterprise in Portugal has taken place since 2000, mostly in the framework of international research projects, and it has identified different types of organisations as social enterprises. Two projects, both carried out in the framework of the EMES Network, identified respectively "cooperatives for the education and rehabilitation of citizens with disabilities" (cooperativas de educação e reabilitação de cidadãos com incapacidade, or CERCIs; Perista 2001) and "insertion enterprises" (empresas de inserção or EIs; Perista and Nogueira 2002) as social enterprises.

Perista (2001) described CERCIs as an example of social enterprise. CERCIs emerged within the cooperative movement's revival, linked to the Democratic Revolution of 25 April 1974; they were initiated by groups of parents of disabled children and professionals, with the support of local municipalities and public administration. They were later included in the branch of social-solidarity cooperatives.

Perista and Nogueira (2002) also studied the case of insertion enterprises (EIs) for the inclusion of disadvantaged people in the labour market, analysing these as a form of work-integration social enterprise (WISE). EIs were created under a government programme called the "Social Employment Market", which was launched to promote the employment of vulnerable groups. The authors also identified as WISEs "sheltered-employment centres and enclaves" (centros de emprego protegido ou enclaves), created in 1983 and later integrated in the Social Employment Market programme.

Another international study defined a social enterprise as a "not-forprofit, privately owned organisation, aiming at some social, solidarity or local-development purpose". The study distinguished between two 


\section{Ferreira \& Almeida}

groups: (1) cooperatives with social and developmental aims and (2) non-profits, in particular those with the statute of "private socialsolidarity institution" (instituição particular de solidariedade social, or IPSS) (Heckl and Pecher 2007: 2). The IPSS status is awarded by the social-welfare administration, which checks the organisation's activities and its capacity to pursue them.

In 2014, IPSSs and social-solidarity cooperatives were also considered to fit the European Commission's criteria defining a social enterprise: engagement in economic activity; explicit and primary social aim; organisational autonomy from the state; and defined rules regulating the distribution of profits (European Commission 2014).

A recent international study provided a general definition of social enterprises as "organisations that use market-based activities to alleviate societal needs" (Stephan 2017). Various legal forms-social-economy organisations, commercial enterprises and individual entrepreneurswere included in the surveyed sample (SEFORÏS 2016).

As evidenced by these various studies, the concept of social enterprise is used in research to refer to different types of organisations and traditions. None of the various meanings given to the term, though, was adopted in policy or by practitioners.

\subsubsection{The Political Debate About Social Enterprise}

The attempt at drawing a Framework Law on the Social Economy came from the centre-right party, in September 2010. The parties on the left and centre-left voted against it. In September 2011, with a new coalition in government of centre-right (PSD) and right (CDS-PP) political parties, the draft was resubmitted to the Parliament and passed, despite the abstention of the centre-left party (PS) and votes against by the left-wing parties (BE and PCP). The Law was then discussed in a specialised parliamentary commission, which carried on a large consultation with the main actors of the social economy, experts and labour-union confederations. The resulting draft was approved unanimously in the Parliament and the Law came into force in 2013.

Among the contested topics was an article concerning "the enactment of a legal framework for social enterprises as entities carrying on a commercial activity with primarily social ends and whose income is essentially allocated to the development of those ends or reinvested in the community" (Draft Law No. 68/XII, article 13, No. 2-c). Actors from the social economy saw in this formulation the opening of the possibility for for-profit businesses to be framed inside the social economy, and a risk for the social economy to lose its core features, due to the expressions "primarily" and "essentially" (Ferreira 2015). The debate was also about whether social enterprises were always social-economy enterprises or whether they constituted a broader set of enterprises, which could 
include as well commercial businesses. Most representatives, therefore, considered that the reference to social enterprises should be removed from the Framework Law on the Social Economy-which was done (Ferreira 2015).

Thus, currently, many social-economy stakeholders associate social enterprises with commercial enterprises and practices; this in turn generates resistance to the term, so that others prefer not to use it at all.

\subsubsection{Other Related Concepts}

Other related concepts-such as the non-profit sector, the social economy, social entrepreneurship and social innovation-have become much more popular than that of social enterprise among the research community and practitioners.

Drawing inspiration from the work carried out by the CIRIEC and Eurostat to adapt the UN Satellite Account, the National Statistics Institute (INE) and Cooperativa António Sérgio para a Economia Social (CASES) elaborated a Satellite Account of the Social Economy in Portugal (INE and CASES 2013, 2016). In 2019, the revised version of the UN Satellite Account on Nonprofit and Related Institutions and Volunteer Work was adopted to produce the third edition of the Satellite Account (INE and CASES 2019). According to the Satellite Account, in 2016 , the Portuguese social economy included 71,885 organisations and accounted for 234,886 paid employees (representing $6.1 \%$ of the country's total employment) (INE and CASES 2019).

The concept of social entrepreneurship has been addressed from the point of view of two major schools of thought that can also be found internationally-one focused on the organisational and collective dimensions of social entrepreneurship, and the other focused on the individual dimension of the social entrepreneur. Parente (2014) found that, among social-economy organisations (SEOs), an understanding of social entrepreneurship emphasising sustainability based on market resources and business practices dominated.

The concept of social innovation is usually used in the field of SEOs, and often associates these to their role in local and territorial development (Bernardino and Freitas Santos 2017). This concept has also been used to describe projects with entrepreneurial features carried out by SEOs, public agencies and commercial enterprises (IES/ IPAV 2015).

As for the concept of social solidarity, several authors have analysed the Portuguese reality in the light of this concept, pointing out its specificities (Amaro 2009) but also its weak institutional recognition (Hespanha et al. 2015) and its relation to the social economy (Namorado 2009). 


\subsubsection{Governmental Programmes and Measures}

Two policy streams are currently enabling the development of social enterprises: one related to the social economy and the other linked to social-innovation and social-entrepreneurship initiatives.

The last decade, since 2009, has witnessed a unique political attention for the social economy and the convergence of the different actors in the field. The first step was the setting up of CASES, which resulted from the evolution of a former public institute supporting the cooperative sector. CASES is a cooperative of public interest whose members are socialeconomy confederations and the government. ${ }^{3}$

In 2010, at the beginning of the crisis, the government created the Support Programme for the Development of the Social Economy (Programa de Apoio ao Desenvolvimento da Economia Social, or PADES), whose aim was to enhance the access of SEOs to funding and technical support. The National Council for the Social Economy (Conselho Nacional para a Economia Social, or CNES), a consultative body on issues related to the promotion of the social economy, was created in the same year.

The Framework Law on the Social Economy, as mentioned above, came into force in 2013. This law defines SEOs according to their legal form or statute and their compliance with a set of principles: (1) primacy of people and social objectives; (2) free and voluntary participation; (3) democratic control by the members; (4) values of solidarity, nondiscrimination, social cohesion, justice, equity, transparency, shared responsibility and subsidiarity; (5) autonomous and independent management; and (6) distribution of surplus according to the ends of the organisation and the general interest.

A revision of the legal regimes of entities covered by the Framework Law (the IPSS statute, the Cooperative Code and the Code of Mutual Associations) ensued from the enactment of the Framework Law. The goal of the revision was to adapt these various legal regimes to the new law; adjustments also resulted in a strengthening of the entrepreneurial/ market dimension and the multi-stakeholder governance of these entities, and of the accountability rules they must comply with.

In the ambit of the Social Emergency Programme (a governmental action plan operated between October 2011 and December 2014 to address the effects of the crisis), a set of measures were enacted, including support to non-profits to help them achieve financial equilibrium and professionalisation, and a guaranteed credit line (Social Investe).

CASES has been at the core of governmental strategies to promote the social economy. This includes programmes to support youth cooperative entrepreneurship and a microcredit programme made available to microbusinesses and small cooperatives. These measures are oriented towards the promotion of employment of disadvantaged groups. 
Another significant stream of policy measures, involving also philanthropic foundations and consultants, is taking place around the concept of social investment. The landmark is the "Portugal-Social Innovation" (Portugal-Inovação Social) initiative-a pilot programme created in 2014 and funded by the European Commission. Its measures include capacity building for social investment, impact partnerships between SEOs and for-profit and public social investors, social-impact bonds, and a social-innovation fund, which supports social-economy and commercialbusiness investment in social innovation. Within this framework, the emphasis is on high-impact social innovation; the legal form is irrelevant.

Nowadays, official references to social enterprise are to be found in operational programmes of EU structural funds and in the Code of Public Contracts, in the article related to the right to reserve contracts for certain services to certain types of organisations. Social enterprises are defined as

those [enterprises] that are dedicated to the production of goods and services with a strong component of social entrepreneurship or social innovation, and [which promote] integration within the labour market, through the development of research, innovation and social-development programmes in the areas of the considered services.

They have the following features (similar to SEOs' principles): they pursue a public-service mission, related to certain services in the fields of health, social services, education and culture; their profits are reinvested or distributed in a participative manner; and workers are also the organisation's owners, or the organisation has multi-stakeholder participatory governance (Decree-Law No. 111-B/2017, 31/08, article 250-D).

Despite the contested and varied meanings given to the concept, social enterprises are de facto not absent in Portugal. One way to unravel the empirical and discursive diversity is to analyse these organisations in terms of their institutional trajectories and organisational frameworks.

\subsection{SE Models in Portugal}

The dominant conceptual framework through which social enterprises are approached and analysed in Portugal is the social economy. As mentioned above, the legal forms of SEOs include associations $(92.9 \%)$, mutual associations $(0.1 \%)$, foundations $(0.9 \%)$, mercy houses $(0.5 \%)$, cooperatives $(3.3 \%)$ and self-management and community organisations $(2.3 \%)$. Traditionally, these forms were considered as complementary in their roles, with an organisational form connected to their function, but boundaries have become blurred with the evolution of certain types of organisation towards less clear-cut categories. 


\section{Ferreira \& Almeida}

The social economy is strongly influenced by the features of the Portuguese welfare state (Ferreira 2015). In 2016, SEOs in the field of social services and health care represented $48.9 \%$ of paid employment in the social economy, although the largest number of organisations $(46.9 \%)$ were in culture, communication and recreation. Social services, health and education organisations also accounted for $57.2 \%$ of sales and user fees in the social economy (INE and CASES 2019).

The social economy has a solid legal foundation. The National Constitution, approved in 1976, after the Democratic Revolution, included cooperatives in a third sector in terms of ownership of the means of production (beside two other sectors, characterised respectively by private and public ownership of the means of production), and later came to include in this sector the other types of SEOs.

The following identification of different SE models is founded on previous studies and our empirical research. We present five models, four of which can be included in the social economy and one in the market economy. The five models, their characteristics and legal forms are presented in table 11.1.

\subsubsection{The Entrepreneurial Non-Profit (ENP) Model}

This model is found in Portugal as in other countries; its emergence is related to trends of welfare-state retrenchment (Defourny and Nyssens 2017) and, in the case of Portugal, also to a structural weakness of the welfare state. We identify this model mostly among social-service nonprofits, which implement income-generating strategies through users' payments and the setting-up of commercial activities. ${ }^{4}$

The dominant organisations among social enterprises belonging to this model are the IPSSs, but some IPSSs' key stakeholders prefer not to use the SE label due to its for-profit connotation. Although IPSSs only represent about $9 \%$ of the total number of SEOs, they represent $63.4 \%$ of the whole employment in the sector (INE and CASES 2013: 41).

The definition of the IPSS status includes social, economic and governance-related dimensions. IPSSs are described as

collective, not-for-profit persons, constituted exclusively on the initiative of private persons, with the purpose of giving organised expression to the moral duty of justice and solidarity, contributing to the effectiveness of citizens' social rights, and which are not administered by the state or another public body.

(Decree-Law No. 172-A/2014, 14/11, art. 1, 1)

The legal forms of IPSSs include associations, foundations, mercy houses, mutual associations and Catholic-Church institutes and organisations. 


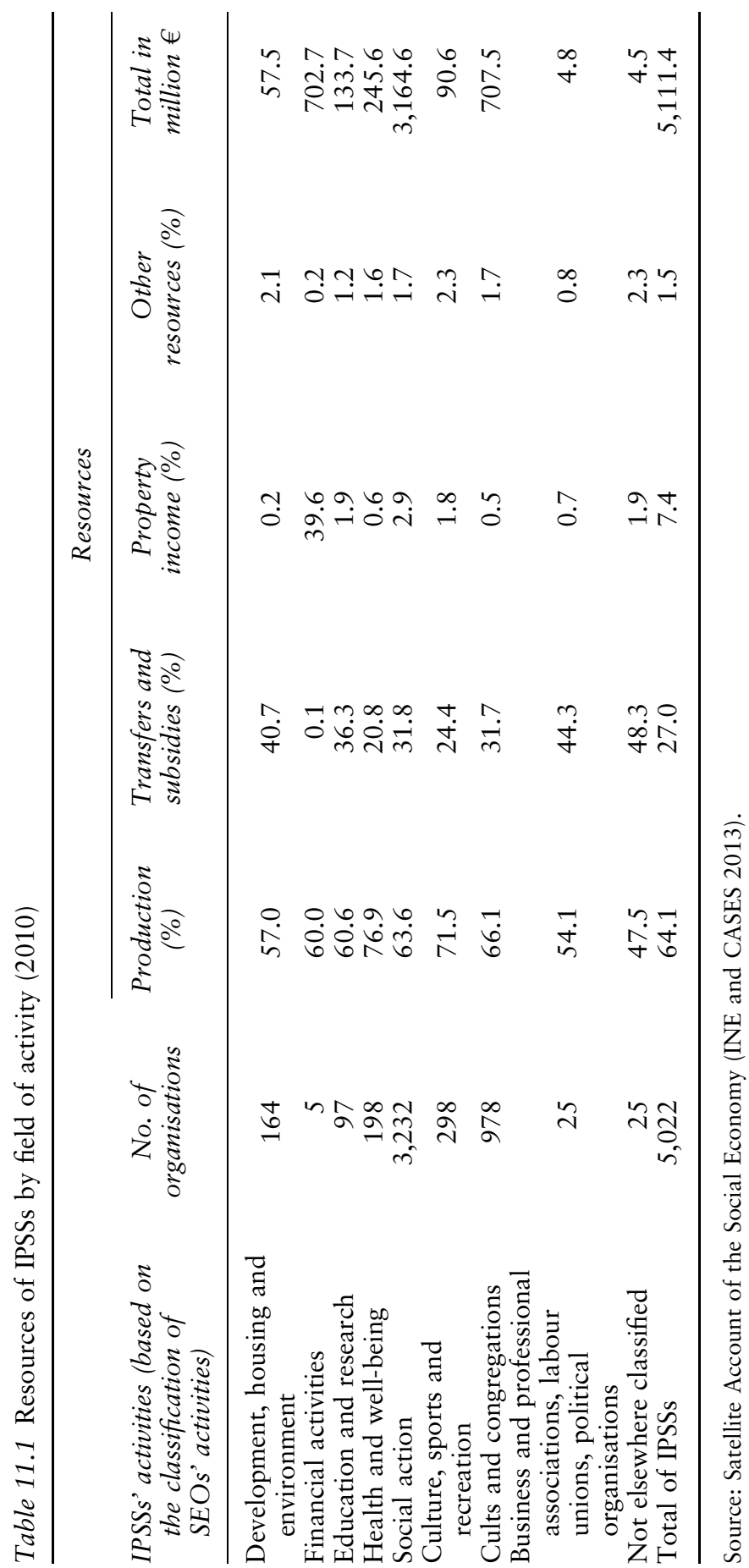


Since its creation, in 1979, the status of IPSS has entitled the organisations that obtain it to a special relation with the welfare state, sometimes called a "public/social partnership", which has evolved, as the principle of subsidiarity became increasingly important, towards these organisations being in charge of an increasing share of social services provision.

Table 11.2 shows the resource structure of IPSSs by activity area in 2010 (the only year for which these data are available in the Satellite Account series). Subsidies and transfers to IPSSs represent $27 \%$ of their total income; this is not sufficient to cover the costs of wages (which represent $31.6 \%$ of their total budget) (INE and CASES 2013).

The reliance of IPSSs on users' payments (which represent the largest share of the "production" category in table 11.2) has been a structural feature linked to the welfare state's weakness. The government regulates the amounts paid, which depend on users' income; it also transfers to organisations a fixed amount per user, under "cooperation agreements". Organisations balance their budgets thanks to the fact that payments by users with the highest income make up for the lower contributions by users with the lowest income. This reliance on the user's payments is also made possible by the weight that family services (children and elderly services) provision has in comparison to provision of services to specific disadvantaged groups (Ferreira 2015).

The resource structure of IPSSs, which are highly reliant on user fees, is one of the reasons why they were highly affected by the crisis that started in 2010. In the context of the emergency policies that were implemented at the time, there was a reinforcement of the role of these organisations in welfare provision and increased public transfers to fund such provision.

There is a strong rhetoric about the need for IPSSs to become more market-oriented. Two main arguments have been put forward: (1) IPSSs have been judged to be excessively dependent on state subsidies; and (2) the control exercised by the government, under current arrangements, has been deemed excessive, so that market-like contracts between public administration and IPSSs would be preferred.

Stakeholders are concerned that a stronger market orientation will lead to mission drift, and the recent change in the IPSS statute, which facilitates the development of so-called "instrumental commercial activities", is not consensually seen as a good thing.

\subsubsection{The Work-Integration Social Enterprise (WISE) Model}

Insertion enterprises (EIs) and sheltered-employment centres and enclaves were analysed as forms of WISE. They have not been a success story so far, but stakeholders consider that nowadays appropriate conditions for their development are in place, provided the definition of the 
concept of WISE is clarified and clear public-policy support is implemented. Employment promotion continues to be regarded as a priority in the political agenda and a set of tools, including structural funds and a new public-procurement framework, may constitute an opportunity to revive the interest in WISEs.

Insertion enterprises are enterprises dependent on public policy and mostly managed by non-profit organisations and social cooperatives; they are usually units of production within these organisations, so they are not distinct legal entities. This form of WISE was created by public policy in 1996, under a top-down logic, with a view to promoting the employment of socially vulnerable groups. Legal limits were imposed upon them regarding the areas of activity within which they were allowed to operate; these were areas that were less attractive in terms of market potential. Sheltered-employment centres are adapted units of production, created by public, private or cooperative organisations and aiming to provide access to paid work to people with disability, whereas enclaves are groups of production integrated by people with disability within a regular work environment. No data are available on the current number of WISEs in the country.

Perista and Nogueira (2004) showed that WISEs were able to combine work-integration activities with the production and sale of goods/services and a local-development goal, and they highlighted the hybridity of WISEs' resource mix. According to stakeholders, the work-integration orientation is what defines a WISE, regardless of its legal form. This orientation is about more than merely having a certain percentage of workers pertaining to vulnerable groups; it also implies that the social enterprise is structured in such a way that it empowers vulnerable people through training, skills development, quality work and decent wages.

The programme that had led to the creation of EIs was progressively downsized, and it was finally terminated in 2015. Most EIs did not survive the end of public support. Only a few became independent organisations, while some others became units within non-profit organisations, providing goods and services for internal consumption. In addition to the lack of political willingness to support EIs, stakeholders and researchers identify several factors that contributed to the end of most EIs, such as the lack of preparation and training of managers, workers' low skills; and legal obstacles preventing these enterprises from acting freely in the market or, conversely, from being duly recognised as in need of public support.

\subsubsection{The Social-Cooperative (SC) Model}

This model has been described internationally as the most typical form of social enterprise in Portugal (Galera and Borzaga 2009). 


\section{Ferreira \& Almeida}

CERCIs, which belong to this model, started as special-education schools for children with mental handicap or learning difficulties, in a context characterised by the lack of adequate public and non-profit solutions. CERCIs were oriented towards work and social integration and had a participatory type of governance and a mixed membership. The first CERCI was created in 1975. The movement then spread throughout the country and organisations scaled up to provide services covering all the stages of mentally disabled people's life: education, professional training, residencies, occupational activities, sheltered employment, selfemployment and home care.

With the revision of the Cooperative Code, in 1996, a new cooperative branch - that of social-solidarity cooperatives (cooperativas de solidariedade social)—was created, and CERCIs were included therein. The advantages to which IPSSs are entitled were extended to these cooperatives. Socialsolidarity cooperatives aim to fight social exclusion through support to vulnerable groups, disadvantaged families and communities, and people in situations of disease, old age, disability and poverty; they provide education, training and work integration for disadvantaged people.

According to the Satellite Account (INE and CASES 2013), in 2010, of the 2,117 existing cooperatives, 136 were social-solidarity cooperatives, most of which (109) were active in the field of social action and social security. Subsidies and transfers linked to social action and social security were particularly significant in these organisations' resource mix: they represented $66 \%$ of cooperatives' financial resources, whereas sales and user fees represented $31.6 \%$. This can be accounted for by the fact that cooperative users' ability to pay is lower than that of IPSSs' users.

Like in the case of IPSSs, some stakeholders claim that social-solidarity cooperatives too are excessively dependent on the state, qua organisations developed to provide services that the state funds as a public duty, and that this dependence leads to the loss of cooperatives' original advocacy orientation.

Key stakeholders in this field describe a tendency, among socialsolidarity cooperatives, towards developing new income-generating strategies, like selling their specialised services and infrastructure to the community (swimming-pool access, special transport, educative and therapeutic services).

The democratic governance and the entrepreneurial character of cooperatives are brought up by stakeholders to argue that social cooperatives are the best example of social enterprise.

\subsubsection{The Solidarity-Economy Enterprise Model}

Organisations within this model are diverse, but they share the same institutional trajectory and the same institutionalised networks and frameworks. Two different origins, in the 1990s-2000s, can be identified; 
both streams then converged in the 2010s. One stream derives from local-development initiatives (Moreno 2003), and another from the first use of the solidarity-economy concept in Azores, to describe a shift from a charitable orientation towards employment-promotion initiatives (Amaro 2009). Both streams were enhanced by EU-funded projects for rural and disadvantaged areas and target groups. These initiatives were led by organisations oriented towards local/territorial development, which put in place programmes to fight against the economic, demographic and social decay of these areas by resorting to economic activities and the market. More recently, they were joined by new types of organisations, mostly cooperatives, set up around concerns related to local and sustainable development and environmental protection, articulated with the willingness to carry out economic activity differently.

Most of these initiatives are gathered in the ANIMAR Network (which is oriented towards local development) and in the Portuguese Network for the Solidarity Economy, whose respective memberships partly overlap. As the concept of solidarity economy gained ground in the Portuguese context, these initiatives started to identify with it. Solidarity-economy enterprises demonstrate a concern for well-organised management, and they aim to show that it is possible to be successful in the market with a human-oriented economic stance. They also promote a strong sense of community participation, participatory democracy and local governance, and strive to develop a sustainable relation between people and the planet. Estivill (2009) argues that, due to its characteristics in Portugal, the solidarity economy is strongly linked to local territorial development.

This group of initiatives is also characterised by its diversity in terms of legal forms; it includes both social-economy organisations-the large majority-and commercial businesses. The latter are used as a way to support local and human development. Moreno (2003) identified 300 local-development initiatives, including associations (70\%), cooperatives $(10 \%)$, foundations $(6 \%)$, mercy houses $(6 \%)$, public organisations $(5 \%)$ and commercial organisations (less than $3 \%$ ).

One important feature of these initiatives is their involvement in the communities where they operate. Their proximity to the needs of the community contributes to their evolution in terms of services provided and legal forms adopted to respond to those local demands. Regarding this proximity, some stakeholders stress that ideas such as "scaling-up" endanger the very essence of this type of social enterprise as they pose challenges in terms of participatory governance.

\subsubsection{The Social-Business Model}

The social-business model is often associated with the idea that the commercial form may be the most adequate legal form for social 


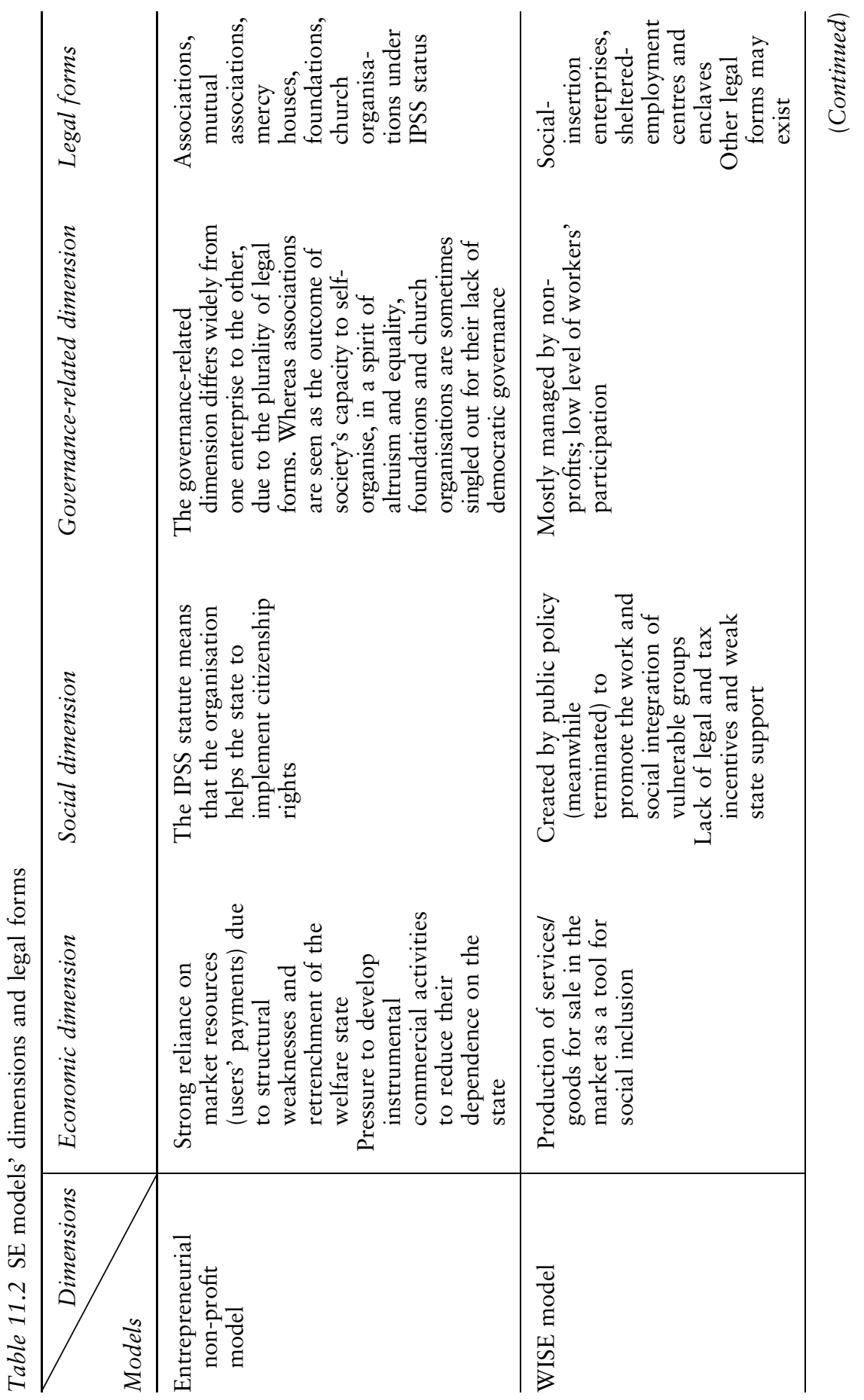




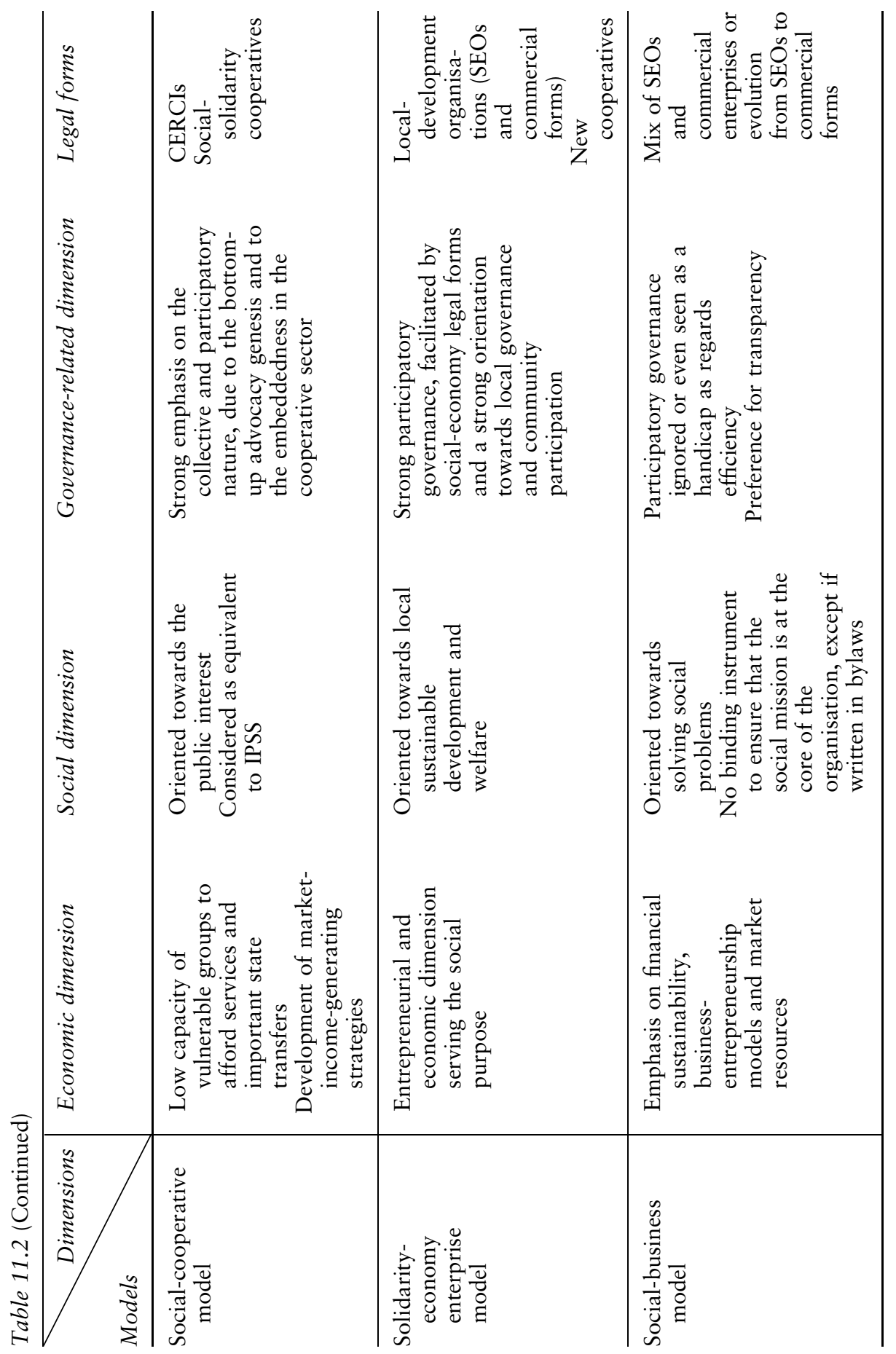




\section{Ferreira \& Almeida}

enterprise as long as it balances social and market goals. This in turn is linked to the idea that market resources and models offer the best solutions to implement socially innovative and entrepreneurial activities.

The adoption of the European Commission's policies and guidelines on social innovation and social entrepreneurship, including the Social Business Initiative, have been highly influential in the country, and the "Portugal-Social Innovation" pilot programme for the development of a social-investment market is a major reference among social enterprises belonging to this model.

Indeed, several initiatives carried out by consultants, business schools, foundations and support organisations have tried to foster social businesses. For them, social enterprises are organisations launched by social entrepreneurs that aim at high-impact social innovation. In that perspective, the initiative's legal form is not a major concern.

These new actors are concerned with aspects such as the business plan, sustainability, scaling up and social-impact measurement, and they have little concern for governance. Moreover, some stakeholders underline that investors are reluctant to support SEOs, which they associate with an idea of backwardness. SEOs are seen as unable to scale up social innovations, which is considered as a condition for financial sustainability. Moreover, some financial instruments cannot be operationalised under social-economy legal forms, since they require private capital ownership. Social entrepreneurs are described as business-oriented young people who aim at business success while simultaneously contributing to society.

In practice, various projects inside this model have resorted (sometimes simultaneously) to several legal forms in order to take advantage of both public support and philanthropy funding and social finance and markets. In some cases, these initiatives combine a nonprofit and a commercial legal form, corresponding to two sides of the same project; in other cases, they emerged as associations or projects inside associations and evolved into limited-liability or joint-stock companies.

Their trajectories reflect the lack of a specific legal framework for this new type of business. These initiatives were set up with a view to solving a social problem, sometimes described as a market gap, like school dropout, youth unemployment and so on. Stakeholders put a strong emphasis on social impact.

Boundaries in this area are blurred, particularly as regards the practices linked to corporate social responsibility (CSR) and the changes taking place in the way in which businesses and funders implement CSR strategies. The label of certified B Corps recognises some of these social businesses, just as it acknowledges some "regular" commercial businesses. 


\section{Conclusion}

In this chapter, we provide a description of the landscape of social enterprise and related concepts in Portugal. The concept of social enterprise is not widely used in the country; it is subject to different interpretations and has contested meanings, as there is no specific legal form or status for social enterprise. The official recognition and definition of the (related) concept of social economy has been the subject of major efforts by successive governments, though, and the institutional framework is strengthening.

The diverse types of social enterprise identified in the research are not usually characterised as such and, currently, many actors explicitly avoid the use of the term. However, the need for some kind of legal definition (legal form or statute) is acknowledged by most stakeholders, and we consider that a debate on the social, economic and governance boundaries of social enterprises is lacking.

Through a review of the literature on that topic, policy analysis and key stakeholders interviews, five models of social enterprise can be identified in Portugal (some of which correspond to models put forward at the international level; see Defourny and Nyssens 2017): the entrepreneurial non-profit model; the WISE model, whose emergence and development are essentially linked to a public policy; the socialcooperative model, which was inspired by the cooperative revival of the Democratic Revolution; the solidarity-economy SE model, whose roots are to be found in local, social, economically and environmentally sustainable initiatives; and the more recent, widely EU-driven socialbusiness model.

We detect a double movement in the field of social enterprise: on the one hand, some organisations are becoming more market-oriented, thereby responding to the retrenchment of the welfare state and the emergence of social-investment actors and tools; on the other hand, other organisations are becoming increasingly oriented towards the common good/public interest, in a context characterised by social/political pressure to become more democratic and/or socially responsible. These institutional trajectories, which demonstrate an adaptive capacity to different demands, redefine the boundaries between the state, the market and the society (Defourny and Nyssens 2017).

\section{Notes}

1 TIMES (POCI-01-0145-FEDER-030612) is funded by the Foundation for Science and Technology (FCT/MEC) and FEDER, through the Operational Competitiveness and Innovation Programme COMPETE 2020.

2 Framework Law on the Social Economy, Law No. 30/2013, May 8.

3 The state holds $66.22 \%$ of the capital and votes, and the remaining capital and votes are equally distributed among the other members $(5.63 \%$ each). 


\section{Ferreira \& Almeida}

4 Income-generating strategies implemented by non-profits also existed before the development of the welfare state; mutuals and mercy houses owning social pharmacies and savings banks are examples hereof.

\section{References}

Amaro, R. (2009) “A Economia Solidária da Macaronésia - Um Novo Conceito", Revista de Economia Solidária, Vol. 1, pp. 11-28.

Bernardino, S. \& Freitas Santos, J. (2017) "Local development through social and territorial innovation: An exploratory case study", CIRIEC-España, Revista de Economía Pública, Social y Cooperativa, Vol. 90, pp. 159-187.

Defourny, J. \& Nyssens, M. (2017) “Fundamentals for an international typology of social enterprise models", Voluntas: International Journal of Voluntary and Nonprofit Organizations, Vol. 28, No. 6, pp. 2469-2497.

Estivill, J. (2009) "Espacios públicos y privados. Construyendo diálogos en torno a la Economía solidaria", Revista Crítica de Ciências Sociais, Vol. 84, pp. 101-113.

European Commission (2014) A Map of Social Enterprises and their Ecosystems in Europe. Country Report: Portugal, Brussels: European Commission.

Ferreira, S. (2015) "New paths for third sector institutions in a welfare state in crisis: The case of Portugal", Nonprofit Policy Forum, Vol. 6, No. 2, pp. 213-241.

Galera, G. \& Borzaga, C. (2009) "Social enterprise: An international overview of its conceptual evolution and legal implementation", Social Enterprise Journal, Vol. 5, No. 3, pp. 210-228.

Heckl, E. \& Pecher, I. (2007) Study on Practices and Policies in the Social Enterprise Sector in Europe. Final Report, Vienna: Austrian Institute for SME Research.

Hespanha, P., Santos, L. L., Silva, B. C. \& Quiñonez, E. (2015) “Mapeando as iniciativas de Economia Solidária em Portugal: algumas considerações teóricas e práticas", Colóquio Internacional Epistemologias do Sul: aprendizagens globais Sul-Sul, Sul-Norte e Norte-Sul, Vol. 3, p. 14, Coimbra.

IES/IPAV (2015) Mapa de Empreendedorismo e Inovação Social em Portugal $1^{a}$ fase, Lisboa: Instituto e Empreendedorismo Social/Instituto Padre António Vieira.

INE \& CASES (2013) Conta Satélite da Economia Social 2010, Lisbon: INE \& CASES.

INE \& CASES (2016) Conta Satélite da Economia Social 2013, Lisbon: INE \& CASES.

INE \& CASES (2019) Conta Satélite da Economia Social 2016, Lisbon: INE \& CASES.

Moreno, L. (2003) Guia das organizações e iniciativas de desenvolvimento local, Lisbon: Animar.

Namorado, R. (2009) "Para uma economia solidária - a partir do caso português", Revista Crítica de Ciências Sociais, Vol. 84, pp. 65-80.

Parente, C. (ed.) (2014) Empreendedorismo Social em Portugal [PDF], Porto: Universidade do Porto. 
Perista, H. (2001) "Co-operatives for rehabilitation of people with disabilities", in Borzaga, C. \& Defourny, J. (eds) The Emergence of Social Enterprise, New York: Routledge, pp. 192-203.

Perista, H. \& Nogueira S. (2002) "National profiles of work integration social enterprises: Portugal”, EMES Working Papers Series, No. 02/09, Liège: EMES International Research Network.

Perista, H. \& Nogueira, S. (2004) "Work integration social enterprises in Portugal”, EMES Working Papers Series, No. 04/06, Liège: EMES International Research Network.

SEFORÏS (2016) Portugal Country Report. A First Analyses and Profiling of Social Enterprises in Portugal, Brussels: SEFORÏS Research Consortium.

Stephan, U. (2017) "Social enterprises, social inclusion and positive social change”, SEFORÏS Policy Brief, Working Paper 7. 


\title{
12 Social Enterprise in Spain
}

\author{
From a Diversity of Roots to a \\ Tentative Typology of Models
}

\author{
Millán Díaz-Foncea, Esther Villajos, \\ Teresa Savall, Carmen Guzmán, \\ Francisco Javier Santos, Marta Solórzano- \\ García, Chaime Marcuello-Servós, Rafael \\ Chaves-Ávila and Carmen Marcuello
}

\section{Introduction}

This chapter's objective is to analyse the various perspectives on the concept of social enterprise (SE) as well as the different SE models existing in Spain. While the first major section presents the context and the main concepts related to the SE phenomenon in the country, the second one identifies and describes models of social enterprise.

\subsection{Understanding Concepts and Context}

In Spain, the term "social enterprise" has historically been linked to the organisations that promoted the social and labour integration of persons at risk of social and labour exclusion and other similar social activities. These organisations are recognised as part of the social economy, in accordance with the standpoint of European Union institutions (Monzón-Campos and Chaves-Ávila 2017). The fields in which the concept of social enterprise first emerged in Spain are probably academia and politics, which are more connected than field initiatives to debates and research in Europe.

At the beginning of the 1980s, different social organisations that had launched special programmes of training and labour integration, focusing on excluded people or people at risk of exclusion, experienced difficulties with regard to the subsequent social integration of their trainees. They then began to create labour initiatives as a follow-up of the training process they offered. These initiatives can be viewed as the predecessors of work-integration social enterprises (WISEs) in Spain, and they are considered as the country's first "social enterprises" (Vidal 1997; Puig Olle 1998; Álvarez 1999; Rojo Giménez 2000; García and Esteve 2007), although they did not obtain legal recognition until 2007 (Law 44/2007). ${ }^{1}$ Other initiatives that emerged during 
these years and can be linked to social enterprise in Spain include "sheltered-employment centres" (centros especiales de empleo; we will use the English acronym, SEC, hereafter), which dealt with the work integration of disabled people and gained legal recognition in 1982 (Law 13/1982 for the Social Integration of Disabled Persons), and social-initiative cooperatives, similar to Italian social cooperatives, which emerged to manage social services and cultural activities, were precariously financed by the government, and were finally recognised at the national level by Law 27/1999 on Cooperatives. ${ }^{2}$ These three types of organisation can be considered as predecessors of social enterprises in Spain, although they did not really self-identify with this concept, except maybe in the case of those belonging to the first type.

But despite the existence of these initiatives, the recognition of the concept of social enterprise at the general level did not come until 2006, when Ashoka-Spain selected its first fellows, increasing knowledge about social entrepreneurship and social-business activities among the media and thus among a broad sector of society. New consultancies and institutions are related to the understanding that social enterprises are a vehicle for social innovation and bring about solutions to social problems which neither the traditional market nor the public administration can provide.

In fact, the term "social enterprise" is still underused in Spain, and a debate still exists regarding its definition. A mix of perspectives on this concept, with different nuances, can be observed (European Commission 2020) and, following a tendency that Ashoka initiated, the term "social entrepreneur" is now used more frequently than that of "social enterprise". Social-economy entities also contribute to this debate and support the idea that some traditional social-economy organisations-and not only WISEs and SECs—should be recognised as social enterprises. This is the case of some agricultural cooperatives, with a long tradition in Spain, which have empowered people in the country's hinterland and were in many cases the only economic organisations in those areas.

Other business models have also recently emerged with the goals of overcoming the challenges of funding and increasing the viability of nongovernmental organisations (NGOs). Some NGOs started searching for a commercial approach to diversifying their funding sources, following a path that had been opened-although not in a very conscious way-by other NGOs in the mid-1990s.

Finally, the concept of social enterprise has also been used to refer to those social movements, including associations and other transitional movements, which took the leap from the social field to the business arena. They were aware of the need to professionalise the alternatives they proposed, and to give them economic viability to increase the dissemination of their principles and practices in the economic arena, so 
they acquired entrepreneurial characteristics. Likewise, other experiences originated in individual initiatives or informal movements that developed business activities and opened small shops emphasising fair, organic and local trade.

In sum, the debate about the concept of social enterprise is still open in Spain. This concept has roots in the social-economy sector, but organisations with an Anglo-Saxon perspective also use this term with increasing frequency. On the basis of the above analysis and of other works (Chaves-Ávila and Monzón-Campos 2018) about the various sources of the concept of social enterprise in Spain, four major groups can be highlighted within the existing range of organisations and businesses linked to this concept:

- organisations coming from the social-economy tradition (socialintegration cooperatives, sheltered-employment centres);

- organisations linked to social innovation and encouraged by platforms such as Ashoka;

- transitional movements seeking new business models in different areas (e.g., the solidarity economy, the "Som" movements ${ }^{3}$ );

- for-profit enterprises seeking to improve their social impact (B Corps, common-good economy, enterprises implementing social-responsibility practices).

\subsection{Identification of SE Models}

\subsubsection{Methodology and Data Collection Strategy}

We used the EMES ideal type of social enterprise (Defourny and Nyssens 2012) to classify social enterprises in Spain. With a view to obtaining a fuller picture of the SE phenomenon in the country, we added one indicator to each of the dimensions highlighted by EMES: the self-financing degree to the economic dimension; the focus on a social-transformation mission to the social dimension; and membership in external networks to the governance dimension. We also decided to somehow enrich the evaluation of the "economic risk", an important indicator of social enterprises' economic dimension: when applicable, the economic risk was also apprehended through the initial investment made by founding members.

Since no SE models, apart from that of work-integration social enterprise, are clearly identified in Spain, and no database or contact directory is available, we used a sector-based approach to construct our typology. We identified eight main economic sectors and then differentiated between two groups of organisations within each sector. Our approach was based on a brainstorming exercise involving the authors of this chapter and a review of the publications in the field; the resulting 
overview of the different groups of actors in the SE field was then submitted for feedback to social-economy practitioners.

We then assessed (on a scale from 0 to 2) the degree to which each of the twelve selected indicators (nine EMES indicators and three additional indicators) could be considered to be present or absent in the organisations belonging to each group: " 0 " refers to the absence of the considered element in most organisations in the group; " 1 " indicates that the element is observed in some organisations but not in a majority, or in most organisations but to a limited extent; and " 2 ", that the element is present in most organisations in the group. Results are shown in table 12.1 (see section 12.2.3).

Finally, on the basis of these results, we identified five major categories of social enterprise in Spain.

\subsubsection{Results: Analysis by Fields of Activity and Groups ${ }^{4}$}

\section{Work and Social Integration}

\section{GROUP 1: WORK-INTEGRATION SOCIAL ENTERPRISES (WISES)}

The characteristics of WISEs and the requirements they have to meet are defined by Law 44/2007. These characteristics and requirements are aligned with the social economy' principles and values: the enterprise's goal is the social integration of people at risk of social exclusion; the distribution of profit is limited; the promoter(s) and owner(s) is (are) one or more non-profit organisation(s); workers must be qualified by the Public Employment Service as being "at risk of social exclusion and unemployed"; the enterprise must participate in the market through the sale of goods and services, and this has to be its main source of income; and the enterprise must serve as a bridge between a situation of social exclusion/unemployment and the labour market.

In sum, WISEs fit all the requirements to be considered as social enterprises, except those related to governance. As far as the economic dimension is concerned, WISEs are conventional firms with a special qualification. They produce goods and services, mainly related to public services, and assume an economic risk. Regarding the social dimension, WISEs' main goal is the work integration of their target workers. They strive to change their social environment, and not just the situation of this group. The enterprise's main owner has to be a non-for-profit organisation. Finally, as regards governance, although WISEs can use the legal form of worker cooperative, most of them are limited-liability companies (only $8 \%$ are cooperatives), in which workers have a low decision-making power. WISEs are grouped in regional and national federations. 
204 Díaz-Foncea, Villajos, Savall, Guzmán et al.

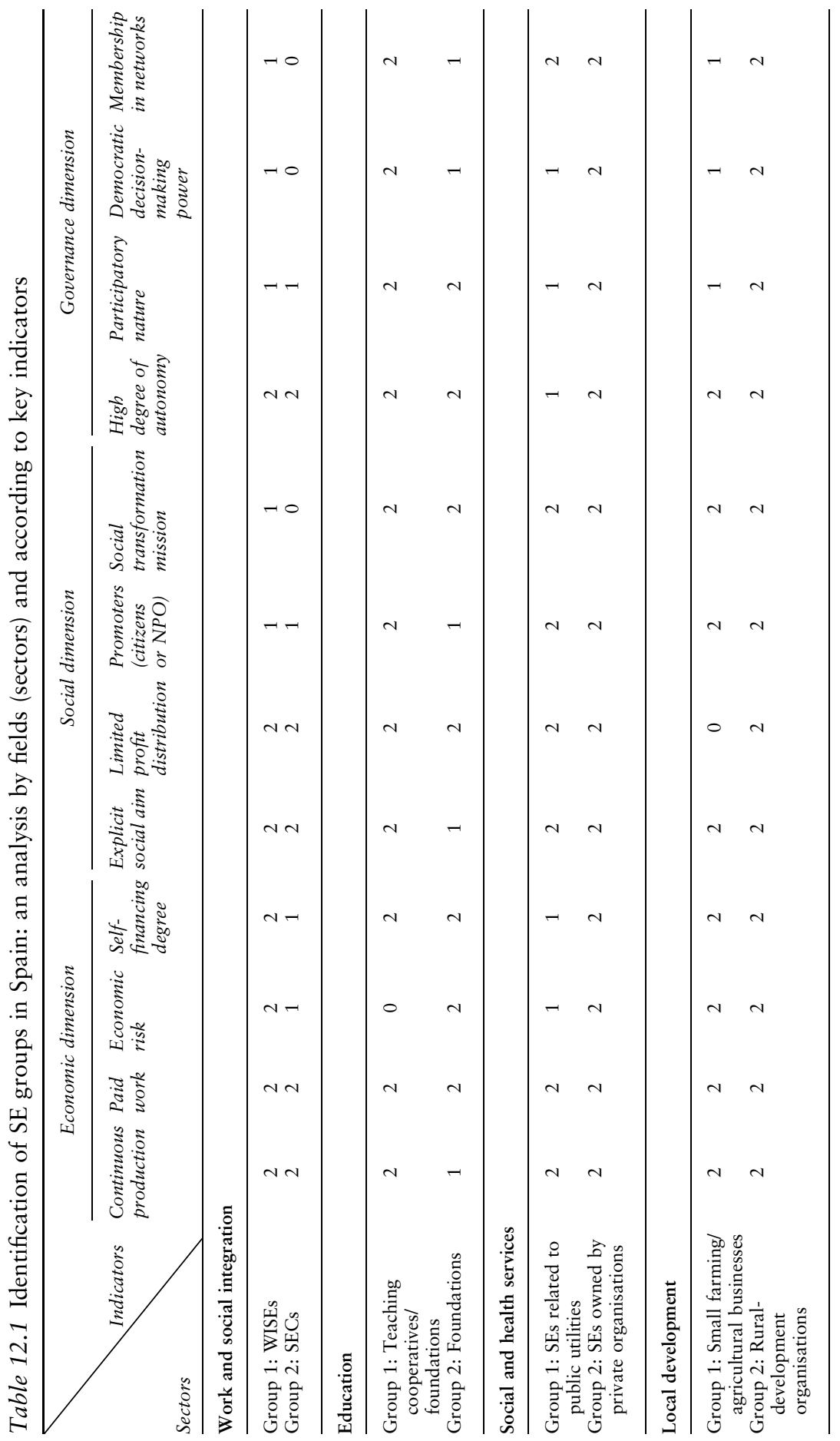


Spain 205

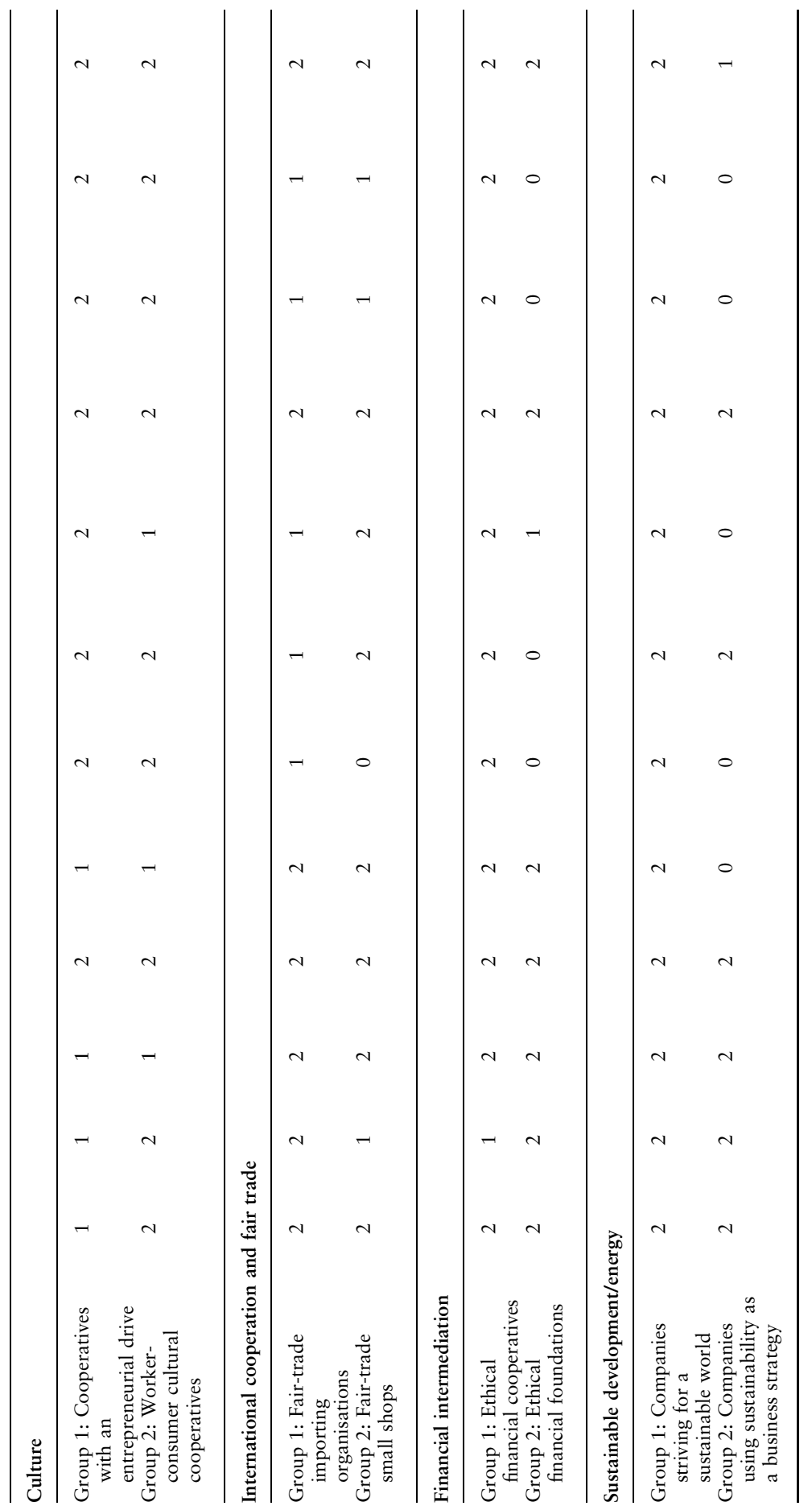


GROUP 2: SPECIAL-EMPLOYMENT CENTRES (SECS)

SECs constitute the legally recognised form of employment of disabled people. They are defined by Law LISMI 1982 as follows: at least 70\% of employees have to be legally recognised as being disabled (physical, mental or sensory disability); SECs can be promoted by the public or the private sector, and they can be for-profit or non-profit entities; they are market-oriented, although, due to their employees' low productivity, additional public and private funding is necessary to ensure the organisation's financial sustainability.

As regards the economic dimension, SECs have to obtain a significant share of their revenues from the sale of goods or services on the market. As far as the social dimension is concerned, SECs are primarily promoted by social movements, associations of parents of people with disabilities and people related to social services. Due to SECs' diversity in terms of economic goals, in some regions, the law differentiates between non-profit and for-profit SECs. Regarding the governance dimension, no requirements are imposed on SECs in terms of organisational or decision-making structure. The level of participation in the organisation thus depends on its organisational culture.

\section{Education}

GROUP 1: TRADITIONAL TEACHING COOPERATIVES AND FOUNDATIONS

Teaching cooperatives are schools managed by teachers or the students' parents, which appeared in Spain in the late 1960s, first in the Basque country and Catalonia. Currently, there are around 500 teaching cooperatives in Spain, representing between $10 \%$ and $12 \%$ of the privateschool network. These schools have a turnover of $€ 320$ million per year and $75 \%$ are secular.

Regarding indicators defining the ideal-typical social enterprise, we can point out that, in general, these enterprises meet the four indicators selected for each one of the three dimensions, except the indicator about the "economic risk" (economic dimension): these organisations' score for this indicator is very low because their main source of income is government support, granted through public agreements, for their education activities, and these organisations' members know well in advance if they are going to have the necessary number of pupils to obtain such support.

GROUP 2: FOUNDATIONS

Foundations in the field of education are non-profit organisations operating in the areas of training or research through the organisation of 
activities such as courses, free talks or conferences of general interest. They implement institutional mechanisms that promote exchanges and cooperation between all types of organisations and social-economy enterprises, as well as among industry players across the Spanish state and abroad.

Regarding indicators defining the ideal-typical social enterprise, we can point out that these entities fully meet seven of the twelve indicators selected for the three dimensions. They score medium for five indicators: they do not always rely on continuous production; they do not always meet a social need; some of them have been created by for-profit organisations; their decisions are significantly influenced by their main financer; and, finally, although they belong to networks related to education, their actual involvement in these networks is limited.

\section{Social and Health Services}

GROUP 1: SOCIAL ENTERPRISES RELATED TO PUBLIC UTILITIES

Social enterprises in this group arose when public-health institutions transferred to families most of the responsibility for the provision of care to patients with certain health problems-in particular mental health problems. ${ }^{5}$ Groups of promoters, usually consisting of relatives and health professionals working in fields linked to the illness, then founded associations to support these patients and their families.

Many of these social enterprises' activities focus on providing social services in cooperation with local, regional or national governments-an activity for which they receive payments. They also act as representatives of patients and relatives. The main sources of financing of these organisations consist of subsidies and public aid, but they also rely on aid from private entities, donations, membership fees and other resources of their own. Recently a need and a trend have been emerging among these organisations, which now look for clients outside the public administration to generate revenue for the company's productive activity. These social enterprises are usually non-profit organisations, legally registered either as associations or as foundations. With regard to staff, these organisations have both hired workers and volunteers, with the former outnumbering the latter.

\section{GROUP 2: SOCIAL ENTERPRISES OWNED BY PRIVATE ORGANISATIONS}

Social enterprises owned by private organisations are companies with a social objective, which aim to achieve a positive transformation of the society within which they develop their activities. They have a clear socio-economic model, linked to the company's mission, which prioritises the social objective over the financial one, but without forsaking 
the financial sustainability that is necessary for the survival of the organisation. Their income depends on their productive activity: customers pay for the services they receive. These social enterprises' financial resources do not come from subsidies or grants. As far as their legal form is concerned, they are registered as cooperatives or limited companies, and they are non-profit.

Whatever their legal form, they involve their stakeholders in their operational procedures, and their management system is based on respect for their employees, ethical behaviour and democratic, participatory and cooperative principles that promote community development. ${ }^{6}$

\section{Local/Rural Development}

GROUP 1: SMALL FARMING/AGRICULTURAL BUSINESSES

Small farming/agricultural businesses often use the legal forms of cooperative, private-liability company or self-employed worker. Their activities focus on ecological livestock production, eco-tourism and artisan work, and some of them are part of the recent movement for sustainable land stewardship and preservation of old customs and traditions.

These companies often combine a production activity with distribution. The main economic activity is the maintenance of traditional agriculture and traditional livestock farming, which respect the environment and avoid the costs, inconveniences and pressures usually imposed by large intermediaries. The key feature of these initiatives is their will to offer high-quality products and services at reasonable prices.

These firms ${ }^{7}$ insist on the idea of cooperation and mutual support among farmers, highlighting the fact that such synergies are crucial to face the hegemony of multinational food chains. Therefore, these organisations have initiated an association movement. They implement good working and social practices, based on respect of human and social rights. The farming model is also based on respect for all the actors involved in the process of production and distribution, who all receive fair and equitable treatment. The participative and sustainable business model adopted is integrated with the surrounding society, and it seeks to contribute to making an equitable and healthy world possible for all.

\section{GROUP 2: RURAL-DEVELOPMENT ORGANISATIONS}

Rural development is a process bringing about positive changes in rural areas, which can improve the lives of people taking part in the movement as well as the quality of life of society as a whole. Rural-development organisations help the communities achieve food self-sufficiency in a sustainable and environmental-friendly way, while preserving their cultural identity and the integrity of resources. The sustainable, integrated 
and human rural development promoted by these organisations involves the management of resources in an economically viable, environmentally healthy, socially just and culturally acceptable way.

These initiatives provide services to people on a continuous basis and their financial resources come from trading activities, public subsidies and voluntary resources. The level of economic risk they support is very high as their financial viability depends entirely on the efforts of their members to secure adequate resources to support the organisation's social mission. They combine monetary and non-monetary resources, and voluntary and paid workers.

These initiatives, which are launched by a group of citizens or civilsociety organisations, pursue a goal of social transformation. They have an explicit social aim, namely to improve the lives of people involved in the movement, as well as the quality of life in society as a whole. Because of the social principles upon which they are built and of the social objective they pursue, their distribution of benefits is limited by internal rules. These social principles are also reflected in their governance model: they have a high degree of autonomy, their decision-making process is democratic, their nature is highly participatory, and they involve the rural communities in their activities. ${ }^{8}$

\section{Culture}

GROUP 1: COOPERATIVES WITH AN ENTREPRENEURIAL DRIVE

Cooperatives with an entrepreneurial drive in the field of culture are a kind of cooperative that is officially recognised by the laws of two Spanish regions only, namely Andalusia and Cantabria. These enterprises are similar to the "umbrella companies" which are well known in other countries, like the UK. These companies are intermediate platforms which act as an employer, entering a business-to-business contract with an employment agency.

These cooperatives are formed by experienced professionals with knowledge in social enterprises and unemployed workers looking for a job. Both groups become worker members of the cooperative, which offers them technical and managerial support. Furthermore, these entities "channel" the members' entrepreneurial initiatives with the aim of conducting activities in the market.

These entities meet eight of the twelve indicators selected. They completely meet the four indicators of the governance dimension and, regarding the social dimension, the only indicator in which they show a medium level is that about the explicit social aim. However, the most important weak points are in the economic dimension: except for the indicator on financing, for which they score high, they show a medium level of compliance with all the indicators of the economic dimension. Indeed, these enterprises, since they mostly provide technical and managerial 
support, can be considered as having only a medium level of continuous production, and the salaries are mostly symbolic or are covered by other organisations involved in the initiative. Moreover, members can usually not afford a very high initial investment (medium level of economic risk).

GROUP 2: WORKER-CONSUMER CULTURAL COOPERATIVES

Worker-consumer cultural cooperatives are very recent and innovative initiatives in the cultural field. Unlike initiatives in the previous group, in which all members are also necessarily workers, worker-consumer cultural cooperatives offer their customers the possibility to become members and to receive certain advantages (to which non-member consumers are not entitled). This is the reason why they are considered as mixed cooperatives: they are both worker and consumer cooperatives.

These entities score high for nine of the twelve indicators selected. They fully meet the four indicators of the governance dimension. They also achieve a high performance in the economic dimension, in which the only indicator for which they show a medium level of compliance is that related to the "economic risk"; in this respect, they implement mechanisms, such as the inclusion of their customers as collaborators/ members, in order to "spread" the level of risk among the stakeholders. Finally, regarding the social dimension, these entities have a limited profit distribution, and they are launched by a group of citizens; they thus score high for these two indicators. But their offer of culture-related services can be considered as an only "moderately" explicit social aim, and they can also be considered as only partially pursuing social transformation, since their main aim is to promote culture and create jobs.

\section{International cooperation/fair trade}

\section{GROUP 1: FAIR-TRADE IMPORTING ORGANISATIONS}

Fair-trade importing organisations ${ }^{9}$ import all kinds of fair-trade products from Southern countries. They contact producers directly and manage the import logistics; sometimes, they transform the raw materials (e.g., coffee) into the final product; they help local farmers in the south by providing them with training and financial support; they carry out education and advocacy campaigns; and they work with corporate (physical or on-line) shops to sell the products.

As far as the economic dimension is concerned, these organisations have a continuous production; they operate in the market and assume an economic risk. Their main source of income is the sale of products. Regarding the social dimension, these initiatives have a clear social aim, namely to ensure fair wages for the producers, but the extent to which they meet the indicators relating to the limitation imposed on profit 
distribution and to the "citizen-initiated nature" varies from one organisation to the other. Finally, as regards the governance dimension, these organisations have a high degree of autonomy, and although they usually evolve towards the implementation of participatory mechanisms to give voice to both workers in the North and producers in the South, not all organisations have a democratic way of making decisions.

\section{GROUP 2: FAIR-TRADE SMALL SHOPS}

These are the most typical organisations related with the distribution of fair-trade products. They are usually small, but their managers and promoters have a strong commitment to fair-trade activities.

As far as the economic dimension is concerned, these organisations' main source of income is the sale of fair-trade products (94\% approximately); they also usually receive subsidies or donations. They bear significant economic risk and they rely on volunteers, although some of them also have paid workers, mainly for administrative tasks. Regarding their social dimension, they have a clear commitment to improving the living conditions of producers from the South. They are launched by a group of citizens or a civil-society organisation. However, in most organisations, there is no rule to avoid or limit profit distribution. As regards the governance dimension, these small businesses are highly autonomous and are part of networks, but their decision-making processes have only a medium level of participatory nature and democratic decision-making.

\section{Financial Intermediation}

\section{GROUP 1: ETHICAL FINANCIAL COOPERATIVES}

Ethical financial cooperatives are initiated by groups of citizens who want their savings to finance projects that are socially responsible and sustainable. These citizens thus come together and set up their own entity, guaranteeing the responsible destination of the money in the financial intermediation services.

Regarding the economic dimension, these entities have a continuous economic activity in the market; the people involved in these organisations are usually volunteers or workers with only a symbolic salary; the members cannot afford any initial investment, so they try to invest only in selfsustainable projects; and these companies are self-financed through their financial products. Regarding the social-dimension indicators, entities in this group pursue an explicit social aim of creating a financial system based on the values shared by their initiators and members; they do not distribute profits, as all profits are reinvested in the organisation's objective; and their social-transformation objective can be considered as strong, since they want to change the economic system through the financial system. 


\section{Díaz-Foncea, Villajos, Savall, Guzmán et al.}

Finally, regarding governance factors, these initiatives are completely independent from any other entity; they have a highly participatory nature; their decision-making process is democratic and not based on capital ownership; and their participation in networks is high.

\section{GROUP 2: ETHICAL FINANCIAL FOUNDATIONS}

This group includes financial-intermediation firms that only support sustainable and socially responsible projects but do not pursue a socialtransformation goal. These entities are thus similar to conventional banks in terms of organisation and management.

Regarding the economic dimension, these initiatives develop an economic activity and have a continuous production; their employees receive a salary for their work; they invest in sustainable projects, but the level of economic risk they bear remains high; and they are self-financed through their financial products. Regarding the social dimension, these initiatives have an explicit social aim-namely financing sustainable projects; they distribute profits as any other commercial bank; and they are only rarely really launched by a group of citizens. In terms of governance indicators, enterprises in this group have a high degree of autonomy; their participatory nature is low; their decision-making process is not democratic; and their participation in networks is high.

\section{Sustainable Development/Energy}

\section{GROUP 1: COMPANIES STRIVING FOR A SUSTAINABLE WORLD}

This group consists of companies that strive for a sustainable world; they have been emerging mainly since $2010 .^{10}$ Two major kinds of initiative can be distinguished in this group. The first one corresponds to energy companies aiming to spread and promote the use of renewable energy and to develop a participatory energy model in setting prices-namely consumer cooperatives or "energy cooperatives" (Zaad 2012). The second one consists of companies engaged in organic farming and environmental protection, whose purpose is to convert conventional farms to the practice of sustainable agriculture (e.g., integrated organic production, fight against erosion).

These initiatives produce and distribute green energy or organic food on a continuous basis; they do rely on paid work; the economic risk is supported by the members; and they are self-financing. Entities in this group have an explicit objective of social transformation; they have a limited profit distribution (they reinvest their profit in sustainable projects); and they are initiatives launched by a group of citizens. Finally, they have a high degree of autonomy and a highly participatory nature; their decision-making process is democratic and not based on capital ownership; and their participation in networks is high. 
This group consists of companies that use sustainability (e.g., green energy or organic-food distribution) as a business strategy to attract customers, without having the specific purpose of striving for a sustainable society. These companies describe themselves as "social firms", but the analysis of their functions, structure and activity shows that their business model is close to the capitalist model.

These companies have a continuous production and paid workers and they are self-financed. The founding partners make an initial investment in the start-up stage of the firm and bear a high economic risk. In general, entities in this group are initiatives launched by a group of citizens, but they do not have an explicit social aim and they do not impose limitations on profit distribution. Finally, these organisations have a high degree of autonomy, but their participatory nature is very low; their decision-making process is based on capital ownership; and membership in networks can be considered to be of a medium level, as they sometimes belong to associations and networks related to the social economy and social entrepreneurship in order to take advantage of their support.

\subsubsection{Identification of SE Models}

Table 12.1 summarises the characteristics of the various groups of social enterprise identified in Spain in terms of correspondence with the indicators defining the ideal-typical social enterprise (i.e., the nine EMES indicators and the three indicators that have been added to analyse the phenomenon of social enterprise in Spain). However, the number of items presented in the table made it difficult to discern models, and in order to generate a more usable set of data, we grouped the four indicators in each of the three major dimensions (economic, social and governance dimensions), and thus obtained a score comprised between 0 and 8 points for each dimension. ${ }^{11}$ We are aware that such grouping entails a "simplification" that could hide nuances among groups; however, we accept this problem with a view to operationalising our data and to offering a first proposal of SE typology.

In the analysis of data, we considered that, for each of the three dimensions, 7-8 points corresponded to a high level; 5-6 points, to a medium level; and less than 5 points, to a low level. Of course, we acknowledge the fact such classification is closer to the idea of a continuum than to a typology stressing structural differences among SE models. However, instead of basing our analysis on a single key criterion (like the degree of market reliance, for instance), we combined a set of significant indicators and gave a similar importance to all three SE key dimensions. Such an integrated "multi-criteria" basis allowed us to identify five SE categories (see table 12.2) according to their overall "compliance" with the enlarged EMES framework. 
214 Díaz-Foncea, Villajos, Savall, Guzmán et al.

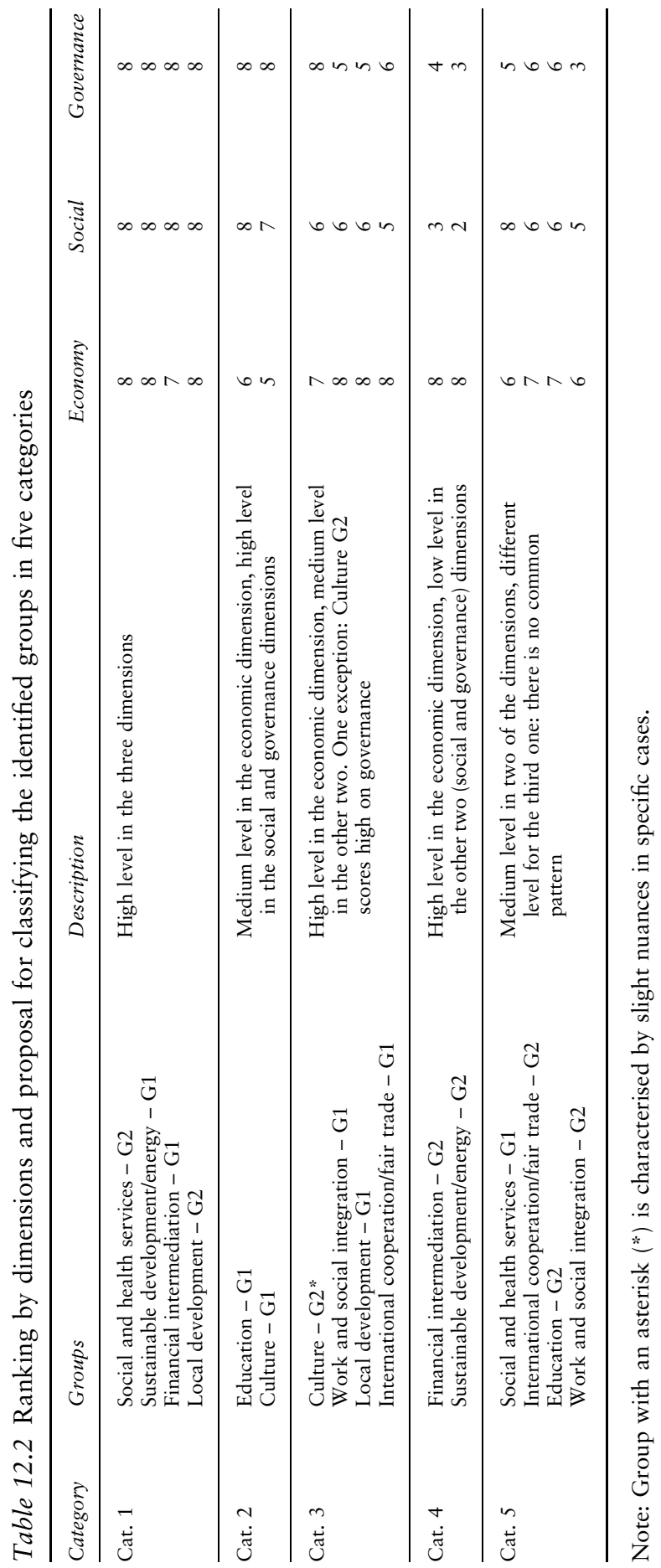




\section{Conclusion}

In the present work, we attempted to identify models of social enterprise in Spain. We first reviewed the origins of social enterprises and the existing approaches from a theoretical point of view. We identified four "matrices" of social enterprise in Spain: (1) organisations whose origins are to be found in the social-economy tradition; (2) organisations linked to social innovation and encouraged by platforms such as Ashoka; (3) transitional movements seeking new business models in different areas; (4) for-profit enterprises seeking to improve their social impact.

In a second stage, we carried out empirical observations in the field. On this basis, we identified five different categories of social enterprise in Spain, in terms of correspondence with the various indicators retained to characterise social enterprises (nine EMES indicators and three additional ones).

To conclude, it appears that, although the rise of the concept of social enterprise in Spain is strongly related with the establishment of organisations inspired by the Anglo-Saxon tradition and with the discussions about the concept in the EU, the characteristics of the organisations must be mainly related to the way of working of social-economy organisations. Indeed, Spain is one of the European countries where the social economy has been most widely acknowledged and promoted, and long before the emergence of the SE notion. Further research should look more precisely at the types of relations that will be developed between the "SE stream" and the whole social economy. Their respective roles in the design and implementation of public policies would also deserve researchers' attention.

\section{Notes}

1 Law 44/2007, on work-integration enterprises (Ley 44/2007, de 13 de diciembre, para la Regulación del Régimen de las Empresas de Inserción).

2 Law 27/1999, on cooperatives (Ley 27/1999, de 16 de julio, de cooperativas).

3 The term "Som" could be translated as "we are" and comes from the name of the first renewable energy cooperative in Spain, "Som Energia", created in 2010. Since then, a new generation of consumer cooperatives have emerged using the term "Som" as a reference to citizen engagement in consumption: Som Conexion (telecommunications), Som Mobilitat (transport), Som Alimentació (supermarkets), etc. The concept refers to companies born from the mobilisation of civil society in search of economic alternatives and social transformation.

4 The length of this chapter being limited, the description of the different groups presented here is quite succinct; a more extensive analysis of each sector and group can be found in Díaz-Foncea et al. (2017).

5 Representative examples of this group are AFES (https://saludmentalafes.org/) and FUNCASOR (http://funcasor.org/).

6 Representative examples of this group are Fundación Espriu (Grupo ASISALavinia and Group Assistència-SCIAS) (http://www.fundacionespriu.coop/) and COS, Cooperativa de salut (http://www.cos.coop/es/). 


\section{Díaz-Foncea, Villajos, Savall, Guzmán et al.}

7 Representative examples of this group are L'Olivera (http://www.olivera.org/ php/index.php) and Huertos de Soria (https://www.huertosdesoria.org/).

8 Representative examples of this group are CIFAES-URPF en Tierrra de Campos (https://coop57.coop/es/entidad/cifaes-universidad-rural-paulofreire-en-tierra-de-campos) and Heliconia (https://www.heliconia.es/).

9 Eleven importing organisations exist in Spain: Adsis Equimercado, Alternativa 3, Espanica, Fundación COPADE, Fundación Vicente Ferrer, IDEAS, Intermón Oxfam, Mercadeco, SETEM, Taller de Solidaridad and Xarxa de Consum Solidari.

10 Examples of companies striving for a sustainable world include Som Energia, S. Coop. and other similar renewable-energy cooperatives.

11 As explained in section 12.2.1, we assessed the degree to which each of the twelve selected indicators could be considered to be present or absent in the organisations belonging to each group on a scale from 0 to 2 .

\section{References}

Álvarez, M. I. (1999) "Las Empresas de inserción social como nueva forma de organización empresarial. Especial referencia a su régimen jurídico", CIRIEC-España, Revista de economía pública, social y cooperativa, No. 31, pp. 47-84.

Chaves-Ávila, R. \& Monzón-Campos, J. L. (2018) "La economía social ante los paradigmas económicos emergentes: innovación social, economía colaborativa, economía circular, responsabilidad social empresarial, economía del bien común, empresa social y economía solidaria”, CIRIEC-España, Revista de economía pública, social y cooperativa, No. 93, pp. 1-34.

Defourny, J. \& Nyssens, M. (2012) "El enfoque EMES de la empresa social desde una perspectiva comparada", CIRIEC-España, Revista de economía pública, social y cooperativa, No. 75, pp. 7-34.

Díaz-Foncea, M., Marcuello, C., Marcuello, C., Solorzano, M., Navío, J., Guzmán, C., de la O Barroso, M., Rodríguez, M. J., Santos, F. J., Fisac, R., Alguacil, P., Chaves, R., Savall, T. \& Villajos, E. (2017) "Social Enterprise in Spain: A Diversity of Roots and a Proposal of Models", ICSEM Working Papers No. 29, Liege: The International Comparative Social Enterprise Models (ICSEM) Project.

European Commission (2020) Social Enterprises and Their Ecosystems in Europe. Updated Country Report: Spain (authors: Díaz, M., Marcuello, C. \& Nogales, R.), Luxembourg: Publications Office of the European Union. Available HTTP: https://europa.eu/!Qq64ny.

García, A. \& Esteve, M. (2007) "Las Empresas de Inserción en España: normativa y características", CIRIEC-España, Revista de economía pública, social y cooperativa, No. 59, pp. 153-178.

Monzón-Campos, J. L. \& Chaves-Ávila, R. (2017) Recent Evolutions of the Social Economy in the European Union, Brussels: European Economic and Social Committee.

Puig Olle, A. (1998) "Las empresas de inserción. El papel de las fundaciones y las asociaciones en la creación de las empresas”, REVESCO: Revista de Estudios Cooperativos, No. 65, pp. 69-71. 
Rojo Giménez, C. (2000) "Empresas de inserción en Castilla y León”, CIRIECEspaña, Revista de economía pública, social y cooperativa, No. 36, pp. 97-115.

Vidal, I. (1997) “Associacions i inserció social pel treball a l'Estat espanyol”, Nexe, Quadern d'autogestió i economia cooperativa, Vol. 0, pp. 89-99.

Zaad, M.-H. (2012) "Cooperativas de producción, distribución y consumo de electricidad en España en el primer tercio del siglo XX. Un análisis económico", Simposio Internacional Globalización, innovación y construcción de redes técnicas urbanas en América y Europa, 1980-1930, Universidad de Barcelona, January 23-26, 2012. 


\title{
13 Social Enterprises in Sweden Intertextual Consensus and Hidden Paradoxes
}

\author{
Malin Gawell
}

\section{Introduction}

The concept of social enterprise, as well as that of social entrepreneurship, were introduced in Sweden in the 1990s and have since then become increasingly common in practice, policy and academy. They are often used together with-and sometimes as synonymous with-societal entrepreneurship. The debates in which these concepts are used are also often related to discussions on the role of the public sector, civil society and (ordinary) enterprises in the organisation of the commons as well as to the issue of meeting and coping with current and future challenges. This means that these concepts relate, on the one hand, to a debate about society at large, and on the other hand, to discussions within a specific emerging field.

But the "phenomenon"-or "phenomena"—of social enterprise (SE) as such has/have a much longer history in the country. Without going back to the "dawn of time", the current practice of and debate on social enterprises are based on and palpably influenced by the extensive and strong welfare state that emerged in the region during the early 20th century and has since then characterised the Swedish (and Nordic) society (see Andersen et al. 2016).

Methodologically, this chapter is based on many years of research on social enterprise, social entrepreneurship and civil society, as well as work on "mainstream" entrepreneurship, where business logic dominates the field. In total, these studies have covered over 150 cases/initiatives and analyses of policy development related to these phenomena. A more developed methodological account of the approach used here is found in Gawell (2014a, 2014b).

\subsection{Concepts in (Swedish) Context}

This section starts with a description of Swedish historical trajectory; it is followed by an account of the current context and debate related to social enterprise. This account also includes other concepts than social 
enterprise, which, in different ways, portray both the historical trajectory and the current context.

\subsubsection{Historical Trajectory}

During the 19th century, poor people's protests were partly hearkened by an emerging middle class that was influenced by an international humanistic movement. There were several initiatives to reach out to poor people and others in need during this time. Some of those initiatives became the basis for today's large organisations. In Sweden, the labour movement, the temperance movement and the religious revivalist movement played an important role in the transformation towards a democratic welfare society during the latter part of the 19th century and early part of the 20th century. In this transformation, which was highly influenced by the social democratic movement, the state was ascribed an active role in creating a welfare society as a good home for all citizens based on consensus and equality. This concept was referred to as "people's home" (folkhemmet) and was an important vision in Swedish politics from the 1930s until at least into the 1970s (Larsson 2008). The "spirit" of folkhemmet influenced policies in areas such as housing, education, health care, child care, elderly care and taxation (Larsson 2008).

In the "Swedish model", which dominated Swedish society during a large part of the 20th century, hospitals, schools, child care, etc. were only to a limited extent operated by third-sector organisations (Pestoff 1998; Stryjan 2001). Different types of non-profit organisations did exist, however. The most typical type of organisation was what has been named "popular mass-movement organisations" (folkrörelser). These organisations were, and still are, membership-based non-profit associations with a broad and open membership base and democratic governance structures. Leisure associations and alternative educational organisations with roots in adult education and other sectors made up (both in terms of number of associations and in terms of financial turnover) for the relatively small size of the third sector in the fields of health and social services, thus providing Sweden with a non-profit sector comparable in size to that of many other Western countries-but with special characteristics (Lundström and Wijkström 1997). These organisations were supported by the state, based on arguments that they fostered democracy and mobilised social values such as solidarity, humanity and public health (SOU 2007: 66). The cooperative movement was also integrated in the development of folkhemmet, and the cooperative principles are to a large extent consistent with the principles of folkrörelser, even though there are some differences, relating primarily to members' economic interest (Pestoff 1998; Stryjan 2001). It can be argued that cooperatives were a kind of "folkrörelse-businesses" in which people mobilised collective economic interests. 


\section{Gawell}

The relationship between the (local, regional and national) governments and civil society was, however, paradoxical. On the one hand, this relationship was centralised and corporatist, but on the other hand, Sweden was a democratic society in which citizens had access to politicians through both formal channels and informal networks (Trägårdh 2007). The paradox was partly resolved by governance through formal control. But every so often, a strong emphasis on finding collaborative solutions facilitated a "consensus spirit" with corporatist tendencies.

In the 1980s, and even more explicitly during the 1990s, shifts in debate and policy could be noticed. Deregulations were carried out in the financial sector, rail transport and electricity distribution. In 1992, a school reform facilitated the access of private schools to public funding. The same year, a more general law on public procurement was passed as a part of the adjustments implemented to prepare membership in the European Union (Sweden joined the EU in 1995). Since then health care, elderly care and other related types of welfare services have, to a large extent, become subject to competition through procurements or different client-choice models. As a result, the number of private for-profit and non-profit service providers has increased. These changes were made both under social-democratic-led governments (1982-1991 and 1994-2006) and liberal/conservative-led governments (1991-1994 and 2006-2014).

During these decades, economic, industrial and enterprise policies dominated the political debate (Gawell 2014a). The focus on economic growth almost displaced the third sector from public policies. Competitiveness and commercialisation were highlighted. The third sector, and discussions related to it, still existed, however-even though they were slightly "put aside" until rather recently, when there was a renewed interest in civil society. This time, the interest was, first and foremost, for civil society as a "glue"—holding society together; a creator of social capital, facilitating financial growth, and important for the advancement of innovations (Swedish Government Statement 2008, 2012a).

Parallel to the economic-growth-oriented policies, there was also a shift in terminology of the third sector. The folkrörelse concept was to a large extent replaced by the term ideell organisation (non-profit organisation), which is more "neutral" in terms of specific characteristics or structures and allowed international comparisons, for example, within the John Hopkins project on non-profit organisations (Lundström and Wijkström 1997).

With EU membership (1995), the term social economy was also introduced in Sweden (Swedish Ministry of Interior 1998; Swedish Ministry of Culture 1999). In Sweden, the discourse on the social economy was largely influenced by cooperative principles and the traditional folkrörelse model, which share many similarities. By contrast, some other types of non-profit organisations, such as charities, had little 
influence; the term charity was even taboo in Sweden for decades, since it was associated with inequality and unfair dependency.

The term "civil society" (civilsambälle) has become increasingly common since the turn of the millennium in general discussions, politics and research (Amnå 2005). The government used the concept of civil society when it launched a policy bill in this field in 2009 (Prop 2009/ 10:55). Even though this bill refers to the more traditional concepts, as well as to social enterprise and social and societal entrepreneurship, it also introduced a policy approach to the organisations that differs from the former focus on folkhem/folkrörelse relationship in that it makes a more abstract reference to a sphere of initiatives, without defining specific characteristics (Gawell 2014a).

This briefly sketched historical trajectory of the Swedish setting constitutes the background against which the current debate on social enterprise takes place. There is, on the one hand, an approach explicitly highlighting the aspiration for equality, (democratic) participation and bottom-up processes in which people (i.e., beneficiaries) have a right to represent themselves. This approach has a strong position both among representatives of traditional organisations and in public policies related to so-called disability or user organisations. On the other hand, there is an approach in which the identification of the needs to be met relies on civil servants and/or individuals who do not necessarily belong to the group of beneficiaries nor formally involve these beneficiaries in decision-making processes. The way in which the interventions are initiated and governed is in this case more "top-down", or "from-theside", and beneficiaries' possibilities to influence these interventions are arbitrary (Gawell 2011, 2013).

Grounded in the historical trajectory described above, competitive bidding within spheres of public and social services has facilitated the promotion of ventures led by private for-profit and non-profit actors. Policy-makers have explicitly argued that competitive bidding and different client-choice models should be neutral and not favour specific types of actors (Gawell 2014a). This means that private actors have entered the welfare scene without having to abide by the traditional principles of the Swedish public sector, such as shared responsibility, citizens' influence, equality and democracy (Ringqvist 1996), and with the language and practices of businesses (Lundström and Sundin 2008).

\subsubsection{Current Context and State of the Art of Social Enterprise in Sweden}

The concept of social enterprise started to be used in Sweden in the mid1990s. It was then first and foremost used by groups within the cooperative movement, which started to call social cooperatives social enterprises. References were often made to the Italian model(s) (Nutek 2007). 


\section{Gawell}

This model of social enterprise has since then developed, partly through support from the European Social Fund (ESF).

One specific project, funded by ESF's Equal programme 2004-2007 and carried out by a so-called "thematic group on social enterprises", focused on the national development of social enterprise in Sweden. Within this project, the criteria for the initiatives that later came to be referred to as "work-integration social enterprises" (WISEs) were defined. These criteria are to a large extent in line with the EMES Network's ${ }^{1}$ indicators for social enterprise. Later on, the thematic group's criteria were adopted by the Swedish Agency for Economic and Regional Growth, as well as by the Ministry of Enterprise (Nutek 2007); they define WISEs as "enterprises conducting business activities [that] have an overarching aim to integrate, into working life and society, people who experience great difficulties getting or keeping a job”. Furthermore, these enterprises are to create participation through ownership or documented participatory working methodology. They are also to reinvest profits in their own or similar activities, and to be organisationally independent from the public sector. ${ }^{2}$ Based on these criteria, the Swedish Agency for Economic and Regional Growth has developed a list of social enterprises, which includes approximately 300 social enterprises. ${ }^{3}$

But WISEs are not the only type of social enterprise in Sweden. There are discussions (partly parallel) about the concept of social enterprise as well as other closely related concepts such as social entrepreneurship and social innovation among field practitioners, policy-makers and researchers. Apart from the above-mentioned model, at least three other social enterprise models—or rather, sets of models—have been identified (Gawell 2014b). These models will be elaborated on in the next section.

\subsection{Identification of SE models}

Even though there are no specific legal structures for social enterprises in Sweden, such initiatives do exist, to the extent that some ventures combine a social mission with running some kind of business activity. As mentioned before, four major models ${ }^{4}$ of social enterprise have been identified in Sweden (Gawell 2014b). The model with the strongest policy framework is that of work-integration social enterprise (WISE). The second model is referred to here as the non-profit social enterprise model; it is closely connected to discussions in and about the non-profit sector. The third model, namely that of social-purpose business, is influenced by the so-called business-school approach to social entrepreneurship. Furthermore, there is a fourth model that is highlighted in this chapter; it relates to discussions on societal entrepreneurship, which is sometimes used as synonymous with social entrepreneurship, but with a slightly different application (see below). 


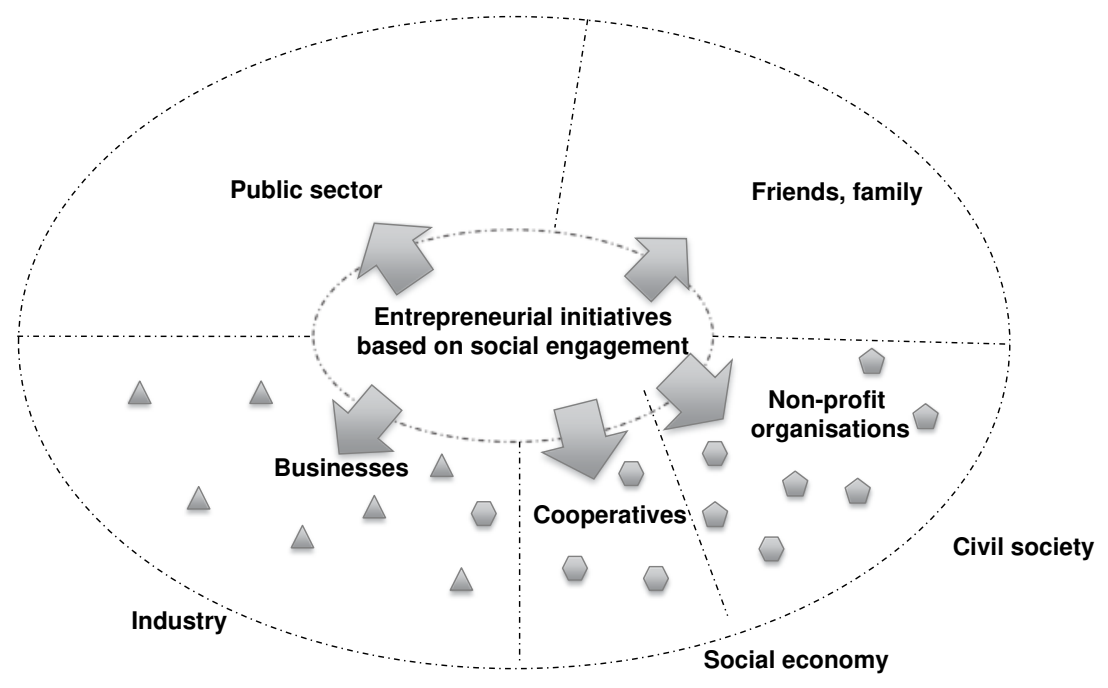

Source: based on Gawell (2014b).

Figure 13.1 Different models of social entrepreneurship and social enterprise. Source: Based on Gawell (2014b).

Figure 13.1 illustrates the different models of social enterprise that emerge through entrepreneurial processes with different types of characteristics. The choices from which these models result, are sometimes well-thought-out, but in other cases, they rather seem to be based on former experiences, skills or what comes in handy (for further discussions, see Gawell 2014b). The illustration draws on practice, but has been further developed, based on analysis of a large number of social enterprises. The first three models referred to above can be found in the lower part of the figure: symbols in the different areas represent different models of social enterprise, which are further described in the sections below.

\subsubsection{Work-Integration Social Enterprises (WISEs)}

In the WISE model, Nordic traditional well-known aspects (such as a participatory approach) are combined with (southern) European traditions to organise social services. In the beginning (in this case, the mid-1990s), general social aims, such as empowerment for personal well-being, were highlighted in discussions on WISEs, and work was presented as a tool to reach those social aims. Many of these social enterprises stated that they wanted to work with "the ones that needed it most" (Gawell 2011, 2013). Gradually, a strong focus on long-time unemployed people emerged, partly due to a policy interest to use this SE model as labour-market tools for 


\section{Gawell}

on-the-job training and as a way to offer adjusted work opportunities to people with employment problems. Many of these social enterprises still express a broader social aim when interviewed, but they rather stress the "work line" when they position themselves towards public actors (Gawell 2013).

As far as their income mix is concerned, most WISEs combine revenue from the sale of work-rehabilitation services to local or national authorities, public subsidies compensating for individuals' reduced working capacity (connected to individuals and channelled through employers, be they non-profit or for-profit organisations and private or public employers), and income from the sale of products or services such as carpentry, art work, cafés or hotel accommodation. There are no specific subsidies for work-integration social enterprises. This means that any type of organisation or enterprise can sell the same services as those offered by WISEs and benefit from public subsidies, compensating for individuals' reduced working capacity. In practice, however, few for-profit enterprises employ people with great needs for adjustment or support.

Among the long-time unemployed, there are many people with disabilities, mental illness, drug problems, etc. Some WISEs target specific groups such as these, but many of them do not. Generally, WISEs do not want to focus on their beneficiaries' problems, and instead stress the importance of building on everyone's abilities and the right to work at " $100 \%$ of one's capacity"-even though this is only, in some cases, for a few hours a week. ${ }^{5}$

In line with the ideal-typical indicators of social enterprise such as they have been identified by the EMES network (Defourny and Nyssens 2012), these social enterprises support individuals' possibilities on the labour market in general but also the possibility for their beneficiaries to become co-owners in the enterprise. There is, however, a great variation in how this is being implemented. In some enterprises, most participants only take part in limited training programmes, while other enterprises have systematic on-the-job training and schemes for co-ownership.

The government has commissioned public agencies for enterprises, labour-market policies and social insurance to collaborate to improve the conditions under which work-integration social enterprises operate. In 2013, there were almost 300 WISEs identified by the Swedish Agency for Economic and Regional Growth. Almost 9,000 people participated in their activities (e.g., training programmes), and 2,500 of these were employed. ${ }^{6}$

\subsubsection{Non-Profit Social Enterprises}

The interest in non-profit social enterprises has also increased recently; this trend is particularly linked to the increased interest in private socialservice providers in welfare-policy areas. Non-profit organisations have 
to compete with each other as well as with private for-profit enterprises as public authorities manage competitive bidding or different kinds of client-choice models in health care, child/elderly care, education and psychiatry. These services are still basically publicly funded, but nonprofit organisations operating in these fields have to adjust to market-like conditions, and can thus be referred to as non-profit social enterprises. There are also several non-profit organisations promoting themselves as (social) enterprises based on non-profit principles (Gawell 2014b); they are also referred to here as non-profit social enterprises, even though not all of them use this specific term. Among these ventures, there is a great variety of organisational/business models (Wijkström and Lundström 2002; SCB 2014). Without going into details, some highlights will be addressed here.

The first model of non-profit social enterprise of interest to current studies of social enterprise is the so-called "user-based organisation" (brukarorganisation), in which, for example, people with disabilities organise both service provision and interest-based advocacy. Typical of these organisations is the fact that, as already discussed in the first part of this chapter, the targeted people (e.g., people who are affected by disabilities, or former drug abusers) represent themselves and have the power to influence decision making. In this sense, these organisations are the opposite of charitable organisations, in which resourceful people articulate other peoples' needs and control how those needs are addressed. These user-based organisations are primarily structured according to the traditional popular mass movements' principles, with membership and democratic decision-making structures.

Social-service-delivery organisations constitute a second model of nonprofit social enterprise. An example is provided by faith-based organisations, which have, for a long time, provided social services at the periphery of the strong public sector. They are now operating on a competitive market for public contracts in health, social care, education, etc. They compete with other non-profit organisations, other models of social enterprise and for-profit enterprises. Activities funded through public contracts are also, of course, regulated by public authorities. Some of these non-profit social enterprises have governance structures based on democratic principles; others do not. Many non-profit organisations, at least among the largest ones, are registered with the Tax Authority since they have business activities to fund their social activities.

\subsubsection{Social-Purpose Businesses}

There is currently a "trend" among (ordinary) enterprises to relate to the SE discourse in their presentations. Some present themselves as entrepreneurs committed to and engaged in social services, for example, in elderly care or education, and therefore state that they run social enterprises. 


\section{Gawell}

Others argue that their economic priorities (including making a profit and distributing it to owners) are just a practical means to reach social aims. Some even argue that profit-making and profit-distribution to owners/investors represent an important drive that benefits social aims. These different models of social enterprise cannot be distinguished from each other in statistics, and cases thus have to be identified through qualitative means.

There is an unknown number of smaller and especially new enterprises using the SE terminology. Some present themselves as social entrepreneurs or social enterprises with a double or a triple bottom line-that is, combining economic, ecologic and/or social aims in their business model. They often present a variety of arguments to support these statements. These arguments are sometimes related to the social outcome of their commercial business, or to the entrepreneurs' intentions. Others relate to alternative business models, which differ from those commonly used in commercial enterprises. Sources allowing to determine exact numbers are not available, but the emergence of people (and especially young people) adopting the Anglo-American business-based approach to social entrepreneurship and social enterprise is undeniable.

As yet, there are no public policies for these models of social enterprise. They operate under the same legal forms and are submitted to the same taxes as other businesses.

\subsubsection{Societal Entrepreneurship}

In the discussions related to social enterprise, another concept is also discussed in Sweden-that of societal entrepreneurship (sambällsentreprenörskap). The term was first used in the mid-1980s, when Johannisson (1985) and Alänge (1987) used it with reference to entrepreneurial initiatives focusing on local community development. The authors of these articles then translated sambällsentreprenörskap to community entrepreneurship in English. The term was not commonly used until the early 2000s; from then on, it started to be used with the basic definition of "innovative initiatives with public benefits" (Holmberg et al. 2007; Gawell et al. 2009).

Societal entrepreneurship has primarily been used as an umbrella concept including what would be referred to, at the international level, as social entrepreneurship, community entrepreneurship, cross-sectoral initiatives or social enterprises, but also for-profit businesses engaging in public activities, such as cultural entrepreneurs (Gawell et al. 2009). Societal entrepreneurship, and specific ventures belonging to this sphere, are often presented as responsible actors, with high-profile aims to contribute to the societal/community development and not only to their own performances. Even though individual entrepreneurs are also elaborated on, this "sub-field" is dominated by collective processes, which 
often stretch across sectoral boundaries (Gawell et al. 2009; Berglund et al. 2013; von Friedrichs et al. 2014).

There are no statistical accounts or other systematic investigations of this model of social enterprise either. There are, however, studies including several different cases of societal entrepreneurship (Johannisson 1985; Alänge 1987; Holmberg et al. 2007; Gawell et al. 2009; Berglund et al. 2013; von Friedrichs et al. 2014).

\subsection{Institutional Trajectories of Social Enterprises in Sweden}

As mentioned earlier in this chapter, there are no specific legal forms for or regulations addressing social enterprise in Sweden. People operating social enterprises rely on "ordinary" regulations for different forms of business and/or non-profit associations or foundations. Some, but not all, argue that there is a need for an institutional recognition to facilitate the development of social enterprise in the country.

As a result of this lack of a specific legal form for social enterprises, it is difficult to analyse social enterprises' institutional trajectories in terms of legal structures; however, the SE models identified in section 13.2 relate to overarching discussions of private actors in a welfare society and the "division of labour" between the state, social enterprises and other types of actors/institutions, and evolutions in this regard constitute interesting elements when it comes to analysing the institutional trajectories of social enterprise in Sweden. Policy decisions leading to competition for public contracts during the last two or three decades, in particular, have had a strong influence on the development of social enterprises and other actors in many-not to say most-social branches.

In this section, we will first discuss current explicit policy measures related to social enterprises. These measures provide a framework for social enterprise. Secondly, the observed shifts in the Swedish welfare mix will be related to the "welfare triangle" that has been developed to understand the interplay between sectors in welfare societies. Finally, this chapter ends with a concluding discussion on the state of discussions about social enterprise in Sweden.

\subsubsection{Current Explicit Policy Measures}

Relevant policies for work-integration social enterprises (WISEs) are primarily labour-market policies and enterprise policies at the national level. These two policy fields are also relevant at the regional or local (municipality) level, but at the regional/local level, the way in which social matters are handled varies. Indeed, at this level, the extent of and routines for procurements/client-choice models differ from one region/municipality to the other; this impacts social enterprises as well as 


\section{Gawell}

other actors. At the national level, as mentioned above, public agencies for enterprises, labour-market policies and social security have been commissioned to cooperate, to improve information and possibilities for social enterprises to operate within ordinary regulations. It has to be noted, though, that the collaboration between actors at the regional and local levels is also improving.

WISEs are influenced by the conditions and terms under which compensation aiming to make up for the reduced working capacity of targeted workers (lönebidrag) is granted; they are also impacted by rehabilitation assignments and other services that they are expected to provide for public authorities. The level of public funding in these social enterprises, primarily through sales, is high-as in any for-profit or nonprofit enterprise/organisation providing social services in Sweden. WISEs are, therefore, dependent on the emerging SE market, whose terms are dictated by public policies and public authorities. And WISEs struggle to survive-especially when they target those that need it most (Gawell 2013). Many WISEs have been granted project support from the European Social Fund (ESF) or the Swedish Heritage Fund (Arvsfonden) (Gawell 2013).

Non-profit social enterprises are also affected by the shifts in welfare structure and the introduction of public procurements, but also by policy changes, which at times also mean reductions in the grants that previously funded their activities. Some of the well-established organisations had developed (non-profit) business models that relied on policy structures and on the resources that were channelled through these for many years, and the downsizing - and in some cases even disappearance-of these policy structures undermines their sustainability. Depending on how well these ventures fit or adapt to the evolution of policies, the shift means increased opportunities or increased struggle. For some, this has primarily been a shift in routines rather than in actual resources.

An "Agreement" (Överenskommelsen) ${ }^{7}$ was launched in 2008 to support non-profit organisations and other "idea-based" organisations (such as cooperatives with a social aim and asset lock), whether they themselves used the term social enterprise or not, to operate in the new welfare structures. This Agreement, which recognises the organisations' rights to independence, sustainability, dialogue, transparency, quality and diversity, brings together the Swedish government, approximately 70 organisations and the Association for Local Governments and Regions; it was initially limited to the fields of health and social care and later on (2018) broadened to become a more general "agreement".

Social-purpose businesses are primarily affected by the general business climate, but also by conditions of procurements, depending on their ventures/services. Examples indicate that these social enterprises are more market dependent than other models of social enterprise, and that they attract private investments through owners as well as philanthropic 
donations, but since there are no formal criteria to identify socialpurpose businesses, it is difficult—and even close to impossible- to give an account of the effects of current policy measures on this model of social enterprise.

Societal entrepreneurship has been increasingly used as an umbrella concept for a variety of models and can, therefore, be affected by all the above structures and institutions, depending on the specific types of activities that the venture engages in.

In addition, regional development policies, including European Structural Funds policies are important for the development of societal entrepreneurship and social enterprises, since these policy measures also address issues emphasised by the third sector. Social enterprises and similar types of organisations sometimes receive project grants from regional funds, mostly through collaborative partnership with, for example, regional universities and other public authorities.

In national innovation strategy, civil society has been highlighted as a driving force for innovations that can "meet future challenges", alongside businesses, the public sector and academia (Swedish Government Statement 2012b). Social enterprises and social or societal entrepreneurship were also highlighted in this strategy, although not to the same extent as the concept of civil society. This was a clear change compared to former innovation strategies, which did not pay attention to any third-sector-related concept (Gawell 2014b). However, in the grand historical narrative on popular mass movements in Sweden, the innovative role of these movements was highlighted as they initially provided social services and then participated actively in the construction of welfare structures. The Red Cross, for example, provided school lunches and dental care for children; thus meeting the need for better nutrition and health that characterised the first part of the 20th century. Other organisations, like the Temperance movement, at the same time initiated reading groups, alternative education programmes and what later became libraries. These services then became part of the public agenda and the responsibility for their provision was transferred to the public sector as it developed during the 20th century (Gawell 2014a).

\subsubsection{Social Enterprises in the Welfare Triangle}

The evolution of the Swedish welfare state and the shift of roles can be analysed using the welfare triangle, which elaborates on the position of the third sector in relation to the state, market and community (figure 13.2).

There has been a palpable shift towards more market-like conditions for the increased number of service providers in Sweden during the last three decades, due to policy shifts. Many of these new service providers are private for-profit enterprises, but social enterprises also operate to a 


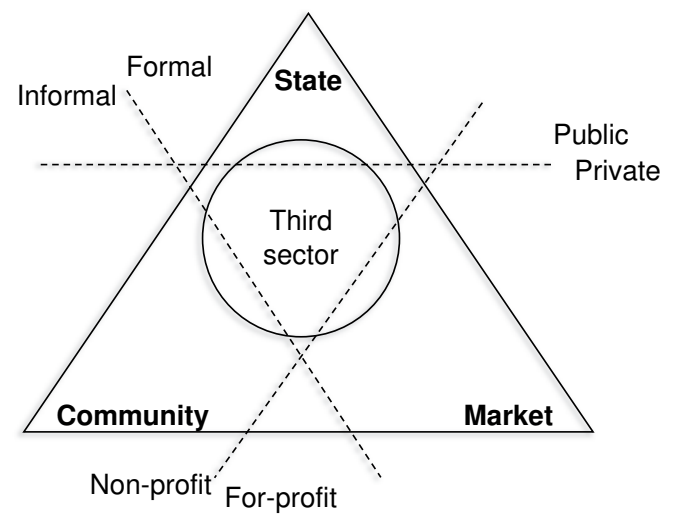

Figure 13.2 The third sector and the welfare mix. Source: Pestoff (1998).

large extent in the market part of the welfare triangle. Labour-market policies particularly affect the market for work-integration social enterprises (WISEs), while health- and social-care policies affect the market for other non-profit social enterprises to a larger extent. Since health and social services are still publicly funded, shifts in policies entail renewed partnerships between the state and private actors.

There are still non-profit-oriented social enterprises that primarily rely on public grants and are therefore positioned as third-sector organisations close to the state in the welfare triangle; however, there are indicators that the number of such organisations and the extent of this type of funding have been decreasing during the last decade. On the other hand, social enterprises that rely on marketbased funding, and are thereby positioned closer to the market-based part of the welfare triangle, are increasingly highlighted in the debate.

Even though there is an overall evolution towards more market-like conditions for the third sector and social enterprises, they remain highly dependent on public authorities; paradoxically, the extent to which public authorities control these organisations (through funding conditions) has even increased, and the possibility to propose and try out new and/or alternative activities has decreased in some areas-in spite of a policy rhetoric that highlights freedom of choice and diversity. The arrows added to the welfare triangle in figure 13.3 illustrate the shifts in policies in the last two decades that affect the current situation of social enterprises. 


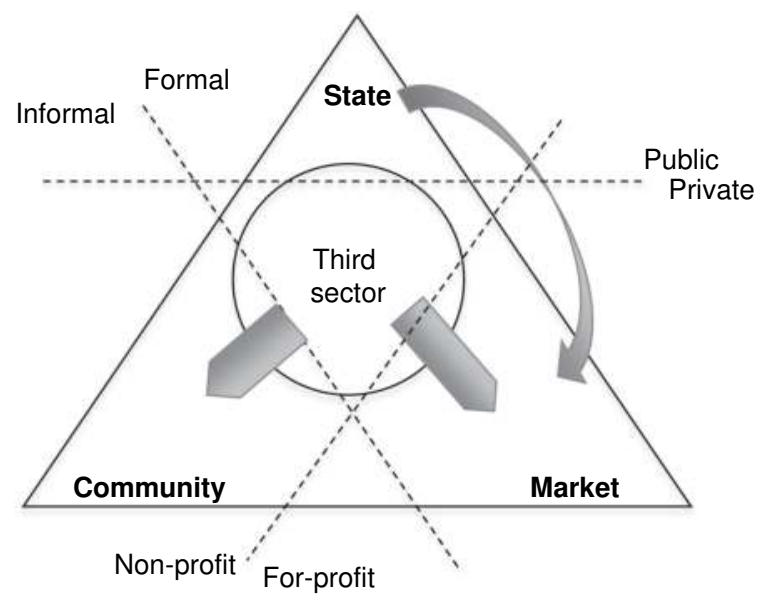

Figure 13.3 The third sector and the welfare mix: illustration of current paradoxes in Sweden.

Based on Pestoff (1998). Modification: Arrows added by the author to illustrate shifts in the early 2000 s.

\subsubsection{Social Enterprise in Sweden: Intertextual Consensus and Hidden Paradoxes}

The discourse on social enterprise has a very positive connotation in Sweden. Liberal and right-wing-oriented politicians argue that these initiatives stand for free enterprising individuals providing diverse welfare services. Socio-democratic and left-wing politicians argue that social enterprises provide participation-based and co-owned services. There is an altogether common, intertextual vision of social enterprise as being part of a "good development"- even though the phenomenon is ascribed slightly different roles by different actors. ${ }^{8}$

Between 2006 and 2014, Sweden had what - in Swedish terms-is called a right-wing government. This government argued that the policy shift it implemented, which led to an increase in the number of private service providers, also benefited the development of social enterprises. There is, however, a paradox: the same government also prioritised financial restraints and even cutbacks in public spending. This resulted in an economic pressure which, combined with competition among enterprises (including private for-profit enterprises), led to opportunities to act, but also to a financially difficult situation for many enterprises, and especially for those ventures dealing with social problems that demand great resources over time.

There is yet another paradox behind the positive rhetoric on social enterprises. Behind the promotion of client-choice models and choices of service distributors is a funding system that is influenced, to a large extent, 


\section{Gawell}

by so-called new public management (NPM), which controls in detail what should be done and how this should be accounted for. NPM has influenced the organisation of the public sector for approximately three decades (Jacobsson et al. 2015), and it has spread to social enterprises and other types of private actors through the different types of reimbursement systems during the last decade or two, depending on the branch of activity.

\section{Conclusion}

Behind the expressed positive intertextual consensus and hidden paradoxes are many initiatives, in a society with relatively good living conditions and a traditionally high level of commitment to social values. Still, not everyone shares a sense of well-being, and many social enterprises struggle to mobilise resources in their search to find solutions to what they perceive to be necessary to act upon. Many involved in social enterprises and the third sector at large raise concerns over increased inequalities and increased challenges in society, due for example, to stricter insurance coverage and migration linked to conflicts and poverty-in Sweden and globally. These concerns are combined with a struggle to mobilise resources, especially for the everyday work with groups that are in need of intense social care. Due to the transformation of the prior general welfare structures, the burden of mobilising resources is at least partly transferred to third-sector organisations and individuals in the community.

\section{Notes}

1 See www.emes.net.

2 See http://www.sofisam.se/vad-ar-sociala-foretag/definition.html; author's translation.

3 See http://www.sofisam.se/hitta-sociala-foretag.html.

4 Due to the lack of formal regulations, there are overlaps between the different major models of initiatives; this is why, in prior work, the different models were referred to as "versions" rather than as "categories" or "models". However, the term "model" is used in this chapter for reasons of coherency across chapters.

5 See www.sofisam.se.

6 See www.sofisam.se.

7 See www.overenskommelsen.se.

8 Intertextual refers here to the fact that the vision of the concept is based on various policies, which shape and influence each other. See also the discussion in Gawell Pierre and von Friedrichs (2014) on societal entrepreneurship in local and regional development discussions.

\section{References}

Alänge, A. (1987) Acquisition of Capabilities through International Technology Transfer, Gothenburg: Chalmers University of Technology. 
Amnå, E. (2005) “Scenöppning, scenvridning, scenförändring”, in Amnå, E. (ed.) Civilsambället. Några forskningsfrågor, Stockholm: Riksbankens Jubileumsfond in collaboration with Gidlunds förlag, pp. 9-36.

Andersen, L. L., Gawell, M. \& Spear, R. (eds) (2016) Social Entrepreneurship and Social Enterprises. Nordic Perspectives, New York and London: Routledge.

Berglund, K., Johannisson, B. \& Schwartz, B. (2013) Societal Entrepreneurship. Positioning, Penetrating, Promoting, Cheltenham: Edward Elgar.

Defourny, J. \& Nyssens, M. (2012) "The EMES Approach of Social Enterprise in a Comparative Perspective", EMES Working Papers, No. 12/03, Liege: The EMES International Research Network.

Gawell, M. (2011) Inte vilket entreprenörskap som helst, Stockholm: Tillväxtverket.

Gawell, M. (2013) Socialt företagande och försöken att finna fungerande sätt, Stockholm: Arvsfonden.

Gawell, M. (2014a) "Social entrepreneurship and the negotiation of emerging social enterprise markets", International Journal of Public Sector Management, Vol. 27, No. 3, pp. 251-266.

Gawell, M. (2014b) "Soci(et)al Entrepreneurship and Different Forms of Social Enterprise”, in Lundström, A., Zhou, C., von Fridrichs, Y. \& Sundin, E. (eds) Social Entrepreneurship. Leveraging Economic, Political and Cultural Dimensions, Heidelberg, New York and London: Springer.

Gawell, M., Johannisson, B. \& Lundqvist, M. (2009) Entrepreneurship in the Name of Society, Stockholm: KK-stiftelsen.

Gawell, M., Pierre, A. \& von Friedrichs, Y. (2014) "Societal entrepreneurship - a cross-boundary force for regional and local development cherished for multiple reasons", Scandinavian Journal for Public Administration, Vol. 18, No. 4, pp. 109-130.

Holmberg, L., Kovacs, H. \& Lundqvist, M. (2007) Sambällsentreprenör - en förstudie, Stockholm: KK-stiftelsen.

Jacobsson, B., Pierre, J. \& Sundström, G. (2015) Governing the Embedded State. The Organisational Dimension of Governance, Oxford: OUP.

Johannisson, B. (1985) Business and Local Community - Swedish Experiences in Bottom -planning for Local Industrial Development, Report 1985: 4, Östersund: University of Östersund.

Larsson, J. (2008) Folkhemmet och det europeiska huset. Svensk välfärdsstat $i$ omvandling, Stockholm: Hjalmarsson \& Högberg förlag.

Lundström, A. \& Sundin, E. (2008) Perspektiv på förnyelse och entreprenörskap $i$ offentlig verksambet, Örebro: Swedish Foundation for Small Business Research.

Lundström, T. \& Wijkström, F. (1997) The nonprofit sector in Sweden, Manchester: Manchester University Press.

Nutek (2007) Programförslag för fler och växnade sociala företag, Dnr 0122007-4248, Stockholm: Nutek.

Pestoff, V. (1998) Beyond the Market and State. Social Enterprises and Civil Democracy in a Welfare Society, Ashgate: Aldershot.

Prop (2009/10:55), En politik för det civila sambället, Ministry of gender equality and integration. 


\section{Gawell}

Ringqvist, M. (1996) Om den offentliga sektorn: Vad som ger och vad den tar, Stockholm: Publica.

SCB (2014) Det civila sambället 2011-2012, Örebro: Statistics Sweden.

SOU (2007) Rörelser i tiden, Stockholm: Statens offentliga utredningar.

Stryjan, Y. (2001) "The emergence of work-integration social enterprises in Sweden”, in Borzaga, C. \& Defourny, J. (eds) The Emergence of Social Enterprise, London: Routledge.

Swedish Government Statement (2008) Regeringsförklaringen. Available HTTP: http:// www.regeringen.se/content/1/c6/11/10/80/483f5bc2.pdf (accessed May 25, 2013).

Swedish Government Statement (2012a) Regeringsförklaring. Available HTTP: http://www.regeringen.se/sb/d/3039 (accessed May 25, 2013).

Swedish Government Statement (2012b) Den nationella innovationsstrategin. Available HTTP: http:/www.regeringen.se/content/1/c6/20/11/84/529b3cb3. pdf (accessed May 25, 2013).

Swedish Ministry of Culture (1999) Social ekonomi. En tredje sektor för välfärd, demokrati och tillväxt?, Stockholm: Regeringskansliet.

Swedish Ministry of Interior (1998) Social ekonomi i EU-landet Sverige. En tradition och förnyelse $i$ samma begrepp, Ds 1998:48, Stockholm: Regeringskansliet.

Trägårdh, L. (2007) State and Civil Society in Northern Europe: The Swedish Model Reconsidered, New York: Berghahn Books.

von Friedrichs, Y., Gawell, M. \& Wincent, J. (2014) Sambällsentreprenörska samverkande för lokal utveckling, Östersund: Mid Sweden University Press.

Wijkström, F. \& Lundström, T. (2002) Den ideella sektorn. Organisationer i det civila sambället, Stockholm: Sober förlag. 


\title{
14 Social Enterprise Approaches in Switzerland
}

\author{
Michaël Gonin, Nicolas Gachet and \\ Philipp Erpf ${ }^{1}$
}

\section{Introduction $^{2}$}

Switzerland's specific position at the crossroads of the German, French and Italian cultures results in a complex and rather segmented field of social enterprise (SE). Language and cultural barriers often make it difficult for actors across the country to collaborate and institutionalise a nation-wide understanding of the concept. There are many nation-wide umbrella structures with different approaches of social enterprise; moreover, these structures are often rather weak and sometimes separated into German and Romance-language structures, leading to a high diversity of definitions.

Originally, the SE concept in the Swiss context referred mainly to work-integration social enterprises (WISEs) and, by extension, to some social-work organisations with a business activity (e.g., second-hand shops). In the past years, though, international trends have led to a much broader use of the SE concept. In Western Switzerland, the French influence of the social and solidarity economy (SSE) movement gives a specific orientation to the emerging SE research, while the commongood, non-profit and volunteering approaches dominate the Germanspeaking research in the country. Consequently, and although both approaches are permeated by the social-entrepreneurship movement, ${ }^{3}$ no unified terminology exists in Switzerland, and a multitude of terms are used in relation to these actors, such as civil society, associations' sector, intermediary organisations, public-utility organisations, non-business organisations, non-governmental organisations (NGOs), social sector or voluntary sector (Helmig et al. 2009).

The confusion is maintained through specific characteristics of Swiss politics. The subsidiarity principle implies that any task falls de principio under the responsibility and authority of the cantons, unless an explicit constitutional article assigns the responsibility for it to the federal government. ${ }^{4}$ As a result, important domains such as social policies, public health and economic promotion are managed extensively by the cantons; and in the absence of a unifying legal framework for social enterprise, a 
diversity of local approaches and practices can be observed among social enterprises, in SE networks (where local networks exist) and in government support. Most umbrella organisations are organised around specific themes (microfinance, local agriculture, work integration, etc.) rather than around specific understandings of the third sector or of social enterprise.

The not-for-profit vs. for-profit differentiation requires additional clarification. Very often, the notions of "business", "economic objectives" or even "management" are conflated, in the view of third-sector actors, with the for-profit character, whereas non-profit is assimilated with "non-commercial". In this perspective, the third sector only includes traditional associations and foundations. These organisations can hire staff, produce goods and services, and innovate, but they secure their budget through donations, subsidies (nowadays increasingly through public procurement) and grants-not through attempting to sell their goods or services to other private actors or to the state as "customer". With this interpretation of the third sector, which is prevalent in most studies on the subject in Switzerland (e.g., Helmig et al. 2009), hybrid actors, with commercial and social mindsets-typically social enterprises-become difficult to "locate" on the field, as they are too "economic" for the third sector and too "social" for the business world.

In line with the EMES approach to social enterprise used as a frame of analysis in the ICSEM Project, we use the word economic in a broad sense to refer to paid staff, continuous production and a risk component.

The general structure of this contribution is the following: First, the traditional, third-sector approach to social enterprise is explained. Then, three SE approaches influenced by models from other countries are discussed, namely the social and solidarity economy, the economy for the common good and the social-entrepreneurship approaches. We end this contribution by highlighting two main challenges raised by these three approaches.

\subsection{The Traditional Third-Sector Approach to Social Enterprise}

While social enterprises are often seen as part of the third sector, some third-sector actors do not show the economic orientation necessary to qualify as social enterprise. In addition, most public-support measures to the field are still oriented towards the third sector in its older understanding, and not specifically towards social enterprise. Furthermore, while public authorities support third-sector organisations through various means, there is no overarching policy that would provide a unified conceptual framework and coordinate the various measures, which are taken mainly by the towns and the cantons. Most of the demands made by members of cantonal or national parliaments to boost 
the third sector and the social economy have been rejected by the respective chambers, and only few cantonal governments have specifically invested in this field, even though some cantonal constitutions mention the importance of associations and of support to these organisations. ${ }^{5}$ Interventions usually rather focus on specific domains: organisations active in the domains of culture, sports, child care, migrant populations, etc. are supported by a diversity of departments and services at various levels.

Nevertheless, despite the multitude of terms and the complexity of public policies, there seems to be a consensus that the third sector is clearly distinct from the state and from the business world. Switzerland has a long history of local associations and groups providing many services to society. In addition to serving their members' interest, these organisations play a central role in tackling many social needs identified by community members. Home-care services, cultural associations, local sports clubs and other social services are provided by local associations that show high independence from the local, regional or national governments. Switzerland also has a long tradition of volunteering and civic engagement, coupled with a culture of a rather limited state, be it municipal, cantonal or national (Stadelmann-Steffen et al. 2010).

The result of all this is that the Swiss third sector has long been equated with non-profit organisations (NPOs). It is composed of a variety of mainly local NPOs, with only a few bigger players (mainly those originally related to confessional organisations). And unlike what is the case in other countries, these bigger players have not imposed an oligopoly situation. The absence of oligopoly is further maintained through the weakness of umbrella structures; these often remain "federations of local groups" in which the latter keep their autonomy for most decisions and actions. Until recently, top-down management remained the exception, even among bigger structures. However, despite the small number of large organisations, the non-profit sector nevertheless represents about $5 \%$ of the gross domestic product and of the jobs in the country. In addition, formal volunteering in NPOs added up to 224 million hours in $2016,{ }^{6}$ surpassing the equivalent of 80,000 fulltime jobs previously estimated by Helmig et al. (2010). Most of the actors within this sector are foundations and associations.

In the last three decades (1990s-2010s), the business $v s$. third sector distinction has however been challenged by public-policy changes related to the new public management (NPM) trend. The NPM overhauled the functioning of the public administration as well as its relations to service providers, especially those in the social sector. As a result, public/ private partnerships based on public procurement procedures have become standard, pushing NPOs to become more entrepreneurial and competitive in their relation to the state and to each other. This evolution is not seen as a blessing by some third-sector actors, especially when 


\section{Gonin, Gachet \& Erpf}

short-term public procurement contracts, including narrowly defined requirements in terms of performance measurement, replace former long-term, privileged relations with public actors. Many smaller organisations relying to a significant extent on volunteering struggle to compete with bigger, sometimes for-profit organisations that have a higher paid/unpaid staff ratio, are better structured and labelled, and do not necessarily see an opposition between social work and competition. For these smaller organisations, the NPM shift is more imposed than embraced, and it is perceived as a threat to solidarity and to high-quality social work. Consequently, many actors implement the required changes reluctantly and in rather superficial manners (Battaglini and Dunand 2005; Perrot et al. 2006). They use the NPM language in tenders and reporting with the state, but they do not undergo a real organisational culture change to embrace the entrepreneurial mindset.

\subsection{New Approaches to Social Enterprise}

Three SE approaches coming from other countries are currently challenging traditional definitions and are therefore important to take into account when attempting to evaluate the future use of the SE concept in Swiss politics, research and practice. These are the French "social and solidarity economy" (économie sociale et solidaire, hereafter referred to as SSE), the German "economy for the common good" (GemeinwohlÖkonomie, ECG), and the "social-entrepreneurship" trend, coming from the US and UK. These three new trends are summarised in figure 14.1, and they are discussed in the following sections. Table 14.1 provides an overview of these three new approaches in light of the EMES indicators defining the ideal-typical social enterprise.

\subsubsection{Social Enterprises as SSE Organisations}

The concept of social and solidarity economy (SSE) has a long tradition in various countries, such as neighbouring France. However, in Switzerland, this terminology was seldom used until the creation of the Geneva Chamber of Social and Solidarity Economy (APRÈS-GE) in 2004. Following this, two other chambers were created, respectively, in the canton of Vaud and in the Bern-Jura-Neuchatel area. However, while the APRÈS-GE has become an established actor of the socio-political and economic life of the Geneva area, the concept remains only weakly established outside Geneva and is still totally unknown in the Germanspeaking part of the country. The references to the SSE theory, terminology and philosophy are mainly defended by Romance-language authors, and the links to existing international networks also mainly bring together Romance-language members, making an expansion in the German-speaking part of the country difficult. 

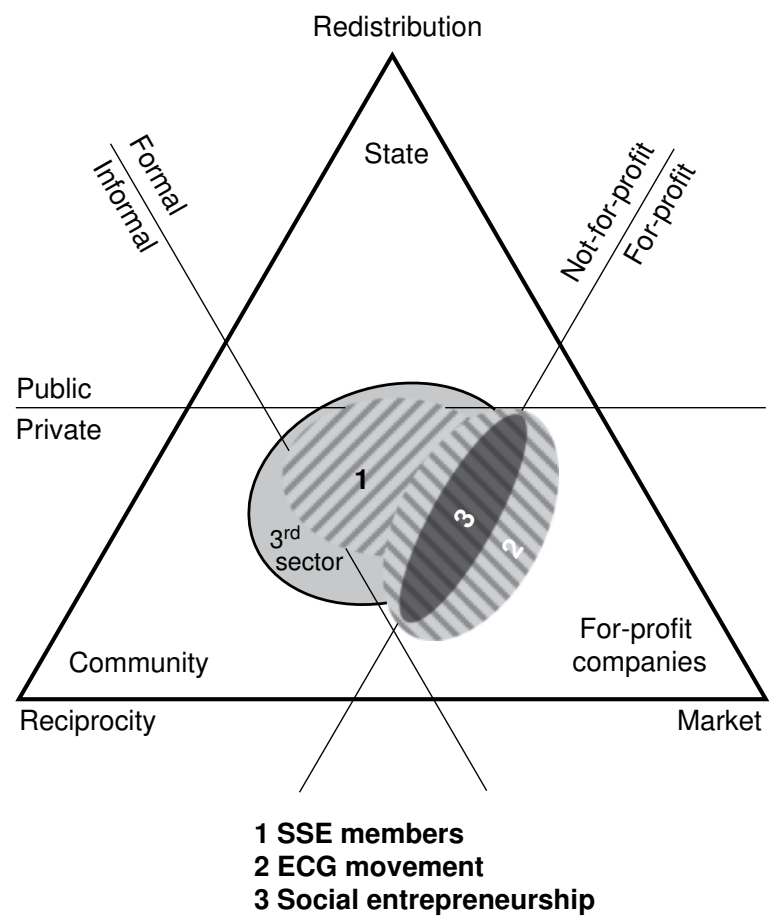

Figure 14.1 Positioning of the three SE approaches derived from current approaches.

Even though the concept remains unknown for the majority of the population, various studies show that actors that would correspond to the definition of the SSE represent an important part of the country's local economy and employment. ${ }^{8}$ Two Swiss SSE chambers benefitted from an EU Interreg funding to collaborate with SSE chambers in two neighbouring French areas. Nevertheless, this seemed not to suffice to make the SSE a widely acknowledged economic model and to create an SSE network for the entire Western Switzerland. A study of the definition and criteria of APRÈS-GE (that serves as the basis for the definition adopted by the other chambers) shows an interesting combination of the traditional definition of the SSE in France, the EMES indicators and a "Swiss twist" (Baranzini and Swaton 2013). The chambers, for instance, do not use the legal form as a criterion for accepting or refusing new members, but they rather verify whether core principles, such as participative governance and contribution to social welfare, are respected in the spirit of the organisation. This approach based on principles and criteria can lead to the inclusion of some corporations (which, in Switzerland, might apply to be recognised as not-for-profit in some situations) as well as to 


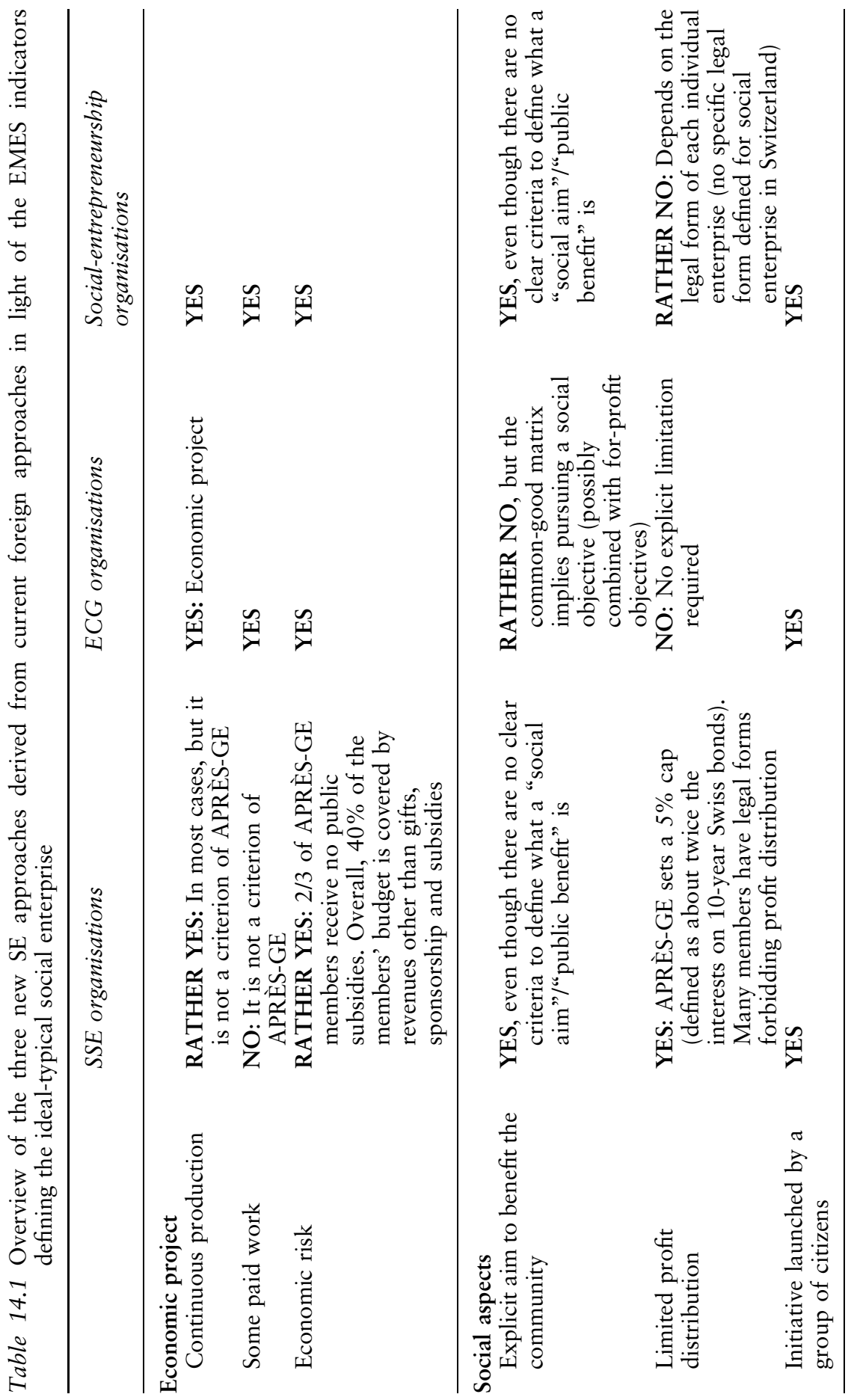




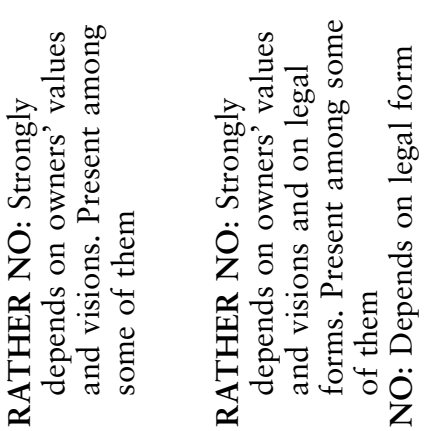

离
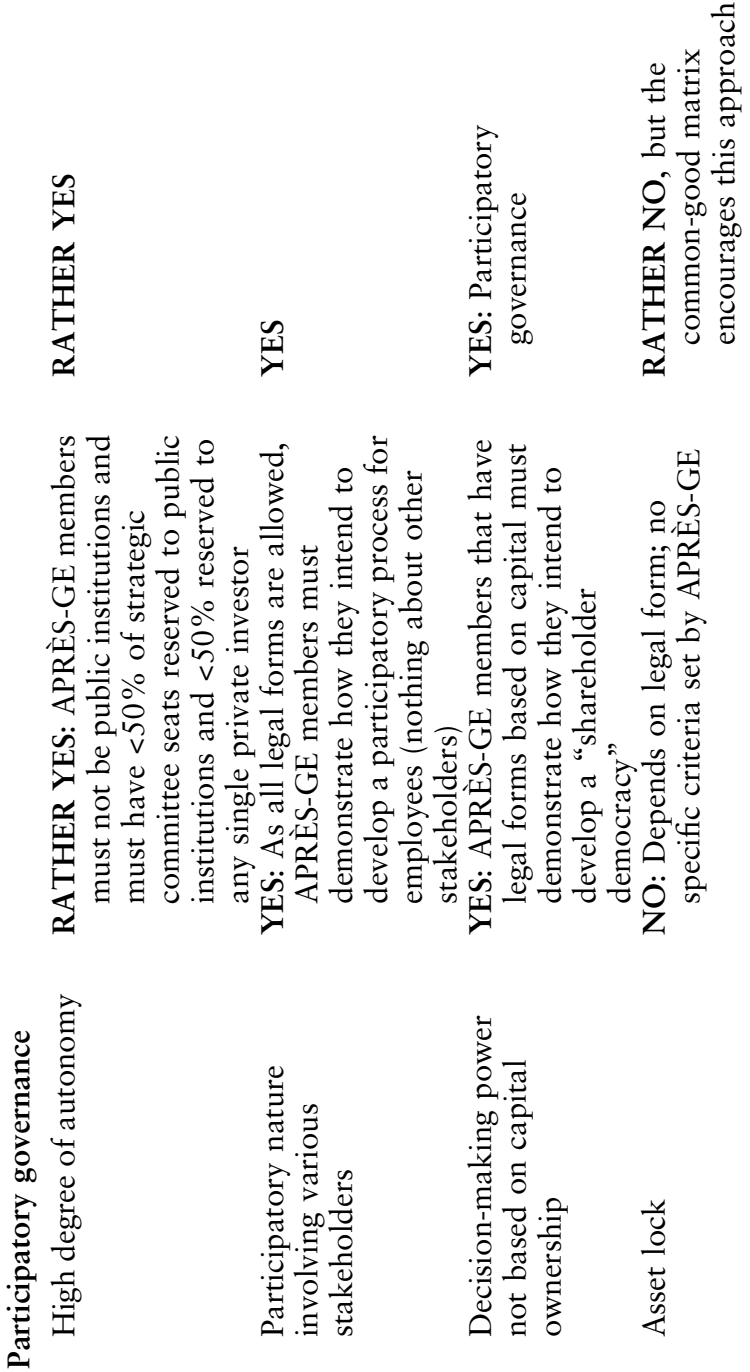


\section{Gonin, Gachet \& Erpf}

the possible exclusion of some associations, cooperatives and foundations that would have been included, had a "legal" definition of the field been used. It is also worth noting that (limited) profit distribution is better accepted within the Swiss SSE movement than in other SSE movements, which brings them closer to the social-entrepreneurship movement than to the French SSE, for instance.

APRÈS-GE's charter defines seven principles: social well-being ("to be, not to have"); participative citizenship and democracy ("each voice counts"); ecology ("produce to live, don't live to produce"); autonomy ("autonomous but not individualistic"); solidarity (" $1+1>2$ "); diversity ("rich in our differences"); and coherence ("say what we do and do what we say"). ${ }^{9}$ These principles have been refined in a series of criteria that are summarised in table 14.1 against the EMES indicators defining the ideal-typical social enterprise. While the economic dimension seems to be secondary in the criteria of APRÈS-GE (continuous production and paid work do not represent formal criteria, and although most members bear some economic risk, there is no "requirement" to do so), the social dimension is more explicit. Indeed, there must be an explicit social aim, profit distribution must be limited and transparency about profit distribution must be ensured, ${ }^{10}$ and a private initiative must be at the origin of the creation of the organisation. This focus on the social dimension might be the result of the influence of the third-sector approach that dominated in Switzerland. Anecdotical evidence for this is given by the fact that many members of APRÈS-GE come from the third sector. As for participatory governance, the degree of autonomy is an important criterion, and organisations that are directly submitted to public or private structures cannot become members of the chamber. Moreover, the participatory nature is encouraged as member organisations must demonstrate how they intend to develop the participatory process for their employees. Nevertheless, as all legal forms are allowed (including limited-liability companies and self-employed persons), participatory governance is not legally guaranteed, and it is moreover formally focusing on employees-even though APRÈS-GE promotes a broader understanding of stakeholder involvement. Finally, members (including those having legal forms based on capital) must provide the APRÈS-GE management committee with a self-assessment and with information about how they plan to meet their chamber's criteria within 2 years. ${ }^{11}$

This approach, based on principles and practices, allows for more flexibility than approaches based on legal forms, and it also challenges associations, cooperatives and foundations that do not necessarily respect all the principles despite their "SSE legal form". This allows for the integration of a multitude of actors that share most of the SSE values without necessarily having explicitly thought about it when they were created (as the SSE concept was not explicitly discussed in Switzerland until the 2000s). Nevertheless, as the Chambers grow, and also due to 
the emergence of the social-entrepreneurship approach, the Chambers will have to make their criteria more precise. For example, the fact that the movement is rooted in the political and the third-sector conceptions of the SSE as participatory and striving for the common good rather than for profit makes some of its proponents very wary of the socialentrepreneurship approach, which does not insist as much on participation (see Swaton 2011).

\subsubsection{Social Enterprises as ECG Organisations}

The second movement, namely that of the "economy for the common good" (ECG), seems to be emerging from Austria and Germany; it is found mainly in the German-speaking part of Switzerland. The ECG concept relies on a common-good notion that is well known in the area. The importance of the common good and of the community members' contributions to the latter is strongly rooted in many areas of Swiss social and political life. Illustrations of this are numerous, even though specialisation and professionalisation are leading to a decay of this common-good-contribution habit. For example, part of the agriculture, especially in Alpine areas, functioned based on the "commons", as studied by Nobel Prize laureate Ostrom. The "militia mindset" prevails in the political system (officially, politicians are non-professional), in fire brigades and in the army. Beyond these more official and state-related functions, the service-for-the-common-good mindset can be observed among the many people volunteering in either formal or informal ways for the local community (Schön-Bühlmann 2011).

The ECG proposes a political and economic system (including a taxation reform) that would better take into account the (positive and negative) social contributions of each organisation. Like in the SSE movement, the concept of social enterprise, in the ECG perspective, does not refer to a specific field of activity but rather reflects a particular, holistic understanding of business/society relations. Proponents of the ECG movement aim at bringing together enterprises that are strongly embedded in the local community and that abide by ECG values and contribute to the common good as "Sozialunternehmen" ("social enterprises" in German). Some networks related to the ECG movement seem to be emerging, such as the "common-good-economy movement" (Gemeinwohl-Ökonomie; see Felber and Maskin 2015). Yet, as with SSE organisations, the use of this term to refer to this group of organisations and the organisations themselves are not well known outside the ECG movement; and unlike the SSE movement, the ECG movement seems to be still very small. Indeed, although it concerns various regions in the German-speaking part of Switzerland, with many local groups being created, these groups are small and little known in their respective geographic areas. Much like the social-entrepreneurship movement, and 


\section{Gonin, Gachet \& Erpf}

perhaps in contrast to the SSE movement, the ECG movement's main strength in terms of further growth lies in its more business-like language, which might better reach out to organisations in the mainstream economy that consider themselves as "businesses", in opposition to the often negatively connoted "social enterprises". The risk in this approach is however the dilution of the core values into some "CSR-washing".

The proximity to the traditional business sector implies that ECG social enterprises easily fulfil the three indicators put forward by the EMES Network to describe the economic dimension of initiatives. As far as the social dimension is concerned, the explicit aim of benefitting the community is replaced by a more general notion of contribution to the common good. While this notion seems less clear than those of public interest and social aim, the ECG evaluation matrix nevertheless offers a clear operationalisation of the concept, as well as a system to evaluate organisations in this regard, based on four core principles (human dignity; solidarity and social justice [including minimisation of dividends paid]; environmental sustainability; and transparency and co-determination) that are each applied to a broad array of stakeholders, including suppliers, investors, employees and business owners, customers and partners, as well as to the organisation's social environment (region, electorate, future generations, civil society, fellow human beings, animals and plants). ${ }^{12}$ Like the SSE chambers, the movement seeks to motivate its members to progress on these various dimensions-not all actors focus on the same dimensions at the beginning. The participatory governance is thus also valued by the model: Indeed, its "transparency and co-determination" principle includes criteria such as the inclusion, in decision-making processes, of employees (also for the election of managers) and of local stakeholders and NGOs.

While still young, the movement is not to be ignored, for multiple reasons. Firstly, the German-speaking part of the country represents about two-thirds of the population and hence might have more weight in national public policy than other parts of the country. ${ }^{13}$ Secondly, the ECG movement has international connections and is related to professors in the academia in several countries. Thirdly, it raises interest among traditional businesses seeking to enhance and promote their social dimension. Finally, the ECG mindset is strengthened through the parallel re-emergence of cooperatives, which are often considered as the prototypical hybrid, socio-economic organisational form. Cooperatives were the most used legal form for businesses in Switzerland at the end of the $19^{\text {th }}$ century, but they have lost much influence during the $20^{\text {th }}$ century; yet various cooperatives have been attempting to give a new impetus to this legal form since the 2008 financial crisis. Cooperatives include older banks and insurance companies, traditional housing cooperatives, as well as new, creative consumer cooperatives (or even mixed producer/consumer cooperatives) in all sectors of activities; in 
addition, some worker cooperatives emerged too (Gachet and Gonin 2013). A new umbrella organisation for large cooperative enterprises has recently been created (Interessengemeinschaft Unternehmensgenossenschaft, now idée coopérative) and signs point to emerging networks for smaller cooperatives.

\subsubsection{Social enterprises as Social-Entrepreneurship Actors}

While not nationally unified in a single movement, the socialentrepreneurship movement, which originated in the US and UK, shows some characteristics that suggest a potentially important impact on the Swiss SE field in the coming years. Actors in the SE ecosystem (entrepreneurs, foundations, academics, etc.), whatever the school of thought they refer to, use the concept of social entrepreneurship in one way or another and want to promote it.

Two major trends can be identified within the social-entrepreneurship movement. The first trend is observed among traditional third-sector organisations that develop commercial activities as a source of revenue for their social mission (see the review by Defourny and Nyssens 2010).

The second trend is the social-innovation trend, which insists on the innovation part rather than on the form of organisation (Drayton 2002). Socially entrepreneurial individuals can either be found within existing social enterprises or non-profit structures or start a new organisation, independently from existing structures. In both cases, what distinguishes these actors from the traditional non-profit sector is not so much their relation to the social issue they tackle as their relation to the entrepreneurial and commercial dimension of their project. While nonprofit organisations and the SSE are often in opposition to-or at least in tension with-the mainstream business sector, social entrepreneurs seek to overcome this dichotomous approach and combine social and entrepreneurial/business-oriented mindsets.

Both trends of the social-entrepreneurship movement are also present in Switzerland. Ashoka and the Schwab Foundation (with headquarter in Geneva) but also organisations such as Euforia, seif, the Social Impact Hubs and Social Business Models are developing various programmes to foster social entrepreneurship. In addition, Switzerland is playing a major role in the field of microfinance investment funds and sustainable finance (in its broadest sense), ${ }^{14}$ and while the pioneering funds were created within the traditional NPO world, new actors with commercial and profit-oriented intentions, closer to the social-entrepreneurship mindset, followed (e.g., BlueOrchard and ResponsAbility). ${ }^{15}$

As a consequence of social entrepreneurship's roots being closer to the business world than to non-profits, the economic and especially the entrepreneurial dimensions of social enterprises belonging to this trend are well developed. All three EMES indicators related to the economic 


\section{Gonin, Gachet \& Erpf}

dimension of initiatives are fulfilled. As far as social aspects are concerned, while social entrepreneurship implies an explicit social aim and results from a private initiative, the indicator about a limited profit distribution, submitted to a social aim, is debated within this trend. While some social entrepreneurs exclude any possibility of profit distribution, others consider a "reasonable" profit distribution as acceptable-without necessarily offering a clear definition of what would be reasonable. Finally, as regards participatory governance, autonomy is often very important among these social entrepreneurs, even though some social-impact investment funds and "social-business angels" are strongly involved in the development and strategy definition of the funded organisations. Participation and democratic decision-making remain however two dimensions that are not explicitly addressed in the social-entrepreneurship approach and are therefore often overseen, unless explicitly implemented by the actor. Nevertheless, some networks implement well-developed participatory governance systems, based for instance on models such as holacracy and sociocracy.

\subsection{Challenges}

The three SE approaches discussed in section 14.2 are challenging the traditional definitions referred to in section 14.1. The following section discusses two of these challenges for future research and practice in the field of social enterprise: (1) the blurring of SE boundaries and (2) the reshaping of the public-policy and research context.

\subsubsection{Blurry SE Boundaries and New Synergies}

The emergence of new approaches to social enterprise blurs the boundaries of the third sector/SE field. Among other implications, this evolution raises the question of actors located at the periphery of the field. For instance, many SMEs, though being, from the formal and legal point of view, for-profit enterprises, are locally embedded and want to remain local. Their involvement in the local community might, on some dimensions, locate them close to the third sector/SE field. It also appears that, conversely, some third-sector actors are located at the periphery of the SE world, either because they have only a social purpose but no real economic dimension or because their social objective is questioned by part of the population or even missing (some non-profit organisations clearly assert their primary intent of serving their members and not the common good).

Despite the theoretical challenges that such a redrawing of boundaries in more permeable terms implies, a discussion of the new boundaries allows for the development of new synergies that can be better exploited by various types of actors (Gonin and Erpf 2018). Further studies are 
required to clarify the context and evaluate whether the inclusion/exclusion of the various actors located at the periphery of the field would be appropriate or not. By actively seeking the involvement of SMEs in its networks, the ECG movement, for instance, opens the question of the relation of SMEs to social enterprise. More generally, while some SE-like SMEs would probably refuse to be called SEs, the three movements discussed here seem to lead slowly to new collaborations and the setting up of common platforms that include both traditional SMEs, social enterprises, and even traditional non-profits (see, e.g., Drayton and Budinich 2010). Regularly, collaboration platforms are organised locally in Switzerland to foster exchanges of expertise and collaboration between businesses and non-profits. More broadly, the development of the B-Corp label and the concept of hybrid value chain represent important growth factors and lead to changes within the business world and in the latter's relation to social enterprise. ${ }^{16}$

Even among actors clearly identified as social enterprises, some differences that arise are based more on differences in terminology or in the philosophical streams adhered to than on actual differences in practices. For instance, the evolution of the fair-trade movement points to the limits of clear-cut boundaries and predefined categorisations within the SE field. Indeed, this movement started within the traditional NPO world, with some associations selling a few fair-trade products (e.g., TerrEspoir, Magasin du Monde, Claro); it has since extended to the Max Havelaar fair-trade label, commercialised by the biggest Swiss retailers. In addition, some businesses have developed or joined industry-specific fair-trade labels, such as UTZ for chocolate, coffee and tea.

Finally, the study of the various approaches highlights that, while most criteria are fulfilled by the different SE approaches identified in this study, none of these approaches clearly fulfils the participatorygovernance indicators if this aspect is to include stakeholders beyond the members and/or the employees of the organisation. Formal participatory governance remains therefore an important challenge, whatever the approach considered (Gachet and Gonin 2015a). What seems essential however at this stage is the development of a clear definition of the "social aim", with a view to establishing a clear delineation of the SE field and distinguishing it from mainstream CSR, and from some social businesses and some third-sector actors promoting their own interests, which are not necessarily considered as "social aims" (see Gachet and Gonin 2015b). While the notions of common good and social aims are used by many movements and actors, and are widely mentioned in the literature, their exact definition indeed seems to remain an almost unaddressed issue among practitioners and scholars alike-as if these definitions could be "taken for granted". Yet important questions remain: Who is to define, and according to which rules, what is "social"? What is the cultural part of this definition, which seems to evolve over time? 


\subsubsection{Public-Policy and Research Context}

The second challenge lies in the fact that specific support from local governments for the SE field as such (regardless of the trend considered) is very limited and that no intercantonal coordination of such support seems to emerge. Public support is mainly indirect; it comes from the attribution of specific public procurements to social enterprises, and it is not intended to encourage a specific type of business, economic ideology or social-service structure. Such attitude, however, tends to favour a status quo in which burgeoning initiatives struggle to be recognised and to access public support or economic promotion, as the existing authorities do not necessarily make the effort to understand their specificities and find ways to accommodate them within the existing framework. An exception here is the increasing support provided by local authorities, mainly in the domain of housing cooperatives. The latter receive special access to land property to build affordable housing (see, e.g., the measures implemented in Lausanne and Geneva).

From a legal perspective, there is no specific legal form for social enterprise in Switzerland, and there is no project of creating one. Social enterprises are the result of practices and mindsets rather than of a structured legal framework or adhesion to a specific movement. This should not be considered as a tremendous problem, though, as the existing legal framework allows much freedom within the existing legal forms. Associations can have commercial activities, and corporations can be non-profit. Nevertheless, the typical hybrid form, namely that of cooperative, is currently neglected by agencies responsible for economic promotion, which do not know the specificities of this form and, consequently, do not promote it. Regularly, hybrid actors, such as cooperatives, complain that some laws (e.g., the banking law) do not take the specificities of the cooperative legal form into consideration and impose regulatory constraints which are not adapted to their specific legal form-either the law tackles an issue that is already implicitly solved by the legal form and, in so doing, still adds constraints and administrative burdens on the cooperative, which thus loses a competitive advantage, or its application in a cooperative is more burdensome than in a corporation and might even weaken the cooperative mindset.

In this context, instead of pushing for the creation of a rigid framework, the many burgeoning initiatives need to acknowledge their respective strengths and work together to strengthen the civil-society sector, which seems to suffer from the NPM and raising individualism.

As for research, there is no extensive and coordinated research project across SE approaches in Switzerland. Such a project might be a condition to increase the visibility and legitimacy of the SE field in general, beyond ideological boundaries and throughout the country, and to obtain substantive formal support from governments at the local, state and federal levels. 


\section{Conclusion}

In addition to the original conception of social enterprise in Switzerland, namely WISEs and, by extension, hybrid economic social-service actors, three new approaches contribute to making the SE concept both more visible and blurrier. On the one hand, the multiplication of definitions, criteria and umbrella structures makes it difficult to extract a full-yet coherent-definition of the sector that would allow social enterprise to gain specific support from authorities and increased legitimacy as a research field. On the other hand, this multiplication leads to increased visibility, which in turn fosters debates and challenges both traditional businesses and traditional NPOs to review their dichotomous conception of private actors, perhaps pulling many actors of these two spheres closer to the hybrid centre of social enterprise.

The most important conclusion from this study is that there is currently a shift in Switzerland from the original definition of social enterprise, confined to WISE, to a broader use, which included, in a first stage, other social-work organisations, and now also includes members of the three new movements observed in Switzerland, namely the SSE, the ECG and the social-entrepreneurship movements. Furthermore, we also observe a renewed interest, among various types of actors and industry sectors, for the cooperative form, because of its combination of economic and social characteristics.

\section{Notes}

1 All authors contributed equally to this chapter.

2 Due to length restrictions, only the main approaches and the main references are given in this chapter. A full version, including the development of the typology and detailed references and bibliography, can be found in Gonin and Gachet (2015).

3 "Social entrepreneurship" and "social entrepreneur" refer in this chapter to the specific movement that originated in the US/UK and that tends to dominate the literature in the Anglosphere.

4 Switzerland is a federal state composed of 26 states, called "cantons".

5 Interestingly, these constitutional provisions seem to focus on legal forms more than on a specific socio-economic approach. For example, the Constitutions of the Cantons of Vaud (art. 70) and Geneva (art. 211) state that associations are to be supported and volunteering promoted.

6 See detailed data of the Federal Statistical Office at https://www.bfs.admin. $\mathrm{ch} / \mathrm{bfs} / \mathrm{en} /$ home/statistics/work-income/unpaid-work/household-productionsatellite-account.html.

7 The triangle opposes the three main Polanyian principles of economic exchange, namely market, redistribution and reciprocity, and it positions three different kinds of actor according to the extent to which they rely on these three principles for their operation: the state, which is mainly a redistributive institution; private for-profit companies, whose operation is mainly based on the market logic; and the community, which is mainly based on reciprocity. Three axes differentiate the resources and rationales on which these actors 
rely to develop their activities: formal $v s$. informal, public $v s$. private and notfor-profit $v s$. for-profit (Defourny and Nyssens 2012).

8 See Chambre de l'économie sociale et solidaire Après-GE (2010, 2015), as well as Gachet and Gonin (2015b).

9 See http://apres-ge.ch/node/32136 and http://apres-ge.ch/node/34120.

10 This transparency is however limited, as the organisation can choose to have its financial reports examined by a fiduciary that certifies the fulfilment of the criteria, rather than submitting its reports to the APRES-GE management committee or to the public at large.

11 The criteria of transparency, collective interest/collective good, autonomy and limited profit must be met in order to join APRÈS-GE. The criteria of respect for the environment, participatory management and social management may not be fully met upon entry. In this case, organisations have 2 years to comply with them.

12 See the full matrix at https://www.ecogood.org/en/our-work/common-goodbalance-sheet/common-good-matrix/.

13 However, the subsidiarity principle mitigates any vision of a nationally enforced SE policy, and implies that regional differences will always remain.

14 Thirty-four percent of worldwide microfinance assets are managed by funds located in Switzerland (Symbiotics Research \& Advisory S.A., 2018; see also networks such as Sustainable Finance in Geneva). In addition, networks such as the network wise impact the philanthropy field by promoting impact-oriented philanthropy (see https://www.ville-geneve.ch/actualites/detail/article/1570091187building-bridges-semaine-finance-durable-geneve/).

15 In some cases, these funds have even put the profit objective above the social ones, causing tremendous damages among those who should have benefitted from these funds (see publications by Jean-Michel Servet [Graduate Institute, Geneva] and the Centre for Sustainable Finance and Private Wealth [University of Zurich]).

16 See https://www.bcorp-switzerland.ch, https://bestforgeneva.ch as well as Drayton and Budinich (2010) and Porter and Kramer (2011).

\section{References}

Baranzini, L. \& Swaton, S. (2013) “Définir la nouvelle économie sociale par les critères plutôt que par les statuts? Une analyse théorique à partir des critères retenus en Suisse par APRÈS-GE”, in Defalvard, H., L'Horty, Y., Legendre, F. \& Narcy, M. (eds) Les nouvelles frontières de l'économie sociale et solidaire, Louvain-la-Neuve: Presses universitaires de Louvain.

Battaglini, M. \& Dunand, C. (2005) "Les relations entre État et associations: Quels modèles pour quelles relations?”, Bulletin de La FEAS, Vol. 2, pp. 12-21.

Chambre de l'économie sociale et solidaire Après-GE (2010) Etude statistique. Photographie de l'économie sociale et solidaire à Genève, Geneva: Chambre de l'économie sociale et solidaire Après-GE.

Chambre de l'économie sociale et solidaire Après-GE (2015) Panorama de l'économie sociale et solidaire à Genève. Étude statistique 2015, Geneva: Chambre de l'économie sociale et solidaire Après-GE.

Defourny, J. \& Nyssens, M. (2010) "Conceptions of social enterprise and social entrepreneurship in Europe and the United States: Convergences 
and divergences", Journal of Social Entrepreneurship, Vol. 1, No. 1, pp. 32-53.

Defourny, J. \& Nyssens, M. (2012) "The EMES approach of social enterprise in a comparative perspective", EMES Working Papers Series, No. 12/03, Liège: EMES International Research Network.

Drayton, W. (2002) "The citizen sector: Becoming as entrepreneurial and competitive as business", California Management Review, Vol. 44, No. 3, pp. 120-132.

Drayton, B. \& Budinich, V. (2010) "A new alliance for global change", Harvard Business Review, Vol. 88, No. 9, pp. 56-64.

Felber, C. \& Maskin, E. (2015) Change Everything: Creating an Economy for the Common Good, London: Zed Books.

Gachet, N. \& Gonin, M. (eds) (2013) La coopérative, un modèle d'avenir? Colloque interdisciplinaire sur le présent et devenir des coopératives en Suisse romande, Lausanne: Université de Lausanne, projet ESS-VD.

Gachet, N. \& Gonin, M. (eds) (2015a) La gouvernance participative dans les coopératives. Colloque interdisciplinaire sur les défis et les bonnes pratiques en matière de gouvernance participative, Lausanne: Université de Lausanne, projet ESS-VD.

Gachet, N. \& Gonin, M. (2015b) Spécificités et contributions de la nébuleuse de l'économie sociale et solidaire. Une réflexion à partir du contexte vaudois, Lausanne: Université de Lausanne, projet ESS-VD.

Gonin, M. \& Erpf, P. (2018) "Sinnfindung und Sinngebung jenseits von Sektorendenken", in Gmür, M., Andessner, R., Greiling, D. \& Theuvsen, L. (eds) Wohin entwickelt sich der Dritte Sektor. Konzeptionelle und empirische Beiträge aus der Forschung, Fribourg: Verbandsmanagement Institut VMI, pp. 135-140.

Gonin, M. \& Gachet, N. (2015) "Social enterprise in Switzerland: An overview of existing streams, practices and institutional structures", ICSEM Working Papers, No. 03, Liège: The International Comparative Social Enterprise Models (ICSEM) Project. Available HTTP: http://www.iap-socent.be/sites/ default/files/Switzerland\%20-\%20Gonin\%20\%26\%20Gachet_0.pdf.

Helmig, B., Bärlocher, C. \& von Schnurbein, G. (2009) "Defining the nonprofit sector: Switzerland", Working Papers of the Johns Hopkins Comparative Nonprofit Sector Project, No. 46, Baltimore: The Johns Hopkins Center for Civil Society Studies.

Helmig, B., Lichtsteiner, H. \& Gmür, M. (eds) (2010) Der dritte Sektor der Schweiz. Länderstudie zum Johns Hopkins Comparative Nonprofit Sector Project (CNP), Bern: Haupt.

Perrot, M.-D., DuPasquier, J.-N., Joye, D., Leresche, J.-P. \& Rist, G. (eds) (2006) Ordres et désordres de l'esprit gestionnaire: où vont les métiers de la recherche, $d u$ social et de la santée, Lausanne: Editions Réalités sociales.

Porter, M. E. \& Kramer, M. R. (2011) "Creating shared value", Harvard Business Review, Vol. 89, No. 1/2, pp. 62-77.

Schön-Bühlmann, J. (2011) Le travail bénévole en Suisse en 2010, Report No. 425-1100, Neuchâtel: Office fédéral de la statistique. Available HTTP: https:// www.bfs.admin.ch/bfsstatic/dam/assets/348258/master. 
Stadelmann-Steffen, I., Traunmüller, R., Gundelach, B. \& Freitag, M. (2010) Freiwilligen-Monitor Schweiz 2010, Zürich: Seismo.

Swaton, S. (2011) Une entreprise peut-elle être "sociale" dans une économie de marché?, La Question, Charmey: L'hèbe.

Symbiotics Research \& Advisory S. A. (2018) 2018 Symbiotics Microfinance Investment MIV Survey, Market Data \& Peer Group Analysis, Geneva: Symbiotics. 


\title{
15 Social Enterprise in the UK Models and Trajectories
}

\author{
Mike Aiken, Roger Spear, Fergus Lyon, \\ Simon Teasdale, Richard Hazenberg, \\ Mike Bull and Anna Kopec Massey
}

\section{Introduction}

There is a growing interest in the social-enterprise (SE) arena in the UK, but this term encompasses a highly diverse community of organisations. In the Anglo-Saxon context, organisations have developed in different policy or business fields, with distinctive legal or governance models. They may also originate from very different historical periods. For example, some may be recent organisations setup with a specific SE focus and, in some cases, with a strong business orientation. At the other extreme, there are organisations with roots in charitable or cooperative entities founded in previous centuries, and these origins continue to affect their aspirations and organisational model today. Overall, the wide degree of variety and hybridity within the field has created difficulties in defining or counting social enterprises in the UK.

At a policy level, in the last 20 years, policymakers have moved from a position of relative neglect of social enterprises towards taking a strong interest in their development. Hence, there have been new or amended legal identities, encouragement for these organisations to acquire physical assets or engage in the delivery of public-sector services, and an endorsement at policy and practice level of the importance of these entrepreneurial organisations. It is also worth mentioning that social enterprises are more common in certain arenas of the economy (particularly in the field of human services) and less common in others (such as high-tech manufacturing), although there are exceptions.

It is also important to indicate the nature of devolved powers to the constituent countries within the UK over the last 20 years. This has led to some divergent policies towards social enterprises being pursued in Northern Ireland, Scotland and Wales. For simplicity, the discussion here mainly refers to the English situation, unless stated otherwise. 


\subsection{Different Types of Social Enterprise}

In some countries, a precise legal structure defines what is, and is not, a social enterprise. This is not the case in the UK, where social enterprises use a wide variety of legal forms. These include charities, charitable incorporated organisations, companies limited by guarantee (CLGs), community interest companies (CICs), industrial and provident societies (I\&PSs), companies limited by shares, sole traders and partnerships. The CIC, of which there are two types, is the only form specifically dedicated to social enterprise. A brief overview of these various legal forms is given here, before proceeding to discuss the contested narratives that surround the SE sector.

Charities form the most prominent part of the SE sector, and their legal structures have been enhanced to facilitate entrepreneurial activity through the new legal form of charitable incorporated organisation (CIO). However, many charities may not self-identify as social enterprises, partly because of the business-orientated definition of social enterprise in the UK.

Prior to the legislative changes that took place in 2014, cooperatives were formed under two legal structures: as companies limited by guarantee (CLGs) or as industrial and provident societies (I\&PSs). In August 2014, the Cooperative and Community Benefit Societies Act came into force. This was largely a consolidation of existing legislation. Since that date, new cooperative organisations have registered as either a " $\mathrm{CO}$ operative" or a "community benefit society", although existing I\&PSs have been permitted to retain that legal title if they wish. There is little substantive change. Cooperatives remain a small but important part of the SE population, and public-sector spin-outs may have multistakeholder forms with cooperative components.

The community interest company (CIC) legal form was specifically developed by the government to support the development of social enterprises and increase their visibility and legitimacy. This legislation has only existed for 10 years and is currently still used only by a small proportion of British social enterprises.

For-profit social enterprises-that is, companies limited by shares, sole traders and partnerships-constitute a relatively under-researched group, and they are not included in all definitions.

Policy narratives, mixed with cultural and historical factors, have played a strong role in shaping or contesting the nature of the field over the last 20 years (Teasdale 2012). Furthermore, Spear et al. (2014: 154) point to path dependency among social enterprises, where hybrid forms emerge from four main origins: mutualism and cooperativism; trading charities; public sector spin-offs; and new-start social enterprises. These origins, combined with dominant policy narratives, still play a role-rhetorically or otherwise-in shaping enterprises' practices (Spear 2011) and development trajectories. 
The remainder of this chapter is structured as follows. In section 15.2, an orientation is given via illustrations of social enterprises operating in three diverse fields. We then examine, in section 15.3, how social enterprises have been conceptualised in the UK by shifting narratives and social-policy changes, and we provide a brief analysis of the institutional trajectories of certain SE models, before some concluding remarks. The overview offered in this chapter is necessarily brief; however, a more detailed account is available in Spear et al. (2017).

\subsection{Illustrations of British Social Enterprises in Three Fields}

The British approach to social enterprise recognises the potential for forming social enterprises in a wide variety of areas. In this section, there are illustrations of social enterprises from three fields: work integration for disadvantaged people, community businesses and public services. Other fields-including the production or sale of fair-trade or ecological products or services-are also important in the British context but are not discussed here.

\subsubsection{Work-Integration Social Enterprises (WISEs)}

Work-integration social enterprises (WISEs) constitute a prominent field in many countries. These are organisations that aim to assist people on the margins of society to reintegrate into employment, and prevent their permanent exclusion from the labour market and civil society (Spear and Bidet 2005).

There are significant differences between the British field and its counterparts elsewhere in Europe. The goals and structures of WISEs in the UK have been significantly shaped by the unemployment rate, centralised labour-market policy and historical development of the field. WISEs have roots in worker cooperatives dating from the 19th century (Somers 2005; Aiken 2007). In the British policy environment, work integration has been highly centralised and subject to fluctuations arising from high unemployment (1980s); then low unemployment (mid-1990s to 2008); and, since the global recession, back to high unemployment or under-employment (Aiken 2007). At times, policy and funding focused on small numbers of severely disadvantaged people (low volume), while at other times, there was a concentration on large numbers, with strict outcome targets (high volume). WISEs tended to flourish in the first scenario and flounder in the second. The government's focus has tended to be on hard outputs (i.e., exact numbers of individuals placed into employment) (Spear 2001), while softer outcomes, such as increased selfefficacy and confidence, have not been valued (Hazenberg et al. 2013). 
Overall, the rapid changes in policy priorities and funding arrangements have hampered the stability of British WISEs.

\subsubsection{Community Businesses}

Community businesses are a highly successful model for local community development. They can be effective in motivating and supporting local communities by, typically, providing transport, shops or pubs. The approach involves members of the community taking a share in the organisation and playing a role in its governance. The community business typically develops various projects that address social-exclusion problems in disadvantaged inner-city and rural areas. This is a self-help approach to regeneration by strengthening community structures and services in a community/member-led, democratically controlled organisation. The model has also been used in parallel initiatives such as City Farms. Locality, one of the national umbrella bodies, sees these businesses as organisations run by and for their communities. They may receive support or start-up help by organisations such as Power to Change or Plunket Foundation.

\subsubsection{Social Enterprises Providing Public Services}

The UK has a very high level of public services delivered by independent private or third-sector organisations. Julius (2008) estimated that private-sector delivery (including delivery by the third sector) represented over $30 \%$ of total British public-sector expenditure. Only a small proportion of these services are delivered by social enterprises but this small share makes up a large proportion of SE activity. Social enterprises in this field have emerged from policy initiatives that sought to privatise or reform public services. Four types can be distinguished: first, housing associations, which are regulated charities that took over localauthority (municipal) housing; secondly, leisure trusts, which are staffcontrolled multi-stakeholder cooperatives that manage municipal leisure services; thirdly, academies and cooperative schools, which are multistakeholder charitable trusts with some parental and staff involvement in governance; and fourthly, public-service mutuals, which represent a recent spin-off from the public sector but are typically management-led, albeit with substantial staff ownership and participation.

Housing associations have Victorian philanthropic roots, including the Peabody Trust and Guinness Trust. The Thatcher government's privatisation of public-housing provision implicated these formerly independent non-profit organisations as providers of social housing, albeit within highly regulated markets. The government considered them to be part of the third sector (Mullins 2010), as did other third-sector researchers (Kendall and Knapp 1993, 1996). Yet Mullins (2010) argued 
that increases in scale, a decline of voluntarism and tight government regulation had distanced housing associations from the third sector.

Leisure trusts are staff-controlled, multi-stakeholder organisations for community benefit. Most emerged after 1993, when municipal leisure services were privatised. For example, Greenwich Leisure Ltd, a charitable social enterprise, has established 115 sport and leisure facilities. Their usual legal identity is an I\&PS or a CLG (Simmons 2008).

Academies and cooperative schools form the major part of the growing independent school sector. Since 1988, schools have been given the option to opt out of local government control and gain funding directly from central government. New Labour legislated for foundation (trust) schools in 1997; this was followed by legislation for academies, which are usually constituted as non-profit charitable trusts. The governance requirements of academies are based on business terminology and despite the possible presence of employee and parental representatives in governance, democratic control is limited. In contrast, at the time of writing, there were around 800 cooperative trust schools operating as multi-stakeholder charitable trusts, with more democratic and accountable structures, and a large proportion of the preschools and nurseries were also being run as social enterprises.

Public-service mutuals have emerged as spin-offs from the public sector amid new public management trends. They are active in health and social care alongside spin-offs from social work, probation, children and youth services, and libraries. Their precise legal form and management/stakeholder structures vary. Further, there are increasing numbers of public-service/third-sector hybrids (Spear 2015) with "mixed" characteristics. These include most hospitals, which have converted into foundation trusts, amid promises of greater financial and governance autonomy. Membership structures exist within highly marketised contexts. These mutuals claim "significant" employee control (Mutuals Task Force 2012: 8) but fewer user involvement features (Ellins and Ham 2009). The spin-out process, supported by $£ 100$ million (approximately $€ 116$ million) from the government's Social Enterprise Investment Fund, was often supported by senior staff (Hazenberg and Hall 2016). The scale of public spin-outs is large in terms of staff numbers and turnover. A survey of 27 health and social-care spin-outs found that their annual turnover averaged $£ 18$ million (about $€ 21$ million); most were registered as CICs (Social Enterprise UK/Dan Gregory 2013).

\subsection{History, Policy and Context}

In this section, we examine the changing narratives and social-policy shifts over the last 20 years in order to better understand how social enterprises have been conceptualised, as well as the current diversity and hybridity in the UK SE sector. 


\subsubsection{UK Concept of Social Enterprise}

Prior to the election of a Conservative-led coalition government in 2010, the UK-or, more precisely, England-was seen as having one of the most developed institutional support structures for social enterprise (Nicholls 2010). Despite this, a great deal of misunderstanding remains about the definition of a social enterprise, the number of social enterprises in the country and the legal structures they adopt.

Overall, the British discourse about social enterprise, from an international perspective, appears more business oriented than the EMES ideal type. That focus is clear in the government's definition of social enterprise:

A social enterprise is a business with primarily social objectives, whose surpluses are principally reinvested for that purpose in the business or in the community, rather than being driven by the need to maximise profit for shareholders and owners.

DTI (2002: 8)

This formulation differs from conceptualisations derived from notions of the social economy, which give greater prominence to governance or stakeholder engagement; the British conceptualisation, unlike the EMES model, focuses only on social and economic dimensions. Nevertheless, as many British third-sector social enterprises use non-profit or cooperative forms, the engagement of stakeholders is, in practice, mostly operationalised. The British definition also creates problems for organisations such as charities, which do not identify themselves as social enterprises because of the definitional focus on business.

The particularity of the British scene-that is, the absence of a governance-related dimension in the definition of social enterprise-also applies to the emblematic legal form of social enterprise in the UK, namely the community interest company (CIC). This type of social enterprise has an additional-but rather weak-requirement for a stakeholder report. It is also noteworthy that government statistics on social enterprises are collected through data from small-business surveys. This is consistent with a broader business-oriented conceptualisation of the field, which values the employee-ownership route of the John Lewis Partnership (a popular commercially-run chain of British retail stores with an employeestakeholder system) as well as for-profit models. Overall, though, the government's view contrasts with many academic and third-sector umbrella organisations, which emphasise the third-sector form of social enterprise.

It is useful to examine how the UK's definition of social enterprise is operationalised (particularly in surveys) and the issues this raises.

First, the organisation needs to be trading to generate a certain percentage of its income. The percentage of income requirement from 
trading by selling goods and/or services may range from $25 \%$ to $50 \%$ of the enterprise's income, depending on the particular type of social enterprise and criteria employed by a given agency. This includes trading in private markets and public-procurement markets. There also needs to be one or more paid workers, and this criterion is applied in reporting and analysis of survey data.

Secondly, the primary purpose of the organisation needs to be the pursuit of social/environmental goals, rather than purely for-profit goals. The definition explicitly includes environmental and social purposes. However, because businesses are not classified using Standard Industrial Classification (SIC) or International Classification of Non-profit Organisations (ICNPO), the social character of the goal depends on the assessment of the person responding to the survey.

Thirdly, the organisation should principally reinvest profits/surplus into the organisation or community to further social/environmental goals. Charities may not distribute profits. CICs are only allowed to distribute a maximum of $35 \%$ of profits; in practice, most CICs have no profit distribution at all. For-profit social enterprises have no regulation on the extent of their profit distribution.

Fourthly, some official surveys involving CICs also include a "selfidentification" criterion, asking if the organisation sees itself as a business with primary social/environmental objectives. For example, the British Annual Small Business Survey (ASBS) asks additional questions to identify social enterprises. However, this results in the inclusion in the SE sector of a large number of private-sector legal forms, which would not meet the definition used for entitlement to many forms of support and membership of the main SE associations, such as SEUK and SENSCOT (in Scotland).

These complexities point to difficulties in establishing what counts as a social enterprise and how many exist. A contrasting approach is to see them as part of the social economy or as part of a much larger third sector. This is common in the UK (particularly in Scotland) and within the EMES Network.

\subsubsection{Legal Structures}

Some countries have specific legal forms for social enterprises, which can thus be identified on this basis. In the UK, as mentioned above, a social enterprise may use a wide range of legal structures, even though only the community interest company (CIC) has been specifically designed to identify social enterprise. The other possible legal forms are: company limited by shares (CLS), public limited company (PLC), partnership, industrial and provident society (I\&PS), company limited by guarantee (CLG), friendly society and, since 2013 , charitable incorporated organisation $(\mathrm{CIO})$. 
In response to questions concerning (1) what counts as a social enterprise and (2) how many exist, recent surveys have adopted contrasting approaches. They have either used a sampling frame of the third sector or a sampling frame of businesses. This has led to two divergent estimates of the SE population, based on two broad types of social enterprise-with either a third-sector or a private-sector orientation.

There have been five widely different survey-based estimates of the population of social enterprise since 2005 in England, as summarised by Teasdale et al. (2013). The complexities of the different sampling frames and the vastly different number of totals of social enterprises that emerged from the different surveys are discussed elsewhere (Spear et al. 2017; Salamon and Sokolowski 2018).

\subsubsection{Understanding the British Context Through the Discourse-Historical Approach}

The legal structures and associated surveys, while helpful, do not provide clarity on the size or shape of the SE sector. Hence, a discourse-historical approach is taken to trace the development of social enterprise in England and Wales since the late 1990s by considering specific time periods (Ridley Duff and Bull 2011; Teasdale 2012; Sepulveda 2015). In this way, social enterprise is understood as a contested and flexible concept, which refers to various organisational types, at separate time periods, by different social actors. Below we explore the case of England in depth and then reflect on differences with Scotland.

\section{7-2000: The Construction of an SE "Movement"}

The first usage of "social enterprise" in ways close to contemporary usage has been traced to Freer Spreckley's writings (Ridley Duff and Bull 2011), in the late 1970s. However, it is Social Enterprise London (SEL), established in 1997 by cooperative practitioners, that brought the concept into popular usage (Ridley Duff and Bull 2011; Teasdale 2012). SEL's objects were

to promote cooperative solutions for economic and community development [and] to promote social enterprises, in particular cooperatives and common ownerships, social firms, and other organisations and businesses which put into practice the principles of participative democracy, equal opportunities and social justice (...).

Cited in Teasdale (2012: 109)

At this time, a network of people close to the New Labour government began to build on SEL's framework. They included Baroness Thornton 
(Labour Peer with a cooperative background), Ed Mayo and Andrea Westall (New Economics Foundation), and Patricia Hewitt (who later became a government minister); they all saw social enterprise as a possible model for mutual structures in public services.

As Roy et al. (2015) and Pearce (2003) identified, British social enterprise has also roots in the community-business movement in Ireland and Scotland. This led to the "development-trust" model, whereby community organisations owned or managed assets to encourage local regeneration. These organisations shared the democratic values of SEL's worker cooperatives, but had less reliance on trading income. The goals of community enterprises, when contrasted with those of worker cooperatives, were less radical, and they constituted "a response to market failure, rather than (...) an alternative to capitalism" (Teasdale 2012: 109).

The New Labour government, elected in 1997, initiated rapid policy change with strong commitments to social and economic reform. However, New Labour's "third-way" project also marked a rejection of state ownership and acceptance of market principles (Newman and Clarke 2007). This opened a policy space for SEL and their political allies. This broader notion of social enterprise held out the promise that these organisations could tackle regeneration in disadvantaged areas (Ridley Duff and Bull 2011). Within 18 months of SEL's formation, "social enterprise" was cited in the Neighbourhood Renewal Unit report (HM Treasury 1999), drawing from SEL's material (Brown 2003), but the range of organisational types had become significantly broader and now included large insurance mutuals, retail cooperatives, smaller cooperatives, employee-owned businesses, WISE projects, social firms and social-housing initiatives (HM Treasury 1999: 105).

A national SE strategy (Grenier 2009) was developed with representatives from cooperatives and development trusts, but also from social businesses where democratic ownership did not feature. The main focus was on organisational structures favoured by cooperatives and community enterprises (such as I\&PSs and CLGs), following the rationale that social enterprises mainly used these forms (IFF Research 2005). The SE construct had widened further.

\section{1-2005: Business Solutions to Social Problems}

In 2001 the Social Enterprise Unit (SEU) was formed and the construct still expanded to fully incorporate social businesses. The policy environment was receptive to the argument that the organisational form was irrelevant. This diluted the influence of cooperative and communityenterprise discourses, which emphasised participative processes (Pearce 2003). Critical voices began to see social enterprise as a neoliberal response to perceived state failure (Blackburn and Ram 2006). The policy 


\section{Aiken, Spear, Lyon, Teasdale, Hazenberg et al.}

emphasis favoured social-business discourses, although documentation still maintained that social enterprises embodied "stakeholder participation" and "democratic and participative management" (DTI 2002). Policymakers were constructing a platform to include all groups claiming to be social enterprises (Bland 2010). Meanwhile, government's interest was shifting to the role that these organisations could play in delivering public services.

In 2001, Patricia Hewitt was given SE development as a priority in her government role in the Department of Trade and Industry (DTI; see Bland 2010). Her Social Enterprise Unit (SEU) deliberately created a loose definition of social enterprise to include many organisational forms (DTI 2002). As noted by Brown (2003), after lobbying from different parts of the SE community, the DTI's definition of social enterprise (presented in section 15.3.1 and still in use today) had expanded. For instance, the reference to surpluses that must be "principally" reinvested in the business or in the community was, according to Brown (2003), intended to permit the inclusion of worker cooperatives, whose members have a financial stake in the enterprise, but this also allowed the inclusion of for-profit businesses with social objectives. The final version noted that social enterprises adopt a wide range of legal forms, including that of private "companies limited by share" (DTI 2002: 7). Hence, the social-business discourse, in which social and economic objectives were not mutually exclusive, gained ground. Furthermore, social enterprise began to be seen as a response to state, rather than market, failure. The new legal form initiated in 2005-namely the community interest company (CIC) - had no requirement for democratic control and ownership (Smith and Teasdale 2012).

\section{6-2009: Moving in with the Third Sector}

In a third phase, in 2006, responsibility for social enterprise was transferred to the Office of the Third Sector (OTS). The policy emphasis was on the fact that social enterprises were part of the broad "third sector". The SE construct widened to include earned-income discourses (see Defourny and Nyssens 2010) as an approach-to echo Lester Salamon's argument-to voluntary failure. The government needed to invest in capacity building in order to prepare these organisations for publicservice delivery. Infrastructure bodies, including the National Council for Voluntary Organisations (NCVO) and Social Enterprise UK (formerly Social Enterprise Coalition), received considerable resources for this work. Meanwhile, researchers identified links between social enterprise and public-sector privatisation (Haugh and Kitson 2007; Di Domenico et al. 2009).

Infrastructure organisations, such as the Charities Aid Foundation (CAF), had a long interest in alternative income streams for their 
members. By 2000, NCVO also used the "earned-income" discourse to encourage members in SE activities (NCVO 2010). Meanwhile, the Association of Chief Executives of Voluntary Organisations (ACEVO) encouraged voluntary organisations' role in public-service delivery by adopting SE terminology (Davies 2008; Ainsworth 2010).

This "earned-income" discourse marked a policy shift away from social business and cooperative/community enterprise and towards incorporating voluntary organisations as public-service deliverers, a position promoted by policy entrepreneurs (see Kingdon 1995). By 2009, the OTS' vision for public-service reform saw social enterprises as "innovative; entrepreneurial (...). [Social] justice is their guiding principle (...). They enable access to public services (...). They improve outcomes for those "hardest to help" (Office of the Third Sector [OTS] 2009: 1). Given these mythical attributes, what policymaker would dare ignore social enterprise as a policy tool?

\section{0-2015: New Government, Same Direction?}

A Conservative-led coalition government gained power in 2010, amid economic crisis and ambitions to cut public spending. The OTS, now renamed the "Office for Civil Society" (OCS), cut funding to infrastructure bodies, including Social Enterprise UK, although rhetorical support for social enterprise increased. The new prime minister, David Cameron, saw "Big Society" as a counterbalance to the "Big State" (Alcock 2012), with important roles for voluntary, community and SE organisations in delivering public services (Cabinet Office 2010; HM Government 2011). A new Conservative MP, Chris White, introduced a private-members bill to boost social enterprise through encouraging social-value measures in public procurement. However, due to the complexity of defining social enterprise and social value, these notions remained vague, and commissioners of public services were free to decide whether organisations from the third sector, democratically-owned cooperatives and large private-sector corporations created social value. Much attention shifted to finance instruments for social enterprises with the formation of Big Society Capital, which provided wholesale finance to lending intermediaries.

\section{6-2018: A Period of Uncertainty}

A new conservative government continued with austerity policies, resulting in a continued decline in SE support and an emphasis on social investment or repayable finance for social enterprises. SE policy was distanced from the "centre" of government when the Office for Civil Society was moved from the Cabinet Office to the Department for Digital, Culture, Media and Sport. As public policy became increasingly 
focused on Brexit plans for leaving the European Union, less attention was given to social enterprise. Exceptions include, firstly, the push to boost community businesses by Power to Change Trust's large investment aimed at supporting the spin-out of public services from government and, secondly, the ongoing interest in social investment.

Social enterprise remains a contested concept, whose meaning is culturally, historically and politically variable. In some respects, the English discourse has moved closer to that in the US, construed as liberal (Defourny and Nyssens 2010). However, the socially contested nature of social enterprise is typified within the UK context by the differing experiences of Scotland and England. Indeed, Scotland has seen the emergence of a less business-centric "community-business" model, which is grounded in this country's differing legal and historical traditions and greater commitment to localism, and has a greater focus on collective social outcomes than its English counterparts, which are more individualistic and economically focused (Hazenberg et al. 2016).

In summary, British developments have included creating favourable legal and regulatory mechanisms and encouraging non-governmental actors in public procurement. Support, delivered via infrastructure organisations, sought to strengthen social enterprises through business training, capacity building, development of a supportive ecosystem, and finance and funding. Capacity building aimed to scale up impacts, and achievements have been celebrated through awards and public events.

Social investment, grant-based finance and repayable loans made available through philanthropic funds and social investment banks (such as Triodos or Charity Bank) have been important; such finance mechanisms range from grant-like funds to commercial loans/equity finance (Nicholls 2009; Nicholls et al. 2015). However, demand-side constraints remain, as trustees or board members are cautious about loans for initiatives involving risk (Lyon and Owen 2019).

\section{Conclusion}

This chapter offers a brief review of important features of the British SE sector and examines the changing discourses surrounding social enterprises' trajectories. The British case has sometimes been presented as an exemplary model of SE development; however, a more critical perspective reveals ambiguities and challenges.

The development of SE policy within the Department of Trade and Industry led to a business-oriented definition that has affected subsequent developments. From the late 1990s onward, government discourses led to broad understandings of the notion of social enterprise and ambiguous data about the number of these initiatives. At different times, policymakers emphasised the social goals of cooperatives; cited the importance of community businesses for addressing market failures 
in disadvantaged communities; incorporated the charitable sector into the SE arena; enhanced capacity building in charities to "reform" publicservice delivery; or advocated the role of business models in publicservice provision, encouraging the spinning out of public-sector services, by contracting out or transferring parts of these services to private-sector organisations and social enterprises. As was noted earlier, the experience in Scotland-where there has been a greater focus on community business and less focus on public-service delivery-has been very different from that in England and Wales.

Policy discourse helped shape extensive support for social enterprise and legitimise different types. However, this downplayed wider factors that influence practice, including international movements of social entrepreneurship, traditional patterns of community self-help, and collective entrepreneurship supported by voluntary and cooperative institutions. Legal structures remain very flexible, and this institutional framework has resulted in a high degree of hybridity in the sector. The creation of the CIC legal identity accepts two legal forms (i.e., a company limited by guarantee or a company limited by shares) and, due to the fact that this legislation is relatively recent, only covers a minority of social enterprises.

Extensive policy attention has been given to transforming the voluntary and charitable sector towards markets and mixed economies. However, the responses have been mixed, with some resistance (Oliver 1991; Buckingham 2010). Indeed, the reconfiguration of charities towards SE models has been problematic for some (Spear 2016), and questions remain about democratic deficits in public-sector spin-outs. Furthermore, there is evidence of the scope of WISEs and social enterprises working in welfare services being reduced and of less new social cooperatives being created than in the past decades. However, in a period of public-sector austerity and recession, social enterprises have continued to grow. Looking ahead, the high degree of hybridity among social enterprises raises questions about future trajectories. Will there be convergence or institutionalisation of types of social enterprise, or semipermanent hybridisation? The diversity of social enterprise may continue with social entrepreneurs in different parts of the UK finding different ways to combine the social and commercial objectives in order to have an impact.

\section{References}

Aiken, M. (2007) What is the role of social enterprise in funding, creating and maintaining employment for disadvantaged groups? Available HTTP: https:// emes.net/publications/members-publications/dr-mike-aiken-think-piece-what-isthe-role-of-social-enterprise-in-finding-creating-and-maintaining-employment-fordisadvantaged-groups/ (accessed August 20, 2020). 
Ainsworth, D. (2010) "New social enterprise model proposed for public services", Third Sector, May 18. Available HTTP: https://www.thirdsector.co.uk/newsocial-enterprise-model-proposed-public-services/finance/article/1003522.

Alcock, P. (2012) “The Big Society: A new policy environment for the third sector", TSRC Working Paper, No. 82, Birmingham: University of Birmingham.

Blackburn, R. \& Ram, M. (2006) "Fix or fixation? The contributions and limitations of entrepreneurship and small firms to combating social exclusion", Entrepreneurship and Regional Development, Vol. 18, No. 1, pp. 73-89.

Bland, J. (2010) Social Enterprise Solutions for 21st Century Challenges: The UK Model of Social Enterprise and Experience, Finland: Ministry of Employment and Economy.

Brown, J. (2003) "Defining social enterprise", Paper presented at the Small Business and Entrepreneurship Development Conference, Guildford: University of Surrey.

Buckingham, H. (2010) "Capturing diversity: A typology of third sector organisations", TSRC Working Paper, No. 41, Birmingham: Third Sector Research Centre, University of Birmingham.

Cabinet Office (2010) Modernising Commissioning: Increasing the Role of Charities, Social Enterprise, Mutuals and Cooperatives in Public Service Delivery, London: HMSO.

Davies, S. (2008) "Contracting out services to the third and private sectors: A critique", Critical Social Policy, Vol. 28, No. 2, pp. 136-164.

Defourny, J. \& Nyssens, M. (2010) “Conceptions of social enterprise in Europe and the United States: Convergences and divergences", Journal of Social Entrepreneurship, Vol. 1, No. 1, pp. 32-53.

Di Domenico, M., Tracey, P. \& Haugh, H. (2009) "Social economy involvement in public service delivery”, Regional Studies, Vol. 43, No. 7, pp. 981-992.

DTI (2002) Social Enterprise: A Strategy for Success, London: Department for Trade and Industry.

Ellins, J. \& Ham, C. (2009) NHS Mutual - Engaging Staff and Aligning Incentives to Achieve Higher Levels of Performance, London: Nuffield Trust.

Grenier, P. (2009) "Social entrepreneurship in the UK: From rhetoric to reality", in Ziegler, R. (ed.) An Introduction to Social Entrepreneurship, Cheltenham: Edward Elgar.

Haugh, H. \& Kitson, M. (2007) "The third way and the third sector: New labour's economic policy and the social economy", Cambridge Journal of Economics, Vol. 31, No. 6, pp. 973-994.

Hazenberg, R., Bajwa-Patel, M., Roy, M. J., Mazzei, M. \& Baglioni, S. (2016) "A comparative overview of SE 'ecosystems' in Scotland and England: An evolutionary perspective”, International Review of Sociology, Vol. 26, No. 2, pp. 205-222.

Hazenberg, R. \& Hall, K. (2016) "Public service mutuals: Towards a theoretical understanding of the spin-out process", Policy \& Politics, Vol. 44, No. 3, pp. 441-464.

Hazenberg, R., Seddon, F. \& Denny, S. (2013) "Investigating the outcome performance of work-integration social enterprises (WISEs)", Public Management Review, Vol. 16, No. 6, pp. 876-899. 
HM Government (2011) Open Public Services White Paper, London: HMSO.

HM Treasury (1999) Enterprise and Social Exclusion, London: Neighbourhood Renewal Policy Action Team.

IFF Research (2005) A Survey of Social Enterprises Across the UK, London: Small Business Service.

Julius, D. (2008) Public Services Industry Review: Understanding the Public Services Industry, Department for Business, Enterprise and Regulatory Reform.

Kendall, J. \& Knapp, M. (1993) Defining the Nonprofit Sector: The United Kingdom, Baltimore: John Hopkins IPS.

Kendall, J. \& Knapp, M. (1996) The Voluntary Sector in the United Kingdom, Manchester: Manchester University Press.

Kingdon, J. (1995) Agendas, Alternatives and the Public Policies, 2nd ed., London: Longman.

Lyon, F. \& Owen, R. (2019) "Financing social enterprises and the demand for social investment", Strategic Change, Vol. 28, No. 1, pp. 47-57.

Mullins, D. (2010) “Housing associations", TSRC Working Paper, No. 16. Available HTTP: https://www.birmingham.ac.uk/documents/college-socialsciences/social-policy/tsrc/working-papers/working-paper-16.pdf.

Mutuals Task Force (2012) Public Service Mutuals: The Next Steps. Available HTTP: https://assets.publishing.service.gov.uk/government/uploads/system/ uploads/attachment_data/file/61776/Public-Service-Mutuals-next-steps.pdf (accessed November 4, 2019).

NCVO (2010) Sustainable Funding Project, London: NCVO. Available HTTP: https://www.ncvo.org.uk/advice-support/fundingfinance/sustainable-funding (accessed April 1, 2011).

Newman, J. \& Clarke, J. (2007) Creating Citizen-Consumers: Changing Relationships and Identifications. London, Sage.

Nicholls, A. (2009) “'We do good things, don't we?': 'Blended Value Accounting' in social entrepreneurship”, Accounting, Organizations and Society, Vol. 34, No. 6-7, pp. 755-769.

Nicholls, A. (2010) "Institutionalizing social entrepreneurship in regulatory space: Reporting and disclosure by community interest companies", Accounting, Organizations and Society, Vol. 35, No. 4, pp. 394-415.

Nicholls, A., Paton, R. \& Emerson J. (2015) Social Finance, Oxford: Oxford University Press.

Office of the Third Sector (OTS) (2009) Enterprising Services, London: Cabinet Office.

Oliver, C. (1991) "Strategic responses to institutional processes", Academy of Management Review, Vol. 16, No. 1, pp. 145-179.

Pearce, J. (2003) Social Enterprise in Anytown, London: Gulbenkian Foundation.

Ridley Duff, R. \& Bull, M. (2011) Understanding Social Enterprise: Theory and Practice, London: Sage.

Roy, M., McHugh, N., Huckfield, L., Kay, A. \& Donaldson, C. (2015) “The most supportive environment in the world...?", Voluntas, Vol. 26, No. 3, pp. $777-800$. 
Salamon, L. S. \& Sokolowski, W. (2018) "Beyond nonprofits: In search of the third sector”, in Enjolras, B., Salamon, L. M., Sivesind, K. H. \& Zimmer, A. (eds) The Third Sector as a Renewable Resource for Europe, London: Palgrave Macmillan, pp. 7-48.

Sepulveda, L. (2015) "Social Enterprise-A new phenomenon in the field of economic and social welfare?", Social Policy \& Administration, Vol. 49, No. 7, pp. 842-861.

Simmons, R. (2008) "Harnessing social enterprise for local public services: The case of new leisure trusts in the UK", Public Policy and Administration, Vol. 23, No. 3, pp. 278-301.

Smith, G. \& Teasdale, S. (2012) "Associative democracy and the social economy: Exploring the regulatory challenge", Economy and Society, Vol. 41, No. 2, pp. 151-176.

Social Enterprise UK/Dan Gregory (2013) Spin Out, Step Up, London: SEUK.

Somers, A. B. (2005) "Shaping the balance scorecard for use in UK social enterprises", Social Enterprise Journal, Vol. 1, No. 1, pp. 43-56.

Spear, R. (2001) "United Kingdom: A wide range of social enterprises", in Borzaga, C. \& Defourny, J. (eds) (2001) The Emergence of Social Enterprise, London: Routledge, pp. 312-332.

Spear, R. (2011) "Hybridité des coopératives”, in Blanc, J. \& Colongo, D. (eds) (2011) Les contributions des coopératives à une économie plurielle, Paris: L'Harmattan.

Spear, R. (2015) "Mapping social enterprise in the UK: Definitions, typologies and hybrids", in Bouchard, M. \& Rousselière, D. (eds) (2015) The Weight, Size and Scope of the Social Economy: an International Perspective, Brussels: Peter Lang.

Spear, R. (2016) "Critical reflections on the development of the social enterprise sector in the UK", Paper presented at the ISIRC Conference, Glasgow.

Spear, R. \& Bidet, E. (2005) "Social enterprises for work integration in 12 European countries: A descriptive analysis”, Annals of Public and Cooperative Economics, Vol. 76, No. 2, pp. 195-231.

Spear, R., Cornforth, C. \& Aiken, M. (2014) "Major perspectives on governance of social enterprise", in Defourny, J., Hulgård, L. \& Pestoff, V. (eds) Social Enterprise and the Third Sector: Changing European Landscapes in a Comparative Perspective, London: Routledge.

Spear, R., Teasdale, S., Lyon, F., Hazenberg, R. G., Bull, M., Aiken, M., and Kopec-Massey A. (2017) "Social enterprise in the UK: Models and trajectories”, ICSEM Working Papers, No. 40, Liege: The International Comparative Social Enterprise Models (ICSEM) Project.

Teasdale, S. (2012) "What's in a name? Making sense of social enterprise discourses”, Public Policy and Administration, Vol. 27, No. 2, pp. 99-119.

Teasdale, S., Lyon, F. \& Baldock, R. (2013) "Playing with numbers: A methodological critique of the social enterprise growth myth", Journal of Social Entrepreneurship, Vol. 4, No. 2, pp. 113-131. 


\section{Part II \\ Comparative Analyses and Perspectives}




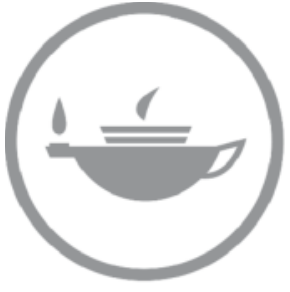

Taylor \& Francis Taylor \& Francis Group http://taylorandfrancis.com 


\title{
16 Social Enterprises in France, Portugal and Spain
}

\author{
Between Path Dependence and \\ Institutional Creation?
}

\author{
Francesca Petrella, Nadine Richez-Battesti, \\ Marta Solórzano-García and \\ Sílvia Ferreira
}

\section{Introduction}

Social enterprise (SE) is a notion that has been little discussed in France, Spain and Portugal by comparison with other national contexts. In this chapter, we first explain that this situation can be accounted for by a strong social-economy tradition in these three countries-which also share the fact that the social economy as a sector has recently been institutionalised through the adoption of a specific law (in 2011 in Spain, 2013 in Portugal and 2014 in France). A majority of French, Spanish and Portuguese organisations that display the characteristics of the ideal-typical social enterprise such as they have been described in the EMES approach are recognised as social-economy organisations. Nevertheless, in the three countries, the notion of social enterprise is currently at the heart of important debates.

This chapter compares the emergence and development of social enterprise in France, Spain and Portugal, which is linked, to a large extent, to the social-economy tradition. These countries have also experienced the emergence of new initiatives, promoted by citizens willing to democratise society and contribute to its social transformation through solidarity practices that do not always adopt social-economy legal forms or traditions. Most of these initiatives are considered today as part of the solidarity economy. Finally, more recently, these countries have seen the emergence of socially innovative and more market-oriented enterprises, which are often described as social enterprises.

The guiding hypothesis of this chapter is that the notion of social enterprise, as initially conceptualised within the EMES International Research Network (Defourny 2004), is scarcely used in the three countries because it does not correspond to a stabilised approach and takes different forms and meanings. Building upon the country reports, we analyse social enterprises as organisations that are located between three poles that coexist in France, Spain and Portugal: the social economy, the solidarity economy and social entrepreneurship. 


\section{Petrella, Richez-Battesti et al.}

The criteria traditionally defining the social economy in France, Spain and Portugal are as follows: objective of serving the members or the community rather than making profit; managerial autonomy; democratic control by the members; primacy of persons and social objective over capital in the distribution of surpluses (CWES 1990; CEP-CMAF 2002). The definition of the social economy also takes into consideration the legal forms of the organisations (associations, cooperatives, mutuals, etc.). These criteria are included in these countries' framework laws, in the form of principles and legal forms.

The solidarity economy brings together all the activities contributing to the democratisation of the economy through citizens' involvement. It considers these activities from the point of view of their dual-economic and political-dimension (Dacheux and Laville 2003; Eme and Laville 2006); their legal form is not the basic criteria to define solidarityeconomy initiatives.

The aim of social entrepreneurship, as it is generally understood, is to create a profitable, market-oriented and innovative economic activity responding to social or environmental needs in the framework of a private initiative serving the general interest. In principle, at least part of the economic surpluses is reinvested into the social mission. In France, Spain and Portugal, the notion of social entrepreneurship is closely related to that of "social entrepreneur", which, as suggested by Mair and Marti (2006), focuses on the individual characteristics of the entrepreneur and on his/her behaviour. In the rest of this chapter, when mentioning "social entrepreneurship", we will bear this focus in mind.

Within this context, our aim is to identify what types of organisations could be considered as social enterprises in France, Portugal and Spain. Using the EMES ideal type of social enterprise as a basis to delineate the SE field in the three countries, we adopt a systemic and comparative point of view. The systemic approach drives us to analyse social enterprise as part of a system of interactive institutional agents. The comparative approach helps us to understand the common responses, materialised in SE models, to similar transformation processes of the environments.

This chapter is structured in four parts. First, we present our analytical framework, building upon an institutional perspective. In the second part, we briefly present the institutional and economic environments in France, Spain and Portugal, with a view to better understanding and comparing these countries. The third part identifies and presents the different SE models in the three countries. The last part concerns our major conclusions.

\subsection{An Institutional Framework}

One of the most consolidated theoretical approaches employed in the field of the social economy is provided by institutional theory (Powell 
and DiMaggio 1991; Scott 1995: 33). It suggests that institutions consist of cultural-cognitive, normative and regulative structures, activities and resources that provide stability and meaning to social life. Institutional environments are "characterised by the elaboration of rules and requirements to which individual organisations must conform in order to receive legitimacy and support" (Scott 1995: 132).

Institutional environments have a significant influence on the emergence and implementation of social initiatives (Borzaga and Defourny 2001; Mair and Marti 2006; Salamon and Sokolowski 2010; Kerlin 2013).

Our hypothesis is that institutional factors and organisational inertia have led social enterprises into a path-dependent process, in the sense that solutions adopted by social enterprises today are contingent on the past and on their institutional environment, and that they are selfreinforcing, leading to the persistence of social-economy traditions. However, we complete our analysis by introducing the agency and organisational levels into our study of the dynamics observed. We adopt a point of view based on a path-creation dynamic, considering that "actors mobilise the past not necessarily to repeat or avoid what happened but instead to generate new options" (Garud et al. 2010: 770). In other words, initial conditions are not simply imposed onto but "enacted" by the actors; indeed, although actors are embedded in their environment, contingent elements of the institutional environment are seen more as opportunities for new actions than as factors limiting them.

Building upon Skelcher and Smith (2015: 439), we consider SE models from an institutional-logic approach, as "contingent settlements between plural institutional logics within one organisational entity”. Each model is the result of the interaction between historical contingency, normative frames, organisational form and individual agency.

We analyse both the evolution of the institutional environment and that of the organisational fields in which social enterprises are embedded. We consider that path creation (or institutional creation) occurs when changes are observed within the field's boundaries (for instance when new entrants arrive in the field) or in the governance structures. Emerging SE models contribute to these changes in the organisational field (Scott et al. 2000: 24-25).

\subsection{Comparative Analysis of Environmental Evolutions: A Long Process of Institutionalisation Leading to Path Dependence}

While the relative size of the social economy is larger in France (around $10 \%$ of total employment) than in Spain (around 7\%) and Portugal (around 6\%), this sector has existed for a long time in all three countries, and it has undergone a long process of institutionalisation, a milestone of which was the adoption of a law dedicated to the social economy. ${ }^{1}$ 


\section{Petrella, Richez-Battesti et al.}

This process of institutionalisation has been deeply marked, in all three countries, by a tradition of collaboration between social-welfare social-economy organisations and public authorities in relation to the expansion of the welfare state. France is characterised by a corporatist welfare-state regime relying on social-security contributions from employers and employees and on the presence of associations, which benefit from significant public support and are major providers of social services, complementing public provision. Spain and Portugal have a Mediterranean welfare-state regime, characterised by the presence of elements of corporatism and gaps in terms of protection; the welfare system developed belatedly, the role of civil society is limited and social organisations show a strong dependence on public administrations (Ruiz Olabuenaga 2006; Ferreira 2015).

The change in the political scene and the new economic situation in Spain during the 1970s led to the rise of social-economy organisations and generated new dynamics in their relations with the state. Four phases can be distinguished in the evolution of social-economy entities in the country. The first phase, namely the phase of emergence (1970-1980), refers to the period when, following the fall of the dictatorial regime, Spanish civil society emerged with a renewed and mobilising strength. The second phase, namely that of consolidation (1980-1990), occurred after the political transition. Once democracy was established, a strong social demobilisation followed; it caused a transformation of the socialeconomy sector into organisational forms that were more "stable" (to the extent that they corresponded to legally recognised forms) but were characterised by low economic resources and poor social leadership. A phase of expansion (1990-2000) followed, during which a significant number of social entities became services providers for the public administration. Finally, the institutionalisation phase (from 2000 onward) started when legislation for the sector was adopted; the sector became recognised as a legitimate interlocutor for public and private bodies (Rodríguez Cabrero 2003).

In Portugal, social-economy organisations already existed in the 19th century, but the dictatorship (1926-1974) limited their development until the Democratic Revolution. As in Spain, the social economy then re-emerged and evolved towards an increasing role for some organisations in the provision of social services and an increasing number of organisations. Nevertheless, the field remained fragmented until 2010. With the support of the government and political parties and the mobilisation of the main actors of the sector, a range of bodies and policies dedicated to the social economy were set up then, including the Framework Law on the Social Economy. A new institutional path was initiated, reinforced by latent institutional elements (Ferreira 2015). The concepts of "solidarity economy" and "social enterprise", though, were left outside the Framework Law on the Social Economy. 
France adopted a similar path of institutionalisation of what is now referred to as the "social and solidarity economy". Although the concept of social economy had already appeared in the 19th century, its development is inseparable from the emergence of the state/market synergy during the "Glorious Thirty", that is, the 30 years (from 1945 to 1975) following the end of World War II, which were marked by rapid economic growth in France. The social economy became stabilised as a set of organisations whose operating rules were distinct from those of commercial enterprises, but their scope remained limited. In 1981, social-economy organisations (mutual societies, cooperatives and associations), which had expanded, were recognised as belonging to a common sector through a "Charter of the social economy". After 1981, the social economy was consolidated, but with a tendency towards banalisation and isomorphism with either commercial enterprises (for cooperatives in particular) or public services (for welfare-services associations). The solidarity economy emerged in a context of crisis in reaction to these tendencies; it emphasised participation and social transformation. The alliance of the social economy and the solidarity economy appeared necessary to strengthen their position in the dialogue with public bodies; a compromise was reached in the 2000s on the term "social and solidarity economy" (SSE), which was consolidated by the Law on the Social and Solidarity Economy in July 2014 (for more details, see Fraisse et al. 2016). This process has structured the relationship of the French SSE with the public sector, providing the system with greater stability.

In the three countries, the institutionalisation process has also led to the regulation of social-economy organisations, to their diversification and increasing complexity, and to a trend towards their professionalisation and specialisation, in particular for welfare-services associations. In Spain and France, during the last two decades, social-economy organisations have evolved from voluntary-based associations to more professionalised and efficient ones. In Portugal, a similar trend has been at work since the 1980s, due to the combined effect of the central role of these organisations in the welfare state and of the scarcity of state funding. Since the 2010s, there has been a shift from a discourse emphasising social-economy organisations' role in social welfare to a discourse focusing on their role in the economy (Ferreira 2015).

Many organisations have become service-providing non-profit "businesses", increasingly giving importance to their members' professional qualification and replacing volunteers with paid workers (Salinas Ramos 2001; Rodríguez Cabrero 2003). The main sources of funding are however still public grants (Pérez Diaz and López Novo 2003; Marbán Gallego and Rodríguez Cabrero 2006) or a combination of public grants and user fees (Ferreira 2015).

From these perspectives, most social-economy organisations have revisited their models to adapt to their new environment. 


\section{Petrella, Richez-Battesti et al.}

\subsection{Models of Social Enterprise}

As a result of the evolution of institutional environments in the three studied countries, organisations meeting the EMES indicators of the ideal-typical social enterprise are mostly-but not only-social-economy organisations that had to adapt and experiment new organisational forms and new ideas. Different responses are identified along the axis between path dependence and path creation.

We identify four SE models, which are similar in the three countries. Indeed, although each model presents country-specific features, the transformation processes of traditional legal forms have been similar in France, Portugal and Spain. The first model includes specific forms of cooperatives, with more explicit social or general-interest goals than traditional cooperatives. The second model corresponds to entrepreneurial non-profit organisations, that is, associations (and some foundations) that carry out economic activities and strengthen their entrepreneurial dimension. The third model concerns WISEs, which have deeply changed in the last decade. The last model consists of social businesses or emerging forms of social enterprise-not all of which are considered to be part of the social economy.

\subsubsection{Social or General-Interest Cooperatives}

Historically, cooperatives were those social-economy organisations that typically carried out an economic activity on the market. Traditional cooperatives were mainly governed by one type of stakeholder (workers, consumers, producers). However, as in many other European countries, the need to take into account the interests of a plurality of stakeholders and to pursue a general-interest purpose under a cooperative form has gradually emerged in France, Spain and Portugal in the last decades.

In France, this led to the creation, in 2001, of a new legal form, namely the "collective-interest cooperative" (société coopérative d'interêt collectif, or SCIC). The objective of SCICs is the provision of goods or services of collective interest that have a social-utility character (Law of 17 July 2001). The economic activity is carried out to the benefit of the community rather than to the benefit of the organisation's members alone, and the social-utility character of the production is recognised by public authorities. This cooperative legal framework requires a multiplestakeholder ownership, with a governance by several possible "colleges", rooted in the territory in which they operate and representing the collective-interest dimension of the cooperative (Fraisse et al. 2016). Another new cooperative legal form was adopted in France and recognised by law in 2014 (Fraisse et al. 2016), namely the "activity and employment cooperative" (coopérative d'activité et d'emploi, or CAE), which aims to create jobs and support the creation and development of 
economic activities. The CAE is an original form: its members' status combines characteristics of the status of entrepreneur and of that of paid worker.

In Spain, national Law 27/1999 on Cooperatives recognises twelve types of cooperatives. Beside these types, the law introduces the status of social-initiative cooperative, which can be granted to any cooperative belonging to one of the twelve types (Solórzano-García et al. 2018a), provided that it meets the following requirements:

- The cooperative must be non-profit.

- The cooperative's social purpose must be to provide welfare services in health-related, educational, cultural or other activities of a social nature; or to develop any economic activity whose object is the work integration of people suffering from any kind of social exclusion; or, more generally, to satisfy social needs left unmet by the market.

In addition to national-level legislation, Spanish regional communities can develop their own legal framework for cooperatives, thereby introducing different approaches to social-initiative cooperatives. These initiatives can thus be referred to by different terms in the different regions-"social-interest", "social-integration", "social-services" or "social-welfare" cooperatives. The regulative framework for these initiatives is the relevant regional legislation.

In Portugal, the legislation has been slow to adapt to the emergence of cooperatives oriented towards the general interest. In legal terms, the only cooperative branch where cooperatives are assumed to be oriented towards the general interest is that of social-solidarity cooperatives, created in 1997 in the Cooperative Code, and inspired by a specific type of cooperative set up in 1975, namely the "cooperative for the education and rehabilitation of citizens with disabilities" (cooperativa de educação e reabilitação de cidadãos com incapacidade, or CERCI) (Perista 2001). CERCIs provide social services to vulnerable groups and communities, access to education, training and work inclusion. They have multistakeholder governance, involving workers and users. Another specific type of cooperative, namely that of public-interest cooperatives, legally created in 1984, is also characterised by a multi-stakeholder nature; another distinctive trait of these initiatives lies in the fact that they include public bodies among their members. On the other hand, cultural and consumption cooperatives may apply for the public-benefit status. Since 2000s there has been a blossoming of new cooperatives with environmental and local-sustainability missions that are framed in the traditional cooperative branches, and many describe themselves as pertaining to the solidarity economy. A change in the Cooperative Code in 2015 introduced the possibility to include, as full members of the cooperative, investors who contribute only with funding. This was also 
associated with a move towards market models as, in certain cooperative branches, the possibility of linking the voting power to the amount of shares owned was established for cooperatives with more than 20 members.

These examples illustrate the move from traditional, mutual-interest cooperatives to more social- or general-interest forms, as well as a move towards market models. The multi-stakeholder (instead of singlestakeholder) ownership and the collective (instead of mutual) interest can be seen as new institutional options for the cooperative form. These evolutions concern not only the regulatory dimension but also the normative and cognitive ones, since they lead to the emergence of new rules and new norms within the cooperative world. As cooperatives also involve new stakeholders, forms of path creation can be identified in terms of new alliances with public or commercial actors, who are offered the possibility to become members. Last but not least, these new organisational forms of cooperatives, in particular those with a clear social aim (social welfare, social services or job creation), contribute to redesigning public policies. Some others adopt a societal aim linked with the solidarity-economy movement.

\subsubsection{Entrepreneurial Non-Profit Organisations}

In France, Spain and Portugal, social services and neighbourhood services have hitherto been provided, to a large extent, by non-profit organisations (NPOs), which gained new impetus in the 1980s and 1990s.

The institutional developments of the 2000s led some segments of the non-profit sector to evolve in a more entrepreneurial direction and to change scale to position themselves on the market and better stand up to the growing competition.

In Spain, for the last several years, there has been a decline in the financial resources of the non-profit sector's entities. Partly due to a decline in support from the private sector (whose total amount has decreased by $11.7 \%$ between 2010 and 2013) and from the public sector, the total financial support to the non-profit sector has been reduced by $22.4 \%$ between 2008 and 2013. This has led to a change in this sector's revenue-raising strategies, which have become more oriented to selffinancing. In fact, self-financing from market activities increased by $47 \%$ between 2008 and 2013 (Solórzano-García et al. 2018b).

In France, the increase in public-procurement practices made up to some extent for the decrease in the traditional mode of financing by grants (Tchernonog and Prouteau 2019). Indeed, the share of public contracts in NPOs' total resource mix increased from $17 \%$ in 2005 to $24 \%$ in 2017 , while the proportion of public grants fell from $34 \%$ to $20 \%$. Such trends call NPOs' project into question, whenever their role becomes restricted to managing local services of general interest, defined 
in a top-down way by public authorities in the framework of public procurement and through managerial requirements. This evolution, combined with the entry of for-profit enterprises into sectors such as those of home-care services (Petrella 2012) or child-care services (Petrella et al. 2014), has led to a diversification of NPOs' strategies to such an extent that it is now sometimes difficult to describe the non-profit sector as a coherent whole. Several strategies of growth (through mergers or takeovers), mutualisation or grouping (through membership in a federation or the creation of territorial or sectoral networks) have been observed within the non-profit sector and have radically changed the structure of supply across the French territory (Richez-Battesti and Malo 2012).

These strategies, which have also been observed in Spain (Marbán Gallego and Rodríguez Cabrero 2013), are accompanied in both countries by cost-cutting rationalisation procedures and by the professionalisation of staff, governance bodies and management tools in most organisations. While this managerial and entrepreneurial turn now predominates in some sectors, it should also be stressed that not all nonprofit organisations have gone so far in this direction.

In Portugal, there is a close relationship between the welfare state and NPOs, which act as providers of social services and have developed gradually since the 1980s and more intensively since the end of the 1990s, as the state invested in this area. Since the 1990s, the offer of family social services (in terms of number of creches and care houses) increased substantially, as did the number of non-profit and for-profit providers. Social-service NPOs are awarded the special status of "private social-solidarity institution" (instituição particular de solidariedade social, or IPSS), and their relationship with the state is framed under a type of contract (namely cooperation agreements) mostly negotiated at the national level between the government and the umbrella bodies. Still, the share of state funding in NPOs' total income $(31.8 \%)$ is lower than the share of sales and user fees (63.6\%) (INE/CASES 2016), and it does not currently cover staff costs. The crisis that started in 2008 affected users' employment and income, which in turn impacted their ability to pay their share; as a result, many organisations have gone through — and are still undergoing-financial problems and are attracted to social entrepreneurship conceived as market-based earned-income strategies (Parente 2014). The new public-procurement rules for reserved contracts, in force since 2017, bring about competition among nonprofits as well as contractual arrangements that are more similar to market-based ones. Another subgroup of NPOs, more territorially oriented to local development, has been shaped by EU policies; they mostly operate under project funding and resort to commercial sources of funding as a complementary source of income. A recent development in this subsector is the development of these organisations' relation with the 
solidarity economy, for instance through gathering under the new solidarityeconomy network (Rede Portuguesa de Economia Solidária, or RedPES).

From the analysis of the French, Spanish and Portuguese cases, we identify a relatively common experience characterised by (1) the strengthening of NPOs' role as providers of services, which implies a progressive professionalisation of the non-profit sector; (2) a relative loss of NPOs' civic/political function; (3) a greater selective competition with the for-profit sector, simultaneously with the development of various forms of cooperation to develop social-inclusion projects; (4) an increasing competition among non-profit organisations, due to funding reductions, but with the emergence of new forms of cooperation and networking; and (5) a reorientation of social work, due to the emergence of new social needs, which demand more complex interventions.

In brief, the resource mix of entrepreneurial NPOs has changed deeply. Some of them grew in size and scale. In some cases, the social or political project and governance were also redefined with the aim of maintaining a strong civic or community-based institutional logic; some of them did so by adopting the principles of the solidarity economy. Relationships among organisations changed dramatically, and the boundaries of the sector changed as well with the entrance of for-profit enterprises in fields that had traditionally been occupied only by public or non-profit organisations. These elements can be interpreted as reflecting institutional creation, with new alliances with the for-profit sector and a more entrepreneurial mindset and management. Through their commitment to meet new or unmet social needs and their search for new financial resources, non-profit organisations contribute to the renewal of social policies and to blurring frontiers between the private, public and non-profit sectors. The emerging path they are charting is not without risk for themselves, since it can affect their very nature, based on voluntary engagement and on democratic principles, and their embeddedness in local and community networks. This (re)orientation of NPOs towards the market economy can also be observed amongst those adhering to the solidarity-economy framework, which is characterised by a stronger emphasis on experimenting with alternatives to the market economy.

\subsubsection{Work-integration social enterprises}

Work-integration social enterprises are no doubt one of the oldest SE models; the first WISE emerged in France in the late 1970s (Gardin et al. 2012), in Spain in the 1980s (Álvarez Vega 1999) and in Portugal in 1983 (Perista and Nogueira 2002). These organisations were progressively institutionalised in the 1990s as an instrument of employment and integration policies.

In France, the term used to refer to WISEs is "organisations for integration through economic activity” (structures d'insertion par l'activité économique). 
Today, four main types of WISE coexist and are recognised by the law on the social and solidarity economy: two of these types correspond to productive types of organisation (namely work-integration enterprises, or entreprises d'insertion, and work-integration workshops and work sites, or ateliers et chantiers d'insertion), while the other two types correspond to organisations that second workers to other organisations (intermediate voluntary organisations, or associations intermédiaires, and temporary work integration enterprises, or entreprises de travail temporaire d'insertion).

Most of these organisations are still operating under an associative (non-profit) legal form, but some adopt a commercial legal form. Some of the historic leaders of the work-integration field define themselves as social entrepreneurs; they are among the founders of the "Movement of social entrepreneurs" (Mouvement des entrepreneurs sociaux, or Mouves), a network of social entrepreneurs created in France in 2010. This "filiation" between work-integration enterprises and social entrepreneurship can be seen as a symptom of a mutation of the work-integration sector, moving beyond a mere role of "intermediation" on the labour market. The 2014 Law on the Social and Solidarity Economy clearly recognises WISEs as belonging to the field of the social and solidarity economy.

In Spain, two main types of WISE are recognised by law: WISEs targeting socially excluded groups, named "work-integration enterprises" (empresas de inserción, or EIs) and WISEs targeting people with disabilities (sheltered integration workshops), referred to as "special employment centres" (centros especiales de empleo).

EIs are regulated by national Law 44/2007. Autonomous communities also have some laws about EIs, which are more detailed developments of the national law. EIs have to be set up as trading companies (possible legal forms thus also include worker-owned companies or cooperatives) and, in order to be officially recognised as EIs, they have to meet specific criteria $(51 \%$ of their social capital must be held by a social organisation or a non-profit entity; more than $30 \%$ of their workforce- $50 \%$ from their fourth year of existence onwards-must be workers engaged in the employment integration process; and they cannot distribute more that $20 \%$ of their benefits); they have to develop an economic activity; and their main objective must be the integration and training of people who are at risk of social exclusion.

The second type of Spanish WISEs, namely special employment centres, was initially established by Law 13/1982 with the aim of pursuing the social integration of people with disabilities into the open employment market. They can adopt any legal form, and their owner(s) can be any natural or legal-public or private-person. They perform productive work, participate in commercial operations, and aim to provide remunerated positions and adequate personal and social services for workers with disabilities (who must constitute at least $70 \%$ of their staff). 
Like Spain, Portugal has work-integration enterprises for people who experience difficulty in gaining access to the labour market, and sheltered employment centres for people with disabilities. However, the Portuguese field of work integration is currently weak, unstructured and unrecognised.

Portuguese work-integration enterprises were set up in the context of a public policy that was terminated in 2015; they have experienced a sharp decline, from 512 in 2004 (Quintão 2008) to only a few enterprises nowadays (exact numbers are not known). Seventy-eight percent of workintegration enterprises were set up by NPOs; some of those that have survived until today have evolved to become non-profit's departments, and a few have become autonomous organisations. The only remaining public policy promoting this type of WISE and a network bringing together seventeen of these enterprises (which describe themselves as pertaining to the solidarity economy) are to be found in the region of Azores.

The second type of Portuguese WISEs, namely sheltered employment centres, are productive structures, most of which do not have an autonomous legal status: they are production units within not-for profit organisations. According to available information, there are less than ten sheltered employment centres in the country. Given the preference of public policy for work integration into the regular labour market, the core of the work carried out by social-economy organisations in this field consists of vocational training, work placement and support to the integration of disadvantaged people into mainstream enterprises.

In the three countries, WISEs developed in close relationship with public policies aiming to reintegrate workers on the labour market. In France and Spain, some WISEs adopt for-profit legal forms to access private capital but with strong governance safeguards and strict profitredistribution rules. This leads to the emergence of new organisational forms, highly professionalised and very innovative in the development of new fields of activities, which can be interpreted as a sign of a pathcreation institutional dynamic. In particular, new governance models are created out of traditional structures, such as commercial holdings or companies in which the majority (or a blocking-minority) shareholder is a non-profit organisation (or several NPOs). These new forms of WISEs also changed the relationship with public bodies, in a context of shrinking public subsidies. WISEs, faced with new entrants in their fields of activity, are contributing to institutional creation, changing relationships among stakeholders, and experimenting new alliances and new forms of governance structures.

\subsubsection{The Social-Entrepreneurship Model}

This fourth model of social enterprise generally emphasises the figure of the social entrepreneur, who is an individual with an entrepreneurial 
spirit dedicated to a social purpose. In the three countries under consideration, such individuals are "steeped" in the world of enterprise and understand how it works, but they aspire to producing useful answers in relation to the transformations of society.

Social entrepreneurs sometimes launch their activity in the form of an association and may go on to develop it within the statutory framework of a cooperative (such as a SCIC or a social cooperative) or as an equity company owned by the association from which it sprang or by the entrepreneur. Some of them may opt for the legal form of an equity company from the outset, or transform the original association into an equity company, or the association and the equity company can coexist. With few exceptions, the legal form appears to be secondary to the social mission. In parallel, consultancies and support organisations have emerged progressively since the early 2000s to support social entrepreneurship (also referred to as "social businesses").

The social-entrepreneurship model is probably, among the four models that we have identified, the one that is the least path-dependent on the social-economy tradition. Given the strength and importance of this tradition in the three countries considered, this can explain, at least partly, why there are so few social-business-type enterprises. However, social enterprises of this type, despite their low number, represent an important development, to the extent that they experience a new combination between market and social or societal institutional logics, leaving aside considerations about legal forms and democratic governance principles. This emerging model is a contentious issue in the social-economy sector.

\section{Conclusion}

This comparative work confirmed the relevance of analysing France, Spain and Portugal together, as they share important common features and transformation trends. Nevertheless, for each model, national specificities have also been found; they are linked to each country's particular environment and cultural traditions.

The strong heritage of the social economy and of its institutionalisation process influences the development of social enterprise, supporting the hypothesis of the existence of a path dependence that could be one reason why the "social-entrepreneurship" model (which, unlike the other three models, is not rooted in the social economy) has not developed-or only marginally - until now. As the models identified above show, most French, Portuguese and Spanish social enterprises are anchored, if not included, in the social economy. Indeed, the ecosystem created in the three countries to support the development of social-economy organisations contributes to the strong proximity of social enterprises with the social economy.

The three laws on the social economy aim to clarify the principles that characterise this sector and to define its boundaries in a changing 
environment. As far as the boundaries are concerned, the comparison shows some differences in the way commercial enterprises are considered. After several debates and consultations, it was decided, in France, to include commercial enterprises that meet certain governance and profitdistribution criteria in the social economy; by contrast, the Spanish and Portuguese parliaments chose to adopt a less inclusive approach.

But beyond this difference, social-economy principles remain predominant in the SE models identified during our study in the three countries. Democratic governance and limited profit distribution (for instance through an asset lock), included in the three laws, remain central to be recognised as a social enterprise in France, Spain and Portugal, since social enterprises are considered to be part of the social economy. The only exception is the small share of commercial enterprises with a social aim (which are part of the social-entrepreneurship model) that do not fulfil these criteria and are outside the social economy. By contrast with other approaches to social enterprise, which give priority to the social mission and to the entrepreneurial dimension, France, Spain and Portugal share the view that the social aim and social innovation are not sufficient for an organisation to be considered as a social enterprise.

Although, at first sight, the law can be considered to reduce the number of possible evolutionary trajectories, three out of the four SE models in the three countries studied can be seen as innovative or revisited models from the social economy, and as different strategic responses to face new environmental constraints. Among those constraints, cutbacks in public grants (and, in the case of France and Spain, the transformation of these grants into contracting-out processes) or the introduction of new performance and quality requirements have generated important organisational pressures. In general, these "new" forms of social-economy organisations, in comparison with their "traditional" counterparts, demonstrate a higher degree of professionalism; are more market-oriented; hybridise, on a larger scale, public and private resources; and involve, more frequently, multiple stakeholders. These evolutions can be understood as new options generated by the actors, in a path-creation process (Garud et al. 2010), while building upon the past. Institutional creation concerns new legal forms or institutional arrangements (such as mergers that change the boundaries of existing organisations), new governance models (e.g., implementing democracy in new ways), new resource mixes, new professions and more professionalised practices. At the organisational field level, important institutional creation has been highlighted in terms of changing relations among field organisations (with a nearly general increase of competition among them) and changing boundaries of the social economy (with the inclusion of some forprofit social enterprises) and of some activity fields, such as social services, where boundaries with the for-profit sector become blurred. The emergence of "social-economy-based" social enterprises illustrates the fact that, although the environment is complex and generates path dependence, the 
creativity and innovation demonstrated by some actors have led to the generation of new institutional paths for social enterprises.

These models are, in the end, not very different from the four SE models identified by Defourny and Nyssens (2017) in the ICSEM Project. We argue, however, that some characteristics of these models are specific to the countries considered, as they are linked to the "anchorage" of social enterprise in the social economy. As far as entrepreneurial non-profits are concerned, they are characterised in France, Portugal and Spain by a trend towards professionalisation and by their resource hybridisation (with a larger part of resources coming from public contracts), rather than by characteristics that can be observed in other countries, such as an increase in the share of market resources in their resource mix, the development of mission-unrelated activities, the creation of for-profit subsidiaries or an increased reliance on philanthropic and sponsoring resources. Social or general-interest cooperatives were created in Portugal, Spain and France after their emergence in Italy, but sooner than in other countries; this could be accounted for by the existence of a particularly strong cooperative tradition in these countries. Unlike Defourny and Nyssens (2017) in their identification of SE models at the global level, we have considered WISEs as a separate model, since they have followed their own development path, with roots in the associative sector (rather than in the cooperative one) and a relatively strong reliance on public policies supporting work integration. Finally, the fourth model-namely that of commercial social enterprises-is, at least for the time being, less developed than in other countries. It should also be noted that we have not identified any publicservice spin-off that could be considered as a social enterprise. Altogether, the social-economy tradition and specific interactions with public policies give a specific "colour" to the SE phenomenon in France, Portugal and Spain. These elements could also apply to Belgium and, to some extent, to Italy, where the social economy has also a long tradition. In countries where the social economy has long played an important role, the institutionalisation of this sector may have contributed to frame the development and the understanding of social enterprises.

\section{Note}

1 A detailed description of the French, Portuguese and Spanish legal frameworks can be found in chapters 4,11 and 12 , respectively.

\section{References}

Álvarez Vega, M. I. (1999) "Las empresas de inserción social como nueva forma de organización empresarial. Especial referencia a su régimen jurídico", CIRIEC-España, Revista de Debate sobre Economía Pública, Social y Cooperativa, Vol. 31, pp. 47-84. 
Borzaga, C. \& Defourny, J. (2001) The Emergence of Social Enterprise, London: Routledge.

CEP-CMAF (2002) Final Common Declaration of the European Organisations of Social Economy, Brussels, June 20.

CWES (1990) Rapport à l'Exécutif Régional Wallon sur le secteur de l'Économie Sociale, Liege: Conseil Wallon de l'Économie Sociale.

Dacheux, E. \& Laville, J.-L. (2003) Économie solidaire et démocratie, Meudon: Hermès, Vol. 36.

Defourny, J. (2004) “L'émergence du concept d'entreprise sociale", Reflets et Perspectives, Vol. XLIII, No. 3, pp. 9-23.

Defourny, J. \& Nyssens, M. (2017) "Fundamentals for an international typology of social enterprise models", Voluntas, Vol. 28, pp. 2469-2497.

Eme, B. \& Laville, J.-L. (2006) "L'économie solidaire", in Laville, J.-L. \& Cattani, A. D. (eds) Dictionnaire de l'autre économie, Paris: Gallimard, coll. "Folio", pp. 303-312.

Ferreira, S. (2015) "New paths for third-sector institutions in a welfare state in crisis: The case of Portugal", Nonprofit Policy Forum, Vol. 6, No. 2, pp. 213-241.

Fraisse, L., Gardin, L., Laville, J.-L., Petrella, F. \& Richez-Battesti, N. (2016) "Social enterprises: at the crossroads of social economy, solidarity economy and social entrepreneurship?”, ICSEM Working Paper Series, No. 34, Liege: The International Comparative Social Enterprise Models (ICSEM) Project.

Gardin, L., Laville, J.-L. \& Nyssens, M. (2012) Entreprise sociale et insertion, Une perspective internationale, Paris: Desclée De Brouwer.

Garud, R., Kumaraswamy, A. \& Karnøe, P. (2010) "Path dependence or path creation?", Journal of Management Studies, Vol. 47, No. 4, pp. 760-774.

INE/CASES (2016) Conta Satélite da Economia Social 2013, Lisbon: INE/CASES.

Kerlin, J. A. (2013) "Defining social enterprise across different contexts: A conceptual framework based on institutional factors", Nonprofit \& Voluntary Sector, Vol. 42, $\mathrm{n}^{\circ} 1$, pp. 84-108.

Mair, J. \& Marti, I. (2006) "Social entrepreneurship research: A source of explanation, prediction, and delight”, Journal of World Business, Vol. 41, No. 1, pp. 36-44.

Marbán Gallego, V. \& Rodríguez Cabrero, G. (2006) "Estado de bienestar y tercer sector social en España. El estado de la investigación social”, CIRIEC-España, Revista de Economía Pública, Social y Cooperativa, Vol. 56, pp. 117-139.

Marbán Gallego, V. \& Rodríguez Cabrero, G. (2013) "Sistemas mixtos de protección social. El tercer sector en la producción de bienestar”, Presupuesto y Gasto Público, Vol. 71, pp. 61-82.

Parente, C. (ed.) (2014) Empreendedorismo social em Portugal, Porto: Universidade do Porto, Faculdade de Letras.

Pérez Diaz, V. \& López Novo, J. P. (2003) El Tercer Sector Social en España, Madrid: Ministerio de Trabajo y Asuntos Sociales.

Perista, H. (2001) "Co-operatives for rehabilitation of people with disabilities", In Borzaga, C. \& Defourny, J. (2001) The Emergence of Social Enterprise, London: Routledge.

Perista, H. \& Nogueira, S. (2002) "National profiles of work integration social enterprises: Portugal”, EMES Working Papers Series, No. 02/09, Liege: The International EMES Research Network. 
Petrella, F. (ed.) (2012) Aide à domicile et services à la personne. Les associations dans la tourmente, Rennes: Presses Universitaires de Rennes, pp. 9-22.

Petrella, F., Richez-Battesti, N., Laurent, A., Chanut-Guieu, C. \& Lhuillier, V. (2014) "La construction sociale de la qualité dans les services d'accueil collectif du jeune enfant. Pluralité de modèles d'organisation et enjeux de gouvernance", Politiques sociales et familiales, Vol. 116, pp. 39-52.

Powell, W. \& DiMaggio, P. (eds) (1991) The New Institutionalism in Organizational Analysis, Chicago: University of Chicago Press.

Quintão, C. (2008) "Dez anos de empresas de inserção em Portugal-revisão dos dados oficiais e de estudos recentes", Paper presented at the VI Congresso Português de Sociologia, Lisbon, 25-28 June.

Richez-Battesti, N. \& Malo, M.-C. (2012) "ESS et mutations organisationnelles", RECMA - Revue Internationale de l'Economie Sociale, Vol. 325, pp. 36-47.

Rodríguez Cabrero, G. (ed.) (2003) Las entidades voluntarias de acción social en España, Madrid: Fundación FOESSA.

Ruiz Olabuenaga, J. I. (ed.) (2006) El sector no lucrativo en España. Una visión reciente, Bilbao: Fundación BBVA.

Salamon, L. \& Sokolowski, S. (2010) “The social origins of civil society: Explaining variations in the size and structure of the global civil society sector", Paper presented at the 9th International Conference of the International Society for Third Sector Research, Istanbul, July 7-10.

Salinas Ramos, F. (2001) "El sector no lucrativo en España: Características de una evolución”, Anuario de estudios cooperativos, Vol. (1), pp. 269-302.

Scott, W. R. (1995) Institutions and Organizations. Ideas, Interests and Identities, New York: Sage Publishing.

Scott, W. R., Ruef, M., Mendel, P. J. \& Caronna, C. (2000) Institutional Change and Healthcare Organizations: From Professional Dominance to Managed Care, Chicago: The University of Chicago Press.

Skelcher, C. \& Smith, S. R. (2015) “Theorizing hybridity: Institutional logics, complex organizations, and actor identities: The case of nonprofits", Public Administration, Vol. 93, No. 2, pp. 433-448.

Solórzano-García, M., Guzmán Alfonso, C., Savall Morera, T. \& Villajos Girona, E. (2018a) "Identidad de la empresa social en España: análisis desde cuatro realidades socioeconómicas", CIRIEC-España, Revista de Economía Pública, Social y Cooperativa, Vol. 92, pp. 155-182.

Solórzano-García, M., Navío-Marco, J. \& Valcárcel-Dueñas, M. (2018b) "Impact measurement for social innovation: Analysis of the Spanish third sector”, in La Torre, M. \& Calderini, M. (eds) Social Impact Investing Beyond the SIB, Basingstoke: Palgrave Macmillan, pp. 195-209.

Tchernonog, V. \& Prouteau L. (2019) Le paysage associatif français, mesures et évolutions, 3rd edition, Lyon: Juris-Editions Dalloz. 


\title{
17 Social Enterprise in Belgium, Germany and the Netherlands Where the Old Meets the New
}

\author{
Philip Marcel Karré
}

\section{Introduction}

This chapter ${ }^{1}$ discusses social enterprise in Belgium, Germany and the Netherlands and focuses especially on the relationship between social start-ups and more traditional organisational forms in the social economy or third sector. The three countries examined here share common borders and cultural traditions and, for better or worse, have a long common history. They are also all adherents of the economic system that has come to be known as "Rhine capitalism" or the "social-market economy", mixing regulated market capitalism with well-developed social policies ensuring both fair competition within the market and the existence of a quite comprehensive welfare system. This type of welfare state is based on the conservative/corporatist model (Esping-Andersen 1991; Evers and Laville 2004), with non-profit private organisations, mainly financed and regulated by public bodies, playing an important role in the provision of social services (Defourny and Nyssens 2010: 35). Such an approach is based on the Catholic principle of subsidiarity, that is, the idea that those closest to a problem are more likely to understand it and better situated relationally to deal with it (Sirico 2014) - hence, the idea that the social unit closest to the person in need (e.g., family, friends, non-profit organisations) should be the first port of call, and direct intervention by government, only the last resort (Zimmer 2013: 684).

Because of the part that private, non-profit bodies traditionally play in the welfare states of all three countries, organisations driven by social aims and playing a role in social-welfare provision do not constitute a new phenomenon in any of them. In international comparative research, Belgium and the Netherlands frequently lead rankings in terms of share of civil-society workforce in the economically active population, with Germany not far behind (Salamon and Sokolowski 2014).

In Belgium (as in neighbouring France), the so-called social economy has a long tradition, alongside the conventional economy, driven mostly by capital interest. Social services are provided both by public bodies and by a strong associative sector, heavily regulated and financed by the state. 
Germany and the Netherlands have also always had a strong third sector, beside the state and the market. In all three countries, citizens tend to organise themselves in associations, either for leisure or with societal or political goals. The Dutch are even world famous for their "polder model", in which non-profits play an important role: due to the fragmented nature of the country's society, which consists of several minorities without a dominant majority, the state does not provide social services itself, but funds services based on societal self-organisation.

Social enterprise as a term and concept has only been introduced in Germany and the Netherlands during the last 10 or 20 years, based on ideas developed in the Anglo-Saxon world and its liberal incarnation of the welfare state. In Belgium, though, the term has been used since the mid-1990s already. Indeed, Belgium has been one of the first countries to introduce a legal framework which recognised the possibility for commercial companies to be driven by social aims ("social-purpose companies").

Even though the term "social enterprise" (SE) has been embraced enthusiastically by some, it poses several difficulties for practitioners and academics alike in all three countries and is thus also often criticised. In this chapter, we will present the argument that this is mainly due to the fact that the term social enterprise and the ideology behind it were developed in a different context and a different type of welfare-state regime, where the dichotomy between public and private is much stronger than in Belgium, Germany or the Netherlands, and where the borders between the realms of state, market and society are therefore much more clearly defined and more impenetrable. We argue that, because of this and even though the concept of social enterprise is now widely used in all three countries, even by actors from the social economy itself, it remains fuzzy and contested.

We will discuss this argument in more detail by exploring the SE sector in these three countries, where the old and the new meet. What does the emergence of a new wave of social enterprise mean for the provision of social services, for the organisations already active in this field as well as for the newcomers operating under the label of social enterprise? We will first look at the historical roots and developments of social enterprise in Belgium, Germany and the Netherlands; then, we will discuss the rise of new-style social enterprises. We will examine what this development means and how it has changed the SE field in Belgium, Germany and the Netherlands and discuss the challenges and opportunities ahead.

\subsection{Historical Roots and Developments}

As mentioned before, Belgium, Germany and the Netherlands all adhere to a type of welfare-state regime in which private non-profit parties play an important role in the provision of social services. Consequently, in order to understand how these three countries perceive the notion of social enterprise, it is necessary to take a closer look at how their version 


\section{Karré}

of the welfare state developed and which types of organisations traditionally play an important role in it.

Non-profit organisations providing social services have existed in all three countries since the Middle Ages. Churches and other religious institutions, for example, played an important role in caring for the poor and the ill. However, there was no real system organising welfare based on individual rights. The poor, the sick and other disadvantaged groups in society relied heavily on the alms and goodwill of those in power. This changed when, due to the negative effects of the industrialisation, social problems such as poverty, illness and bad housing conditions became so severe that the state had to intervene.

Under German chancellor Otto von Bismarck, who tried to maintain traditional relations of authority against the modernist forces of liberalism and socialism (van Kersbergen and Vis 2015: 38), a first social security system was developed in Germany, which is now seen as the basis of the welfare state as we know it in many countries today, including Belgium and the Netherlands. This system was based on mandatory social insurance and supplied direct financial support to those in need through funding a wide range of in-kind benefits and subsidised services (Stolleis 2013). These services were and still are mostly delivered by non-governmental organisations, based on the already mentioned principle of subsidiarity, that is, the idea that social services should rather be provided by societal actors than by the state. Today, the following societal organisations play a role in the welfare states of Belgium, Germany and the Netherlands: voluntary associations, cooperatives, mutual-insurance companies, philanthropic organisations, work-inclusion and integration providers and community action groups (European Commission 2016, 2018, 2019). These different types of organisation will be examined in turn below.

\subsubsection{Voluntary Associations}

Voluntary associations, that is, associations established by a group of individuals (volunteers) to accomplish a specific purpose, were originally often set up by local churches or trade guilds but can now be found in many guises (e.g., football clubs and other sporting associations). During the 20th century, associations also played a pioneering role in the provision of many social services (health, youth centres, domiciliary care, nursing schools, etc.). In all three countries, a significant percentage of the population is still member of at least one association.

\subsubsection{Cooperatives}

Cooperatives were mainly set up in rural areas but were also established by small retailers and workers in cities with the idea that organising would give their members more bargaining power and the possibility to pool resources. 
Examples include consumer cooperatives, retail cooperatives, agricultural cooperatives and cooperative banks (based on the ideas of Friedrich Wilhelm Raiffeisen). In all three countries, the cooperative organisational form and the idea behind it were long seen as old fashioned, but they have experienced a revival recently. Beside more traditional cooperatives, such as cooperative banks and agricultural cooperatives, we now also find new cooperatives, for example, organisations trying to deal with social issues in urban communities or citizen cooperatives involved in short circuits or renewable energy.

\subsubsection{Mutual-Insurance Companies}

Mutual-insurance companies also have a long tradition in all three countries. By joining one of them, individuals can insure themselves and their families against the negative effects of all kinds of disasters, such as fire, poor health and death. These organisations are part, as such, of the social-security system.

\subsubsection{Philanthropic Organisations}

Philanthropists- private individuals who devote their time and money to charitable causes-also play an important role in the provision of welfare and other services, at least in Germany and the Netherlands. In most cases, they are industrialists who start their own foundation, but philanthropic activities can also be started by other types of actors, such as lotteries. In the Netherlands and Belgium, the royal houses also engage in philanthropic activities, though those are mostly funded by the taxpayer.

\subsubsection{Work-Inclusion and Integration Providers}

In the three countries analysed here, people with severe physical or mental handicaps can find opportunities for employment in sheltered workshops, and sheltered employment is the backbone of social services for these populations. The 1990s have seen the development of specific public programmes targeting the field of work-integration social enterprise (WISE) to help low-qualified unemployed people, who are at risk of permanent exclusion from the labour market, and to integrate these people into work and society through a productive activity (Nyssens 2006). This development of WISEs has even led in some cases, like in Belgium, to the concept of social enterprise being systematically associated with such employment-creation initiatives.

\subsubsection{Grassroots Initiatives}

Finally, since the 1970s, there have been many examples of citizens organising themselves in all sorts of grassroots initiatives, for example, 


\section{Karré}

advocating for certain environmental causes or fighting for the quality of life in a certain neighbourhood. These organisations mostly take the form of associations and sometimes turn to philanthropists for (part of) their funding.

\subsubsection{Hybridity as a General Characteristic}

All the organisational forms described above were originally independent from the state: they originated from civil society (e.g., associations, cooperatives) or the private sector (philanthropic organisations, cooperatives). Yet today, they are very much linked to it: they are indeed now often funded by the state and/or conduct activities at its behest and/or deal with public issues that traditionally fall under its purview (Brandsen 2010; Brandsen and Karré 2011; Billis and Rochester 2020; Karré 2020). The hybridisation of various logics that can be observed in these organisations occurred in two steps: In the first stage, organisations began to engage with the state and underwent a process of professionalisation and bureaucratisation (Smith 2014). Later, they were also expected to behave in a more entrepreneurial fashion and to become more market oriented in their activities, as new public management ideas of running government like a business took hold (Barzelay 2001; Christensen and Lægreid 2011).

Because of this hybridisation process, many organisations traditionally active in the social-welfare sector in Belgium, Germany and the Netherlands can now (and could perhaps already before) be called social enterprises, in the sense given to this concept by Defourny and Nyssens (2017), who see social enterprises as hybrid organisations located between the realms of state, market and society and mixing their institutional logics. We thus argue that there had already been social enterprises in all three countries before the rise of the "new-style social enterprises" that are described in the following section.

\subsection{The Rise of New-Style Social Enterprises}

A fairly recent development in Belgium, Germany and the Netherlands is the emergence, from the 1990s onwards and especially during the last 10 to 15 years, of "new-style social enterprises", linked to discussions about social innovation (Nicholls et al. 2015; Brandsen et al. 2016; Anheier et al. 2018). This is a notion inspired by experiences with product testing in the field of technology (Chesbrough 2003; Chesbrough et al. 2006; Howe 2008; Brown and Katz 2009), which postulates that social problems can only be solved by new constellations of social actors that have the freedom to develop new ideas and to test them in real-life settings, such as "living labs" (Bergvall-Kareborn and Stahlbrost 2009; Dutilleul et al. 2010; Puerari et al. 2018). 
These "new-style social enterprises" also strive to solve social problems through economic activity, but there is an important difference with the organisations described in the previous section. The latter-with the exception of cooperatives, which operated on the market from the outset—gradually evolved towards a more entrepreneurial stance mainly as a result of government policy, while the "new-style social enterprises" described in the present section were explicitly established for the purpose of solving social problems through commercial activity and were also explicitly framed as social enterprises from the outset. ${ }^{2}$ They are rooted in the discourse about bridging the divide between social and economic welfare creation through processes of social innovation as it has been developed in the Anglo-Saxon world. There, as already alluded to earlier, the realms of state, market and society are seen as distinct from one another and there is a strict dichotomy between the public and private spheres; in such a context, social enterprise is seen as a way to bridge that divide-which traditionally does not exist to the same extent in the three countries examined in this chapter. Another important difference between new-style social enterprises and their predecessors is that the former typically do not originate from the third sector but from the market sector, as they are established by socially-minded entrepreneurs. As such, they can be labelled as social businesses according to the SE typology put forward by Defourny and Nyssens (2017).

The school of thought on social enterprise as part of social innovation has been introduced in Belgium, Germany and the Netherlands by actors "from the outside", purposefully promoting it. Especially two non-profit foundations played a role in this, namely Ashoka and the Schwab Foundation for Social Entrepreneurship. The first is active in all three countries, while the second one is especially active in Belgium and Germany. Ashoka originates from the US and was founded by Bill Drayton, a management consultant who became a public manager, and who is said to have invented the term social enterprise. The Schwab Foundation was established by Klaus Schwab, who also founded the World Economic Forum (WEF), and his wife. In the Netherlands, Social Enterprise NL, a homegrown non-profit foundation established by Willemijn Verloop, a peace activist, and Mark Hillen, a former management consultant, played a major role in introducing and promoting social enterprise, though Ashoka and the Schwab Foundation are active there as well.

Of course, philanthropism by industrialists and entrepreneurs is no new phenomenon. However, what is new and noteworthy about Ashoka, the Schwab Foundation and Social Enterprise NL is that they do not use social enterprise to achieve certain societal goals; the promotion of social enterprise is their goal. Because of this, they also differentiate themselves from other institutions that promote corporate social responsibility (CSR), where social goals are also striven for but remain 


\section{Karré}

secondary to the organisation's financial goals. They seek to achieve this by various means. Ashoka, for example, affiliates individual social entrepreneurs into the Ashoka organisation and pays them a financial stipend so that they can focus on their activities as social entrepreneurs. The Schwab Foundation publishes research reports and practical guides aimed at helping to develop the skill set of social entrepreneurs. And Social Enterprise NL brands itself as the national membership and campaigning body for the SE movement in the Netherlands. In Belgium, Belgium Impact has recently been created to inspire and connect social entrepreneurs, and in Germany, the Social Entrepreneurship Netzwerk (SEND) aims to represent social entrepreneurs at the national level.

Due to the activities of organisations such as Ashoka, the Schwab Foundation and the national bodies advocating for social enterprise, there is now a-still relatively small but growing-support network for social enterprises in all three countries, which not only promotes the concept and the ideas behind it but also provides hands-on support. In the Netherlands, the buzz about social enterprise has even turned into a hype, with a whole industry of workshops, roundtables and inspirational sessions (ABN AMRO 2017: 5).

As a result of the abovementioned developments and lobbying activities, a small but growing number of new-style social enterprises or social businesses have come into existence in all three countries; they could perhaps best be described as social start-ups, as they have only recently been established in order to tackle certain social problems. They aim to generate their resources mostly through market income and mix a focus on the general interest with the private interest of their founder(s). These organisations can operate under any of the legal forms of their more traditional counterparts. So far, most of them have been established in urban or metropolitan areas. There are hardly any links with more traditional third-sector organisations; on the contrary, these newly established social enterprises often see themselves as antidotes not only to the state but also to service provision by more traditional non-profits, which they see as equally bureaucratic. In the following section, we will look in more detail at these social start-ups and the developments which they have instigated in the SE field.

\subsection{Developments in the SE Field}

Belgium, Germany and the Netherlands do not yet have a special legal form for social enterprises or policies regarding the SE phenomenon in its totality (in Belgium, there are laws and decrees but they relate to special legal forms of social enterprise only).

All three countries also have a wealth of hybrid organisations, located between the social and the economic realms, which, for all intents and purposes, can be called social enterprises, though they often do not use 
that label themselves. That makes establishing the exact number of social enterprises that can be found in each country an arduous task. In all three countries as well, the definition (inspired by the EMES approach) given by the European Union (European Commission 2020) is used when describing social enterprise, but this definition covers all sorts of organisations-traditional social-welfare providers, new cooperatives as well as social start-ups. And in all three countries, the number of organisations reported as being social enterprises differs widely from one estimate to the other. In Belgium, numbers range from the low thousands (between 2,210 and 3,170) to about 18,000 (see chapter 1 in the present volume), depending on the approach that is chosen. In Germany, estimates range from 2,000 to 70,000 social enterprises, based on either a stringent focus on social start-ups only or a more comprehensive approach that also counts traditional social enterprises (European Commission 2018: 57). And in the Netherlands, estimates range from a few hundred social enterprises to several thousands (see chapter 9).

There is no data available yet tallying different types of social enterprise following the typology put forward by Defourny and Nyssens (2017). Some organisations literally call themselves social enterprises or have used the EMES/EC definition as a guideline in setting up their organisational structure, which makes identifying them as such easier. The number of social enterprises rises if one also adds to the equation the more traditional forms of social enterprise that can be found in all three countries, even though they do not call themselves social enterprises (yet) but are active in fields and activities that can be seen as falling within the scope of social enterprise. However, such an approach makes it necessary for the researcher to deal with questions about definition and delineation which are far from straightforward (as described, e.g., in Dart et al. 2010). ${ }^{3}$

In all three countries, we see that the emergence of new-style social enterprises has brought the term social enterprise into the general consciousness and discussion; it had hitherto not been used broadly, even though organisations engaged in what we would now call social enterprise have existed for quite a while in these countries. Social startups and social businesses use the term to distinguish themselves from more traditional organisational forms in the third sector and social economy, which they often see as bureaucratic and not very innovative. They also often complain about facing competitive disadvantages in comparison with more traditional social-welfare providers (Karré and Van Meerkerk 2019). Indeed, as social businesses originating from the market sector, they do not adhere to the traditional ideas of organisations operating in the social-welfare sector and hence often face problems of recognition and awareness, especially in comparison with organisations that already have a long-standing history in that sector. And since their business models are innovative and non-traditional as 


\section{Karré}

well, they also face problems of funding: banks traditionally shy away from investing in risky ventures and impact investment is still in its infancy in all three countries.

Thanks to their modern lobby work and organisations, new social enterprises are often (social) media-savvy and know how to influence politics. This lobby work is mainly aimed at overcoming the abovementioned competitive disadvantages of social start-ups through obtaining special benefits for them, and fostering awareness and recognition. More traditional parties in the welfare sector sometimes criticise these new competitors for "commercialising" social-welfare provision and for "social-washing" commercial activities, but they sometimes call themselves social enterprises as well, especially as the term gathers more traction in the political discourse.

In Germany and the Netherlands, for example, discussions are currently taking place about establishing better support structures for social enterprises in general and about introducing a specific legal form for social enterprises, though these ideas are at very early stages at the moment. These discussions are instigated by SE lobby organisations such as Social Enterprise NL and SEND; they are complicated by the difficulty of defining what to consider as a social enterprise and what not and by debates about possible distortions of competition. Why grant special advantages—and perhaps even privileges- to social start-ups, for example, and not also to already existing players in socialwelfare provision? Why not grant special benefits as well to other enterprises that also try to influence society in a positive way, such as small businesses sponsoring local activities, even though their main business focus is on other activities than social ones (e.g., a baker sponsoring a local football team)? The main question here is whether social businesses can or should be seen as a group or subset of organisations that differ so significantly from more traditional organisations operating in social-welfare provision and have such a big beneficial impact on society that a special treatment is warranted. Whether attempts to develop a special legal form and a specific policy for social enterprises will be successful remains to be seen. In the Netherlands, attempts to devise a comparable special status for another set of hybrid organisations, namely "societal enterprises" (maatschappelijke ondernemingen), have ultimately failed due to similar delineation problems. Discussions are also underway about the motives of the new set of social enterprises, and about whether their activities herald a further commercialisation of the welfare state. As the idea behind social enterprise is seen by some with criticism, it seems unlikely that Belgium, Germany and the Netherlands will adopt in the near future a special legislation for social enterprises similar to the one that is currently found in the Anglo-Saxon world.

\section{Conclusion}

In this chapter, we examined the situation of social enterprise in three countries where new types of social start-ups or businesses are created in 
a context characterised by the previous existence of other organisations that can be considered as social enterprises, even though that term had not hitherto been used to refer to them-hence the chapter's subtitle, "where the old meets the new". What conclusions can be drawn? What is the relationship between old and new forms of social enterprise? Two main conclusions, each linked to recommendations, can be highlighted.

First, transplanting discourses and labels from one welfare-state regime to another is a difficult endeavour. Concepts and conceptualisations do not fit in their new habitat, resulting in friction, confusion and possibly rejection. Those participating in the discussion about social enterprise in Belgium, Germany and the Netherlands (be they entrepreneurs, policy makers, professionals in the social field or academics) should acknowledge that fact, as well as the existence of a wealth of organisations in the three countries that could be labelled social enterprises. More work needs to be done to distinguish between various types of social enterprise, to examine their respective strengths and weaknesses and the part that each of them can play in dealing with societal problems. Such approach appears potentially more fruitful than the ultimately futile quest to devise a special legal form that would encompass all the diversity of social enterprise-an endeavour that seems to be doomed to fail, given the ambiguity of the concept of social enterprise and the fragmentation of the SE sector in all three countries.

Secondly, discussions will have to be conducted on how the relationship between the new generation of social enterprises and the old one can become more productive and more fruitful. How can the two generations learn from one another and reinforce their respective individual efforts? Old and new types of social enterprise in Belgium, Germany and the Netherlands should not see each other as competitors but as supplementary actors, in a world in which societal problems are often ambiguous, complex, volatile, wicked, and have to be dealt with using various approaches (Koppenjan et al. 2019). This is a view that should also be adopted by policy makers. Combining the agility of social start-ups with the continuity and steadfastness of traditional social enterprises can create a world in which social issues are dealt with in various innovative ways, while avoiding the danger of commercialising social care or missing out on the advantages that fresh and creative new approaches to long-term social problems can yield (Osborne 2010; Edelenbos and van Meerkerk 2016).

\section{Acknowledgements}

The author wishes to thank the following persons for discussing this chapter at various stages: Nicole Göler von Ravensburg, Jacques Defourny, Benjamin Huybrechts, and especially Marthe Nyssens, who provided extensive and very valuable feedback on two draft versions of the text. Also many thanks to Sophie Adam for her conscientious 
proofreading and editing. All mistakes and omissions are, of course, very much my own fault.

\section{Notes}

1 This chapter is based on three individual country studies featured in this book (see chapters 1, 5 and 9, about Belgium, Germany and the Netherlands, respectively), as well as on three country reports and a subsequent comparative synthesis that are part of a research project, undertaken at the behest of the European Commission, mapping social enterprises and their ecosystems in Europe (European Commission 2016, 2018, 2019, 2020). It is also based on insights the author could gather in conversations with academic peers in all three countries as well as during a study visit he undertook as part of a team led by the OECD, conducting research on how to boost social enterprise and social innovation in the German federal state of Brandenburg.

2 Each country has its own terminology according to its language(s): "Sozialunternehmen" (German), "entreprise sociale" (French) and "sociale onderneming" (Dutch). The English term "social enterprise" is sometimes used as a substitute, especially in the rather Anglophile Netherlands. In Belgium, the term social business is also sometimes used as a substitute.

3 For information about how this question was addressed when mapping social enterprises in Germany, see appendix 2 of the mapping study published by the European Commission (2018: 116-118).

\section{References}

ABN AMRO (2017) De noodzaak van marktontwikkeling voor sociale ondernemingen. De romantiek voorbij, Amsterdam: ABN Amro.

Anheier, H. K., Krlev, G. \& Mildenberger, G. (2018) Social Innovation: Comparative Perspectives, New York: Routledge.

Barzelay, M. (2001) The New Public Management, Berkeley: University of California Press.

Bergvall-Kareborn, B. \& Stahlbrost, A. (2009) "Living Lab: An open and citizencentric approach for innovation", International Journal of Innovation and Regional Development, Vol. 1, No. 4, pp. 356-370.

Billis, D. \& Rochester, C. (eds) (2020) Handbook on Hybrid Organisations, Cheltenham: Edward Elgar Publishing.

Brandsen, T. (2010) "Hybridity/hybridization", in Anheier, H. K. \& Toepler, S. (eds) International Encyclopedia of Civil Society, New York: Springer US, pp. 839-842.

Brandsen, T. \& Karré, P. M. (2011) "Hybrid organizations: No cause for concern?", International Journal of Public Administration, Vol. 34, No. 13, pp. 827-836.

Brandsen, T., Cattacin, S., Evers, A. \& Zimmer, A. (2016) Social Innovations in the Urban Context, Heidelberg: Springer Verlag GmbH u. Co.

Brown, T. \& Katz, B. (2009) Change by Design: How Design Thinking Transforms Organizations and Inspires Innovation, New York: Harper Business.

Chesbrough, H. W. (2003) Open Innovation: The New Imperative for Creating and Profiting from Technology, Brighton: Harvard Business School Press. 
Chesbrough, H. W., Vanhaverbeke, W. \& West, J. (2006) Open Innovation Researching a New Paradigm, Oxford: Oxford University Press.

Christensen, T. \& Lægreid, P. (2011) The Ashgate Research Companion to New Public Management, Farnham: Ashgate.

Dart, R., Clow, E. \& Armstrong, A. (2010) "Meaningful difficulties in the mapping of social enterprises”, Social Enterprise Journal, Vol. 6, No. 3, pp. 186-193.

Defourny, J. \& Nyssens, M. (2010) “Conceptions of social enterprise and social entrepreneurship in Europe and the United States: Convergences and divergences", Journal of Social Entrepreneurship, Vol. 1, No. 1, pp. 32-53.

Defourny, J. \& Nyssens, M. (2017) "Fundamentals for an international typology of social enterprise models", VOLUNTAS: International Journal of Voluntary and Nonprofit Organizations, Vol. 28, No. 6, pp. 2469-2497.

Dutilleul, B., Birrer, F. A. J. \& Mensink, W. (2010) "Unpacking European Living Labs: Analysing innovation's social dimensions", Central European Journal of Public Policy, Vol. 4, No. 1, pp. 60-85.

Edelenbos, J. \& van Meerkerk, I. (2016) Critical Reflections on Interactive Governance, Cheltenham: Edward Elgar Publishing.

Esping-Andersen, G. (1991) The Three Worlds of Welfare Capitalism, Bristol: Polity Press.

European Commission (2016) Mapping Study on Social Enterprise EcosystemsUpdated Country Report on Belgium, Luxembourg: European Commission.

European Commission (2018) Social Enterprises and Their Ecosystems in Europe. Updated Country Report: Germany, Luxembourg: Publications Office of the European Union.

European Commission (2019) Social Enterprises and Their Ecosystems in Europe. Updated Country Report: The Netherlands, Luxembourg: Publications Office of the European Union.

European Commission (2020) Social Enterprises and Their Ecosystems in Europe-Comparative and Synthesis Report (authors: Borzaga, C., Galera, G., Franchini, B., Chiomento, S., Nogales, R. \& Carini, C.), Luxembourg: Publications Office of the European Union. Available HTTP: https://europa.eu/!Qq64ny.

Evers, A., \& Laville, J.-L. (2004) The Third Sector in Europe, Cheltenham: Edward Elgar Publishing.

Howe, J. (2008) Crowdsourcing: Why the Power of the Crowd Is Driving the Future of Business, New York: Crown Business.

Karré, P. M. (2020) "Chapter 2: Hybrid organisations: Between state and market", in Billis, D. \& Rochester, C. (eds) Handbook on Hybrid Organisations, Cheltenham: Edward Elgar Publishing, pp. 31-47.

Karré, P. M. \& Van Meerkerk, I. (2019) Samen werken aan de wijk. Een bestuurskundige reflectie op de relatie tussen wijkcoöperaties en gemeente in Rotterdam, Rotterdam: Kenniswerkplaats Leefbare Wijken.

Koppenjan, J., Karré, P. M. \& Termeer, K. (eds) (2019) Smart Hybridity: Potentials and Challenges of New Governance Arrangements, The Hague: Eleven International Publishing.

Nicholls, A., Caulier-Grice, J. \& Gabriel, M. (2015) New Frontiers in Social Innovation Research, London: Palgrave Macmillan.

Nyssens, M. (2006) Social Enterprise at the Crossroads of Market, Public Policies and Civil Society, London \& New York: Routledge. 
Osborne, S. P. (2010) The New Public Governance: Emerging Perspectives on the Theory and Practice of Public Governance, Abingdon: Routledge.

Puerari, E., de Koning, J., von Wirth, T., Karré, P., Mulder, I. \& Loorbach, D. (2018) "Co-creation dynamics in urban living labs", Sustainability, Vol. 10, No. 6, 1893.

Salamon, L. M. \& Sokolowski, S. W. (2014) Global Civil Society: Dimensions of the Non-Profit Sector, Volume 2, Baltimore: John Hopkins University.

Sirico, R. A. (2014) "Subsidiarity and the reform of the welfare of the nation state", in Evans, M. \& Zimmermann, A. (eds) Global Perspectives on Subsidiarity, Dordrecht, Netherlands: Springer, pp. 107-127.

Smith, S. R. (2014) "Hybridity and nonprofit organizations: The research agenda", American Behavioral Scientist, Vol. 58, No. 11, pp. 1494-1508.

Stolleis, M. (ed.) (2013) Origins of the German Welfare State: Social Policy in Germany to 1945, Berlin: Springer, pp. 23-176.

van Kersbergen, K. \& Vis, B. (2015) Comparative Welfare State Politics: Development, Opportunities, and Reform, Cambridge: Cambridge University Press.

Zimmer, A. (ed.) (2013) Civil Societies Compared: Germany and the Netherlands, Baden Baden: Nomos Verlagsgesellschaft. 


\title{
18 Between Coercive and Mimetic Institutional Isomorphism
}

\author{
Social Enterprise and the Universal \\ Scandinavian Welfare State
}

\author{
Bernard Enjolras, Linda Lundgaard \\ Andersen, Malin Gawell and Jill M. Loga
}

\section{Introduction}

Social enterprise (SE) is often depicted as combining entrepreneurial and social dimensions, and as operating between the market and the state (Baglioni 2017). Other characterisations (e.g., Nicholls 2006) underscore innovation and market orientation as major features of these initiatives. Social enterprises are innovative in that they generate new organisational forms and leverage market resources for the public good. In doing so, they "challenge the status-quo by reconfiguring accepted value creation boundaries (public/private, for-profit/non-profit, and economic/social)" (Nicholls 2006: 11). However, especially when social enterprises operate within a highly institutionalised ecosystem such as the Scandinavian welfare state, one should not overlook two critical issues related to this particular context: the issue of economic sustainability and the issue of institutional isomorphism.

Social enterprises' economic sustainability, especially for those social enterprises that provide welfare services, is significantly influenced by the institutional arrangements of the welfare state, as these arrangements constitute a major element of their ecosystem. First, the existing welfare arrangements define the opportunity structure for the development of social enterprises. The nature of social rights and benefits (whether they are universal, selective or subsidiary) guaranteed by the state and the type of welfare services that are the responsibility of the state ( $v s$. the citizen, family, community) define the scope of the potential "market" for social entrepreneurs. Secondly, welfare regimes institutionalise different forms of welfare mixes between for-profit, non-profit and public actors, involving different financing and regulatory schemes. Whether welfare services are provided exclusively by public agencies, by nonprofit actors, by for-profit actors or by a combination of public, nonprofit and for-profit actors is the result of sets of regulations that also limit or enable social enterprises.

Furthermore, social enterprises, when operating within the institutional framework of the Scandinavian welfare state, are likely to be 
subjected to different institutional isomorphic pressures (DiMaggio and Powell 1983). Institutional isomorphism refers to "an inexorable push toward homogenisation of institutional fields" driven by-in addition to the isomorphic force of market competition-three institutional isomorphic processes: coercive isomorphism, which stems from political influence and the problem of legitimacy (e.g., government regulation, legal environment and fiscal regulations); mimetic isomorphism, resulting from standard response to uncertainty (e.g., innovation processes, management techniques); and normative isomorphism, associated with professionalisation.

Welfare states grant citizens with social rights (Marshall 1950). For Esping-Andersen (1990), these social rights are characterised by three dimensions: the degree of de-commodification implied by these rights; the system of stratification (into social classes) stemming from these rights; and the repartition of responsibility between the market, civil society, family and the welfare state resulting from these rights (welfare mix). These three dimensions of social rights allow Esping-Andersen (1990), through a cluster analysis of welfare-state variations, to distinguish different types of welfare regimes: a liberal welfare state, a corporatist-statist welfare state and a social democratic welfare state.

The social democratic welfare state is typically found in Scandinavia (Sweden, Norway, Denmark); it is characterised, according to EspingAndersen (1990), by the fact that the principles of universalism and decommodification are extended to the middle class (in contrast to what is the case in the liberal regime, which is characterised by means-tested assistance, and in the corporatist-statist regime, where rights are attached to class and status). The universalistic nature of social rights and the central role played by the state in the Scandinavian welfare state give to the welfare-provision system a particular shape, which also constrains and enables the development of social enterprises.

In this chapter, we delve into how the institutional framework shaped by the universalistic Scandinavian welfare state and the recent reforms of its mode of operation inspired by new public management (NPM) influence the opportunity structure for the development of social enterprises in Scandinavia. More precisely, we examine whether there exists, for social enterprises, within the Scandinavian welfare system, a "third way" between two types of institutional isomorphism (namely coercive and mimetic isomorphism) that would enable social enterprises' innovative capacity and economic sustainability. Indeed, as we will demonstrate, in a highly institutionalised welfare provision system such as the Scandinavian welfare state, and in a context that is simultaneously characterised by the implementation of NPM reforms, social enterprises risk to be caught between the Charybdis of becoming integrated into the public welfare system (through contracting) and the Scylla of behaving like for-profit actors. 
In order to address this question, we first give an overview of the Scandinavian welfare model; we then turn to the recent trends characterising social-policy reforms and SE development in the three Scandinavian countries: Denmark, Sweden and Norway. Finally, we discuss the implications of the institutional landscape shaped by the Scandinavian welfare model for the future development of social enterprise in Scandinavia.

\subsection{The Scandinavian Welfare Model}

The terms "Scandinavian" and "Nordic" are used interchangeably to refer to the political model that is characteristic of Northern Europe. However, geographically speaking, they are not synonymous: "Scandia" was the old Latin name for three countries of northern Europe-namely Denmark (5.8 million people in 2019), Norway (5.3 million people) and Sweden (10.2 million people)—that constitute today the Scandinavian countries. The Nordic countries include, in addition to the Scandinavian countries, Finland and Iceland. The Scandinavian model differs from both the Anglo-Saxon and the continental models (Lane 2016), at least when it comes to two salient features. First, a particularity of the Scandinavian political model, inherent in the Scandinavian culture of compromise, is the strong role played by interest and civil-society organisations in both policymaking and policy implementation processesa feature that has been referred to as corporatism (Olsen 1983). Secondly, Scandinavian countries share specific institutionalised welfare arrangements, referred as the "social democratic welfare regime" (Esping-Andersen 1990)—a term that indicates that the Scandinavian countries constitute a group or "family" of welfare arrangements.

Features of the Scandinavian welfare model include a heavy reliance on universal public social services and transfers (benefiting all citizens)and, consequently, small income differences and low poverty rates-as well as an extensive social legislation, which provides a safety net "from cradle to grave". Additionally, as advanced by Pedersen and Kuhnle (2017: 221), three dimensions might be considered to be characteristic of the Nordic welfare model:

- the active role played by local and national state agencies in providing welfare benefits and services (the Scandinavian welfare model is based on an extensive public responsibility for providing welfare benefits and services);

- the principle of universal social rights (services and cash benefits are not selective nor targeted on the basis of needs, but are available to the entire population, including the middle class);

- the value of equality (Scandinavian countries have historically inherited small class, income and gender differences. The fact that 
child care, elderly care and care for the disabled are a public responsibility enables women's high labour-market participation and reduces gender inequalities).

The Scandinavian model of welfare policies is not only about expenditures and compensation, but also about social investment (Kvist et al. 2012). The Scandinavian social-investment strategy consists of welfare services whose provision is the responsibility of municipalities and which address individual needs in different phases of the life cycle. These welfare services include child care and pre-school education in early childhood, and primary, secondary and tertiary education for young people. Thanks to child care and social care, adults can be active in the labour market, and life-long learning and active labour-market policies help them to update their skills to accommodate changing labour demands. In old age, various policies aim to provide care for the elderly.

\subsection{Welfare Policy Reforms in Scandinavia and their Implications for Social Enterprises}

In the Scandinavian countries, the provision of welfare services has been, since 1945 and until the 1980s, the quasi-monopoly of the public sector, with over $80 \%$ of welfare services provided by the public sector in each of the three countries analysed. During the last decades, NPM socialpolicy reforms have contributed to a more diversified welfare mix and diverging trends in these countries.

Given the centrality of the public sector in the provision of welfare services in Scandinavian countries, welfare policy reforms, inspired by new public management, have focused on the enhancement of productivity, innovation and effectiveness within state agencies and local governments. NPM reforms have involved the introduction of marketbased methods and instruments within the operation of the public sector. These reforms have provoked a reorganisation of the boundaries between-and the relationships among-the public, non-profit and for-profit sectors, and of the practices of the public sector itself. However, within the field of welfare services, the efficacy of pure market mechanisms is limited by a series of market failures. Indeed, welfare services (1) are provided in response to demand from a target group that frequently cannot or can only partly afford to pay for them; (2) are characterised by an informational asymmetry between provider and beneficiary, which means that certain procedures need to be established to guarantee the quality of the services and the protection of these beneficiaries; and (3) generate, at the level of society as a whole, external effects which are not "internalised" by the market. NPM reforms have involved the introduction of an array of marketbased regulatory instruments, including outsourcing, competitive 
tendering, quasi-markets and performance-related funding (Pollitt and Bouckaert 2011). NPM has also emphasised user-driven innovation and free-choice schemes for public-service users-reframing them as "consumers" or "customers"- and the individualisation and personalisation of welfare services.

The introduction of NPM reforms in the Scandinavian countries has its origins in debates related to the "welfare-state crisis" in the 1980s. These discussions lay grounds for subsequent reforms that in many ways were influenced by ideas of new public management. But although NPM reforms were implemented in all three Scandinavian countries from the 1980s onward, Denmark, Norway and Sweden followed different paths in incorporating NPM into their existing welfare institutions and policies, and they have also recently diverged in introducing, especially at the local level, post-NPM reforms.

In Sweden, during the neoliberal transformation in which NPM was massively rolled out in the country's welfare system, political rhetoric embraced civil society as well as references to social entrepreneurship, social enterprise and social innovation-not as constituting a sector in themselves, but as part of private initiatives in general. In addition, these types of initiatives were described as carriers of moral features, but not as actors that were in need of any "special support" from public policies. The opening of welfare services to competition has not led in Sweden to a strengthening of civil society, though, but to the expansion of the business sector into the welfare sector and to the consolidation of international chains specialised in the provision of specific types of welfare services (schools, elderly nursing homes, domiciliary care).

In the 1990s, while Sweden and Finland experienced economic downturns which led to major welfare reforms, Norway's financial situation stabilised. Therefore, the discourse that had prevailed in the 1980s in Norway about the need to mobilise civil society subsided and despite the political aspirations to strengthen civil society's role in the welfare state, non-profit welfare production continued to weaken, partly due to NPM reforms. Faced with competition by profit-making actors, many non-profit organisations lost ground. In Norway, it is only in the 2010s that these experiences have led to discussions on how to protect non-profit welfare production (Meld. St. No. 29 2012-2013; Norwegian Government 2016). The recent increasing focus on innovation in the many different parts of society has been thematised around the need for organisational change and user/citizen involvement, innovation and entrepreneurship. However, while the public debate at the national level about welfare policies is crystallising around the extent to which public welfare services should be provided within a system based on open competition among non-profit and for-profit providers, local public policies at the municipal level have increasingly been informed by postNPM ideas, emphasising collaborative governance and co-production. 
Denmark has also implemented NPM since the mid-1980s and this has been a significant driver of change in the public sector. However, Denmark can be considered to have been a "modernising" nation rather than a "marketising" one (Greve 2006). Compared to other Nordic countries, Denmark has not gone far in privatising and marketising public welfare services and institutions. In general, the Danish public sector

has been built between two contrasting tendencies: decentralisation and centralisation. First, the Danish public sector is decentralised, with a strong emphasis on local government autonomy, which allows local politicians to reach out to citizens. The signal here is decentralisation and popular control. At the same time, the Danish public sector has never quite shaken its roots from a centrally organised state.

Reforms in the Danish public sector have been embedded in the vocabulary of NPM: performance-based management, market mechanisms, quality systems, balanced scorecards, customer orientation, e-government, performance-related pay and contracts, and changed focus from needsoriented categories to issues of competition, efficiency and individualised satisfaction (Jørgensen and Dalsgaard 2009: 8). These reforms also comprised, on the one hand, service and governance innovation (Hartley 2005), as well as institutional in-house collaboration, democracy and co-creation of local budgets in a top-down implementation. On the other hand, this was followed by a bottom-up demand for the public sector to adapt to the interorganisational, intersectoral and open-innovation practices (Hartley et al. 2013), leading to a "pluri-centric" coordination in public governance (see, e.g., Reff et al. 2011 or Buch and Andersen 2013). This development has paved the way for more diversified and plural market-based welfare services of significant importance for social entrepreneurship and social enterprises. Welfare-modernisation programmes have strengthened, within the public sector, a (social) entrepreneurial mindset when it comes to welfare services and organisation, including the introduction of "quasimarket-based" regulatory schemes, self-management and a stronger focus on user influence (Green-Pedersen 2002; Hulgård and Andersen 2009; Andersen 2015).

Table 18.1 shows the respective size of the non-profit, for-profit and public sectors in Scandinavia in terms of paid employment. The forprofit sector, as a result of NPM reforms, has grown significantly in Sweden over the last years; its growth has been more moderate in Norway and Denmark, and the welfare mix in these two countries is, by comparison with Sweden, relatively stable. Today, the relative size of the 
SE and the Scandinavian Welfare State 307

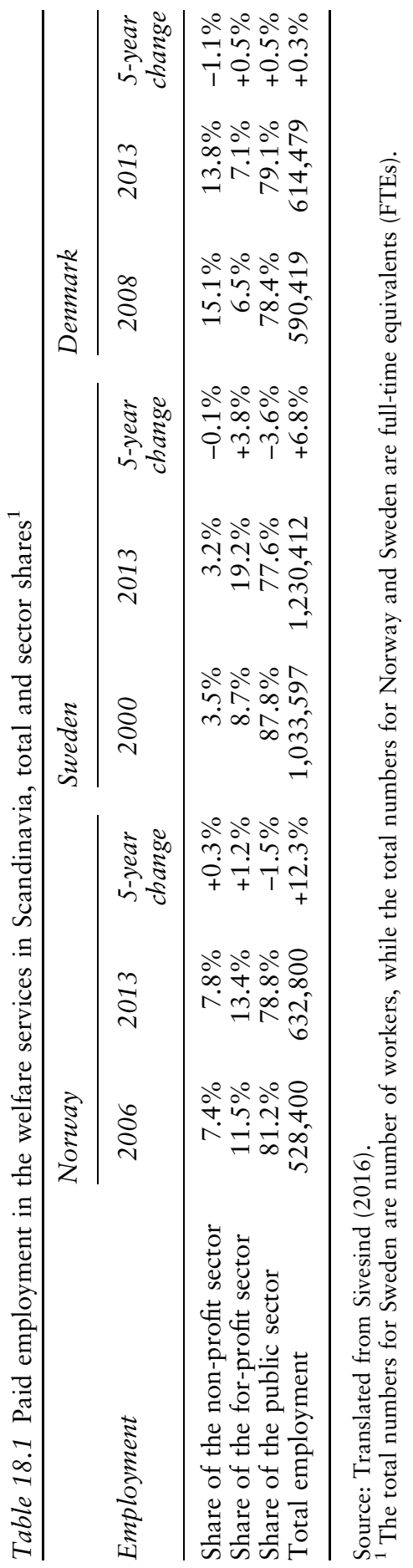


public sector is approximately the same in all three countries, but with a larger non-profit sector in Denmark (Sivesind and Saglie 2017).

As illustrated by this short overview of the Scandinavian welfare-state reforms, the institutional context of SE development in the three countries has, since the 1980s and 1990s, been largely shaped by NPM-inspired public-sector reforms. During the last decade, especially in Denmark and Norway, public-sector reform has taken a "post-NPM" turn, entailing an increasing emphasis on co-production and co-governance and the need for a more holistic "whole-of-government" governance paradigm (Christensen and Lægreid 2007), leading to a complex sedimentation or superposition of policy schemes over time, which has contributed to shaping the opportunity structure for SE initiatives.

\subsection{The Development of Social Enterprise in Scandinavia}

Welfare-state reforms in Denmark, Sweden and Norway constitute, as just explained, the policy context for the emergence of social enterprise. Indeed, in these countries, although the rise of social enterprise is anchored in a strong civil society and cooperative tradition and it has been driven mainly by grassroots entrepreneurial initiatives, the opportunity structure for the emergence and further developments of social enterprises is to a great extent delimited by the framework of welfare policies, which are not necessarily coherent across policy fields. There is also a tension in the three countries between the recent policy discourses at the local level-which emphasise social innovation, civil-society initiatives, collaborative governance-and the policy instruments that (especially at the central level of government) are market oriented and rely on quasi-market mechanisms.

In the three Scandinavian countries, the concept of social enterprise really emerged in the 1990s; however, the phenomenon itself is not new in the region. In Sweden, different types of non-profit organisations have for long had an important economic turnover and activities funded through a mix of grants and contracts. Due to the shift in policies that occurred during the last decades, the share of contract-based revenues in the income mix of NPOs has increased, in comparison to that of grants. Many of these organisations are also democratic membership-based associations; others are operating foundations. Due to the increased interest in the field of social enterprise, these organisations also elaborate on-and some refer to themselves as-social enterprises or non-profit enterprises. Social entrepreneurship has played and continues to play an important role in driving welfare innovations, identifying unsatisfied needs and fostering change.

It is clear that NPM and market-like conditions (Gawell and Westlund 2014; Jacobsson et al. 2015) increasingly characterise the Swedish 
welfare system. The number of private for-profit service providers in health care and social care has increased by over $300 \%$ in the country since the year 2000 (Statistics Sweden 2018). Many non-profit organisations are also faced with an increased prevalence of calls for tenders and/or marketisation in relation to client-choice models. ${ }^{1}$ The clientchoice models do not mean, though, that the client can freely choose the types of services that can be delivered; those are conditioned by public funding. Unlike other services, in sectors that were subject to reforms in the 1990s, social-welfare services have not been deregulated; they have rather been re-regulated. For example, as a result of the reform of homecare services for the elderly entailing detailed public prescriptions of what the client is entitled to, various types of social enterprise as well as for-profit enterprises operate somehow as subcontractors of the public sector, with little space for innovative thinking.

In Norway, while NPM reforms did not lead to a radical privatisation of welfare, they have contributed to the entry, into the welfare sector, of for-profit providers; this has led to changes in public administration, involving a stronger "market way of thinking" and "contract culture", both at the national and local (municipal) levels (Selle et al. 2019). With the increase, in the last decade, in the number of social enterprises, operating under a broad array of public, private and civil-society organisational forms, this "contract culture" also creates challenges for these organisations. There is no doubt that a policy on social entrepreneurship and social enterprises is in its initial stage of development in Norway: there is no legal framework regulating these organisations' activities, nor any specific organisational form for social enterprises (Eimhjellen and Loga 2016). But while the public and political interest for a policy development, up to recently, has remained very limited, there has been an increase, in the last 4 or 5 years, in initiatives seeking to address social entrepreneurship and social enterprises as a policy field. Today, most parties on both sides of the political spectrum highlight social entrepreneurship (Loga et al. 2016; Loga 2018). For the time being, potential public policies toward social enterprises are in gestation, with opposing conceptions around the right-left poles of the Norwegian political spectrum. These policy orientations reflect different conceptions of the role of for-profit-and more generally private-actors within the welfare field, insofar as social enterprises can either contract with public authorities within existing schemes or operate as commercial actors outside public welfare schemes.

Social enterprises in Denmark are engaged in a phase of institutionalisation characterised by the development of coherent SE policies and ecosystems (Hulgård and Andersen 2009; Hulgård and Chodorkoff 2019). The processes of institutionalisation have entailed various aspects, such as the development of supporting public policies, the definition and implementation of national and local strategies, the 
adoption of a government act providing for the possibility for social enterprises to register and the development of an ecosystem and a fiscal framework (Hulgård and Andersen 2009; Hulgård and Chodorkoff 2019). Innovation and social entrepreneurship had existed and had been taking an active part in forming the welfare state long before the recent interest for these notions emerged. However, in the recent decades, an interesting Danish—and perhaps even Nordic - trend in (social) entrepreneurial welfare-state position and practice has emerged that could be labelled the "innovative and entrepreneurial welfare state" (Hulgård and Andersen 2015): the welfare state acts within areas like welfare policy and educational policy, in relation to civil society, in a proactive manner, forming, funding and initiating programmes of "modernisation" (Andersen 2015; Andersen and Hulgård 2016; Andersen et al. 2016).

If social enterprises in the three Scandinavian countries have their roots in a long civil-society and cooperative tradition, their recent development has also been spurred by public-sector reforms inspired by new public management, and influenced by policies from the US and other European countries. However, despite these common roots and influences, the three Scandinavian countries seem to take different developmental paths. The marketisation of welfare services-opening up market opportunities for social enterprises, but also resulting in increased competition from the for-profit sector-is most pervasive in Sweden. Denmark appears to keep a large public sector, which increasingly plays an active role in fostering social innovation and social enterprises. The situation in Norway lays somewhat in between Denmark and Sweden: the country is at a crossroads and has to choose between increasingly relying on market mechanisms, on the one hand, and fostering social innovation based on post-NPM approaches, on the other hand. The three countries are also characterised by different degrees of institutionalisation of their policies toward social enterprise. Denmark has come farthest in designing a (hitherto incomplete) policy framework for social enterprise. Sweden has chosen to include social enterprises (referred to as "social businesses") within a broader strategy of privatisation and marketisation of welfare services. Norway has taken some steps in the direction of a dedicated policy strategy for social enterprise, but still has to choose between the Danish path and the Swedish one.

\subsection{Social Enterprise Between Coercive and Mimetic Isomorphism}

NPM-inspired social-policy reforms might have shaped a new opportunity structure and opened up a "public market" for social enterprises within the framework of the Scandinavian welfare state. However, this 
"market" is highly institutionalised and regulated. One reason is that the principle of universal coverage, which is a hallmark of the Scandinavian welfare state, entails public funding of services and equal access to services based on social rights. Another reason is that most welfare services are characterised by informational asymmetries that require public regulation in order to guarantee minimum standards of quality. Therefore, most social enterprises within the field of welfare services are highly regulated and dependent, at least partially, on public funding. The way in which these public funds are allocated (through competitive tendering, through grants, etc.) has a non-negligible impact not only on social enterprises' opportunity structure but also on their organisational behaviour.

In such a context, there exists, as pointed out by Sivesind and Saglie (2017: 15-16), an important difference between supply-based and demand-based financing of private service providers (see also Ascoli and Ranci 2002: 6-9). Whereas supply-based financing involves the transfer of the responsibility for providing a service to a private agency, demandbased financing gives users the ability to choose the provider from which they will receive the service. Supply-based financing of private providers has a tendency to foster institutional isomorphism; indeed, tenders in which non-profit and for-profit providers compete have been shown to lead to non-profit providers tending to behave like for-profit providers in order to remain competitive (Haugh and Kitson 2007). Supply-based financing coupled with tutelary regulation (through norms in terms of costs and employment) and involving for-profit, non-profit and public providers (Sivesind and Saglie 2017) limits the room for manoeuvre of non-profit or for-profit providers, which then tend to behave like public providers. Demand-based financing (through vouchers or individualised payment schemes) is a viable alternative when the users of services are able to make an informed choice. In this case, the "market" is regulated by competition between providers. Since these services are often characterised by economies of scale (bigger organisations are able to reduce their costs compared to smaller ones), market concentration tends to occur, as has been observed in Sweden in the field of education (Sivesind and Saglie 2017).

Social enterprises operating within the institutional framework of the Scandinavian welfare state are likely to be subjected to different institutional isomorphic pressures (DiMaggio and Powell 1983). A first type of isomorphic pressure occurs when public authorities closely regulate (through quality norms and budgetary control) welfare services. In this case, social enterprises are likely to look and behave like public welfare providers, since they are submitted to the same regulations (coercive isomorphism). A second type of isomorphic pressure is at work when the field of welfare services is open to competition (through demand-based financing schemes); the logics of economies of scale are 


\section{Enjolras, Andersen, Gawell \& Loga}

likely to drive to market concentration and to foster the constitution of welfare-service chains that expand through acquisition of smaller (and often local and committed) providers. In this case, social enterprises are likely to behave like for-profit providers and, with time, are at risk to be merged into a bigger for-profit welfare provider (market-competition isomorphism). Finally, when welfare services are open to public tendering, social enterprises that compete with for-profit actors are likely to behave like them in order to stay competitive (mimetic isomorphism).

In a nutshell, the universalistic characteristic of the Scandinavian welfare state, which entails public responsibility for the funding (either through supply-side or demand-side financing schemes) and regulation of welfare services (whose access is universal and based on social rights), creates an environment for social enterprises in which they are likely to be exposed to different forms of isomorphic pressures. Consequently, social enterprises within such an institutional environment are at risk of losing their institutional specificities (combining economic and social objectives) and their capacity of innovation.

\section{Conclusion}

Is there a way for social enterprises within the Scandinavian welfare state to escape this isomorphic fate, that is, to safeguard their innovative capacity and ensure their economic sustainability within such an environment? It seems that two roads are open to social enterprises in such a context.

First, social enterprises could escape isomorphic pressures from the welfare state by finding developmental niches outside the "core" welfare services that are funded by the welfare state. This implies the necessity for social enterprises to operate at the margin of the welfare state, identifying needs that are not covered by the welfare system and finding funding sources mainly outside established public-policy schemes.

The second possibility that would protect social enterprises from isomorphic pressures would require a more voluntarist policy, directed towards social enterprises, on the part of public authorities. Indeed, a legal recognition of social enterprises through the creation of a specific legal statute would protect social enterprises against different forms of mission drift resulting from isomorphic pressures. In order to protect social enterprises from coercive and mimetic isomorphic forces, such a legal statute should include (1) provisions prohibiting—or at least significantly limiting-profit distribution; and (2) rules providing for an asset lock, that is, prohibiting the distribution of the retained surplus and any other assets owned by the organisation to its owners, directors or other stakeholders (Salamon and Sokolowski 2018). This legal recognition of social enterprise would need to be completed by an active public policy aiming to foster the availability of financial instruments 
facilitating social enterprises' access to capital (implementation of mechanisms to allocate capital for social- as well as economic-value creation [Nicholls et al. 2015]). Such a dedicated policy toward social enterprises would additionally need to be combined with post-NPM public interventions (collaborative governance, co-production) at the local level.

In the current state of the situation, the contours of two different development paths seem to be in a process of consolidation within the Scandinavian welfare model. The first path-illustrated by the Swedish case-is that of the marketisation of universal public-funded welfare services; it entails a risk of mimetic isomorphism for social enterprises. The alternative path is that of the "social entrepreneurial welfare state", which aims to facilitate social innovation based on post-NPM governance methods. The Danish case and, to some extent, the Norwegian case bear testimony to the fact that such a policy roadmap might constitute a viable way of developing social enterprise within the universal framework of the Scandinavian welfare state and of avoiding institutional isomorphism. Future policy developments and welfare reforms in the three Scandinavian countries will show which of these two paths will prevail. However, demographic and financial pressures for social innovation, combined with broad political support in favour of universal welfare schemes, limit the space for potential developments. Post-NPM collaborative schemes and marketisation appear as two alternatives that would have different consequences for the future of social enterprise in Scandinavia.

\section{Note}

1 See chapter 13, "Social Enterprises in Sweden: Intertextual Consensus and Hidden Paradoxes", in the present book.

\section{References}

Andersen, L. L. (2015) "Micro-processes of collaborative innovation in Danish welfare settings: A psychosocial approach to learning and performance", in Agger, A., Damgaard, B., Hagedorn, A. K. \& Sørensen, E. (eds) Collaborative Governance and Public Innovation in Northern Europe, Sharjah: Bentham Science Publishers, pp. 249-268.

Andersen, L. L. \& Hulgård, L. (2016) "Social entrepreneurship: Demolition of the welfare state or an arena for solidarity?”, in Andersen, L. L., Gawell, M. \& Spear, R. (eds) Social Entrepreneurship and Social Enterprises: Nordic Perspectives, London: Routledge, pp. 22-40.

Andersen, L. L., Gawell, M. \& Spear, R. (2016) Social Entrepreneurship and Social Enterprises: Nordic Perspectives, London: Routledge.

Ascoli, U. \& Ranci, C. (2002) "The context of new social policy in Europe", in Ascoli, U. \& Ranci, C. (eds) Dilemmas of the Welfare Mix. The New Structure 


\section{Enjolras, Andersen, Gawell \& Loga}

of Welfare in an Era of Privatization, New York: Kluwer Academic/Plenum Publishers.

Baglioni, S. (2017) “A remedy for all sins? Introducing a special issue on social enterprises and welfare regimes in Europe", Voluntas, Vol. 28, No. 6, pp. 2325-2338.

Buch, A. \& Andersen, V. (2013) “(De)stabilizing self-identities in professional work", Nordic Journal of Working Life Studies, Vol. 3, No. 3, pp. $155-173$.

Christensen, T. \& Lægreid, P. (2007) "The whole-of-government approach to public sector reform", Public Administration Review, Vol. 67, pp. 1059-1066.

DiMaggio, P. \& Powell, W. (1983) “The iron cage revisited: Institutional isomorphism and collective rationality in organizational fields", American Sociological Review, Vol. 48, No. 2, pp. 147-160.

Eimhjellen, I. \& Loga, J. (2016) Utvikling av sosialt entreprenørskap $i$ Norge, Bergen: Uni-Research, Report No. 6/2016.

Esping-Andersen, G. (1990) The Three Worlds of Welfare Capitalism, Oxford: Blackwell Publishing.

Gawell, M. \& Westlund, H. (2014) "Social entrepreneurship as a construct of a liberal welfare regime?", in Douglas, H. \& Grant, S. (eds) Social Entrepreneurship and Enterprises. Concepts in Context, Prahran: Tilde University Press.

Green-Pedersen, C. (2002) "New public management reforms of the Danish and Swedish welfare states: The role of different social democratic responses", Governance, Vol. 15, No. 2, pp. 271-294.

Greve, C. (2006) "Public management reform in Denmark", Public Management Review, Vol. 8, No. 1, pp. 161-169.

Hartley, J. (2005) "Innovation in governance and public services: Past and present”, Public Money \& Management, Vol. 25, No. 1, pp. 27-34.

Hartley, J., Sørensen, E. \& Torfing, J. (2013) "Collaborative innovation: A viable alternative to market competition and organizational entrepreneurship", Public Administration Review, Vol. 73, No. 6, pp. 821-830.

Haugh, H. \& Kitson, M. (2007) "The third way and the third sector: New labour's economic policy and the social economy", Cambridge Journal of Economics, Vol. 31, No. 6, pp. 973-994.

Hulgård, L. \& Andersen, L. L. (2009) Socialt entreprenørskab i Danmark. Status 2009, Copenhagen: CSE Publications. Available HTTP: http://diggy.ruc. dk:8080/retrieve/18174\%5Cnhttp://dspace.ruc.dk/handle/1800/5260.

Hulgård, L. \& Andersen, L. L. (2015) Sosialt entreprenørskap og sosial innovasjon. Kartlegging av innsatser for sosialt entreprenørskap og sosial innovasjon i Norden, Nordisk Ministerråd, TemaNord, 2015: 502.

Hulgård, L. \& Chodorkoff, L. (2019) European Commission. Social Enterprises and Their Ecosystems in Europe. Updated Country Report: Denmark, Luxembourg: Publications Office of the European Union. Available HTTP: https://europa.eu/!Qq64ny.

Jacobsson, B., Pierre, J. \& Sundström, G. (2015) Governing the Embedded State. The Organisational Dimension of Governance, Oxford: OUP.

Jørgensen, H. \& Dalsgaard, L. (2009) Modernisering og kvalitetsreform $i$ den offentlige sektor. 2008-perspektiver på den igangvorende omstilling af det offentlige, 
Aalborg: Centre for Comparative Welfare Studies, Institut for Økonomi, Politik og Forvaltning, Aalborg Universitet.

Kvist, J., Fritzell, J., Hvinden, B. \& Kangas, O. (eds) (2012) Changing Social Equality: The Nordic Welfare Model in the 21st Century, Bristol: Policy Press.

Lane, J. E. (2016) "The Nordic countries: From the Rokkan model ('uns') to the Touraine model ('ich')”, Open Journal of Political Science, Vol. 6, pp. 284-309.

Loga, J. (2018) "Civil society and the welfare state in Norway-Historical relations and future roles", Community Development Journal, Vol. 53, No. 3, pp. 574-591.

Loga, J., Eimhjellen, I., Eschweiler, J., Ingstad, E. L., Stokstad, S. \& Winsvold, M. (2016) Sosialt entreprenørskap - kommunale endringsagenter, Bergen: Uni Research Rokkansenteret, Report 1/2016.

Marshall, T. H. (1950) Citizenship and Social Class, Cambridge: Cambridge University Press.

Meld. St. No. 29 (2012-2013) Morgendagens omsorg, Oslo: Helse- og sosialdepartementet, Norwegian Government.

Norwegian Government (2016) Ideell opprydding-Statlig dekning av ideelle organisasjoners historiske pensjonskostnader, NOU 2016: 12, Oslo: Norwegian government, Kulturdepartementet.

Nicholls, A. (ed.) (2006) Social Entrepreneurship. New Models of Sustainable Social Change, Oxford: Oxford University Press.

Nicholls, A., Paton, R. \& Emerson, J. (eds) (2015) Social Finance, Oxford: Oxford University Press.

Olsen, J. P. (1983) Organized Democracy: Political Institutions in a Welfare State: The Case of Norway, Bergen: Universitetsforlaget.

Pedersen, A. W. \& Kuhnle, S. (2017) “The Nordic welfare state model”, in Knutsen, O. (ed.) The Nordic Model in Political Science, Bergen: Fagbokforlaget.

Pollitt, C. \& Bouckaert, G. (2011) Public Management Reform: A Comparative Analysis-New Public Management, Governance, and the Neo-Weberian State, Oxford: Oxford University Press.

Reff, A. P., Sehested, K. \& Sørensen, E. (2011) "Emerging theoretical understanding of pluricentric coordination in public governance", American Review of Public Administration, Vol. 41, No. 4, pp. 375-394.

Salamon, L. M. \& Sokolowski, W. (2018) "Beyond nonprofits: In search of the third sector", in Enjolras, B., Salamon, L. M., Sivesind, K. H. \& Zimmer, A. (eds) The Third Sector as a Renewable Resource for Europe, London: Palgrave MacMillan.

Selle, P., Strømsnes, K. \& Loga, J. (2019) "State and civil society-A regime change?”, in Enjolras, B. \& Strømsnes, K. (eds) Scandinavian Civil Society and Social Transformation. The Case of Norway, Berlin: Springer.

Sivesind, K. H. (2016) "Endring av fordelingen mellom ideelle, kommersielle og offentlige velferdstjenester i Skandinavia", in Sivesind, K. H. (ed.) Mot en ny skandinavisk velferdsmodell? Konsekvenser av ideell, kommersiell og offentlig tjenesteyting for aktivt medborgerskap, Oslo: Institutt for samfunnsforskning.

Sivesind, K. H. \& Saglie, J. (eds) (2017) Promoting Active Citizenship. Market and Choice in Scandinavian Welfare, London: Palgrave MacMillan.

Statistics Sweden (2018). Available HTTP: www.scb.se (last accessed on August 18, 2019). 


\title{
19 How Context Shapes the Character of Cooperative Social Enterprises
}

\author{
Insights from Various Countries
}

\author{
Nicole Göler von Ravensburg, \\ Richard Lang, Simone Poledrini and \\ Marzena Starnawska
}

\section{Introduction}

The question why social enterprises (SEs) adopt particular governance structures and legal forms is tremendously complex (Ebrahim et al. 2014), and the state of literature on the institutional choice and comparative advantages of the cooperative form is still somewhat poor in several respects. The identification of critical factors determining the attractiveness and relative performance of cooperative social enterprises (CSEs) has remained national and largely monodisciplinary. The approaches adopted by existing comparative analyses so far belong in most cases to the fields of legal studies (Fici 2015), political economy (e.g., Ostrom) or business economics (e.g., Borzaga et al. 2017). These perspectives frequently relate closely to certain schools of economic, political or legal thought (e.g., canonical rational-choice theory, social- and solidarity-economy thinking or liberalism). Empirically based international discussions are rare, since it is difficult to capture the variety of CSEs in their current and historical institutional contexts (see inter alia Teasdale 2011 and Kerlin 2010). Epistemologically, such research should be based on an international comparison and go beyond hermeneutics.

The ICSEM Project offers the possibility for such a non-normative understanding of the prevalence of CSE. By way of a meta-analysis of national ICSEM "country papers"1 (to which we refer henceforth by the acronym CPs) from Europe, North America and Australia, ${ }^{2}$ this chapter tackles the following question: "Which elements of the institutional context shape the characteristics of CSE?". It aims to generate preliminary propositions about how contextual elements interact with certain characteristics of CSE, and how such contextual elements might influence the choice of the cooperative form. Based on such analysis, it puts forward several hypotheses about the relative importance of various contextual elements.

Section 19.1 of this contribution clarifies how we dealt with terminological issues and sketches our inductive methodological approach. 
The developed methodology and analytical framework represent the results of the first phase of our research; they are explained partly in section 19.2 and-for the sake of brevity and on account of their close relationship with the research results-partly in section 19.3 . Section 19.3 presents the results of our second research phase, namely the possible patterns that can be identified in the interplay of contextual factors and CSEs' characteristics. The findings are subject to a critical discussion in the conclusion.

\subsection{Terminological and Methodological Approach}

Rather than relying on a normative definition of social enterprise, the CPs in the ICSEM Project are based on the EMES conceptual approach to social enterprise. This conceptual approach includes three sets of indicators-namely economic, social and governance-related indicators (Defourny and Nyssens 2012: 12-15). These are not criteria to be met in order to deserve an "SE label"; they rather help to characterise groups or categories of social enterprises relative to one another.

This relatively open delineation left CPs' authors with sufficient room to accommodate national perceptions, which represents a good precondition for a non-normative comparative analysis. The same is true for national authors' use of the term "cooperative". From the initial analysis of the CPs, it became clear that the term was mostly used in relation to what national laws and traditions consider as a cooperative. Again, we accepted this for the purpose of our study, even though we are well aware that the essence of cooperative organisation can be found in other legal forms as well, and even in some unincorporated organisations.

In order to avoid normative preconceptions, we followed a strictly inductive process. As underlined above, since the method and results are closely intertwined in such an approach, both are described together in section 19.2 and section 19.3.

Fifteen ICSEM CPs from various countries-namely Canada, France, Germany, Switzerland and the US (with two CPs each) and Australia, Austria, Belgium, Israel and Poland (with one CP each) - had been published by December 31, 2016 and all of them mentioned CSE. Three more papers—on Hungary, Italy and Spain—-that were then in draft stage but almost finalised were made available to us by their authors. It was decided to include these additional papers to enrich the sample, which finally included eighteen CPs.

\subsection{Development of an Analytical Framework}

In order to develop an analytical framework (phase one of the research process), we went through a three-step screening process. This allowed us to identify important contextual factors and CSE's characteristics. 


\subsubsection{Screening Process to Identify Distinctive Dimensions and Variants}

In the first step of developing the analytical framework, all eighteen CPs were screened for the perspectives they offered on CSE. In a qualitative content analysis of the dataset, we identified sections in each CP dealing with the phenomenon of CSE and derived specific perspectives and arguments that national authors thought crucial to the conceptualisation of CSE in their respective context (i.e., at the national level, except for the province of Quebec). We identified five clusters of perspectives:

- wide historical context and cooperative-specific development "paths", including embeddedness in the economic system, company and nonprofit organisation (NPO) law, tax law and institutionalised supervision (Huybrechts et al. 2016);

- CSE in different conceptualisations of societal transformation (from at least three perspectives: cooperative movement, state, non-profit/ common-good sector);

- fields of CSEs' activities/sectors in comparison to social enterprise in general and to institutionalised cooperative sectors;

- role of policies and institutions linking social capital across different societal sectors (e.g., public bodies, philanthropists, private corporate investors, etc.), effective at different spatial scales;

- type of CSE governance.

In the second step, to assess the relevance of the various perspectives identified, all eighteen CPs were analysed to determine which perspectives were shared by more than a third of them. This was the case for the contextual factors outlined in section 19.2.2 and CSEs' characteristics outlined in section 19.2.3. These interim results were suitable to serve as dimensions for the cross-country comparative analysis focusing on the interplay between contextual factors, on the one hand, and characteristics of CSE, on the other hand. Only twelve out of the eighteen papers, however, referred to all the selected dimensions in some depth. So, it was decided to continue the analysis with only these twelve CPs-on Australia, Austria, Belgium, Canada, France, Germany, Hungary, Italy, Poland, Spain, Switzerland and the US.

In the third step of the screening process, these twelve CPs were examined in order to identify variants for each of the dimensions identified. Through an inductive process again, between four and six variants were defined for each dimension. The content of these variants is explained in section 19.3. We decided to follow up on those variants that were present in more than three CPs, so only these have been included in the final analytical framework. 


\subsubsection{Contextual Factors Identified}

Six contextual factors were present in more than a third of the eighteen CPs selected in the first step of phase 1 .

- Nearly all CPs' authors focused, in their accounts of CSE, on historical developments. A range of CPs made clear reference to historical trajectories of the whole socio-economic system in the country, highlighting the links between such contexts and the cooperative sector's organisational models, including CSE.

- Another frequent focus was on the emergence of new social movements. CSEs often seem to emerge in response to socioeconomic crises, for example, to meet the resulting demands for social services and solve unemployment problems, or they aim to promote a "green" sustainability agenda through ecological living.

- Legal provisions for cooperatives often determine CSE activities. Some countries have developed a specific legal framework to regulate the phenomenon of CSE and/or to facilitate its development and stimulate its growth; such a development has been observed in Italy (Poledrini 2015), Poland (Piechowski 2010), France (Hiez 2013) and Hungary (European Commission 2014d) with the creation of the legal form of "social cooperative"; in Spain, with the "social-initiative cooperative" (CIS) legal form; and in the province of Quebec, in Canada, with the "solidarity cooperative" legal form.

- Intermediaries link cooperative organisations and their members to actors in the institutional environment (e.g., government bodies, banks, institutional investors) through lobbying or as regulators of the cooperative sector. These intermediary bodies can also be federations; secondary cooperatives; national, regional or local umbrella organisations (including social enterprises); and research institutions.

- Social-economy-related policies are at the basis of the emergence of CSE especially in Spain, France, Hungary and Poland, ${ }^{3}$ while in other countries, CSE development is influenced by broader social or regional policies. More precisely, the social-economy approach is firmly based on the belief that isomorphism can only be avoided by favouring participatory governance and limited profit distribution (Fici 2015: 26). Consequently, legal provisions to ensure the protection of these features are usually central in the countries where the social-economy approach is important; this is the case for many romance-language countries, as illustrated for example by the French "collective-interest cooperative". By contrast, in North America, Australia, Germany, Austria or Switzerland, the concept of social economy has never, or only very recently, been associated with the concept of cooperatives. 
- Nearly all CPs' authors report that alternative legal forms to the cooperative one do exist in their respective countries/region.

\subsubsection{CSE's Characteristics Identified}

Regarding the characteristics of CSEs, the following eight features were found to be central by most CP authors:

- Autonomy: Two aspects of autonomy can be distinguished. Political autonomy (or autonomy in terms of governance) refers to the influence of political decision-makers and interests on the strategic development of the CSE. A second aspect, namely that of financial autonomy, refers to those situations where (social) policies and subsidies are not vital for the CSE and a diversity of contract partners exists.

- Membership composition: CSE membership composition can be homogenous and/or heterogeneous. Homogenous membership refers to the situation where all members share common interests. By contrast, in organisations with heterogeneous membership, there are different subgroups, with divergent interests. The CPs analysed further suggest to distinguish two major forms of heterogeneous membership: (1) with two subgroups, as for example in credit cooperatives; and (2) with multiple subgroups, as in multi-stakeholder cooperatives, where the different subgroups have at least one common interest but also diverging interests.

- Types of goods and services: Data from the CPs reveal that CSEs provide various kinds of goods and services. Indeed, they can provide private goods, when they address only their members' needs, such as in agriculture, or they can provide public or merit goods, when they generate benefits for non-members. Goods and services can be of a collective type (common goods) or of an individual one (personal services).

- Main source of revenue: Our analysis showed two main sources of revenue for CSEs, namely (market) sales, including sales to government bodies, on the one hand, and public subsidies and grants, on the other hand. From the initial cross-country comparison, we can hypothesise that CSEs are more dependent on sales in liberal market contexts (e.g., the US; see Cooney 2015) than in traditional welfare and corporatist state contexts (e.g., Germany; see Birkhölzer et al. 2015).

- Predominant fields of activity: Across the different countries analysed, three predominant fields of CSE activity can be identified: work integration, personal services (e.g., child care) and local/regional infrastructure development (cooperatives providing public or proximity services).

- Types of benefits/beneficiaries: Another dimension (linked to others) refers to the main benefits that CSEs provide or the main 
beneficiaries that they serve. Based on our analysis, we can distinguish three main categories of benefits/beneficiaries: provision of employment for members; servicing members (hereby leading to indirect benefits for members); and servicing wider groups of beneficiaries, including non-members.

- Participatory character of the governance: Our analysis of CPs suggests three variants: the board can include only members; the board can include (non-member) beneficiaries; there is a possibility for external stakeholders to be part of the board.

- Profit distribution: The dimension of profit distribution can be categorised in the following way: profit distribution can be prohibited or regulated by law; or it can be decided by the members; or there are no restrictions at all.

\subsection{Identifying Interactions Between Contextual Factors and CSEs' Characteristics}

The second phase of our analysis presented us with the challenge of having to identify unambiguous relationships between contextual factors and CSEs' characteristics. The matrix shown in table 19.1 resulted from the steps outlined above. It is both a first finding of our inductive approach and an analytical framework for the next step of analysis. Final findings are presented in more detail in sections 19.3.2 to 19.3.4, where each subsection corresponds to a contextual dimension. The numbering of cells in table 19.1 alludes to the sequence in which findings are covered in sections 19.3.2 to 19.3.4. An additional perspective in our analysis concerned the link between the various contextual dimensions, on the one hand, and the choice of the cooperative form by social enterprises, on the other hand. Whenever elements about this perspective appeared relevant, we included them in the following subsections.

\subsubsection{Overview of Interactions Identified}

Table 19.1 outlines all interactions between contextual factors and CSE's characteristics considered relevant in the CPs. The numbered fields indicate where the CPs gave sufficiently precise information about the relationships for further comparison and conclusions. Where fields are left unnumbered, this was not the case and more research is needed. This is particularly the case with regard to the manifold interactions between two contextual dimensions, namely "historical developments" and "new social movements", on the one hand, and CSEs' characteristics, on the other hand. Although the role of intermediaries was highlighted in several CPs, there was not sufficiently concrete information either about how these intermediaries (cooperative federations or agencies specialised in the promotion of SE) interact with CSEs' characteristics. 
322 Göler von Ravensburg, Lang et al.

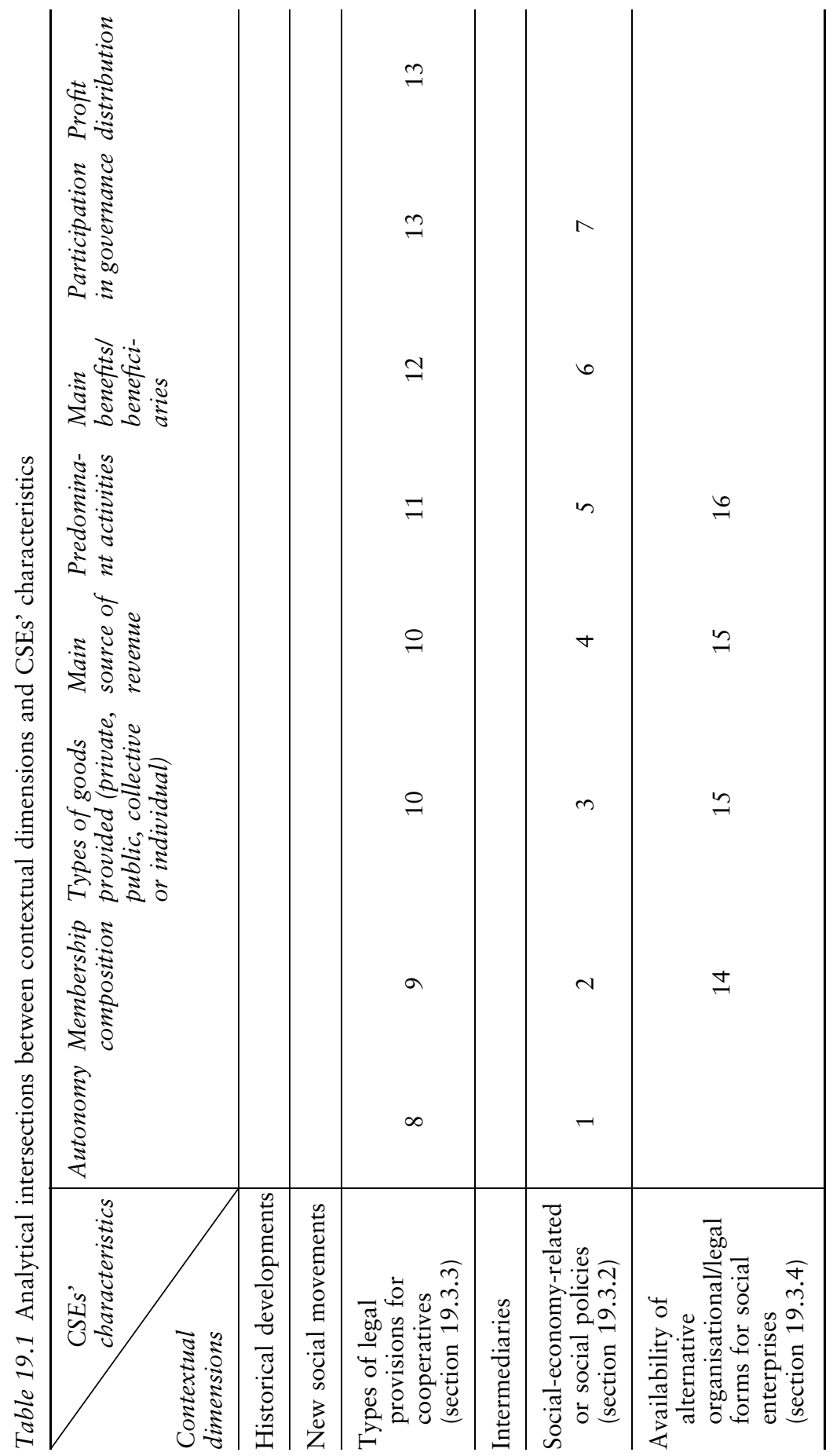




\subsubsection{Interplay Between Social-Economy-Related/Social Policies and CSEs' Characteristics}

The CPs suggest that national, regional, local and sectoral socioeconomic policies do affect social enterprise in general and CSE in particular. While comprehensive national social-economy-related policies exist in Spain, France, Hungary and Poland (Katona 2014; KPRES 2014) and regional ones in the Quebec province in Canada and in Belgium, socio-economic policy measures in Italy, Germany, most of Switzerland, the US and Australia are less general and more issue related. Since literature differentiates these two approaches, we tried to identify interplay mechanisms for each. However, both use various combinations of subsidies and contracts for the provision of public goods and services. Some also entail specific laws governing social enterprise. Thus, on the functional level, we could frequently not differentiate between socialeconomy-related policies and more general social policies; the sample was also too small to do so. We indicated where differentiation was possible, such as in point (6), but overall, we thus confined our analysis to the question of whether socio-economic policies of any kind influenced the central characteristics of CSEs that we had identified. We elaborate on this in detail in the following list, numbering the paragraphs in accordance with the numbering in table 19.1.

1. Our analysis does not support the assumption that public policies would automatically limit the organisations' autonomy. However, the CPs indicate potential limitations of cooperative autonomy due to the representation of public bodies in the governance structure of CSEs in eight countries. In several countries, where CSEs are providing public services governed by social policies, these influence CSEs' production processes. Overall, in all the countries analysed, CSEs seem geared towards achieving financial autonomy by generating at least substantial parts of their turnover from sales. Public policies at times influence this, as do other factors, such as legal barriers to market participation by social enterprises.

2. There does not seem to be a link between public policies and the membership composition of CSEs. While France and Spain-two countries with well-developed social-economy policies-favour multistakeholder CSEs, these also seem to gain popularity in countries without central social-economy policies (e.g., Italy), and multistakeholder CSEs do not exist in Poland and Hungary, despite these countries having a central social-economy policy (Piechowski 2010).

3. CSEs can provide private as well as merit and public goods. Naturally, social-economy policies (e.g., in France or Belgium) as well as socio-economic policies (e.g., housing policy in Austria and Australia) or sector policies (e.g., energy in Germany) aim at the 
production of public and merit goods. CSEs in countries without such policies are also found to produce public goods, but most likely to a lesser extent.

4. As for the main source of revenue of CSEs, there are some hints in the CPs that countries with socio-economic policies to support social enterprise (and particularly with local or regional programmes) are precisely those where CSEs can generate revenue (grants and sales revenues) from public sources. However, except in the case of Italy (Borzaga et al. 2017 and Poledrini 2018), the available data are not strong enough to support a suggestion that the choice of legal form depends on socio-economic policies entailing public support.

5. The link between predominant activities and socio-economic policies remains fuzzy. For example, the work-integration sector is a sector generally strongly dominated by social policy and encompassing many social enterprises. Yet, CSEs do not occur in greater numbers in this sector than in other personal services in nine of the twelve countries analysed. Furthermore, in the German-speaking countries (Austria, Switzerland and Germany) with well-established social policies for work integration, work-integration social enterprises (WISEs) hardly seem to operate in a cooperative form. In other sectors, the existence of socio-economic policies does not seem to be a precondition for the existence of worker cooperatives or cooperative service providers. At the same time, significant numbers of CSEs for local or regional infrastructure development seem to emerge without any or with minor policy-related support in some countries, including the German-speaking ones and Belgium. And a clear link can be seen between certain sector policies and the emergence of CSEs, such as in housing in Austria (Anastasiadis and Lang 2016), and energy, leisure and retail in less densely populated areas in Germany (Blome-Drees et al. 2016).

6. Data from the CPs clearly suggest a link between social-economyrelated policies-as distinct from other socio-economic policies-and the recognition of certain groups of main beneficiaries within CSEs, for example, disabled people. All countries with social-economyrelated policies see CSEs as organisations addressing both the employment and service needs of members and non-members. By contrast, most countries without such policies-including Australia, the English-speaking part of Canada and the German-speaking countries-firmly see CSEs as organisations primarily benefitting their members.

7. Participation of non-members in governance is possible in countries with and without national socio-economic policies. An example of the latter is the US, where many state laws allow government agencies and their representatives to be involved in the governance of CSEs. They can even be owners in purchasing cooperatives or shared-services 
cooperatives; public representatives can also generally be directors of cooperatives in some states. However, the literature at hand does not help to estimate how frequently this legislation is applied.

\subsubsection{Interplay Between Legal Provisions Regulating Cooperatives and Characteristics of CSEs}

Eight countries in our sample have cooperative legislation at the national level, with (e.g., in France) or without (e.g., in Germany) additional sectoral cooperative laws. In three countries, legislation on cooperatives is the responsibility of provinces and federated states (Canada, the US and Australia). Albeit to a different extent, France, Italy and Poland are relying on sectoral cooperative legislation. To fully understand the interplay of legal provisions on cooperatives with CSEs' characteristics, it should be mentioned that, in some countries, a special "social-purpose" qualification was created for companies that want to underline their social aim. Depending on the criteria applicable, this can shape the character of social enterprise towards cooperative-like characteristics. An example is Belgium, where companies applying for such a qualification were first allowed to operate under any company legal form, but the criteria to be met in order to obtain the "social-purpose" qualification influenced the applying enterprises in a cooperative way. Since 2019, this legislation has changed and the cooperative is now the only legal form that may be combined with a "social-enterprise" qualification. ${ }^{4}$

8. The financial autonomy of CSEs seems generally high in our sample of high-income countries. Indications regarding possible limitations of this autonomy are rather connected to the representation of nonmembers, and especially of state representatives, on the boards of CSEs. In Poland, for instance, the law allows public agencies to become board members; they thus become part of the governance structure of CSEs. In some CPs, the presence of state representatives on the boards of CSEs is reported as related to an economic and cooperative history marked by disruption, and it is considered to have a significant influence on current decision-making processes within CSEs (Fekete et al. 2017). However, state representation on boards also occurs in several countries with a "continuous" cooperative history. For instance, the French collective-interest cooperative (société coopérative d'intérêt collectif, or SCIC) is subject to more public control than any other type of cooperative (Hiez 2013: 401). Similar observation has been made in some states in the US and provinces in Canada. There, it can be traced back to CSEs being involved in public (health) programmes. Yet none of the corresponding CPs report any challenges in autonomy. 
9. As far as membership composition is concerned, cooperative legislation in the countries studied seems to be based on open and voluntary membership and on members being the main beneficiaries. These findings concur with the principles of the International Cooperative Alliance (ICA). Yet, it also appears that wherever CSEs are the focus of social-economy-related policies (rather than of more general socio-economic policies), national or provincial legislation on cooperatives often stipulates that membership ought to include more than one interest group. For instance, French collective-interest cooperatives $(\mathrm{SCICs})^{5}$ are multiple-stakeholder organisations with governance by several possible "colleges" (of employees, users, volunteers, local authorities etc); any physical or legal person who contributes to the activity can belong to one of these colleges. SCICs seem to have been modelled on the Italian social cooperatives (Hiez 2013: 400), which encompass similar multi-stakeholder governance.

10. The types of goods provided and the main source of revenue of organisations are usually linked, to the extent that grants and subsidies are means to publicly finance collective goods, while sales are often linked to individual goods and services, be they purchased by private or public customers. Consequently, we decided to present the findings about the interlink of both these aspects with the occurrence of certain legal forms and in particular the cooperative one together. CPs suggest that grants, whether public or private, seem a great deal less important in CSEs' revenue mix than sales. As regards the difference between public and private individual goods, only the Italian and French CPs suggest that the way in which company law, cooperative law or SE-specific laws regulate the functioning of CSE strongly determines whether CSEs deliver public and/or private goods.

11. Looking at what CPs report on the interaction between national patterns or types of cooperative legislation and CSEs' predominant activities, it becomes apparent that sectoral cooperative legislation frequently aims at sectoral activities such as work integration, agriculture or housing. French cooperative legislation is a prime example of this. At the same time as describing activities, such legislation usually also entails criteria for cooperative membership. Meanwhile, national cooperative legislation covering all sectors at once usually makes, at some point, special provisions for certain activities such as banking (see e.g., the German Genossenschaftsgesetz), or it is complemented by special acts (as e.g., in Poland) (Piechowski 2013). Additional literature suggests that, whenever national cooperative laws do not explicitly provide for the existence of a form of social-purpose cooperative, social enterprises are less likely to adopt the cooperative form. 
12. When analysing the main benefit/main beneficiaries of CSEs, we should first keep in mind that the traditional picture of cooperatives benefitting their members appears dominant. In general, a focus on members is of course present in consumer and agricultural cooperatives in many countries. The CPs analysed mostly discuss workers' cooperatives and CSEs providing (social) services (e.g., care for handicapped people, child care, etc.) - that is, fields which are not typical of member-focused cooperatives. However, cooperative legislation does not make special provisions for such activities in all the countries surveyed-it does not make such provisions, for example, in Austria, Switzerland and certain provinces of Canada and Australia, where CSEs providing social services are not as widespread. However, CSEs of this type seem to be currently gaining ground, particularly in cases where common-pool resources tend to become neglected (see, e.g., the development of Swiss alpine-pasture cooperatives) or where social infrastructure is difficult to maintain on account of low population densities, as in the US or Germany (Blome-Drees et al. 2016: 102-103).

\subsubsection{Interplay Between the Availability of Alternative Legal Forms for Social Entrepreneurship and Main Characteristics of CSE}

Phase 1 results suggested there could be interrelations between the availability of alternative legal forms, on the one hand, and the membership composition, goods provided/main revenue sources and the predominant activities of CSE, on the other hand.

14. Our analysis of the CPs reveals that, in virtually all the countries studied, SEs can adopt more than one legal form. In regard to membership composition, the cooperative form is usually chosen where the solution to a social problem requires people with different interests to come together (e.g., buyers, sellers and workers)—which seems to become increasingly frequent. However, this observation does not necessarily point to a comparative advantage of the cooperative form over other legal forms. Corroborating such hypothesis would require a comparison with the development of SEs under other legal forms, as well as a comparison between countries where the law provides for the existence of multi-stakeholder cooperatives and countries where it does not. Still, the indication that a link might indeed exist between the legal existence of multi-stakeholder cooperatives and the share of SEs using the cooperative form should be taken seriously. This contextual factor might prove just as strong, in terms of influence, as SE policies.

15. The majority of CSEs in all the countries analysed produce private goods and services, and obtain most of their revenues from sales, 
regardless of whether or not alternative company forms can be used to organise SE activities. At the same time, the examples of Belgium and France suggest that a link might exist between the production of public goods and SEs using a cooperative form. In the US, Quebec, Germany, Austria, Switzerland, Hungary and Poland (Ministry of Family, Labour and Social Policy 2016), only a minority of CSEs provide public goods. At least for Austria and Germany, this can be attributed to national traditions: in these countries, other forms of organisations-namely not-for-profit associations-have traditionally been providing public goods for a long time (see, e.g., Heitzmann and Simsa 2004, as quoted by European Commission 2014a: 25). There are indications, for example from Germany, though, that a cooperatively organised provision of certain public goods might become more attractive, despite the existence of organisational alternatives. The evidence in the CPs is too scant, however, to come to any firm conclusions in this regard.

16. Whether the availability of alternative legal forms interrelates with the predominant activities of CSEs cannot be answered equally for all countries. In nine of the analysed countries, WISEs and SEs providing personal services are frequently organised in a cooperative form. Quite a different picture presents itself in Austria, Germany and Switzerland. In Austria and Germany, WISEs usually adopt the form of a (public-benefit) limited-liability company (European Commission 2014a: 6, 30 and European Commission 2014b: 35-36). In Switzerland, WISEs are usually organised as associations or foundations (European Commission 2014c: i). There are slightly more CSEs in Austria and Germany in the field of personal-services provision, while there does not seem to be any CSEs operating in this field of activity in Switzerland. However, in all three countries, there is a trend towards the emergence of CSEs for the maintenance of local or regional social infrastructure (Gonin and Gachet 2015: 31; Anastasiadis and Lang 2016: 15; Stappel 2017: 151-153).

This last observation points to two more general analytical results. First, considering the sum of interactions between this last contextual dimension and CSEs' characteristics, it becomes obvious that there appear to be interactions between this contextual dimension and other contextual dimensions. And secondly, there are indications that the reasons to choose specific legal forms to suit a certain membership composition or conduct certain activities are most likely closely linked with socioeconomic policies, traditional welfare delivery structures and certain legal provisions for the cooperative form, rather than with the influence of sectoral cooperative and non-cooperative intermediaries and certain institutional path dependencies. 


\section{Conclusion}

Despite certain methodological constraints and the limited comparability of country data, our analysis provides some findings about the interplay between context and CSEs' characteristics, and resulting trends. Overall, the analysis shows that CSE is a very context-specific phenomenon.

The state appears to be a key enabler of CSE in many countries, for example through specific legislation and funding streams. Recent examples can be found in the fields of renewable energy, resident-led housing or public-service delivery. There seems to be a trend towards the emergence of CSEs across many countries in general, and of cooperative initiatives aimed at managing common-pool resources as well as local and regional infrastructure in particular.

While there are specific policies for social enterprise in some countries, social and economic policies at large also have an influence on the CSE sector. Our findings also suggest a dominance of WISEs in particular among CSEs; such dominance appears to clearly relate to broad socioeconomic policies and not to specific cooperative policies/legislation. The above findings generally support results of previous, mainly qualitative and hermeneutic, studies.

In line with the DNA of strong cooperative movements, CSEs primarily serve their members' interests, and their "concern for the community" currently remains a secondary goal in most cases. At the same time, our findings clearly show that it is their orientation towards the community that distinguishes CSEs from other cooperative-type enterprises. Indeed, CSEs also serve non-members, and even whole communities of place or of interest. They do so more easily with external assistance, but also manage without it.

Notably, what we found in our cross-country study is that CSEs exist virtually everywhere, and that they are private entities, mainly providing private goods and services. Most of their revenue is generated by sales, regardless of their legal form. In fact, the specific legal form for CSEs still varies among the countries studied. Furthermore, CSEs are almost inevitably discussed in conjunction with traditional cooperative sectors. They are characterised by pronounced financial autonomy, which is not necessarily limited by the socio-economic policies supporting them. The most prominent CSE-related policy is definitely the Italian social-cooperative one, which has influenced social-economy-related policies in several Central and Eastern European countries. The possibility to include several interest groups into the membership might be a driving force for the future growth of CSE in most countries. 


\section{Notes}

1 All ICSEM Working Papers-that is, both "country papers" and "transversal papers"-are available online on the ICSEM Project's website: http://www. iap-socent.be/icsem-working-papers.

2 The ICSEM Project generated a set of "country papers" also covering Australia, Canada, Israel, New Zealand, the United Arab Emirates, the United States, Rwanda and South Africa, which did not fit into the "regional approach" adopted for the four ICSEM books. Most of these country papers were published in a special issue of the Social Enterprise Journal, edited by Defourny and Nyssens (2017); some were also included in transversal thematic analyses, as it is the case here.

3 For a wider and deeper analysis of the role of social-economy-related policies, see chapter 16 in this volume.

4 For more details, see chapter 1, devoted to Belgium, in this volume.

5 It has to be noted, though, that SCICs constitute some kind of exception in France (Hiez, 2013: 397), where most types of cooperatives are restricted to servicing their members only.

\section{References}

Anastasiadis, M. \& Lang, R. (2016) "Social enterprise in Austria: A contextual approach to understand an ambiguous concept", ICSEM Working Papers, No. 26, Liege: The International Comparative Social Enterprise Models (ICSEM) Project.

Birkhölzer, K., Göler von Ravensburg, N., Glänzel, G., Lautermann, C. \& Mildenberger, G. (2015) "Social enterprise in Germany: Understanding concepts and context", ICSEM Working Papers, No. 14, Liege: The International Comparative Social Enterprise Models (ICSEM) Project.

Blome-Drees, J., Boggild, N., Degens, P., Michels, J., Schimmele, C. \& Werner, J. (2016) Potenziale und Hemmnisse von unternehmerischen Aktivitäten in der Rechtsform der Genossenschaft, Münster: LIT Verlag.

Borzaga, C., Poledrini, S. \& Galera, G. (2017) "Social enterprise in Italy: Typology, diffusion and characteristics", Euricse Working Papers, No. 95(17) [Also published in the series of ICSEM Working Papers, No. 44, Liege: The International Comparative Social Enterprise Models (ICSEM) Project].

Cooney, K. (2015) "Social enterprise in the United States: WISEs and other worker-focused models", ICSEM Working Papers, No. 09, Liege: The International Comparative Social Enterprise Models (ICSEM) Project.

Defourny, J. \& Nyssens, M. (2012) "The EMES approach of social enterprise in a comparative perspective", EMES Working Papers Series, No. 12/03, Liege: EMES International Research Network.

Defourny J. \& Nyssens, M. (2017) "Mapping social enterprise models: An international perspective", Social Enterprise Journal, Vol. 13, No. 4, pp. 318-442.

Ebrahim, A., Battilana, J. \& Mair, J. (2014) "The governance of social enterprises: Mission drift and accountability challenges in hybrid organizations", Research in Organizational Behavior, Vol. 34, pp. 81-100. 
European Commission (2014a) "Country Report: Austria”, A Map of Social Enterprises and Their Ecosystems in Europe, Brussels: European Commission. Available HTTP: http://ec.europa.eu/social/keyDocuments. jsp? advSearchKey=socentcntryrepts $\&$ mode $=$ advancedSubmit $\&$ langId=en $\&$ policyArea $=\&$ type $=0 \&$ country $=0 \&$ year $=0 \&$ orderBy $=$ docOrder $\quad($ accessed March 27, 2017).

European Commission (2014b) "Country Report: Germany", A Map of Social Enterprises and Their Ecosystems in Europe, Brussels: European Commission. Available HTTP: http://ec.europa.eu/social/keyDocuments. jsp? pager .offset $=10 \& \&$ langId $=$ en $\&$ mode $=$ advanced $S u b m i t \&$ year $=0 \&$ country $=0 \&$ type $=0 \& a d v S e$ archKey $=$ socentcntryrepts $\&$ orderBy $=$ docOrder (accessed on March 27, 2017).

European Commission (2014c) "Country Report: Switzerland", A Map of Social Enterprises and Their Ecosystems in Europe, Brussels: European Commission. Available HTTP: http://ec.europa.eu/social/keyDocuments.jsp? pager . offset $=20 \& \&$ langId $=$ en $\&$ mode $=$ advancedSubmit $\&$ year $=0 \&$ country $=$

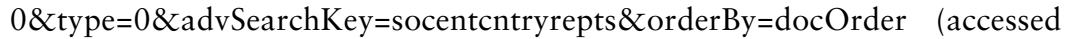
on May 1, 2017).

European Commission (2014d) "Country Report: Hungary”, A Map of Social Enterprises and Their Ecosystems in Europe, Brussels: European Commission. Available HTTP: http://ec.europa.eu/social/BlobServlet?docId=13103\&langId=en (accessed on October 20, 2016).

Fekete, E. G., Hubai, L., Kiss, J. \& Mihály, M. (2017) "Social enterprise in Hungary", ICSEM Working Papers, No. 47, Liege: The International Comparative Social Enterprise Models (ICSEM) Project.

Fici, A. (2015) "Recognition and legal forms of social enterprises in Europe: A critical analysis from a comparative law perspective", Euricse Working Papers, No. 82(15).

Gonin, M. \& Gachet, N. (2015) "Social enterprise in Switzerland: An overview of existing streams, practices, and institutional structures", ICSEM Working Papers, No. 03, Liege: The International Comparative Social Enterprise Models (ICSEM) Project.

Heitzmann, K. \& Simsa, R. (2004) "From corporatist security to civil society creativity: The nonprofit sector in Austria", in Zimmer, A. \& Priller, E. (eds) Future of Civil Society. Making Central European Nonprofit Organisations Work, Wiesbaden: VS Verlag für Sozialwissenschaften, pp. 713-731.

Hiez, D. (2013) “Chapter 17 - France”, in Cracogna, D., Fici, A. \& Henrÿ, H. (eds) International Handbook of Cooperative Law, Heidelberg, New York, Dordrecht \& London: Springer, pp. 393-411.

Huybrechts, B., Defourny, J., Nyssens, M., Bauwens, T., Brolis, O., De Cuyper, P., Degavre, F., Hudon, M., Périlleux, A., Pongo, T., Rijpens, J. \& Thys, S. (2016) "Social enterprise in Belgium: A diversity of roots, models and fields", ICSEM Working Papers, No. 27, Liege: The International Comparative Social Enterprise Models (ICSEM) Project.

Katona, A. (2014) "Social cooperatives in Hungary: The engines of local development?". Available HTTP: https://prezi.com/cav-k5tuptib/socialcooperatives-in-hungary-the-new-engines-of-local-development (accessed on November 11, 2016). 


\section{Göler von Ravensburg, Lang et al.}

Kerlin, J. A. (2010) “A comparative analysis of the global emergence of social enterprise”, Voluntas, Vol. 21, No. 2, pp. 162-179.

KPRES (2014) The National Programme for the Development of Social Economy, Ministry of Family, Labour and Social Policy, Warsaw. Available HTTP: http:// www.ekonomiaspoleczna.pl/files/wiadomosci.ngo.pl/public/korespondenci/portal_ ekonomiaspoleczna/KPRES_23.06.2014.pdf (accessed on October 15, 2014).

Ministry of Family, Labour and Social Policy (2016) Informacja o funkcjonowaniu spółdzielni socjalnych działajacych na podstawie Ustawy $z$ dnia 27 kwietnia 2006 r. o spóldzielniach socjalnych za okres 2014-2015, Warsaw: Ministry of Family, Labour and Social Policy. Available HTTP: http://bip.kprm. gov.pl/download/75/43408/Informacjaofunkcjonowaniuspoldzielnisocjalnych. pdf (accessed on January 10, 2017).

Piechowski, A. (2010) Raport o spółdzielczości polskiej, Warsaw: Krajowa Rada Spółdzielcza.

Piechowski, A. (2013) "Chapter 28- Poland", in Cracogna, D., Fici, A. \& Henry, H. (eds) International Handbook of Cooperative Law, Heidelberg, New York, Dordrecht \& London: Springer, pp. 609-634.

Poledrini, S. (2015) "Unconditional reciprocity and the case of Italian social cooperatives", Nonprofit and Voluntary Sector Quarterly, Vol. 44, No. 3, pp. 457-473.

Poledrini, S. (2018) “The emergence of new social enterprise models in Italy: First insights from the international ICSEM Project”. Impresa Progetto Electronic Journal of Management, Vol. 2, pp. 1-19.

Stappel, M. (2017) "Zu genossenschaftlichen Neugründungen mit sozialer Zielsetzung”, in Schmale, I. \& Blome-Drees, J. (eds) Genossenschaft innovativ, Wiesbaden: Springer VS, pp. 147-160.

Teasdale, S. (2011) "What's in a name? Making sense of social enterprise discourses”, Public Policy and Administration, Vol. 27, No. 2, pp. 99-119. 


\title{
20 Testing the Relevance of Major Social Enterprise Models in Western Europe
}

\author{
Jacques Defourny, Marthe Nyssens and \\ Olivier Brolis
}

\section{Introduction}

Although the notions of social entrepreneurship, social entrepreneur and social enterprise have sometimes been considered as different facets of a same phenomenon, especially in the late 1990s and early 2000s, the last two decades have witnessed clear trends towards distinct research developments about social entrepreneurship (and the related term of social entrepreneur), on the one hand (Dacin et al. 2011; Santos 2012; Alegre et al. 2017, among many others), ${ }^{1}$ and social enterprise, on the other hand $^{2}$ - though, of course, this does not mean that the boundaries between these two research fields are clear cut. In addition to such trends, many conceptual debates are still taking place within each of both "sides", and in particular in the field of research on the concept of social enterprise (SE), which is at the heart of this book as well as of this final chapter. Indeed, the lack of a shared understanding and definition of social enterprise is today acknowledged by most researchers, and it even seems reasonable to speak of the "impossibility of reaching a unified definition of social enterprise".

In response to such conceptual diversity and sometimes confusion, various authors tried to identify categories or types of social enterprise and to propose basic typologies. Alter (2007) was among the first; she put forward various types of operational models, for instance in terms of relations between social enterprises' missions and economic activitieswhich can be, according to the terminology she proposed, missioncentric, mission-related or mission-unrelated. A bit later, Spear et al. (2009) identified four main types of social enterprise in the UK, according to the initiatives' origins and development paths. For the same country, Teasdale (2012) and Gordon (2015) stressed the diversity of discourses or "basic values" shaping SE models, while McMurtry and Brouard (2015) put forward a typology adapted to the Canadian context. For their part, relying mainly on an analysis of the US SE landscape, Young et al. (2016) proposed the metaphor of a "social enterprise zoo", in which different types of animals seek different things-just like 


\section{Defourny, Nyssens \& Brolis}

social enterprises, which differ significantly from each other in the ways in which they combine social and market goals.

When it comes to international comparative works, Kerlin (2013, 2017) adopted an institutional perspective inspired by the "social origins" theory developed by Salamon et al. (2000), identifying key features of macroinstitutional frameworks to suggest how any set of socioeconomic and regulatory institutions at country level tends to shape a specific major SE model per country. Borzaga and Defourny (2001), for the countries that then made up the European Union; Borzaga et al. (2008), for Central and Eastern Europe; Defourny and Kim (2011), for Eastern Asia; and more recently, the European Commission (2020), for the whole of Europe, all made attempts at international comparative analyses, but these analytical grids did not rely on systematic data collection at the enterprise level. ${ }^{3}$

Against such background, we developed a typology of SE models (Defourny and Nyssens 2017), which we also present in the introductory chapter of this book (see section 20.2, about the second phase of the ICSEM Project). This typology highlighted four major SE models: the entrepreneurial non-profit (ENP), the social cooperative (SC), the social business (SB) and the public social enterprise (PSE). As we show, this typology is rooted in theoretical grounds provided by some inspiring works carried out by Gui (1991) and Hansmann (1996) on the very identity of the "third sector". 4

The main objective of this final chapter is to test statistically, at the enterprise level, the relevance of this typology of SE models on the basis of a dataset resulting from a field survey carried out on social enterprises in more than 40 countries across the world. On such basis, we put forward the hypothesis that this typology is neither country-specific nor even, more broadly, context-specific. In other words, we will try to see to what extent each SE model may be identified across countries in every region and across world regions. In such broad perspective, we carried out the statistical testing both at the worldwide level and at the regional level. In line with the whole content of this book, this final chapter of course focuses on Western Europe and on the statistical exploitation of the data collected in this region.

This chapter is organised as follows. We first present the methodology adopted for the empirical survey that is at the very heart of this statistical work: we describe the key dimensions of social enterprise that were captured and the methodological choices that were made for this survey, which was carried out on 721 social enterprises operating in various world regions (section 20.1). We then present the hierarchical cluster analysis that we carried out on the basis of such an outstanding dataset (section 20.2), before discussing the empirical results obtained, especially regarding the existence (or not) of our four theorised SE models (section 20.3). Finally, we conclude with comparisons between the various regions to better apprehend specificities of SE models in their respective contexts. 


\subsection{The ICSEM Survey and Database}

All the researchers involved in the ICSEM Project first had to provide a "country contribution" about the SE landscape in their respective countries. Among other things, researchers were asked to identify and characterise the various SE types or categories they could observe (phase 1 of the ICSEM Project; for a more detailed description of this phase, see the introductory chapter in this volume). Two major distinctive features of this approach should be underlined here. First, no a priori strict definition of social enterprise was imposed for these national contributions. We broadly delineated the field of analysis as "made of organisations that combine an entrepreneurial dynamic to provide services or goods with the primacy of their social aims". The emphasis was put on the embeddedness of the SE phenomenon in local contexts. Secondly, most research was carried out by teams rather than by individual researchers, and this fostered discussion at the local or national level, thereby reducing the risks of biases induced by purely personal perceptions.

In a second phase, in order to address the lack of reliable datasets at enterprise level to undertake international comparative analysis, in-depth information was collected about social enterprises on the basis of a common questionnaire. More precisely, ICSEM research partners interviewed the managers of three to five social enterprises that were deemed emblematic of each SE type identified in the project's first phase. The researchers were asked to collect information regarding more specifically the nature of the social mission or social aims, the type of economic model and the governance structure, as we hypothesised that these three dimensions particularly informed the diversity of social enterprises. Let us recall, in this regard, that the EMES SE ideal type relies on these three dimensions. For each of them, a set of three indicators is put forward. It does not mean, though, that an organisation has to meet all the indicators in order to qualify as a social enterprise; the ideal type is rather used as a yardstick for the comparison and grouping of observed organisations.

As a result, detailed data were collected in a rather homogenous way for 721 social enterprises from 43 countries. Needless to say, such a sample is by no way representative of the SE population across the world. Indeed, not only is the distribution across continents particularly uneven, with a quasi-absence of Africa; more fundamentally, the whole SE population is simply unknown, as there is no universal definition of social enterprise. ${ }^{5}$

As shown in table 20.1, the nineteen European countries covered by the survey account for almost half of all the enterprises surveyed across the world (328 enterprises out of 721). Thanks to the high number of observed social enterprises in Europe, the statistical work could be carried out in separate ways for Western Europe (with 164 surveyed social 
Table 20.1 Social enterprises covered by the ICSEM survey by region/country

\begin{tabular}{lcc}
\hline Regions and countries & $\begin{array}{c}\text { No. of } \\
\text { countries }\end{array}$ & $\begin{array}{c}\text { No. of social } \\
\text { enterprises }\end{array}$ \\
\hline Europe & 19 & 328 \\
Central and Eastern Europe & 7 & 164 \\
Western Europe & 12 & 164 \\
$\quad$ Austria & & 3 \\
$\quad$ Belgium & & 23 \\
$\quad$ Finland & 4 \\
$\quad$ France & & 11 \\
$\quad$ Germany & & 35 \\
$\quad$ Ireland & & 12 \\
$\quad$ Italy & & 13 \\
$\quad$ Luxembourg & & 16 \\
$\quad$ Spain & & 14 \\
$\quad$ Sweden & 5 & 21 \\
$\quad$ Unitzerland & & 7 \\
Asia Kingdom & & 100 \\
Latin America & 9 & 162 \\
US, Canada, Australia and New Zealand & 7 & 45 \\
Middle East (Israel and United Arab Emirates) & 4 & 31 \\
Africa (Rwanda and South Africa) & 2 & 55 \\
Total & 2 & 721 \\
\hline
\end{tabular}

enterprises from twelve countries) and Central and Eastern Europe (with 164 surveyed social enterprises from seven countries). In this volume dedicated to social enterprise in Western Europe, we of course focus mostly on findings for Western Europe. ${ }^{6}$

In spite of limitations in the collection of data at the enterprise level, we argue that our overall research strategy-which combines a theoretical typology and a quite demanding bottom-up empirical approach based on a field survey-constitutes a significant step toward capturing the diversity of SE models. The following step (phase 3 of the ICSEM Project) aimed to exploit the dataset built through the ICSEM survey in order to see if it provided empirical support to the typology of SE models mentioned above and described in more detail in section 2 of the introductory chapter in this volume.

\subsection{A Hierarchical Cluster Analysis to Identify Major SE Categories}

For the purpose of carrying out a cluster analysis, we extracted quantitative and qualitative (nominal and ordinal) variables from the questionnaire. The ultimate goal was to describe each of the 164 social enterprises from Western Europe along five major dimensions: (1) 
general identity (legal form, origin, accreditations); (2) social mission (mission's nature, relation with the social enterprise's main economic activity, price of the goods and services provided, type of innovation); (3) workforce composition (workers and volunteers); (4) financial structure in general and, more precisely, ways in which the social enterprise combines various types of resources; and (5) governance structure and rules regarding the allocation of surplus. As multiple choices and combinations of several choices were possible for many questions, we defined 141 variables.

Before undertaking a hierarchical cluster analysis (HCA) based on Ward's aggregation method, we had to solve two main issues. First, our database included both quantitative and qualitative variables, while HCA cannot be performed on qualitative variables. Secondly, we wanted each of the five predetermined dimensions to have the same weight, which was not the case since some dimensions were composed by a higher number of variables than others. In order to overcome these problems, we therefore performed a multiple factorial analysis (MFA) on the 141 defined variables and selected six factors. Using MFA solved our two problems: first, it made it possible to give the same importance to each of the five pre-determined dimensions; secondly, it enabled us to describe each social enterprise through quantitative indicators only (the social enterprise's coordinates on each factor).

The optimal number of clusters (n) resulting from the HCA corresponds to the number of clusters for which the sum of intracluster variances does not decrease significantly when $n+1$ clusters are considered. Based on that criterion, we identified five major clusters. ${ }^{7}$

\subsection{SE Models in Western Europe: Which Profiles and Relevance?}

The key results of our statistical work are displayed in table 20.2 (at the end of section 20.3.3), where the five clusters are described through the various dimensions listed in the first column. The various clusters are analysed here with the following question in mind: to what extent do these clusters confirm or not the existence of our theorised SE models?

\subsubsection{Two Clusters Converging Towards an Entrepreneurial Non-Profit SE Model}

Clusters 1 and 2 gather almost half of the social enterprises in this Western sample and can be considered as corresponding to "entrepreneurial non-profit social enterprises". Cluster 1 gathers organisations providing mainly education, health and social services, whereas social enterprises in cluster 2 are mainly driven by a mission of 
338 Defourny, Nyssens \& Brolis

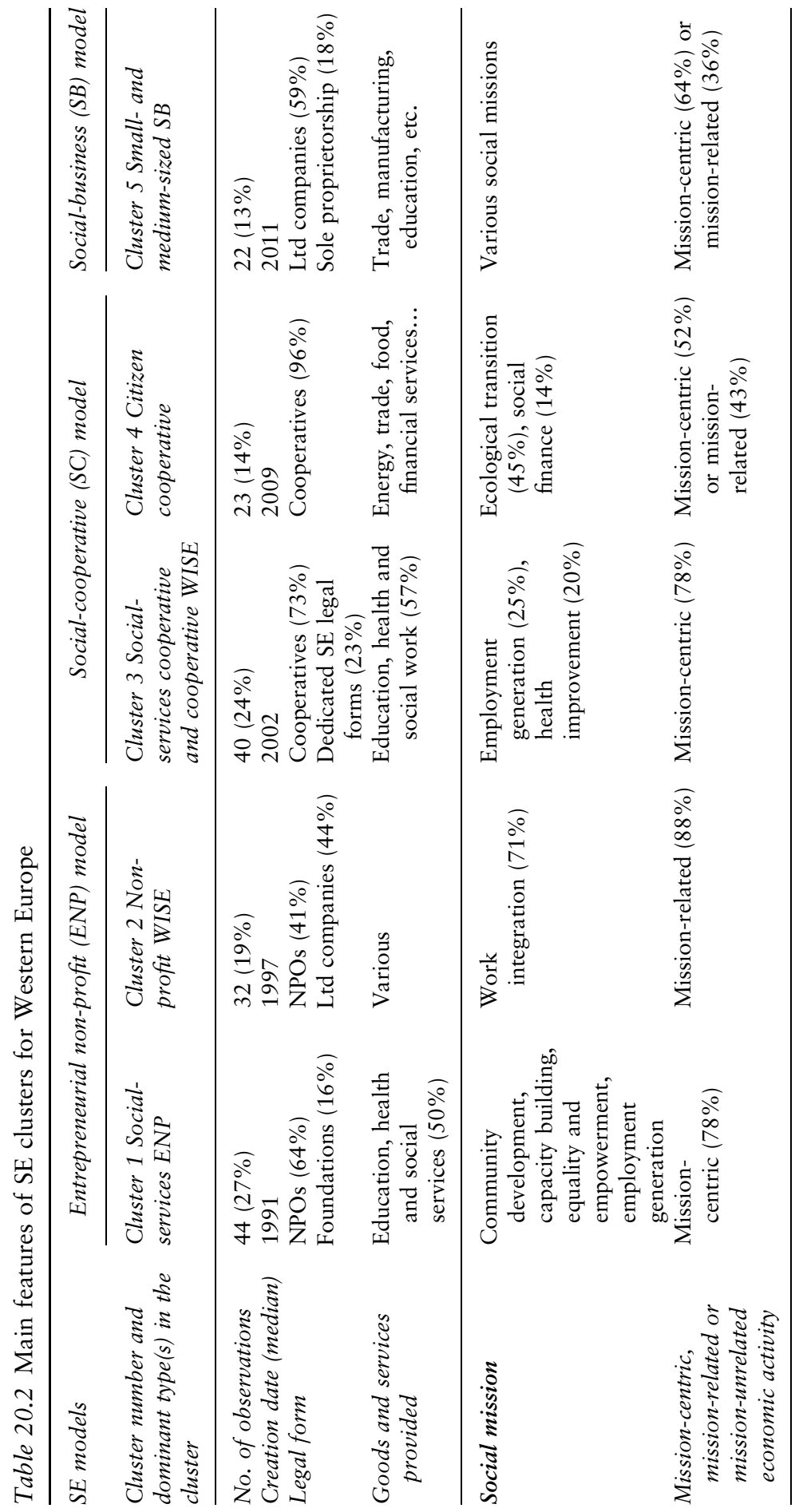


Testing Major SE Models in Western Europe 339

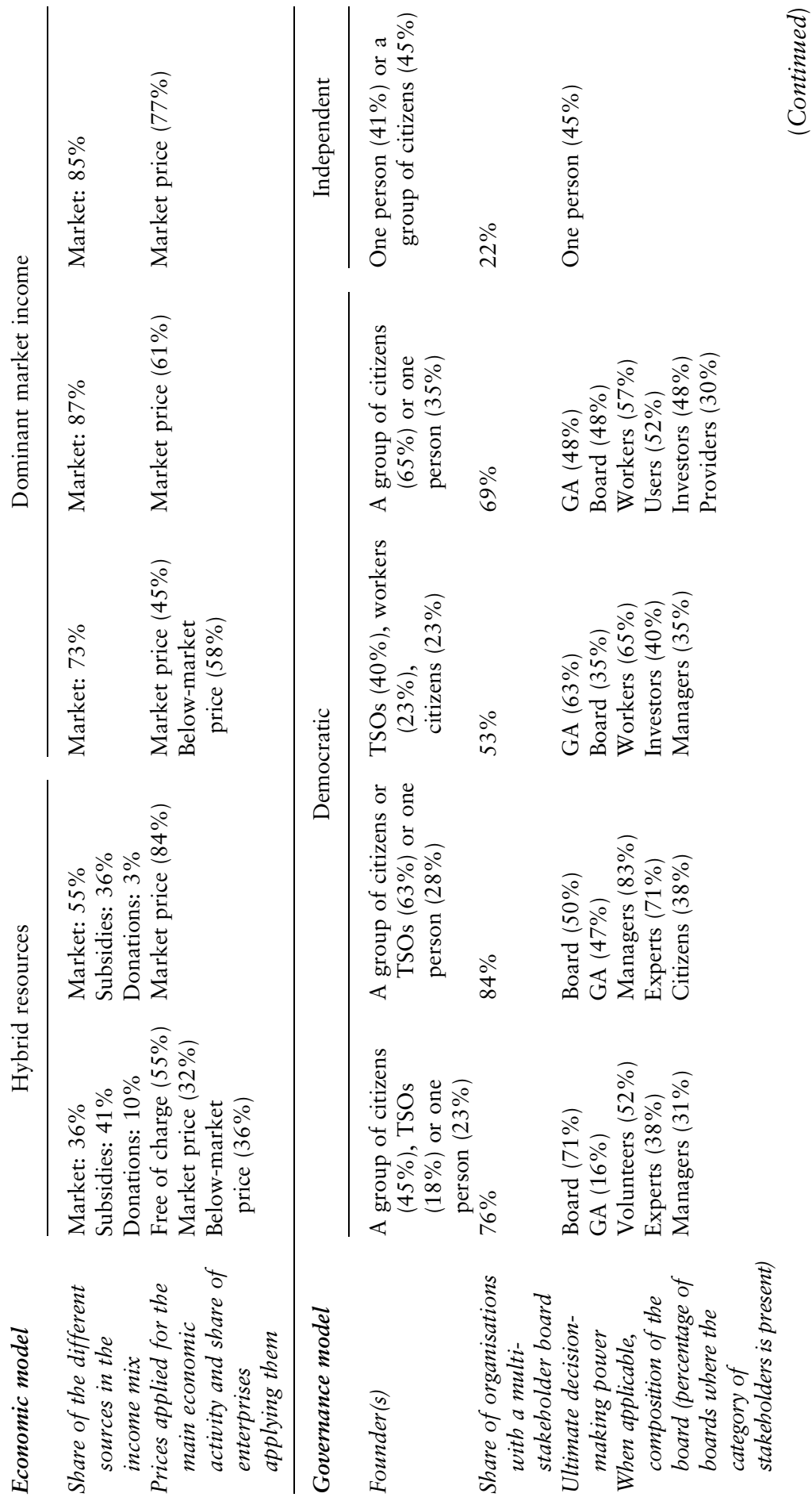




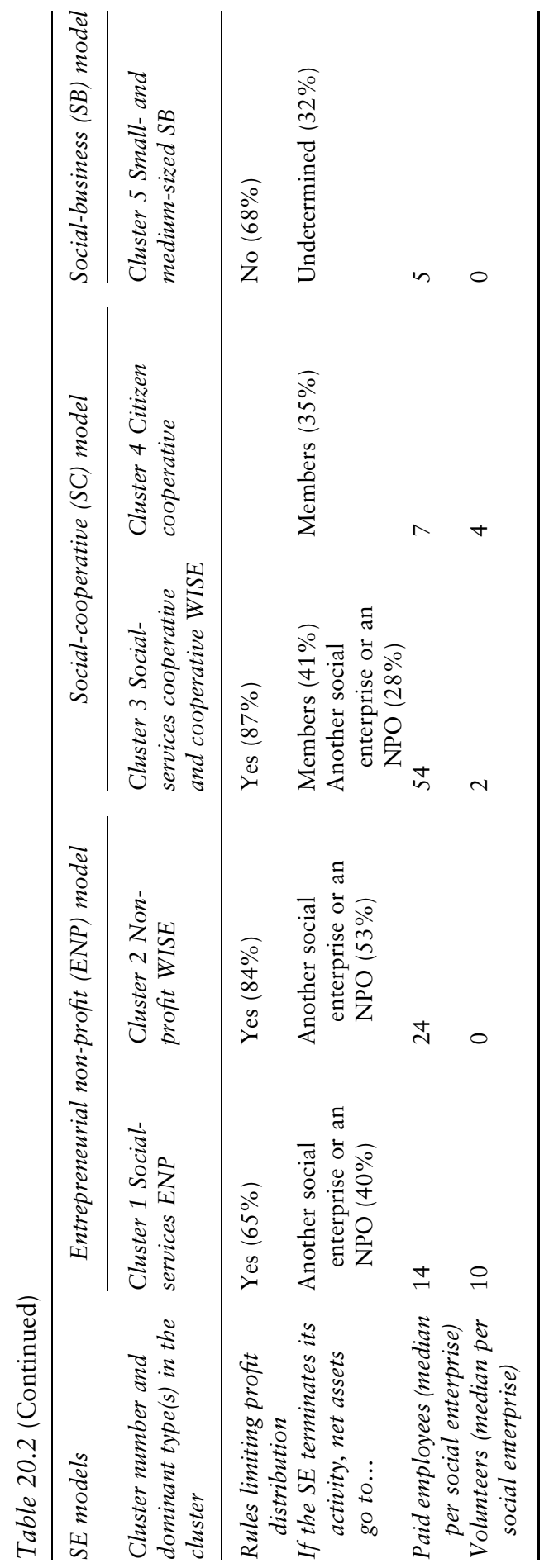


employment generation and may therefore be considered as workintegration social enterprises (WISEs).

In cluster 1 , the dominant legal forms are those of non-profit organisation and foundation. Most enterprises in this cluster have been launched by a group of citizens, sometimes in partnership with another third-sector organisation. In almost one quarter of the cases, a single person is the social enterprise's initiator. These organisations pursue missions such as community development, capacity building, equality and empowerment or employment generation.

Either the board or the GA holds the ultimate decision-making power. In many cases, the board involves volunteers, experts and managers. In $40 \%$ of social enterprises in this cluster, if the activity is terminated, net assets go to another organisation with a similar social mission. Services provided by these social enterprises are mainly "mission-centric", according to Alter's (2007) classification. These organisations have almost as many volunteers as they have employees. Another major distinctive feature of organisations in this cluster is the fact that they are the oldest organisations in the entire sample.

The organisations belonging to this cluster display a wide diversity of resources, with $36 \%$ of income coming from the market and $41 \%$ from public subsidies. Only one-third of these organisations sell some of their services at market price. Indeed, providing at least some services free of charge or at a price not covering most production costs is a widespread practice in this group. In cases where such practice is implemented, the organisation may also receive substantial public subsidies, when its production is considered to contribute significantly to the public good and cannot be financed by private (market and non-market) resources.

Such resource mix could be seen as somehow surprising since a usual approach to social enterprise sees it as "a market solution to a social problem"; in this perspective, the proportion of earned income often constitutes the main indicator to identify social enterprises. For many scholars, however, among which those belonging to the EMES school of thought (Defourny and Nyssens 2010), the entrepreneurial dimension of social enterprise lies, at least partly, in the fact that the initiative bears a significant level of entrepreneurial risk-but not necessarily a market risk. In this broader perspective, the resource mix, which can best support the social mission, is likely to have a hybrid character, as it may combine trading activities with public subsidies and voluntary resources. In a similar way, Maier et al. (2016) identify several dynamics which can characterise "NPOs becoming business-like", beyond the sole market character of financial resources: NPOs can adopt business-like goals (such as commercialisation or/and conversion from an NPO to an FPO legal form); they can also adopt business-like core and support processes (entrepreneurial orientation, professionalisation, business-like philanthropy, etc.) or develop business-like rhetoric. It is thus not surprising 
that many NPOs have been identified as social enterprises by local researchers, even though they have less than $50 \%$ of earned income.

As briefly observed above, cluster 2 gathers mainly work-integration social enterprises (WISEs). The mission of WISEs is to integrate disadvantaged groups back into the labour market and society through a productive activity. In the last two decades, WISEs have been a major focus of policies promoting social enterprise (Nyssens 2006; Cooney et al. 2016). These initiatives sell a wide variety of goods or services, mainly at market price. They rely more heavily on earned income than organisations in cluster 1 , although they are also embedded in a very hybrid economic model. These enterprises' productive activities are mainly "mission-related": indeed, the economic activity is a means to create jobs, whatever the types of products that are commercialised on various markets.

Enterprises in this cluster adopt either the legal form of an NPO or that of a limited company. Most of them have been launched by citizens or third-sector organisations. Like in the previous cluster, a single person is the social enterprise's initiator in about $25 \%$ of cases, thereby reflecting the social entrepreneurial profile of pioneering leaders, who often bring about social innovation or pave the way for new waves of social enterprise. Such social entrepreneurs can be charismatic but they want to adopt democratic governance features. Indeed, either the board or the GA holds the ultimate decision-making power, and the board is composed mainly by managers, experts and citizens. The distribution of profit is limited. If the social enterprise terminates its activity, the net assets are transferred to another social enterprise or to an NPO.

These first two clusters clearly suggest the existence of two major subgroups of social enterprises (one strongly focusing on work integration and another displaying a diversity of other social missions) that share enough features to suggest the existence of a deeply rooted "entrepreneurial non-profit SE model”, covering a spectrum of non-profit social enterprises, as theorised earlier in this volume (see figure 0.1 in the introductory chapter).

\subsubsection{Two Clusters Indicating the Existence of a Social- Cooperative SE Model}

In two clusters among the five (clusters 3 and 4), a large proportion of organisations have adopted the legal form of a cooperative. This is a strong feature, which invites us to look carefully at these two clusters as potentially signalling the existence of a "cooperative-type" SE model. However, we still have to document more strongly the specific "social" nature of enterprises in these clusters, as conventional cooperatives are first and foremost oriented to their members' interests, not the general interest of a larger community, as hypothesised in figure 0.1 . The key 
question is thus the following: how do the organisations belonging to these two clusters differ from conventional cooperatives, to such an extent that they have been regarded as social enterprises by ICSEM researchers, and do their specificity justify their positioning closer to the "social-cooperative" model than to the area of traditional cooperatives?

In cluster 3, about one-fourth of organisations are not legally registered as cooperatives, but this is not necessarily incongruent with our hypothesis of these two clusters signalling the existence of a "cooperativetype" model. Indeed, cooperative principles can also be implemented by social enterprises that are not formally registered as cooperatives. Twenty-three percent of organisations in cluster 3 have adopted dedicated SE legal forms, which vary according to national legislations; some are rather close to-although technically different from-the conventional cooperative status (like the so-called social cooperatives in Italy or the "general-interest cooperative society" in France). In other cases, a label may be combined with various conventional legal forms: until 2018, the "social-purpose company" in Belgium provided a good example of such an SE label that was particularly, although not exclusively, accessible to cooperatives. According to a new law of 2019, only cooperatives now have access to the Belgian SE label. Another case, in the UK, deserves some discussion: since 2008, the British Government has attempted to stimulate development of the "public-service mutual" - a private organisation, characterised by employee rights both to the residual profits and to control. These mutuals thus appear similar to worker cooperatives in that they are oriented to their members' mutual interest; however, they may qualify as social enterprises because they are typically "spin off" from the public sector and provide a public service under contract to a government agency (Le Grand and Roberts 2018). They mostly adopt the legal form of community-interest companies.

The social mission and economic activities are clearly interwoven in the organisations making up cluster 3: almost $80 \%$ of these organisations perform economic activities that are "mission-centric". Organisations in this first cooperative cluster deliver mainly education, health and social services $(57 \%)$-all activities that are meant to serve strong social objectives: they aim mainly at creating jobs for the unemployed or at improving the health of disadvantaged people. These social enterprises rely mainly on market resources ( $73 \%$ of income), although they often sell some of their products below market price, which reflects their general-interest orientation.

In this cluster, most organisations have been launched by third-sector organisations, workers or groups of citizens, and they display democratic governance structures, mainly under the control of their workers and managers (and, in some cases, investors). The distribution of profit is limited or even prohibited in some cases. If the social enterprise terminates its activity, the net assets are transferred to the members or to another social enterprise or NPO. 
With a median workforce of 54 persons, these organisations are the largest social enterprises in the whole sample. On the basis of information not presented in table 20.2, we can add that cluster 3 includes a significant share of Italian social cooperatives, which are emblematic of a legal shift towards a model in which an explicit central place is given to the organisation's general-interest missions. In the late 1980s indeed, in Italy, pioneering cooperative-like initiatives were launched by groups of citizens or workers in the absence of a specific legal form adapted to their characteristics. The conventional cooperative movement, which by then had become aware of new social challenges, decided to support this emerging movement and to lobby for a new type of cooperative, better adapted to these new challenges. Such lobbying led to the development of a supportive ecosystem: creation of a new legal form (namely that of "social cooperative", including "A-type" social cooperatives, targeted at the provision of social services, and "B-type" social cooperatives, which can be considered as work-integration social enterprises), promotion of access to public contracts, etc. A similar movement has since been observed in other European countries, giving birth to social-cooperativetype social enterprises. Indeed, the Italian legal model has since been followed (either fully or partially, with adaptations to national contexts) by the Portuguese (1998), Spanish (1999), Greek (1999) and French (2001) legislators (Fici 2015). ${ }^{8}$

The second cooperative-type cluster (namely cluster 4) gathers almost only cooperatives, displaying the typical cooperative governance structure: a general assembly, and an ownership structure based on shares with a cap imposed on profit distribution. They mostly sell their goods and services at market prices.

Initiatives in this cluster are quite recent (about 10 years old) and much smaller than those in the previous cluster. Most of these social enterprises have been launched by citizens. Almost half of them are driven by an ecological transition mission. Moreover, all social enterprises in our sample that are driven by a social mission of "access to financial services" or "food security" are included in this cluster. This cluster also includes, inter alia, short-circuit agricultural cooperatives, gathering producers and consumers of organic food, and renewableenergy cooperatives, where members' interest is combined with a large societal (environmental) aim. Many of these social cooperatives are multi-stakeholder organisations, involving workers, users, investors and providers in their governance bodies.

Overall, these "citizens' cooperatives" involve committed citizens experimenting with social innovations that respond to the interests and values of local communities. As explained by Seyfang and Smith (2007), this type of cooperative strives to fulfil unmet social needs and develops practices based on alternative goals to economic growth per se, such as achieving a higher quality of life or local-community-oriented development. This is 
certainly one of the most recent generation of cooperatives in Western Europe, and it is embedded in the so-called transition movement (Hopkins 2008, 2013).

The analysis of these two clusters leads us to conclude that our theorisation of social cooperative as a major SE model is supported by strong empirical evidence.

\subsubsection{One Cluster Indicating the Existence of a Social- Business Model}

The last and smallest cluster (cluster 5) gathers the most recent and smallest social enterprises in our sample. It may be identified as gathering organisations that combine a strong commercial orientation and a social mission (which, incidentally, may vary a lot from one enterprise to the other). These features, combined with the legal form of limited company or sole proprietorship, indicate the existence of a "social-business" model.

Data in table 20.2 show that organisations belonging to the socialbusiness cluster and those in the two cooperative-type clusters display very similar economic models: they mostly sell their goods and services at market prices and rely on market resources. As far as their activities and missions are concerned, the economic activity of both social cooperatives and social businesses is either "mission-centric" or "mission-related", which means that they deliver goods or services to a wider population than to the group targeted by the social mission.

Beyond these common characteristics, several other features tend to draw the picture of two quite diverging SE profiles. As regards the ultimate decision-making power, in organisations belonging to this last cluster, it most often belongs to the owner. We can qualify this type of ownership and management as "independent", as these social enterprises are in the hands of a single person. This of course contrasts with the "cooperativetype" clusters, whose organisations display democratic governance structures, with a board and a GA involving a wider diversity of stakeholders. Regarding rules and provisions related to profit distribution, it is striking to note that there is no rule limiting profit distribution in $68 \%$ of organisations in the "social-business" cluster (this feature sharply contrasts with what is found in the cooperative-type clusters). These businesses can adopt an accreditation requiring that social goals be predominant in their mission, but generally, such accreditations (e.g., the private accreditation of "benefit corporation" or "B Corp") do not impose any limit on the distribution of profits. This is not to say, however, that all or most of the profits are usually distributed to owners: a quite common practice (shared by $64 \%$ of organisations in the "social-business" cluster) is to reinvest at least part of the profits in the social enterprise. ${ }^{9}$

In order to better capture the actual profile of social enterprises in the "social-business" cluster, more information is still needed, especially 
about their actual size. At first sight, a good deal of the social-business literature emphasises, promotes and celebrates initiatives launched by or in partnership with multinational corporations, thereby suggesting rather large-size initiatives. The annual Global Social Business Summit and its charismatic leader, Muhammad Yunus, are emblematic of this "school of thought", which stresses four key principles: shareholders in social businesses should not expect any financial return on investment (which is easy for big corporations in the framework of a CSR strategy); all profits should be reinvested for the social mission; goods and services should be sold at low prices to reach a high number of poor people; and the absence of public subsidies should guarantee full independence from the state.

It is precisely that kind of profile we had in mind when we started to conceptualise the social-business model, but our statistical results actually suggest another picture. This cluster is made of small- and mediumsized enterprises operating on the market while simultaneously pursuing a social mission. This feature is consistent with the already observed key role of an individual entrepreneur as the initiative's founder, main owner and dominant decision-maker.

As this combination of economic and social goals is implemented here within less regulated frameworks than those defined by the governance rules and structures in "cooperative-type" social enterprises, the balance between these (potentially conflicting) goals and its evolution over time raise the question of the social mission's sustainability. For instance, $32 \%$ of social enterprises in cluster 5 have no predetermined rule about the distribution of net assets in case the activity is terminated. In such context, it seems critical to observe enterprises' actual practices more in depth: To what extent do social and/or environmental dimensions actually prevail over the profit motive? Are they not mere instruments to better serve the financial interests of the owner(s)? More generally, under which conditions can a social-value-generating economic activity be considered as an expression of social entrepreneurship?

In any case, we can, at this stage, state that this cluster provides support to the idea, already represented in our triangle, that the social businessmodel is also deeply rooted in SMEs' willingness to generate blended value.

\subsubsection{No Public or Quasi-Public SE Model?}

Our theoretical typology also included a public or semi-public SE model, whose existence does not appear to be confirmed in Western Europe by the identification of a distinct cluster. However, some enterprises involve a governmental agency among their founding members. Moreover, a previous EMES research project (Nyssens 2006) revealed the importance of the public sector as the sole or as an associate founder of social enterprises in various countries. In Belgium, Germany, Portugal and 
Sweden, for instance, WISEs may be launched by municipalities or other local public bodies getting together to create jobs in various fields, ranging from cleaning services to social housing. A possible interpretation is that, although they do actively support social enterprises, most public authorities prefer to act as partners-rather than as the main entrepreneur-in the creation and management of WISEs. Another explanation for the absence of a distinct cluster confirming the existence of a public-sector SE model may be linked to the personal perception of the SE phenomenon by local researchers: many of them probably considered a priori social enterprises as private entities by nature, and therefore disregarded public-sector initiatives as potential social enterprises.

\section{Conclusion}

The objective of this last chapter was to test the international typology of SE models that we had previously put forward (Defourny and Nyssens 2017). The major finding is that three of our four theorised SE models are strongly supported by empirical evidence: the existence of a social-business model, a social-cooperative model and an entrepreneurial non-profit model is fully confirmed in Western Europe, as these models clearly emerge from the examination of the five clusters resulting from the statistical analysis.

When adding results from the other regions of the world to the picture, ${ }^{10}$ we are able to confirm the relevance of these three SE models, across countries within each region and across regions. More precisely, these three models are found in 39 countries out of 43, and applying the statistical treatment described in section 20.2 to the data from all 721 surveyed social enterprises actually yielded the same major results. ${ }^{11}$ Referring to the hypothesis that we had put forward in this chapter's introduction, we can now assert that our typology of SE models is neither country-specific nor even, more broadly, region-specific.

These results also suggest that social enterprises do stem from most, if not all, parts of the economy and can be related to different organisational backgrounds-namely the non-profit, the cooperative and the business sectors, which exist in all countries. Of course, this does not mean that social enterprises are not influenced by institutional factors at the meso or macro level; on the contrary, SE models should be considered as both embedded in their local contexts and partly shaped by their institutional environment at the meso and macro levels. Moreover, social enterprises themselves actually contribute in turn to shaping their institutional environment, as will be shown in the concluding section of this book.

\section{Notes}

1 In their classic survey of literature on social entrepreneurship, Dacin et al. (2011) listed some 80 references, among which only one referred to social 
enterprise in its title. On the basis of 307 documents selected because they referred to at least one of the notions of "social enterprise", "social entrepreneurship" and "social entrepreneur" such as they understood them, Alegre et al. (2017) developed a citation map and a cluster analysis of definitions; they came out with five quite distinct groups, among which three focused on social entrepreneurship and a single one, quite isolated, focused on defining social enterprise. For their part, Sassmannshausen and Volkmann (2018) provided an overview of the state of art of research on social entrepreneurship and its establishment as an academic field. See also the Journal of Social Entrepreneurship, launched in 2010.

2 See the Social Enterprise Journal, launched in 2005; most research carried out by or in relation to the EMES International Research Network since the late 1990s; and the recent EU report entitled Social Enterprises and their Ecosystems in Europe (2020).

3 Nyssens (2006) is an exception in this regard, as the work she coordinated relied on a common survey covering 162 work-integration social enterprises (WISEs) from eleven EU countries and almost 1,000 "WISE participants", that is, persons engaged in work-integration trajectories.

4 Kerlin's typology is also rooted in a theory trying to explain the existence and the place of the non-profit (third) sector. However, it is not confronted with empirical evidence at the enterprise level.

5 In a few countries where the notion of social enterprise is defined, for instance through a law, the definition does not generally enable an uncontested mapping and statistical analysis, because such a legal approach is often deemed too large or too narrow.

6 Results for Central and Eastern European countries are presented in the ICSEM book which is devoted to this part of Europe (Defourny and Nyssens 2021). Results for Latin America and Asia are presented in the first two ICSEM books, that is, respectively Gaiger et al. (2019) and Bidet and Defourny (2019).

7 One more cluster, gathering three social enterprises, was identified, but it was dropped because these social enterprises could be considered as "outliers".

8 In the same vein, new legal forms or frameworks promoting social cooperatives also appeared in Central and Eastern European countries, such as Hungary (2006), Poland (2006) and the Czech Republic (2012); see Defourny and Nyssens (2021), "Social Enterprise in Central and Eastern Europe".

9 Data upon which this statement is based do not appear in table 20.2; they come from more detailed results of the clustering.

10 See the other three books that resulted from the ICSEM Project, and in particular chapter 16 in Defourny and Nyssens (2021), chapter 16 in Bidet and Defourny (2019) and chapter 11 in Gaiger et al. (2019), for results about respectively Central and Eastern Europe, Asia and Latin America.

11 This global statistical analysis was first carried out and reported by Defourny et al. (2019) in an ICSEM Working Paper and was then published in Nonprofit and Voluntary Sector Quarterly (Defourny et al. 2020).

\section{References}

Alegre, I., Kislenko, S. \& Berbegal-Mirabent, J. (2017) "Organized chaos: Mapping the definitions of social entrepreneurship", Journal of Social Entrepreneurship, Vol. 8, No. 2, pp. 248-264. 
Alter, K. (2007) Social Enterprise Typology, Friendswood: Virtue Ventures LLC. Bidet, E. \& Defourny, J. (eds) (2019) Social Enterprise in Asia. Theory, Models and Practice, London and New York: Routledge.

Borzaga, C. \& Defourny, J. (eds) (2001) The Emergence of Social Enterprise, London and New York: Routledge.

Borzaga, C., Galera, G. \& Nogales, R. (eds) (2008) Social Enterprise: A New Model for Poverty Reduction and Employment Generation, Bratislava: United Nations Development Programme.

Cooney, K., Nyssens, M., O’Shaughnessy, M. \& Defourny, J. (2016) “Public policies and work integration social enterprises: The challenge of institutionalization in a neoliberal era", Nonprofit Policy Forum, Vol. 7, No. 4, pp. 435-460.

Dacin, M. T., Dacin, P. A. \& Tracey, P. (2011) "Social entrepreneurship: A critique and future directions", Organization Science, Vol. 22, No. 5, pp. 1203-1213.

Defourny, J. \& Kim, S.-Y. (2011) "Emerging models of social enterprise in Eastern Asia: A cross-country analysis”, Social Enterprise Journal, Vol. 7, No. 1, pp. 86-111.

Defourny, J. \& Nyssens, M. (2010) “Conceptions of social enterprise and social entrepreneurship in Europe and the United States: Convergences and divergences", Journal of Social Entrepreneurship, Vol. 1, No. 1, pp. 32-53.

Defourny, J. \& Nyssens, M. (2017) "Fundamentals for an international typology of social enterprtise models", Voluntas, Vol. 28, No. 6, pp. 2469-2497.

Defourny, J. \& Nyssens, M. (eds) (2021) Social Enterprise in Central and Eastern Europe. Theory, Models and Practice, London and New York: Routledge.

Defourny, J., Nyssens, M. \& Brolis, O. (2019) “Mapping and testing social enterprise models across the world: Evidence from the 'International Comparative Social Enterprise Models (ICSEM) Project”, ICSEM Working Papers, No. 50, Liege: The International Comparative Social Enterprise Models (ICSEM) Project.

Defourny, J., Nyssens, M. \& Brolis, O. (2020) “Testing social enterprise models across the world: Evidence from the 'International Comparative Social Enterprise Models' (ICSEM) Project”, Nonprofit and Voluntary Sector Quarterly, forthcoming.

European Commission (2020) Social Enterprises and Their Ecosystems in Europe, Comparative Synthesis Report (authors: Borzaga, C., Galera, G., Franchini, B., Chiomento S., Nogales, R. \& Carini, C.), Luxembourg: Publications Office of the European Union.

Fici, A. (2015) "Recognition and legal forms of social enterprise in Europe: A critical analysis from a comparative law perspective", Euricse Working Papers, No. 82/15, Trento: Euricse.

Gaiger, L. I., Nyssens, M. \& Wanderley, F. (eds) (2019) Social Enterprise in Latin America Theory, Models and Practice, London and New York: Routledge.

Gordon, M. (2015) “A typology of social enterprise traditions", ICSEM Working Papers, No. 18, Liege: The International Comparative Social Enterprise Models (ICSEM) Project.

Gui, B. (1991) "The economic rationale for the third sector", Annals of Public and Cooperative Economics, Vol. 62, No. 4, pp. 551-572. 
Hansmann, H. (1996) The Ownership of Enterprise, Cambridge: Harvard University Press.

Hopkins, R. (2008) The Transition Handbook: From Oil Dependency to Local Resilience, Hartford: Chelsea Green Publishing.

Hopkins, R. (2013) The Power of Just Doing Stuff: How Local Action Can Change the World, Cambridge: Green Books.

Kerlin, J. A. (2013) "Defining social enterprise across different contexts: A conceptual framework based on institutional factors", Nonprofit and Voluntary Sector Quarterly, Vol. 12, No. 1, pp. 84-108.

Kerlin, J. A. (ed.) (2017) Shaping Social Enterprise: Understanding Institutional Context and Influence, London: Emerald Publishing Group.

Le Grand, J. \& Roberts, J. (2018) “The public service mutual: Theories of motivational advantage", Public Administration Review, Vol. 78, No. 1, pp. 82-91.

Maier, F., Meyer, M. \& Steinbereithner, M. (2016) “Nonprofit organizations becoming business-like: A systematic review. Nonprofit and Voluntary Sector Quarterly, Vol. 45, No. 1, pp. 64-86.

McMurtry, J. J. \& Brouard, F. (2015) "Social enterprises in Canada: An introduction", Canadian Journal of Nonprofit and Social Economy Research, Vol. 6, No. 1, pp. 6-17.

Nyssens, M. (ed.) (2006) Social Enterprise: At the Crossroad of Market, Public Policies and Civil Society, London: Routledge.

Salamon, L., Sokolowski, W. \& Anheier, H. (2000) "Social origins of civil society: An overview", Working Paper of the Johns Hopkins Comparative Nonprofit Sector Project, No. 38, Baltimore: The Johns Hopkins Center for Civil Society Studies.

Santos, F. M. (2012) "A positive theory of social entrepreneurship", Journal of Business Ethics, Vol. 111, No. 3, pp. 335-351.

Sassmannshausen, S. \& Volkmann, C. (2018) "The scientometrics of social entrepreneurship and its establishment as an academic field", Journal of Small Business Management, Vol. 56, No. 2, pp. 251-273.

Seyfang, G. \& Smith, A. (2007) "Grassroots innovations for sustainable development: Towards a new research and policy agenda", Environmental Politics, Vol. 16, pp. 584-603.

Spear, R., Cornforth, C. \& Aiken, M. (2009) "The governance challenges of social enterprises: Evidence from a UK empirical study", Annals of Public and Cooperative Economics, Vol. 80, No. 2, pp. 247-273.

Teasdale, S. (2012) "What's in a name? Making sense of social enterprise discourses”, Public Policy and Administration, Vol. 27, No. 2, pp. 99-119.

Young, D., Searing, E. \& Brewer, C. (eds) (2016) The Social Enterprise Zoo, Cheltenham: Edward Elgar Publishing. 


\title{
Conclusion
}

\section{Social Enterprise, Welfare Regimes and Policy Implications}

\author{
Jacques Defourny and Marthe Nyssens
}

As suggested by various authors-like Cooney et al. (2016), Baglioni (2017), Kerlin (2017), Enjolras et al. (chapter 18 in the present volume), Defourny and Nyssens (2010) and in the recent report of the European Commission (2020), trends in the development of social enterprises can be understood in a context of changing forms of government's support to third-sector organisations and new emerging social needs, resulting from the deep evolution of European societies.

\subsection{Social Enterprise and the Welfare State: A Historical Perspective}

On the one hand, from the 1980s onwards, most Western societies have seen the proliferation of new public management (NPM) practices to "modernise" the welfare state. Reforms initiated on this basis have led to the introduction of market mechanisms, for example in the form of calls for public tenders or quasi-markets. This was meant to remedy both (alleged) inefficiencies arising from bureaucratic administration and poor responsiveness to users or payers; citizens' and users' movements criticised the insufficient and standardised supply of public services, and demanded their redeployment around new needs and their adaptation to a greater diversity of life situations.

On the other hand, in the globalised capitalism of recent decades, the market logic has also been criticised for being incompatible with the fight against unemployment and social exclusion, the need for fair trade, the imperatives of ecological transition or the fight against speculative finance. These challenges call for new ways to reconcile economic dynamics with social and environmental goals.

The reconfiguration of the state and the recognition of the limits of a deregulated market have contributed to the opening of spaces for the emergence and development of social enterprise. Social enterprises were, for example, pioneers in tackling the social exclusion of various groups, and especially in promoting their work integration through various models of WISE. As shown in the previous chapter through the analysis of our 


\section{Defourny \& Nyssens}

broad sample of initiatives, social enterprises have proven quite innovative in fields like social services, access to health, ecological transition, social finance and fight against poverty and social exclusion, among others.

The historical perspective shows that these innovative entrepreneurial initiatives have contributed to the development of new public schemes and legal frameworks. Indeed, in general, after a phase of experimentation in social enterprises, the question of the institutionalisation of initiatives arises. When innovation is brought by for-profit enterprises, it is the market that generally sanctions it. In the case of social innovation, analysis of the role of public policies is particularly important. In such perspective, Laville et al. (2006) underline the importance of analysing social enterprises" "political embeddedness", defined as the set of interactions between public authorities and social enterprises; such embeddedness is reflected in mutual effects whose intensity and modalities vary considerably in time. In other words, we cannot fully understand the social construction of social enterprises through an approach that analyses public policies as a separate, autonomous field. Historically, this social construction has been influenced by projects initiated by various social actors who helped shaping public regulation. Social enterprises shape new institutions and norms in society, and it is necessary to recognise their "institutional work" at the meso-economic level, which Lawrence and Suddaby (2006) name "institutional entrepreneurship". Therefore, the development of the SE field cannot be considered as the mere product of a "public" construction; rather, it is the result of interactions between social enterprises and public institutions and policies.

Because of such complex interactions, the design and implementation of SE-related public policies has raised important questions and generated strong debates. More precisely, the nature of social enterprises' mission appears to be a contested issue between promoters of social enterprises and public bodies. Public schemes often frame their objectives in a way that is considered too narrow by some promoters and entails a risk of reducing social enterprises to the status of mere instruments to achieve the specific goals that are given priority on the political agenda. Moreover, the current wave of social enterprises may also be seen as a sign of a process of prioritising and selecting social challenges according to their potential to be addressed in an entrepreneurial way, with a market-based logic. On the other side, it is clear that recognition through public policies has been and still is a key channel for the diffusion of various models of social enterprise throughout Europe.

\subsection{Social Enterprises and their Ecosystems}

Most of these issues are raised and discussed, explicitly or implicitly, across country contributions and through transversal chapters in this book. We can also refer to the "Comparative Synthesis Report" on 
Social Enterprises and their Ecosystems in Europe, recently published by the European Commission (2020). More precisely, this report puts forward a classification of types of welfare systems in Europe and analyses these various types in terms of the "main drivers boosting SE development" with which they are associated (see table 21.1). Most Western European countries, it is argued, tend to correspond to one of the first three types of welfare regimes (and drivers), while Central and Eastern European countries, as well as South Eastern European countries, tend to be associated with the fourth type of welfare system (last row of the table). In the first three types of welfare regimes, the role of bottom-up experimentation by groups of citizens appears to be a major driver for SE development. Social enterprises, federations and platforms have indeed contributed to shaping new public policies and schemes as well as new legislation; but simultaneously, public policies have shaped the development of the SE field through various channels, including the trend

Table 21.1 Drivers and trends of social enterprise

\begin{tabular}{|c|c|c|}
\hline Type of welfare system & $\begin{array}{l}\text { Main drivers boosting SE } \\
\text { development }\end{array}$ & $\begin{array}{l}\text { Examples of } \\
\text { countries }\end{array}$ \\
\hline $\begin{array}{l}\text { Poor supply of welfare } \\
\text { services by public } \\
\text { providers and, } \\
\text { traditionally, gaps in } \\
\text { welfare delivery and } \\
\text { strong civic engagement }\end{array}$ & $\begin{array}{l}\text { Bottom-up experimentation } \\
\text { of new services by groups } \\
\text { of citizensConsolidation of } \\
\text { social enterprises thanks to } \\
\text { public policies that have } \\
\text { regularised social-service } \\
\text { delivery }\end{array}$ & $\begin{array}{l}\text { Greece, Ireland, } \\
\text { Italy, Portugal, } \\
\text { Spain }\end{array}$ \\
\hline $\begin{array}{l}\text { Extensive public supply of } \\
\text { social services, } \\
\text { increasingly contracted } \\
\text { out to private providers }\end{array}$ & $\begin{array}{l}\text { Privatisation of social } \\
\text { servicesBottom-up } \\
\text { dynamics }\end{array}$ & $\begin{array}{c}\text { Denmark, Finland, } \\
\text { Norway, Sweden, } \\
\text { United Kingdom }\end{array}$ \\
\hline $\begin{array}{l}\text { Extensive public and non- } \\
\text { profit welfare structures, } \\
\text { covering the majority of } \\
\text { the needs of the } \\
\text { population }\end{array}$ & $\begin{array}{l}\text { Public support system } \\
\text { designed to support work } \\
\text { integrationBottom-up } \\
\text { emergence of social } \\
\text { enterprises to address new } \\
\text { needs }\end{array}$ & $\begin{array}{l}\text { Austria, Belgium, } \\
\text { France, } \\
\text { Germany, the } \\
\text { Netherlands }\end{array}$ \\
\hline $\begin{array}{l}\text { Welfare systems that have } \\
\text { undergone drastic reforms, } \\
\text { weak associative and } \\
\text { cooperative tradition }\end{array}$ & $\begin{array}{l}\text { Public policies (start-up } \\
\text { grants) specifically tailored } \\
\text { to support } \\
\text { WISE'sinitiatives with } \\
\text { philanthropic background } \\
\text { and donors' programmes }\end{array}$ & $\begin{array}{l}\text { CEE and SEE } \\
\text { countries }\end{array}$ \\
\hline
\end{tabular}

Source: European Commission (2020: 46). 
towards the privatisation of social services and an understanding of the SE field through the narrow lenses of the work-integration mission.

\subsection{Policy Implications}

At this final stage, it makes sense to raise again the question which has been an underlying thread of the whole ICSEM Project: to what extent and why is it important to apprehend and highlight the diversity of SE models?

Let us address this central question in terms of policy implications, not just for institutional policy-makers but also to feed debates in which all types of actors and stakeholders may get involved. Instead of presenting a menu of "best practices" like experts and consulting companies, we prefer to identify some important risks, limitations or even traps to be avoided.

\subsubsection{The Impossible Consensual Definition}

The first and most obvious trap would be to keep devoting a lot of effort, time, energy and skills to the search for a "consensual definition of social enterprise". Indeed, achieving this goal is often perceived as a necessary condition for any advancement of the SE field toward clarity (of borders), measurability (of inputs and outputs) and legitimacy (in the eyes of all actors); but those who cannot live with SE diversity will face major difficulties when discovering that many social enterprises are actually hybrid organisations, living on or close to boundaries. Obstacles are getting even greater when it comes to estimating employment or other key variables in social enterprises: there is a high risk to focus only on SE types targeted by some public schemes, social enterprises registered in the framework of some precise legislation, or social enterprises accredited to be eligible for some forms of support, among others.

\subsubsection{The Search for Heroic Social Entrepreneurs}

Instead of looking for a conceptual consensus, it may be tempting to enhance the understanding of social enterprise by highlighting emblematic social entrepreneurs. Presented as heroes because of their social or societal achievements, they are celebrated around the world by foundations and other international promoting agencies like Ashoka or the British Council, among many others. The founder's profile and the social innovation he or she brings in are presented as central pieces of such beautiful "stories". However, the bulk of theoretical and empirical literature demonstrates that social innovation is more often rooted in collective dynamics than in individual trajectories. Moreover, social innovation in itself has clear limitations as a major criterion to apprehend 
the SE landscape; many fields of action emerge through path-breaking initiatives but then actually grow through social enterprises mainly replicating the pioneering SE initiatives.

\subsubsection{Isomorphic Pressures on WISEs}

A third trap is linked to another, more subtle type of "blindness"; it implies acknowledging the diversity of SE models, but provided all or most models are oriented toward the same single social mission. This risk is currently particularly high as regards the mission of social and economic integration of low-skilled workers, handicapped persons, long-term unemployed or other disadvantaged groups. Indeed, one of the results that emerge clearly from the ICSEM Project is the prevalence of WISEs in all regions of the world and across many SE models, as demonstrated by our statistical analysis. Moreover, a focus on WISEs is most tempting for all actors when public funds are allocated and legal frameworks designed to promote such initiatives because work integration is ranked very high in political agenda. In such context, it may even happen that public authorities impose one or a few very precise types of WISE frameworks, while leaving very little space for autonomy to social enterprises-which then look all similar.

\subsubsection{Still Embryonic Distinct Ecosystems}

Fourthly, it should not be forgotten that the plurality of SE models calls for distinct ecosystems. The fast-growing interest for social enterprise goes hand in hand with the search for the best support schemes and mechanisms: incubators, hubs, social finance, impact investing, venture philanthropy, to name just a few. Although quite fashionable, these practices may tend to focus on just a few social enterprises, selected because they offer good prospects in terms of profitability or scaling-up capacity. But ecosystems also involve other key elements, which should not be under-estimated and are all the more important that they can reach larger SE populations: the existence of specific legal forms, fiscal treatments, access to public procurement, employment subsidies and contributions by volunteers.

\subsection{Synergies and Partnerships Ahead}

The diversity of SE models, instead of leading toward limitations or traps such as those just listed, should be seen and exploited as a key asset. In today's context, indeed, the complexity of social or societal challenges calls for a sound awareness of all models' strengths and weaknesses and for collaboration, synergies and partnerships among social enterprises.

To conclude, what is at stake with the quest for a typology of SE models at the international level is not just a wide, although simplified, view of the 
various SE types. It is not either a "struggle" against too much diversity. It is first and foremost a question of uncovering and acknowledging the fact that today, a wide range of entrepreneurial initiatives, primarily driven by social aims, actually address social or societal challenges, and that these social enterprises stem from all parts of the economy. They can indeed be related to different organisational backgrounds-namely the non-profit, the cooperative and the traditional business sectors. Also worth noting, incidentally, is the fact that social enterprises may be newly launched initiatives or existing organisations shaped by new dynamics.

Recognising this diversity does not only mean acknowledging that social enterprise may generate social impacts by providing goods and services to meet unsatisfied needs through a variety of models. It also means acknowledging these various models' institutional dimension, that is, their potential role in the development of norms and regulations, both at the level of the organisation and beyond, through the "institutional work" of all actors. It is essential not to reduce social enterprises to a dedicated space for "alternatives". Through their innovative dynamics in many fields of activities, they bear a transformative potential for the whole economy, in quest of sustainable models. Indeed, by going beyond the mere "trade-offs" between economic, social and environmental performance, notably through their articulation with the social movements that support them, they can contribute to raising society's awareness and to generating or enhancing a willingness to change on a large scale. Although the social and ecological transition cannot fully take place without deep systemic transformations at the macro level, social enterprises are also contributing to the evolution of production processes and consumption patterns. The challenge is therefore to take the full measure of their contribution and broaden their influence. In this sense, social enterprises are indeed a driving force for the transition.

\section{References}

Baglioni, S. (2017) “A remedy for all sins? Introducing a special issue on social enterprises and welfare regimes in Europe", Voluntas, Vol. 28, No. 6, pp. 2325-2338.

Cooney, K., Nyssens, M., O’Shaughnessy, M. \& Defourny, J. (2016) “Public policies and work integration social enterprises: The challenge of institutionalization in a neoliberal era", Nonprofit Policy Forum, Vol. 7, No. 4, pp. 435-460.

Defourny, J. \& Nyssens (2010) "Social enterprise in Europe: At the crossroads of market, public policies and third sector", Policy and Society, Vol. 29, No. 3, pp. 231-242.

European Commission (2020) Social Enterprises and their Ecosystems in Europe, Comparative Synthesis Report (authors: Borzaga, C., Galera, G., Franchini, B., Chiomento S., Nogales, R. \& Carini, C.), Luxembourg: Publications Office of the European Union. 
Kerlin, J. A. (ed) (2017) Shaping Social Enterprise: Understanding Institutional Context and Influence, London: Emerald Publishing Group.

Laville, J.-L., Lemaître, A. \& Nyssens, M. (2006) "Public policies and social enterprises in Europe: The challenge of institutionalisation", in Nyssens, M. (ed) Social Enterprise: At the Crossroads of Market, Public Policies and Civil Society, London: Routledge, pp. 272-295.

Lawrence, T. B. \& Suddaby, R. (2006) "Institutions and institutional work", in Clegg, S. R., Hardy, C., Lawrence, T. B. \& Nord, W. R. (eds) Handbook of Organization Studies (2nd edition), London: SAGE Publication, pp. 215-254. 


\section{Index}

Ashoka 7, 27, 79, 91, 172, 201, 215, 293, 294, 354

Belgium: associative tradition in 22-3; challenges to SE in 34-5;

cooperative tradition in 23-4, 290-1; corporatist tradition in 7; employment in SE in 32-4, 33; hybridisation of organisations in 292, 294-5; legal and public policies toward SE in 27-9; market-oriented trend in 27; mutualism tradition in 24-5; philanthropic funds in SEs in 26; public authorities' interest in SE in 25-6, 34; rise of new-style social enterprises in 292-4; role of NPOs in 289-90; SE as mission-driven business in 7; SE debates in 21-2; SE models in 30-2, 31; voluntary organisations in 290; welfare state in 288-9

capital interest (CI) 10-1, 10

Centre for Social Economy, Danish cooperative employers' organisation 37,45

Centre for Social Entrepreneurship, Roskilde University, Denmark 37, 43

charitable incorporated organisation (CIO) (in UK) 254, 259

charities 254, 259

citizen's cooperative (in Italy) 131,345

common-good-economy movement 243 community businesses (in UK) 256 community cooperative (in Italy) 131 community enterprise (in Italy) 131 community entrepreneurship (in Sweden) 226-7

community interest companies (CICs)

(in UK) 254, 258, 259, 262

companies limited by guarantee

(CLGs): (in UK) 254, 259, 261; in Ireland 122

cooperativas de educação $e$ reabilitação de cidadãos com incapacidade (CERCIs) (in Portugal) 183, 192

Cooperative and Community Benefit Societies Act (2014) (UK) 254 coopérative d'activité et d'emploi (CAE) (activity and employment cooperative) (in France) 276-7 cooperative social enterprises (CSEs) 8-9, 316; characteristics of 320-1; as context-specific phenomenon 329; factors shaping characteristics of 316-7, 321-8, 322; legislation effects on characteristics of 325-7; mutual interest (MI) of 10-1, 10; profits and 11; social entrepreneurship legalities and effects of on characteristics of 327-8; socioeconomic policies effects on characteristics of 323-5

cooperative tradition $8-9$; in Belgium 23-4

corporate social responsibility (CSR) 11, 91, 122, 196, 293-4, 346 
Defourny, J. 6, 14, 106, 109, 160, 182, 197, 285, 292, 293, 295, 334,351

Denmark: crises leading to development of SE in 39; development of cooperative sector in 38; ecosystem of support for 42-5; factors in institutionalisation of SE in 39-40; modernisation programmes in 42; NPM reforms in 306, 309-10; SE platforms in 45-8, 46,47 ; social economy in $37-8$; welfare state as SE context 8, 37-40, 41-2, 49, 53, 103

EMES International Research Network 1, 2, 69, 74, 75, 76, 78, 79, 81, 85, 97, 102, 106, 183, 213, 215, 224, 236, 239, 244, 271, 272, 317,341 ; approach to SE 5; Europe tradition of 113; ideal type of SE 21, $117,120,121$; indicators from 114, 115; social enterprise definition 134-5, 202, 222, 258, 295

energy cooperatives (in Spain) 212-3

entreprise solidaire d'utilité sociale

(ESUS) label (France) 73

entrepreneurial non-profit (ENP) model 12, 64, 106, 160, 188-9, 194-5, 197, 278-80; clusters of SEs and 337-42, 338-40; missioncentric services provided by 341

European Commission 334, 351, 353

European Social Fund (ESF) 222, 228

European Union 86, 182, 187, 200, 215,220

Finland: alternative economic initiatives in 52, 60-1; economic downturn in 1990s in 305; evolution of new SEs in 54-5; impact businesses and smart-ups in 52, 61-2; institutionalised SE in $55-8,56$; non-institutionalised SE in $55-8$; old cooperative movement in 56-7; SE providing public welfare services in 52, 58-60, 59; socialeconomy organisations in 53-4; social-impact redistributors in 52 , 62-3; social value in SE in 63-4; welfare state as SE context in 52-3, 102

Finnish Foundation Act (1930) 60 folkhemmet (people's home) (in Sweden) 219, 221

folkrörelser (popular mass-movement organisations) (in Sweden) 219, 220, 221

Forfás (Ireland) 118, 119

foundations and religious institutions (in Italy) 142-4, 143, 144

foundations in education (in Spain) 206-7

Framework Law on the Social Economy (Portugal) 182, 184-5, 186

France: collective-interest cooperatives (SCIC) in 276-7; definition of social economy in 69-70, 70, 272; entrepreneurial associations model in 76-7, 79; general-interest and multiple stakeholder models 74-6; institutionalisation in 273-5; legalisation of SE as sector in 6; nonprofit organisations (NPOs) in 278-9; SE diversity in 6; social and solidarity economy (SSE) in 69, 70, 72-4, 79-80; social entrepreneurship aims in 69-70, 70, 272; WISEs in 77-9, 280-1

Funding Centre for Social Welfare and Health Organisations (STEA) (Finland) 53, 63

Gawell, M. 218, 223

Gemeinwohl-Ökonomie (economy for the common good, ECG) 238-43, 239, 240-1, 243-5

general interest (GI) 10-1, 10, 12

Geneva Chamber of Social and Solidarity Economy (APRÈS-GE) 239, 242

Germany: alternative initiatives in 1970s and 1980s in 90-1; citizen foundations in 88-9; cooperative models in 87-8, 290-1; corporatist tradition in 7; development of SE models in 86-91; development of welfare state in 87,94 ; government promotion of SEs in 91-2; hybridisation of organisations in 292, 294-5; philanthropic culture in 93; rise of new-style social enterprises in 292-4; role of civil society in SEs in 93; role of NPOs in 289-90; SE as mission-driven 
business in 7; SE debate in $85-6$; social policy environment for SEs in 95-6; voluntary organisations in 290; welfare system in $87,94-5$, 288-9; WISEs in 89-90

Gui, B. 9, 10

Hansmann, H. 9

housing associations (in UK) 256-7

Iceland: lack of support structures for SE in 108-9; relationship between government and NPOs in 104-5; relationship between government and TSOs in 105-6; roots of SE in 102-3; SE models in 106-8, 107, 109; welfare state as SE context $53,103-4$

ideell organisation (non-profit organisation) (in Sweden) 220

industrial and provident societies (I\&PSs) (in UK) 254, 259, 261 insertion enterprises (EIs) (Portugal) 183, 190, 191

instituição particular de solidariedade social (IPSS) (in Portugal) 184, 188-90, 189, 192

institutional theory 272-3

International Classification of NonProfit Organisations (ICNPO) 114, 259

International Comparative Social Enterprise Models (ICSEM) Project 2, 30, 58, 64, 85, 236, 285, 335-7, $336,354,355$; country papers (CPs) $316,317-28$; phase 1 of $2-3,5-6$, 335 ; phase 2 of 335 ; phase 3 of $13-4$

Interpreters' Cooperative (Finland) 62 Ireland: ambiguous understanding of concepts in 114-6; debates on SE in 1990s and 2000s in 116-7; SE sector in 112-4; social economy in 116-7; types of SE in 118-9; WISE model in 113, 114-5, 119, 122-5

Italian Civil Code 133, 134, 142

Italy: associative social enterprises in 139-42, 140, 141, 142;

characteristics of social cooperatives in 136-9, 137, 138; definition of social cooperatives 136 ; foundations and religious institutions in 142-4, 143, 144; limited-company SEs in
144-5; origins of SE in 132-3; social cooperatives in 131, 134-6; types of SE in 131-2, 134-6, 146; voluntary organisations in 1980s in 133; welfare failings in 1970s in 132-3; WISE in 9

John Hopkins Comparative NonProfit-Sector Project 86; definition of non-profits 113-4

Kerlin, J. A. 334, 351

Law No. 155 (2006) (Italy) 132, 134,144

Law on the Social and Solidarity Economy (2014, France) 73

leisure trusts (in UK) 257

limited-company SEs (in Italy) 145-145

McKinsey (Amsterdam) 155, 156, 159 mission-driven businesses 1 mutual-benefit organisations 9-10 mutual-insurance companies 291 mutual interest (MI) 10-1, 10 mutuals tradition (in Belgium) 24-5

National Council for Cooperation (Belgium) 23

National Council for Voluntary Organisations (NCVO) (UK) 262-3

National Economic and Social Forum (NESF) (Ireland) 116

National Growth Centre for Social Enterprise (Denmark) 43

National liaison committee of mutualist, cooperative and associative activities (CNLAMCA) (France) 71

National Social Enterprise Policy for Ireland (2019-2022) 112, 119-20; definition of SE 120

neoliberal welfare state 177

Netherlands: as consociational state 153-4; cooperatives in 290-1; corporatist tradition in 7 ; diversity of third sector in 153-4; factors in interest in SEs in 152-3; government relations with SEs 160-3; growth and size of SE in 155-6; historical context for SE in 153-4; hybridisation of organisations in 
292, 294-5; lack of legal form of SE in 149, 150-2, 151; legal forms of SE in 151, 152, 157-8; rise of newstyle social enterprises in 292-4; role of NPOs in 289-90; SE as missiondriven business in 7; SE models in 159-60; voluntary organisations in 290; welfare state in 288-9

new public management (NPM) principles $7,8,105,154,168,232$, 237, 238, 248, 302, 304-6, 308, 351 non-governmental organisations

(NGOs) 201, 235, 244

non-profit organisations (NPOs) 6, 104, 237, 278-80, 289-90, 308, 341-2, 343

non-profit social enterprises (in

Sweden) 223, 224-5, 228

Norway: development of SE in 166-7; division of labour in 166, 167; historical context for SE in 167-9; NPM reforms in 305, 309; reasons for slow development of SE in 176-9; relationship between state and civil society in 167-8; SE models in 169-76, 171, 173-4; social entrepreneurship in 171; welfare state as SE context 8, 53, 102, 167-9, 177

Nyssens, M 6, 14, 106, 109, 160, 182, 197, 285, 292, 293, 295, 351

Organisation for Economic Co-operation and Development (OECD) 152, 161

Ostrom, E. 243

path dependence hypothesis 6 Pestoff, V. 230, 231

philanthropic organisations 291 polder model (in Netherlands) 289 pôles territoriaux de coopération économique (PCTEs) (France) 74,75

political embeddedness (of SEs) 352

Portugal: cooperatives in 277-8; definition of social economy in 272 ; government support for SEs in 186-7; institutionalisation in 273-5; legal framework for SE in 184-5; legalisation of SE diversity in 6; research on SE in 183-4; SE diversity in 6; SE models in 187-95; social entrepreneurship in 185,272 ; welfare state and NPOs in 279-80; WISEs in 282

post-NPM approaches 8,308 , 310,313

principles of interest $10-1,10$; capital interest (CI) 10-1, 10; general interest (GI) 10-1, 10; mutual interest (MI) 10-1, 10

public-benefit organisations 9-10

public sector as founder of SE 346-7

public-sector social-enterprise (PSE) model 12, 64, 106-8, 107, 160

public-service mutualism (in UK) 257,343

public services organisations (in UK) 256-7

registered social enterprise tool (RSV) (Denmark) 43-4

Rhine capitalism 288

rural-development organisations (in Spain) 208-9

Salamon, Lester 262, 334 sambällsentreprenörskap (societal entrepreneurship) (in Sweden) 226-7, 229

Scandinavian (Nordic) welfare state 301; characteristics of 303-4; compared to Anglo-Saxon and continental models 303-4; cooperative traditions in 310 ; development of SE in 308-10; informational asymmetries in 311 ; institutional isomorphic pressures in 311-3; regulated and institutionalised markets in 311; SE in 301-2; size of 307 ; welfare policy reforms in 304-5

Schwab Foundation for Social Entrepreneurship 7, 27, 293, 294 selvejende institution (self-governing institutions in Denmark) 40-1 service-voucher system (in Belgium) 26, 28, 29

sheltered-employment centres (SECs) (in Spain) 201, 206

Sivesind, K. H. 307, 311

smart-ups (Finland) 52, 61-2

sociaal ondernemers (social entrepreneurs) (in Netherlands) 150, 153, 157-8, 161 


\section{Index}

sociaal ondernemerschap (social

entrepreneurship) (in

Netherlands) 150

Social and Economic Council of the

Netherlands (SER) 161-2

social and solidarity economy (SSE)

(in France) 70, 72-3, 79-80;

evolution of institutionalisation process 71-4

Social Business Initiative (SBI), European Commission (2011) 115, 169-70; social enterprise (SE) definition 150, 169

social business (SB) model 12, 64, 160, 193-6, 194-5; clusters of SE and 338-40, 345-6

social-cooperative (SC) model 12, 64, 160, 191-2, 194-5; clusters of SE and 338-40, 342-5

social cooperatives $108,131,134-6$; characteristics of Italian 136-9, 137, 138; Italian definition of 136; in Italy 344; types of in Italy 134-6 social democratic welfare state 167-8, 301-3; Scandinavian model of 301-3

social economy: in Denmark 37-8; in France 272; in Ireland 116-7; in Portugal 272; re-emergence of in Denmark from mid-1980s 39; in Spain 272; in Sweden 220-1

Social-Economy Charter (in France) 69, 71

social-economy organisations (SEOs) 271, 276-7; (in Finland) 53-4; in Portugal 185, 186, 187, 188

Social Economy Programme (SEP) (2000, Ireland) 117

Social Enterprise London (SEL) 260-1

Social Enterprise Monitor, Social Enterprise NL 150, 155, 156, 157, 158, 161, 293, 294, 296; definition of SE 160

Social Enterprises and their

Ecosystems in Europe, Comparative Synthesis Report (2020, European Commission) 3, 353

social enterprises (SE) mark (Finland) $54,55,56,58,61,63,65$

social enterprises (SE) models 9-10, 12-3, 21-2, 30-1, 31, 37-9, 86, 106-8, 107, 276-83; comparison of in France, Portugal and Spain
283-5; diversity of as key asset 356-7; institutional-logic approach to 273 ; typology of $333-4$

Social Enterprise Unit (SEU) (UK) 261,262

social entrepreneurs 102, 108, 272; description 1

social entrepreneurship 28, 42, 105 , 183, 218; aim of 272; description 1 , 37-8; in Finland 55, 57-8; in France 69-70, 77-8, 79

social-entrepreneurship model 282-3 social-entrepreneurship movement 235, 238-43, 239, 240-1, 245-6

Social Entrepreneurship Netzwerk (SEND) (Germany) 294, 296

Social Entrepreneurs Ireland 126

sociale ondernemingen (social enterprises) (in Netherlands) 150

Social Impact Fund database, ABN

Amro 155, 156, 157, 158, 159

social-impact redistributors (in

Finland) 52, 62-3

social innovation 102, 108, 183, 245,

352; emblematic social

entrepreneurs and 354-5; in

Portugal 185

social-market economy 288

social or general-interest cooperatives

276-8, 285

social-purpose businesses (in Sweden)

223, 225-6, 228-9

social return on investment (SROI) 34

social solidarity (in Portugal) 185

social-solidarity cooperatives (in

Portugal) 184

social solidarity economy (SSE)

movement 235, 238-43, 239, 240-1

social start-ups 7, 288, 296-7

Social Welfare Act (1961)

(Germany) 89

societal entrepreneurship (in

Sweden) 218-9

société coopérative d'interêt collectif

(SCIC) (collective-interest

cooperative) (in France) 74-5, 276

solidarity economy 271; in France 69;

in Portugal 183

solidarity-economy enterprise model (in Portugal) 192-3, 194

Spain: characteristics of SE groups in 204-5, 213-4; context for SE in 200-3; definition of social economy 
in 272; institutionalisation in 273-5; legalisation of $\mathrm{SE}$ as sector in 6; major categories of SE in 203-13; non-profit organisations (NPOs) in 278, 279; SE diversity in 6; social entrepreneurship in 272; types of cooperatives in 277 ; WISEs in 281-2

Spear, R. 254, 333

structures d'insertion par l'activité économique (SIAE) (France) 77

subsidiarity principle 235,288

Sweden: economic downturn in 1990s in 305; legalities of SEs in 227; neoliberal transformation in 305 ; NPM reforms in 308-9; SE models in 222-7, 223; SE in 221-2; welfare state as SE context 8, 102, 219-21, 229-30

Switzerland: approaches to SE in 238-40, 239; cooperatives in 244-5; public policies towards SE in 248; third sector in 236-8

Teasdale, S. 260, 333

third-sector organisation (TSO) 86, 105-6, 229-30, 230, 231, 245, 256, $262,288,289$; boundary blurring in
Switzerland 246-7; in Switzerland 236-7

United Kingdom (UK): discoursehistorical approach to SEs in 260-4; divergent policies towards SE in 253; government's definition of SE 258; legal structures of SE in 254, 259-60; particularities of SE in 258-9; SE models in 255-7

welfare-mix social businesses 7 welfare states 6 ; social democratic 302; social rights' dimensions in 302; types of 353-4, 353

work-integration social enterprises (WISEs) 6-7, 9, 26, 28, 29-30, 45, 77, 85-6, 89-90, 106, 183, 200, 203, 222, 223-4, 223, 276, 285, 291, 342, 351; in France 280-2; in Ireland 113, 114-5, 119, 122-5; isomorphic pressure on 355; policies for in Sweden 227-8, 230; in Portugal 280-2; in Spain 280-2; in Switzerland 235, 249; in UK 255-6, 265

Young, D. 1, 333 


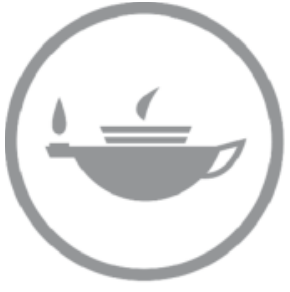

Taylor \& Francis Taylor \& Francis Group http://taylorandfrancis.com 